Denise Loli

Termorregulação colonial e energética individual em abelhas sem ferrão

\author{
Melipona quadrifasciata Lepeletier \\ (Hymenoptera, Apidae, Meliponini)
}

São Paulo

2008 
Denise Loli

\section{Termorregulação colonial e energética individual em abelhas sem ferrão \\ Melipona quadrifasciata Lepeletier (Hymenoptera, Apidae, Meliponini)}

Tese apresentada ao Instituto de Biociências da Universidade de São Paulo, para a obtenção de Título de Doutor em Ciências, na Área de Fisiologia

Orientador(a): Prof Dr. José Eduardo Pereira Wilken Bicudo

São Paulo 2008 
Loli, Denise

Termorregulação colonial e energética individual em abelhas sem ferrão Melipona quadrifasciata Lepeletier (Hymenoptera, Apidae, Meliponini)

Número de páginas: 229

Tese (Doutorado) - Instituto de Biociências da Universidade de São Paulo. Departamento de Fisiologia.

1. Palavra-Chave Principal:

Termorregulação 2. Palavra-Chave Secundária: Abelhas Sem Ferrão 3. Palavra-Chave Secundária: Octopamina I. Universidade de São Paulo. Instituto de Biociências. Departamento de Fisiologia

Comissão Julgadora:

Prof(a). Dr(a).

Prof(a). Dr(a).

Prof(a). Dr(a).

Prof(a). Dr(a).

Prof(a). Dr(a).José Eduardo P. W. Bicudo

Orientador(a) 
Dedicado ao meu pai, Angelo, à minha mãe, Ermínia, à minha irmã Leila, ao amigo Márcio (in memorian) e ao amado Wellington. 
“... e um dia os homens descobrirão que esses discos voadores estavam apenas estudando a vida dos insetos..."

Mario Quintana, Sapato Florido 


\section{Agradecimentos}

- Agradeço ao Prof Dr José Eduardo P. W. Bicudo pelo incentivo e orientação.

- À Fundação de Amparo à Pesquisa do Estado de São Paulo, pelo financiamento deste projeto (processo ${ }^{\circ}$ 02/13973-2).

- Ao Prof. Dr. José Guilherme Chauí-Berlinck pelas valiosas sugestões e discussões referentes a aspectos específicos deste trabalho.

- Aos Profs. Drs. Silvia Cristina Souza, Gilberto Xavier, Carlos Navas, Mirian David Marques, Renata Moreira e Gisele Oda (Departamento de Fisiologia do IBUSP) por todas as dicas e apoio.

- Aos Drs. Sérgio Dias Hilário, Ophelis Françoso-Júnior e Felipe Contrera pelas informações e sugestões a respeito das abelhas sem ferrão.

- Ao Dr. José Eduardo de Carvalho pelo valioso apoio no cálculo de atividade enzimática

-Aos Profs Drs Carlos Ribeiro Vilela, Lyria Mori e José Mariano Amabis, por me apresentarem à ciência.

- Ao Prof Dr Flavio Roces e ao Dr Martin Bollazzi (Biozentrum Universität Wüzburg) pelas dicas, sugestões e por me incentivarem no estudo dos insetos sociais.

- Ao engenheiro Breno Santos pela valiosa ajuda na análise de séries temporais.

- Aos funcionários Márcio, Gisele, Roseli, dona Irani e Rose, pela ajuda e amizade.

- Aos colegas do Departamento de Fisiologia, em especial a Tatiana H. Kawamoto e Lucas Francisco R do Nascimento, pelas dicas para aperfeiçoamento do manuscrito, ao Gustavo Kaneto pelo auxílio na utilização do programa Datacan e a todos que, em algum momento, apoiaram e incentivaram meu trabalho.

- Aos cirurgiões Drs Abner, Eduardo e Martins, por cuidarem tão bem de mim.

- Aos amigos: Sandra, Patrícia, Janaína, Márcia, Marcius, Laura, trupe Nestorenko, Cristiane, Tainá, Adriana, Mack, Isabel, Antonio, Cíntia, Arnaldo, Sachs, Fernando, José, Denise, Bartolomeu, Constantino, Ulysses, Ana Paula, Wilson, Mayara, Paula, pela amizade e alegrais.

- Aos coralistas e regentes do Coral Escola Comunicantus, da ECA-USP, pela acupuntura na alma.

- À arte de Claude Monet pela educação de meus olhos.

- À minha cadela Tica, impagável companheira.

- Ao amigo Marcio Penteado de Souza (in memorian) pelos dias alegres e cheios de esperança.

- Ao amado Wellington, por todo o incentivo, cumplicidade e compreensão. Por ser um modelo de companheiro e profissional, e por me ajudar a descobrir quem eu sou.

- Ao meu pai Ângelo, minha mãe Ermínia e minha irmã Leila pelo grande apoio, carinho e compreensão e amor. 


\section{Índice}

\section{Capítulo 1}

Introdução Geral.

9.

\section{Capítulo 2}

Termorregulação colonial em Melipona quadrifasciata e seus aspectos rítmicos .27

\section{Capítulo 3}

Influências do ciclo claro/escuro e da temperatura sobre a taxa metabólica de abelhas forrageadoras. 91

\section{Capítulo 4}

Efeitos de modificações em vias octopaminérgicas sobre a taxa metabólica, temperatura torácica e utilização de substratos energéticos em abelhas Melipona quadrifasciata.

\section{Capítulo 5}

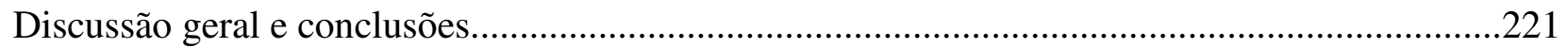

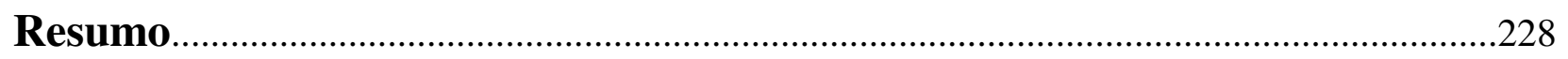
Abstract
229 
Capítulo 1

Introdução Geral

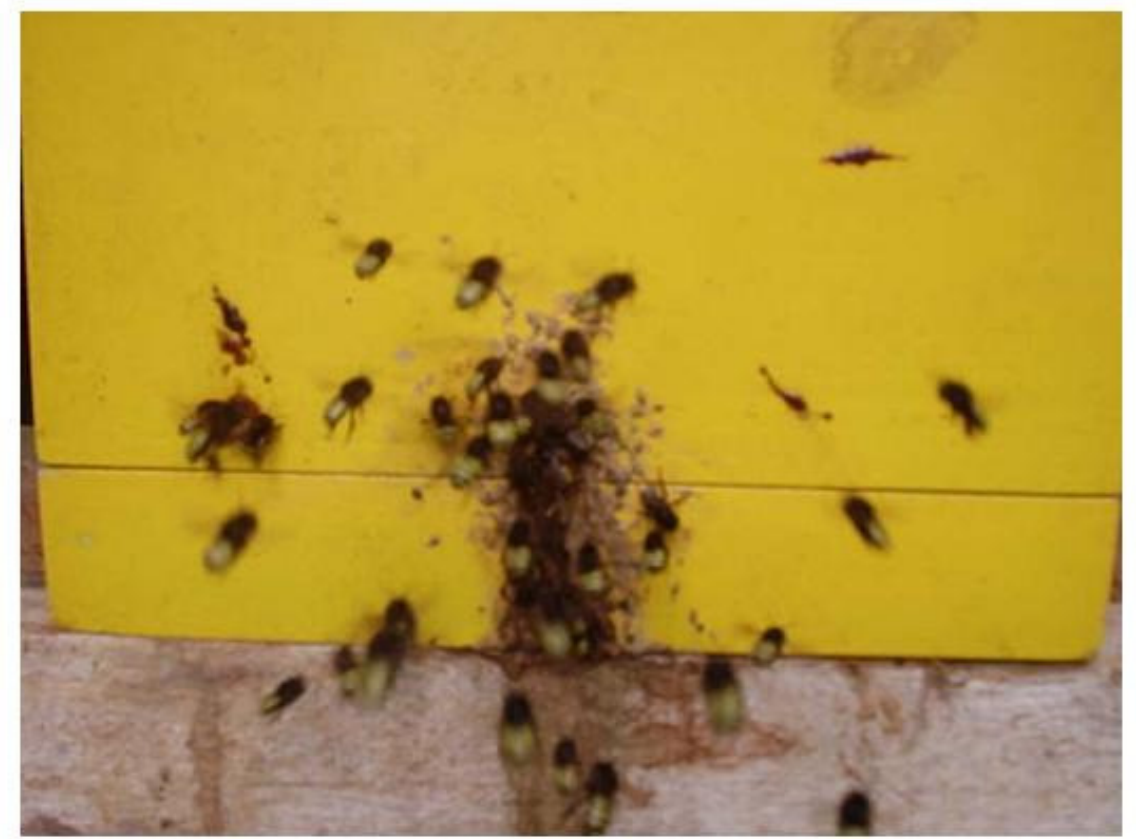




\section{Capítulo 1. Introdução Geral}

Os artrópodes constituem um grupo de animais com grande diversidade adaptativa que lhes permite sobreviver em praticamente todos os habitats. O sucesso evolutivo pode ser medido de diversas formas, e os critérios mais usados são a quantificação do número de espécies e da extensão da sua distribuição geográfica que no caso dos insetos caracteriza uma grande radiação adaptativa. Através desses dois padrões, os insetos constituiriam um grupo de animais de grande êxito e importância ecológica no ambiente terrestre, como agentes de polinização, vetores de doenças, pragas da agricultura, parasitismo, entre outros (HÖLLDOBLER e WILSON, 1990; RUPPERT e BARNES, 1996; HICHMAN et al, 2004). Calcula-se que aproximadamente um terço das espécies de organismos vivos sejam insetos, e essa característica deve-se ao fato de terem sido um dos primeiros grupos de animais que conquistaram o ambiente terrestre (HÖLLDOBLER e WILSON, 1990).

A vida em sociedade favorece a luta pela sobrevivência, torna mais fácil a busca por alimento, aumenta as oportunidades de defesa contra predadores e competidores e, inclusive, pode facilitar o cuidado com a cria e a construção de ninhos. Mas a complexidade de sua estrutura faz com que apareça em poucos grupos, distribuídos em toda a escala filogenética (HÖLLDOBLER e WILSON, 1990), dentre os quais destacam-se os insetos.

As organizações sociais evoluíram em duas Ordens de insetos, os Isoptera (cupins) e os Hymenoptera (que incluem formigas, vespas e abelhas). Os insetos sociais são um grupo muito diverso (WILSON, 1971), e dentre os himenópetros sociais, existe grande variedade na complexidade da organização social. A eussocialidade, o desenvolvimento mais alto da organização social, surgiu, em insetos, apenas nessas duas ordens e aparentemente foi a responsável pelo êxito desses táxons (HERMANN, 1979; RUPPERT e BARNES, 1996; RUPPERT et al, 2005). Os insetos sociais, devido principalmente ao seu papel ecológico, estão entre os grupos animais melhor estudados na atualidade (HEARD, 1999; KEVAN e PHILLIPS, 2001). Os insetos eussociais, particularmente formigas e cupins, tornaram-se espécies dominantes a partir de 50 a 60 milhões de anos atrás (HÖLLDOBLER e WILSON, 1994).

As sociedades eussociais são reconhecidas por três características principais: os membros da sociedade cooperam no cuidado dos juvenis, há divisão reprodutiva de trabalho e há sobreposição de pelo menos duas gerações (Ruppert et al, 2005). Todos os insetos sociais apresentam algum grau de polimorfismo e os diferentes tipos de indivíduos que ocorrem na colônia são denominados castas (Ruppert et al, 2005) que, no caso das abelhas, incluem uma fêmea madura sexualmente (a rainha), alguns zangões, que são machos sexualmente maduros, e várias operárias, que são fêmeas 
reprodutivamente inativas. Wilson e Hölldobler (2005b) apresentam uma revisão sobre as origens e consequências da eussocialidade em insetos sociais, focando em formigas.

Nos insetos sociais, a habilidade de reconhecer os membros da mesma colônia é um requisito para evitar que organismos externos entrem e perturbem a estrutura social da colônia (WILSON, 1971). Segundo Farina e Wainselboim (2001), a troca de alimento em insetos eusociais (trofaláxis) contribui para a organização de atividades sociais complexas. No caso das abelhas melíferas Apis, as forrageadoras que retornam de uma fonte de néctar transferem o alimento coletado para abelhas receptoras, na colônia, por meio de contato oral.

\section{ABELHAS E ORGANIZAČ̃̃O SOCIAL}

As abelhas possuem uma das mais complexas organizações dentre os insetos sociais (HICKMAN et al, 2004) e a abelha melífera Apis mellifera é o inseto social mais conhecido e estudado. Acredita-se que essa espécie tenha se originado na África e tenha sido introduzida nas regiões temperadas de todo o planeta recentemente (NOGUEIRA-NETO, 1997; RUPPERT et al, 2005). Danforth (2002) apresenta revisão sobre a evolução da socialidade em linhagens primitivas de abelhas, como o surgimento do comportamento eussocial e a reversão do comportamento eussocial para o solitário.

Dentre as abelhas eussociais nativas do Brasil, destaca-se a Melipona quadrifasciata Lepeletier, popularmente conhecida como mandaçaia, sistema biológico em estudo nesta tese. Melipona é um gênero exclusivamente Neotropical, sendo a tribo Meliponini (sub-tribo Meliponina segundo Silveira et al, 2002) o grupo com o maior número de espécies (MICHENER, 2000; SILVEIRA et al, 2002).

As abelhas da subfamília Meliponinae são conhecidas como abelhas indígenas sem ferrão por serem nativas do Brasil e possuírem ferrão atrofiado, constituem um grupo amplamente distribuídas nas regiões Neotropicais, ocorrendo principalmente no continente americano desde o Estado de Sonora (México) até o Estado do Rio Grande do Sul. Aproximadamente 300 das 400 espécies descritas ocorrem na América do Sul, distribuídas em 30 gêneros (NOGUEIRA-NETO, 1997). Os Meliponíneos compreendem duas tribos: Trigonini e Meliponini (CAMARGO, 1989; MICHENER, 2000), esta última consistindo de abelhas sem ferrão que apresentam organização social (KERR et al, 1999).

Melipona quadrifasciata Lepeletier ("mandaçaia") inclui duas subespécies, M quadrifasciata quadrifasciata e M quadrifasciata anthidioides (SCHWARZ, 1932). As subespécies podem ser facilmente reconhecidas morfologicamente pelo padrão de bandas tergais (listras amarelas no abdômen), do terceiro ao sexto tergito. $M q$ quadrifasciata exibe bandas contínuas, enquanto $M q$ anthidioides exibem bandas interrompidas na parte central (AIDAR, 1996; 
SCHWARTZ, 1932; MELO e CAMPOS, 1987). Todavia, a distribuição geográfica parece ser distinta para cada uma das subespécies. M q quadrifasciata é mais abundante no Paraná e Santa Catarina (MONTEIRO, 2000), mas é também encontrada em altitudes acima de 1500m em São Paulo, Rio de Janeiro e Minas Gerais (MOURE, 1975). Por outro lado, $M q$ anthidioides é freqüente no Rio de Janeiro e Minas Gerais (AIDAR, 1996). Em regiões do Estado de São Paulo e Sul de Minas Gerais, existe uma zona de hibridação onde são encontrados híbridos com vários padrões na distribuição das bandas amarelas nos tergitos abdominais (MOURE e KERR, 1950; KERR, 1951; MOURE, 1975). O valor econômico de $M$ quadrifasciata, bem como sua atratividade para interessados em sua criação, tem encorajado a prática de comércio e troca de rainhas e de colônias inteiras entre criadores. Estas práticas podem promover contato entre as duas subespécies e levar a fluxo gênico e desenvolvimento de populações híbridas secundárias. O desenvolvimento de marcadores genéticos e estudos do DNA mitocondrial, tais como trabalhado em Weinlich et al (2004) e Moretto e Arias (2005) é benéfico para a identificação da origem materna em populações comerciais ou de subespécies em populações naturais (MORETTO e ARIAS, 2005).

As abelhas eussociais como Melipona quadrifasciata apresentam grande plasticidade comportamental e, nas colônias, dispõem de sistemas altamente flexíveis de divisão de trabalho (SEELEY, 1995). Os diversos aspectos das decisões comportamentais das abelhas são complexos e podem sofrer influências tanto de fatores ambientais (como temperatura, umidade relativa, disponibilidade de recursos etc.) quanto fatores coloniais (número de indivíduos na colônia, necessidades coloniais, ferormônios, entre outros).

As operárias mais velhas tendem a desenvolver atividades de forrageadoras (campeiras) realizando vôos para coleta de recursos alimentares e materiais. Nisso ocorre transição do microambiente colonial controlado para o ambiente externo heterogêneo. Há alterações, por exemplo, nos níveis de percepção de pistas ambientais, além de alterações fisiológicas, como maturação dos músculos torácicos de vôo, com alterações hormonais, metabólicas etc.

Dentre os meliponíneos, as abelhas do gênero Melipona têm sido estudadas sob vários aspectos comportamentais, principalmente quanto à ovipostura, aprovisionamento, atividade externa e divisão de trabalho, fornecendo dados importantes para serem correlacionados com estudos fisioecológicos (FRANÇOSO-JÚNIOR, 1999).

Trabalhos sobre manejo e multiplicação de colônias com abordagens mais específicas vêm sendo publicados a partir da década de 1940, período em que as características reprodutivas, biológicas e genéticas das abelhas nativas começaram a ser estudadas e esclarecidas pelos primeiros trabalhos sobre os assuntos: manejo de criação de abelhas indígenas (a partir de KERR, 1945); formação de castas nos meliponíneos (a partir de KERR, 1946); processos de enxameagem e pilhagem (NOGUEIRA-NETO, 1948); estudos de biologia e genética do gênero Melipona (KERR, 
1948); arquitetura de ninhos de meliponíneos (KERR et al., 1967); acasalamento controlado em laboratório com Melipona quadrifasciata (CAMARGO, 1976; AIDAR, 1995a e b); alimentação artificial (KERR, 1987; NOGUEIRA-NETO, 1993; AIDAR et al, 1994; ZUCOLOTO, 1994); colméias racionais (NOGUEIRA-NETO, 1993; KERR, 1995), entre outros.

O metabolismo e a termorregulação em insetos sociais são aspectos pouco estudados mas importantes para entender a sua socialidade. Economicamente, estudos de parâmetros fisiológicos das abelhas sem ferrão ajudam a melhorar a manutenção de meliponários e a realizar planejamentos de polinização agrícola mais eficazes (FRANÇOSO-JÚNIOR, 1999).

\section{IMPORTÂNCIA ECONÔMICA E ECOLÓGICA}

A meliponicultura é uma atividade vital em nossa sociedade, não apenas para a produção de mel e outros subprodutos, mas também para a manutenção da vida vegetal nos trópicos por meio da polinização. Dependendo do ecossistema, as abelhas sem ferrão podem se responsáveis por 40 a 90\% da polinização (KERR et al, 1996) de vegetais de fecundação cruzada, contribuindo para o aumento da diversidade genética das espécies vegetais (ALMEIDA, 1997) e sucesso reprodutivo das árvores que têm flor (KERR, 1994). Em contrapartida, as abelhas dependem nutricionalmente das plantas com flor que fornecem néctar e pólen. Assim, as abelhas sem ferrão podem ser empregadas em programas de polinização, em ambiente aberto ou em estufas de cultivo.

Incentivando o uso dessas abelhas na polinização pode aumentar a procura por seus ninhos para uso na agricultura, podendo inclusive ser fonte de renda para os produtores e habitantes de zonas rurais, além de contribuir para a conservação das espécies de abelhas nativas. As abelhas sem ferrão também podem ser largamente empregadas para a produção de própolis, pólen, cera e mel. $\mathrm{Na}$ literatura existem alguns trabalhos sobre as características físico-químicas de amostras de mel de abelhas sem ferrão como Oliveira et al (2005).

Ecologicamente, o desaparecimento de espécies de meliponíneos, por desmatamento ou extrativismo, implica na extinção de espécies vegetais importantes em nossos ecossistemas, desencadeando um ciclo de desequilíbrio ecológico destas espécies inter-relacionadas (KERR, 1978 e 1994; ROUBIK, 1989; KERR et al, 1994a).

\section{ESCOLHA DA ESPÉCIE}

A mandaçaia foi escolhida para estudos fisiológicos devido seus possíveis usos em programas de polinização, para a produção de mel e também devido às seguintes características:

- Seu tamanho $(0,8$ a $1 \mathrm{~cm})$, que possibilita bons sinais de taxa metabólica e facilita a manipulação e colocação em câmaras respirométricas, por exemplo;

- Baixa agressividade (não ferroam, apenas mordiscam quando muito irritadas); 
- Freqüente emprego em meliponários para criação racional;

- O tipo de nidificação (construção de ninhos em ocos de árvores), podendo ser criadas racionalmente em caixas simples de madeira Normalmente, os meliponíneos fazem seus ninhos em ocos de árvores vivas (IHERING, 1903; CAMARGO, 1994) e esta interação está associada à existência de árvores com diâmetro maior ou igual a 10,0 cm, (RODRIGUES e VALLE, 1964; WALKER, 1991)

- Fácil manejo da colônia, com conhecidas técnicas de criação em caixas racionais;

- e principalmente a possível ocorrência de produção de calor (termogênese), incluindo-se essas abelhas no grupo de insetos endotermos-heterotermos.

\section{ENDOTERMIA}

Um conjunto não muito extenso de princípios e processos bioquímicos é explorado em animais endotermos (mamíferos, aves, alguns peixes e alguns insetos) e em certas plantas (HOCHACHKA e SOMERO, 2002). Há diversos trabalhos de revisão focados na origem da endotermia, como recentemente os de Hillenius e Ruben (2004), Portner et al (2004) e de Grigg et al (2004), que enfatizam os vertebrados terrestres. Em insetos, destaca-se o trabalho de Heinrich (1974). Muitos insetos são primariamente ou exclusivamente poiquilotérmicos; outros são ectotérmos periódicos e/ou endotermos periódicos, sendo classificados como heterotermos. Alguns insetos endotérmicos regulam a sua temperatura corpórea, e todos os insetos endotérmicos são heterotérmicos (BARTHOLOMEW, 1981). A endotermia é cara em animais pequenos como os insetos, que se aquecem durante períodos de intensa atividade e podem se resfriar, mantendo a sua temperatura corpórea próxima à do ambiente (JOSEPHSON, 1981).

Em Insecta, a endotermia de origem muscular é largamente distribuída entre os grupos. A termogênese em insetos ocorre durante diversos tipos de atividade, como vôo, corrida, canto, aquecimento pré-vôo, atividades sociais e incubação da cria, entre outros (BLOCK, 1994). Bartholomew (1981) compara a endotermia entre diversos grupos de animais. Existe a hipótese de que a endotermia evoluiu repetidamente e independentemente em espécies pertencentes a várias ordens e famílias em Insecta e também provavelmente surgiu várias vezes em mamíferos e aves. A múltipla convergência de padrões fisiológicos comuns observada em tipos de animais tão diferentes seria uma evidência de que a heterotermia é fortemente favorecida pela seleção natural (BARTHOLOMEW, 1981).

\section{MECANISMOS DE REGULACÃO DE TEMPERATURA (TERMORREGULAC̃̃O)}

Um aspecto importante da socialidade nas abelhas é a manutenção da homeostase na colônia, com o controle de variáveis como a umidade relativa e temperatura colonial. Tal controle 
pode ser importante para a incubação da cria em condições controladas e para a sobrevivência de colônias no inverno, por exemplo. A termorregulação colonial pode ocorrer por mecanismos comportamentais (escolha do local de nidificação, em ocos de árvores, que propiciam bom isolamento; construção de invólucro e lamelas na região dos discos de cria, para isolamento e manutenção do microclima etc.) e por mecanismos fisiológicos (termogênese individual de abelhas que se colocam próximas a cria), alvos deste estudo.

A capacidade termorreguladora nas colônias de abelhas sem ferrão seria atribuída, em parte, às características estruturais do próprio ninho, como invólucro e batume, que garantem bom isolamento térmico (ZUCCHI e SAKAGAMI, 1972). Por outro lado, a termorregulação colonial pode se dar também devido à ocorrência de endotermia em Melipona spp (ROUBIK e PERALTA, 1983).

No Brasil, diversos autores (CASTRO, 2001; MARTINS et al, 2001; ANTONINI, 2002; OLIVEIRA, 2002; BATISTA, 2003, entre outros) enfocam uma preferência dos meliponíneos por nidificar em certas espécies de arvores, que provavelmente exibam boas condições para que essas abelhas termorregulem. Roubik (2002) enfatizou que a eliminação de locais de nidificação de abelhas sociais levou ao declínio da população de polinizadores de cafeeiros. Assim, a termorregulação tem efeito na distribuição geográfica das abelhas e, consequentemente, na polinização das plantas e sucesso das espécies vegetais.

\section{MECANISMOS FISIOLÓGICOS DE TERMORREGULACÃO}

A forma mais comum e imediata de geração de calor nos músculos é o tremor muscular, que envolve o funcionamento controlado de ATPases do sistema contrátil muscular. (HEINRICH, 1974, 1979). Como as contrações musculares são ineficientemente disparadas e mutuamente opostas, elas não produzem trabalho, mas a energia química liberada durante a contração muscular aparece como calor (RANDALL et al., 2000). As contrações tetânicas produzem considerável tensão e muito calor, tanto para um aquecimento pré-vôo como para termorregular (HEINRICH e ESCH, 1994). A termorregulação em insetos endotérmicos envolve o uso de sistemas neuromusculares e circulatórios pré-existentes adaptados primariamente para outras funções. A produção de calor durante o aquecimento pré-vôo seria uma variação do comportamento de vôo propriamente dito. Existem outras atividades também associadas com a termogênese, além do aquecimento pré vôo, como o canto em gafanhotos (HEATH e JOSEPHSON, 1970), e incubação da cria em abelhas (BARTHOLOMEW, 1981). O tremor muscular é comum em mamíferos, aves e em certos insetos (HEINRICH, 1974, 1979), sendo aparentemente uma resposta generalizada dos endotermos ao frio (HEINRICH, 1996). 
O aquecimento por tremor muscular é encontrado em insetos grandes, como libélulas (Odonata), mariposas e borboletas (Lepidoptera), certos gafanhotos (Ortophetera), cigarras (Homoptera), moscas (Diptera), besouros (Coleoptera), vespas e abelhas (Hymenoptera). Ou seja, o aquecimento é encontrado nas formas mais primitivas, como Odonata, e nas mais derivadas, como Diptera, Coleoptera, e Hymenoptera. A evolução dos tremores musculares é relacionada com a evolução do vôo, mas não com a localização do inseto na árvore filogenética (HEINRICH, 1996).

Além do tremor muscular, tem sido descrito em certas espécies de abelhas do gênero Bombus (mamangavas) a ocorrência de termogênese por ciclos fúteis envolvendo hidrólise de ATP via funcionamento simultâneo de fosfofrutoquinase (PFK, uma enzima importante da glicólise) e de frutose-1,6-bifosfatase (FBPase, envolvida na gliconeogênese) (HOCHACKA e SOMERO, 1984). Este esquema foi desenvolvido por Newsholme et al (1972), e depois estendido por Clark et al. (1973). Um sinal regulatório neste sistema seria o $\mathrm{Ca}^{2+}$ (HOCHACKA e SOMERO, 1984). Heinrich (1993) discute as características e inconsistências do modelo, como as poucas espécies nas quais ocorre. Este tipo de ciclo fútil poderia ser útil para suplementar a termogênese ou amplificar o fluxo glicolítico (STAPLES et al, 2004). Todavia, estudos com abelhas sem ferrão Melipona bicolor (FRANÇOSO-JÚNIOR, 1999) e com espécies de Bombus norte-americanas (STAPLES et al, 2004) detectaram baixa atividade de FBPase, provavelmente não ocorrendo ciclos fúteis envolvendo FBPase nessas abelhas.

Diversos mecanismos de termogênese têm sido descritos para as células musculares dos endotermos, envolvendo alterações nas concentrações de $\mathrm{Ca}^{2+}$ citoplasmático, produção/quebra de ATP e ativação, por potenciais de ação de nervos motores e/ou por vias de segundos mensageiros ativadas por receptores específicos (BLOCH, 1994). Tais mecanismos poderiam ocorrer nas células musculares de insetos, que também são endotermos, mas não há detalhamentos na literatura sobre esse assunto.

As proteínas desacopladoras (UCPs) pertencem a uma larga família de proteínas transportadoras mitocondriais, que parecem ter surgido de um gene comum codificado por um transportador ancestral (FLEURY et al, 1997; ARGYOPOULOS e HARPER, 2002). Os homólogos de UCPs, desde mamíferos e aves, até insetos, peixes e plantas, poderiam desempenhar papéis importantes no metabolismo mitocondrial e/ou papéis na termogênese (ARGYOPOULOS e HARPER, 2002). Nos vertebrados endotermos tem sido descritos mecanismos de termogênese envolvendo proteínas desacopladoras (UCPs), que, em vertebrados, envolvem lipólise, liberação de ácidos graxos e sinalizações com $\mathrm{Ca}^{2+}$. É possível que catecolaminas estejam envolvidas nesses ciclos fúteis de $\mathrm{Ca}^{2+}$ mediados por ácidos graxos, em mamíferos (BLOCK, 1994). Os insetos possuem proteínas desacopladoras, com atividade desacopladora aumentada por ácidos graxos e inibida pelo nucleotídeo purina GDP, compartilhando com as outras UCPs os mecanismos 
reguladores de UCP conhecidos até o momento (FRIDELL et al, 2004), mas funções termogênicas das UCPs nos insetos ainda não estão esclarecidas.

A fim de contextualizar os estudos sobre metabolismo energético e termorregulação em $M$ quadrifasciata, com as abordagens colonial e individual, a seguir há detalhamento de características coloniais estruturais, comportamentais e fisiológicas das abelhas sem ferrão.

\section{HOMEOSTASE COLONIAL}

A homeostasia dentro do ninho é uma das grandes vantagens e desafios dos insetos com organização social (WINSTON, 2003). De acordo com Michener (1974), um dos principais atributos do comportamento eussocial é conferir à colônia a habilidade de controlar as condições de vida no interior do ninho. A homeostasia social envolve virtualmente todas as funções da colônia, incluindo suprimento de alimento, defesa da colônia contra inimigos naturais, bem como controle das condições físicas dentro do ninho. Um aspecto muito importante da homeostasia é a termorregulação colonial (SEELEY e HEINRICH, 1981; HEINRICH, 1985, 1996; WINSTON, 2003). As colônias de abelhas regulam, também, outras condições ambientais, além da temperatura, tais como o nível de gás carbônico (LACHER, 1964; SEELEY, 1974) e umidade relativa (KLINGER et al, 2005).

Nos meliponíneos, os graus de controle de temperatura são variados. Alguns são bons termorreguladores, similarmente à A mellifera, enquanto outros são deficientes e muito dependentes do ambiente no qual habita ou das estruturas de ninho ou, ainda, de ambos (DARCHEN, 1973; MICHENER, 1974; PACHECO e KERR, 1989). Diante disso, não é indicado fazer generalizações dos padrões térmicos das colônias de uma espécie para a outra, uma vez que há uma grande variedade de comportamentos, arquiteturas de ninho, locais de ocorrência, entre outros.

Nas colônias de mandaçaias há duas regiões principais, a região dos potes de alimentos, contendo néctar e pólen, construídos de cerume (cera + resina), e a região dos discos de cria, contendo ovos, larvas e pupas. Essas duas regiões coloniais são consideradas nos estudos sobre termorregulação colonial do Capítulo 2. Para a conservação de calor nos discos de cria, a fim de beneficiar o seu desenvolvimento, alguns meliponíneos apresentam diversas lamelas de cerume, concêntricas e irregulares, em torno da região dos discos de cria, denominadas de invólucro (NOGUEIRA-NETO, 1997).

Nas colônias de Melipona, as abelhas forrageadoras procuram atender as necessidades da colônia, como alimento (pólen, néctar), água, matérias de construção (resinas, barro) e limpeza do ninho (eliminação de detritos como restos da colônia, abelhas mortas). Além das condições internas da colônia, fatores ambientais também podem influenciar a atividade das abelhas forrageadoras, determinando diferentes padrões de forrageamento (HILÁRIO et al 2000). Assim, em colônias 
mantidas abertas ao ambiente externo foram realizados estudos de atividade de vôo, concomitante a estudo de séries temporais de temperatura e umidade relativa.

A termorregulação colonial não havia sido relatada anteriormente para mandaçaia, mas sim para outras abelhas sem ferrão como, por exemplo, Trigona spinipes (ZUCCHI e SAKAGAMI, 1972), Melipona rufiventris, Melipona seminigra (ROUBIK e PERALTA, 1983), Tetragonisca angustula angustula, Tetragonisca angustula fiebrigi (PRONI e HEBLING, 1996), Melipona beecheii (MOO et al, 2000), Melipona bicolor (HILÁRIO e IMPERATRIZ-FONSECA, 2002), Frieseomellita varia (ALMEIDA, 2004). Os mecanismos ativos de termorregulação nos Meliponini independem de processos relacionados a aglomerados de indivíduos, como ocorrem com Apis (ZUCCHI e SAKAGAMI, 1972). Estudos de termorregulação em abelhas A mellifera incluem aqueles realizados por Free e Spencer-Booth (1958), Sumpter e Broomhead (2000), Bujok et al (2002), Kleinhenz et al (2003), Stabentheiner et al (2003). Ritmos de taxa metabólica colonial foram abordados por Kronenberg (1979) e Soutwich (1982).

Ritmos biológicos ocorrem em meliponíneos, principalmente no tocante à oviposição e construção de células de cria, as quais são produzidas e ovipositadas de modo rítmico em algumas espécies (SOMMEIJER e DE BRUIJN, 1984; BELLUSCI e MARQUES, 2001), além da atividade de vôo, que sofre influência de componentes rítmicos do comportamento de abelhas (HILÁRIO e IMPERATRIZ-FONSECA, 2002; HILÁRIO et al, 2003; ALMEIDA, 2004). Todavia, muito pouco se conhece sobre a possível ritmicidade no controle da temperatura e umidade relativa dentro da colônia de mandaçaia.

\section{ABORDAGEM COLONIAL}

Nesta tese a termorregulação em abelhas sem ferrão $M$ quadrifasciata é estudada sob os pontos de vista colonial e individual. As perguntas da abordagem colonial (Capítulo 2) incluem 1) quais as características das variações de temperatura e umidade relativa dentro das colônias de mandaçaia, e 2) quais os seus aspectos rítmicos. Foram estudadas séries temporais de temperatura e umidade relativa na região dos discos de cria e dos potes de alimento, em colônias mantidas abertas ou fechadas, e análises das séries temporais por meio de Análise Espectral e de Entropia Aproximada (ApEn). Como objetivos específicos, destacam-se descrever séries temporais de temperatura e umidade relativa, dentro e fora das colônias; relacionar a termorregulação colonial com a variação diária da atividade interna e externa, verificar se há ritmicidade na termorregulação em colônias mantidas em condições constantes e estudar os efeitos de bloqueadores octopaminérgicos no controle de temperatura e umidade relativa coloniais.

\section{ENERGÉTICA E TERMORREGULACÃO INDIVIDUAL}


A segunda parte da tese aborda aspectos do metabolismo energético de operárias individuais, englobando estudos de taxa metabólica $\left(\mathrm{VO}_{2}\right)$, quociente respiratório $(\mathrm{QR})$, atividade enzimática (Vmax) e temperatura torácica $(\mathrm{Tt})$ de indivíduos em diversas condições experimentais, justificadas e detalhadas adiante. Está-se interessado no cálculo de taxa metabólica de operárias, e então alguns aspectos metodológicos foram estudados em experimentos piloto do capítulo 3, a fim de determinar condições experimentais para experimentos posteriores, tais como condições de luminosidade e temperatura.

\section{CONDICÕES DE LUMINOSIDADE E TAXA METABÓLICA}

O estudo de componentes rítmicos de diversas variáveis, tais como a taxa metabólica, pode ser uma ferramenta importante para propiciar uma visão geral de como determinada variável se comporta ao longo do tempo. Conhecendo a variação diária e/ou sazonal de determinada variável em estudo, pode-se eleger com mais segurança quais serão os horários (“janelas temporais”) para a tomada de dados. Com isso, a coleta de dados pode ser mais confiável e menos tendenciosa.

Os ritmos endógenos podem ser sincronizados por fatores abióticos e bióticos. Os sincronizadores são ciclos ambientais mais comumente conhecidos como Zeitgebers (MARQUES et al., 1997; FOURCASSIÉ et al., 1999). Nas abelhas, alguns Zeitgebers conhecidos são: a interação social (SOUTHWICK e MORITZ, 1987; FRISCH e KOENIGER, 1994), a temperatura, a luz (MOORE e RANKIN, 1993; PRONI et al, 2002); a presença da rainha (MORITZ e SAKOFSKY, 1991); os ciclos de alimentação (MOORE et al., 1989). Contudo, o Zeitgeber mais importante para a atividade das abelhas é o ciclo claro-escuro (MOORE et al. 1989; MOORE, 2001), abordado no Capítulo 3.

Nesses experimentos, objetivou-se o estudo de ritmos diários de taxa metabólica de operárias forrageadoras e influências do fotoperíodo e escolha de condições experimentais relacionadas às condições de iluminação (ciclo claro-escuro) e fotoperíodo. No Capítulo 3 são discutidos os efeitos de diferentes fotoperíodos sobre a taxa metabólica de forrageadoras, abordando seus ritmos endógenos (em claro e escuro constante), exógenos (respostas a mudanças no ambiente, como no caso do fotoperíodo invertido), arrastamento por Zeitgebers e a plasticidade envolvida. Como objetivos específicos, estão verificar se diferentes ciclos claro/escuro interferem no ritmo de taxa metabólica das forrageadoras, se há variação diária da taxa metabólica de forrageadoras em fotoperíodo $12 \mathrm{~h}: 12 \mathrm{~h}$, em fotoperíodo invertido e em claro e escuro constante, verificar efeitos do tempo de confinamento sobre a taxa metabólica.

\section{TEMPERATURA E TAXA METABÓLICA}


Durante a vida, abelhas do gênero Apis podem ser submetidas a uma variedade de temperaturas ambientais, de quase $0^{\circ} \mathrm{C}$ até mais do que $40^{\circ} \mathrm{C}$ (HEINRICH, 1993). O mesmo pode ocorrer com as abelhas indígenas sem ferrão. A biologia termal das abelhas tem sido objeto de investigações há muitos anos (HEINRICH, 1993, 1996). Com relação aos meliponíneos, apesar das características básicas de sua biologia indicarem um bom controle da temperatura dos ninhos, ainda são raros os trabalhos relacionando temperatura e taxa metabólica (MACIEIRA e Proni, 2005).

Há uma série de estudos relatando o $\mathrm{Q}_{10}$ da taxa metabólica em insetos e nos invertebrados em geral, inclusive abelhas (STABENTHEINER et al, 2003). Na maioria dos insetos, a taxa metabólica apresenta valores de $\mathrm{Q}_{10}$ variando de 2,0 a 2,5 (NESPOLO et al, 2003), com valores extremos de 1,0 e 4,6 (FORLOW e MACMAHON, 1988; COOPER, 1993; CHOWN et al, 1997, NESPOLO et al, 2003). Resultados de $\mathrm{Q}_{10}$ ajudam a prever as localidades onde se esperaria encontrar abelhas como do gênero Melipona de acordo com as condições climáticas e fisionômicas prevalecentes, sendo que os dados de distribuição muitas vezes são relativamente escassos. Tais dados também podem ser aplicados quanto à manutenção de colméias aquecidas artificialmente em laboratórios: esse tipo de criadouro pode contribuir para um maior gasto energético ao invés de permitir uma economia através de uma redução da taxa metabólica em dias mais frios (FRANÇOSO-JÚNIOR, 1999).

Diversos estudos disponíveis na literatura abordam as influências da temperatura ambiente sobre a taxa metabólica de abelhas A mellifera, por exemplo, aqueles relatados por Cahill e Lustick (1976), Verma e Edwards (1971), Shueel e Dixon (1968), Crailsheim et al. (1999), Blatt e Roces (2001) e Stabentheiner et al (2003). Na literatura pode-se constatar que a maioria dos trabalhos indica que, de modo geral, o consumo de $\mathrm{O}_{2}$ aumenta com a elevação da temperatura ambiente. Para abelhas sem ferrão, padrões semelhantes também detectados por Macieira et al (2001) para operárias de Nannotrigona postica (de 5 a $40^{\circ} \mathrm{C}$ ) e por Macieira e Proni (2005), com operárias de Trigona spinipes (de 5 a $35^{\circ} \mathrm{C}$ ). Ao se considerar também a idade das operárias estudadas, Stabentheiner et al (2003) mostraram que a relação taxa metabólica e temperatura ambiente tende a ser invertida, ao se considerar abelhas jovens e forrageadoras com diferentes níveis de atividade locomotora dentro da câmara. Segundo os autores, abelhas forrageadoras tendem a apresentar maiores taxas metabólicas a $15^{\circ} \mathrm{C}$, as quais decrescem, atingindo os menores valores a $40^{\circ} \mathrm{C}$.

No Capítulo 3 também se aborda o metabolismo energético das abelhas sem ferrão no contexto térmico, utilizando como ferramentas os cálculos de taxa metabólica e quociente respiratório $(\mathrm{QR})$ de indivíduos mantidos em diferentes temperaturas. Como objetivos específicos, estão comparar os valores de taxa metabólica e QR de abelhas operárias forrageadoras (coletoras de néctar/água ou de pólen) de 10 a $40^{\circ} \mathrm{C}$ e verificar se há diferenças entre as coletoras de néctar/água e de pólen com relação a essas variáveis. 


\section{MODIFICACÕES EM VIAS OCTOPAMINÉRGICAS}

Nos endotermos, há um conjunto de substâncias envolvidas em diversas ações fisiológicas e comportamentos atuantes em quase todos os órgãos, que são as aminas biogênicas, sintetizadas a partir de três diferentes aminoácidos (BLENAU e BAUMANN, 2001). Em vertebrados, as principais aminas biogênicas identificadas são dopamina, norepinefrina, epinefrina, serotonina e histamina, sendo geralmente a norepinefrina a envolvida nas sinalizações ligadas à termogênese sem tremor. Em invertebrados, as aminas biogênicas são dopamina, tiramina, octopamina, serotonina e histamina. Uma vez que a octopamina e a norepinefrina são compostos muito similares, tem sido sugerido que o sistema adrenérgico/noradrenérgico dos vertebrados é funcionalmente substituído pelo sistema tiraminérgico/octopaminérgico em invertebrados (EVANS, 1985, 1993; ROEDER, 1999, BLENAU e BAUMANN, 2001; ROEDER, 2005).

As aminas biogênicas, em especial a octopamina, desempenham um amplo espectro de funções nos insetos, como neurotransmissores, neuromoduladores e neurohormônios (HOMBERG, 2002; ROEDER, 1999; 2005). Além disso, a octopamina pode ser utilizada como um sinal que predispõe os insetos ao aumento do exercício, da taxa metabólica e termogênese (BELZUNCES et al, 1996, CANDY et al, 1997), requeridos, por exemplo, para escapar e para o vôo, sendo uma situação semelhante à "luta ou fuga" descrita para vertebrados, sob a ação da norepinefrina (CANDY et al, 1997).

O hormônio juvenil (HJ) influencia diversos aspectos da maturação de abelhas adultas que são envolvidos na divisão de trabalho, incluindo secreções exócrinas nas abelhas, responsividade a estímulos olfativos, idade do início da atividade de vôo (revisto por BLOCH et al, 2002) e níveis de octopamina nos lobos antenais (SCHULZ et al., 2002). Condições externas e de dentro da colônia afetam os níveis de aminas biogênicas no sistema nervoso central de abelhas operárias. Esses níveis, por outro lado, podem ajustar o desempenho de tarefas de operárias individuais por modulação dos níveis de HJ (HARTFELDER, 2000). O HJ afeta o início do forrageamento de abelhas, pelo menos em parte, ao aumentar os níveis cerebrais de octopamina (SCHULZ et al, 2001). Uma hipótese é que a octopamina seja um neuromodulador natural da produção de HJ pelos corpora allata (CA), regulando seus canais iônicos (THOMPSON et al., 1990). O HJ influencia diversos aspectos da maturação de abelhas adultas que são envolvidos na divisão de trabalho, incluindo secreções exócrinas nas abelhas, responsividade a estímulos olfativos, idade do início da atividade de vôo (revisto por BLOCH et al., 2002) e níveis de octopamina nos lobos antenais (SCHULZ et al.., 2002). Contudo, esses trabalhos se referem às abelhas do gênero Apis, e Apini e Meliponini podem diferir quanto a esses aspectos. 
Em abelhas melíferas, Belzunces et al. (1996) investigaram os efeitos de compostos "adrenérgicos" na termorregulação de indivíduos mantidos a $22^{\circ} \mathrm{C}$ e com temperatura torácica monitorada por infravermelho, tratados com agonistas adrenérgicos epinefrina e efedrina e com agente beta-bloqueador alprenolol. Baixas doses de agonistas não têm efeito, mas altas doses causam hipotermia. Alprenolol também leva a uma hipotermia, dose dependente. Segundo esses autores, um mecanismo semelhante ao beta-adrenérgico de vertebrados parece estar envolvido na termorregulação de abelhas melíferas e particularmente na termogênese. A via "adrenérgica" pode estar envolvida diretamente na regulação central ou periférica da temperatura corpórea (BELZUNCES et al. 1996). Esse tipo de inibição da termogênese também ocorre em vertebrados. Por exemplo, o propanolol, um agente bloqueador beta-adrenérgico, drasticamente interferiu com as capacidades termorregulatórias de pintinhos de 5 dias de idade mantidos em ambiente frio $\left(10^{\circ} \mathrm{C}\right)$ (WEKSTEIN e ZOLMAN, 1968).

Agentes beta-bloqueadores em abelhas podem antagonizar os efeitos da octopamina, uma vez que os receptores de octopamina de insetos são considerados homólogos aos receptores adrenérgicos de vertebrados (BOUNIAS, 1986; ROEDER, 1995). A respeito dessas questões, redigimos um artigo de revisão (LOLI e BICUDO, 2005) que aborda os mecanismos regulatórios de termogênese em insetos voadores e aves, com enfoque comparativo dos mecanismos de produção de calor.

A octopamina poderia atuar nas células de insetos regulando os suplementos de energia necessários para a termogênese. O bloqueio de seus receptores, e possível diminuição de estímulos ao fluxo glicolítico e de mobilização de carboidratos, poderia ativar vias alternativas de catabolismo de substratos, envolvendo, por exemplo, a prolina, que é abundante nos corpos gordurosos de abelhas e que podem ser utilizadas durante o vôo, apesar de em proporção baixa quando comparada com a utilização de carboidratos (MICHEU et al, 2000). Os lipídios também poderiam ser candidatos, entretanto, têm sido observadas baixas atividades de hidroxiacil Coa desidrogenase (HOAD), uma enzima envolvida na oxidação de ácidos graxos, em abelhas (FRANÇOSOJÚNIOR, 1999; Suarez et al, 2005). No Capítulo 4 é abordada também a atividade de enzimas envolvidas em diversas vias, tais como hexoquinase, HOAD, trealase e glicogênio fosforilase.

As vias semelhantes às de norepinefrina (como octopamina) poderiam ser candidatas para o controle neural e metabólico da termorregulação em abelhas. A localização exata dos centros neurais e metabólicos termorregulatórios em abelhas não são conhecidos. A demonstração de vias neurais envolvidas na termorregulação necessita de mais pesquisas (BELZUNCES et al, 1996).

No capítulo 4 busca-se evidências de vias envolvendo octopamina nos processos relacionados à termogênese em abelhas $M$ quadrifasciata. É baseado nas várias funções do 
hormônio juvenil e da octopamina em insetos, no fato de que em insetos existem proteínas desacopladoras, e na possibilidade do envolvimento de via adrenégica (octopaminergica) na termogênese de abelhas, podendo existir outros mecanismos de termogênese sem tremor muscular, semelhantes em parte ao de vertebrados homeotermos (LOLI e BICUDO, 2005). Além disso, no Capítulo 4 também são abordados efeitos de bloqueadores octopaminérgicos (alprenolol e mianserina) nas séries temporais de temperatura e umidade relativa coloniais, como forma de integração da termorregulação colonial e individual.

\section{REFERÊNCIAS BIBLIOGRÁFICAS}

AIDAR, D.S. (1996) A mandaçaia: biologia de abelhas, manejo e multiplicação artificial de colônias de Melipona quadrifasciata Lep. (Hymenoptera, Apidae, Meliponinae). SERIE MONOGRAFIAS $\mathrm{N}^{\circ}$ 4. Sociedade Brasileira de Genética.

ALMEIDA, G.F. (2004) Estudo de componentes rítmicos detectados na colônia de Frieseomelitta varia (Hymenoptera: Apidae: Meliponinae). Dissertação de Mestrado, FFCLRP-USP.

ARGYOPOULOS, G.; HARPER, M. (2002) Invited review: uncoupling proteins and thermoregulation. J. Appl. Physiol. 92: 2187-98.

BARTHOLOMEW, G.A. (1981) A matter of size: an examination of endothermy in insects and terrestrial vertebrates. In: Insect thermoregulation (B. Heinrich, ed.) Wiley-Interscience Publication, USA.

BELLUSCI, S; MARQUES, M.D. (2001) Circadian activity rhythm of the foragers of a eusocial bee (Scaptotrigona affdepilis, Hymenoptera, Apidae, Meliponinae) outside the nest. Biological Rhythm Researc 32(2): 117-24.

BELLUSCI, S. (1998) Caracterização do ritmo de atividade / repouso em livre curso de Scaptotrigona aff. depilis (Moure, 1942) (Hymenoptera: Apidae: Meliponinae). Dissertação de Mestrado FFCLRPUSP.

BELLUSCI, S. (2003). Colônia de abelhas eussociais: modulação de ritmos com ênfase no processo de construção de células de cria e postura em duas espécies de abelhas sem ferrão, Frieseomellita doederleini e Frieseomellita varia (Hymenoptera, Apidae). Tese de Doutorado. FFCLRP, USPRP.

BELLUSCI, S. e MARQUES, M.D. (2001) Circadian activity rhythm of the foragers of a eusocial bee (Scaptotrigona aff depilis, Hymenoptera, Apidae, Meliponinae) outside the nest. Biological Rhythm Research 32(2): 117-24.

BELZUNCES, L.P.; VANDAME, R. And GU, X. (1996) Modulation of honeybee thermoregulation by adrenergic compounds. Neuroreport. 7(10):1601-4.

BLATT, J e ROCES, F. (2001) Haemolymph sugar levels in foraging honeybees (Apis mellifera): dependence on metabolic rate and in vivo measurement of maximal rates of trehalose synthesis. J Exp Biol 204: 2709-16.

BLENAU, W. and BAUMANN, A. (2001) Molecular and pharmacological properties of insect biogenic amines receptors: lessons from Drosophila melanogaster and Apis mellifera. Archives of Insect Biochemistry and Physiology 48: 13-38.

BLOCH, G.; SULLIVAN, J.P.; ROBINSON, G. (2002) Juvenile hormone and circadian locomotor activity in the honey bee Apis mellifera. J Insect Physiol 48(12): 1123-32.

BLOCK, B.A. (1994) Thermogenesis in muscle. Annu. Rev. Physiol. 56: 535-77.

BUJOK, B.; KLEINHEINZ, M.; FUCHS, S.; TAUTZ, J. (2002) Hot spots in bee hive. Naturwissenschaften 89: 299-301.

CAMARGO, J.M.F. (1989) Comentários sobre a sistemática de Meliponinae (Hymenoptera, Apidae). In: An. XIV Simp. Anual da ACIESF 68 supl: 41-61.

CANDY, D.J.; BECKER, A.; WEGENER, G. (1997). Coordination and integration of metabolism in insect flight. Comp Biochem Physiol 117B(4): 497-512. 
DARCHEN, R. 1973. La thermoregulation et 1' ecologie de quelques especies d'abeilles sociales d'Afrique (Apidae, Trigonini et Apis mellifica Var. Adansonii). Apidologie, 4:341-370.

FARINA, W.M.; WAINSENLBOIM, A J. (2001) Changes in thoracic temperature of honeybees while receiving nectar from foragers collecting at different reward rates. J Exp Biol 204: 1653-8.

FRANÇOSO-JR, O A. (1999) Estudo comparativo do metabolismo aeróbico de Melipona bicolor Lepeletier (Hymenoptera: Apidae: Meliponinae). Tese de Doutorado, Instituto de Biociências da USP.

FRIDELL, Y.C.; SANCHES-BLANCO, A.; SILVIA, B.A.; HELFAND, S.L. (2004) Functional characterization of a Drosophila mitochondrial uncoupling protein. J Bioenergetics and Biomembranes 36(3):219-28.

HEINRICH, B. (1980) Mechanims of body temperature regulation in honeybees, Apis mellifera. J Exp Biol 85: 61-87.

HEINRICH, B. (1993) The Hot-Blooded Insects. Cambridge, MA. Harvard University Press.

HEINRICH, B. (1979) Keeping a cool head: honeybee thermoregulation. Science 205: 1269-71.

HEINRICH, B. (1993) The Hot-Blooded Insects. Cambridge, MA. Harvard University Press.

HEINRICH, B. (1996) The thermal warriors: strategies of insect survival. Cambridge, Mass. Harvard University Press.

HEINRICH, S.D. e RAVEN, P.H. (1972) Energetics and pollination ecology. Science 176(4035): 597-602.

HICKMAN , C. (2004) Princípios integrados de zoologia. Rio de Janeiro : Guanabara Koogan.

HILÁRIO, S.D.; IMPERARIZ-FONSECA, V.L. (2002) Thermorregulation of Melipona bicolor bicolor under special conditions. Encontro sobre Abelhas, Ribeirão Preto.

HILÁRIO, S.D.; IMPERATRIZ-FONSECA, V.L.; KLEINERT, A M.P. (2001) Responses to climatic factors by foragers of Plebeia pugnax Moure (IN LITT) (Apidae: Meliponinae). Rev Brasil Biol 61(2):191-6.

HILÁRIO, S.D; IMPERATRIZ-FONSECA, V.L.; KLEINERT, A (2000) Flight activity and colony strenght in the stingless bee Melipona bicolor bicolor (Apidae: Meliponinae). Rev Bras Biol 60(2): 299306.

HILÁRIO, S.D.; IMPERATRIZ-FONSECA, V.L.; KLEINERT, A M.P. (2001) Responses to climatic factors by foragers of Plebeia pugnax Moure (Apidae: Meliponinae). Rev Brasil Biol 61(2):191-6.

HILÁRIO, S.D. e IMPERARIZ-FONSECA, V.L. (2002) Thermorregulation of Meliponabicolor bicolor under special conditions. Proceedings of the V Encontro sobre Abelhas, Ribeirão Preto.

HILÁRIO, S.D. \& IMPERARIZ-FONSECA, V.L. (2002) Thermorregulation of Melipona bicolor bicolor under special conditions. Proceedings of the V Encontro sobre Abelhas, Ribeirão Preto.

HILÁRIO, S.D. \& IMPERATRIZ-FONSECA, V.L. (2003) Thermal evidence of the invasion of a stingless bee nest by a mammal. Braz J Biol 63(3): 457-62.

HILÁRIO, S.D. (2005) Atividade de vôo e termorregulação de Plebeia remota (Holmberg, 1903) (Hymenoptera, Apidae, Meliponini). Tese de Doutorado, Instituto de Biociências da USP; 124p

HOCHACHKA, P.; SOMERO, G.N. (1984) Biochemical adaptation. Princeton University Press.

HOCHACHKA, P.; SOMERO, G.N. (2002) Biochemical adaptation - mechanisms and process in physiological evolution. Oxford University Press.

HÖLLDOBLER, B..; WILSON, E (1990) The ants. Cambridge, Belknap/Harvard University Press

HOMBERG, U. (2002) Neurotransmitters and neuropeptides in the brain of the locust. Microscopy Res and Tech 56: 189-209.

Kevan, P.G.; Phillips, T.D. (2001) The economic impacts of pollinator declines: an approach to assessing the consequences. Conserv Ecol 5(1): 8.

KERR, W. E.; SANTOS NETO, G.R . (1956) Contribuição para o conhecimento da bionomia dos Meliponini. V. Divisão de trabalho entre as operárias de Melipona quadrifasciata quadrifasciata Lep.. Insectes Sociaux 3: 423-430.

KERR, W.E.; CUNHA, R. ; PISANI, J.F. (1978) Genética de determinação de sexo. Aplicação de métodos numéricos para agrupar sexos e castas de Melipona quadrifasciata anthidioides Lep. (Apidae). Revista Brasileira de Biologia, Rio de Janeiro, 38: 319-394.

KERR, W.E.; CARVALHO, G.A; NASCIMENTO, V.A (1996) Abelha uruçu: biologia, manejo e conservação. Belo Horizonte, Ed. Fundação Acangaú, XII+143p.

KLEINHENZ, M.; BUJOK, B.; FUCHS, S.; TAUTZ, J. (2003) Hot bees in empty broodnest cells: heating from within. J Exp Biol 206: 4217-31. 
KLINGNER, R.; RICHTER, K.; SCHMOLZ, E.; KELLER, B (2005) The role of moisture in the nest thermoregulation of social wasps. Naturwissenschaften 92: 427-30.

LOLI, D. e BICUDO, J.E.P.W. (2005) Control and regulatory mechanisms associated with thermogenesis in flying insects and birds. Bioscience Reports 25 (3/4): 149-80.

MARQUES, M. D.; GOLOMBEK, D.; MORENO, C. Adaptação Temporal. In: Marques, N. \& MennaBarreto, L. 1997) Cronobiologia: princípios e aplicações. EDUSP, São Paulo.

MICHENER, C.D. (1974) The social behavior of the bees. Cambridgs, Massachusts: The Belknap Press of Harvard University Press.

MICHENER, C.D. (2000) The bees of the world. Baltimore and London, The John Hopkins University Press. 913p.

MICHEU, S.; CRAILSHEIM, K.; LEONHARD, B. (2000) Importance of proline and other amino acids during honeybee flight. Amino Acids 18: 157-75.

MOORE, D.; SIEGFRIED, D.; WILSON, R.; RANKIN, M (1989) The influence of time of day on the foraging behavior of the honeybee Apis mellifera. J Biol Rhythm 4: 305-25.

MOORE, D.; RANKIN, M (1993) Light and temperature entrainment of a locomotor rhythm in honeybees. Physiol Entomol 18: 271-8.

MOORE, D. (2001) Honey bee circadian clocks: behavioral control from individual workers to wholecolony rhythms. J Insect Physiol 47: 843-57.

NOGUEIRA-NETO, P. (1948) Notas bionômicas sobre meliponíneos. Rev Bras Biol 8: 465-88.

NOGUEIRA-NETO, P. (1997) Vida e criação de abelhas indígenas sem ferrão. São Paulo, Nogueirapis.

PACHECO, R.L.F.; KERR, W.E. (1989) Temperaturas em abelhas da espécie Melipona compressipes fasciculata. Ciên. E Cult 41(5): 490-5.

PRONI, E.; HEBLING, M.J. (1996) Thermoregulation and respiratory metabolism in two Brazilian stingless bee subspecies of different climatic distribution, Tetragonica angustula fiebrigi and $T A$ angustula (Hymenoptera: Apidae: Meliponinae). Entomologia Generalis 20(4): 281-9.

PRONI, E. A (1995) Fisiologia e capacidade de termorregulação em ninhos de Tetragonisca angustula e Plebeia juliani. Tese de Doutorado, UNESP, Rio Claro.

PRONI, E.A. MACIEIRA, OJD.; Franchi, M.N. Morais, A.; Tristão, F.S. (2001) V Congresso Brasileiro de Ecologia, Brasil.

RANDALL, D.; BURGGREN, W. and FRENCH, K. (2000) Eckert - Fisiologia animal: princípios e aplicações. Guanabara Koogan S.A

ROEDER, T. (1995). Pharmacology of the octopamine receptor from locust central nervous tissue (OAR3). Br J Pharmacol. 114(1):210-6.

ROEDER, T. (1999) Octopamine in invertebrates. Prog. Neurobiol. 59: 533-61.

ROEDER, T. (2005) Tyramine and octopamine: ruling behavior and metabolism. Annu Rev Entomol 50: 447-77.

ROUBIK, D.W. (1989) Ecology and natural history of tropical honeybees. Cambridge Univ. Press, New York.

ROUBIK, D.W. \& BUCHMANN, S.L. (1984) Nectar selection by Melipona and Apis mellifera (Hymenoptera: Apidae) and the ecology of nectar intake by bee colonies in a tropical forrest. Oecologia (Berlin) 61: 1-10.

ROUBIK, D.W.; PERALTA, F.J.A. (1983) Thermodinamics in nests of two Melipona species in Brazil. Acta Amaz 13(2): 453-66.

RUPPERT, E.; BARNES, R (2005) Zoologia dos invertebrados : uma abordagem funcional-evolutiva. São Paulo : Roca, 2005.

SCHULZ, D.J.; SULlIVAN, J.P.; ROBINSON, G. (2002) Juvenile hormone and octopamine in the regulation of division of labor in honeybees colonies. Horm Behav 42(2): 222-31.

SILVEIRA, F (2002) Abelhas brasileiras : sistemática e identificação. Belo Horizonte.

SOMMEIJER, M. J.; VAN ZEIJL, M.; DOHMEN, M. R. (1984). Morphological differences between worker-laid eggs from a queenright colony and queenless colony of Melipona rufiventris paraensis (Hymenoptera: Apidae). Entomologische Berichichten 44(1):91-95

STAPLES, J.F.; KOEN, E.L. ;LAVERTY, T.M. (2004) 'Futile cycle' enzymes in the flight muscles of North American bumblebees. J. Exp. Biol. 207(Pt 5): 749-54.

SUMPTER, D.J.T.; BROOMHEAD, D.S. (2000) Shape and dynamics of thermoregulating honey bee clusters. J Theor Biol 201: 1-14. 
STABENTHEINER, A; PRESSL, H.; PAPST, T.; HRASSNIGG, N.; CRAILSHEIM, K. (2003) Endothermic heat production in honeybee winter clusters. J Exp Biol 206: 353-8

SUAREZ, R.K.; et al (2005) Energy metabolism in orchid bees flight muscles: carbohydrate fuels all. J Exp Biol 208: 3573-9.

SUAREZ, R.K.; DARVEAU, CA; HOCHACHKA, P.W. (2005). Roles of hierarchical and metabolic regulation in the allometric scaling of metabolism in Panamanian orchid bees.. J EXP BIOL. 208(PT 18):3603-7.

THOMPSON, C.S.; YAGI, K.J.; CHEN, Z.F. and TOBE, S.S. (1990) The effects of octopamine on juvenile hormone biosynthesis, electrophysiology, and cAMP content of the corpora allata of the cockroach Diploptera punctata. J. Comp. Physiol. B. 160(3): 241-9

WILSON, E.O. (1971) The Insect Societes. Harvard University Press, Cambridge.

WILSON, E.O. (1975) Sociobiology. Cambridge: Belknap Press of Harvard Univesity Press. 697 p.

WILSON, E.; HÖLLDOBLER, B (2005) Eusociality: origin and consequences. PNAS USA 102(38): 13367-71

ZAR, J.H. (1999) Biostatistical analysis. Upper Saddle River, N.J : Prentice Hall

ZUCCHI, R.; SAKAGAMI, S.F. (1972) Capacidade termo-reguladora em Trigona spinipes e em algumas outras espécies de abelhas sem ferrão (Hymenoptera: Apidae: Meliponinae), p. 301-309. In: C. Cruz-Landim; N.J. Hebling,; E. Lello \& C.S. Takahashi (Eds). Livro em Homenagem a Warwik Estevan Kerr. Rio Claro, Ed. UNESP.

ZUCCHI, R.; SILVA-MATOS, E. V. D NOGUEIRA-FERREIRA, F. H.; AZEVEDO, G. G. (1999). On the cell provisioning and oviposition process (POP) of the stingless bees nomenclature reappraisal and evolutionary considerations (Hymenoptera, Apidae, Meliponinae). Sociobiology 34(1):6586 


\section{Capítulo 2}

\section{Termorregulação colonial em Melipona quadrifasciata e seus aspectos rítmicos}

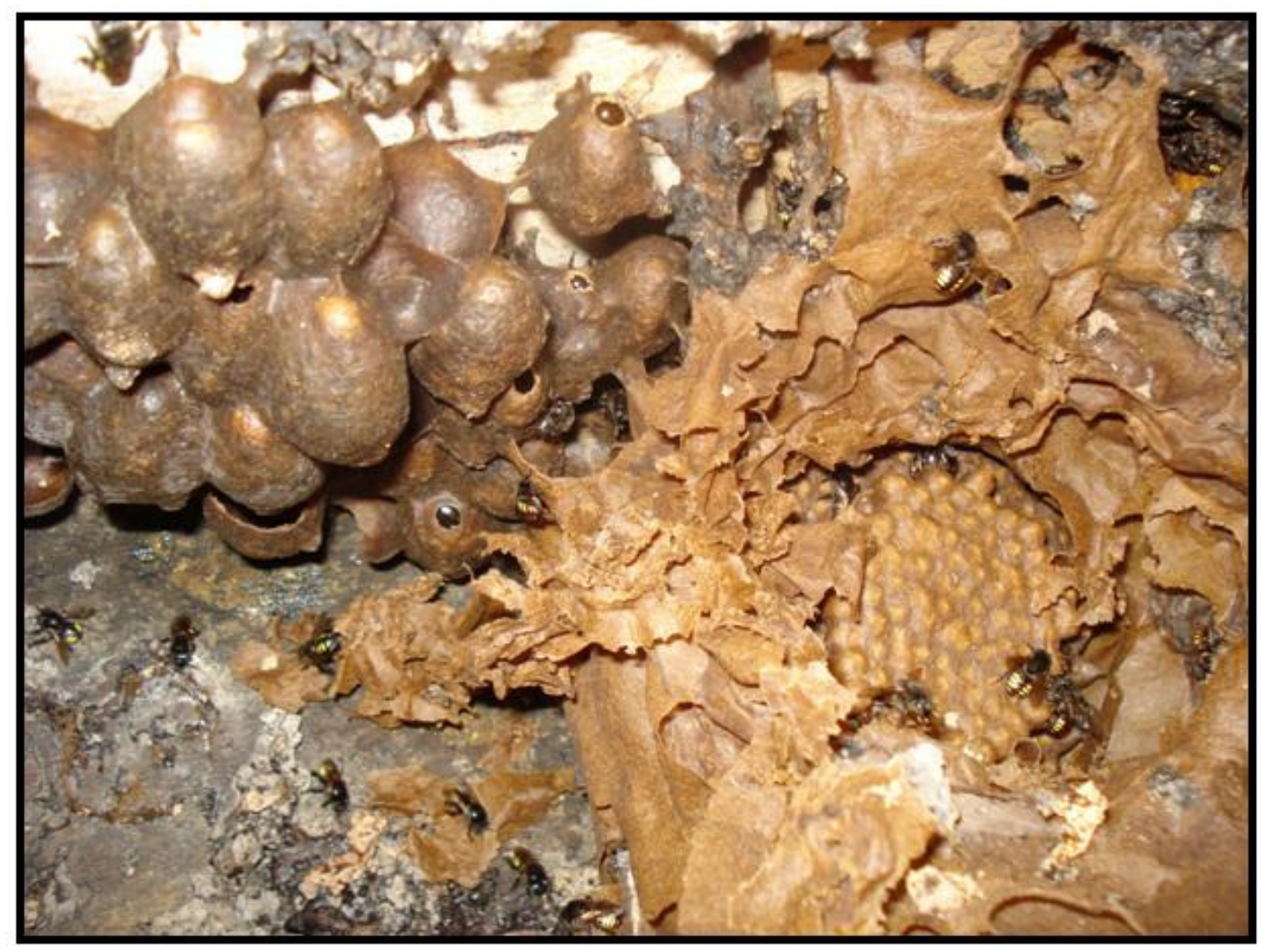




\section{Capítulo 2. Termorregulação colonial em Melipona quadrifasciata e seus aspectos rítmicos}

\section{$\underline{\text { RESUMO }}$}

Em abelhas eussociais o controle das condições internas coloniais é importante para a incubação da cria e sobrevivência da colônia. Um dos mecanismos para controle da temperatura colonial é a escolha do local de nidificação. As abelhas sem ferrão Melipona quadrifasciata constroem seus ninhos em ocos de troncos de árvores, que proporcionam um ambiente propício ao controle de temperatura. As abelhas obtêm recursos alimentares por meio da atividade de vôo, que é influenciada tanto por condições internas da colônia como pelas condições ambientais. Neste capítulo objetivou-se estudar a termorregulação colonial dentro de ninhos de M. quadrifasciata na região dos discos de cria e dos potes de alimento, por meio de registro de atividade interna colonial, atividade externa de vôo e séries temporais de temperatura e umidade relativa (com carregadores de dados). Além disso, verificaram-se influências de bloqueadores octopaminérgicos (Alprenolol e Mianserina) nesses processos. As colônias estudadas eram mantidas abertas ao ambiente externo ou fechadas dentro de câmara climática em condições de temperatura e escuro constantes. O interesse aqui foi verificar se há ritmicidade no controle de temperatura e umidade relativa, e quais as influências de fatores ambientais. Foi detectada ritmicidade nas séries temporais de colônias abertas, com influência das periodicidades da temperatura ambiente, umidade relativa do ambiente e luminosidade, sobre as séries temporais registradas dentro da colônia. As séries temporais de atividade de vôo apresentavam periodicidades similares às ambientais, mas também eram relacionadas às da região dos discos de cria. Em colônias fechadas, as séries temporais na região dos discos de cria apresentaram periodicidades próximas a $24 \mathrm{~h}$ e $12 \mathrm{~h}$, mesmo em temperatura e escuro constantes, sugerindo aspecto endógeno da regulação de temperatura e umidade próximo à cria. Colônias tratadas com bloqueadores octopaminérgicos parecem apresentar periodicidades mais similares à da umidade relativa do ambiente e menos à da temperatura ambiente, sugerindo menor resposta às variações de temperatura. Conclui-se que há controle de temperatura e umidade dentro de ninhos de $M$. quadrifasciata, com variação diária, relacionada, em colônias abertas, a ciclos ambientais como a temperatura, umidade relativa e luminosidade, podendo também haver ritmos endógenos em colônias fechadas.

\section{INTRODUCÃO}

Um dos principais atributos do comportamento eussocial, de acordo com Michener (1974), é conferir à colônia a habilidade de controlar as condições no interior do ninho. Em colônias de 
insetos sociais, a homeostasia da colônia é uma das grandes vantagens e desafios dos insetos com organização social, sendo a manutenção da temperatura do ninho e de outras condições ambientais a níveis relativamente constantes e regulados (WINSTON, 2003). Um aspecto muito importante da homeostasia da colônia é a termorregulação colonial (SEELEY e HEINRICH, 1981; HEINRICH, 1985, 1996; WINSTON, 2003), que abrange uma interação complexa de mecanismos de construção e comportamentais que influenciam a termodinâmica do ninho (HEINRICH, 1993; KLINGNER et al., 2005).

O primeiro mecanismo para controlar a temperatura na colônia reside na escolha do local de nidificação, que em abelhas sem ferrão oferecem possibilidades de manutenção de temperatura estável para a cria em desenvolvimento. As abelhas Melipona quadrifasciata constroem seus ninhos em ocos de troncos de árvores, em altura mediana. A entrada do ninho é construída por geoprópolis (uma mistura de barro com resinas extraídas de plantas) e a partir do orifício de entrada, encontra-se um canal que desemboca próximo aos discos de cria, os quais são envolvidos por lamelas de cerume chamadas de invólucro. Esta estrutura é constituída de uma mistura de cera e própolis e uma de suas finalidades é conservar a temperatura na região onde se encontra a cria (NOGUEIRA-NETO, 1997).

A capacidade de termorregulação nas colônias de abelhas sem ferrão pode ser atribuída, em parte, às características estruturais do próprio ninho, como invólucro e batume, que garantem bom isolamento térmico (ZUCCHI e SAKAGAMI, 1972). Nas abelhas sem ferrão os graus de controle de temperatura dentro dos ninhos são variados. Alguns são bons termorreguladores, similarmente à Apis mellifera, enquanto outros são muito dependentes do ambiente no qual habitam e/ou das estruturas do ninho (DARCHEN, 1973; MICHENER, 1974; PACHECO e KERR, 1989). As temperaturas nos discos de cria de abelhas sem ferrão são geralmente maiores e estáveis em relação à temperatura ambiente (ZUCCHI \& SAKAGAMI, 1972; MICHENER, 1974; ROUBIK e PERALTA, 1983; AMANO et al., 2000; MOO-VALLE, 2000).

Embora não se conheça em detalhes de onde vem o aquecimento (MICHENER, 1974), acredita-se que este seja produzido nos músculos torácicos de vôo das abelhas, similarmente a Apis mellifera (ENGELS et al., 1995), ocorrendo endotermia em Melipona spp (ROUBIK e PERALTA, 1983). As colônias de abelhas regulam, também, outras condições ambientais, além da temperatura, tais como o nível de gás carbônico (LACHER, 1964; CHAUVIN, 1968; SEELEY, 1974) e umidade relativa (KLINGER et al, 2005).

Tem sido relatado na literatura a ritmicidade na termorregulação colonial de diversas abelhas sem ferrão, principalmente na região onde se encontra a cria, ressaltando a importância do controle de temperatura nesta região da colônia. Por exemplo, Moo et al (2000) em Melipona beecheii, Hilario e 
Imperatriz-Fonseca (2002) em Melipona bicolor, Almeida (2004) em Frieseomelitta varia, Proni e Hebling (1996) em Tetragonisca angustula fiebrigi e Tetragonisca angustula angustula.

A manutenção e controle da temperatura dentro da colônia, próximo à área dos discos de cria, é importante para o sucesso do desenvolvimento da cria, e também para a sobrevivência de abelhas jovens e de larvas (PETZ et al, 2004), que são provavelmente "ectotérmicas", com taxa metabólica dependente da temperatura ambiente. Além disso, Jones et al (2005) demonstraram que temperaturas anormais de incubação da cria, em colônias de abelhas A mellifera, podem afetar as habilidades de aprendizagem e memória de curta duração de operárias quando adultas, provavelmente devido a deficiências neurais afetando os centros de memória de curta duração, ressaltando a importância da termorregulação colonial.

Dentro de colônias de abelhas sociais, como M. quadrifasciata, pode haver controle de temperatura e umidade relativa, sendo possível obtenção de séries temporais dessas variáveis. A idéia básica de uma série temporal é de um conjunto de observações ordenadas no tempo, feitas em diferentes instantes, e sujeitas a variações aleatórias (PEREIRA et al, 1986; MORETTIN e TOLOI, 2006).

Muitas vezes, uma série temporal discreta é obtida através da amostragem de uma série temporal contínua em intervalos de tempo iguais, $\Delta \mathrm{t}$ (MORETIN e TOLOI, 2006). As observações vizinhas são, em geral, dependentes e o estudo de uma série temporal consiste, então, em analisar e modelar esta dependência (PEREIRA et al, 1986). O que é chamado de série temporal é na realidade parte de uma trajetória, dentre muitas que poderiam ter sido observadas. Em algumas situações, quando se tem dados experimentais, é possível observar algumas trajetórias do processo sob consideração (MORETIN e TOLOI, 2006).

A atividade de vôo em abelhas sem ferrão tem sido pesquisada e descrita para vários gêneros, como Partamona (AZEVEDO, 1997), Melipona (GUIBU e IMPERATRIZ-FONSECA, 1984; HILÁRIO et al, 2000), Trigona (HEARD e HENDRIKZ, 1993), Tetragonisca (IWANA, 1977; IMPERATRIZ-FONSECA e AGUILAR, 1984), Plebeia (OLIVEIRA, 1973; KLEINERTGIOVANNINI, 1982; IMPERATRIZ-FONSECA et al, 1985; HILÁRIO et al, 2001), entre outros.

A atividade de vôo das abelhas é influenciada tanto por condições internas da colônia como pelas condições ambientais (HILÁRIO et al, 2000). A temperatura, a umidade relativa, a intensidade luminosa, a chuva e a velocidade do vento, são fatores que podem influenciar a atividade de vôo dessas abelhas (IWANA, 1977; GUIBU e IMPERATRIZ-FONSECA, 1984; IMPERATRIZ-FONSECA et al, 1985; HEARD \& HENDRIKZ, 1993). Tais fatores climáticos podem modificar, modular ou mesmo suprimir a atividade das abelhas. Além destes, é preciso considerar fatores bióticos, como a influência do tamanho da própria colônia (BELLUSCI, 1998), disponibilidade e características das fontes de alimento, e a eficaz comunicação entre os indivíduos 
promovida principalmente por feromônios (ENGELS et al., 1997). O conhecimento das condições ótimas para a atividade de vôo das abelhas, e os seus limites, é importante, por exemplo, para permitir o uso dessas espécies em projetos de polinização (CORBET et al, 1993).

As perguntas principais contidas neste capítulo são se há controle de temperatura dentro de ninhos de Melipona quadrifasciata, se há variação diária e como fatores ambientais influenciam a termorregulação colonial.

\section{OBJETIVO GERAL}

Estudar variações de temperatura dentro de ninhos de Melipona quadrifasciata

\section{OBJETIVOS ESPECÍFICOS:}

- Descrever séries temporais de temperatura e umidade relativa, dentro e fora das colônias;

- Relacionar a termorregulação colonial com a variação diária da atividade interna (dentro da colônia) e externa (atividade de vôo);

- Verificar se há ritmicidade na termorregulação em colônias mantidas em condições constantes;

- Estudar os efeitos de bloqueadores octopaminérgicos (Alprenolol e Mianserina) no controle de temperatura e umidade relativa coloniais.

\section{MATERIAIS E MÉTODOS}

\section{SISTEMA BIOLÓGICO}

O sistema biológico utilizado foi constituído por colônias de Melipona quadrifasciata anthidioides (daqui em diante denominada M. quadrifasciata) provenientes de São Gonçalo, RJ.

Foram utilizadas sete colônias mantidas em caixas-ninho de observação (medidas internas aproximadas: comprimento $30 \mathrm{~cm}$, largura $21 \mathrm{~cm}$, altura $14 \mathrm{~cm}$ ) construídas em madeira com espessura mínima de $2,5 \mathrm{~cm}$. As caixas eram tampadas por placas de vidro ou acrílico transparente, cobertas com isopor e tampa de madeira ou tecido escuro (figura 1A).

Os ninhos foram mantidos à temperatura ambiente nas dependências do Departamento de Fisiologia do Instituto de Biociências da Universidade de São Paulo (IBUSP), São Paulo (Latitude: $23^{\circ} 33^{\prime}$ S0.92"S, Longitude: $46^{\circ} 43^{\prime} 49.27^{\prime \prime}$ ) onde podiam forragear nos jardins do IBUSP. As caixas eram mantidas abertas, isto é, conectadas ao ambiente externo, por meio de tubo plástico que atravessava a janela do laboratório (figura 1B). Em algumas situações, colônias foram mantidas na residência da aluna, no bairro Butantã, próximo ao campus da USP, em local aberto (Latitude: 23o34'47.26"S Longitude: 46o45'33.03" O), devido à reforma do Edifício Ernesto Markus, onde está localizado o Departamento de Fisiologia do IBUSP. 
Periodicamente as colônias recebiam alimentação artificial, constituída de pólen e/ou solução de sacarose $50 \%$ fervida e colocada, após esfriar, embebida em algodão, dentro de pote plástico (NOGUEIRA-NETO, 1997), ou em bebedouros, na região dos potes de alimento dentro da colônia (figura 2). A alimentação artificial era fornecida exceto durante o período dos experimentos de termorregulação colonial e atividade externa (PIERROT e SCHLINDWEIN, 2003).

\section{AVALIACÃO DAS CARACTERÍSTICAS DAS COLÔNIAS}

Colônias de diferentes características foram avaliadas e comparadas quanto à termorregulação colonial, análise espectral, entropia aproximada, atividade externa e interna, descritos adiante. As colônias podiam ser classificadas como "fortes" ou "fracas" baseado em alguns critérios, tais como:

- Número de indivíduos no ninho, verificado por inspeção visual, ressaltando-se extremos (colônias com poucos ou com muitos indivíduos);

- Diâmetro dos discos de cria (KLEINERT-GIOVANINNI, 1989; HILÁRIO et al, 2000);

- Quantidade de cria;

- Quantidade de movimentação de abelhas;

- Quantidade e qualidade dos potes de alimento;

- Agressividade (colônias "fortes" tendem a ser agressivas).

\section{COLÔNIAS ABERTAS}

Nas colônias abertas, isto é, com livre acesso ao ambiente externo, foi estudada a termorregulação colonial por meio de séries temporais de temperatura dentro e fora da colônia. Além disso, em alguns casos, foram registradas séries temporais de umidade relativa ambiental e colonial, além da luminosidade externa. E em algumas colônias o registro de séries temporais foi concomitante a estudos de atividade interna e externa, detalhados adiante.

As variações de temperatura e umidade relativa foram estudadas em duas regiões da colônia, a região dos potes de alimento (com estoques de mel e pólen) e a região dos discos de cria (contendo células com ovos, larvas e pupas) (figura 3), além do ambiente externo.

\section{REGISTRO DE SÉRIES TEMPORAIS}

As séries temporais de temperatura, umidade relativa e luminosidade foram obtidas por meio de carregadores de dados HOBO e StowAway (Onset Computer Corporation, Estados Unidos da América), que apresentam a vantagem de serem programáveis e evitarem perturbações à colônia durante a coleta de dados. Os sensores dos carregadores de dados podem estar no próprio aparelho 
ou, no caso dos de temperatura, na extremidade de um termopar, útil para um ajuste mais fino de qual região da colônia se quer obter as séries temporais. Os carregadores foram programados para coleta de dados durante vários dias consecutivos, a cada 5, 15 ou 30 minutos, segundo coleta de dados preliminares.

Na maior parte dos experimentos, foram colocados dois ou três sensores em cada região do ninho (entre os discos de cria e ao lado dos potes de alimento), para ser possível calcular a média dos dados no mínimo em duplicata.

Carregadores de dados com sensores de umidade foram colocados no ambiente externo à colônia e dentro desta, próximo aos potes de alimento e sobre os discos de cria, após remoção de parte de seu invólucro. Os sensores não foram colocados exatamente entre os discos de cria (como ocorre com os sensores de temperatura), devido ao seu tamanho, pelo fato de o sensor não ser na extremidade de termopar e também por ter que ser colocado dentro de uma tela protetora, inteiramente dentro da colônia.

As séries temporais estão representadas como:

- “Ambiente": temperatura ambiente, na região externa à colônia;

- "Cria": temperatura na região dos discos de cria, onde há incubação da cria;

- "Potes": temperatura na região dos potes de alimento, escolhida por ser um local intermediário entre a cria e o ambiente;

- "UR\% Ambiente": umidade relativa no ambiente externo à colônia

- "UR\% Cria": umidade relativa na região dos discos de cria;

- "UR\% Potes": umidade relativa na região dos potes de alimento;

- "Vôo": atividade externa de vôo (número total de entradas e saídas).

\section{ATIVIDADE EXTERNA DE VÔO}

As observações de atividade externa de vôo foram registradas nos períodos de primavera/verão e de outono/inverno, baseadas em metodologias de Hilário et al (2000, 2001) para Melipona bicolor e Plebeia pugnax, respectivamente, de Pierrot e Schlindwein (2003) para Melipona scutellaris e de Borges e Blochtein (2005) para Melipona marginata.

Foram empregadas colônias fortes de M. quadrifasciata que não foram alimentadas artificialmente durante o período de experimento, para não influenciar as necessidades da colônia, a quantidade de pólen e mel estocados devido à alimentação artificial (PIERROT e SCHLINDWEIN, 2003).. As observações foram realizadas, junto à entrada dos ninhos, do início até o término das atividades de vôo, com auxílio de contador manual e tabelas. Foram realizadas observações durante 5 minutos, a cada meia hora, das $5 \mathrm{~h}$ às $19 \mathrm{~h}$ e foi considerado nas análises o número total de entradas e saídas. 


\section{$\underline{\text { ATIVIDADE INTERNA }}$}

Foram realizados alguns testes preliminares a fim de eleger qual a melhor maneira de detectar a variação da atividade interna colonial ao longo dos dias. Um dos arranjos experimentais consistia na colocação de lâmpada quente de 40W logo acima do acrílico que cobre a colônia (que permanece tampada com acrílico e pano escuro) (figura 4). O arranjo visaria manter a região próxima aos discos de cria aquecida (pelo calor da lâmpada), e assim as abelhas não apresentariam o comportamento de reconstruir o invólucro, retirado para registro de fotos.

Alternativa testada foi a monitoração da atividade interna por meio de câmera com infravermelho (Color Super Infra), com obtenção de vídeos (em preto e branco, devido ao escuro total) da atividade das abelhas registrados de hora em hora (figura 5). Foram colocados na colônia aberta os sensores dos carregadores de dados de umidade relativa e temperatura, na região dos discos de cria e dos potes de alimento. Em seguida a câmera infravermelha era direcionada para os discos de cria ou para a região dos potes e invólucro, de acordo com o experimento. O sistema era ligado a um vídeo cassete e a um monitor de TV. Foram realizadas gravações durante 2 minutos, de hora em hora, durante as 24 horas do dia, a fim de registrar a atividade interna das abelhas na colônia ao longo de todo o dia, com concomitante obtenção de séries temporais de umidade e temperatura, e registro de atividade externa de vôo.

\section{COLÔNIAS FECHADAS}

Em colônias mantidas fechadas foi estudada a regulação de temperatura e umidade relativa com obtenção de séries temporais de maneira similar ao descrito anteriormente para colônias abertas, mas com algumas modificações:

As caixas com colônias de $M$. quadrifasciata foram fechadas com tela metálica na entrada do ninho, para ventilação, e colocadas dentro de câmara climática ELETROlab 122FC/1, com temperatura controlada e escuro constante. Foram colocados pedaços de algodão embebido em água dentro da câmara climática, a fim de se tentar minimizar variações de umidade. Foram tomados cuidados em se evitar ciclos de qualquer tipo que pudessem perturbar e influenciar a expressão dos ritmos da colônia, tais como ciclos de abertura da câmara e ciclos de sons. As temperaturas testadas foram entre 18 e $25^{\circ} \mathrm{C}$ as quais, segundos experimentos preliminares, possibilitam a visualização da expressão da ritmicidade da regulação da temperatura e umidade relativa na região dos discos de cria.

Também foram colocados carregadores de dados dentro da câmara climática, pois a temperatura no visor do aparelho poderia não corresponder à temperatura real dentro da câmara. Foi utilizado como controle caixa de madeira contendo uma colônia de M. quadrifasciata morta, ou 
seja, sem as abelhas. Este controle é importante, pois possui toda a arquitetura de uma colõnia, exceto as abelhas, e assim pode-se verificar como a temperatura se comporta dentro da estrutura de um ninho, independentemente da presença de abelhas. Foram colocados sensores na região dos discos de cria e dos potes ("controle cria" e "controle pote").

\section{TRATAMENTOS COM BLOQUEADORES}

Algumas colônias foram tratadas com Alprenolol $10^{-2} \mathrm{M}$ e com Mianserina $10^{-3} \mathrm{M}$, semelhante ao também exposto no capítulo 4, em abelhas individuais. Esse tratamento visa verificar efeitos dos bloqueadores nas características de termorregulação colonial, ApEn e periodicidades nas séries temporais, uma vez que Alprenolol pode afetar a termorregulação em abelhas melíferas (BELZUNCES et al, 1996). A Mianserina também foi empregada por ser o bloqueador de receptor de Octopamina com a maior afinidade pelo receptor segundo Degen et al (2000).

As substâncias foram oferecidas diluídas em solução de sacarose 50\% e colocadas em copos plásticos com algodão, semelhante à situação mostrada na figura 2A.

\section{ANÁLISE DE SÉRIES TEMPORAIS}

Foi inicialmente descrito o comportamento das séries temporais com construção de gráficos da série (temperatura versus tempo e umidade relativa versus tempo), seguido de análises da complexidade (irregularidade em séries temporais) e das periodicidades relevantes nos dados.

As séries temporais foram analisadas por meio de Análise Descritiva, Análise Espectral e Entropia Aproximada (ApEn). Além da inspeção dos dados brutos, foi realizado também o cálculo da média dos valores de diferentes dias medidos no mesmo horário (médias horárias). Todavia, tal procedimento visa apenas sintetizar a variação diária, e não é empregado em análises de séries temporais.

A Análise Espectral e os valores de Entropia Aproximada (ApEn) foram calculados a partir das séries temporais de temperatura, no programa Matlab 7.0.4, por meio de implementação de algoritmos.

\section{$\underline{A p E n}$}

A Entropia Aproximada (ApEn) (PINCUS, 1991; PINCUS e GOLDBERGER, 1994) é uma medida de complexidade (irregularidade em séries temporais) e é aplicada em dados com ruído (PINCUS, 1991). A ApEn é definida como a probabilidade logarítmica com que os padrões dos dados que são próximos entre si irão permanecer próximos na comparação seguinte. Um sinal determinístico de alta regularidade tem uma maior probabilidade de permanecer próximo para vetores mais longos das séries e, portanto possui um valor de ApEn muito baixo. Por outro lado, um 
sinal aleatório possui uma regularidade muito baixa e produz altos valores de ApEn (RAJENDRA et al., 2005).

Em outras palavras, a ApEn varia inversamente com a regularidade da curva temporal. Provêm informações para o conhecimento da série temporal na qual valores sucessivos podem ser usados para predizer valores subseqüentes; e será maior na medida em que os valores seguindo valores conhecidos se tornem mais imprevisíveis. Então, curvas mais complexas terão valores de ApEn maiores, e o maior valor será de séries aleatórias (VARELA et al., 2003). Valores menores de ApEn implicam em maior probabilidade que certos padrões de medidas serão seguidos por medidas similares (RAJENDRA et al, 2005). Para utilizar a ApEn, os dados devem ser estacionários. Os valores de ApEn não são números absolutos, mas podem ser comparados entre si.

\section{$\underline{\text { Análise Espectral }}$}

$\mathrm{Na}$ análise feita no domínio da freqüência o interesse está na freqüência com que certos eventos ocorrem em determinado período de tempo (movimentos cíclicos, por exemplo). No domínio de freqüências há a análise espectral (PEREIRA et al, 1986; BENEDITO-SILVA, 1999; MORETIN e TOLOI, 2006), que consiste em decompor a série dada em componentes de freqüências, onde a existência do espectro é a característica fundamental (MORETIN e TOLOI, 2006).

Para cálculo das periodicidades significativas foram obtidos no Matlab gráficos, periodogramas, nos quais as abscissas correspondem às freqüências em $\mathrm{Hz}$ (número de ciclos por intervalo de amostragem) e as ordenadas representam as contribuições espectrais. Para o cálculo dos principais períodos (em horas ou dias) da série temporal, foram detectados no periodograma os picos e as suas frequiências $(\mathrm{Hz})$ e potência $\left({ }^{\circ} \mathrm{C}^{2} / \mathrm{Hz}\right)$ correspondentes. Com esses valores, foi realizado o seguinte cálculo:

Período $=1$ / Freqüência (segundos)

Para a conversão do valor, em segundos, em horas ou dias, o valor foi dividido por 60 (para minutos), novamente por 60 (para horas) e também por 24 (para dias, se fosse o caso). As horas não estão considerando os minutos, e sim subdivisões do valor de hora: por exemplo, a periodicidade de 24h30min está indicada como 24,5h, para facilitar os cálculos.

\section{$\underline{\text { Valores de ApEn e periodicidades }}$}

Os valores de ApEn e de periodicidades (estas obtidas pela Análise Espectral) foram incluídos em tabelas para facilitar a verificação de ocorrência de periodicidades semelhantes entre diferentes séries temporais. A primeira coluna contém o nome da série temporal analisada seguido de seu valor de ApEn. A primeira linha, de cabeçalho, contém novamente o nome da série 
temporal. Os resultados de periodicidade que são exclusivos daquela série estão incluídos na célula que une a coluna e a linha daquela série, por exemplo, valores na célula "UR\% Cria versus UR\% Cria" são exclusivas a esta série.

Em cada tabela foram incluídas, nesta ordem, primeiramente as periodicidades das condições ambientais (temperatura ambiente, UR\% ambiente e luminosidade), seguidas da temperatura na região dos discos de cria (onde se quer analisar a ritmicidade colonial) e da temperatura nos potes de alimento (que é um local intermediário entre o local de incubação da cria e as condições ambientais externas) e, por fim, a atividade de vôo.

Por exemplo, primeiro foram incluídas as periodicidades da temperatura ambiente, na célula “Ambiente versus Ambiente". A seguir, foram incluídos os dados de UR\% ambiente, da seguinte maneira: quando há coincidência entre as periodicidades da UR\% ambiente com as da temperatura ambiente, os valores são incluídos na célula “UR\% Ambiente versus Ambiente”, para mostrar que há coincidência de valores. Nas tabelas, os valores em negrito destacam a mesma periodicidade detectada em duas ou mais séries temporais.

\section{$\underline{\text { Outras análises }}$}

Para comparações de 2 grupos de dados foi utilizado o teste não paramétrico Mann-Whitney (ZAR, 1999; CALLEGARI-JACQUES, 2003; VIEIRA, 2003), que testa a hipótese de que duas populações têm a mesma distribuição, sendo baseado em postos e é uma alternativa não paramétrica ao teste t no caso de amostras independentes. A estatística de Mann Whitney é também conhecida como U, e é utilizada para o cálculo de $\mathrm{z}$, que é normalmente comparado com o valor crítico, dado em tabela de distribuição normal padronizada, para o nível estabelecido de significância (VIEIRA, 2003).

Os cálculos estatísticos foram realizados com o auxílio dos softwares Statistica 5.0 e GraphPad Prism 3.02.

\section{RESULTADOS}

\section{COLÔNIAS ABERTAS}

Na figura 6 estão apresentados gráficos das séries temporais de temperatura e de umidade relativa no ambiente externo ao ninho e dentro deste, na região dos discos de cria e dos potes de alimento, representados como "Ambiente", "Cria" e "Potes", respectivamente. De forma geral, as temperaturas na região dos discos de cria eram mantidas mais elevadas do que na região dos potes de alimento e no ambiente externo, com amplitudes menores, sugerindo controle de temperatura próximo à cria. 
Na figura 7 estão os mesmos valores apresentados na figura 6, mas com as médias horárias nos diferentes dias. Este método de visualização de resultados permite verificar a variação diária. A desvantagem deste método de análise descritiva é que os valores de desvio padrão equivalentes às diferenças horárias nos diferentes dias são elevados, refletindo as variações dos diferentes dias e dificultando a caracterização da série temporal. Assim, na tabela 1 estão apresentados resultados da análise espectral e os valores de ApEn dessas séries temporais, das figuras 6 e 7.

Conforme já explicado no item Materiais e Métodos, as tabelas contém na primeira coluna o nome da série temporal analisada seguido de seu valor de ApEn. A primeira linha, de cabeçalho, contém novamente o nome da série temporal. Os resultados de periodicidade que são exclusivos daquela série estão incluídos na célula que une a coluna e linha daquela série, por exemplo, valores na célula "UR\% Cria versus UR\% Cria" são exclusivas àquela série. Quando as periodicidades coincidem, considera-se a coluna com o nome da série temporal em questão, A linha da série na qual coincide, por exemplo, ao se incluir a periodicidade de $11,384 \mathrm{~h}$ da região da Cria, verifica-se que esta coincide com uma das periodicidades da UR\% Ambiente e então é incluída na célula da linha "UR\% Ambiente" versus coluna "Cria", indicando que os valores de periodicidade nas séries temporais de temperatura dessas duas regiões coincidem. Este procedimento foi realizado em todas as tabelas.

Tabela 1. Valores de ApEn e periodicidades detectadas por Análise Espectral de séries temporais de temperatura e umidade relativa em colônia aberta.

\begin{tabular}{|c|c|c|c|c|c|c|c|}
\hline & Amb & $\begin{array}{l}\text { UR\% } \\
\text { Amb }\end{array}$ & Lumin & Cria & Potes & UR\% Cria & $\begin{array}{l}\text { UR\% } \\
\text { Potes }\end{array}$ \\
\hline Amb & $22,769 h$ & $22,769 h$ & $22,769 h$ & $22,769 h$ & $22,769 h$ & $22,769 h$ & $22,769 h$ \\
\hline ApEn $=0,2077$ & $\begin{array}{c}\mathbf{1 2 , 4 0 1 h} \\
\mathbf{2 , 8 9 4 d} \\
13,617 \mathrm{~h} \\
\mathbf{8 , 0 2 8 h} \\
\mathbf{9 , 1 0 7 h}\end{array}$ & $\begin{array}{l}8,028 \mathrm{~h} \\
9,107 \mathrm{~h}\end{array}$ & $12,401 \mathrm{~h}$ & $\begin{array}{c}12,401 \mathrm{~h} \\
2,894 \mathrm{~d} \\
8,028 \mathrm{~h}\end{array}$ & $\begin{array}{l}8,028 h \\
9,107 h\end{array}$ & & \\
\hline $\begin{array}{c}\text { UR\% Amb } \\
\text { ApEn= } \\
0,23009\end{array}$ & --- & $\begin{array}{r}5,673 d \\
11,384 h\end{array}$ & & $11,384 \mathrm{~h}$ & $11,384 \mathrm{~h}$ & $\begin{array}{l}5,673 \mathrm{~d} \\
11,384 \mathrm{~h}\end{array}$ & $\begin{array}{r}5,673 \mathrm{~d} \\
11,384 \mathrm{~h}\end{array}$ \\
\hline $\begin{array}{l}\text { Luminosidade } \\
\text { ApEn=0,43338 }\end{array}$ & --- & --- & $\begin{array}{c}\mathbf{5 , 9 3 5 h} \\
\mathbf{8 , 5 2 1 h} \\
6,505 \mathrm{~h} \\
4,708 \mathrm{~h}\end{array}$ & $5,935 \mathrm{~h}$ & $5,935 \mathrm{~h}$ & & $8,521 \mathrm{~h}$ \\
\hline $\begin{array}{c}\text { Cria } \\
\text { ApEn }=0,4199\end{array}$ & --- & --- & --- & & & & \\
\hline Potes & --- & --- & --- & --- & $5,787 \mathrm{~d}$ & & \\
\hline
\end{tabular}


$\mathrm{ApEn}=0,30902$

$\begin{array}{ccccccc}\text { UR\% Cria } & --- & --- & --- & --- & -- & 7,59 \mathrm{~h} \\ \text { ApEn=0,23771 } & & & & & 5,692 \mathrm{~h} \\ \text { UR\% Potes } & --- & --- & --- & --- & --- & --- \\ \text { ApEn=0,16089 } & & & & & & 9,746 \mathrm{~h}\end{array}$

Os valores em negrito destacam a mesma periodicidade detectada em duas ou mais séries temporais

A temperatura ambiente, a umidade relativa e a luminosidade são variáveis ambientais que apresentam periodicidades semelhantes, já que estão todas submetidas aos ciclos geofísicos do ambiente. Estas três variáveis medidas parecem influenciar ou "arrastar" as séries temporais coloniais, mas é difícil afirmar qual delas é o maior responsável, já que se interrelacionam. Há também periodicidades exclusivamente coloniais, que ocorrem apenas nas séries temporais de temperatura e umidade dentro da colônia.

Na figura 8 estão apresentadas outras séries temporais de temperatura e umidade relativa, conforme descrito para a figura 6 , com coleta de dados a cada 5 minutos, durante 3 dias. Resultados das análises estão apresentados na tabela 2.

Tabela 2. Valores de ApEn e periodicidades detectadas por Análise Espectral de séries temporais de temperatura e umidade relativa em colônia aberta

\begin{tabular}{|c|c|c|c|c|c|c|c|}
\hline & $\mathrm{Amb}$ & $\begin{array}{l}\text { UR\% } \\
\text { Amb }\end{array}$ & Lumin & Cria & Potes & UR\% Cria & $\begin{array}{l}\text { UR\% } \\
\text { Potes }\end{array}$ \\
\hline T Amb & 27,889h & 27,889h & 11,973h & 27,889h & 27,889h & 27,889h & 3,486d \\
\hline ApEn = & 11,973h & $11,973 h$ & 27,889h & 3,858d & 3,858d & $3,486 \mathrm{~d}$ & 27,889h \\
\hline \multirow[t]{4}{*}{0,19065} & $3,486 d$ & $5,974 h$ & $8,367 h$ & $11,973 h$ & $11,973 h$ & $11,973 h$ & $11,973 h$ \\
\hline & $5,974 h$ & $8,367 h$ & 5,974h & $8,367 h$ & & $8,367 h$ & \\
\hline & $3,985 h$ & $3,486 \mathrm{~d}$ & 3,985h & $5,974 h$ & & & \\
\hline & $8,367 h$ & $3,985 \mathrm{~h}$ & & & & & \\
\hline $\mathrm{UR} \% \mathrm{Amb}$ & --- & & & & & & \\
\hline \multicolumn{8}{|l|}{$\mathrm{ApEn}=$} \\
\hline \multicolumn{8}{|l|}{0,21682} \\
\hline Luminosidade & --- & --- & $20,885 \mathrm{~h}$ & & & & \\
\hline$A p E n=0,36516$ & & & $4,925 \mathrm{~h}$ & & & & \\
\hline Cria & --- & --- & --- & $4,183 \mathrm{~h}$ & & & \\
\hline \multicolumn{8}{|l|}{$A p E n=0,66044$} \\
\hline Potes & --- & --- & --- & --- & $7,610 h$ & & 7,610h \\
\hline \multicolumn{8}{|l|}{$\mathrm{ApEn}=0,10845$} \\
\hline UR\% Cria & --- & --- & --- & --- & --- & $6,430 \mathrm{~h}$ & \\
\hline$A p E n=0,40331$ & & & & & & $3,485 \mathrm{~h}$ & \\
\hline UR\% Potes & --- & --- & --- & --- & --- & --- & $6,979 \mathrm{~h}$ \\
\hline
\end{tabular}


ApEn $=0,15253$

Os valores em negrito destacam a mesma periodicidade detectada em duas ou mais séries temporais

\section{COLÔNIAS ABERTAS COM ATIVIDADE DE VÔO}

Nas figuras 9 a 14 estão apresentadas séries temporais de colônias mantidas abertas com registro de atividade de vôo (número total de entradas e saídas). As figuras 9 a 11 representam dados coletados na primavera/verão, e as figuras 12 a 14, no outono/inverno. O intervalo de amostragem considerado nas análises foi de 30 minutos, devido à atividade de vôo, que era registrada dessa forma. Os resultados das análises dessas séries temporais estão mostrados nas tabelas 3 a 8 , respectivamente.

\section{COLÔNIAS ABERTAS - PRIMAVERA/VERÃO}

Tabela 3. Valores de ApEn e periodicidades detectadas por Análise Espectral de séries temporais de temperatura e umidade relativa em colônia aberta com registro de atividade de vôo, na primavera/verão. Séries temporais na figura 9.

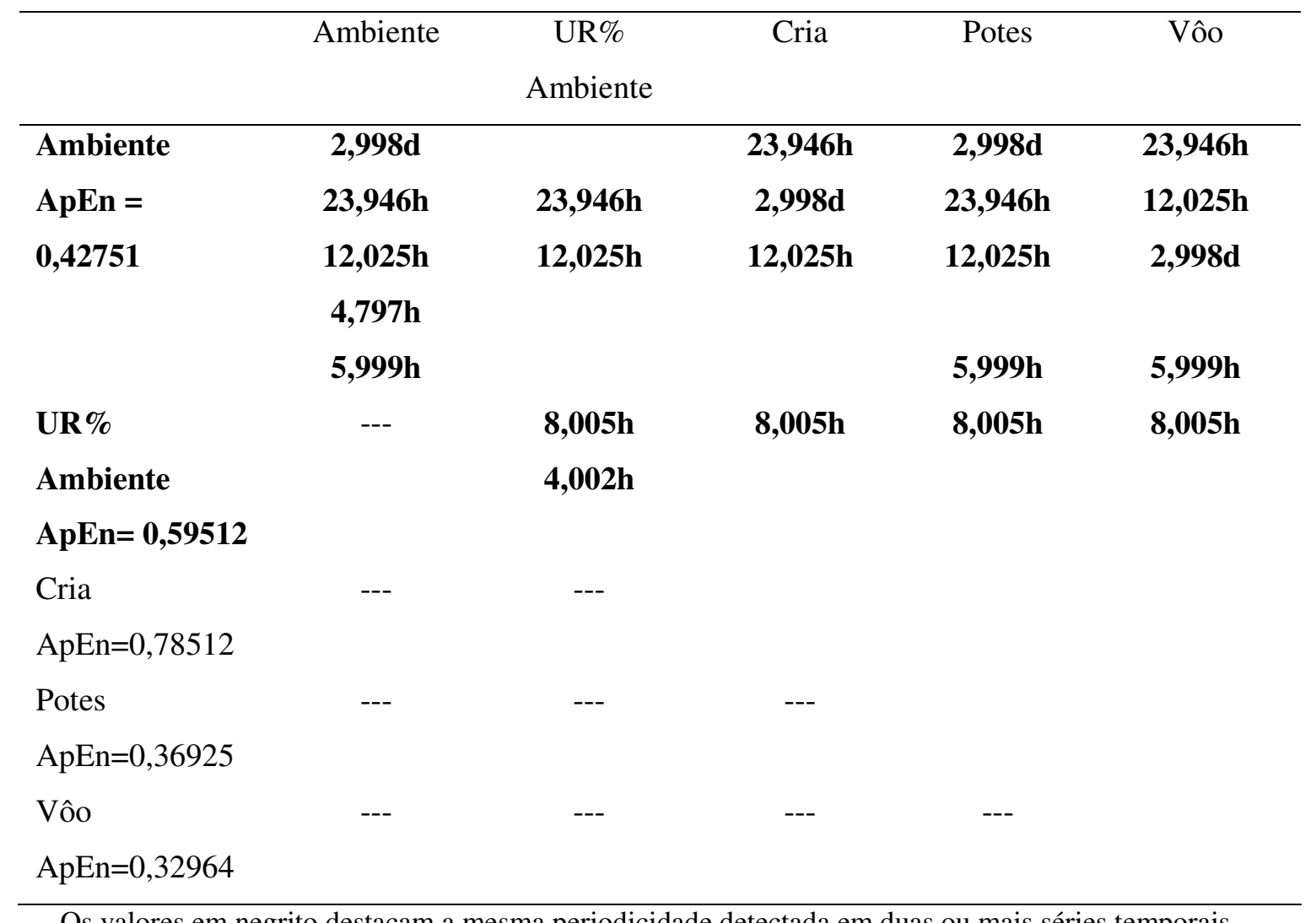


Tabela 4. Valores de ApEn e periodicidades detectadas por Análise Espectral de séries temporais de temperatura e umidade relativa em colônia aberta com registro de atividade de vôo, na primavera/verão. Séries temporais na figura 10.

\begin{tabular}{|c|c|c|c|c|c|}
\hline & Ambiente & UR\% Amb & Cria & Potes & Vôo \\
\hline Ambiente & $23,946 h$ & $23,946 h$ & $23,946 h$ & $23,946 h$ & $23,946 \mathrm{~h}$ \\
\hline $\operatorname{ApEn}=$ & 2,998d & $12,025 \mathrm{~h}$ & $12,025 h$ & 2,998d & $12,025 \mathrm{~h}$ \\
\hline \multirow{3}{*}{0,43063} & $14,393 \mathrm{~h}$ & 2,998d & $5,999 \mathrm{~h}$ & $12,025 h$ & $5,999 \mathrm{~h}$ \\
\hline & $5,999 h$ & & & $5,999 h$ & \\
\hline & $12,025 \mathrm{~h}$ & & & & \\
\hline $\mathrm{UR} \% \mathrm{Amb}$ & --- & $8,989 h$ & & & \\
\hline$A p E n=0,5771$ & & $6,551 \mathrm{~h}$ & & & \\
\hline Cria & --- & --- & $10,288 \mathrm{~h}$ & & $8,005 h$ \\
\hline$A p E n=0,61616$ & & & $8,005 h$ & & \\
\hline Potes & --- & --- & --- & & \\
\hline \multicolumn{6}{|l|}{$\mathrm{ApEn}=0,52425$} \\
\hline Vôo & --- & --- & --- & --- & $4,797 \mathrm{~h}$ \\
\hline $\mathrm{ApEn}=0,41395$ & & & & & \\
\hline
\end{tabular}

Tabela 5. Valores de ApEn e periodicidades detectadas por Análise Espectral de séries temporais de temperatura e umidade relativa em colônia aberta com registro de atividade de vôo, na primavera/verão. Séries temporais na figura 11.

\begin{tabular}{|c|c|c|c|c|c|c|c|c|}
\hline & $\mathrm{Amb}$ & $\begin{array}{l}\text { UR\% } \\
\text { Amb }\end{array}$ & Lumin & Cria & Potes & $\begin{array}{l}\text { UR\% } \\
\text { Cria }\end{array}$ & $\begin{array}{l}\text { UR\% } \\
\text { Potes }\end{array}$ & Vôo \\
\hline Amb & $25,252 h$ & $25,252 \mathrm{~h}$ & $25,252 \mathrm{~h}$ & $25,252 h$ & $25,252 h$ & $25,252 \mathrm{~h}$ & $25,252 \mathrm{~h}$ & $25,252 \mathrm{~h}$ \\
\hline \multirow[t]{4}{*}{$\operatorname{ApEn}=0,38471$} & $12,684 h$ & $12,684 h$ & $12,684 h$ & $12,684 h$ & $12,684 h$ & $3,162 d$ & $3,162 d$ & $7,589 \mathrm{~h}$ \\
\hline & $3,162 d$ & $3,162 d$ & $7,589 \mathrm{~h}$ & $7,589 \mathrm{~h}$ & $7,589 \mathrm{~h}$ & $12,684 \mathrm{~h}$ & $12,684 h$ & $5,848 \mathrm{~h}$ \\
\hline & $7,589 h$ & $7,589 \mathrm{~h}$ & $5,848 \mathrm{~h}$ & $5,848 \mathrm{~h}$ & & $7,589 \mathrm{~h}$ & $7,589 \mathrm{~h}$ & \\
\hline & $5,848 \mathrm{~h}$ & $5,848 \mathrm{~h}$ & & & & & & \\
\hline $\mathrm{UR} \% \mathrm{Amb}$ & --- & & & & & & & \\
\hline $\mathrm{ApEn}=0,49814$ & & & & & & & & \\
\hline Luminosidade & --- & --- & $4,748 \mathrm{~h}$ & & & & & \\
\hline \multicolumn{9}{|l|}{ ApEn=0,33721 } \\
\hline Cria & --- & --- & --- & & & & & \\
\hline \multicolumn{9}{|l|}{ ApEn=0,7302 } \\
\hline Potes & --- & --- & --- & --- & $2,893 \mathrm{~d}$ & & & \\
\hline ApEn $=0,33497$ & & & & & & & & \\
\hline
\end{tabular}




\begin{tabular}{|c|c|c|c|c|c|c|c|c|}
\hline UR\% Cria & --- & --- & --- & --- & --- & $8,443 \mathrm{~h}$ & & \\
\hline \multicolumn{9}{|l|}{$\mathrm{ApEn}=0,73277$} \\
\hline UR\% Potes & --- & --- & --- & --- & --- & --- & $9,512 \mathrm{~h}$ & \\
\hline \multicolumn{9}{|l|}{$A p E n=0,35711$} \\
\hline Vôo & --- & --- & --- & --- & --- & --- & --- & $10,851 \mathrm{~h}$ \\
\hline $\mathrm{ApEn}=0,38553$ & & & & & & & & $5,069 \mathrm{~h}$ \\
\hline
\end{tabular}

Os valores em negrito destacam a mesma periodicidade detectada em duas ou mais séries temporais

As periodicidades da Cria, Potes e Vôo estão relacionadas principalmente às condições ambientais como a temperatura, umidade relativa e luminosidade. No caso da atividade de vôo, esta também pode estar relacionada a processos coloniais, baseado nas mesmas periodicidades detectadas com a região dos discos de cria.

\section{COLÔNIAS ABERTAS - OUTONO/INVERNO}

Tabela 6. Valores de ApEn e periodicidades detectadas por Análise Espectral de séries temporais de temperatura e umidade relativa em colônia aberta com registro de atividade de vôo, no outono/inverno. Séries temporais na figura 12.

\begin{tabular}{cccccc}
\hline & Amb & UR\% Amb & Cria & Potes & Vôo \\
\hline Ambiente & $\mathbf{2 3 , 9 4 6 h}$ & $\mathbf{2 3 , 9 4 6 h}$ & $\mathbf{2 3 , 9 4 6 h}$ & $\mathbf{2 3 , 9 4 6 h}$ & $\mathbf{2 3 , 9 4 6 h}$ \\
ApEn $=$ & $\mathbf{2 , 9 9 8 d}$ & $\mathbf{2 , 9 9 8 d}$ & $\mathbf{2 , 9 9 8 d}$ & $\mathbf{2 , 9 9 8 d}$ & $\mathbf{2 , 9 9 8 d}$ \\
$\mathbf{0 , 2 6 9 1 4}$ & $\mathbf{1 2 , 0 2 5 h}$ & $\mathbf{1 2 , 0 2 5 h}$ & $\mathbf{1 2 , 0 2 5 h}$ & $\mathbf{1 2 , 0 2 5 h}$ & \\
& $\mathbf{5 , 5 3 3 h}$ & & & & \\
UR\% Amb & & $5,999 \mathrm{~h}$ & & & \\
ApEn=0,3494 & & & $\mathbf{8 , 0 0 5 h}$ & \\
Cria & & $5,005 \mathrm{~h}$ & \\
ApEn=0,93524 & & & & \\
Potes & & & & \\
ApEn=0,34323 & & & & \\
Vôo & & & & \\
ApEn=0,83167 & & & & \\
Os valores em negrito destacam a mesma periodicidade detectada em duas ou mais séries temporais &
\end{tabular}

Tabela 7. Valores de ApEn e periodicidades detectadas por Análise Espectral de séries temporais de temperatura e umidade relativa em colônia aberta com registro de atividade de vôo, no outono/inverno. Séries temporais na figura 13. 


\begin{tabular}{|c|c|c|c|c|c|c|}
\hline & T Ambiente & $\begin{array}{c}\text { UR\% } \\
\text { Ambiente }\end{array}$ & T Cria & T Potes & $\begin{array}{l}\text { UR\% } \\
\text { Potes }\end{array}$ & Vôo \\
\hline T Ambiente & $24,802 \mathrm{~h}$ & $24,802 h$ & $24,802 h$ & $24,802 h$ & $8,267 d$ & $24,802 \mathrm{~h}$ \\
\hline \multirow[t]{5}{*}{$\operatorname{ApEn}=0,66848$} & $8,267 d$ & $8,267 d$ & $12,456 h$ & $8,267 d$ & $24,802 h$ & $11,721 \mathrm{~h}$ \\
\hline & $39,796 \mathrm{~h}$ & $11,721 \mathrm{~h}$ & $11,721 \mathrm{~h}$ & $12,456 h$ & $12,456 h$ & $12,456 h$ \\
\hline & $11,721 \mathrm{~h}$ & $18,03 h$ & & & & \\
\hline & $12,456 h$ & & & & & \\
\hline & $18,037 \mathrm{~h}$ & & & & & \\
\hline UR\% Ambiente & & $15,347 \mathrm{~h}$ & & & & \\
\hline \multicolumn{7}{|l|}{$\operatorname{ApEn}=0,65929$} \\
\hline T Cria & & & $33,148 h$ & $33,148 h$ & & $7,959 \mathrm{~h}$ \\
\hline \multirow[t]{2}{*}{$\mathrm{ApEn}=0,98877$} & & & $7,959 \mathrm{~h}$ & & & \\
\hline & & & $14,245 \mathrm{~h}$ & & & \\
\hline T Potes & & & & $4,148 d$ & & \\
\hline \multicolumn{7}{|l|}{$A p E n=0,8369$} \\
\hline UR\% Potes & & & & & $19,841 \mathrm{~h}$ & \\
\hline $\operatorname{ApEn}=1,0381$ & & & & & $2,762 d$ & \\
\hline Vôo & & & & & & $5,999 \mathrm{~h}$ \\
\hline ApEn=0,30--- & & & & & & \\
\hline
\end{tabular}

Os valores em negrito destacam a mesma periodicidade detectada em duas ou mais séries temporais

Tabela 8. Valores de ApEn e periodicidades detectadas por Análise Espectral de séries temporais de temperatura e umidade relativa em colônia aberta com registro de atividade de vôo, no outono/inverno. Séries temporais na figura 14.

\begin{tabular}{|c|c|c|c|c|c|c|c|c|}
\hline & $\mathrm{T} \mathrm{Amb}$ & UR\% & Lumin & T Cria & T Potes & UR\% & UR\% & Vôo \\
\hline & & Amb & & & & Cria & Potes & \\
\hline T Amb & $28,002 \mathrm{~h}$ & $28,002 h$ & $28,002 h$ & $28,002 h$ & $28,002 h$ & $3,497 d$ & 3,497d & $28,002 h$ \\
\hline \multirow[t]{3}{*}{ ApEn $=0,43649$} & $12,025 \mathrm{~h}$ & $12,025 h$ & $12,025 \mathrm{~h}$ & $12,025 h$ & $12,025 \mathrm{~h}$ & $28,002 h$ & & $12,025 h$ \\
\hline & $3,497 d$ & $8,392 h$ & $3,497 d$ & & & & & 3,497d \\
\hline & 8,392h & & 8,392h & & & & & $8,392 h$ \\
\hline UR\% Amb & & $5,999 h$ & & & & & & $5,999 \mathrm{~h}$ \\
\hline \multicolumn{9}{|l|}{ ApEn= 0,43399 } \\
\hline Luminosidade & & & $6,997 \mathrm{~h}$ & & & & & \\
\hline$A p E n=0,20777$ & & & $5,600 \mathrm{~h}$ & & & & & \\
\hline T Cria & & & & 9,321h & 9,321h & $9,321 \mathrm{~h}$ & & 9,321h \\
\hline \multicolumn{9}{|l|}{$A p E n=0,67407$} \\
\hline T Potes & & & & & $21,044 h$ & & $21,044 h$ & \\
\hline \multicolumn{9}{|l|}{$A p E n=0,51468$} \\
\hline UR\% Cria & & & & & & $16,835 \mathrm{~h}$ & & \\
\hline \multicolumn{9}{|l|}{$A p E n=0,61823$} \\
\hline UR\% Potes & & & & & & & $14,029 \mathrm{~h}$ & \\
\hline
\end{tabular}


Vôo

ApEn $=0,31069$

Os valores em negrito destacam a mesma periodicidade detectada em duas ou mais séries temporais

As condições ambientais (temperatura, umidade relativa, luminosidade) parecem influenciar as periodicidades das séries temporais de temperatura e umidade relativa, registradas dentro da colônia, na região dos discos de cria e dos potes de alimento, havendo também algumas periodicidades exclusivas à colônia.

As periodicidades das séries temporais de atividade de vôo parecem ser influenciadas pelas ambientais, e também pela temperatura na região da cria, principalmente no outono/inverno, quando as complexidades nas séries temporais de temperatura na região da cria são maiores que na primavera/verão.

\section{COLÔNIAS FECHADAS}

Tabela 9. Valores de ApEn e periodicidades detectadas por Análise Espectral de séries temporais de temperatura em colônia forte mantida fechada a $20^{\circ} \mathrm{C}$ Estão consideradas também séries temporais de temperatura nos controles (ninhos sem abelhas), na região dos discos de cria e potes de alimento. Séries temporais na figura 15.

\begin{tabular}{llllll}
\hline & T Câmara & Contr Cria & Contr Potes & Cria & Potes \\
\hline Câmara & $\mathbf{4 , 3 6 8 d}$ & $\mathbf{4 , 3 6 8 d}$ & $\mathbf{4 , 3 6 8 d}$ & $\mathbf{4 , 3 6 8 d}$ & $\mathbf{4 , 3 6 8 d}$ \\
ApEn=0,3004 & $\mathbf{2 6 , 2 0 5 h}$ & $\mathbf{6 , 5 6 7 h}$ & $\mathbf{2 6 , 2 0 5 h}$ & & $\mathbf{2 6 , 2 0 5 h}$ \\
& $\mathbf{1 5 , 0 1 5 h}$ & & & $\mathbf{1 5 , 0 1 5 \mathbf { h }}$ \\
& $\mathbf{6 , 5 6 7 h}$ & & & \\
Contr Cria & & & & \\
ApEn=0,1166 & & & & \\
Contr Potes & & & $\mathbf{2 1 , 0 4 4 h}$ & $\mathbf{2 1 , 0 4 4 h}$ \\
ApEn=0,11771 & & & $11,671 \mathrm{~h}$ & \\
Cria & & & $6,173 \mathrm{~h}$ & \\
ApEn=0,6046 & & & $8,075 \mathrm{~h}$ & \\
& & & & \\
Potes & & & & \\
ApEn=0,60146 & & & & \\
\hline
\end{tabular}

Tabela 10. Valores de ApEn e periodicidades detectadas por Análise Espectral de séries temporais de temperatura em colônia fraca mantida fechada a $20^{\circ} \mathrm{C}$ Estão consideradas também séries 
temporais de temperatura nos controles (ninhos sem abelhas), na região dos discos de cria e potes de alimento. Séries temporais na figura $\mathbf{1 6 .}$

\begin{tabular}{llllll}
\hline & Câmara & Contr Cria & Contr Potes & Cria & Potes \\
\hline Câmara & $\mathbf{5 , 0 1 1 d}$ & $\mathbf{5 , 0 1 1 d}$ & $\mathbf{5 , 0 1 1 d}$ & $\mathbf{5 , 0 1 1 d}$ & $\mathbf{5 , 0 1 1 d}$ \\
ApEn=0,20746 & $\mathbf{4 0 , 0 2 5 h}$ & $\mathbf{1 7 , 1 4 7 h}$ & $\mathbf{1 7 , 1 4 7 h}$ & $\mathbf{4 0 , 0 2 5 h}$ & $\mathbf{4 0 , 0 2 5 h}$ \\
& $\mathbf{1 7 , 1 4 7 \mathbf { h }}$ & & & \\
& $8,573 \mathrm{~h}$ & & & & \\
& $4,287 \mathrm{~h}$ & & & & \\
Contr Cria & --- & $\mathbf{1 9 , 9 8 4 h}$ & $\mathbf{1 9 , 9 8 4 h}$ & & \\
ApEn=0,13732 & & & & & \\
Contr Potes & --- & --- & $29,998 \mathrm{~h}$ & & \\
ApEn=0,16539 & & & & & \\
Cria & --- & --- & & $\mathbf{2 3 , 9 4 6 h}$ & $\mathbf{2 3 , 9 4 6 h}$ \\
ApEn=0,90801 & & & & $\mathbf{7 , 5 0 7 h}$ & $\mathbf{7 , 5 0 7 h}$ \\
& & & $-12,025 \mathrm{~h}$ & \\
Potes & --- & -- & - & $13,355 \mathrm{~h}$ \\
ApEn=0,3095 & & & & & $9,992 \mathrm{~h}$ \\
\hline
\end{tabular}

Tabela 11. Valores de ApEn e periodicidades detectadas por Análise Espectral de séries temporais de temperatura em colônia forte mantida fechada a $25^{\circ} \mathrm{C}$ Estão consideradas também séries temporais de temperatura nos controles (ninhos sem abelhas), na região dos discos de cria e potes de alimento. Séries temporais na figura 17.

\begin{tabular}{llllll}
\hline & Câmara & Contr Cria & Contr Potes & Cria & Potes \\
\hline Câmara & $\mathbf{7 , 0 5 7 d}$ & $\mathbf{1 6 , 9 3 8 h}$ & $\mathbf{7 , 0 5 7 d}$ & $\mathbf{7 , 0 5 7 d}$ & $\mathbf{2 , 3 4 8 d}$ \\
ApEn=0,20949 & $\mathbf{2 , 3 4 8 d}$ & $\mathbf{2 , 3 4 8 d}$ & $\mathbf{2 , 3 4 8 d}$ & $\mathbf{1 6 , 9 3 8 h}$ & $\mathbf{7 , 0 5 7 d}$ \\
& $21,204 \mathrm{~h}$ & & $\mathbf{1 6 , 9 3 8 h}$ & & \\
& $12,980 \mathrm{~h}$ & & & & \\
& $\mathbf{1 6 , 9 3 8 h}$ & & & $\mathbf{2 4 , 1 5 1 h}$ & $24,151 \mathrm{~h}$ \\
Contr Cria & & & $\mathbf{1 1 , 2 4 6 h}$ & $11,246 \mathrm{~h}$ \\
ApEn=0,020267 & & & $7,673 \mathrm{~h}$ & \\
& & & & \\
Contr Potes & & & & & \\
ApEn=0,0758 & & & & & \\
Cria & & & & \\
ApEn=0,87881 & & & & & \\
Potes & & & & \\
ApEn=0,55114 & & & & & \\
\hline
\end{tabular}

Tabela 12. Valores de ApEn e periodicidades detectadas por Análise Espectral de séries temporais de temperatura em colônia fraca mantida fechada a $25^{\circ} \mathrm{C}$. Estão consideradas também séries 
temporais de temperatura nos controles (ninhos sem abelhas), na região dos discos de cria e potes de alimento. Séries temporais na figura 18.

\begin{tabular}{llllll}
\hline & Câmara & Contr Cria & Contr Potes & Cria & Potes \\
\hline Câmara & $\mathbf{3 , 9 6 4 d}$ & $\mathbf{3 , 9 6 4 d}$ & $\mathbf{3 , 9 6 4 d}$ & $\mathbf{3 , 9 6 4 d}$ & $\mathbf{3 , 9 6 4 d}$ \\
ApEn=0 & $\mathbf{9 , 5 1 3 h}$ & $\mathbf{8 , 6 2 7 h}$ & & & $\mathbf{9 , 5 1 3 h}$ \\
& $\mathbf{8 , 6 2 7 h}$ & $\mathbf{9 , 5 1 3 h}$ & & & \\
Contr Cria & & $21,505 \mathrm{~h}$ & & & \\
ApEn=0,13679 & & & & & \\
Contr Potes & & & & $\mathbf{2 3 , 7 4 2 h}$ & $\mathbf{2 3 , 7 4 2 h}$ \\
ApEn=0,013049 & & & $10,562 \mathrm{~h}$ & \\
Cria & & & $13,550 \mathrm{~h}$ & \\
ApEn=0,9293 & & & & & \\
& & & & & \\
Potes & & & & & \\
ApEn=0,914h
\end{tabular}

Parece haver diferenças na termorregulação entre colônias fortes e fracas, principalmente com relação à amplitude da temperatura na região dos discos de cria e a complexidade de séries temporais nesta região, quantificada pelo ApEn.

Além disso, nos "controles" "Contr Cria" e "Contr Potes" as periodicidades detectadas na série temporal equivalem à da temperatura na câmara, parecendo não haver influências da estrutura do ninho por si só, em condições de temperatura constante.

Tabela 13. Valores de ApEn e periodicidades detectadas por Análise Espectral de séries temporais de temperatura e umidade relativa em colônia mantida fechada a $22^{\circ} \mathrm{C}$. Séries temporais na fig 19.

\begin{tabular}{cccccc}
\hline & Câm & UR\% Câm & Cria & Potes & UR\% Potes \\
\hline Câmara & $\mathbf{2 1 , 7 0 2 h}$ & $\mathbf{2 1 , 7 0 2 h}$ & $\mathbf{2 1 , 7 0 2 h}$ & $\mathbf{2 1 , 7 0 2 h}$ & $\mathbf{2 1 , 7 0 2 h}$ \\
ApEn=0,73971 & $\mathbf{1 2 , 4 0 1 h}$ & $\mathbf{3 , 6 2 8 d}$ & $\mathbf{3 , 6 2 8 d}$ & $\mathbf{3 , 6 2 8 d}$ & $\mathbf{1 2 , 4 0 1 \mathbf { h }}$ \\
& $\mathbf{3 , 6 2 8 d}$ & & & $\mathbf{1 2 , 4 0 1 \mathbf { h }}$ & $\mathbf{7 , 9 1 4 h}$ \\
& $43,471 \mathrm{~h}$ & & & & \\
& $9,679 \mathrm{~h}$ & & & & \\
& $\mathbf{7 , 9 1 4 h}$ & & & $\mathbf{7 , 2 5 3 h}$ & $\mathbf{7 , 2 5 3 h}$ \\
UR\% Câmara & --- & $14,467 \mathrm{~h}$ & & & \\
ApEn=0,66302 & & $8,708 \mathrm{~h}$ & & & \\
& & $\mathbf{7 , 2 5 3 h}$ & & $\mathbf{2 3 , 9 4 6 h}$ & \\
Cria & --- & -- & $\mathbf{2 3 , 9 4 6 h}$ & & \\
ApEn=0,71802 & & & $12,401 \mathrm{~h}$ & & \\
& & & $6,693 \mathrm{~h}$ & &
\end{tabular}


$\mathrm{ApEn}=0,73065$

UR\% Potes

Tabela 14. Valores de ApEn e periodicidades detectadas por Análise Espectral de séries temporais de temperatura e umidade relativa em colônia mantida fechada a $20^{\circ} \mathrm{C}$. Séries temporais na fig 20 .

\begin{tabular}{|c|c|c|c|c|c|c|}
\hline & Câmara & UR\% Câm & Cria & Potes & UR\% Cria & UR\% Potes \\
\hline Câmara & $47,081 \mathrm{~h}$ & & $11,770 h$ & & $11,770 h$ & $11,770 h$ \\
\hline \multirow[t]{4}{*}{ ApEn $=0,31475$} & $11,770 h$ & & $7,847 \mathrm{~h}$ & & $9,416 h$ & \\
\hline & 9,416h & & $5,885 h$ & & & \\
\hline & 7,847h & & & & & \\
\hline & $5,885 h$ & & & & & \\
\hline UR\% Câmara & --- & $2,151 \mathrm{~d}$ & & 8,599h & & \\
\hline \multirow[t]{4}{*}{$\mathrm{ApEn}=1,0775$} & & $17,253 \mathrm{~h}$ & & & & \\
\hline & & 8,599h & & & & \\
\hline & & $3,446 \mathrm{~h}$ & & & & \\
\hline & & $3,689 \mathrm{~h}$ & & & & \\
\hline Cria & --- & --- & $23,148 h$ & $23,148 h$ & & \\
\hline$A p E n=1,1133$ & & & $3,858 \mathrm{~d}$ & & & \\
\hline Potes & --- & --- & --- & $1,929 d$ & & $6,284 h$ \\
\hline \multirow[t]{2}{*}{ ApEn $=0,14082$} & & & & $10,482 \mathrm{~h}$ & & \\
\hline & & & & $6,284 h$ & & \\
\hline UR\% Cria & --- & --- & --- & --- & $5,231 \mathrm{~h}$ & $3,923 d$ \\
\hline ApEn=0,10659 & & & & & 3,923d & \\
\hline UR\% Potes & --- & --- & --- & --- & --- & $18,896 \mathrm{~h}$ \\
\hline $\mathrm{ApEn}=0,12525$ & & & & & & $6,726 \mathrm{~h}$ \\
\hline
\end{tabular}

Nas colônias fechadas a temperatura e a umidade relativa na região da cria continuam apresentando 1 ou 2 periodicidades similares às da câmara climática, mas também apresentam ritmicidades exclusivas, próximas a 24h e 12h, indicando um possível ritmo endógeno na regulação de temperatura e umidade relativa dentro da colônia. Esses ritmos na região da cria parecem influenciar e/ou "arrastar" os ritmos de temperatura na região dos potes de alimento.

\section{COLÔNIAS TRATADAS COM ALPRENOLOL OU MIANSERINA}

\section{COLÔNIAS ABERTAS - ALPRENOLOL/MIANSERINA}

Nas figuras 21 a 23 e tabelas 15 a 17 estão apresentados os resultados da exposição de colônias a bloqueadores Alprenolol e Mianserina. 
Tabela 15. Valores de ApEn e periodicidades detectadas por Análise Espectral de séries temporais de temperatura e umidade relativa em colônia aberta tratada com Alprenolol $\mathbf{1 0}^{-2} \mathbf{M}$. Séries temporais na figura 21.

\begin{tabular}{|c|c|c|c|c|c|c|c|}
\hline & \multirow[t]{2}{*}{ Amb } & UR\% & \multirow[t]{2}{*}{ Lumin } & \multirow[t]{2}{*}{ Cria } & \multirow[t]{2}{*}{ Potes } & \multirow{2}{*}{$\begin{array}{l}\text { UR\% } \\
\text { Cria }\end{array}$} & \multirow{2}{*}{$\begin{array}{l}\text { UR\% } \\
\text { Potes }\end{array}$} \\
\hline & & $\mathrm{Amb}$ & & & & & \\
\hline $\mathrm{Amb}$ & $23,946 h$ & $23,946 h$ & $23,946 h$ & $23,946 h$ & $23,946 h$ & $4,005 d$ & $4,005 d$ \\
\hline $\mathrm{ApEn}=$ & $4,005 d$ & $4,005 d$ & $12,025 h$ & $12,025 h$ & $12,025 h$ & $23,946 h$ & $12,025 \mathrm{~h}$ \\
\hline \multirow[t]{4}{*}{0,23797} & $12,025 \mathrm{~h}$ & $12,025 \mathrm{~h}$ & $6,400 \mathrm{~h}$ & $8,735 h$ & & $12,025 h$ & \\
\hline & $6,400 h$ & $8,735 h$ & $7,388 \mathrm{~h}$ & & & & \\
\hline & $7,388 h$ & $7,388 \mathrm{~h}$ & $4,005 d$ & & & & \\
\hline & $8,735 h$ & $6,400 \mathrm{~h}$ & & & & & \\
\hline $\mathrm{UR} \% \mathrm{Amb}$ & & $4,569 \mathrm{~h}$ & & & & $4,569 h$ & $4,569 h$ \\
\hline \multicolumn{8}{|l|}{$\mathrm{ApEn}=$} \\
\hline \multicolumn{8}{|l|}{0,22545} \\
\hline Luminosidade & & & $5,051 \mathrm{~h}$ & $5,051 \mathrm{~h}$ & & & \\
\hline \multirow[t]{2}{*}{$A p E n=0,28266$} & & & $3,557 \mathrm{~h}$ & $4,171 \mathrm{~h}$ & & & \\
\hline & & & $4,171 \mathrm{~h}$ & $3,557 \mathrm{~h}$ & & & \\
\hline Cria & & & & $3,858 d$ & $3,858 d$ & & \\
\hline \multicolumn{8}{|l|}{$\mathrm{ApEn}=0,46562$} \\
\hline Potes & & & & & $8,005 h$ & $8,005 h$ & $8,005 h$ \\
\hline \multirow[t]{2}{*}{$A p E n=0,10847$} & & & & & $4,797 \mathrm{~h}$ & $5,999 h$ & \\
\hline & & & & & $5,999 h$ & & \\
\hline UR\% Cria & & & & & & $5,332 \mathrm{~h}$ & $5,332 h$ \\
\hline$A p E n=0,26772$ & & & & & & $6,859 \mathrm{~h}$ & \\
\hline UR\% Potes & & & & & & & $15,96 \mathrm{~h}$ \\
\hline$A p E n=0,20024$ & & & & & & & \\
\hline
\end{tabular}

Tabela 16. Valores de ApEn e periodicidades detectadas por Análise Espectral de séries temporais de temperatura e umidade relativa em colônia aberta tratada com Alprenolol $\mathbf{1 0}^{-2} \mathbf{M}$, com registro de atividade de vôo. Séries temporais na figura 22.

\begin{tabular}{lllllllll}
\hline & Amb & UR\% & Lumin & Cria & Potes & UR\% & UR\% & Vôo \\
& & Amb & & & & Cria & Potes & \\
\hline Amb & $\mathbf{2 6 , 9 6 9 h}$ & $\mathbf{2 6 , 9 6 9 h}$ & $\mathbf{2 6 , 9 6 9 h}$ & $\mathbf{2 6 , 9 6 9 h}$ & $\mathbf{2 6 , 9 6 9 h}$ & $\mathbf{2 6 , 9 6 9 h}$ & $\mathbf{2 6 , 9 6 9 h}$ & $\mathbf{2 6 , 9 6 9 h}$ \\
ApEn = 0,42135 & $\mathbf{1 1 , 5 7 4 h}$ & & $\mathbf{1 1 , 5 7 4 h}$ & $\mathbf{3 , 8 5 8 d}$ & $\mathbf{3 , 8 5 8 d}$ & $\mathbf{1 1 , 5 7 4 h}$ & $\mathbf{8 , 0 9 8 h}$ & $\mathbf{1 1 , 5 7 4 h}$ \\
& $\mathbf{3 , 8 5 8 d}$ & & $\mathbf{8 , 0 9 8 h}$ & & $\mathbf{1 1 , 5 7 4 h}$ & $\mathbf{8 , 0 9 8 h}$ & $\mathbf{1 1 , 5 7 4 h}$ & $\mathbf{8 , 0 9 8 h}$ \\
& $\mathbf{8 , 0 9 8 h}$ & & & & $\mathbf{8 , 0 9 8 h}$ & & & \\
& & & & & & & & \\
UR\% Amb & & $\mathbf{1 3 , 4 8 4 h}$ & & $\mathbf{1 3 , 4 8 4 h}$ & & & & $\mathbf{6 , 2 2 8 h}$ \\
ApEn= 0,57791 & & $\mathbf{6 , 2 2 8 h}$ & & $\mathbf{6 , 2 2 8 h}$ & & & & \\
\end{tabular}




\begin{tabular}{|c|c|c|c|c|c|c|}
\hline Luminosidade & $5,787 \mathrm{~h}$ & & $6,742 \mathrm{~h}$ & $5,787 \mathrm{~h}$ & $5,787 \mathrm{~h}$ & $4,765 h$ \\
\hline \multirow{2}{*}{$A p E n=0,28201$} & $6,742 \mathrm{~h}$ & & & & $6,742 \mathrm{~h}$ & $5,787 \mathrm{~h}$ \\
\hline & $4,765 h$ & & & & & \\
\hline Cria & & $7,368 \mathrm{~h}$ & & & & \\
\hline $\mathrm{ApEn}=0,6971$ & & $4,502 \mathrm{~h}$ & & & & \\
\hline \multicolumn{7}{|l|}{ Potes } \\
\hline \multicolumn{7}{|l|}{$A p E n=0,41439$} \\
\hline \multicolumn{7}{|l|}{ UR\% Cria } \\
\hline \multicolumn{7}{|l|}{$A p E n=0,65303$} \\
\hline UR\% Potes & & & & & $8,989 \mathrm{~h}$ & \\
\hline \multicolumn{7}{|l|}{$\mathrm{ApEn}=0,46275$} \\
\hline \multicolumn{7}{|l|}{ Vôo } \\
\hline ApEn=0,32998 & & & & & & \\
\hline
\end{tabular}

Tabela 17. Valores de ApEn e periodicidades detectadas por Análise Espectral de séries temporais de temperatura e umidade relativa em colônia aberta tratada com Mianserina $\mathbf{1 0}^{-3} \mathbf{M}$. Séries temporais na figura 23.

\begin{tabular}{|c|c|c|c|c|c|c|c|}
\hline & $\mathrm{Amb}$ & $\begin{array}{l}\text { UR\% } \\
\text { Amb }\end{array}$ & Lumin & Cria & Potes & $\begin{array}{l}\text { UR\% } \\
\text { Cria }\end{array}$ & $\begin{array}{l}\text { UR\% } \\
\text { Potes }\end{array}$ \\
\hline $\mathrm{Amb}$ & $23,148 \mathrm{~h}$ & $5,787 d$ & $8,417 h$ & 5,787d & $5,787 d$ & $5,787 d$ & $5,787 d$ \\
\hline \multirow[t]{7}{*}{$\operatorname{ApEn}=0,22519$} & $27,778 \mathrm{~h}$ & $6,46 h$ & $5,787 d$ & & $14,620 \mathrm{~h}$ & $4,085 h$ & \\
\hline & $5,787 d$ & & $4,085 h$ & & $8,417 h$ & & \\
\hline & $12,077 \mathrm{~h}$ & & & & & & \\
\hline & $14,620 h$ & & & & & & \\
\hline & $6,46 h$ & & & & & & \\
\hline & $8,417 h$ & & & & & & \\
\hline & $4,085 h$ & & & & & & \\
\hline $\mathrm{UR} \% \mathrm{Amb}$ & & $22,401 \mathrm{~h}$ & $22,401 h$ & $22,401 \mathrm{~h}$ & $12,183 \mathrm{~h}$ & $22,401 \mathrm{~h}$ & $22,401 h$ \\
\hline \multirow[t]{3}{*}{$\mathrm{ApEn}=0,24601$} & & $12,183 \mathrm{~h}$ & $12,183 h$ & $12,183 h$ & & $12,183 h$ & $12,183 h$ \\
\hline & & $10,326 h$ & $10,326 h$ & $7,891 \mathrm{~h}$ & & & \\
\hline & & $7,891 \mathrm{~h}$ & & & & & \\
\hline Luminosidade & & & $6,105 h$ & $6,105 h$ & & $6,105 h$ & $6,105 h$ \\
\hline$A p E n=0,40655$ & & & $7,068 \mathrm{~h}$ & & & & \\
\hline Cria & & & & $4,97 \mathrm{~h}$ & & & \\
\hline $\mathrm{ApEn}=0,72566$ & & & & & & & \\
\hline
\end{tabular}


Potes

$26,709 h$

ApEn=0,093435

UR\% Cria

33,548h 33,548h

ApEn=0,24911

$\mathbf{9 , 5 7 8 h} \quad \mathbf{9 , 5 7 8 h}$

UR\% Potes

ApEn=0,16801

As periodicidades na região da cria se relaciona com as condições ambientais (temperatura, umidade relativa e luminosidade), mas não se sabe quais destas 3 seria o sincronizador principal dos ritmos. Além disso, a temperatura na região da cria apresentava periodicidades semelhantes às periodicidades exclusivas da luminosidade e UR\% Ambiente, o que não ocorria nas colônias abertas não tratadas.

\section{COLÔNIAS FECHADAS - ALPRENOLOL/MIANSERINA}

Tabela 18. Valores de ApEn e periodicidades detectadas por Análise Espectral de séries temporais de temperatura e umidade relativa em colônia mantida fechada e tratada com Mianserina 10-3M. Séries temporais na figura 24.

\begin{tabular}{|c|c|c|c|c|c|c|}
\hline & Câmara & $\begin{array}{c}\text { UR\% } \\
\text { Câmara }\end{array}$ & Cria & Potes & UR\% Cria & UR\% Potes \\
\hline T Câmara & 6,502d & 6,502d & 6,502d & 6,502d & 6,502d & 6,502d \\
\hline \multirow[t]{4}{*}{ ApEn $=0,14948$} & $39,09 \mathrm{~h}$ & 17,361h & & & & \\
\hline & 17,361h & & & & & \\
\hline & $9,781 \mathrm{~h}$ & & & & & \\
\hline & $8,218 \mathrm{~h}$ & & & & & \\
\hline UR\% Câm & --- & $31,281 \mathrm{~h}$ & $13,041 h$ & $13,041 h$ & $31,281 \mathrm{~h}$ & \\
\hline \multirow[t]{5}{*}{$A p E n=1,2197$} & & $19,562 \mathrm{~h}$ & & $11,156 h$ & $13,041 \mathrm{~h}$ & \\
\hline & & $11,156 h$ & & $8,680 h$ & & \\
\hline & & $7,104 \mathrm{~h}$ & & & & \\
\hline & & $8,680 h$ & & & & \\
\hline & & $13,041 h$ & & & & \\
\hline Cria & --- & --- & $22,401 h$ & $22,401 h$ & $22,401 \mathrm{~h}$ & $22,401 \mathrm{~h}$ \\
\hline \multirow[t]{3}{*}{ ApEn=0,79677 } & & & $12,025 \mathrm{~h}$ & & $7,824 h$ & $12,025 h$ \\
\hline & & & $14,245 \mathrm{~h}$ & & & \\
\hline & & & $7,824 h$ & & & \\
\hline Potes & --- & --- & --- & $5,211 \mathrm{~h}$ & & \\
\hline $\mathrm{ApEn}=0,18666$ & & & & $5,787 \mathrm{~h}$ & & \\
\hline
\end{tabular}




\begin{tabular}{ccccccc} 
UR\% Cria & --- & --- & -- & -- & $2,171 \mathrm{~d}$ & \\
ApEn=0,34773 & & & & & $7,447 \mathrm{~h}$ & \\
UR\% Potes & --- & --- & --- & --- & -- & $15,605 \mathrm{~h}$ \\
ApEn=0,057711 & & & & & & $6,012 \mathrm{~h}$ \\
\hline
\end{tabular}

Tabela 19. Valores de ApEn e periodicidades detectadas por Análise Espectral de séries temporais de temperatura e umidade relativa em colônia mantida fechada e tratada com Alprenolol 10-2M. Séries temporais na figura 25.

\begin{tabular}{|c|c|c|c|c|c|c|}
\hline & Câmara & $\begin{array}{c}\text { UR\% } \\
\text { Câmara }\end{array}$ & Cria & Potes & UR\% Cria & UR\% Potes \\
\hline Câmara & $5,787 \mathrm{~d}$ & & & $4,848 h$ & & \\
\hline $\mathrm{ApEn}=0,54382$ & $\begin{array}{c}19,425 \mathrm{~h} \\
10,562 \mathrm{~h} \\
29,087 \mathrm{~h} \\
\mathbf{4 , 8 4 8 h}\end{array}$ & & & & & \\
\hline $\begin{array}{c}\text { UR\% Câm } \\
\text { ApEn=0,80743 }\end{array}$ & --- & \begin{tabular}{r|}
$\mathbf{4 , 8 4 3 d}$ \\
$14,543 \mathrm{~h}$ \\
$\mathbf{8 , 3 1 7 h}$ \\
$\mathbf{4 , 6 5 3 h}$
\end{tabular} & $\begin{array}{l}8,317 \mathrm{~h} \\
4,653 \mathrm{~h}\end{array}$ & $14,543 \mathrm{~h}$ & $\begin{array}{l}8,317 \mathrm{~h} \\
4,843 \mathrm{~d}\end{array}$ & $\begin{array}{l}8,317 \mathrm{~h} \\
4,843 \mathrm{~d}\end{array}$ \\
\hline $\begin{array}{c}\text { Cria } \\
\text { ApEn }=0,44315\end{array}$ & --- & --- & $\begin{array}{c}23,343 h \\
12,919 h \\
6,118 h\end{array}$ & $23,343 h$ & $\begin{array}{l}23,343 h \\
12,919 h\end{array}$ & $23,343 h$ \\
\hline $\begin{array}{c}\text { Potes } \\
\text { ApEn }=0,12515\end{array}$ & --- & --- & --- & $\begin{array}{c}4,787 \mathrm{~d} \\
11,625 \mathrm{~h} \\
7,759 \mathrm{~h}\end{array}$ & & \\
\hline $\begin{array}{c}\text { UR\% Cria } \\
\text { ApEn=0,4667 }\end{array}$ & --- & --- & --- & --- & $5,014 \mathrm{~h}$ & \\
\hline $\begin{array}{c}\text { UR\% Potes } \\
\text { ApEn }=0,097547\end{array}$ & --- & --- & --- & --- & --- & $\begin{array}{c}38,796 \mathrm{~h} \\
5,291 \mathrm{~h} \\
8,960 \mathrm{~h}\end{array}$ \\
\hline
\end{tabular}

Nas colônias fechadas, tratadas com Mianserina e Alprenolol, as periodicidades das séries temporais na região dos discos de cria estão relacionadas à temperatura da câmara em no máximo 1 periodicidade.As demais periodicidades são exclusivas da cria ou relacionadas à UR\% da câmara, o que não ocorria nas colônias não tratadas. .

\section{ATIVIDADE INTERNA}

Concomitantemente com a coleta de séries temporais de umidade e temperatura, foram realizados alguns testes a fim de se eleger qual a melhor forma de detectar a variação da atividade 
interna ao longo dos dias. O primeiro teste foi com o uso de lâmpada incandescente logo acima da colônia, próximo à região onde se encontra a cria (figura 4). Este tipo de registro, apesar de "flagrar" a atividade interna colonial, apresenta alguns problemas. Um deles é o fato de a qualidade da imagem não ser muito boa, devido à barreira constituída pelo acrílico. Outro problema é que, durante a noite, ao se retirar o pano escuro para fotografia, artificialmente se ilumina toda a colônia, que naturalmente estaria em escuro total neste horário. Um terceiro problema é que com a lâmpada há o aumento proposital da temperatura colonial (na tentativa de evitar que as operárias reconstruam o invólucro), e então as séries temporais, assim obtidas, acabam representando dados artificiais (figura 26).

$\mathrm{Na}$ figura 26 pode ser observado que a temperatura medida logo abaixo da lâmpada incandescente (representada como "temperatura abaixo da lâmpada") é cerca de $4-5^{\circ} \mathrm{C}$ acima da temperatura ambiente, medida distante da lâmpada. Além disso, a temperatura na região dos potes de alimento é mais elevada do que aquela que seria obtida normalmente. Assim, uma vez que se pretende analisar a atividade interna com a concomitante obtenção de séries temporais, tal arranjo não seria o ideal, uma vez que a temperatura na colônia fica artificialmente alterada.

Outra opção foi a colocação de câmera infravermelha dentro da colônia, próxima a região dos discos de cria e potes de alimento (figura 5). Foi realizada uma série de experimentos preliminares para obtenção de melhores imagens, com testes de qual a melhor fonte (para ligação da câmera de vídeo) que fornecesse corrente suficiente e que tivesse potência adequada, as quais influenciam na qualidade da imagem. Após a colocação dos sensores de temperatura e umidade, a câmera era direcionada para a área que se desejava filmar no experimento, como por exemplo, exposto na figura 5A e 5B. As imagens obtidas eram em preto e branco devido ao escuro total. Nas figuras 5C e 5D estão exemplos de imagens de atividade interna obtida durante o dia (9h e 13h) e nas figuras 5E e 5F estão imagens obtidas de madrugada (1h e 3h). Por inspeção visual do vídeo nota-se que durante o dia o número de abelhas e a sua movimentação entre os discos de cria são mais elevados do que de madrugada. Além disso, à noite as abelhas que mais frequentemente passam entre a cria são abelhas jovens (com pelos torácicos mais claros).

\section{DISCUSSÃO}

\section{COLÔNIAS ABERTAS}

As diferentes periodicidades detectadas nas séries temporais poderiam estar ligadas às variações ambientais (temperatura, umidade relativa, pressão etc.) e de disponibilidades de recursos, além da possível ritmicidade endógena arrastada pelos ciclos ambientais. Ao analisar visualmente as séries temporais obtidas nas colônias abertas, verifica-se que as temperaturas na 
região dos discos de cria são mantidas mais elevadas do que na região dos potes de alimento e no ambiente externo, com amplitudes menores, sugerindo controle de temperatura próximo à cria.

Há uma série de fatores que podem influenciar o padrão rítmico das séries temporais de temperatura na região dos discos de cria, como a própria ritmicidade da taxa metabólica das abelhas, além do fotoperíodo, as flutuações de temperatura ambiente e umidade relativa, e os aspectos comportamentais de atividade de vôo e forrageio por recursos. As colônias abertas estão expostas a inúmeros fatores, mensuráveis ou não, que podem afetar a tomada de decisões individuais, coloniais e as estratégias de divisão de trabalho dentro da colônia.

A análise espectral aplicada às séries temporais revelou que a temperatura ambiente, a umidade relativa e a luminosidade são variáveis ambientais que apresentam periodicidades semelhantes, já que estão todas submetidas aos ciclos geofísicos do ambiente. Estas três variáveis medidas parecem influenciar ou arrastar as séries temporais coloniais. Todavia, apesar de ser sugerido que o ciclo claro/escuro (MOORE, 2001) e a temperatura (SAUNDERS, 2002) são importantes Zeitgebers em abelhas, é difícil afirmar qual deles é o maior responsável neste caso, já que se interrelacionam. Há outros fatores ambientais que podem influenciar séries temporais de temperatura e umidade relativa que não foram quantificados diretamente neste trabalho, tais como o fotoperíodo, pressão, velocidade do vento, quantidade de chuva, entre outros.

Em abelhas, não se sabe como cada operária reage na termorregulação, se elas formam uma resposta termorregulatória de grupo, com termogênese coordenada, ou se a termorregulação colonial é subproduto da produção individual de calor (BÜDEL, 1968; HEINRICH, 1996; WEINDELMÜLLER et al, 2002). Grupos de forrageadoras poderiam medir todos os parâmetros relevantes e processar informações relacionadas aos recursos ambientais e necessidades da colônia a fim de aperfeiçoar as suas decisões de termorregulação e forrageio (OSTER e WILSON, 1978; SCHMID-HEMPEL et al, 1985). Em ambientes instáveis e variáveis, pode haver vantagem em fazer decisões rápidas e, além do mais, diversos mecanismos podem ter sido selecionados e permitem que as sociedades animais tenham respostas adaptativas a um meio ambiente complexo, apesar da simplicidade de algumas decisões individuais (CAMAZINE et al, 2001; DETRAIN e DENEUBOURG, 2002).

\section{PROCESSOS DENTRO DAS COLÔNIAS}

Além das periodicidades coloniais similares às ambientais, foram identificadas também periodicidades exclusivamente coloniais, as quais ocorrem apenas nas séries temporais de temperatura e umidade dentro da colônia.

É possível que haja relações entre a atividade interna colonial e a diminuição da temperatura na região dos discos de cria, principalmente de madrugada a partir da 1 h. Por inspeção visual dos 
vídeos de atividade interna notou-se que durante o dia o número de abelhas e a sua movimentação entre os discos de cria são mais elevados do que de madrugada. $\mathrm{O}$ registro de atividade interna pode ajudar a entender esse processo rítmico, e se durante a noite as abelhas estariam em um estado semelhante ao "sono", como sugerido por Kaiser (1988) e Sauer et al (1998, 2003, 2004), com base em investigações eletrofisiológicas, eletromiográficas e comportamentais em Apis mellifera. Mas devido a problemas com a análise das imagens, seus resultados não foram expostos e considerados neste trabalho, e assim não respondendo adequadamente questões relativas à variação diária da atividade interna colonial.

Uma vez que a termorregulação nos discos de cria é cíclica, seria esta ritmicidade uma necessidade fisiológica da cria ou um subproduto da divisão de trabalho na colônia? Dentro das colônias há diversas atividades que podem influenciar a ritmicidade das operárias e, consequentemente, a termorregulação colonial. As alterações na termorregulação colonial em colônias abertas poderiam ser, além de resultado de influências ambientais, um subproduto das modificações na divisão de trabalho nesse horário. Em tal contexto se insere a questão da ritmicidade no processo denominado POP, que se constitui em uma cadeia de eventos integrados, com a construção de novas células de cria, seguida pelo aprovisionamento com alimento, a oviposição pela rainha e a operculação das células. É um processo cíclico, rigidamente marcado por intervalos definidos e específicos para cada espécie (SOMMEIJER et al, 1984; ZUCCHI, 1993; BELLUSCI, 2003), e pode estar relacionado a ritmos ultradianos em abelhas (TEIXEIRA, 2003, 2006).

\section{OUTROS FATORES AMBIENTAIS E COLONIAIS}

Nas colônias abertas foi observado, pelos gráficos e pelas periodicidades nas séries temporais, que os valores de periodicidades referentes à região dos potes de alimento são similares principalmente às da temperatura ambiente e também da temperatura e umidade relativa na região dos discos de cria. No caso das séries temporais dos potes de alimento, elas parecem sofrer mais influências da temperatura ambiental, estando quase sempre em valores intermediários entre a temperatura ambiental e a dos discos de cria.

Além da temperatura, a umidade relativa é um fator que pode influenciar o comportamento colonial. A umidade relativa do ar pode influenciar a atividade de vôo em diversas espécies de abelhas sem ferrão, como em Tetragonisca angustula (IWANA, 1977), Plebeia emerina (KLEINERT-GIOVANINNI, 1982), Melipona quadrifasciata (GUIBU e IMPERATRIZFONSECA, 1984) e em Melipona bicolor (HILÁRIO et al, 2000). A respeito da umidade relativa do ar, Kleinert-Giovannini (1982) verificou que a atividade de vôo em meliponíneos é controlada por uma complexa interação entre vários fatores climáticos e que níveis altos de umidade relativa 
são fatores limitantes de sua atividade externa. Guibu e Imperatriz-Fonseca (1984) encontraram uma correlação positiva entre a atividade de vôo e umidade relativa em Melipona quadrifasciata, tendo sido obtidos resultados semelhantes para Melípona bicolor. Estas duas espécies vivem em locais de alta umidade relativa, com neblina abundante (HILÁRIO et al, 2000)

Um dos primeiros trabalhos que discutem a umidade relativa dentro de ninhos de Hymenoptera foi o de Klingner et al. (2005), em seu estudo com vespas. O regime de umidade e as elevadas temperaturas no ninho resultam em uma alta umidade relativa colonial com reduzida flutuação circadiana (KLINGNER et al., 2005), ressaltando a importância da manutenção de níveis controlados de umidade relativa dentro das colônias.

Na região dos discos de cria parece haver controle da umidade relativa, a qual pode ser favorecida pela presença do invólucro ao redor dos discos de cria, o mesmo ocorrendo com o controle de temperatura nesta região. A umidade relativa na região dos potes de alimento, geralmente mais elevada, pode se dever à perda de água pelos insetos, oralmente, transcutaneamente e através da respiração (PRANGE, 1996), e também à evaporação de substâncias líquidas do ninho, como o mel estocado nos potes de alimento.

\section{ATIVIDADE DE VÔO E MOVIMENTACÃO DE FORRAGEADORAS}

A termorregulação colonial pode também estar relacionada à atividade de vôo e movimentação de operárias. Assim como obtido com Cria e Potes, as periodicidades das séries temporais de atividade de vôo estão relacionadas principalmente às condições ambientais como a temperatura, umidade relativa e luminosidade. Também podem estar relacionadas a processos coloniais, baseados nas mesmas periodicidades detectadas com a região dos discos de cria, principalmente no outono/inverno, quando as temperaturas ambientais tendem a ser menores. Tal condição requer esforços termorregulatórios dentro da colônia e a necessidade de reservas energéticas na colônia para manutenção da temperatura em níveis controlados, podendo afetar as estratégias de vôo.

Tem sido sugerido que a atividade de vôo das abelhas é altamente dependente das condições ambientais, e esta influência é extensamente documentada na literatura, sobre o comportamento de abelhas. Pode ser influenciada por fatores climáticos como temperatura, luminosidade, umidade relativa, chuva e vento (IWANA, 1977; KLEINERT-GIOVANNINI e IMPERATRIZ-FONSECA, 1986; HILÁRIO e IMPERATRIZ-FONSECA, 2002; CONTRERA et al, 2005), condições internas da colônia (KLEINERT-GIOVANNINI, 1982; HILÁRIO et al, 2000), tamanho das abelhas (IMPERATRIZ-FONSECA et al, 1985; HILÁRIO et al, 2001), disponibilidade de recursos florais (PIERROT e SCHILINDWEIN, 2003), diapausa reprodutiva (PICK e BLICHTEIN, 2002), entre outros. A sazonalidade também pode afetar a atividade de vôo, por exemplo, com relação ao 
fotoperíodo e às diferenças sazonais de temperatura e umidade relativa do ambiente, levando a diferentes estratégias sazonais.

O fluxo de entrada e saída de abelhas do ninho, com o tórax aquecido, poderia contribuir para o aumento da temperatura na região da cria, de manhã, já que, nas colônias testadas, o túnel de ingresso na colônia, do ambiente externo para o interior da colônia, é próximo à região da cria. Somado a isto, há também o aumento da temperatura ambiente, mas este parece não ser o único fator, já que nas colônias fechadas a característica rítmica da temperatura nos discos de cria parece se manter. Segundo Büdel (1968) a presença de forrageadoras de Apis mellifera eleva a temperatura colonial, da região próxima ao orifício de entrada, mesmo durante a noite. $\mathrm{O}$ autor também mencionou que o movimento das forrageadoras chegando e saindo da colônia provoca pequenas correntes de ar quente no orifício de entrada. Em abelhas Apis saindo do ninho, a temperatura torácica de forrageadoras foi maior do que a de abelhas retornando (HEINRICH, 1979b). Mas em operárias de Melipona compressipes fasciculata Pacheco e Kerr (1989) sugerem temperaturas torácicas similares nas abelhas que entravam e saíam da colônia.

Nas colônias de abelhas melíferas as forrageadoras são primariamente localizadas na periferia do ninho (SEELEY e TOWNE, 1992; SEELEY, 1995), onde há mudanças de temperatura periódicas e diárias, de aproximadamente $10^{\circ} \mathrm{C}$ (FAHRENHOLZ et al, 1989). Segundo Fuchikawa e Shimizu (2007) essas observações podem indicar que condições térmicas localizadas resultantes da produção de calor podem funcionar como Zeitgebers sincronizadores dos ritmos circadianos de abelhas individuais dentro da colônia.

Os valores de ApEn de atividade de vôo estão entre os menores, comparados aos das demais séries temporais analisadas, indicando que apresentam maior regularidade e maior previsibilidade do que as séries de temperatura e umidade relativa coloniais, por exemplo, registrados com o mesmo intervalo de amostragem.

A atividade de vôo e forrageio por recursos tem sido pesquisada em vários gêneros de abelhas indígenas sem ferrão, como Partamona (AZEVEDO, 1997), Melipona (KLEINERTGIOVANNINI, 1982; GUIBU e IMPERATRIZ-FONSECA, 1984; BUIJN e SOMMEIJER, 1997; HILÁRIO et al, 2000), Trigona (HEARD e HENDRIKZ, 1993), Tetragonisca (IWANA, 1977; IMPERATRIZ-FONSECA e AGUILAR, 1984), Plebeia (OLIVEIRA, 1973; KLEINERTGIOVANNINI, 1982; IMPERATRIZ-FONSECA et al, 1985; HILÁRIO et al, 2001), Paratrigona (MOUGA, 1984), Frieseomellita (TEIXEIRA, 2003) e Scaptotrigona (MECCA, 2003).

Segundo Guibu e Imperatriz-Fonseca (1984), para M. quadrifasciata, o horário ótimo de atividade de vôo é das 7 às $11 \mathrm{~h}$, quando é maior a tendência de coleta de alimento. Resultados semelhantes também foram obtidos neste trabalho, com maior atividade de vôo entre $6 \mathrm{~h}$ e $12 \mathrm{~h}$. $\mathrm{O}$ período no qual a temperatura na cria tende a aumentar (início da manhã) parece coincidir com os 
horários de maior atividade de vôo, quando haveria menor número de forrageadoras (que termorregulam) na colônia, e também provavelmente maior trânsito e movimentação de operárias, quando há aumento da temperatura na região dos discos de cria.

Segundo Heinrich e Raver (1972), os custos energéticos são maiores para as espécies de abelhas (geralmente as de maior tamanho) que deixam o ninho mais cedo ou em temperaturas mais baixas, mas a recompensa calórica é maior do que para as abelhas que deixam o ninho em horários mais tardios. Bruijn e Sommeijer (1997) sugerem que o pico de forrageio durante a manhã, em Melipona, pode ser considerado adaptativo, uma vez que, nas regiões tropicais, a disponibilidade de pólen não é um fator limitante, mas uma competição intra-específica pode ocorrer, envolvendo colônias fracas, médias e fortes.

\section{CONTROLE DE TEMPERATURA DENTRO DO NINHO}

Há diversos motivos para o controle da temperatura e da umidade relativa na região dos discos de cria, como a importância para o sucesso do desenvolvimento da cria e, assim, para a sobrevivência da colônia, envolvendo também escolha de local de nidificação mais adequado, que ofereça possibilidades de manutenção do microclima estável para a cria em desenvolvimento.

A termorregulação colonial poderia ser importante, também, para a sobrevivência de abelhas jovens e de larvas. As abelhas jovens são, provavelmente, ectotérmicas no sentido estrito do termo, com temperatura corpórea dependente da temperatura ambiente. Assim, as operárias jovens se beneficiariam do controle de temperatura realizado pelas operárias mais maduras. Além disso, uma série de características das abelhas jovens, com possíveis níveis menores de octopamina e de hormônio juvenil (WAGENER-HULME et al, 1999; FAHRBACH, 1997; HUANG et al, 1994; ROBINSON et al, 1989; FAHRBACH et al, 1997 [A mellifera]), indicam que os músculos de vôo destas abelhas ainda não estão maduros para a termogênese e vôo. Mas estes dados a respeito de hormônio juvenil se referem a A. mellifera, e o padrão poderia ser diferente em $M$. quadrifasciata (SANTANA e HARTFELDER, 2002).

Conhecimentos a respeito da idade das abelhas que termorregulam na região dos discos de cria, e se estas abelhas termorreguladoras desempenham exclusivamente essa função, ou se elas também realizam outras atividades, como forrageio, seriam interessantes para auxiliar na resposta a diversas questões a respeito de insetos sociais. É possível que as operárias termorreguladoras sejam as de idade média, nas quais os músculos de vôo já tenham se desenvolvido o suficiente para gerar calor. Mesmo que as forrageadoras não participem ativamente do processo de termorregulação colonial (por estarem fora da colônia boa parte do tempo), elas podem fornecer, para as operárias dentro da colônia, informações a respeito das condições ambientais. Um dos processos poderia ser, por exemplo, o sugerido por Farina e Wainselboim (2001), que demonstraram que forrageadoras de 
Apis mellifera fornecem calor às outras operárias durante os contatos trofaláticos, transmitindo informações. Não se sabe como cada operária reage na termorregulação, se elas formam uma resposta termorregulatória de grupo, com termogênese coordenada, ou se a termorregulação colonial é subproduto da produção individual de calor (BÜDEL, 1968; HEINRICH, 1996; WEINDELMÜLLER et al, 2002).

Abelhas A. mellifera mantém elevadas temperaturas dentro dos ninhos também para facilitar a defesa contra predadores e pragas, de acordo com Starks et al (2000). Esses autores relatam que as abelhas geram "febre" na região da cria em resposta a infecção colonial pelo patógeno Ascophaera apis, que é termo-sensível. Esta resposta ocorre antes que as larvas sejam mortas pela infecção e é um exemplo notável de evolução convergente entre este organismo e outros animais que apresentam estado febril diante a presença de patógenos (STARKS et al, 2000).

\section{COLÔNIAS FECHADAS E RITMICIDADE}

Nas colônias fechadas a temperatura e a umidade relativa na região da cria continuam apresentando uma ou duas periodicidades similares às da câmara climática, mas também ritmicidades exclusivas, próximas a $24 \mathrm{~h}$ e $12 \mathrm{~h}$, indicando um possível ritmo endógeno na regulação de temperatura e umidade relativa dentro da colônia. Em condições controladas de temperatura e escuro, as séries temporais de temperatura, umidade relativa e taxa metabólica colonial podem refletir a ritmicidade endógena da espécie, com relação a estas variáveis, uma vez que os seus ritmos não estão sob influência de ciclos ambientais Zeitgebers, como ocorre em colônias abertas. Tais padrões poderiam integrar a expressão de rimos de operárias individualmente (segundo a hipótese da "operária individual" proposta por HEINRICH [1985]), e/ou da colônia como um “superorganismo" (SOUTWICK e MUGAAS, 1971). Os experimentos deste capítulo não são capazes de diferenciar entre estas hipóteses, pois não há abordagem do comportamento individual de cada abelha.

Dentro das colônias, na região dos potes de alimento, os ritmos de temperatura e umidade relativa poderiam ser influenciados e/ou arrastados pelos ritmos na região da cria. Outra hipótese é que a temperatura na região dos potes de alimento seja um subproduto do fluxo de calor dentro do ninho. Tem sido detectada na literatura ritmicidade na termorregulação colonial de diversas abelhas sem ferrão, principalmente na região onde se encontra a cria, ressaltando a importância do controle de temperatura nesta região da colônia. Por exemplo, Moo et al (2000) em Melipona beecheii, Hilario e Imperatriz-Fonseca (2002) em Melipona bicolor, Almeida (2004) em Frieseomelitta varia, Proni e Hebling (1996) em Tetragonisca angustula fiebrigi e Tetragonisca angustula angustula.

Evidências de termorregulação também foram relatadas por Hilario e Imperatriz-Fonseca (2002), que investigaram como colônias de Melipona bicolor se comportam em relação à 
termorregualação em condições constantes de temperatura e escuro. Ritmos de temperatura foram facilmente visualizados em todas as colônias testadas, com maiores picos de temperatura durante a noite. Estimativas do período em livre curso foram 23, $9+2,24.1+3,4,22,8+2.5$ e 22,8+1,7, para cada uma das quatro colônias testadas. Os resultados desses autores indicam a existência de ritmo circadiano em relação à produção de calor em Melipona bicolor. Almeida (2004) relata evidências de termorregulação nas colônias de Frieseomelitta varia e um padrão rítmico na oscilação da temperatura no interior do ninho, mais particularmente na região onde se encontra a cria, com padrão rítmico de geração de calor pelas abelhas que participam de funções junto à cria.

Para a confirmação da existência do ritmo endógeno seriam interessantes experimentos e análises adicionais, como curvas de resposta de fase, conforme também sugerido por Hilário e Imperatriz-Fonseca (2002).

As coletas de séries temporais com colônias fechadas não puderam ser realizados por muito mais do que cinco dias consecutivos devido à diminuição das reservas alimentares e menor entrada de energia para a manutenção da capacidade termorregulatória, que é dispendiosa.

Ao se realizar uma análise espectral é normal associar-se periodicidades a picos do periodograma, mas nem todos os picos deste estimador espectral seriam necessariamente causados pela existência de termos harmônicos, os mesmo podendo ocorrer devido a flutuações aleatórias. Assim, é necessário decidir se um pico do periodograma implica na presença de um termo estritamente periódico na série observada, ou não, surgindo a utilização de testes de hipótese estatísticos para detectar a existência de tais componentes (BENEDITO-SILVA, 1993). Os primeiros pesquisadores a se preocuparem com o problema dos testes de hipótese estatísticos para detectar a existência de componentes periódicos num estimador espectral foram Schuster (1898) e Fisher (1929) (Benedito-Silva, 1993). Vários autores, dentre eles Whittle (1952) e Shimshoni (1971), estenderam o teste de Fisher para incluir o segundo maior pico. Siegel (1980) propôs um teste de periodicidade que contém o teste de Fisher, como um caso particular, sendo um teste mais flexível que permite que frequiências importantes além da fundamental sejam consideradas (BENEDITO-SILVA, 1993).

\section{COLÔNIAS FORTES E FRACAS}

Parece haver diferenças na termorregulação entre colônias fortes e fracas, principalmente com relação à amplitude da temperatura na região dos discos de cria. As diferenças observadas entre colônias fracas e fortes poderiam ser um subproduto do número de abelhas disponíveis para a termorregulação e da preocupação em manter a cria em temperatura adequada para o seu desenvolvimento e sobrevivência da colônia. Colônias "fracas", com poucos indivíduos, poderiam modificar as suas expressões rítmicas a fim de acelerar o desenvolvimento da cria e aumentar o 
número de indivíduos, favorecendo a sobrevivência da colônia. Quanto maior a população, maior a eficiência da termorregulação, segundo Engels et al. (1995). Existem alguns procedimentos para atribuição de valor numérico para representar o estado de desenvolvimento da colônia: por observação direta dos elementos de uma colônia de Melipona quadrifasciata, pode-se atribuir uma nota de 1 a 10 (KERR, 1954; AIDAR, 1995).

Nas colônias "fracas" foi obtido que os valores de ApEn, na região dos discos de cria, são maiores que os valores das demais colônias fortes e que, deste modo, as séries temporais obtidas em colônias "fracas" seriam mais aleatórias, imprevisíveis e complexas. O aumento na complexidade em séries temporais poderia ser uma resposta adaptativa, e as perturbações ambientais parecem aumentar a complexidade dos processos fisiológicos (SOUZA et al., 2004). As colônias fracas poderiam estar então em um estado "patológico" e/ou sob perturbações ambientais, uma vez que apresentam maior complexidade nas séries temporais de temperatura nos discos de cria, do que colônias fortes;. Além disso, poderiam estar investindo energia na manutenção de temperaturas maiores, para adequada incubação da cria e sua própria sobrevivência. Mas só se pode afirmar que a ApEn é maior em colônias fracas ou na região dos discos de cria em relação às demais séries temporais, se a observação estiver amparada em análise estatística, o que não foi possível com os valores de ApEn devido o número amostral exigido para os testes.

Os dados de taxa metabólica colonial, concomitantes com a coleta de dados de termorregulação, em colônias fortes e fracas, poderiam fornecer pistas a respeito das estratégicas energéticas empregadas pelas colônias fracas na termorregulação, e também sobre a manutenção dos favos de cria em temperaturas relativamente mais altas e constantes, em relação às colônias fortes. Isto foi objeto de diversas coletas de dados preliminares referentes à taxa metabólica colonial, cuja padronização da metodologia passou por problemas. A idéia seria obter informações a respeito da variação diária do gasto energético colonial, ficando como sugestão para trabalhos futuros e podendo ajudar a responder perguntas, como, por exemplo, se há relações entre os padrões de variação diária da taxa metabólica colonial e individual, e se nas colônias fracas seriam os gastos energéticos da termorregulação maiores do que em colônias fortes, na tentativa de acelerar o desenvolvimento da cria e garantir a reposição das operárias.

\section{A VARIACÃO DIÁRIA DA TEMPERATURA COLONIAL}

É de interesse observar o comportamento das abelhas e o que acontece dentro da colônia entre $2 \mathrm{~h}$ e $5 \mathrm{~h}$ da madrugada, período no qual a temperatura nos discos de cria diminui, voltando a aumentar após às 6h da manhã. Esta queda da temperatura nos discos de cria é um dado empírico importante para ajudar a compreender o que ocorre dentro da colônia e sua termorregulação. 
Algumas hipóteses sobre a queda da temperatura na região dos favos de cria naqueles horários incluem a questão do "sono" das abelhas adultas durante a fase de escuro (SAUER, 2004), o que seria mantido mesmo em colônias fechadas. Além disso, Schmolz et al (2002) sugerem que, durante a noite, as abelhas não "dormem" meramente para conservar energia, mas também para facilitar processos restaurativos no corpo e no sistema nervoso das abelhas, e que, portanto, a temperatura durante o sono não pode ser extremamente baixa, a fim de permitir tais processos restaurativos.

A menor temperatura na região dos discos de cria de madrugada pode estar relacionada à menor movimentação das abelhas na região da cria à noite (quando as forrageadoras poderiam estar em estado de "sono"), quando há maior frequiência de abelhas mais jovens nesta região (que não gerariam calor endogenamente) e possivelmente menor ocorrência de POP, aliado a aumento da atividade interna e externa na colônia no início da manhã (quando a temperatura na cria aumenta), sendo interessante análises de imagens coletadas dentro das colônias ao longo do dia.

Nos controles "Controle Cria" e "Controle Pote", as periodicidades detectadas na série temporal equivalem à da temperatura na câmara, parecendo não haver influências da estrutura do ninho por si só, em condições de temperatura constante. Como sugestão, seria o emprego deste tipo de controle também nas colônias abertas, a fim de verificar se a diminuição da temperatura colonial mais tardiamente que a temperatura ambiente seria devido ao isolamento proporcionado pelas estruturas da arquitetura do ninho, ou se há outros processo envolvidos, como a manuteção de temperaturas elevadas por um tempo maior devido a necessidade de processos restaurativos durante o "sono" (SCHMOLZ et al, 2002).

Neste capítulo foram empregadas, nos diversos experimentos, sete colônias de $M$ quadrifasciata. $\mathrm{O}$ quanto os resultados aqui obtidos podem ser ampliados à espécie e/ou às abelhas sem ferrão em geral ainda depende de uma resposta definitiva. A vantagem de usar diversas colônias reside, entre outros fatores, na ampliação da variabilidade genética e melhora da verificação de padrões comuns à espécie.

\section{COLÔNIAS TRATADAS COM BLOQUEADORES ALPRENOLOLE MIANSERINA}

Nas colônias abertas tratadas com bloqueadores, as periodicidades na região da cria se relacionam com as condições ambientais (temperatura, umidade relativa e luminosidade), mas não se sabe quais destas três seria o sincronizador principal dos ritmos. Além disso, a temperatura na região da cria apresentava periodicidades semelhantes às periodicidades exclusivas da luminosidade e UR\% Ambiente, o que não ocorria nas colônias abertas não tratadas.

Nas colônias fechadas, tratadas com Mianserina e Alprenolol, as periodicidades das séries temporais na região dos discos de cria estão relacionadas à temperatura da câmara em no máximo 1 
periodicidade, as demais periodicidades sendo exclusivas da cria ou relacionadas à UR\% da câmara, o que também não ocorria nas colônias não tratadas. .

Parece que com o uso de bloqueadores as abelhas "respondam menos" à temperatura. Os bloqueadores poderiam atuar em termoreceptores e/ou na termossensibilidade das abelhas de um modo geral, já que as periodicidades nas séries temporais de temperatura na região da cria são similares às da luminosidade e UR\% Ambiente, diferente do obtido em colônias não tratadas. Para elucidar esta questão, sugerem-se experimentos com maior número de colônias, com coleta de dados simultaneamente entre colônias tratadas e não tratadas, o que não foi aqui possível devido o número de carregadores de dados.

Há ocorrência de octopamina e seus receptores no cérebro de abelhas A. mellifera (BICKER, 1999; GROHMANN et al, 2003; FAROOQUI et al, 2004; SINAKEVITCH et al, 2005), nos corpos cogumelo (FAHRBACH et al., 1997) e nos lobos antenais (Schulz et al.., 2002) envolvidos no processamento de informação sensorial e antenal, como a termossensibilidade.

Os efeitos do bloqueio de receptores de octopamina são ainda discutidos no capítulo 4 e na discussão geral.

\section{CONCLUSÕES}

- há controle de temperatura dentro de ninhos de Melipona quadrifasciata;

- a regulação de temperatura e umidade relativa dentro da colônia apresenta variação diária, relacionada, em colônias mantidas abertas, à temperatura ambiente, umidade relativa do ambiente e/ou luminosidade, além de ritmos endógenos.

- as periodicidades detectadas na atividade externa de vôo parecem estar relacionadas às periodicidades de fatores ambientais (temperatura ambiente, umidade relativa do ambiente e/ou luminosidade) e também de fatores coloniais, como a temperatura na região dos discos de cria;

- a regulação da temperatura e da umidade relativa dentro da colônia, na região dos discos de cria, parece expressar uma ritmicidade endógena quando em condições de temperatura e escuro constante;

- bloqueadores de receptores de octopamina afetam o padrão das periodicidades das séries temporais, sugerindo que as colônias tratadas respondem menos à temperatura ambiente e mais à umidade relativa do ambiente. 


\section{REFERÊNCIAS BIBLIOGRÁFICAS}

AIDAR, D.S. (1996) A mandaçaia: biologia de abelhas, manejo e multiplicação artificial de colônias de Melipona quadrifasciata Lep. (Hymenoptera, Apidae, Meliponinae). SERIE MONOGRAFIAS $\mathrm{N}^{\circ}$ 4. Sociedade Brasileira de Genética.

ALMEIDA, G.F. (2004) Estudo de componentes rítmicos detectados na colônia de Frieseomelitta varia (Hymenoptera: Apidae: Meliponinae). Dissertação de Mestrado, FFCLRP-USP.

AZEVEDO, G.G. (1997) Atividade de vôo e determinação do número de instares larvais em Partamona helleri (Friese). Dissertação de Mestrado, Departamento de Biologia, UFV, Viçosa.

BELLUSCI, S. (1998) Caracterização do ritmo de atividade / repouso em livre curso de Scaptotrigona aff. depilis (Moure, 1942) (Hymenoptera: Apidae: Meliponinae). Dissertação de Mestrado FFCLRPUSP.

BELLUSCI, S. (2003). Colônia de abelhas eussociais: modulação de ritmos com ênfase no processo de construção de células de cria e postura em duas espécies de abelhas sem ferrão, Frieseomellita doederleini e Frieseomellita varia (Hymenoptera, Apidae). Tese de Doutorado. FFCLRP, USPRP.

BELLUSCI, S. e MARQUES, M.D. (2001) Circadian activity rhythm of the foragers of a eusocial bee (Scaptotrigona aff depilis, Hymenoptera, Apidae, Meliponinae) outside the nest. Biological Rhythm Research 32(2): 117-24.

BELZUNCES, L.P.; VANDAME, R. And GU, X. (1996) Modulation of honeybee thermoregulation by adrenergic compounds. Neuroreport. 7(10):1601-4.

BENEDITO-SILVA, A A (1999) Aspectos metodológicos da Cronobiologia. In: Marques, N \& MennaBarreto, L. Cronobiologia - Princípios e Aplicações. Editora da Universidade de São Paulo, São Paulo.

BICKER, G (1999). Biogenic amines in the brain of the honeybee: cellular distribution, development, and behavioral functions. Microsc Res Tech. 44(2-3):166-78.

BRUIJN, M. L.L.; SOMMEIJER, M.J. (1997) Colony foraging in different species of stingless bees (Apidae, Meliponinae) and the regulation of individual nectar foraging. Insectes Sociaux 44: 3547.

BÜDEL, A (1968) Le microclimat de la ruche. In: Chauvin, R (ed). Traité de Biologie del'Abeille. Paris: Masson \& Cie 4:2-53

CALLEGARI-JACQUES, Sm. M. (2003) Bioestatística - Princípios e Aplicações. Artmed Editora S.A, São Paulo.

CAMAZINE, S. et al (2001). Self-Organization in Biological Systems. Princeton, New Jersey. Princeton University Press.

CHAUVIN, R. (1968) Énergetique calorimetric des abeilles. In: Traité de biologie de l’abeille I : Biologie et Physiologie Générales. Masson, Paris, 245-61.

DARCHEN, R. 1973. La thermoregulation et 1' ecologie de quelques especies d'abeilles sociales d'Afrique (Apidae, Trigonini et Apis mellifica Var. Adansonii). Apidologie, 4:341-370.

DEGEN, J.; GEWECKE, M.; ROEDER, T. (2000) Octopamine receptors in the honey bee and locust nervous system: pharmacological similarities between homologous receptors of distantly related species. British Journal of Pharmacology 130, 587-594.

DETRAIN, C..; DENEUBOURG, J.L. (2002) Complexity of environment and parsimony of decisions rules in insect societies. Biol Bull 202: 268-74.

ENGELS, W.; ROSENKRANZ, P.; ENGELS, E (1995) Thermoregulation in the nest of the neotropical stingless Scaptotrigona postica and a hypotheiss on the evolution of temperature homeostasis in highly eusocial bees. Studies on Neotropical Fauna and Environment 30(4): 193-205.

ENGELS, W.; et al. (1997) Mandibular gland volatiles and their ontogenetic patterns in queen honey bees, Apis mellifera carnica. J Insect Physiol 43: 307-13.

Engels, W. et al (1997) Mandibular gland volatiles and their ontogenetic patterns in queen honey bees, Apis mellifera carnica. J Insect Physiol 43: 307-13.

FAHRBACH, S.E. (1997) Regulation of age polyethism in bees and wasps by juvenile hormone. Adv. Study Behav. 26: 285-316. 
FAHRBACH, S.E.; GIRAY, T.; FARRIS, S.M.; ROBINSON, G.E. (1997) Expansion of the neuropil of the mushroom bodies in male honeybees is coincident with initiation of flight. Neurosci. Lett. 236(3):135-8.

FARINA, W.M.; WAINSENLBOIM, A J. (2001) Changes in thoracic temperature of honeybees while receiving nectar from foragers collecting at different reward rates. J Exp Biol 204: 1653-8.

GROHMANN, L. et al (2003) Molecular and functional characterization of an octopamine receptor from honeybee (Apis mellifera) brain. J. Neurochem. 86(3):725-35.

GUIBU, L.S.; IMPERATRIZ-FONSECA, V.L. (1984) Atividade externa de Melipona quadrifasciata Lepeletier (Hymenoptera, apidae, Meliponinae), Ciên e Cult. 36 supl. (7): 623.

HEARD, T.; HENDRIKZ, J.K. (1993) Factors influencing flight activity of colonies of the stingless bee Trigona carbonaria (Hymenoptera, Apidae) Austral J Zool 41(4): 343-53.

HEINRICH, S.D.; RAVEN, P.H. (1972) Energetics and pollination ecology. Science 176(4035): 597-602.

HEINRICH, B. (1980) Mechanims of body temperature regulation in honeybees, Apis mellifera. J Exp Biol 85: 61-87.

HEINRICH, B. (1993) The Hot-Blooded Insects. Cambridge, MA. Harvard University Press.

HEINRICH, B. (1979) Keeping a cool head: honeybee thermoregulation. Science 205: 1269-71.

HEINRICH, B. (1993) The Hot-Blooded Insects. Cambridge, MA. Harvard University Press.

HEINRICH, B. (1996) The thermal warriors: strategies of insect survival. Cambridge, Mass. Harvard University Press.

HEINRICH, S.D. e RAVEN, P.H. (1972) Energetics and pollination ecology. Science 176(4035): 597-602.

HILARIO, S.D. (1999) Considerações sobre atividade do vôo das abelhas indígenas, com ênfase em Plebeia pugnax Moure e Melipona bicolor Lepeletier, 1836 (Apidae, Meliponinae). Dissertação de Mestrado, Instituto de Biociências da USP.

HILÁRIO, S.D.; IMPERARIZ-FONSECA, V.L. (2002) Thermorregulation of Melipona bicolor biclor under special conditions. Encontro sobre Abelhas, Ribeirão Preto.

HILÁRIO, S.D.; IMPERATRIZ-FONSECA, V.L.; KLEINERT, A M.P. (2001) Responses to climatic factors by foragers of Plebeia pugnax Moure (IN LITT) (Apidae: Meliponinae). Rev Brasil Biol 61(2):191-6.

HILÁRIO, S.D; IMPERATRIZ-FONSECA, V.L.; KLEINERT, A (2000) Flight activity and colony strenght in the stingless bee Melipona bicolor bicolor (Apidae: Meliponinae). Rev Bras Biol 60(2): 299306.

HILÁRIO, S.D.; IMPERATRIZ-FONSECA, V.L.; KLEINERT, A M.P. (2001) Responses to climatic factors by foragers of Plebeia pugnax Moure (Apidae: Meliponinae). Rev Brasil Biol 61(2):1916.

HILÁRIO, S.D. e IMPERARIZ-FONSECA, V.L. (2002) Thermorregulation of Meliponabicolor bicolor under special conditions. Proceedings of the V Encontro sobre Abelhas, Ribeirão Preto.

HILÁRIO, S.D. \& IMPERARIZ-FONSECA, V.L. (2002) Thermorregulation of Melipona bicolor bicolor under special conditions. Proceedings of the V Encontro sobre Abelhas, Ribeirão Preto.

HILÁRIO, S.D. \& IMPERATRIZ-FONSECA, V.L. (2003) Thermal evidence of the invasion of a stingless bee nest by a mammal. Braz J Biol 63(3): 457-62.

HILÁRIO, S.D. (2005) Atividade de vôo e termorregulação de Plebeia remota (Holmberg, 1903) (Hymenoptera, Apidae, Meliponini). Tese de Doutorado, Instituto de Biociências da USP; 124p

IMPERATRIZ-FONSECA, V.L.; KLEINERT-GIOVANINI, A ; PIRES, J.T. (1985) Climate variations influence on the flight activity of Plebeia remota Hilmberg. Rev Bras Entomol 29(3/4): 427-34.

IWANA, S. (1977) A influência dos fatores climáticos na atividade externa de Tetragonisca angunstula (Apidae: Meliponinae) Bolm Zool Univ S Paulo 2: 189-201.

JONES, J.C. et al (2005). The effects of rearing temperature on developmental stability and learning and memory in the honey bee, Apis mellifera. J Comp Physiol A Neuroethol Sens Neural Behav Physiol. 191(12):1121-9.

KAISER, W. (1988) Busy bees need rest, too - behavioural and electromyographical sleep signs in honeybees. J. Comp. Physiol. A, 163: 565-584.

KLEINERT-GIOVANINI, A (1982) The influence of climatic factors on flight activity of Plebeia emerina Friese (Hymenoptera: Apidae: Meliponinae) in winter. Rev Brasil Ent 26(1): 1-13.

KLEINERT-GIOVANNINI, A e IMPERATRIZ-FONSECA, V.L. (1986) Flight activity and responses to climatic conditions of two subspecies of Melipona marginata Lepeletier (Apidae, Meliponinae). J Apicult Res 25(1): 3-8. 
KLINGNER, R.; RICHTER, K.; SCHMOLZ, E.; KELLER, B (2005) The role of moisture in the nest thermoregulation of social wasps. Naturwissenschaften 92: 427-30.

MECCA, G.F. (2003) O comportamento forrageio das operárias de Scaptotrigona aff depilis (Hymenoptera, Apidae, Meliponini) relacionado a fatores climáticos. Dissertação de Mestrado. FFCLRP, USP. Ribeirão Preto.

MECCA, G.F.; BEGO, L.R.; MATHEUS, S. (2002) Influência de fatores climáticos no comportamento forrageiro de Scaptotrigona aff. depilis (Hymenoptera: Apinae). Anais do V Encontro sobre Abelhas, Ribeirão Preto, SP.

MICHENER, C.D. (1974) The social behavior of the bees. Cambridgs, Massachusts: The Belknap Press of Harvard University Press.

MICHENER, C.D. (2000) The bees of the world. Baltimore and London, The John Hopkins University Press. 913p.

MOO, V.H; QUEZADA, E.J.J.; NAVARRO, J.; RODRIGUES, C.L. (2000) Patterns of intranidal temperature flutuations for Melipona beecheii colonies in natural nesting cavities. J Apicultural $\operatorname{Res}(1-2): 3-7$.

MOORE, D. (2001) Honey bee circadian clocks: behavioral control from individual workers to wholecolony rhythms. J Insect Physiol 47: 843-57.

MOUGA, M.D.S. (1984) Atividade de coleta de Paratrigona subnuda Moure (Apidae, Meliponinae). Dissertação de Mestrado, Instituto de Biociências, USP, São Paulo, 86p

OLIVEIRA, M.A.C. (1973) Um método para avaliação das atividades de vôo em Plebeia saiqui (Friese) (Hymenoptera, Meliponinae). Boletim de Zoologia e Biologia, São Paulo, 30: 625-631

OSTER, G.F.; WILSON, E.O. (1979). Caste and ecology in the social insects. Monogr Popul Biol. 12:1-352

PACHECO, R.L.F.; KERR, W.E. (1989) Temperaturas em abelhas da espécie Melipona compressipes fasciculata. Ciên. E Cult 41(5): 490-5.

PETZ, M.; STABENTHEINER, A.; CRAILSHEIM, K. (2004). Respiration of individual honeybee larvae in relation to age and ambient temperature. J Comp Physiol 174: 511-8.

PICK, R.A; BLOCHTEIN, B (2002). Atividades de vôo de Plebeia saiqui (Holmberg) (Hymenoptera, Apidae, Meliponinae) durante o período de postura da rainha e em diapausa. Revista Brasilieira de Zoologia 19(3): 827-39.

PIERROT, L.M.; SCHLINDWEIN, C. (2003) Variation in daily flight activity and foraging patterns in colonies of uruçu - Melipona scutellaris Latreile (Apidae, Meliponini). Rev Brasil Zool 20(4): $565-71$.

PINCUS, S.M. (1991) Approximate entropy as a measure of system complexity. PNAS USA 88: 2297-301.

PINCUS, S.M.; GOLDBERGER, A L (1994) Physiological time-series analysis: what does regularity quantifies? Am J Physiol 266: III643-56.

PRONI, E.; HEBLING, M.J. (1996) Thermoregulation and respiratory metabolism in two Brazilian stingless bee subspecies of different climatic distribution, Tetragonica angustula fiebrigi and $T$ A angustula (Hymenoptera: Apidae: Meliponinae). Entomologia Generalis 20(4): 281-9.

PRONI, E. A (1995) Fisiologia e capacidade de termorregulação em ninhos de Tetragonisca angustula e Plebeia juliani. Tese de Doutorado, UNESP, Rio Claro.

PRONI, E.A. MACIEIRA, OJD.; Franchi, M.N. Morais, A.; Tristão, F.S. (2001) V Congresso Brasileiro de Ecologia, Brasil.

ROBINSON, G.E., PAGE, J.RE., STRAMBI, C. and STRAMBI, A. (1989) Hormonal and genetic control of behavioral integration in honey bee colonies. Science 246: 109-12.

SANTANA, W.C.; HARTFELDER, K. (2002) Hormônio juvenil e ecdisteróides na vida adulta de machos, rainhas e operárias de Melipona quadrifasciata Lep (Apidae. Meliponinae): relação com a reprodução e divisão de trabalho. Dissertação de Mestrado, FFCLRP, SP.

SAUNDERS, D.S. (2002) Insect Clocks $3^{\text {rd }}$ ed. Elsevier Science, Amsterdam.

SAUER, S., HERRMANN, E. and KAISER, W. (1998) Covariation of behavioural sleep signs and resting respiration in honey bees. J. Sleep Res., 7 (Suppl. 2): 240.

SAUER, S.; KINKELIN, M.; HERRMANN, E.; KAISER, W. (2003) The dynamics of sleep-like behaviour in honeybees. J Comp Physiol A 189: 599-607

SAUER, S.; HERRMANN, E.; KAISER, W. (2004) Sleep deprivation in honey bees. J Sleep Res 13: 14552.

SCHMID-HEMPEL, P. (1984). The importance of handling time for the flight directionality in bees. Behav Ecol Sociobiol 15: 303-9. 
SCHMOLZ, E.; et al (2000) Thermoanalitical investigations on paper cover of social wasps. Thermochimica Acta 361(1-2): 121-9.

SCHMOLZ, E.; HOFFMEISTER, D.; LAMPRECHT, I. (2002). Calorimetric investigations on metabolic rates and thermoregulation of sleeping honeybees (Apis mellifera carnica). Thermochimica Acta 382(1):221-227(7)

SINAKEVITCH, I.; NIWA, M.; STRAUSFELD, N. (2005) Octopamine like- immunoreactivity in the honeybee and cockroach: comparable organization in the brain and subesophageal ganglion. $\mathbf{J}$ Comp Neurol 488: 233-54.

SOMMEIJER, M.J. e DE ROOY, Y,G.A.; PUNT, W.; BRUIJN, L.L.M. (1993) A Comparative Study of Foraging Behavior and Pollen Resources of Various Stingless Bees (Hym., Meliponinae) and Honeybees (Hym., Apinae) in Trinidad, West-Indies. Apidologie. 14(3): 205-224

SOMMEIJER, M. J.; VAN ZEIJL, M.; DOHMEN, M. R. (1984). Morphological differences between worker-laid eggs from a queenright colony and queenless colony of Melipona rufiventris paraensis (Hymenoptera: Apidae). Entomologische Berichichten 44(1):91-95

TEIXEIRA, L.V. (2003). Aspectos temporais em colônias de Frieseomellita varia: influência das estações do ano, hora do dia e clima nas atividades de construção de células e de vôo. Hymenoptera: Apinae: Meliponini). Monografia. FFCLRP-USP, Ribeirão Preto.

TEIXEIRA, L.V. (2006) Variações ontogenéticas nos parâmetros do ritmo respiratório de operárias de Meliponaquadrifasciata (Hymenoptera, Apidae, Meliponini). Dissertação de Mestrado, FFCLRP, Ribeirão Preto, SP.

VIEIRA, S. (2003) Bioestatística - Tópicos Avançados. Editora Campus Ltda, Rio de Janeiro.

Wagener-Hulme, C.; et al (1999) Biogenic amines and division of labor in honey bee colonies. J. Comp. Physiol. A, 184: 471-479

WEINDENMULLER, A; KLEINEDAM, C; TAUTZ, J (2002) Collective control of nest climate parameters in bumblebees colonies. An Behav 63(6): 1065-71.

ZAR, J.H. (1999) Biostatistical analysis. Upper Saddle River, N.J : Prentice Hall

ZUCCHI, R.; SAKAGAMI, S.F. (1972) Capacidade termo-reguladora em Trigona spinipes e em algumas outras espécies de abelhas sem ferrão (Hymenoptera: Apidae: Meliponinae), p. 301-309. In: C. Cruz-Landim; N.J. Hebling,; E. Lello \& C.S. Takahashi (Eds). Livro em Homenagem a Warwik Estevan Kerr. Rio Claro, Ed. UNESP.

ZUCCHI, R.; SILVA-MATOS, E. V. D NOGUEIRA-FERREIRA, F. H.; AZEVEDO, G. G. (1999). On the cell provisioning and oviposition process (POP) of the stingless bees nomenclature reappraisal and evolutionary considerations (Hymenoptera, Apidae, Meliponinae). Sociobiology 34(1):65-86 


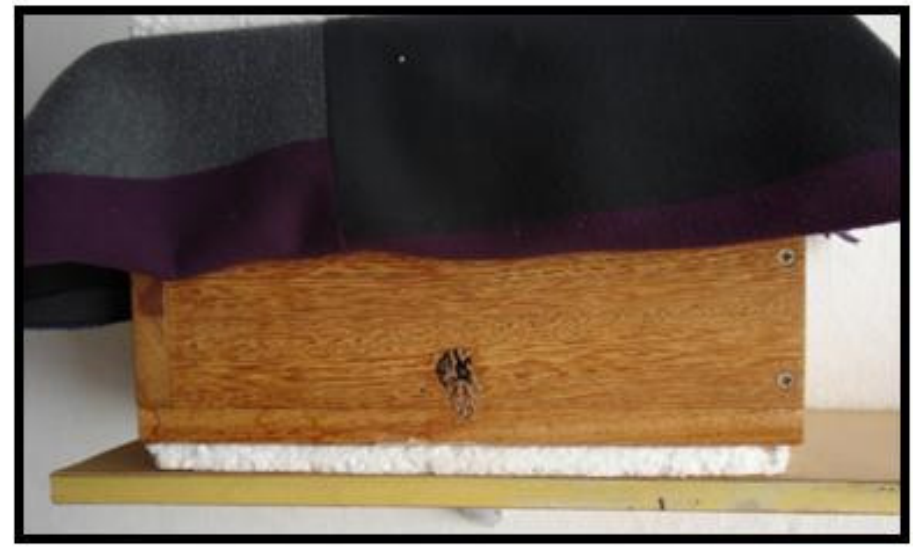

A

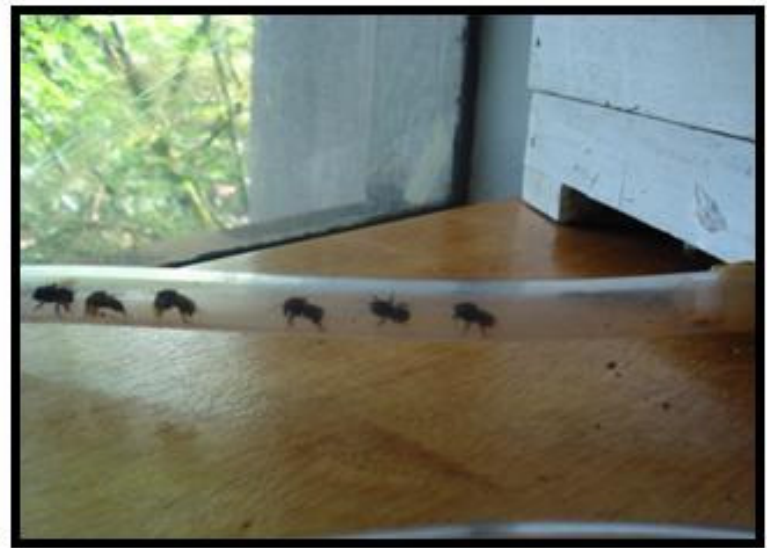

B

Figura 1. Ninhos de $M$ quadrifasciata acondicionados em caixas de madeira, com abertura para saída das abelhas (A). No laboratório, os ninhos eram mantidos em bancadas, e conectados ao ambiente externo por meio de mangueira plástica (B). Fotos de D. Loli

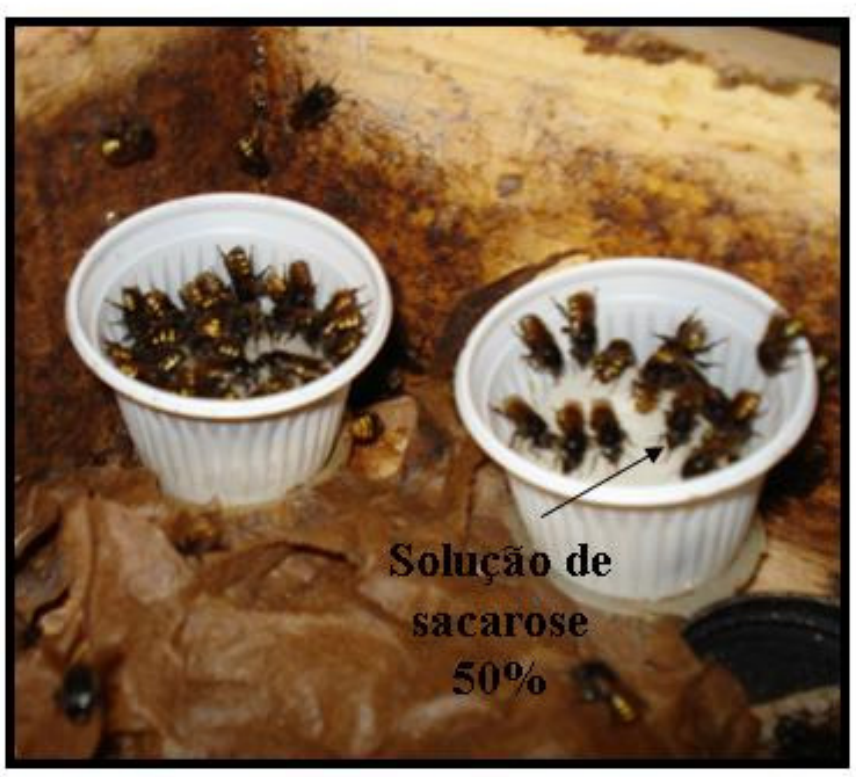

A

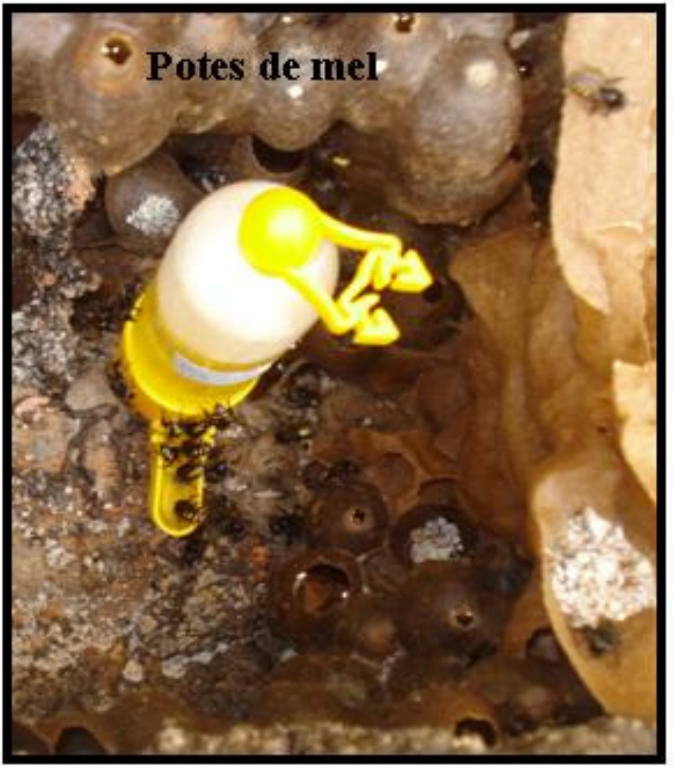

B

Figura 2. Alimentação artificial fornecida às colônias, constituída por solução de sacarose $50 \%$ oferecida em algodão (A) ou em bebedouros (B). $O$ alimento era colocado dentro da colônia, próximo aos potes de mel e pólen do ninho. 


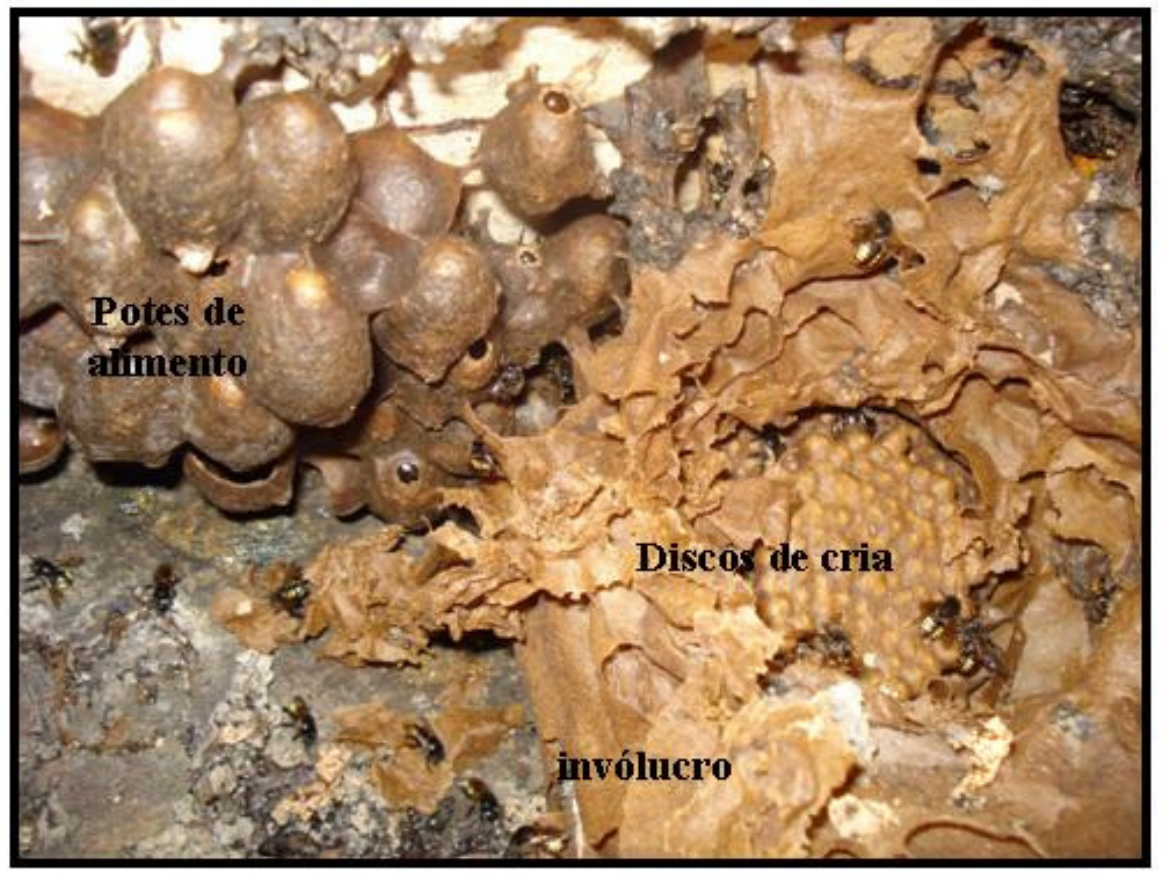

A

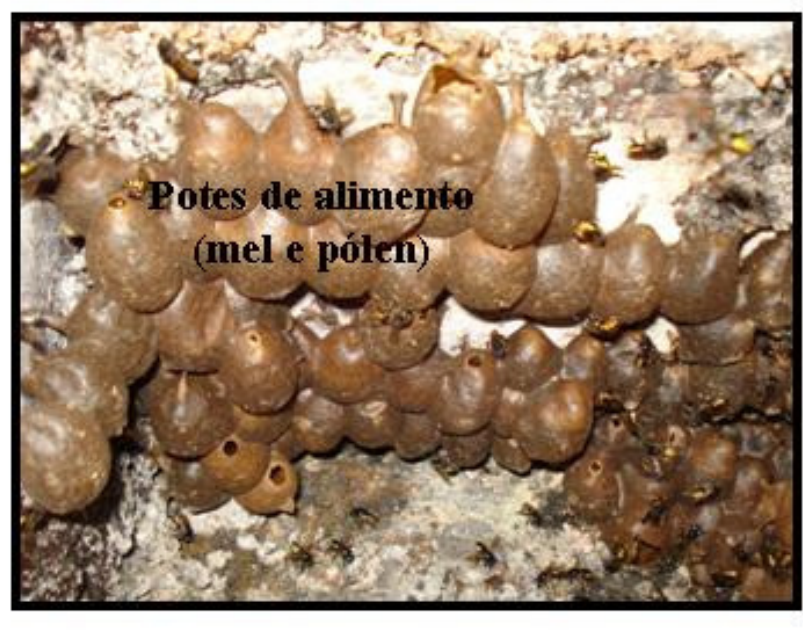

B

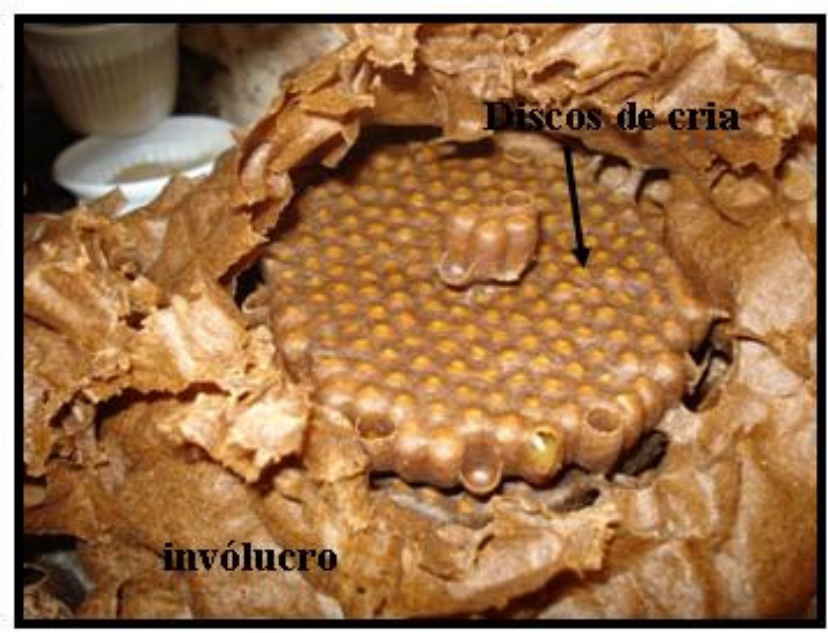

C

Figura 3. Séries temporais de temperatura e umidade relativa foram estudadas dentro do ninho (A) na região dos potes de alimento (estoques de mel e pólen) (B) e na região dos discos de cria (com ovos, larvas e pupas) (C). 

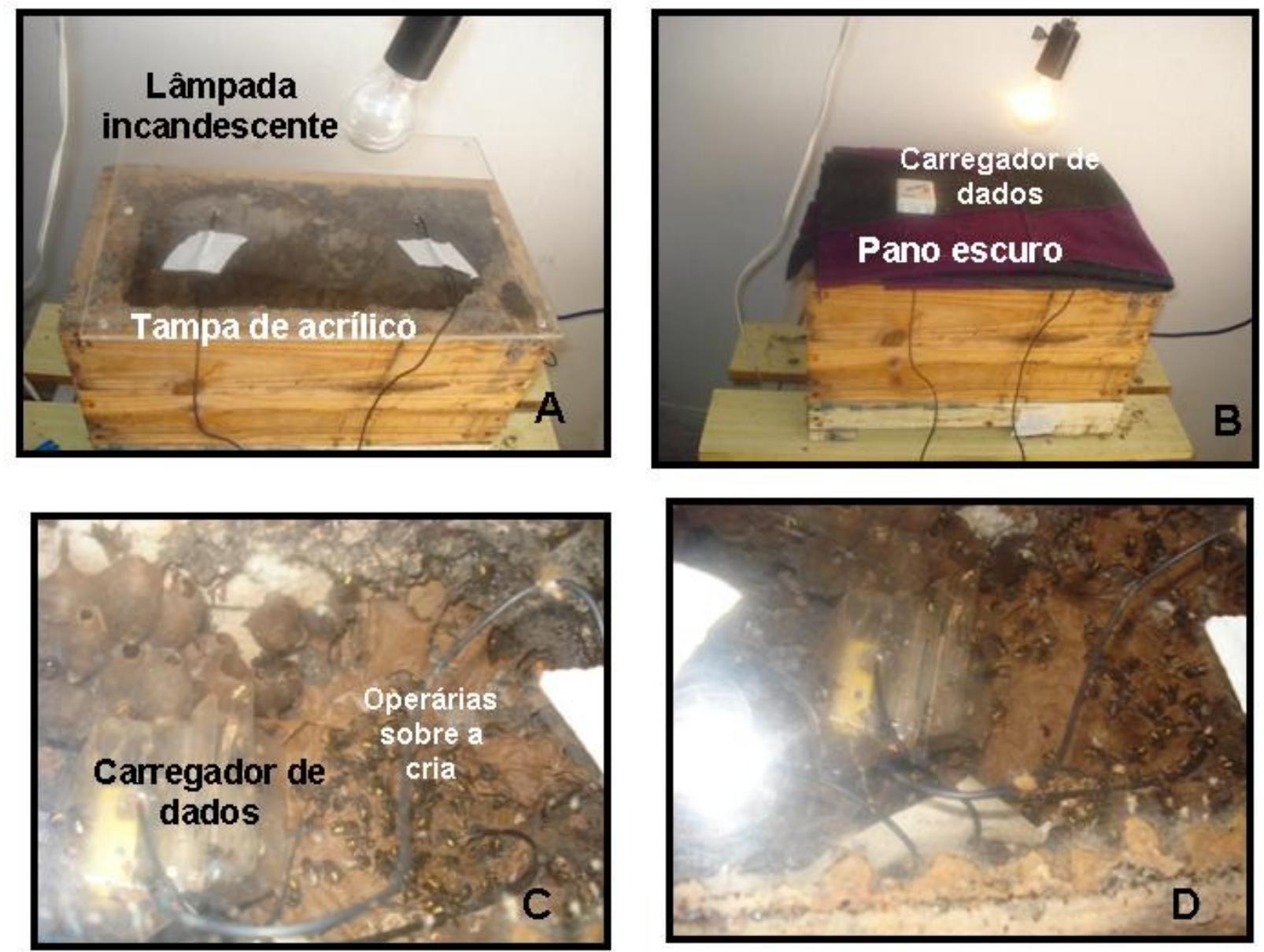

Figura 4. Teste de procedimentos para registro de variação de atividade interna colonial, com o uso de lâmpada incandescente concomitantemente a coleta de séries temporais de umidade e temperatura. A: a colônia forte é tampada com peça de acrílico transparente, visando possibilitar registro fotográfico. B: acima do acrílico é colocado pano escuro. C e D: exemplos de fotografias registradas através da tampa de acrílico. 


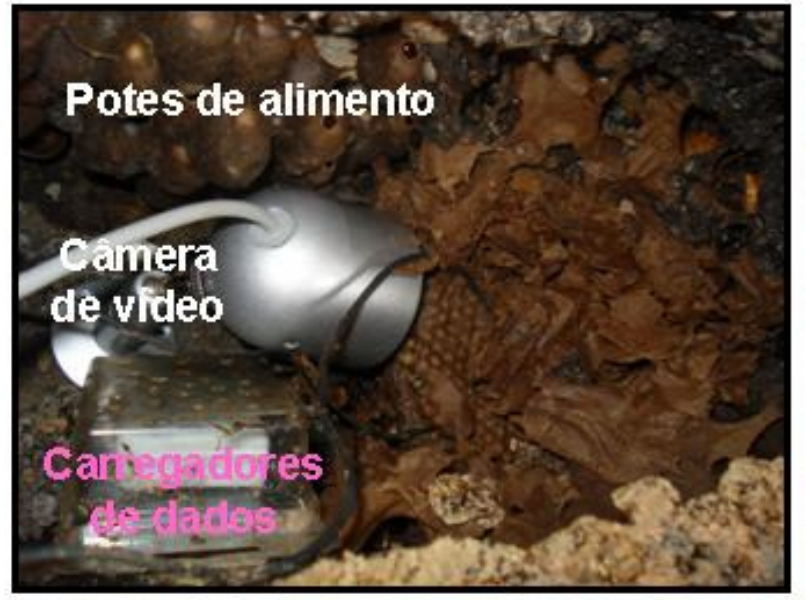

A

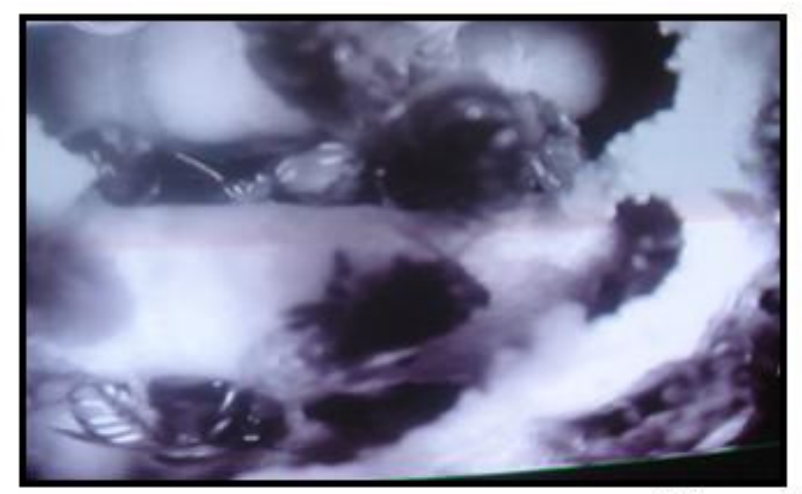

C

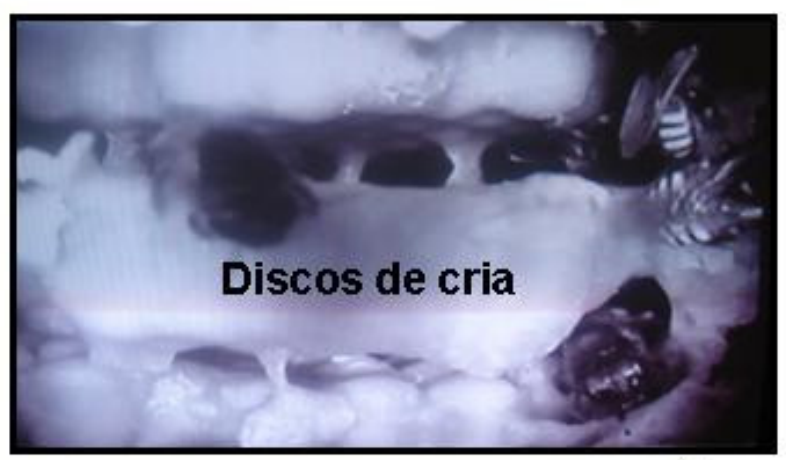

$\mathbf{E}$

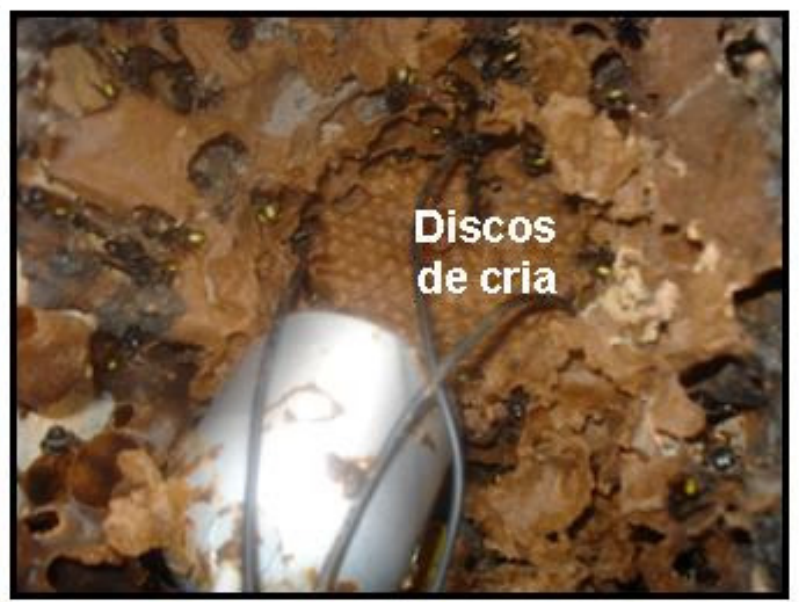

B

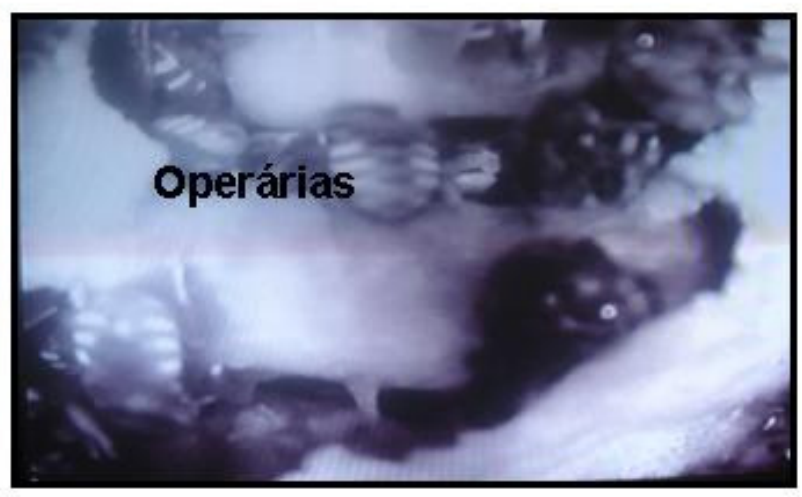

D

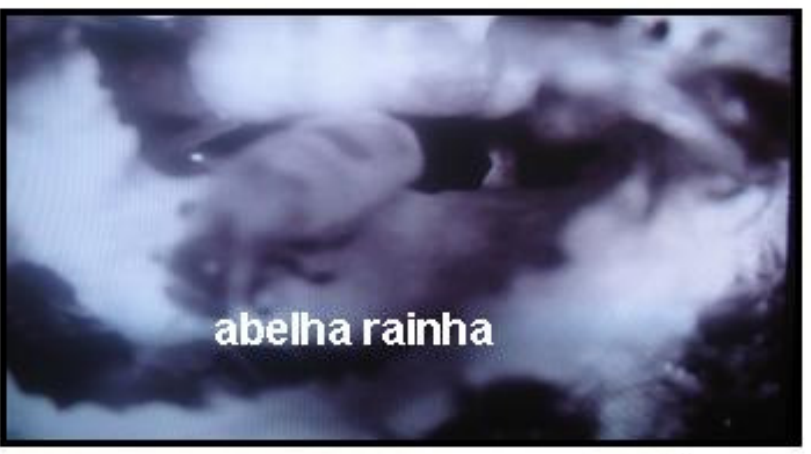

$\mathbf{F}$

Figura 5. Teste de procedimento para registro de variação da atividade interna colonial, com uso de câmera de vídeo com infravermelho para escuro total. A e B: após a colocação de sensores de temperatura e umidade, a câmera era direcionada para a região da colônia onde se deseja registrar a atividade interna. C e D: imagens de atividade interna obtidas durante o dia ( $9 \mathrm{~h}$ e $13 \mathrm{~h}$ ). E e F: imagens de atividade interna obtidas durante a madrugada (1h e $3 \mathrm{~h}$ ). Em F, note a presença da abelha rainha. 


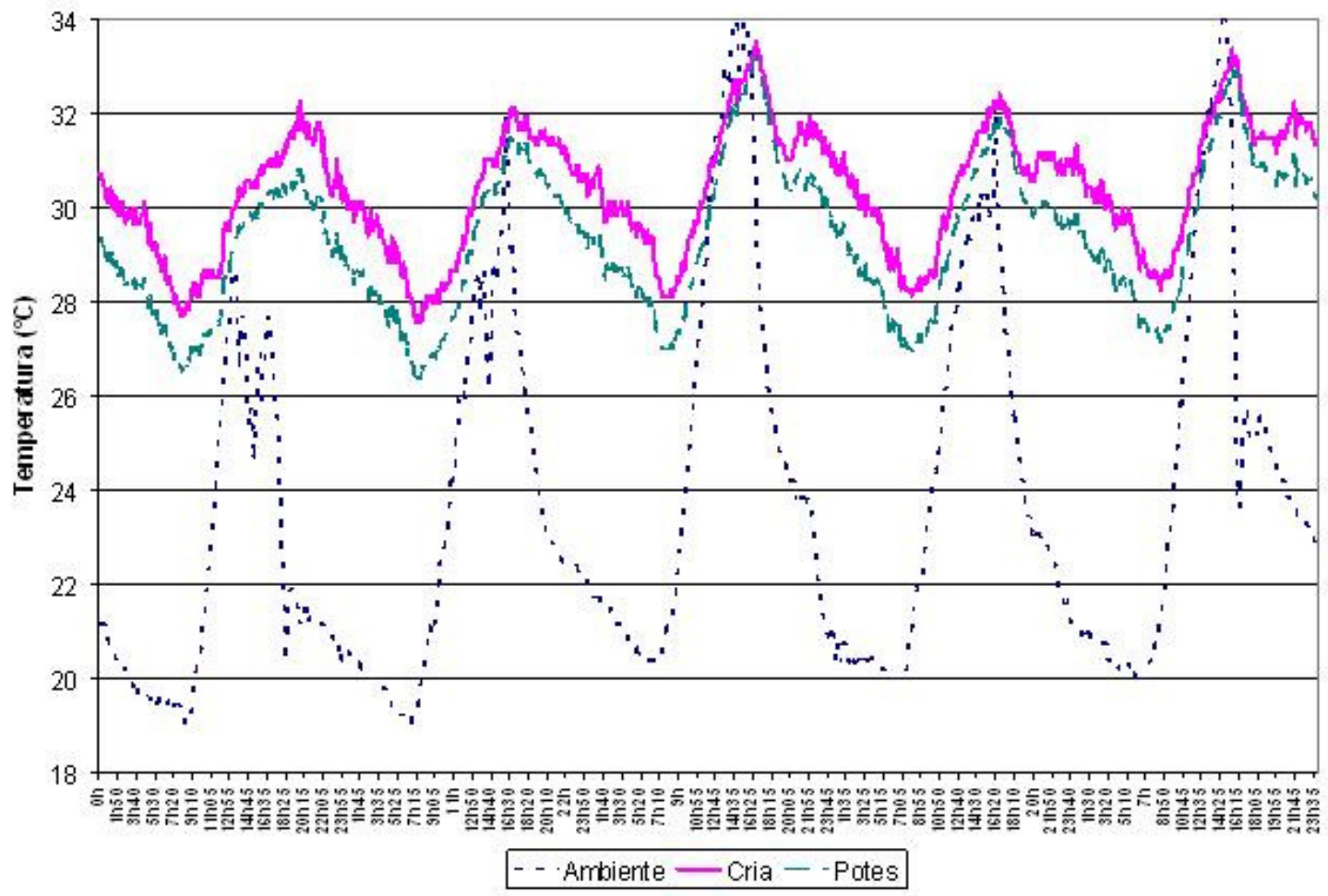

A

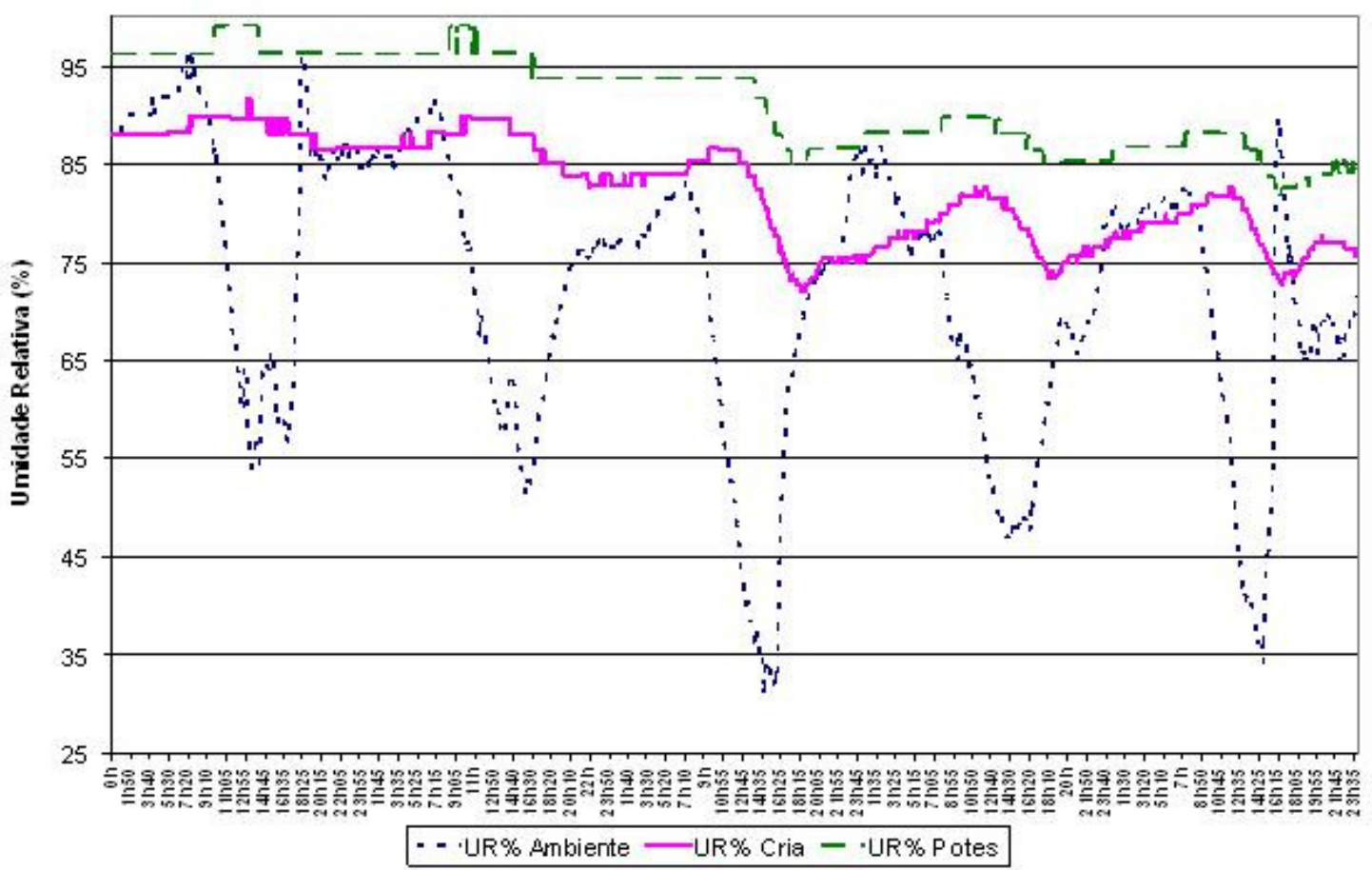

B

Figura 6. Séries temporais de temperatura (A) e de umidade relativa (B) ao longo de 5 dias consecutivos, em colônia aberta ao ambiente externo. As séries foram registradas no ambiente externo ao ninho e dentro deste, na região dos discos de cria e dos potes de alimento, representados como "Ambiente", "Cria" e "Potes", respectivamente. Resultados de análises das séries temporais na tabela 1. 

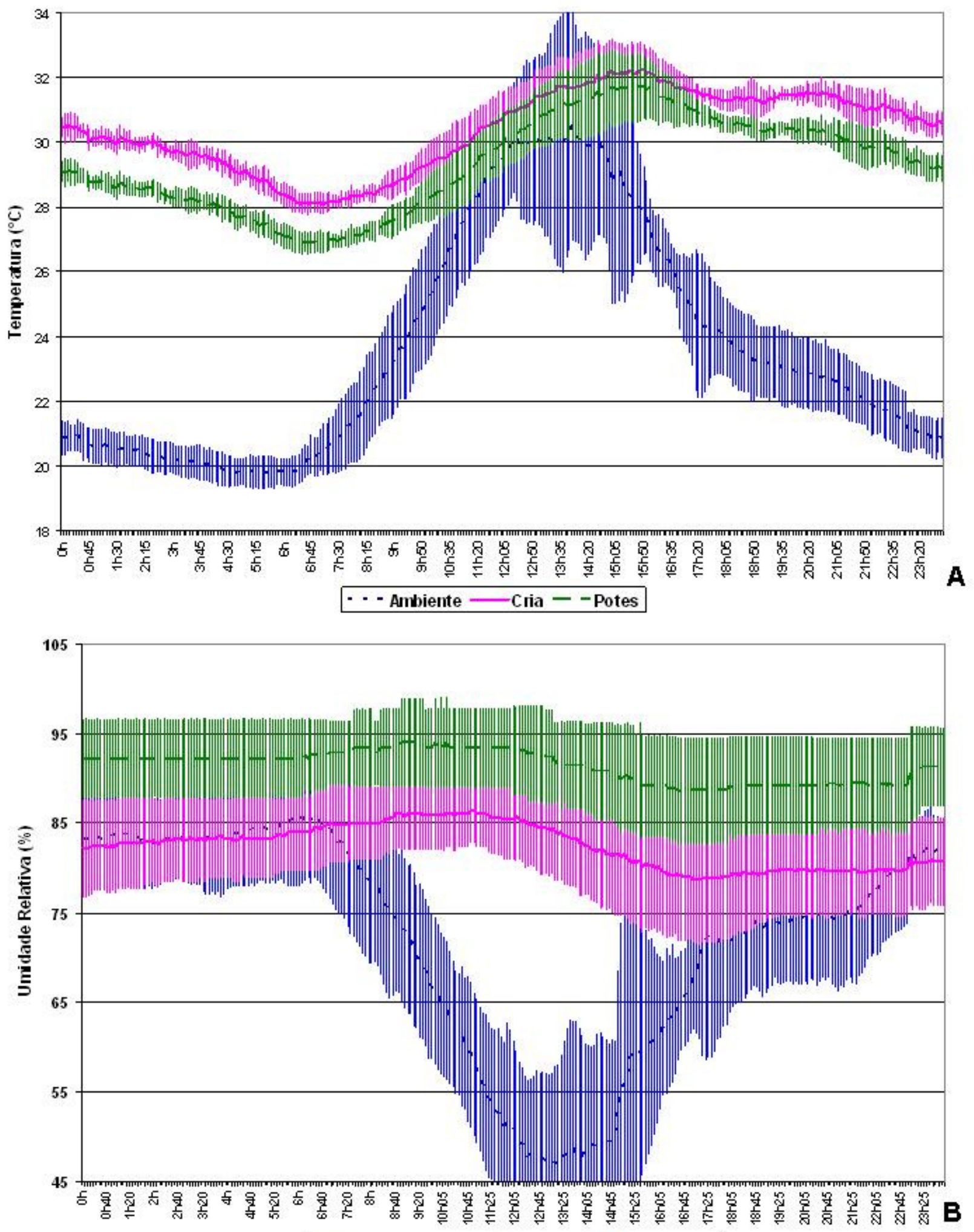

- - UR\% Ambiente - UR\% Cria - - UR\% Potes

Figura 7. Médias horárias e desvio padrão dos valores de temperatura (A) e de umidade relativa (B) ao longo de 5 dias consecutivos, em colônia aberta ao ambiente externo. 

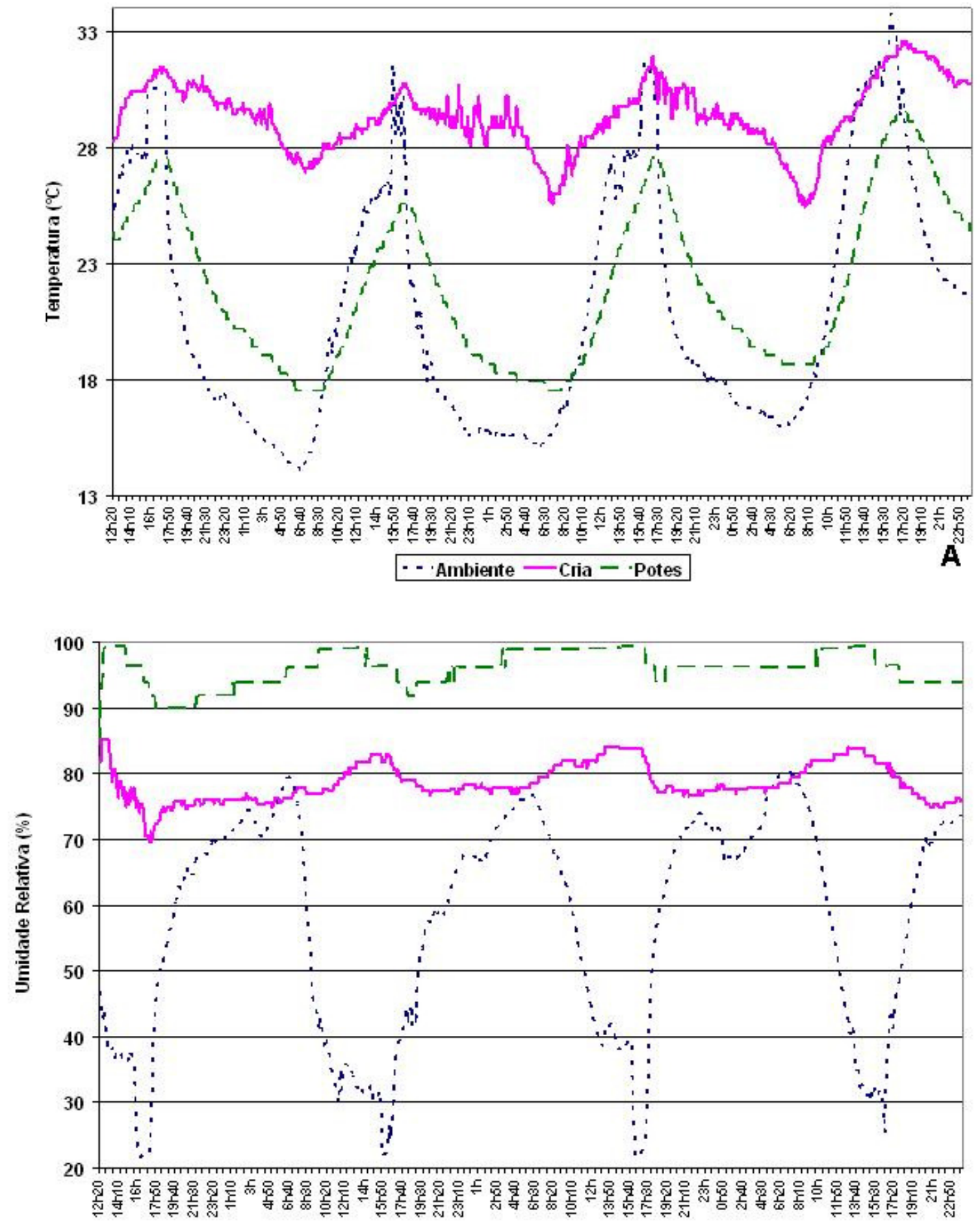

Figura 8. Séries temporais de temperatura (A) e umidade relativa (B) registradas em colônia aberta. De forma geral, as temperaturas na região dos discos de cria são mantidas mais elevadas do que na região dos potes de alimento e no ambiente externo, com amplitudes menores. Resultados de análises das séries temporais na tabela 2 . 


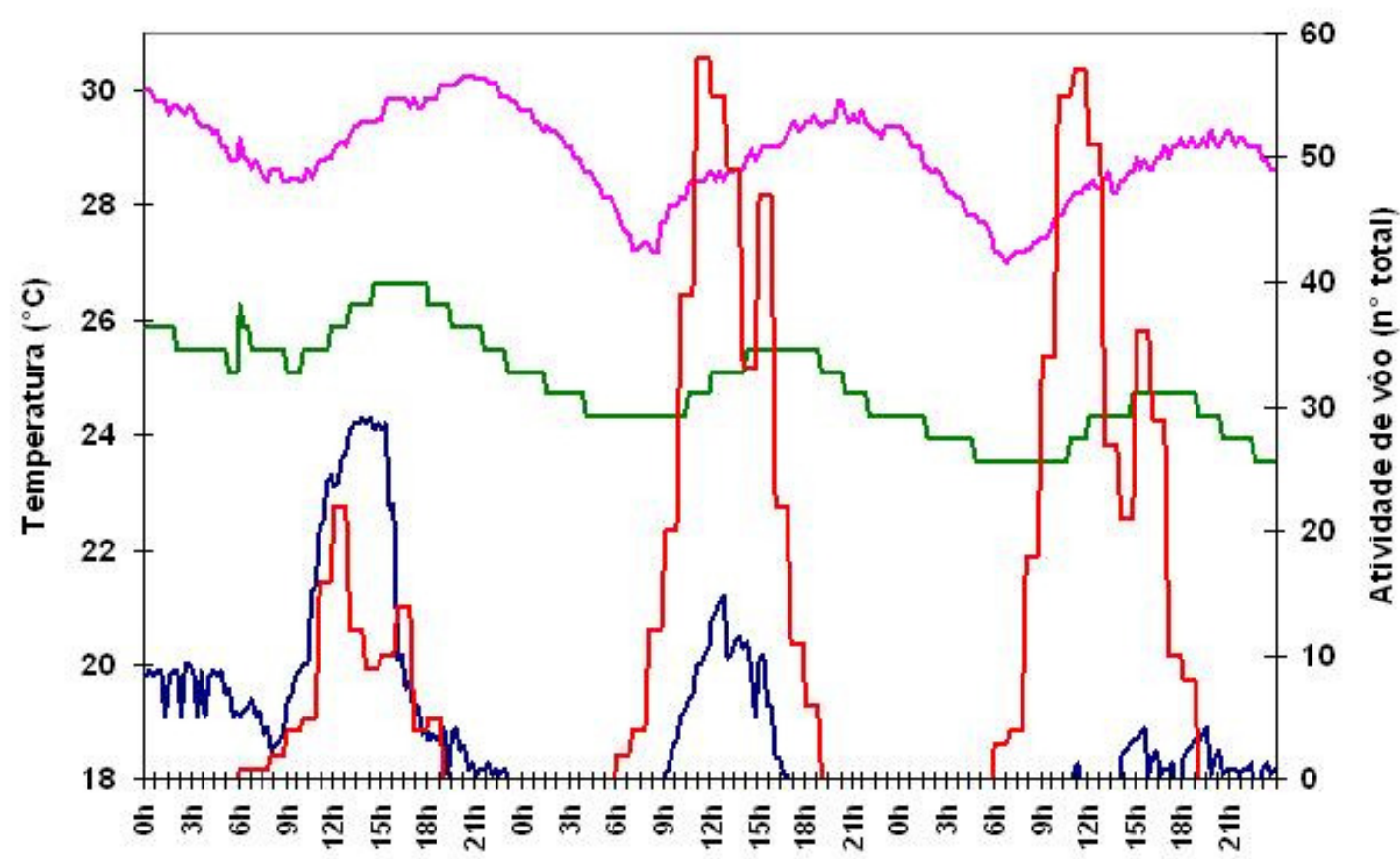

-Cria -Potes -Ambiente - Vôo

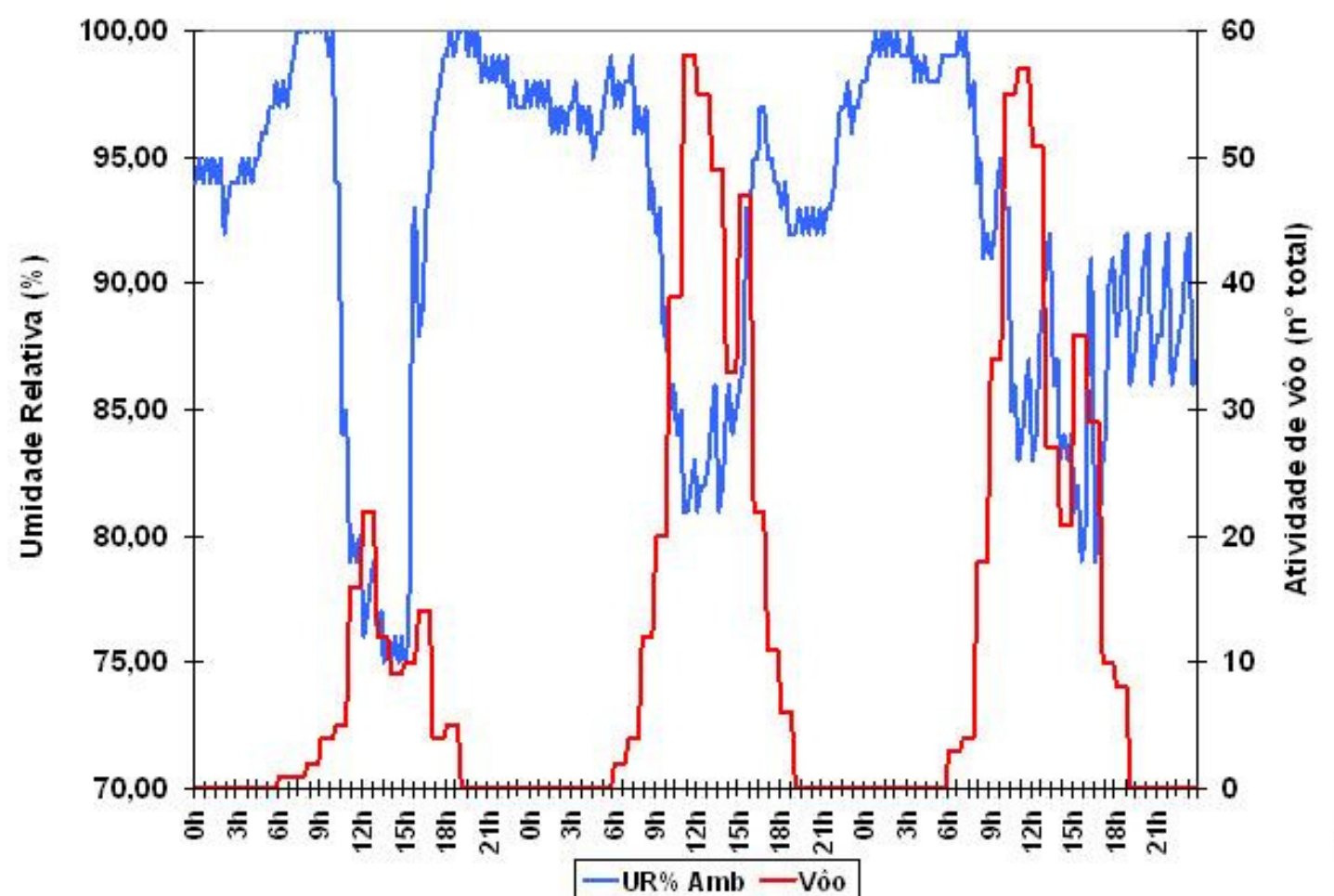

$\mathbf{B}$

Figura 9. Séries temporais de temperatura (A) e umidade relativa (B), considerando-se também a atividade de vôo (número total de entradas e saídas), na primavera/verão. Resultados das análises das séries temporais na tabela 3 . 

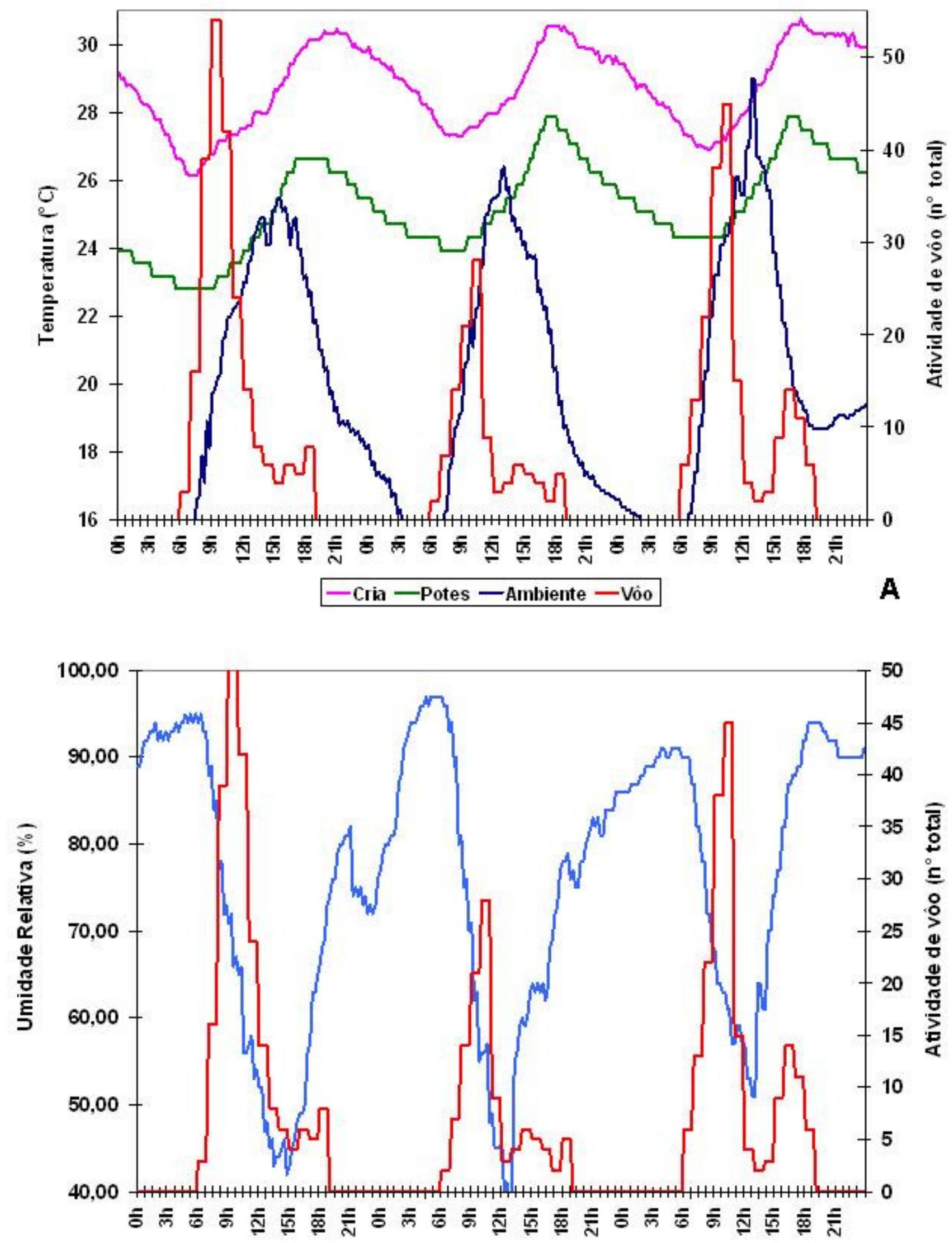

-UR\% Amb - Vôo

Figura 10. Séries temporais de temperatura (A) e umidade relativa (B), considerando-se também a atividade de vôo (número total de entradas e saídas), na primavera/verão. Resultados das análises das séries temporais na tabela 4 . 

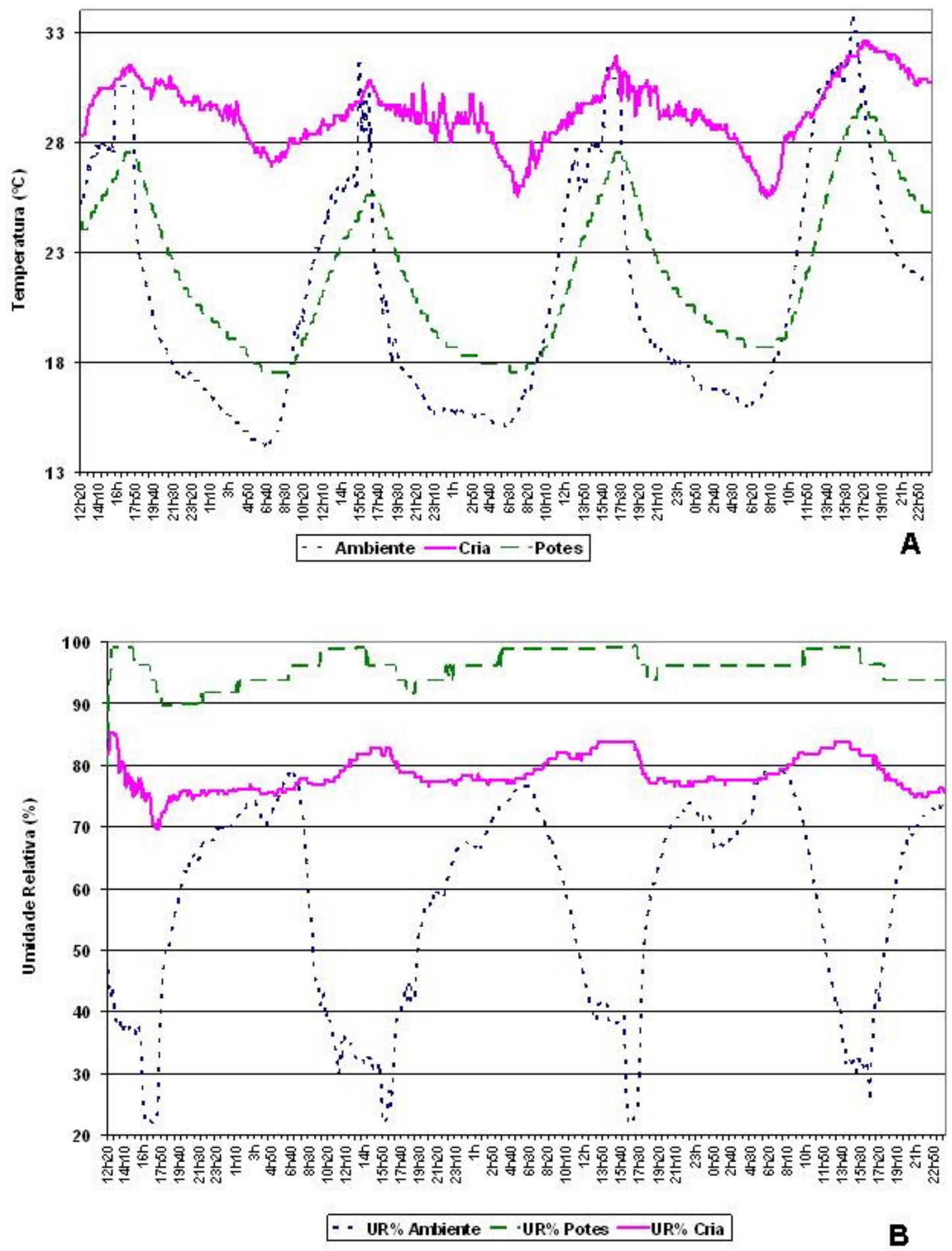

Figura 11. Séries temporais de temperatura (A) e umidade relativa (B), considerando-se também a atividade de vôo (número total de entradas e saídas), na primavera/verão. Resultados das análises das séries temporais na tabela 5 . 


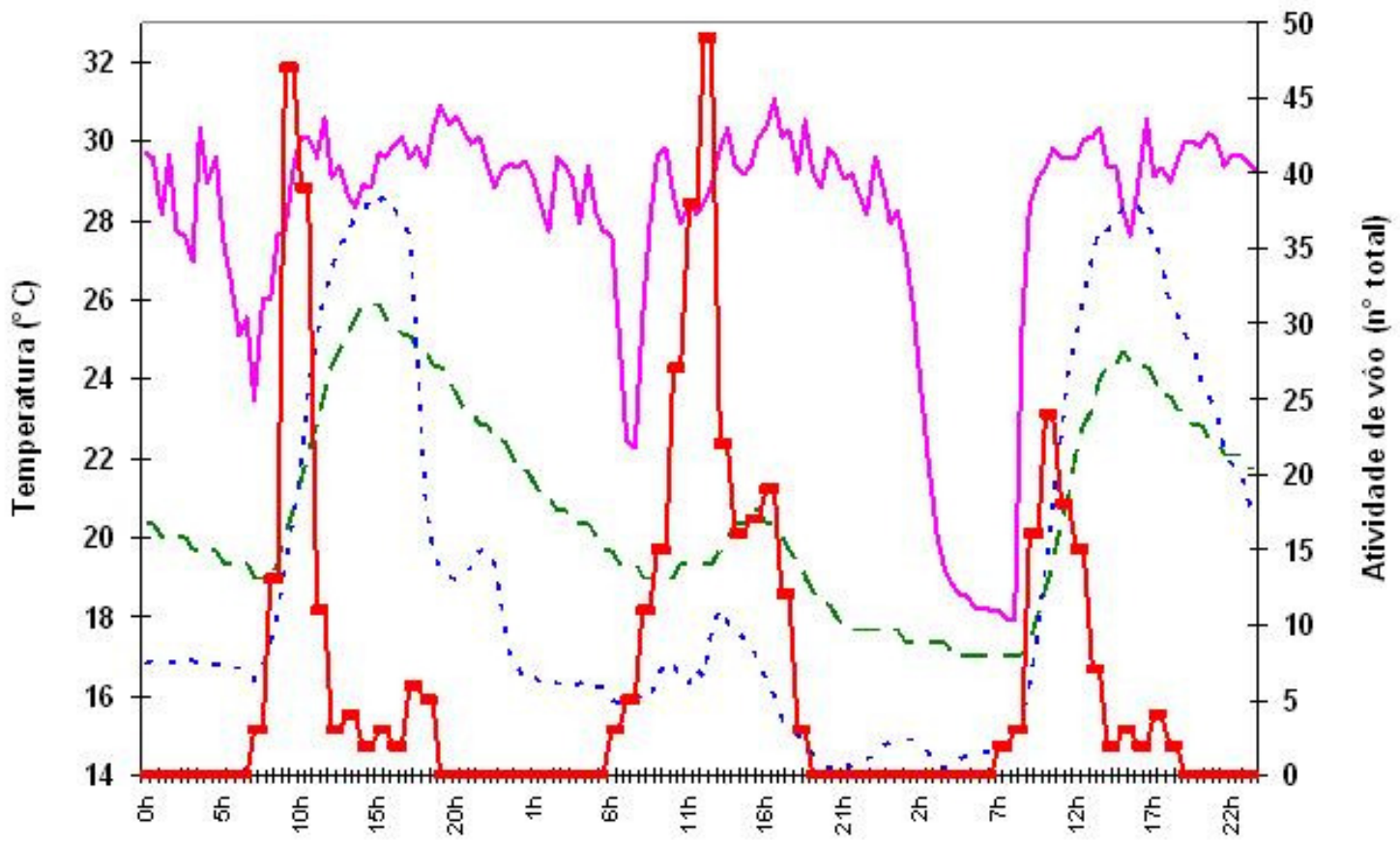

- Cria - -Potes -- Ambiente $\rightarrow$-Vôo

A

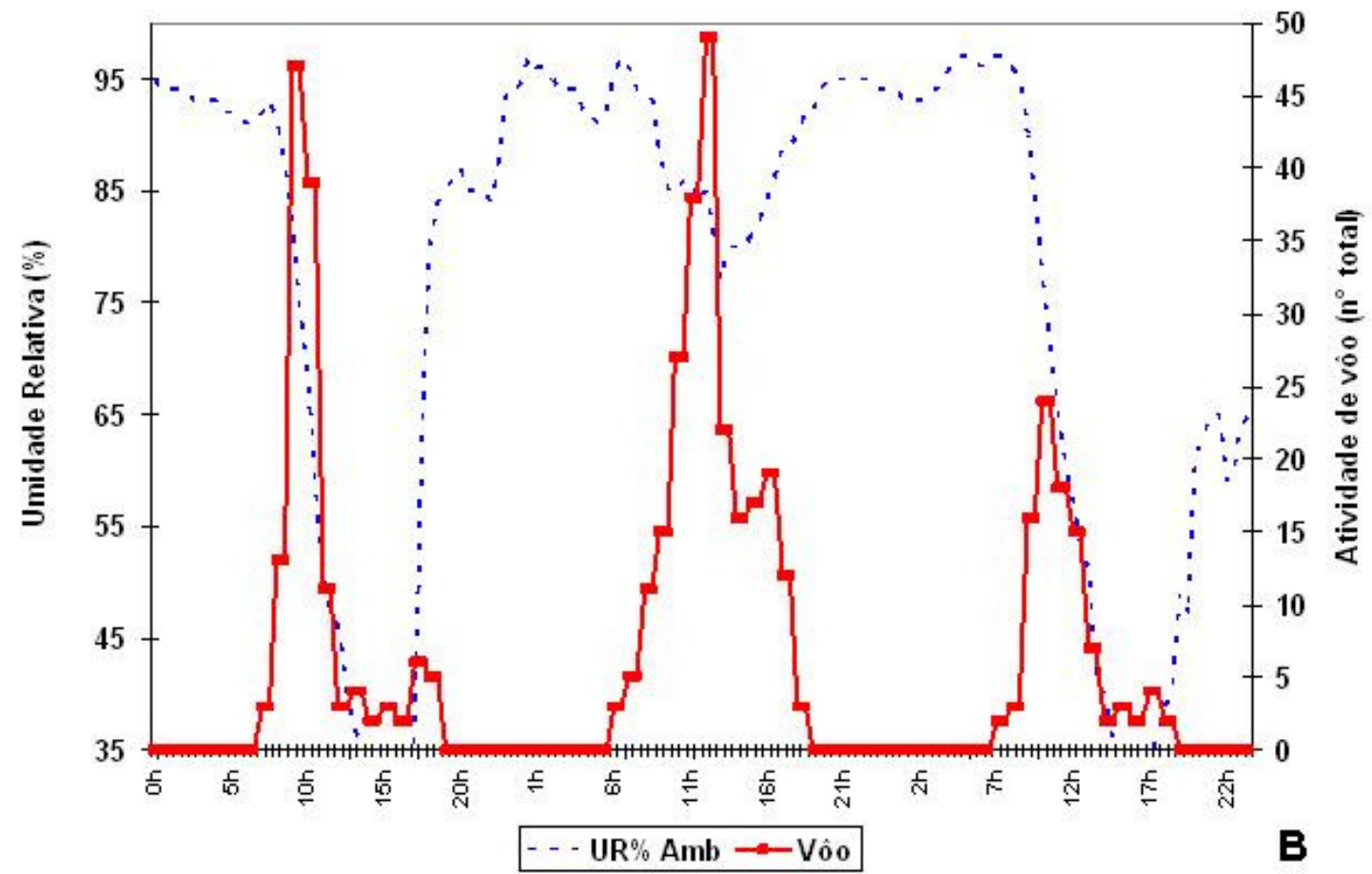

Figura 12. Séries temporais de temperatura (A) e umidade relativa (B), considerando-se também a atividade de vôo (número total de entradas e saídas), no outono/inverno. Resultados das análises das séries temporais na tabela 6. 


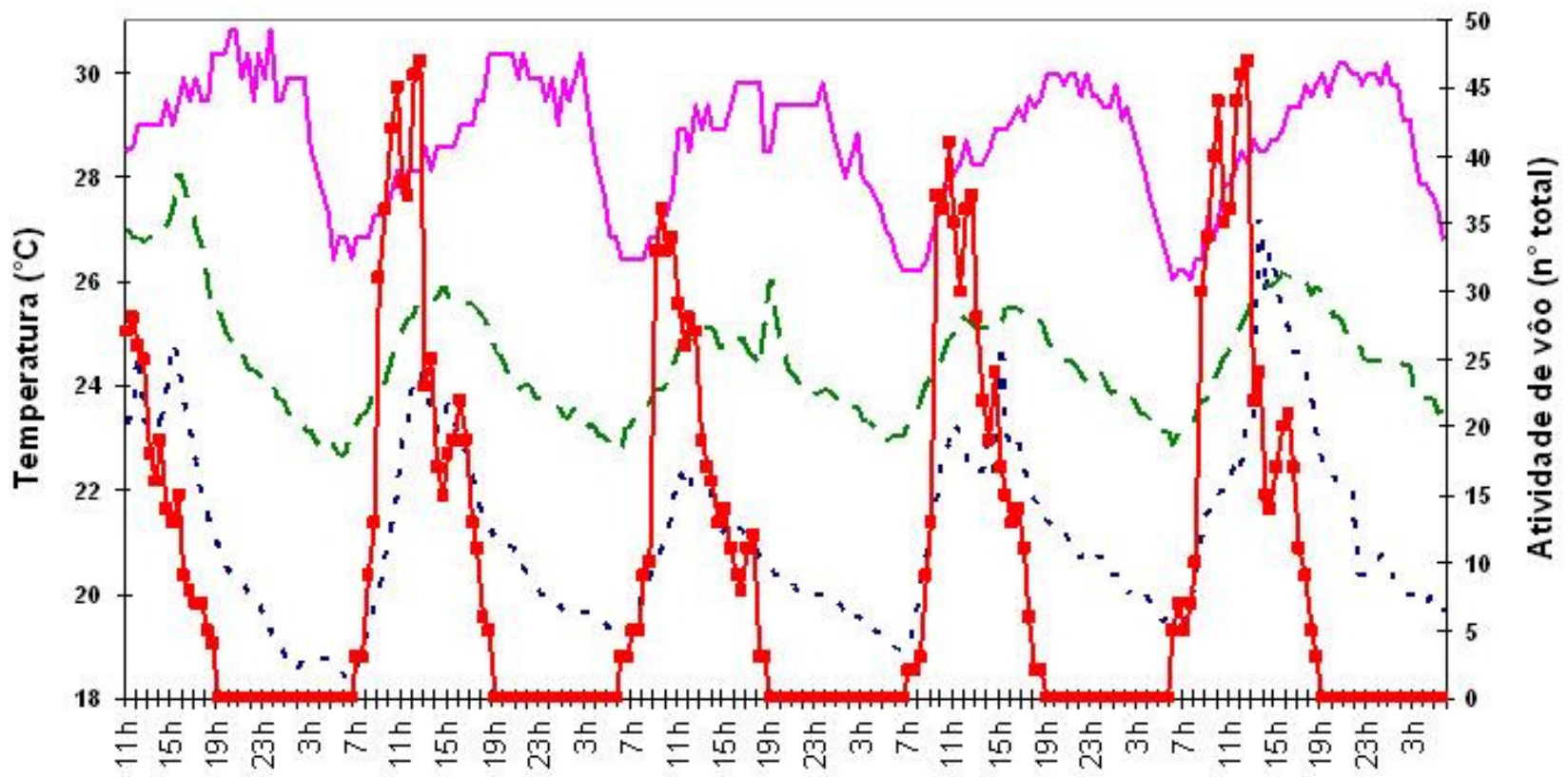

- - -Ambiente - Cria - -Potes - - Vôo

A

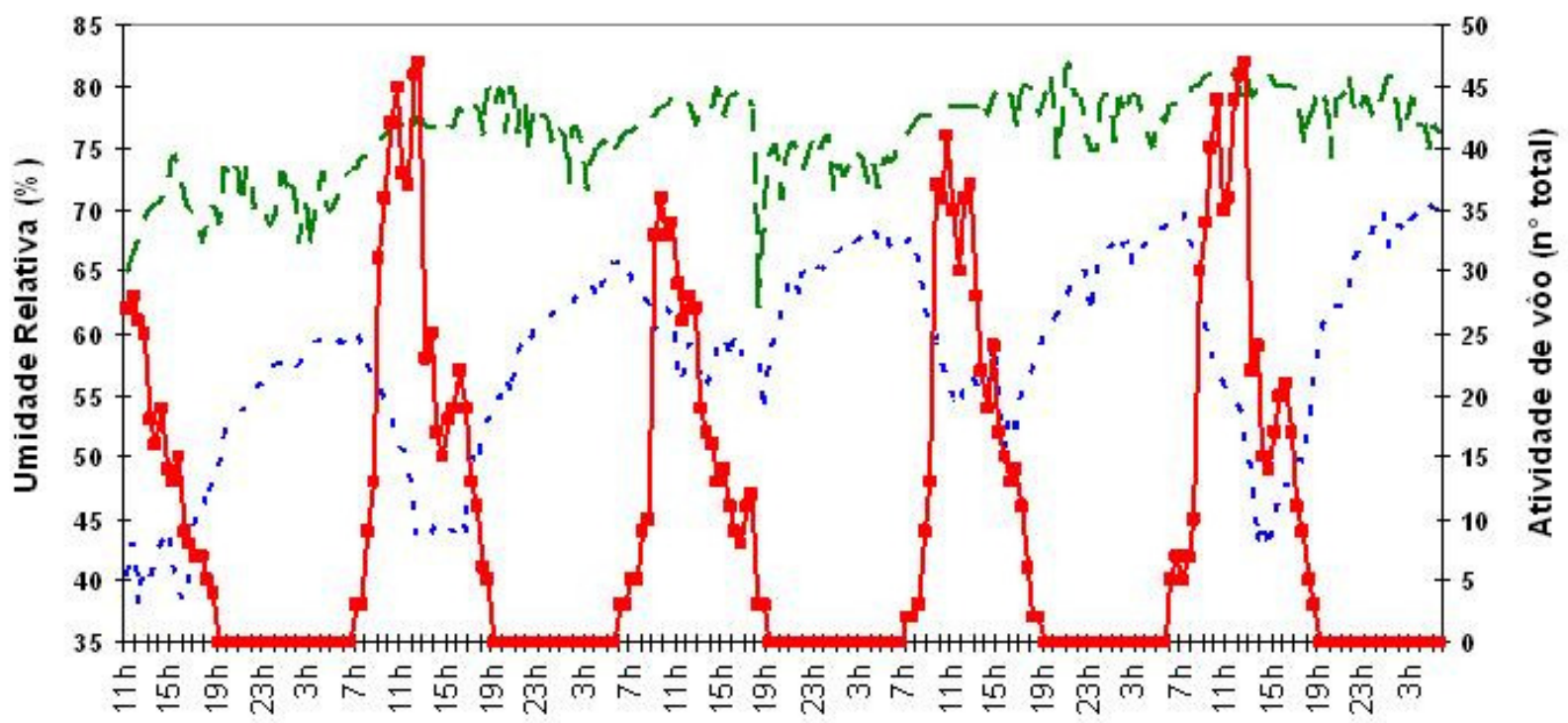

- - -UR \% ambiental - -UR \% colonial - -Vôo

Figura 13. Séries temporais de temperatura (A) e umidade relativa (B), considerando-se também a atividade de vôo (número total de entradas e saídas), no outono/inverno. Resultados das análises das séries temporais na tabela 7 . 


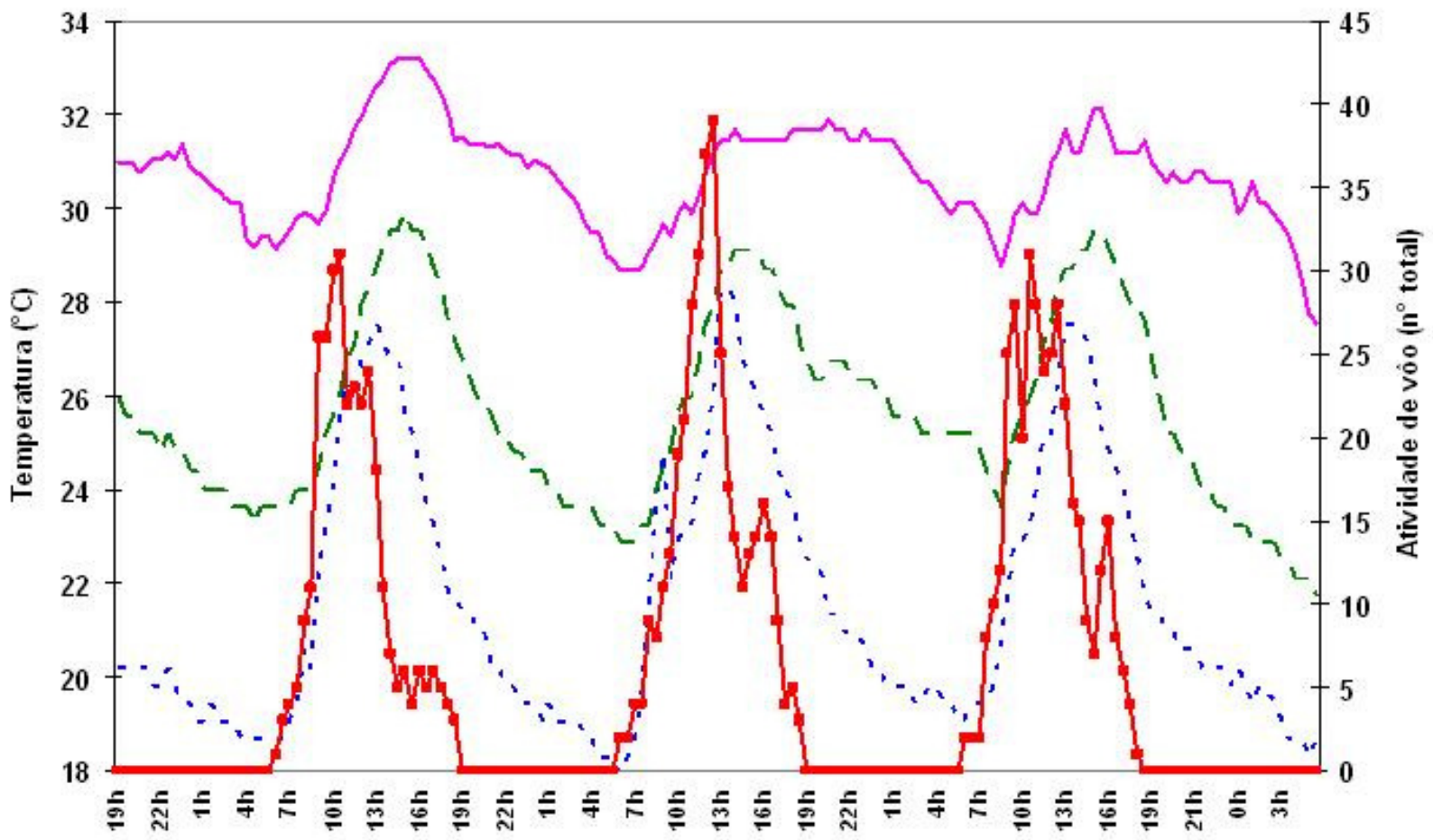

- Ambiente $\longrightarrow$ Cria - -Potes $\rightarrow-$ Vôo

A

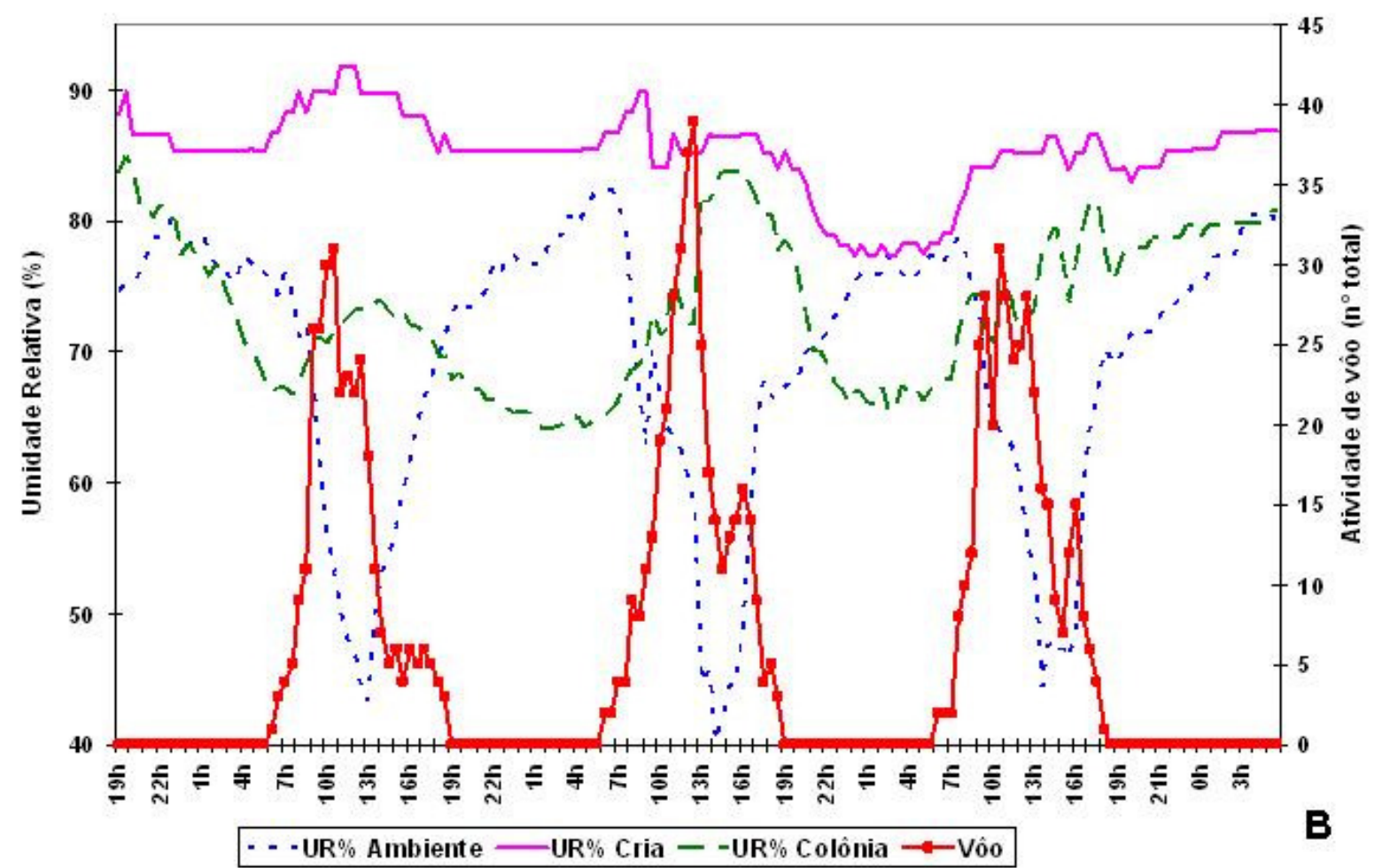

Figura 14. Séries temporais de temperatura (A) e umidade relativa (B), considerando-se também a atividade de vôo (número total de entradas e saídas), no outono/inverno. Resultados das análises das séries temporais na tabela 8 . 


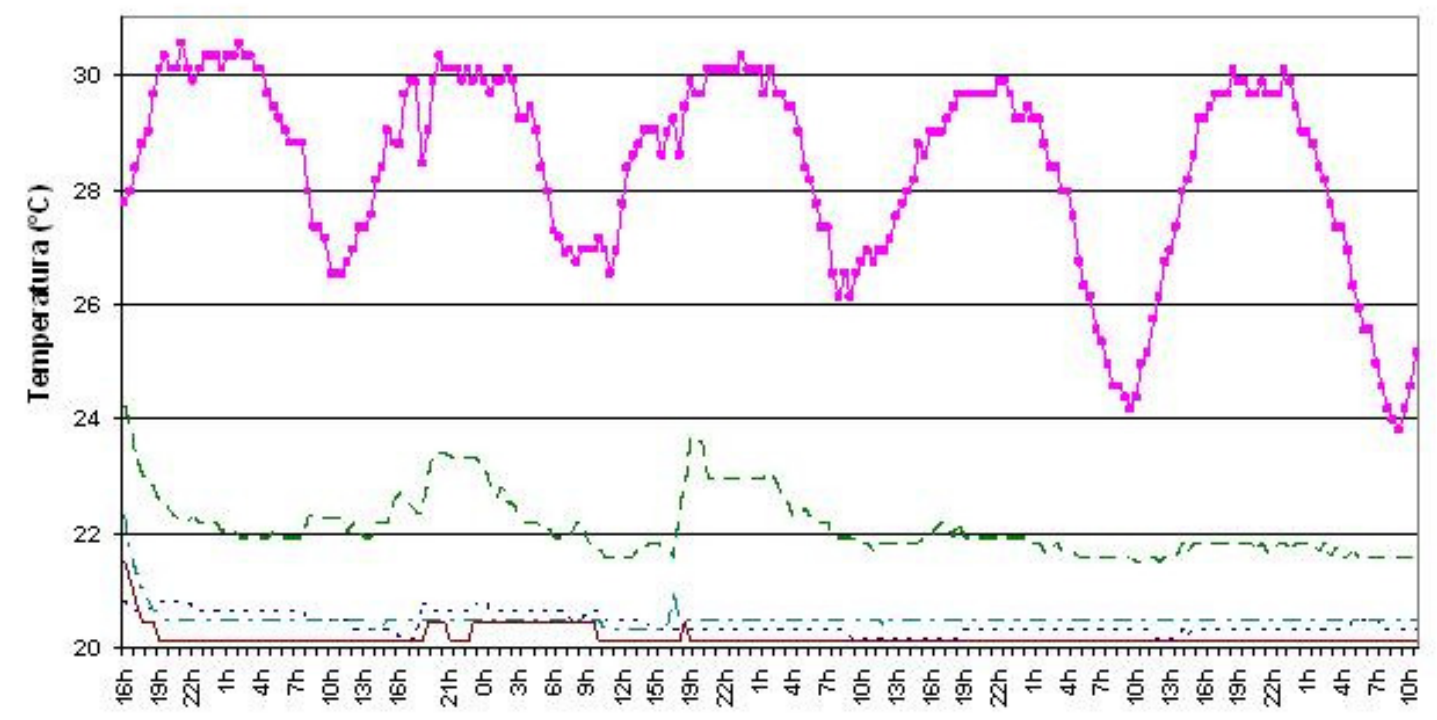

$\cdots$ - câmara - controle favo $-\cdots$ controle pote $\rightarrow$ favos -- potes

Figura 15. Séries temporais de temperatura em colônia forte, mantida fechada em câmara climática a $20^{\circ} \mathrm{C}$. Estão considerados também os valores de controles (ninhos sem abelhas). Resultados das análises de séries temporais na tabela 9 .

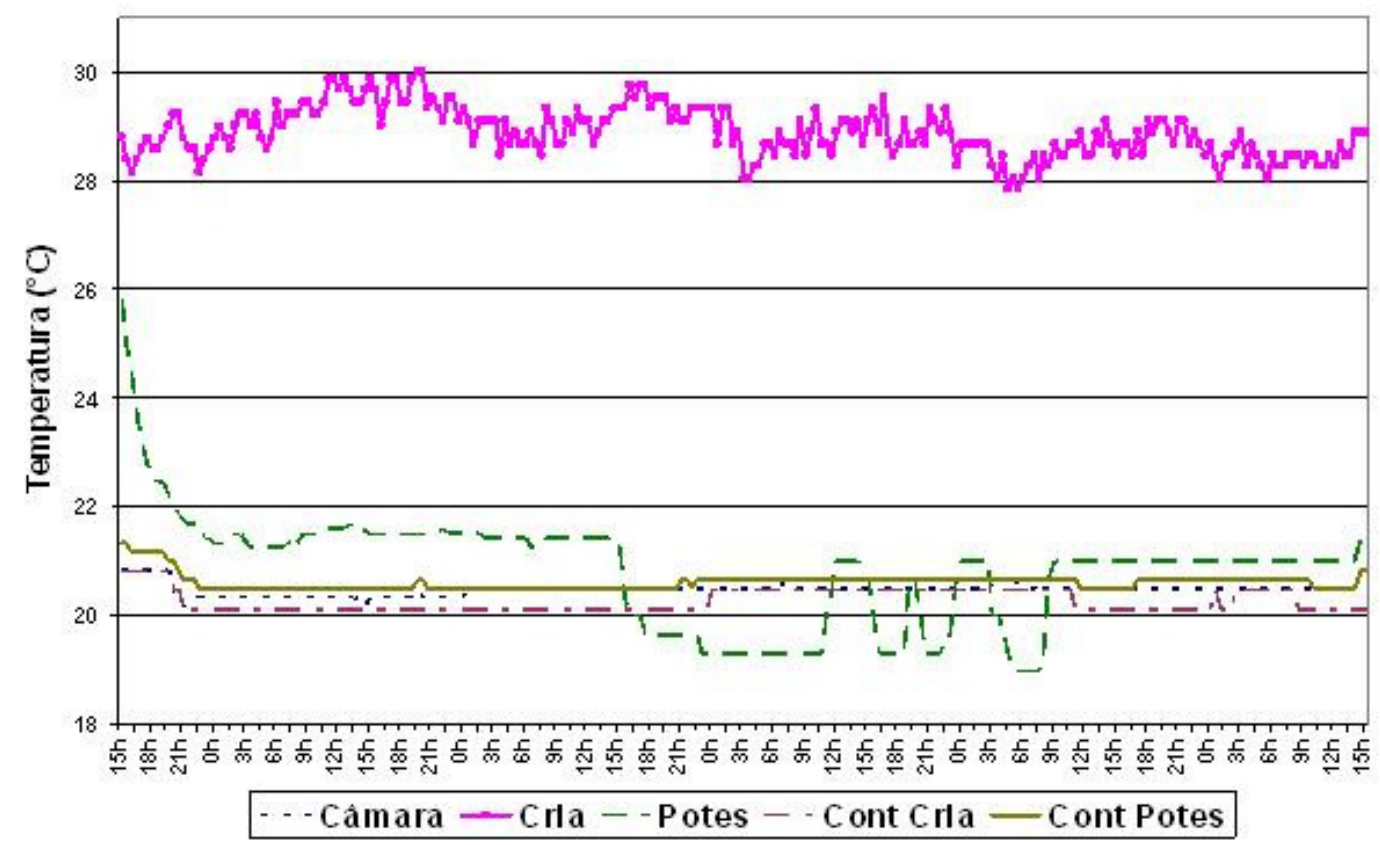

Figura 16. Séries temporais de temperatura em colônia fraca, mantida fechada em câmara climática a $20^{\circ} \mathrm{C}$. Estão considerados também os valores de controles (ninhos sem abelhas). Resultados das análises de séries temporais na tabela 10 . 


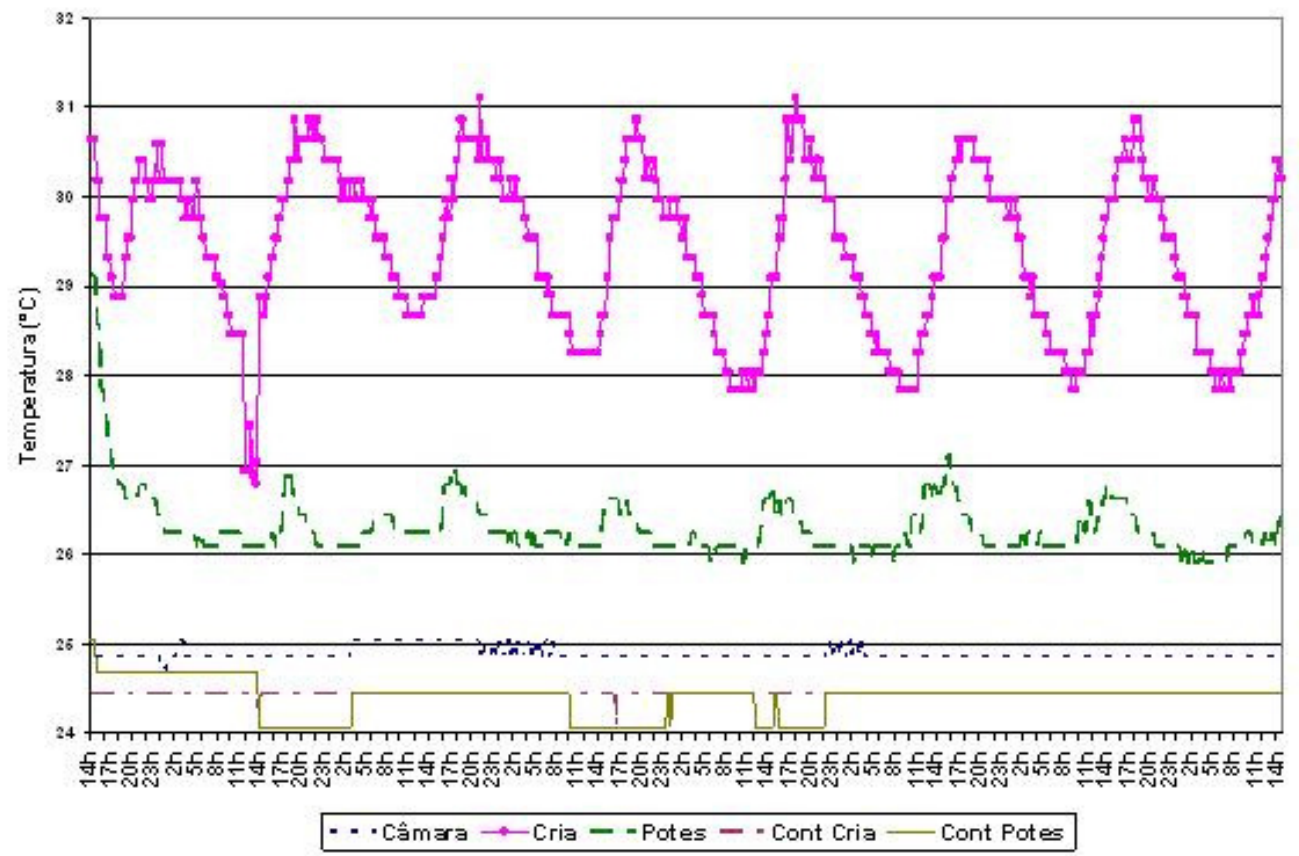

Figura 17. Séries temporais de temperatura em colônia forte, mantida fechada em câmara climática a $25^{\circ} \mathrm{C}$. Estão considerados também os valores de controles (ninhos sem abelhas). Resultados das análises de séries temporais na tabela 11 .

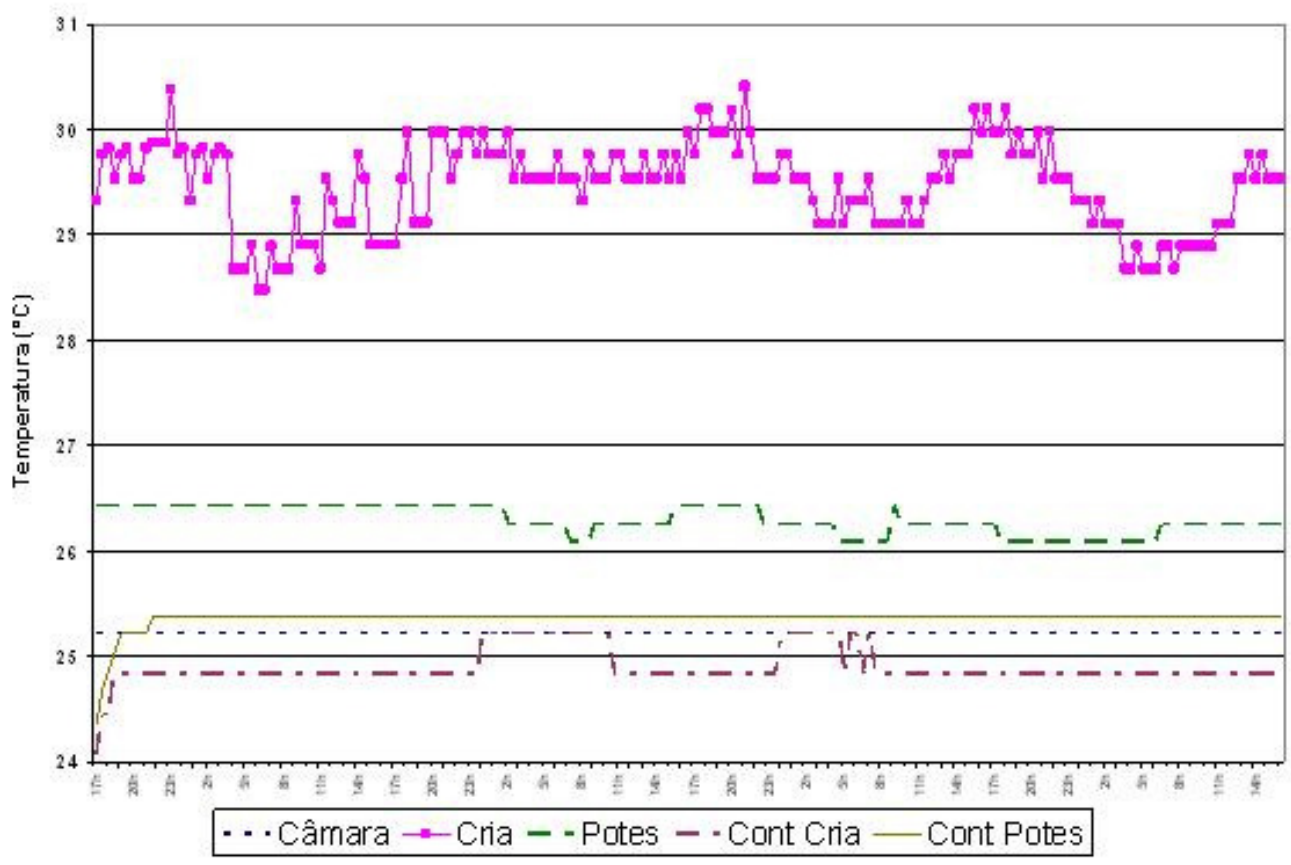

Figura 18. Séries temporais de temperatura em colônia fraca, mantida fechada em câmara climática a $25^{\circ} \mathrm{C}$. Estão considerados também os valores de controles (ninhos sem abelhas). Resultados das análises de séries temporais na tabela 12 . 

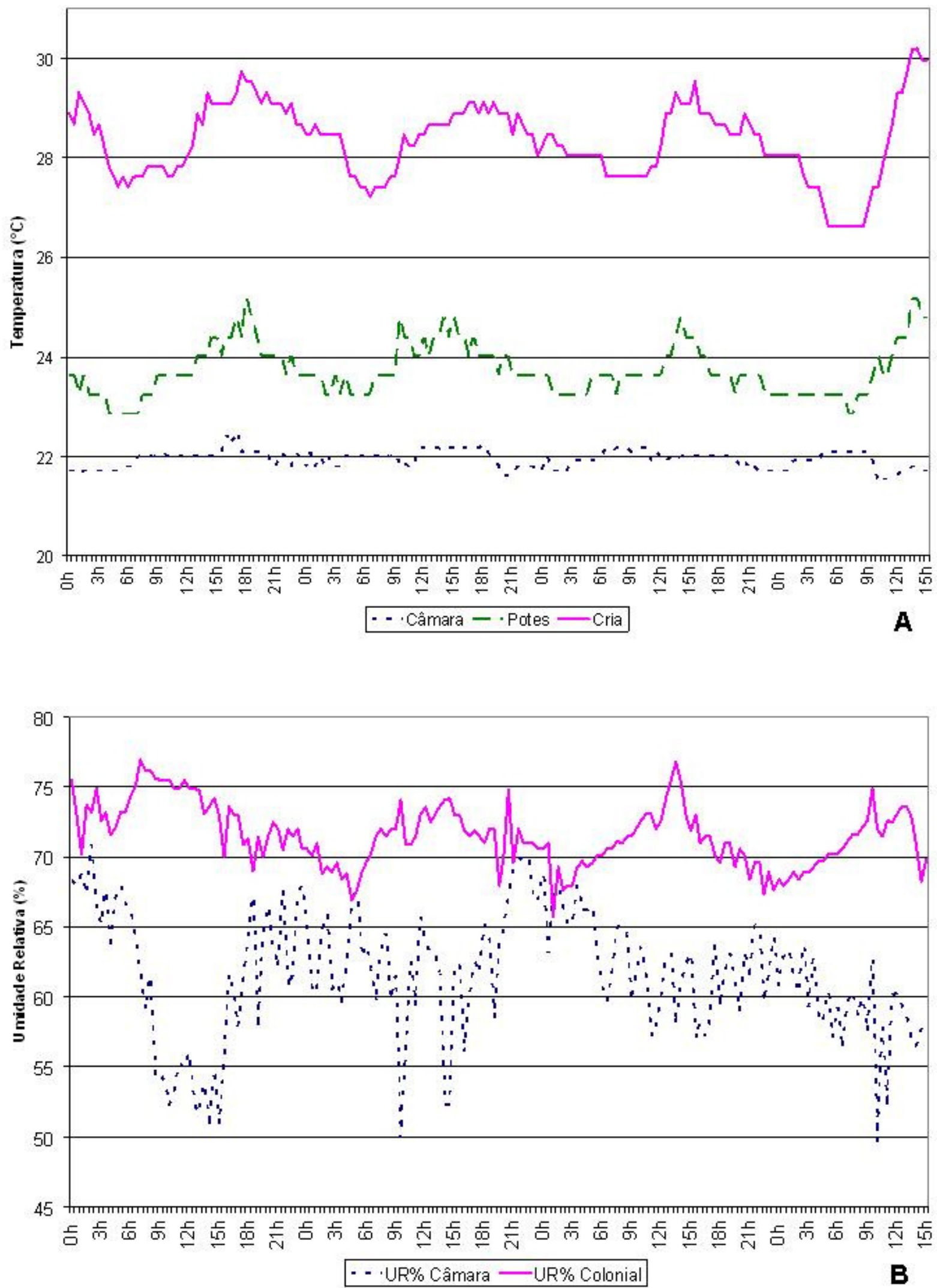

Figura 19. Séries temporais de temperatura (A) e de umidade relativa (B) em colônia mantida fechada em câmara climática Resultados das análises de séries temporais na tabela 13 . 

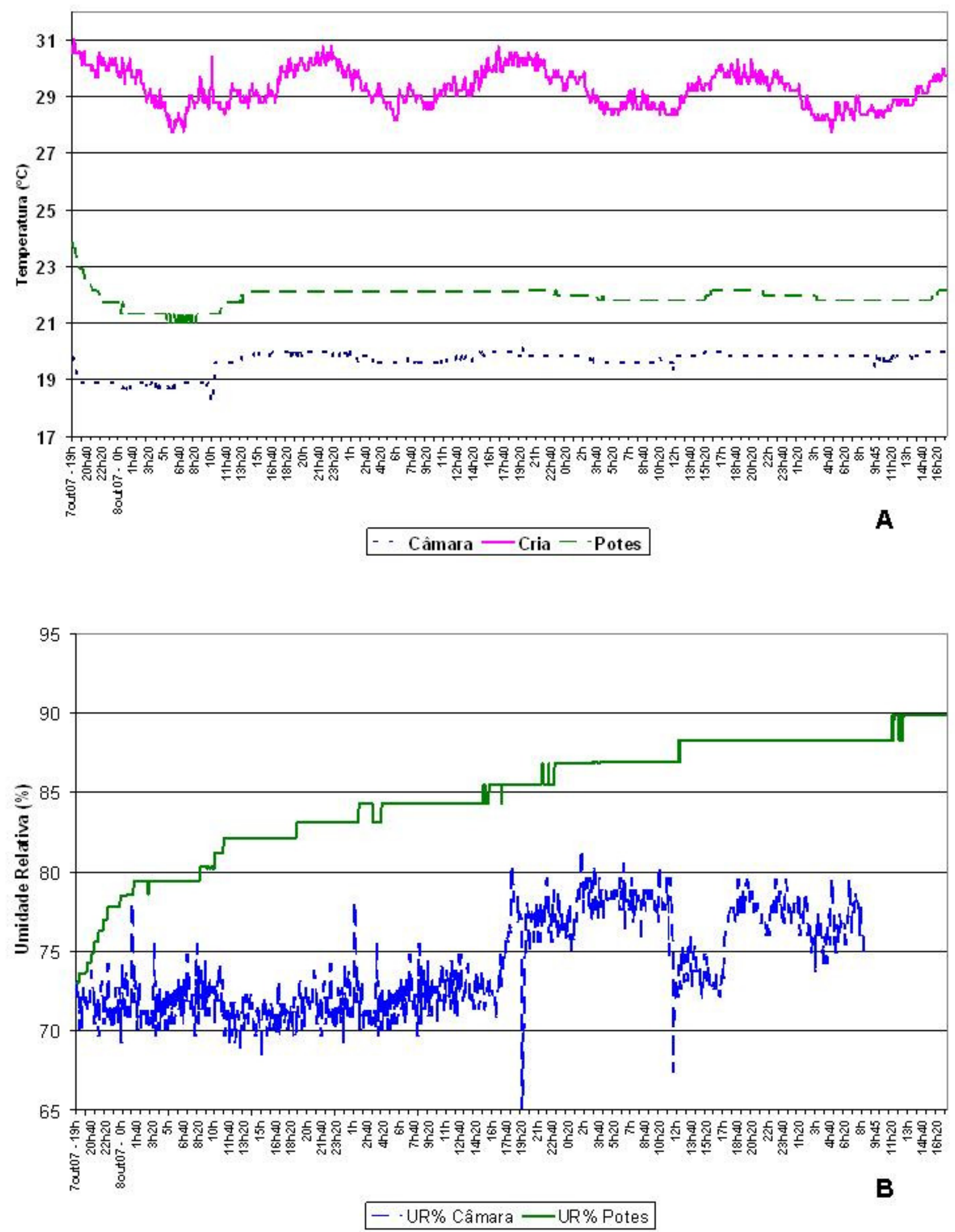

Figura 20. Séries temporais de temperatura (A) e de umidade relativa (B) em colônia mantida fechada em câmara climática Resultados das análises de séries temporais na tabela 14 . 

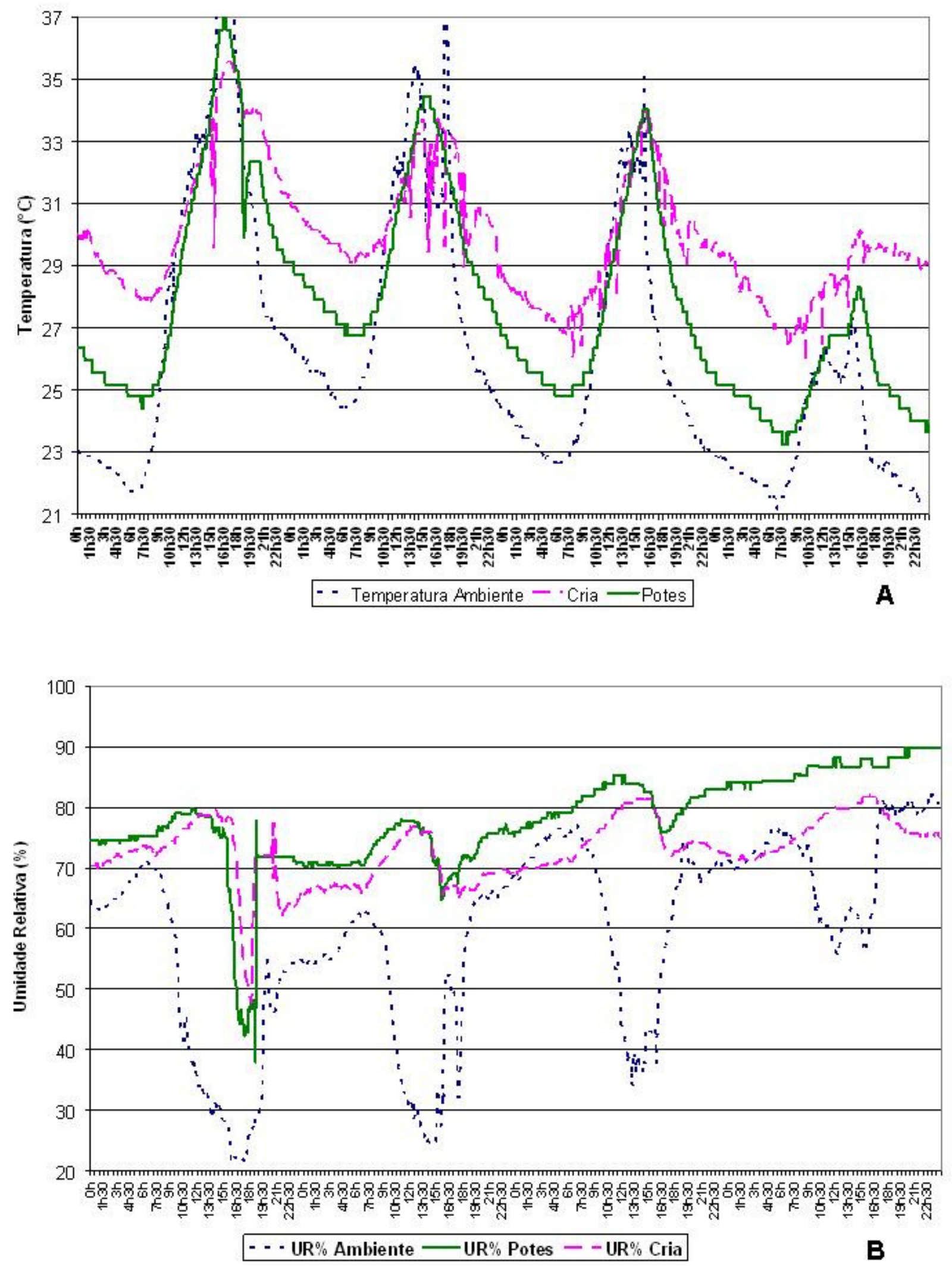

Figura 21. Séries temporais de temperatura (A) e de umidade relativa (B) de colônia aberta tratada com Alprenolol. Resultados das análises de séries temporais na tabela 15 . 


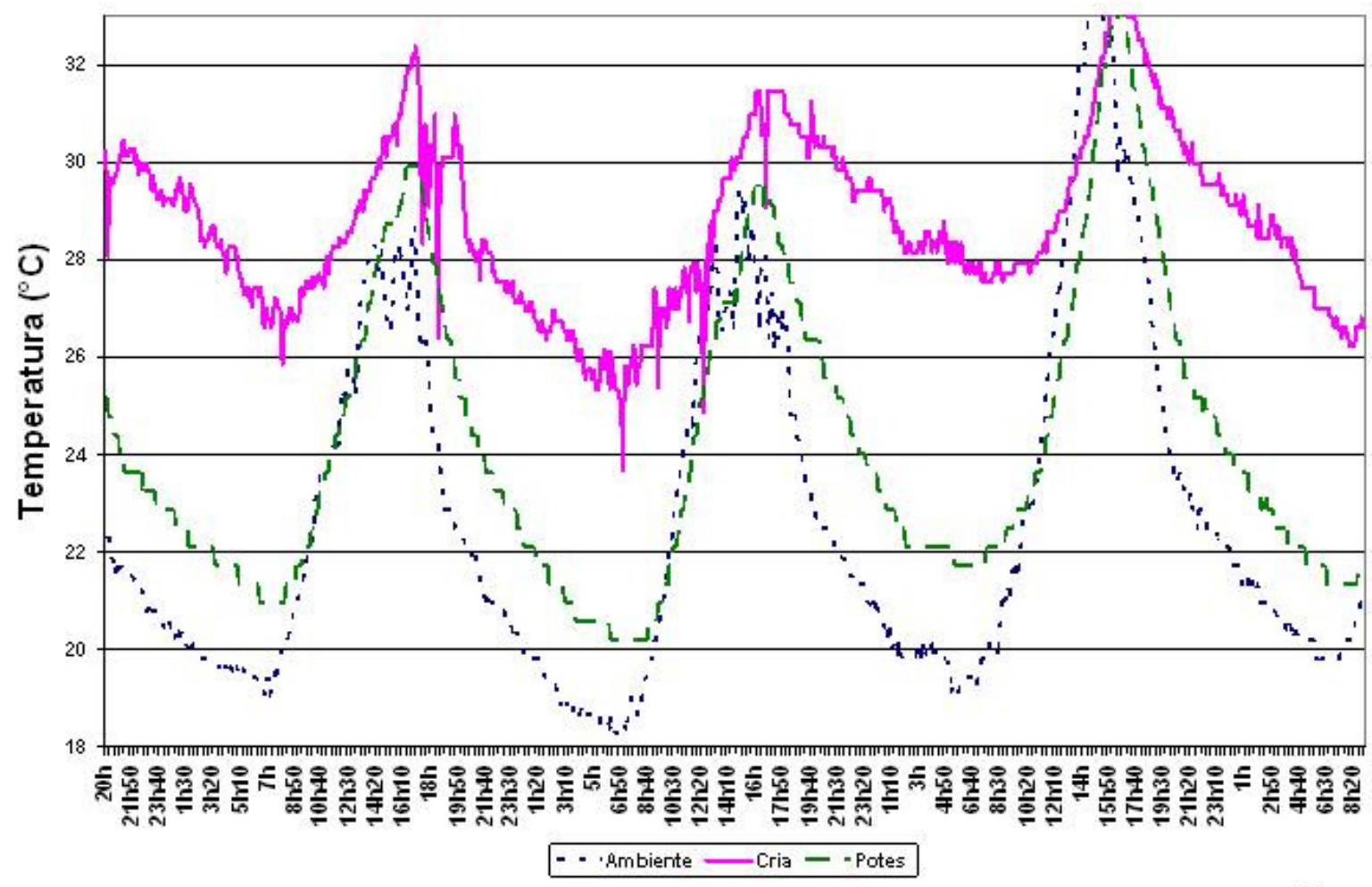

A

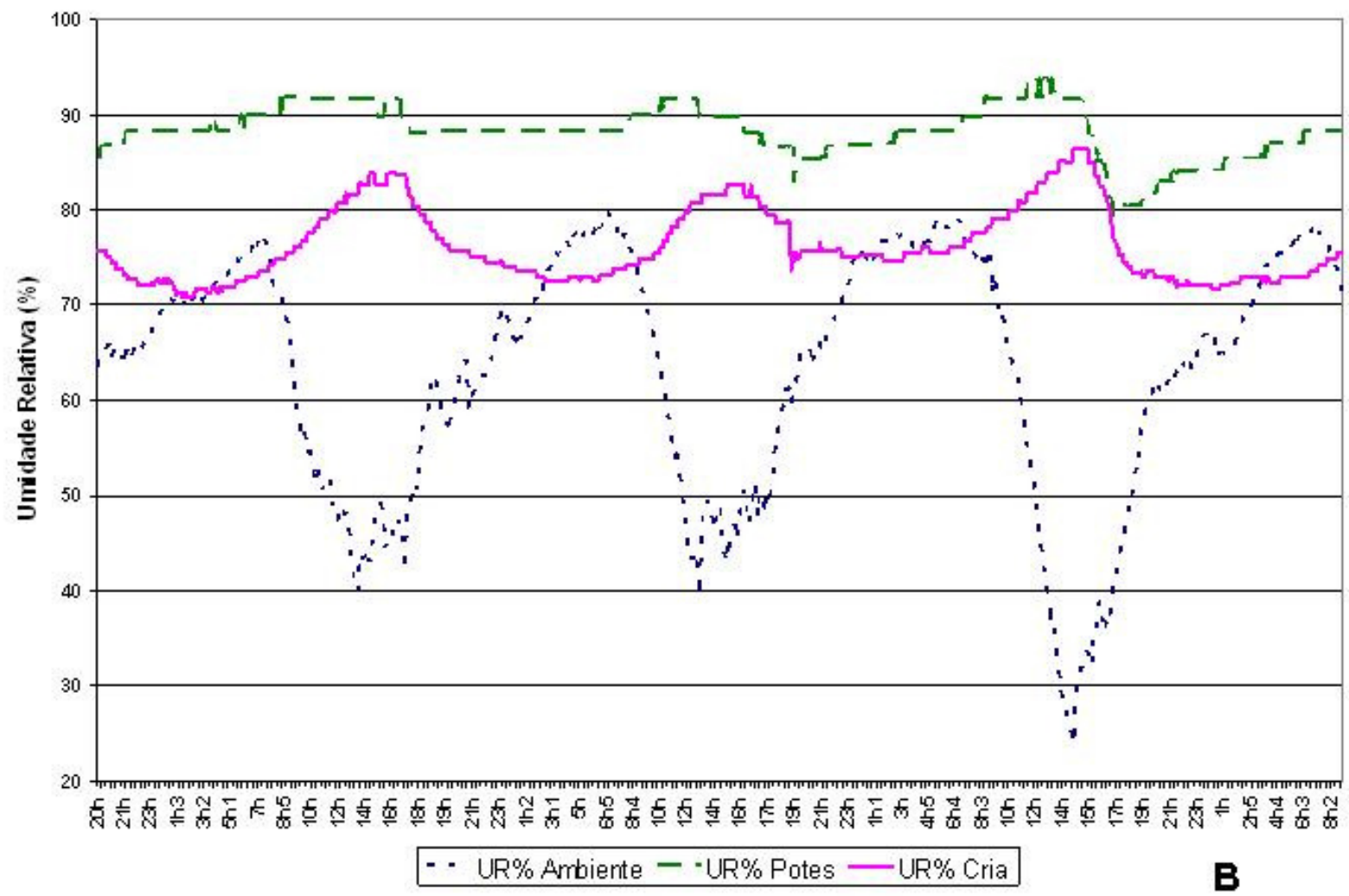

Figura 22. Séries temporais de temperatura $(A)$ e de umidade relativa $(B)$ de colônia aberta tratada com Alprenolol. Resultados das análises de séries temporais na tabela 16 . 


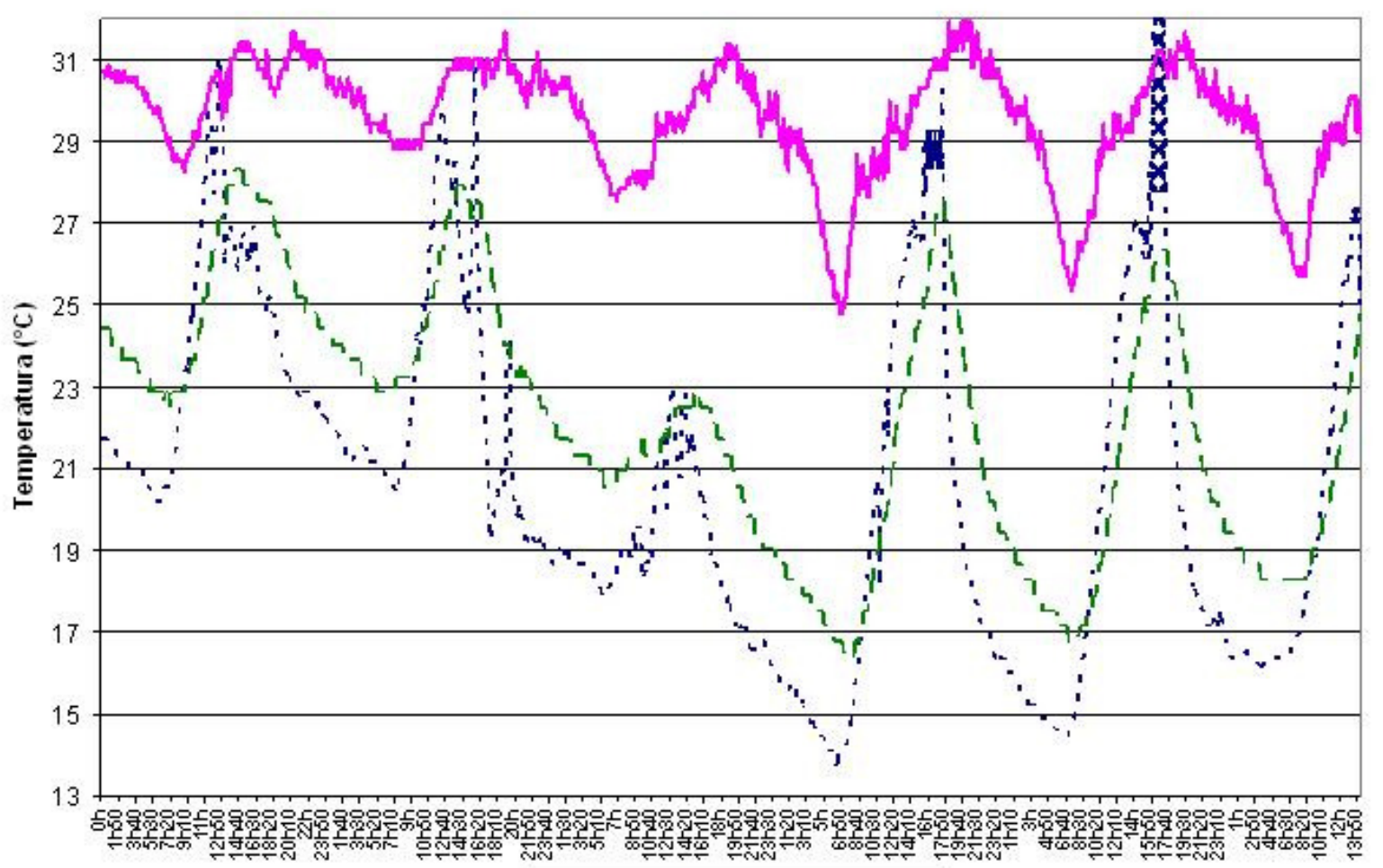

- - Ambiente -Cria - Potes

A

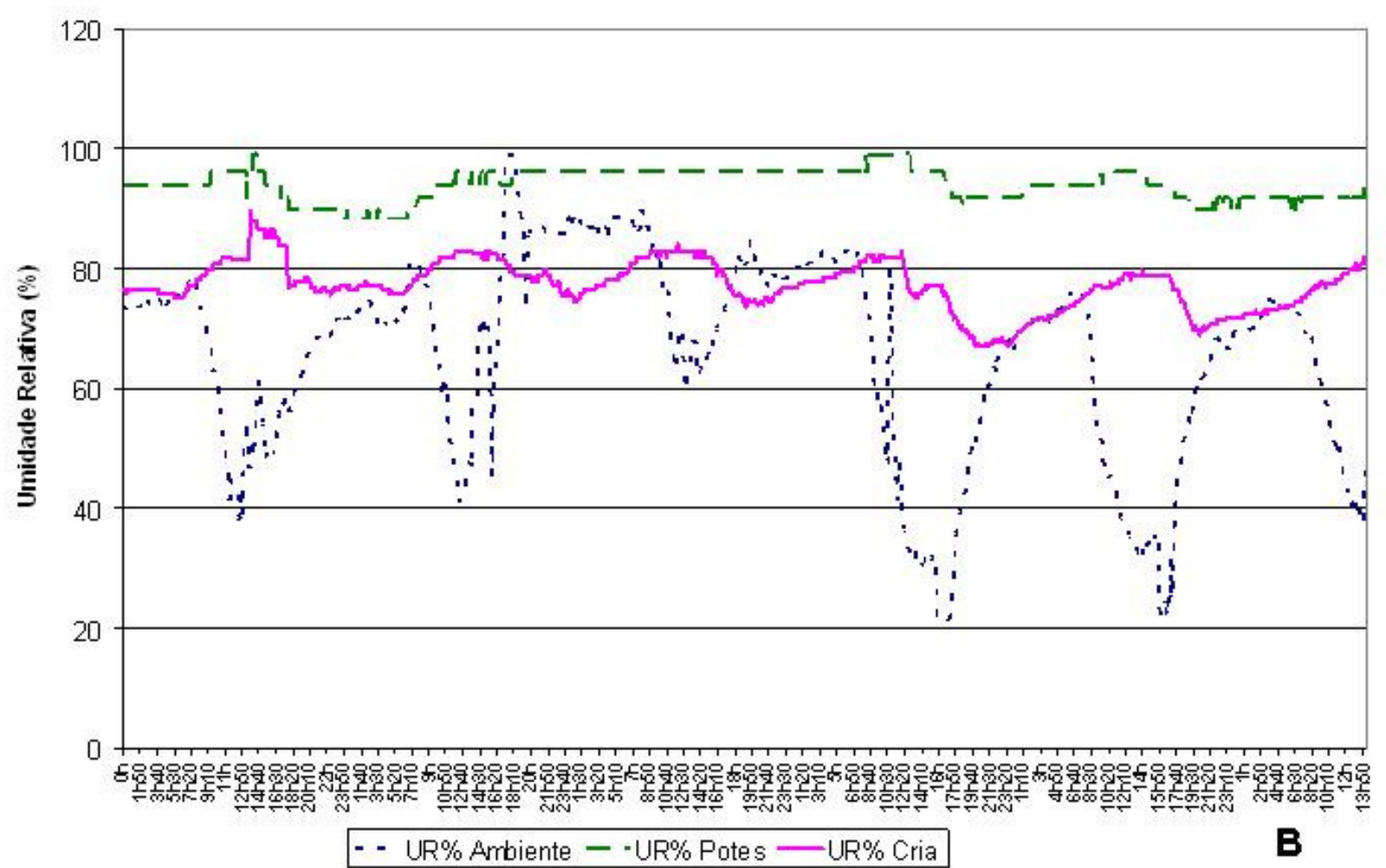

Figura 23. Séries temporais de temperatura $(A)$ e de umidade relativa $(B)$ de colônia aberta tratada com Mianserina. Resultados das análises de séries temporais na tabela 17 . 


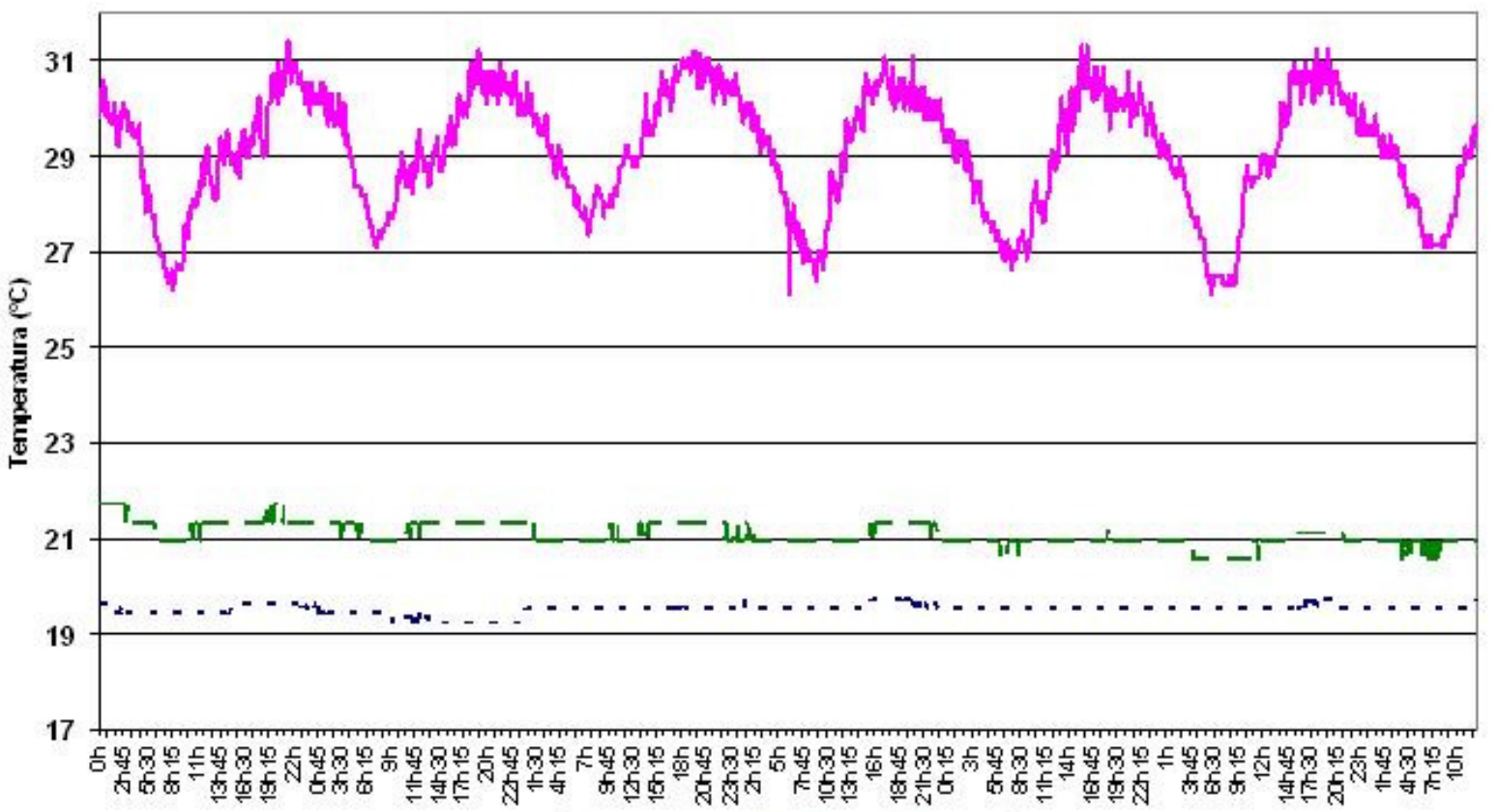

- - Ambiente - Cria - Potes

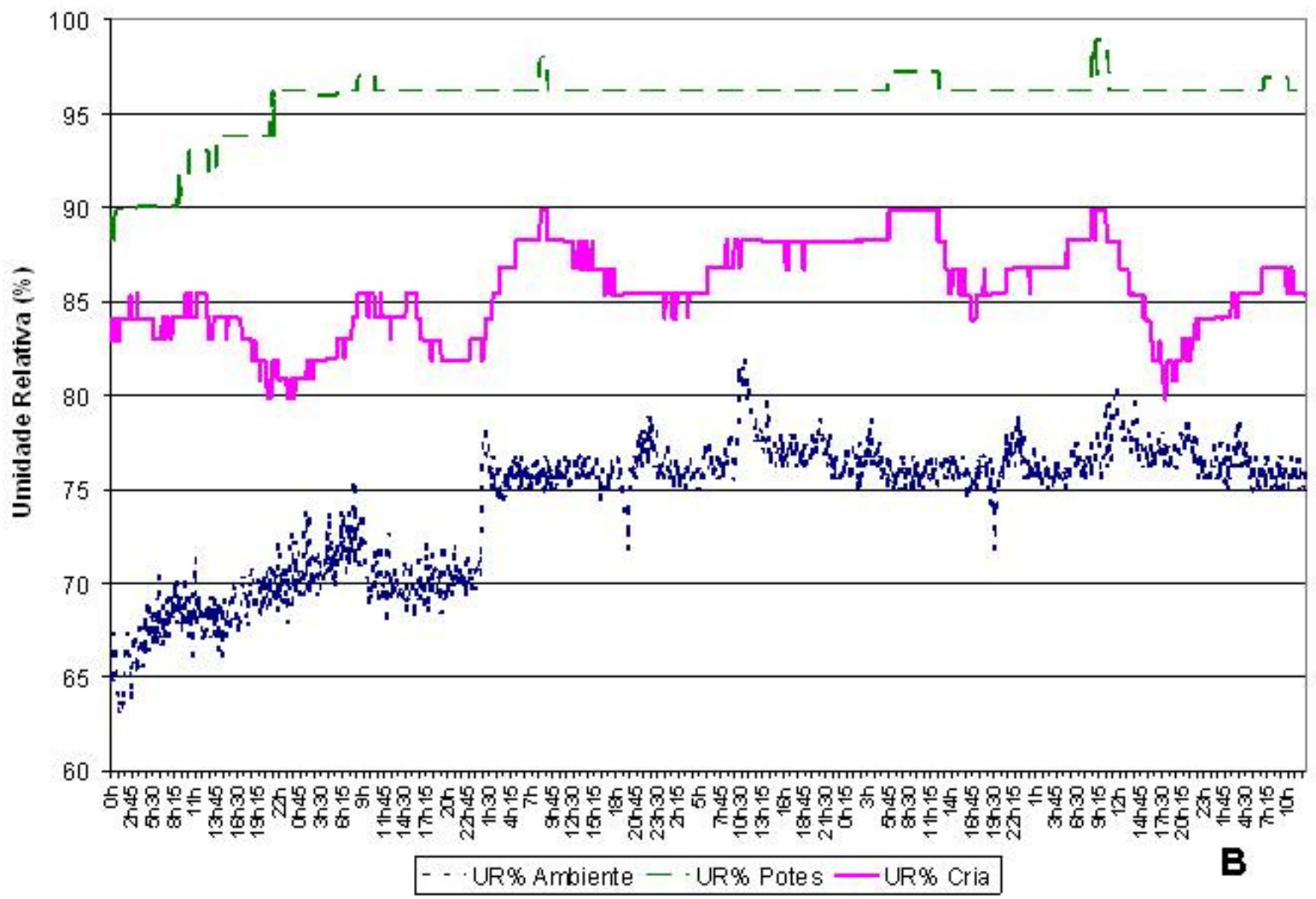

Figura 24. Séries temporais de temperatura (A) e de umidade relativa (B) de colônia tratada com Mianserina mantida fechada a $20^{\circ} \mathrm{C}$. Resultados das análises de séries temporais na tabela 18 . 

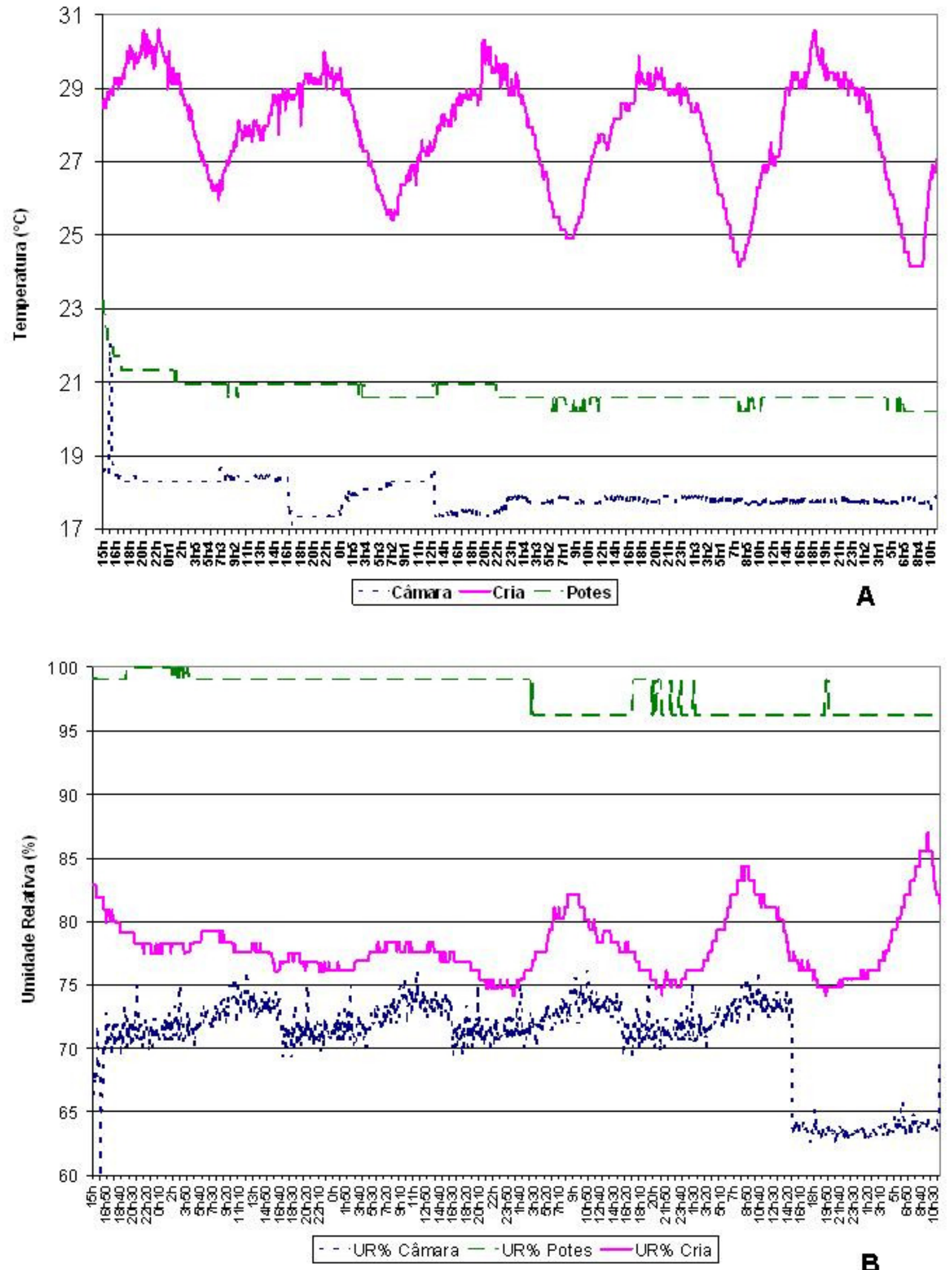

Figura 25. Séries temporais de temperatura (A) e de umidade relativa (B) de colônia tratada com Alprenolol mantida fechada a $20^{\circ} \mathrm{C}$. Resultados das análises de séries temporais na tabela 19 . 

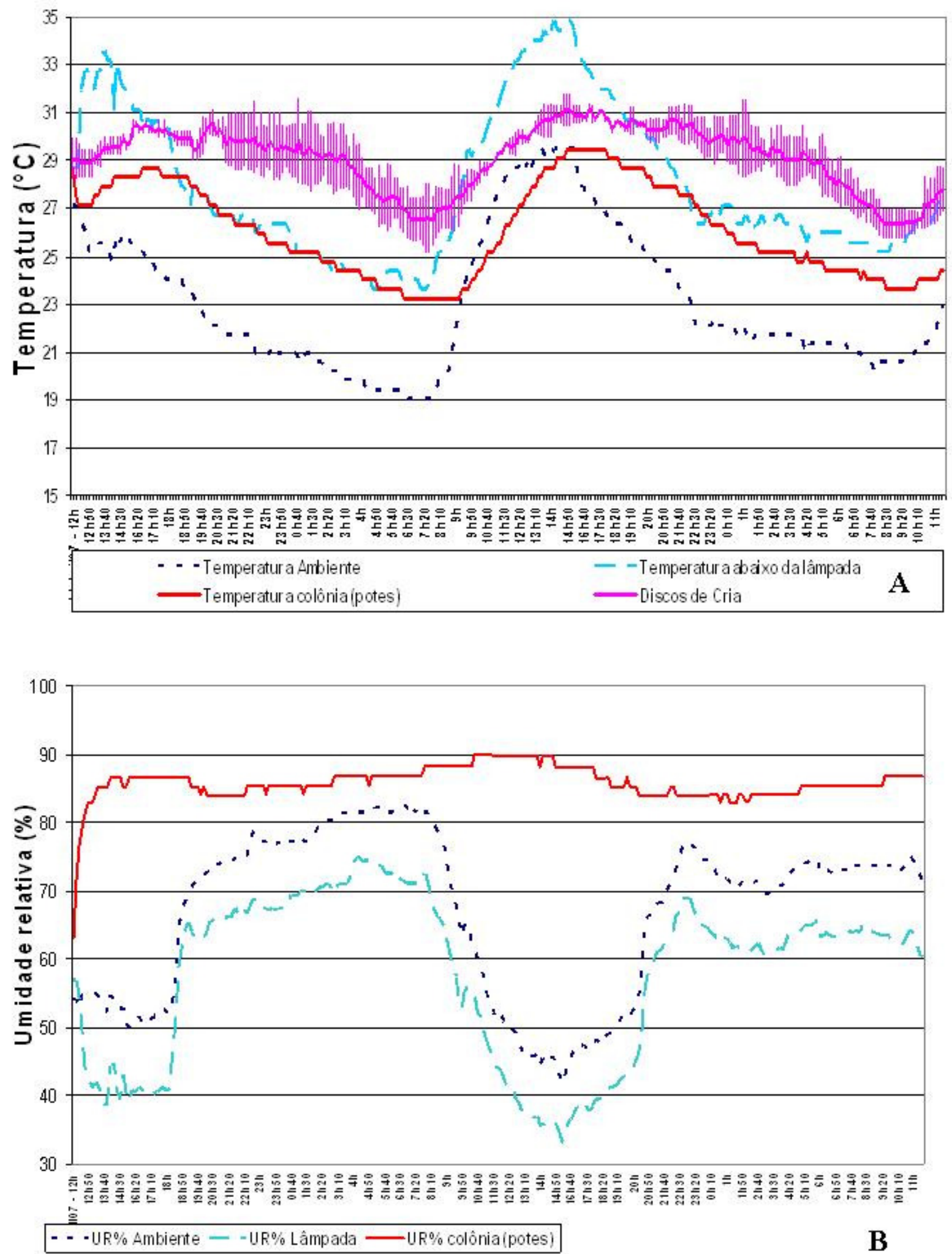

Figura 26. Séries temporais de temperatura (A) e umidade relativa (B) coletadas em colônia submetida a testes de procedimentos para registro de atividade interna colonial com emprego de lâmpada incandescente. 

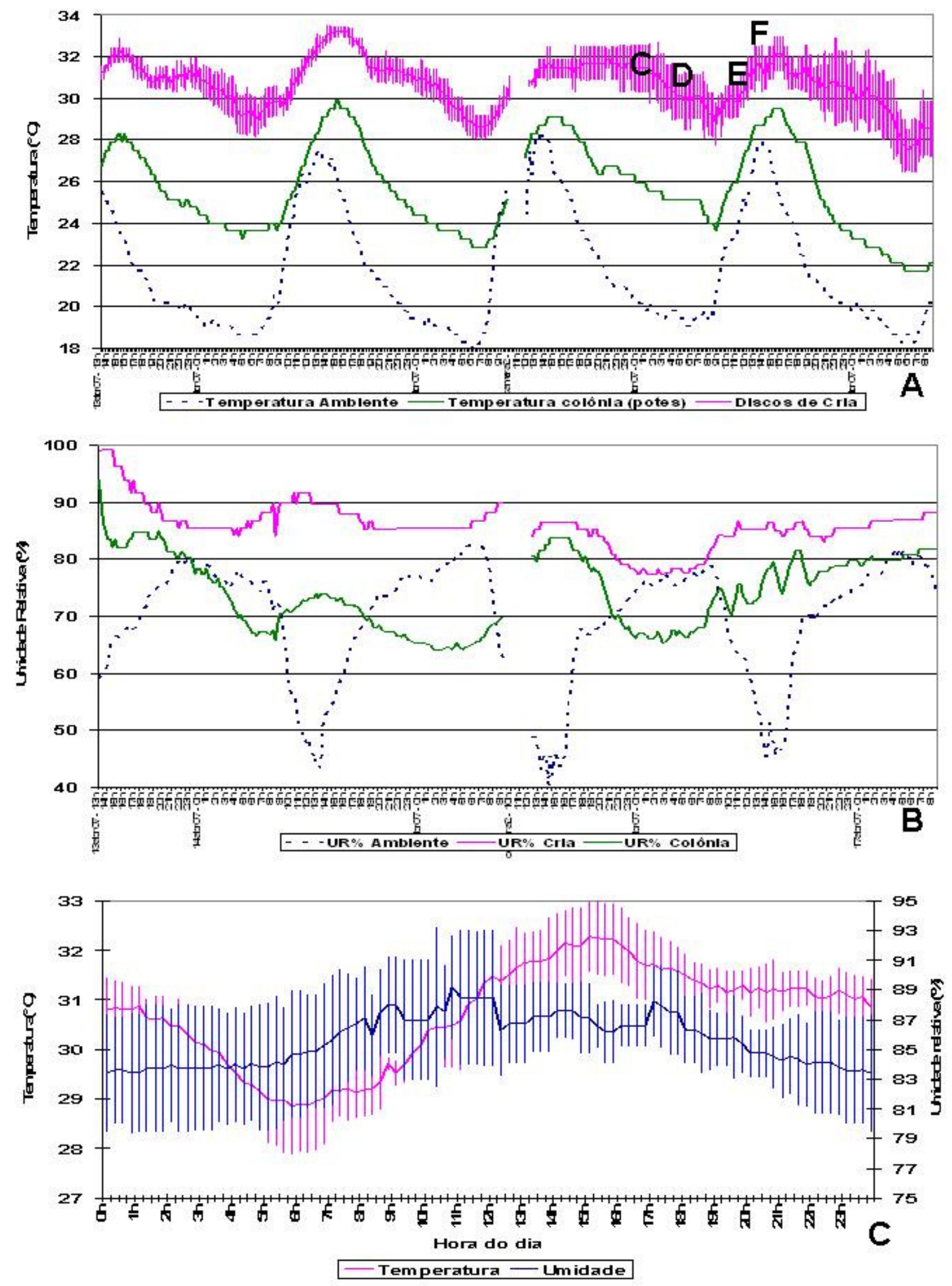

Figura 27. Séries temporais de temperatura (A), umidade relativa (B) e média horária dos diversos dias (C), coletadas em colônia submetida a testes de procedimentos para registro de atividade interna colonial com emprego de câmera de vídeo com infravermelho. Em A estão marcados os momentos das imagens citadas 


\section{Capítulo 3}

\section{Influências do ciclo claro/escuro e da temperatura sobre a taxa metabólica de abelhas forrageadoras}

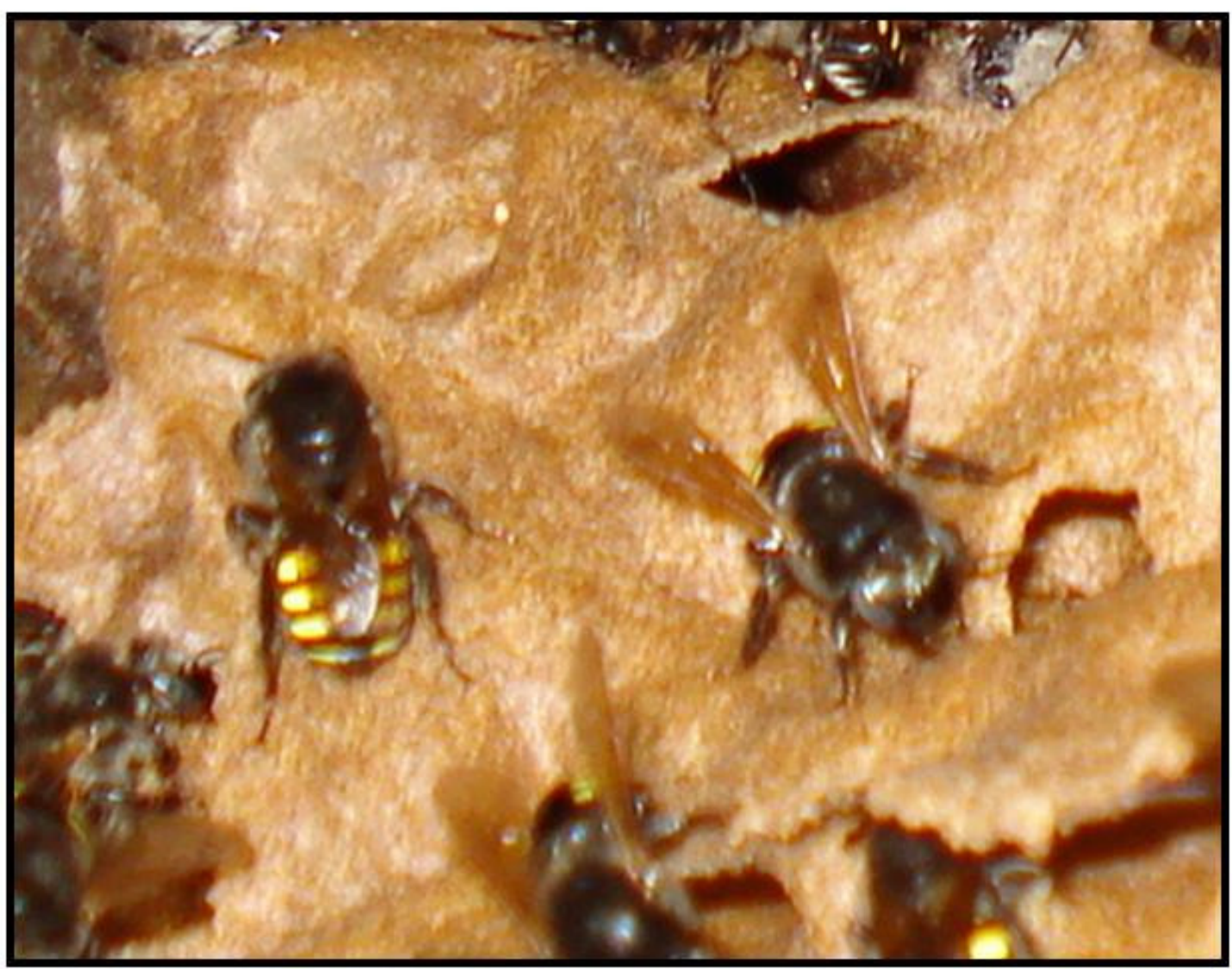




\section{Capítulo 3. Influências do ciclo claro/escuro e da temperatura sobre a taxa metabólica de abelhas forrageadoras}

\section{RESUMO}

Nas abelhas, alguns ciclos ambientais (Zeitgeber) que influenciam os seus ritmos endógenos são, entre outros, a temperatura, a interação social e o ciclo claro/escuro. Este último afeta principalmente a divisão de trabalho na colônia, a atividade de vôo, atividade locomotora e a taxa metabólica de abelhas. As variações de temperatura exercem também efeitos consideráveis em diversos processos fisiológicos. O objetivo deste capítulo foi caracterizar o efeito do tipo de iluminação e de diferentes temperaturas sobre a taxa metabólica de forrageadoras de $M$. quadrifasciata. Também objetivou-se eleger condições experimentais adequadas para experimentos posteriores, como janelas temporais para coleta de dados e faixa de temperatura na qual a taxa metabólica não varia por influência térmica. As abelhas estudadas foram forrageadoras coletoras de néctar/água e de pólen, consideradas separadamente. Foram estudados, por meio de respirometria intermitente, os efeitos do ciclo claro/escuro a $28^{\circ} \mathrm{C}$ (fotoperíodo normal, fotoperíodo invertido, claro e escuro constante) sobre a taxa metabólica, e os efeitos de diferentes temperaturas ambientais $\left(10\right.$ a $\left.40^{\circ} \mathrm{C}\right)$ sobre a taxa metabólica e quociente respiratório $(\mathrm{QR})$ de forrageadoras. Os diferentes ciclos de claro/escuro afetaram a taxa metabólica das abelhas, constituindo-se, em fotoperíodo normal e claro constante, por dois "patamares" com valores de taxa metabólica baixos entre 19h e 5h. Em fotoperíodo invertido valores diminuídos foram registrados na fase de escuro, que ocorria entre $6 \mathrm{~h}$ e $18 \mathrm{~h}$, obtendo-se um padrão invertido de taxa metabólica, sugerindo a ocorrência de um ritmo exógeno que surge como resposta a mudanças fotoperiódicas. A janela temporal eleita foi entre $7 \mathrm{~h}$ e $17 \mathrm{~h} 59$, no claro, quando não há diferenças estatisticamente significativas na taxa metabólica das forrageadoras. A temperatura tem um efeito significativo sobre a taxa metabólica e QR das forrageadoras, com valores diminuídos a 35 e $40^{\circ} \mathrm{C}$ e mais ainda a $10^{\circ} \mathrm{C}$. Entre 15 e $30^{\circ} \mathrm{C}$ não há diferenças significativas, sendo esta faixa de temperatura adequada para estudos com esta espécie. Parece haver diferenças nos valores de taxa metabólica e QR de forrageadoras conforme função no forrageio (coleta de néctar/água ou de pólen), sendo importante atentar a este fato na escolha de forrageadoras para experimentos de taxa metabólica e QR.

\section{INTRODUČ̃̃O}

\section{RITMOS BIOLÓGICOS E ZEITGEBERS EM ABELHAS}


Muitos estudos com abelhas A mellifera têm focado nos mais variados aspectos dos ritmos circadianos, incluindo a orientação pelo sol (LINDAUER, 1960), interações sociais na colônia (SOUTHWICK e MORITZ, 1987; FRISCH e KOENINGER, 1994; MORITZ E KRYGER, 1994), padrões de atividade de vôo e forrageio (FRISCH e ASCHOFF, 1987; MOORE et al., 1989; MARQUES et al., 1997; MOORE, 2001), memória temporal (BELING, 1929; WAHL, 1932), entre outros. A "memória temporal" permite às abelhas procurar alimento na hora adequada, todos os dias (SAUNDERS, 1982), é uma forma especializada de arrastamento e assegura que os visitantes retornem à fonte de alimento diariamente à mesma hora, ou mesmo que antecipem este comportamento (ASCHOFF, 1986).

A ocorrência de ritmos circadianos em abelhas A mellifera é mais forte em grupos de forrageadoras, as quais saem para forragear e são menos ativas à noite, comparadas com as operárias nutridoras (CRAILSHEIM et al, 1996; MOORE, 2001)., mas o estado da colônia pode modificar esse comportamento (BLOCH e ROBINSON, 2001). A natureza endógena dos ritmos é revelada quando as forrageadoras são removidas de seu ambiente natural e colocadas em condições de claro ou escuro constante (MOORE e RANKIN, 1985).

Nas abelhas sem ferrão, a ritmicidade é abordada com relação a ritmos de forrageamento e atividade de vôo (BELLUSCI, 1998; BELLUSCI e MARQUES, 2001; HILÁRIO et al, 2000; TEIXEIRA, 2003), de atividade na colônia (GIMENES, 2001; ALMEIDA, 2004), de construção de células de cria e de postura pela rainha (BELLUSCI, 2003; GIANINNI, 1998), de trofalaxis (CONTRERA et al, 2002) e de ritmicidade na taxa metabólica (PRONI et al, 2001; PRONI et al, 2004; PRONI e MACIEIRA, 2004; TEIXEIRA, 2006).

Nas abelhas, alguns Zeitgebers conhecidos são: a temperatura, a interação social, a luz (SOUTHWICK e MORITZ, 1987; SAUNDERS, 2002; FUCHIKAWA e SHIMIZU, 2007), a presença da rainha, os ciclos de alimentação (FRISCH e ASCHOFF, 1987; MOORE et al., 1989). Contudo, o Zeitgeber mais importante para a atividade das abelhas é o ciclo claro-escuro (MOORE et al., 1989; MOORE e RANKIN, 1993; MOORE, 2001), influenciando a divisão de trabalho na colônia, os padrões de forrageamento, de atividade de vôo e "arrastando" os seus ritmos endógenos. Alguns estudos com abelhas Apis têm examinado os efeitos de ciclos claro/escuro como, por exemplo, os de Moore e Rankin (1985) e Fuchikawa e Shimizu (2007a,b), em ritmos de atividade locomotora. Neste capítulo são estudados efeitos de diferentes fotoperíodos sobre a taxa metabólica de forrageadoras.

\section{VARIACÕES DE TEMPERATURA E NÍVEIS DE ORGANIZACÃO}

Muitos organismos exibem plasticidade fenotípica na expressão do metabolismo energético, podendo haver variações da taxa metabólica e de vias do metabolismo para ajuste a variações no 
suprimento de recursos ou variações de demanda frente alterações nas condições ambientais, destacadamente a temperatura (BROWN et al, 2004). As variações de temperatura exercem efeitos consideráveis em vários processos fisiológicos (RANDALL et al, 2000) afetando essencialmente toda a célula. Trata-se, portanto, de uma variável ambiental com importantes papéis na evolução.

Para uma análise ampla dos efeitos da temperatura nos organismos, e as respostas adaptativas deles às perturbações térmicas, é necessário conduzir um tipo duplo de análise, envolvendo as abordagens reducionista e integrativa (HOCHACHKA e SOMERO, 2002). Reducionismo refere-se à divisão do todo em partes, os processos sendo assim "reduzidos" a unidades mais básicas (ANH et al, 2006). Os avanços conseguidos com o método científico reducionista são inquestionáveis, tendo sido o paradigma predominante na ciência nos dois séculos passados, além de responsável por diversos sucessos na medicina (AHN et al, 2006), ciências biológicas, ciências exatas, entre outros. O reducionismo tem sido objeto de diversas pesquisas e discussões, como o reducionismo biológico frente à ciência pós-genômica (SCHIOCCHET, 2006) e o "determinismo reducionista biológico" (CARVALHO NETO e MENEZES, 2007), e também alvo de diversas críticas (GOULD, 1977; GOULD E LEWONTIN, 1969; KELLER, 2002; NATÉRCIA, 2005; AHN et al, 2006).

Para uma abordagem mais ampla de problemas e soluções, não basta ficar em uma visão reducionista (VECCHIATTI, 2004). Ao se estudar os efeitos da temperatura sobre o animal, é importante primeiro reconhecer a natureza reducionista da ciência e entender as suas limitações (HOCHACHKA E SOMERO, 2002; ANH et al, 2006) abordando um conjunto de elementos presentes no sistema e questões pontuais, por exemplo, de que forma classes particulares de componentes, como proteínas, são afetados pela temperatura. Mas é também crucial adotar uma abordagem integrativa (HOCHACHKA e SOMERO, 2002) que junte os efeitos da temperatura em diferentes constituintes das células e tecidos, de forma que possa ser apreciada a interrelação entre esses constituintes em adquirir a adaptação à temperatura. Além de uma visão sistêmica, identificando as ligações de fatos particulares do sistema social como um todo (HOCHACHKA e SOMERO, 2002; MARTINELLI, 2006). O pensamento sistêmico é uma concepção basicamente "holística", apresentada por Ludwig von Bertalanffy (1975) em sua teoria geral dos sistemas. A visão holística vem há tempos contestando o pensamento reducionista, mas é necessário um equilíbrio entre holismo e reducionismo (Morin, 1977).

Não é totalmente correto fazer inferências de dados obtidos em diferentes níveis de organização, por exemplo, usar dados obtidos no nível molecular para inferir efeitos para um organismo inteiro. Alguns trabalhos abordam o contexto térmico discutindo a respeito de inferências entre os vários níveis de organização biológica (CHAUÍ-BERLINCK et al, 2002, 2004; 
BROWN et al, 2004; PORTNER ET AL, 2006), tão debatidas entre os estudos sobre reducionismo e holismo.

Chauí-Berlinck et al $(2002,2004)$ trabalham questões relativa à adequação do uso de conceitos derivados da teoria molecular nas respostas fisiológicas integrativas dos organismos, discutindo com relação ao $\mathrm{Q}_{10}$. Este parâmetro é calculado pela equação $\left[\mathrm{Q}_{10}=\left(\mathrm{k}_{2} / \mathrm{k}_{1}\right)^{10 / \mathrm{T} 2-\mathrm{T} 1}\right]$ onde $\mathrm{k}_{1}$ e $\mathrm{k}_{2}$ são as velocidades correspondentes às temperaturas $\mathrm{T}_{1}$ e $\mathrm{T}_{2}$, respectivamente. Segundo Chauí-Berlinck et al (2002) há um longo debate na literatura a respeito da extensão na qual os valores de $\mathrm{Q}_{10}$ podem ser utilizados para tirar conclusões sobre o controle regulatório do metabolismo energético, com o principal ponto de discordância sendo sobre se é ou não adequado usar os conceitos derivados da teoria molecular nas respostas fisiológicas integrativas dos organismos. Os valores de $\mathrm{Q}_{10}$ apenas informam sobre a sensibilidade térmica de certo fluxo no oraganismo como um todo, sob determinadas condições, e não podem ser usados para propor mecanismos subjacentes ou eventos no nível bioquímico (CHAUÍ-BERLINCK et al, 2004).

Nesta tese estão embutidos tanto o aspecto reducionista - focando os efeitos do ciclo claro/escuro e da temperatura reduzidos à taxa metabólica - quanto integrativo - discutindo o animal como um todo, as interações entre as partes, buscando princípios integrativos de organização comportamental que se aplicam na espécie.

\section{EFEITOS DA TEMPERATURA NAS ABELHAS}

As taxas de reação bioquímicas, a taxa metabólica e quase todas as demais taxas de atividade biológica aumentam exponencialmente com a temperatura. Esta cinética é descrita pelo fator de Boltzmann ou a relação Van’t Hoff-Arrenhius (BOLTZMANN, 1872; ARRENHIUS, 1889 apud BROWN et al, 2004). A temperatura na qual os animais vivem normalmente varia entre os grupos taxonômicos e, no caso das abelhas melíferas, elas podem ser submetidas de quase $0^{\circ} \mathrm{C}$ até mais do que $40^{\circ} \mathrm{C}$ (HEINRICH, 1993) durante a vida.

Além do ciclo claro/escuro, a temperatura ambiente é um dos principais Zeitegebers que influenciam o ritmo circadiano de insetos (SAUNDERS, 2002), incluindo as abelhas melíferas, com ciclos de $10^{\circ} \mathrm{C}$ de amplitude podendo "arrastar" (ajustar temporalmente o ritmo) a atividade locomotora de forrageadoras (MOORE e RANKIN, 1993; FUCHIKAWA e SHIMIZU, 2007).

Nas colônias de Melipona, as abelhas forrageadoras procuram atender as necessidades da colônia, como alimento, água, matérias de construção e limpeza do ninho. Além das condições da colônia, fatores ambientais também podem influenciar a atividade de vôo das forrageadoras, determinando diferentes padrões de forrageio (HILÁRIO et al 2000). A temperatura ambiente, a umidade relativa, a intensidade luminosa, a chuva e a velocidade do vento podem influenciar a atividade de vôo das abelhas indígenas sem ferrão, apesar de que nem sempre com a mesma 
intensidade (IWANA, 1977; GUIBU e IMPERATRIZ-FONSECA, 1984; IMPERATRIZFONSECA et al, 1985; HEARD e HENDRIKZ, 1993).

Entre as operárias forrageadoras de abelhas do gênero Apis podem ocorrer diferenças entre as coletoras de néctar e de pólen, com relação à taxa metabólica (FEUERBACHER et al, 2003) e níveis de melatonina (YANG et al, 2007), e assim o tipo de carga da forrageadora merece ser considerado. Em M quadrifasciata, a atividade de vôo das abelhas se relaciona com a temperatura ambiente (capítulo 2), sendo este um fator importante para diversos aspectos da fisiologia e comportamento desta espécie.

Além das influências da temperatura ambiente, há a questão da endotermia e termogênese individual. As abelhas melíferas são insetos heterotérmicos, com a habilidade de endotermia (HEINRICH, 1979; SCHMARANZER e STABENTHEINER, 1988; STABENTHEINER et al, 1995; 2002; KOVAC et al, 2007). Quando as abelhas saem para forragear (aquecimento pré-vôo) ou quando incubam sua cria (termorregulação colonial), elas são capazes de regular a temperatura corpórea, através da produção fisiológica de calor, mantendo a temperatura torácica controlada (HEINRICH, 1980; KAISER, 1988; PACHECO e KERR, 1989; HEINRICH e ESCH, 1994; BARTHOLOMEW, 1981; BLOCK, 1994). Com relação aos meliponíneos, apesar da sua biologia indicar um bom controle da temperatura dos ninhos, são ainda raros os trabalhos relacionando temperatura e taxa metabólica (MACIEIRA e PRONI, 2005).

A termorregulação propiciou o desenvolvimento de uma vida social e a conquista de ambientes diversos (MICHENER, 1974; HEINRICH e ESCH, 1994). Segundo Grodzicki e Caputa (2005), comparadas com outros insetos, as abelhas melíferas exibem uma combinação interessante de características: (i) como indivíduos separados da colônia elas são endotérmicas durante períodos de atividade motora e ectotérmicas durante inatividade (HEINRICH, 1993, 1996; ROBERTS e HARRISON, 1998, 1999; CRAILSHEIM et al, 1999); (ii) elas cooperam para a manutenção da temperatura da colônia quase constante durante o ano (KRONENBERG e HELLER, 1982; SOUTWICK, 1982, FAHREHNHOLZ et al, 1989; GRODZICKI e CAPUTA, 2005).

Neste capítulo 3 são estudados os efeitos do ciclo claro/escuro na taxa metabólica de forrageadoras, com foco na variação diária. O estudo de componentes rítmicos de variáveis, como a taxa metabólica, pode ser uma ferramenta importante para propiciar uma visão geral de sua variação diária, podendo-se eleger com mais segurança os horários (“janelas temporais”) para a coleta de dados, que pode ficar mais confiável e menos tendenciosa. São também abordados os efeitos da temperatura na taxa metabólica e quociente respiratório, considerando o tipo de material coletado pela forrageadora.

\section{OBJETIVOS}


O objetivo geral deste capítulo é caracterizar o efeito do tipo de iluminação (ciclo claro/escuro) e de diferentes temperaturas sobre a taxa metabólica de operárias forrageadoras de Melipona quadrifasciata.

Aliado a este, está o objetivo de escolher condições experimentais e procedimentos adequados para cálculo de taxa metabólica das forrageadoras, envolvendo:

- configuração do sistema de respirometria e do software de coleta e análise de dados;

- características e condições das câmaras respirométricas, envolvendo a circulação de ar e umidade;

- condições da câmara climática, como iluminação e temperatura;

- horários adequados para coleta de operárias;

- "largura" de janelas temporais de tomada de dados

\section{FOTOPERÍODOS}

OBJETIVO GERAL:: Estudo de ritmos diários de taxa metabólica de operárias forrageadoras e influências do fotoperíodo.

\section{OBJETIVOS ESPECÍFICOS}

- Verificar se diferentes ciclos claro/escuro interferem no ritmo de taxa metabólica das forrageadoras;

- Verificar se há variação diária da taxa metabólica de forrageadoras em fotoperíodo $12 \mathrm{~h}: 12 \mathrm{~h}$ (dia/claro, noite/escuro), em fotoperíodo invertido e em claro e escuro constante;

- Verificar efeitos do tempo de confinamento sobre a taxa metabólica;

- Escolher condições experimentais relativas à luminosidade e a "largura" das janelas temporais adequadas para a tomada de dados para experimentos posteriores.

\section{TEMPERATURA}

OBJETIVO GERAL: Caracterizar a taxa metabólica e o quociente respiratório (QR) de operárias forrageadoras em diferentes temperaturas.

\section{OBJETIVOS ESPECÍFICOS}

- Comparar os valores de taxa metabólica e QR de abelhas operárias forrageadoras (coletoras de néctar/água ou de pólen) de 10 a $40^{\circ} \mathrm{C}$;

- Verificar se há diferenças na taxa metabólica e QR entre as coletoras de néctar/água e de pólen;

- Eleger faixa de temperatura ideal para experimentos posteriores.

\section{MATERIAIS E MÉTODOS}


Foram empregadas operárias campeiras (forrageadoras), sem material aparente nas corbículas (figura 1A), presumivelmente coletoras de néctar ou de água. Para determinar se as forrageadoras sem pólen nas corbículas seriam forrageadoras de néctar ou de água, seria necessário remover os conteúdos do papo e determinar a concentração do soluto. As abelhas com concentração menor do que 5\% seriam classificadas como forrageadoras de água (FEUERBACHER et al, 2003) (esses dados se referem a $A$ mellifera). Como tal procedimento não seria possível em nossos experimentos, as abelhas sem pólen nas corbículas eram reunidas no grupo forrageadoras de néctar/água. Além disso, para os experimentos em diferentes temperaturas foram empregadas forrageadoras coletoras de pólen (contendo pólen nas corbículas) (Figura 1B). Foram também realizados experimentos preliminares com operárias jovens, coletadas dentro da colônia, entre os discos de cria.

Uma vez que em $M$ quadrifasciata há organização eussocial, optou-se por empregar forrageadoras isoladas da interferência de fatores sociais, a fim de melhor caracterização das respostas individuais.

\section{COLETA DE OPERÁRIAS}

As forrageadoras foram coletadas na entrada externa do ninho (figura 2), após retornarem de vôos de forrageamento (FEUERBACHER et al, 2003; MESH e BLOCH, 2007). Tal procedimento visava uma tentativa de padronização da idade da abelha, uma vez que as forrageadoras provavelmente são as mais velhas na colônia. Não foram utilizadas abelhas simplesmente coletadas quando paradas no tubo de saída, para evitar a coleta de abelhas guardas ou de outras tarefas diferentes de forrageadoras.

Após a coleta, as abelhas eram pesadas e acondicionadas individualmente em câmaras respirométricas, cerca de 2 minutos após a captura (FEUERBACHER et al, 2003), e assim mantidas por no mínimo $1 \mathrm{~h}$ (no claro) ou $2 \mathrm{~h}$ (no escuro) antes do início dos experimentos. As câmaras respirométricas eram mantidas em câmara climática (figura 3) com controle de temperatura e fotoperíodo (Eletrolab 122 FC), ou em câmara climática provisória confeccionada com caixa de isopor, tubulação de água e banho termostático 116 Fanem-Unitemp (figura 4), baseada em no estudo de Françoso-Júnior (1999). Essa câmara provisória foi utilizada antes da aquisição de uma câmara climática Eletrolab. Consistia de caixa de isopor, com serpentinas de cobre e plástico enrolada em sua superfície interna. As serpentinas eram conectadas a banho ultratermostático por mangueiras, para controle da temperatura, e as câmaras respirométricas eram colocadas no interior da caixa térmica.

Foram realizados diversos experimentos preliminares de padronização da temperatura do banho termostático e do tempo para estabilização da temperatura, importantes para que, no 
momento do experimento, todas as condições já estivessem previamente controladas e calculadas, para evitar perda de tempo e material. As temperaturas de dentro do laboratório, da água do banho ultratermostático e de dentro da caixa térmica foram obtidas por meio de termopares conectados a carregadores de dados (Data Loggers Onset CO. Hobo e StowAway), com sensor na extremidade do termopar.

As câmaras respirométricas (figura 3) eram cilíndricas, construídas de acrílico e hermeticamente fechadas (medidas externas: diâmetro $6 \mathrm{~cm}$, altura $6 \mathrm{~cm}$ ) e permitiam que o animal se movesse e que houvesse espaço para a colocação de alimento (algodão embebido em solução de sacarose 50\%). Essa solução também servia para manter a umidade e evitar a desidratação das abelhas devido ao fluxo freqüente de ar.

\section{CALORIMETRIA INDIRETA}

$\mathrm{Na}$ oxidação aeróbia, a quantidade de calor produzido está relacionada à quantidade de oxigênio consumido e assim as medidas da tomada de $\mathrm{O}_{2}$ e produção de $\mathrm{CO}_{2}$ podem ser usadas para se calcular a taxa metabólica (RANDALL et al, 2000). A calorimetria indireta é o método no qual o gasto energético é estimado através da medição das trocas respiratórias, ou seja, do volume de oxigênio consumido $\left(\mathrm{VO}_{2}\right)$ e do volume de gás carbônico produzido $\left(\mathrm{VCO}_{2}\right)$ (FERRANNINI, 1988). A calorimetria indireta baseia-se nos princípios de que não existe uma reserva apreciável de oxigênio no organismo; que o oxigênio consumido reflete a oxidação dos nutrientes e que toda a energia química no organismo é proveniente da oxidação de carboidratos, gorduras e proteínas. (WAHRLICH e ANJOS, 2001). A determinação da taxa metabólica pelo consumo de $\mathrm{O}_{2}$ apóia-se em algumas premissas, tais como as reações químicas relevantes serem aeróbias (RANDALL et al, 2000).

Neste trabalho, a taxa metabólica foi calculada por meio de calorimetria indireta, utilizando como ferramenta a respirometria. O consumo de oxigênio e a produção de gás carbônico das abelhas foram determinados por meio de respirometria intermitente, com lavagens periódicas, durante as quais o teor de oxigênio e de gás carbônico no ar das câmaras metabólicas, contendo o animal, misturado com o ar das lavagens, era analisado (WITHERS, 1977, FRANÇOSO-JÚNIOR, 1999, CHAUÍ-BERLINCK e BICUDO, 2006). As abelhas apresentam os padrões rítmicos típicos de "discontinuous gas cycle" (DGC) (LIGHTON e LOVEGROVE, 1990, KOVAC et al, 2007) que são encontrados em diversos insetos em repouso (HADLEY, 1994; LIGHTON, 1994, 1996; SLÁMA, 1999; HETZ e BRADLEY, 2005). Mas este sistema de respirometria não pretende medir a taxa instantânea de metabolismo, nem resolver a troca descontinua de gases (CHAPPELL e ROGOWITZ, 2000) uma vez que cada medição é uma média do consumo de $\mathrm{CO}_{2}$ ao longo de vários minutos. 
A respirometria intermitente foi escolhida baseada em algumas considerações. Nem sempre é possível obter condições de fluxo mínimo necessário para manter as leituras do sensor dentro de sua acuidade e precisão, apesar da grande sensibilidade dos sensores contemporâneos; nestas circunstâncias, a respirometria aberta não poderá ser empregada. A limitação básica se encontra na amplitude do sinal a ser obtido, que é dada pela relação entre o fluxo de entrada e o consumo de oxigênio do animal, sendo então a limitação em decorrência de consumos baixos. Desse modo, os animais muito pequenos, ou em condições de depressão metabólica, estivação etc, são os exemplos básicos de situações nas quais a técnica aberta poderá estar impossibilitada de ser empregada. Nessas situações, pode-se empregar a técnica fechada ou a técnica intermitente.

Comparando a respirometria fechada com a respirometria intermitente, as vantagens da intermitente são que, caso se tenha um sensor de oxigênio que opere com a passagem de fluxo, a intermitente garante um ambiente mais controlado, com menores graus de hipóxia e hipercapnia ao longo do experimento. Em segundo lugar, em um sistema fechado, o modelo da dinâmica do sinal obtido é extremamente variável, dependendo do modo como se procede o experimento. Além disso, se não há a reposição do gás retirado, há queda da pressão de $\mathrm{O}_{2}$ e elevação da pressão de $\mathrm{CO}_{2}$ na câmara e o experimento deve ser encerrado após algumas amostragens, uma vez que se terá criado um ambiente mais e mais hipóxia/hipobárico com o progredir do tempo.

\section{MONTAGEM GERAL DO SISTEMA}

A respirometria intermitente combina elementos e características da respirometria aberta (na qual é mantido um fluxo de ar nas câmaras respirométricas) com características da respirometria fechada (sem fluxo de ar).

Na figura 5 há esquema geral do sistema de respirometria intermitente, baseado em ChauíBerlinck e Bicudo (2006). O animal é deixado na câmara respirométrica por um intervalo de tempo pré-estabelecido, em uma condição fechada (sem fluxo de ar), período no qual consome oxigênio e gera gás carbônico, fazendo $\mathrm{f}_{\mathrm{cx}}$ (concentração fracionária de oxigênio no interior do sistema) cair e

$\mathrm{f}_{\mathrm{cy}}$ (concentração fracionária de gás carbônico no interior do sistema) subir. Durante o intervalo as abelhas consomem $\mathrm{O}_{2}$ e produzem $\mathrm{CO}_{2}$, alterando a concentração fracionária destes gases dentro da câmara respirométrica.

$\mathrm{O} \mathrm{CO}_{2}$ deverá ser sempre absorvido antes do fluxo de saída passar pelo sensor de oxigênio, e assim obtém-se leituras do tipo independentes, o que facilita bastante os cálculos. No sistema empregado, o vapor de água era absorvido com sílica gel e o $\mathrm{CO}_{2}$ com ascarite, em tubos cilíndricos hermeticamente fechados com rolhas e algodão. 
O estabelecimento da linha de base depende de um fluxo de gás padrão bombeado para os sensores de $\mathrm{O}_{2}$ e $\mathrm{CO}_{2}$, no caso, o ar do ambiente externo do laboratório, que é de composição de gases conhecida (os valores considerados são 20,94\% de $\mathrm{O}_{2}$ e $0,03 \%$ de $\mathrm{CO}_{2}$ ).

Ao final do período fechado, o fluxo de ar é restabelecido pelo sistema, bombeado novamente às câmaras respirométricas de forma a 'lavar' o seu ambiente interno, e passa por um frasco contendo sílica gel azul, para remoção de vapor de água. Em seguida, o ar flui inicialmente para o sensor de $\mathrm{CO}_{2}$, que faz a leitura da quantidade de $\mathrm{CO}_{2}$ presente no fluxo de ar, fornecendo um sinal que indica a fração de $\mathrm{CO}_{2}$ produzida nas câmaras respirométricas durante a fase fechada, em comparação com o inicial. A seguir, flui por um tubo contendo ascarite, para absorção do $\mathrm{CO}_{2}$, e depois para o sensor de $\mathrm{O}_{2}$, passando pelo fluxímetro e bomba de sucção. Os sinais elétricos detectados nos sensores são transferidos para os analisadores. Entre os analisadores de gases e o computador, existe uma interface, envolvida na conversão dos dados elétricos dos analisadores em dados para o software. Os dados de respirometria intermitente são registrados em computador, com auxílio de programas de aquisição e análise de dados de respirometria (Datacan V, Sable Systems).

Enquanto o ar existente nas câmaras respirométricas (que estavam fechadas) é lavado, concomitantemente ar ambiente é bombeado para dentro da câmara, para evitar hipoxia/hipercapnia e queda da pressão dentro da câmara. Quando o sinal retorna à linha de base (ou próxima a ela) e fica estável, o experimento é interrompido e nova coleta de dados é realizada com outro animal. Após a lavagem da câmara respirométrica com o ar do ambiente externo, os gases presentes na câmara voltam a apresentar as características conhecidas que definiam a linha de base nos sensores. Enquanto outro animal está sendo testado, os demais continuamente recebem fluxo de ar do ambiente externo. O fluxo é escolhido de forma a garantir que, após um certo tempo de lavagem da câmara, o sinal retorne à linha de base. Utilizou-se $190 \mathrm{~mL} \min ^{-1}$, determinado por meio de fluxímetro ligado à bomba de sucção. Na figura 5 o trajeto do ar está representado por meio de flechas verdes contínuas, e o trajeto do sinal elétrico do sistema, por meio de flechas roxas descontínuas.

$\mathrm{Na}$ respirometria intermitente está-se interessado no sinal obtido enquanto as leituras se encontram fora da linha de base. A integral do sinal indica quanto de $\mathrm{O}_{2}$ ficou ausente no fluxo de ar bombeado para o sensor após passagem pelas câmaras respirométricas, ou seja, fornece a quantidade de oxigênio retirado do gás da câmara durante o tempo $\tau$ (o mesmo se aplica para o sensor de gás carbônico e o $\mathrm{CO}_{2}$ adicionado).

Como antes de se iniciar o fluxo de ar pelas câmaras respirométricas fechadas as leituras se encontravam na linha de base, $\mathrm{t}_{0}$ é o tempo antes que se inicie qualquer deflexão nas leituras, ou qualquer tempo anterior ao início da lavagem. t é o tempo após o retorno à linha de base (CHAUÍBERLINCK e BICUDO, 2006). O cálculo da integral do sinal de saída obtido ao longo do tempo 
de lavagem, entre $t_{0}$ e $t_{f}$, corresponde ao total de oxigênio ausente no fluxo que passou pelo sensor, e tende a um valor fixo quanto t tende ao infinito. $\mathrm{O} \mathrm{t}_{0}$ é o tempo antes da saída do sinal da linha de base e o $t_{\mathrm{f}}$ será o tempo quando o sinal houver retornado, dentro da sensibilidade do sensor, à linha de base. A figura 6 mostra o tipo de sinal que é obtido, durante uma lavagem em um sistema de respirometria intermitente, para o consumo de $\mathrm{O}_{2}$ e produção de $\mathrm{CO}_{2}$.

\section{CÁLCULOS}

É necessário que se multiplique cada uma das integrais pelo fluxo, para que se obtenha o total Tx retirado. O produto da integral pelo fluxo resulta em Tx com unidades de moles de oxigênio. A integral referida é calculada por algoritmos pré-programados no aplicativo utilizado (no caso, Datacan V, Sable Systems).

A taxa de consumo de oxigênio $\left(\mathrm{V}_{\mathrm{x}}\right.$ ou $\left.\mathrm{VO}_{2}\right)$ pode ser obtida ao se dividir $\mathrm{T}_{\mathrm{x}}$ pelo intervalo de tempo durante o qual a câmara ficou fechada (em minutos):

Tx = integral $\mathrm{x}$ fluxo

$\mathrm{Vx}=\mathrm{Tx} /$ tempo fechado

Taxa de consumo de $\mathrm{O}_{2}\left(\mathrm{~V}_{\mathrm{x}}\right.$ ou $\left.\mathrm{VO}_{2}\right)=$ (fluxo $\mathrm{X}$ integral) / tempo fechado

Em suma, o volume de $\mathrm{O}_{2}$ consumido pela abelha foi calculado pela equação:

$\mathrm{VO}_{2}=-\mathrm{I} * \mathrm{f} * \mathrm{t}-1$

Onde

$\mathrm{VO}_{2}$ : volume de $\mathrm{O}_{2}$ consumido $\left(\mathrm{mL} \mathrm{O}_{2} \min ^{-1}\right)$

I: integral do sinal obtido em relação à linha de base

F: fluxo de ar utilizado $\left(\mathrm{mL} \mathrm{min}^{-1}\right)$

t: intervalo de tempo em que a câmara respirométrica permaneceu fechada (min)

\section{EQUIPAMENTOS DO SISTEMA DE RESPIROMETRIA}

É útil que diversas forrageadoras possam ser coletadas e analisadas no mesmo dia, o que é possibilitado pelo controle da circulação de ar pelas câmaras respirométricas e pelo sistema de respirometria. Para evitar hipóxia e hipercapnia dos animais não analisados no momento, o sistema permite que ar externo seja circulado nas diversas câmaras respirométricas dentro da câmara 
climática por meio de bombas de ar independentes do sistema de respirometria (flechas azuis descontínuas da figura 7)

Devido a problemas com o controlador lógico programável (CLP) interposto entre o computador e o sistema de válvulas solenóides, pré-existentes no laboratório, optou-se pela construção de um sistema de válvulas manuais para gases (Sondaplast Materiais Hospitalares) com bombas de ar (Compressor de Ar Junior Master) independentes da bomba de sucção (Flow Control R1 Ametek) do sistema de respirometria (esquema na figura 7). Conforme exposto anteriormente, a câmara respirométrica contendo a abelha é fechada por um intervalo adequado e enquanto isso há a passagem de gás padrão do experimento (ar ambiente) pelo sensor, vindo através de um desvio, ou seja, sem passar pela câmara respirométrica. Esses desvios são possíveis devido ao posicionamento das válvulas manuais. Tal procedimento fornece a linha de base para os sensores, com o ar do ambiente externo.

Após o tempo em que ficou fechada, a câmara respirométrica contendo a abelha analisada é aberta, com o auxílio de válvulas manuais, e os gases são direcionados ao sistema de respirometria por sua bomba de sucção (flechas vermelhas da figura 7).

$\mathrm{O}$ analisador de $\mathrm{O}_{2}$ utilizado neste trabalho foi o "Oxygen Analyzer S-3AI Ametek", que provém medições de concentrações de $\mathrm{O}_{2}$ de $0-100 \%$ e também em $\mathrm{mV}$. $\mathrm{O}$ analisador permite manutenção periódica do sensor ("cell restore"), permite indicação da temperatura do forno do sensor, ajustes para um gás de referência e calibrações, e contém mostrador digital. Por exemplo, ao se circular ar ambiente seco pelo sensor, o analisador deverá marcar 20,94\%, que é a concentração nominal de $\mathrm{O}_{2}$ no ar seco. O sensor é o "Oxygen Sensor N-22M Ametek"e sua cabine contém célula eletroquímica de zircônia que trabalha a altas temperaturas (para medições da pressão parcial de $\mathrm{O}_{2}$ ), forno para manter a célula a $750^{\circ} \mathrm{C}$ (equivalente a $6,79 \mathrm{mV}$ ) e circuito de sensor de temperatura. $\mathrm{O}$ fluxo de ar ideal é entre 50 e $300 \mathrm{~mL} / \mathrm{min}$. A célula de zirconia estabilizada, a altas temperaturas, torna-se um condutor eletrolítico de íons oxido, e a condutividade eletrônica leva à diminuição da voltagem da célula e assim à produção do sinal elétrico.

$\mathrm{O}$ analisador de $\mathrm{CO}_{2}$ é o "Carbon Dioxide Analyzer CD-3A Ametek". O equipamento contém mostrador digital $0-15 \%$ de $\mathrm{CO}_{2}$, que equivale a $0-7,5 \mathrm{~V}$. O sensor de $\mathrm{CO}_{2}$ é o "Carbon Dioxide Sensor P-61B Ametek", que contém uma fonte infravermelha. A taxa de fluxo ideal deve estar entre 50 e $500 \mathrm{~mL} \mathrm{~min}^{-1}$.

A bomba de sucção (Flow Control R1 Ametek) dirige o ar ambiente e/ou o ar da câmara respirométrica através do sensor. O fluxímetro (FL 1495 G Omega) controla o fluxo, em $\mathrm{mL} \mathrm{min}^{-1}$.

Os sensores e analisadores de oxigênio e de gás carbônico são muito sensíveis a variações na rede elétrica, uma vez que os dados são sinais elétricos. Assim, toda a aparelhagem do sistema de respirometria intermitente foi ligada à rede elétrica por meio de um "Nobreak" (Vision II, SMS), 
que propicia controle eletrônico de variação de sub e de sobre-tensão e propicia maior confiabilidade aos resultados.

\section{CUIDADOS NECESSÁRIOS NA RESPIROMETRIA INTERMITENTE}

\section{A ESCOLHA DE $t_{0}$ e $t_{f}$}

Os tempos de fechamento foram estabelecidos, em experimentos piloto, de forma que o consumo de $\mathrm{O}_{2}$ e a produção de $\mathrm{CO}_{2}$ fossem suficientes para a geração de um sinal para a realização dos cálculos necessários. Porém, com o cuidado de o fluxo de ar não secar a água e o alimento do algodão na câmara respirométrica e respeitando as condições internas da câmara para evitar hipóxia e hipercapnia. Dentro dessa perspectiva, o cuidado foi para que a pressão parcial de $\mathrm{O}_{2}$ no interior das câmaras não caísse para menos de $19,5 \%$ oxigênio, sendo que tal valor foi estabelecido a partir de Van Nerum e Buelens (1997), que mostraram que, em A mellifera, a taxa metabólica é mantida inalterada para pressões parciais de oxigênio entre 21 e 19,5\%, mesmo em níveis altos de $\mathrm{CO}_{2}$ (até 6\%).

Alguns cálculos baseados em estimativas de consumo/produção do animal, bem como correções após experimentos-piloto são necessários para se estabelecer qual o período que deve e que pode ser deixado o animal em condições fechadas. Tais experimentos-piloto e estimativas por dados da literatura se constituíram nos passos iniciais, para que se obtivesse uma idéia preliminar do tempo de fechamento das câmaras. A partir dessa estimativa, pode, eventualmente, haver a necessidade de se estabelecer um menor tempo para evitar condições de hipoxia/hipercapnia. Por outro lado, pode haver a necessidade de se estabelecer um tempo maior, quando não se obtém deflexão significativa nos sensores (CHAUÍ-BERLINCK e BICUDO, 2006).

\section{O “GERADOR DE SINAL” (ANIMAL) MANTIDO SEM PERTURBAÇÕES}

Após a coleta das abelhas e medição da massa, os animais foram colocados nas câmaras respirométricas, acondicionados na câmara climática, e mantidos pelo menos 1 hora sem perturbações. Além disso, esse é o tempo mínimo que os sensores e analisadores precisam ficar ligados antes do início da coleta dos dados.

Para a confiabilidade dos dados de taxa metabólica, o "gerador de sinal" no sistema de respirometria (o animal) precisa ser mantido em condições controladas de temperatura e iluminação, sem perturbações, mantido sem manipulações que possam alterar a sua taxa metabólica. Uma maneira que encontramos de satisfazer essas situações foi manter a câmara respirométrica contendo o animal dentro da câmara climática pré-programada para a temperatura e para os ciclos de iluminação; e as válvulas manuais, para alterações no sentido do fluxo de gases na 
tubulação, dispostas fora da câmara climática. Assim, foi possível fazer todas as modificações na tubulação sem interferências ao animal (figura 7).

Para evitar o jejum e diminuições drásticas na umidade relativa dentro da câmara respirométrica, era colocado juntamente com o animal um algodão embebido em solução de sacarose $50 \%$, que propicia umidade ao meio e alimento ao animal.

\section{O USO DE “CONTROLES”}

A fim de eliminar erros decorrentes de respiração de microorganismos que poderiam estar contidos na solução de sacarose ofertada às abelhas, foram utilizadas, como "controles", câmaras contendo algodão embebido na solução de sacarose, mas sem a abelha e o valor da integral do sinal das câmaras-controle era descontado dos valores de integral das câmaras contendo abelha.

\section{CALIBRAÇÕES NOS SENSORES E NO SOFTWARE}

O erro sistemático mais comum que afeta o resultado de uma medição realizada com um instrumento é o erro de calibração (Vuolo, 1992). Calibrações precisam ser realizadas, para diminuição dos erros sistemáticos e aumento da acurácia. Com relação aos sensores de $\mathrm{O}_{2}$ e de $\mathrm{CO}_{2}$, o equipamento era ligado durante 1 hora, quando então eram realizados ajustes finos no analisador, ao se circular ar do ambiente externo da sala.

No programa de aquisição de dados do sistema de respirometria (Datacan V, Sable Systems) eram realizadas calibrações periódicas do programa contra o aparelho. A marcação de \% no analisador é alterada, e os diversos valores de \% são inseridos no software, que a partir desses valores de porcentagem inseridos calculam a equação da reta, a partir, por sua vez, dos valores de voltagens enviados pelo analisador, por meio da interface. Com isso, os valores apresentados no software estão na forma de porcentagem, e não em voltagem, o que facilitava a coleta de dados e a detecção e solução de problemas.

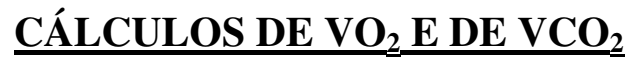

A massa corpórea de abelhas Apis vivas pode variar de mais de 100\% (de 75 a 165 mg, em A mellifera), sendo uma boa parte devido aos conteúdos do sistema digestório das abelhas (estômago, papo, intestino) (Stabentheimer et al, 2003). Assim, optamos por manter como referência a unidade $\mathrm{mL} \mathrm{CO}_{2} \min ^{-1}$ abelha ${ }^{-1}$ (representando como $\mathrm{VCO}_{2}$ ) e $\mathrm{mL} \mathrm{O}_{2}$ min $^{-1}$ abelha ${ }^{-1}$ (representado como $\mathrm{VO}_{2}$ ), e não considerar a massa corpórea, pois como as forrageadoras obtidas provavelmente estavam retornando de vôos de coleta de alimento, elas possivelmente continham néctar ou água armazenado em seu sistema digestório e a massa dessas substâncias não seria descontada no presente estudo, afetando a confiabilidade das medições de massa. 
As padronizações de $\mathrm{VO}_{2}$ e de $\mathrm{VCO}_{2}$ para as condições normais de temperatura e pressão são realizadas por meio da equação $\mathrm{VO}_{2(\mathrm{CNTP})}=\mathrm{VO}_{2} *(\mathrm{~Pb}$ local $/ 760) *\left(273,15 /\left(273,15+\mathrm{T}{ }^{\circ} \mathrm{C}\right)\right.$, onde $\mathrm{Pb}$ é a pressão barométrica no local da medida e $\mathrm{T}^{\circ} \mathrm{C}$ é a temperatura da medida em ${ }^{\circ} \mathrm{C}$. Os valores de $\mathrm{Pb}$ foram obtidos do Master - Meteorologia aplicada a sistemas de tempo regionais, do IAG-USP.

\section{CÁLCULOS DO QUOCIENTE RESPIRATÓRIO (QR)}

O quociente respiratório $(\mathrm{QR})$ é uma razão que reflete as proporções de carbono e hidrogênio nas moléculas dos alimentos oxidados e informa qual o substrato energético predominantemente oxidado (carboidratos, lipídios e/ou proteínas), já que os QRs de diferentes tipos de substratos energéticos podem ser calculado a partir de uma formulação de suas reações de oxidação. Na oxidação completa dos carboidratos, o oxigênio é usado efetivamente apenas para oxidar o carbono para formar $\mathrm{CO}_{2}$. Cada mole de carboidrato produz n moléculas de $\mathrm{H}_{2} \mathrm{O}$ e de $\mathrm{CO}_{2}$ e consome $\mathrm{n}$ moles de $\mathrm{O}_{2}$. Tipicamente, o QR da oxidação de lipídios é 0,71 , de proteínas é 0,80 e de carboidratos é 1,00 (RANDALL et al, 2000).

O quociente respiratório $(\mathrm{QR})$ é obtido através da razão $\frac{\dot{\mathrm{V}}_{\mathrm{CO}_{2}}}{\dot{\mathrm{V}}_{\mathrm{O}_{2}}}$

Por exemplo, no caso de serem oxidados ácidos graxos, o valor de QR tende a 0,7, o que gera uma conseqüência direta na respirometria. Neste caso, não se pode inferir a taxa metabólica a partir da produção de $\mathrm{CO}_{2}$, pois este gás estará sendo produzido em menor quantidade, por razões estequiométricas, e não refletirá exatamente o metabolismo energético do organismo.

Nos experimentos de fotoperíodo foi calculado apenas a produção de $\mathrm{CO}_{2}\left(\mathrm{~mL} \mathrm{CO}_{2}\right.$ min-1), pois, no período desses experimentos, o analisador e o sensor de oxigênio estavam sendo consertados nos Estados Unidos. Isso foi possível, pois como a alimentação principal das forrageadoras consiste de carboidratos, utilizaram-se somente forrageadoras coletoras de água/néctar, nas quais provavelmente o valor de QR é 1,0 (ROTHE e NACHTIGAL, 1989 para $A$ mellifera; FRANÇOSO-JÚNIOR, 1999 para Melipona bicolor), sendo então possível utilizar os valores de $\mathrm{VCO}_{2}$ como estimativa da taxa metabólica das forrageadoras, como também empregado por Blatt e Roces (2001) para A mellifera carnica.

\section{CICLO CLARO/ESCURO}

Em experimentos envolvendo conceitos de cronobiologia, é muito importante que o ciclo claro/escuro seja controlado, registrado e explicitado, já que este ciclo é considerado o principal Zeitgeber em abelhas. Outros sincronizadores, tais como mudanças cíclicas na temperatura, barulho, cheiros, umidade e disponibilidade de alimento, devem ser mantidos em níveis 
relativamente constantes, permitindo que apenas o ciclo claro/escuro atue como sincronizador (BENEDITO-SILVA, 1999).

O ciclo claro/escuro é o período que identifica fases de claro e escuro, como por exemplo, ciclo claro/escuro de 12:12h (CE 12:120), que identifica um ciclo de $24 \mathrm{~h}$ com $12 \mathrm{~h}$ de claro e $12 \mathrm{~h}$ de escuro. A resposta fotoperiódica é a reação ao comprimento da fase clara (ou escura) que induz o organismo a adotar uma estratégia de adaptação sazonal, por exemplo. Neste capítulo, o fotoperíodo é $12 \mathrm{~h}: 12 \mathrm{~h}$, por exemplo ciclo CE 12:12, exceto nos casos do claro constante e escuro constante, sendo o fotoperíodo então o tamanho (duração) de um ciclo claro/escuro e refere-se especialmente à proporção horas de claro/horas de escuro.

A taxa metabólica de forrageadoras foi calculada em diversas condições de claro/escuro, a $28^{\circ} \mathrm{C}$. Em experimentos de termorregulação colonial verificou-se que a temperatura dentro de colônias de Melipona quadrifasciata gira em torno de 27 a $29^{\circ} \mathrm{C}$ e, desse modo, escolheu-se $28^{\circ} \mathrm{C}$ como temperatura para os experimentos deste tópico.

Os valores de taxa metabólica das forrageadoras foram apresentados como média \pm desvio padrão, separadas de hora em hora. Os dados de cada hora representam os dados coletados em 3 dias diferentes, de abelhas diferentes, pois em isolamento a sobrevida das operárias é curta e não é permissivo deixar as abelhas isoladas por mais de 48 horas, com o aparelho ligado, segundo experimentos preliminares. Além disso, as abelhas aqui empregadas são eussociais, desempenhando funções semelhantes na colônia, o que leva a alta similaridade de ritmicidade entre as forrageadoras de uma mesma colônia, de idade e atividade semelhantes.

Durante os períodos de escuro, foram tomados cuidados para que as abelhas não percebessem nenhum ponto de luz. Durante o claro, a iluminação foi propiciada pela câmara climática equipada com controlador de fotoperíodo e com lâmpadas frias. Tais procedimentos não tiveram como objetivo determinar especificamente o tau (período do ritmo em livre curso).

Os ciclos de claro e de escuro empregados foram:

- Ciclo claro/escuro (CE): ciclo de $24 \mathrm{~h}$ com 12h de claro e 12h de escuro, (CE 12:12); luzes da câmara climática acesas às $6 \mathrm{~h}$.

- Fotoperíodo invertido (dia/escuro, noite/claro): inversão das fases de claro e de escuro; luzes acesas às $18 \mathrm{~h}$ e apagadas às $6 \mathrm{~h}$.

- Claro constante (CC)

- Escuro constante (EE)

\section{COLETA DE DADOS}


A taxa de amostragem mínima depende muita da variável que se está investigando e dos objetivos do experimento. Em geral, quando se sabe pouco sobre a forma da onda da variável, deve-se medir pelo menos 6 pontos por ciclo (MINORS e WATERHOUSE, 1989). Se for necessária uma melhor caracterização do ritmo, uma frequiência de amostragem ainda mais alta é necessária. Se uma taxa alta de amostragem não for possível ao longo de todo o ciclo, convém fazer mais medidas quando as flutuações são mais rápidas e menos medidas quando as mudanças são mais lentas (BENEDITO-SILVA, 1999).

No caso da coleta de dados de taxa metabólica nos diferentes fotoperíodos, a frequiência de amostragem esteve subordinada ao que foi permissivo pelo procedimento de respirometria intermitente. Neste, a câmara precisa ser fechada por tempo suficiente para que o sinal detectado seja satisfatório, além de haver o tempo de "lavagem" da câmara respirométrica.

\section{ANÁLISE DE DADOS}

Os métodos estatísticos habitualmente usados para comparar duas ou mais populações exigem pressuposições a respeito das distribuições das variáveis em análise, como normalidade e homogeneidade de variância (VIEIRA, 2003; ZAR, 1999). Assim, foram realizados testes de normalidade (do software SPSS: testes de Kolmogorov-Smirnov e Shapiro-Wilk) e de homogeneidade de variâncias a fim de verificar se a população original de onde os dados são provenientes (taxa metabólica [no claro] de abelhas forrageadoras alimentadas com sacarose 50\% a $28^{\circ} \mathrm{C}$ ) segue uma distribuição normal e se testes estatísticos paramétricos são adequados. Foi escolhido o claro por ser a condição natural das abelhas no horário da coleta.

Para se comparar médias entre vários horários de medida, e avaliar se as variações entre esses horários são significantemente maiores que a variação aleatória inerente aos dados, utilizou-se o teste de Kruskal-Wallis (não-paramétrico). O teste de Kruskal Wallis é útil para testar a hipótese de que várias populações têm a mesma distribuição, sendo uma alternativa para a análise de variância com uma (1) classificação (ANOVA one way), sendo também referido na literatura como análise de variância por postos (ANOVA by ranks tests). Este teste deve ser aplicado se a amostra for pequena e/ou pressuposições exigidas para testes paramétricos estiverem comprometidas (VIEIRA, 2003). No teste de Kruskal-Wallis, um valor significativo de H não indica entre quais grupos, especificamente, ocorrem as diferenças. Para identificar diferenças significativas entre grupos tomados 2 a 2, uma possibilidade é usar um procedimento não-paramétrico de comparações múltiplas semelhantes ao teste paramétrico de Tukey, denominado Teste de Dunn. O método é aplicado sobre os postos médios obtidos nas amostras (CALLEGARI-JACQUES, 2003). Ocorreram situações nas quais excepcionalmente foram aplicados testes paramétricos (ANOVA one way), que estão explicitadas ao longo do texto. 
Nos gráficos, os valores são apresentados como média \pm desvio padrão. Médias indicadas pela mesma letra (sobrescritas, nos gráficos) não diferem significantemente entre si pelo Teste de Dunn $(\alpha=0,05)$. Os dados estão separados por horários, ou seja, o grupo experimental “8h", por exemplo, representa os dados coletados entre $8 \mathrm{~h}$ e $8 \mathrm{~h} 59$. O horário de verão foi desconsiderado.

\section{INFLUENCIAS DA TEMPERATURA SOBRE AS ABELHAS}

Escolhemos a faixa de temperaturas de 10 a $40^{\circ} \mathrm{C}$ para os experimentos, a qual já foi empregada anteriormente por Stabentheiner et al (2003) para abelhas A mellifera. Essa faixa é próxima às temperaturas médias extremas nas quais as abelhas $M$ quadrifasciata poderiam ser submetidas na natureza e nas quais há modificações no comportamento de atividade de vôo.

As abelhas foram submetidas a várias temperaturas num mesmo experimento, começando pela temperatura próxima à do ambiente no momento (por exemplo, 20, $25 \mathrm{ou} 30^{\circ} \mathrm{C}$ ) e aumentando ou diminuindo em seqüência, em intervalos de $5^{\circ} \mathrm{C}$, permanecendo cerca de 2 horas em cada temperatura.

O comportamento das abelhas dentro das câmaras respirométricas era inspecionado visualmente após as abelhas estarem no mínimo 1 hora submetidas a cada temperatura, para que fosse possível a verificação dos padrões de movimentação corporal (por exemplo, agitação das asas, movimentos abdominais) e de atividade locomotora (o caminhar, a realização de pequenos vôos na câmara etc.), nas diferentes temperaturas.

Nas diferentes temperaturas, foram coletados dados de $\mathrm{VO}_{2}$ e $\mathrm{VCO}_{2}$, para posterior cálculo do QR.

\section{ANÁLISE DE DADOS}

Realizou-se a coleta das abelhas no mesmo horário (entre $7 \mathrm{~h} 30$ e 8h30) as quais foram mantidas na câmara respirométrica por ao menos 1 hora (com renovação do ar por meio de bombas de ar e válvulas [figura 7]), para se tentar assegurar uniformidade na aclimatação antes da coleta de dados. A coleta de dados foi realizada entre $10 \mathrm{~h}$ e $18 \mathrm{~h}$.

O desenho experimental deste tópico inclui 4 variáveis: 2 variáveis categóricas (material coletado [pólen ou néctar/água] e temperatura ambiente $\left[10,15,20,25,30,35,40^{\circ} \mathrm{C}\right.$ ]) e 2 variáveis contínuas (taxa metabólica e QR). Nos gráficos os dados estão representados como média \pm desvio padrão. Os dados estão separados por horários, ou seja, o grupo experimental " 8 h", por exemplo, representa os dados coletados entre $8 \mathrm{~h}$ e $8 \mathrm{~h} 59$.

A fim de verificar se há correlação entre variáveis, como por exemplo, valores de $\mathrm{VO}_{2} \mathrm{e}$ QR, utilizou-se o cálculo do Coeficiente de Correlação de Spearman, que é uma alternativa nãoparamétrica para o Coeficiente de Correlação de Pearson (VIEIRA, 2003). O Coeficiente de 
Correlação de Spearman é uma medida do grau de associação (ou dependência) entre duas variáveis. Varia entre $-1,00$ (correlação perfeita negativa) e $+1,00$ (correlação perfeita positiva). A hipótese da nulidade é a de que nas populações, as variáveis X e Y não estão correlacionadas. Os valores de $r_{s}$ são comparados com tabelas dos valores críticos para os diversos níveis de significância (VIEIRA, 2003).

Para comparar valores de VO2 e de QR de forrageadoras coletoras de néctar/água e de pólen, dentro da mesma temperatura, foi aplicado o teste de Mann Whitney, que serve para testar a hipótese de que duas populações têm a mesma distribuição..Este teste encontra-se baseado em postos e é uma alternativa não paramétrica ao teste t no caso de amostras independentes. A estatística de Mann Whitney é também conhecida como U, e é utilizada para o cálculo de z, que é normalmente comparado com o valor crítico, dado em tabela de distribuição normal padronizada, para o nível estabelecido de significância (VIEIRA, 2003).

O VO2 e o QR são funções da temperatura, neste caso, e assim o procedimento adequado para análise deve incluir a temperatura como variável independente. Uma vez que não estamos interessados em estabelecer um modelo preciso para a dependência do $\mathrm{VO}_{2}$ e do $\mathrm{QR}$ em relação à temperatura, mas, sim, em caracterizar se abelhas do grupo "Néctar" e do grupo "Pólen" resultam em diferentes dependências, optou-se pela regressão linear (por mínimos quadrados, RegLin). Utilizou-se funções internas do software GraphPad Prism 3.02 para a obtenção das retas de regressão e comparação entre as inclinações e interceptos. Uma vez que em temperaturas mais extremas $\left(10,35\right.$ e $\left.40^{\circ} \mathrm{C}\right)$ os valores de $\mathrm{VO}_{2}$ e de $\mathrm{QR}$ tendem a ser menores, a RegLin considerada entre 10 e $40^{\circ} \mathrm{C}$ apresentaria um viés. Assim, consideraram-se os intervalos 10 a $25^{\circ} \mathrm{C}$ e 25 a $40^{\circ} \mathrm{C}$ separadamente nas análises.

Os grupos que difiram entre si num nível de significância maior que 0,05 estão indicados, nas figuras e nas tabelas, através de um “*” sobrescrito, ou através de letras sobrescritas (letras iguais indicam médias que não diferem significantemente entre si).

Os cálculos estatísticos foram realizados com o auxílio dos softwares Statistica 5.0 e GraphPad Prism 3.02.

\section{$\underline{\text { RESULTADOS }}$}

\section{CONDICÕES DAS ABELHAS E ARRANJO EXPERIMENTAL}

No interior das câmaras respirométricas, as operárias dispunham de espaço suficiente para caminhar. No claro, as forrageadoras apresentaram atividade locomotora, chegando a dar pequenos vôos no interior das câmaras. Após a coleta de dados em todos os fotoperíodos testados as abelhas 
estavam vivas e ativas. Esta observação é importante, para não serem computados valores de taxa metabólica de abelhas em condições precárias de saúde.

A disposição dos cabos, mangueiras de ar e equipamentos do sistema de respirometria, considerada a mais parcimoniosa, está apresentada na figura 5. A escolha da melhor distribuição das válvulas manuais e bombas de ar, independentes do sistema de respirometria envolveu diversos testes e modificações, mas a que se mostrou mais eficaz foi a apresentada na figura 7.

$\mathrm{O}$ sistema de válvulas criado permite que, enquanto um animal tem o seu consumo de $\mathrm{O}_{2}$ e produção de $\mathrm{CO}_{2}$ registrados, outros 9 animais possam permanecer dentro das câmaras respirométricas, acondicionadas dentro da câmara climática, com controle de temperatura e de fotoperíodo. É possível que as diversas manipulações no fluxo de gases, pelas diversas mangueiras de ar do sistema, possam ser realizadas sem perturbação às abelhas analisadas. Testes variando os tempos de fechamento das câmaras levaram a diferentes resultados de integral das curvas de deflexão, contudo, quando o cálculo da $\mathrm{VO}_{2}$ é realizado (considerando o tempo de fechamento), obtém-se o mesmo valor de taxa metabólica, independente do tempo de fechamento utilizado, desde que não se criem situações de hipóxia/hipercapnia prejudiciais.

Além disso, os resultados obtidos com as operárias jovens não estão aqui computados devido problemas metodológicos e de número amostral, conforme será abordado na discussão.

\section{VARIACÃO DIÁRIA DA TAXA METABÓLICA EM FOTOPERÍODO 12H:12H}

$\mathrm{Na}$ figura 8A está apresentada a taxa metabólica $\left(\mathrm{mL} \mathrm{CO}_{2} \min ^{-1}\right.$ abelha $\left.{ }^{-1}\right)$ de forrageadoras mantidas em fotoperíodo normal 12h:12h (dia/claro, noite/escuro), que praticamente apresentou-se como dois patamares, um no claro e outro no escuro. Os dados apresentam-se como média \pm desvio padrão. O padrão assemelha-se ao obtido em claro constante (figura 9A).

A análise estatística indica que as médias dos valores de $\mathrm{VO}_{2}$ nos diferentes horários diferem significantemente $(\mathrm{P}<0,0001)$ com o teste de Kruskal-Wallis $(\mathrm{H}=84,33)$, parecendo haver arrastamento de um possível ritmo endógeno de $\mathrm{VO}_{2}$ pelo ciclo claro/escuro. Todavia, ao se aplicar o pós-teste de Dunn, não foram identificados os grupos nos quais há diferenças significativas.

A ANOVA one way foi aplicada neste caso uma vez que é um procedimento estatístico robusto e que fornece resultados confiáveis mesmo com considerável heterocedasticidade e com uma variável que tenha uma distribuição bastante desviada da normal (ZAR, 1999; CALLEGARIJACQUES, 2003).

Similar ao obtido com teste de Kruskal Wallis, com a ANOVA verificou-se que as médias dos valores de taxa metabólica diferem significantemente $(\mathrm{P}<0,0001), \mathrm{F}=56,76$. Nas comparações múltiplas entre médias do teste de Tukey, foram identificados os horários nos quais os valores de taxa metabólica diferem, apresentados na tabela 1. Optou-se nestes tópicos por apresentar os 
resultados da análise estatística em tabela e não nos gráficos, como letras sobrescritas, devido ao grande número de pontos considerados no eixo x, que dificultaria a visualização.

Tabela 1. Resultados de comparações múltiplas entre médias (teste de Tukey) de taxa metabólica em fotoperiodo $12 \mathrm{~h}: 12 \mathrm{~h}$

\begin{tabular}{|c|c|c|}
\hline Horário & $\mathrm{VCO}_{2}$ méc & \\
\hline $\mathrm{Oh}$ & 0,003601 & $\mathrm{~A}$ \\
\hline $1 \mathrm{~h}$ & 0,003465 & A \\
\hline $2 \mathrm{~h}$ & 0,003572 & A \\
\hline $3 \mathrm{~h}$ & 0,003603 & A \\
\hline $4 \mathrm{~h}$ & 0,003698 & A \\
\hline $5 \mathrm{~h}$ & 0,003295 & A \\
\hline $6 \mathrm{~h}$ & 0,027497 & $\mathrm{C}$ \\
\hline $7 \mathrm{~h}$ & 0,06352 & $\mathrm{~B}$ \\
\hline $8 \mathrm{~h}$ & 0,070879 & B \\
\hline $9 \mathrm{~h}$ & 0,065659 & B \\
\hline $10 \mathrm{~h}$ & 0,06751 & B \\
\hline $11 \mathrm{~h}$ & 0,064024 & $\mathrm{~B}$ \\
\hline $12 \mathrm{~h}$ & 0,073432 & B \\
\hline $13 \mathrm{~h}$ & 0,066114 & B \\
\hline $14 \mathrm{~h}$ & 0,069493 & B \\
\hline $15 \mathrm{~h}$ & 0,070431 & B \\
\hline $16 \mathrm{~h}$ & 0,061458 & $\mathrm{~B}$ \\
\hline $17 \mathrm{~h}$ & 0,062518 & $\mathrm{~B}$ \\
\hline $18 \mathrm{~h}$ & 0,007481 & A \\
\hline $19 \mathrm{~h}$ & 0,006108 & A \\
\hline $20 \mathrm{~h}$ & 0,004146 & A \\
\hline $21 \mathrm{~h}$ & 0,003086 & A \\
\hline $22 \mathrm{~h}$ & 0,003241 & A \\
\hline $23 \mathrm{~h}$ & 0,003587 & A \\
\hline $\begin{array}{l}\text { Médias } \\
(\alpha=5 \%)\end{array}$ & erem sign & \\
\hline
\end{tabular}


Como pode ser observado na figura 8B, as forrageadoras apresentam um padrão invertido de taxa metabólica, quando comparadas com abelhas mantidas em condições fotoperiódicas normais (figura 8A), embora, no claro, os valores de $\mathrm{VCO}_{2}$ se mantenham em patamares mais baixos do que no claro do fotoperíodo normal. Parece haver arrastamento de um possível ritmo endógeno pelo ciclo claro/escuro, surgindo um ritmo exógeno em resposta a mudanças no ambiente.

Nos resultados coletados em fotoperíodo invertido (figura 8B) a análise estatística indica que as médias dos valores de taxa metabólica diferem significantemente $(\mathrm{P}<0,0001)$ com o teste de Kruskal-Wallis $(\mathrm{H}=86,5)$, mas, de forma semelhante ao obtido em fotoperíodo normal, ao se aplicar o pós-teste de Dunn, não foram identificados os grupos nos quais há diferenças significativas.

A ANOVA one way foi aplicada, e as médias dos valores de taxa metabólica diferem significantemente $(\mathrm{P}<0,0001)$, (F 0,05; 23; 59 = 20,93). Nas comparações múltiplas entre médias do teste de Tukey, foram identificados os horários nos quais os valores de taxa metabólica diferem (Tabela 2).

Tabela 2. Resultados de comparações múltiplas entre médias (teste de Tukey) de taxa metabólica em fotoperíodo invertido.

\begin{tabular}{|c|c|c|}
\hline Horário & $\mathrm{VCO}_{2}$ mé & \\
\hline $\mathrm{Oh}$ & & \\
\hline & 0,031371 & A \\
\hline $1 \mathrm{~h}$ & 0,031375 & A \\
\hline $2 \mathrm{~h}$ & 0,033488 & A \\
\hline $3 h$ & 0,032161 & A \\
\hline $4 h$ & 0,041144 & $\mathrm{C}$ \\
\hline $5 \mathrm{~h}$ & 0,045309 & A \\
\hline $6 \mathrm{~h}$ & 0,005079 & $\mathrm{D}$ \\
\hline $7 \mathrm{~h}$ & 0,005916 & $\mathrm{D}$ \\
\hline $8 \mathrm{~h}$ & 0,004037 & $\mathrm{~B}$ \\
\hline $9 \mathrm{~h}$ & 0,006373 & B \\
\hline $10 \mathrm{~h}$ & 0,006712 & $\mathrm{~B}$ \\
\hline $11 \mathrm{~h}$ & 0,007043 & $\mathrm{~B}$ \\
\hline $12 \mathrm{~h}$ & 0,006282 & $\mathrm{~B}$ \\
\hline $13 \mathrm{~h}$ & 0,007763 & B \\
\hline $14 \mathrm{~h}$ & 0,006671 & B \\
\hline
\end{tabular}


$15 \mathrm{~h}$

$16 \mathrm{~h}$

$17 \mathrm{~h}$

$18 \mathrm{~h}$

19h

$20 \mathrm{~h}$

$21 \mathrm{~h}$

$22 \mathrm{~h}$

$23 \mathrm{~h}$
0,007014

0,008261

0,009369

0,067851

0,074619

0,049528

0,053285

0,038095

0,041382
B

B

B

E

E

A

A

A

A

Médias indicadas pela mesma letra não diferem significantemente entre si pelo Teste de Tukey $(\alpha=5 \%)$

\section{VARIAÇ̃̃O DIÁRIA DA TAXA METABÓLICA EM CLARO CONSTANTE}

No claro constante (figura 9A) o padrão geral é semelhante ao obtido em fotoperíodo normal 12h:12h (figura 8A), entretanto, no claro constante as mudança de "patamares" de taxa metabólica parecem menos bruscas do que em fotoperíodo $12: 12 \mathrm{~h}$, principalmente entre 5 e $8 \mathrm{~h}$ e entre 18 e $21 \mathrm{~h}$.

A análise estatística indica que as médias dos valores de taxa metabólica diferem significantemente com $\mathrm{p}<0,0001$, segundo teste de Kruskal-Wallis $(\mathrm{H}=102,5)$.

A ANOVA one way foi aplicada, e as médias dos valores de taxa metabólica diferem significantemente $(\mathrm{P}<0,0001)$, ( F 0,05; 23; 100 = 22,64). Nas comparações múltiplas entre médias do teste de Tukey, foram identificados os horários nos quais os valores de taxa metabólica diferem, apresentados na tabela 3 .

Tabela 3. Resultados de comparações múltiplas entre médias (teste de Tukey) de taxa metabólica em claro constante.

\begin{tabular}{lll}
\hline Horário & $\mathrm{VCO}_{2}$ médio & \\
\hline Oh & 0,004755 & $\mathrm{~A}$ \\
$1 \mathrm{~h}$ & 0,004922 & $\mathrm{~A}$ \\
$2 \mathrm{~h}$ & 0,004393 & $\mathrm{~A}$ \\
$3 \mathrm{~h}$ & 0,004262 & $\mathrm{~A}$ \\
$4 \mathrm{~h}$ & 0,007922 & $\mathrm{~A}$ \\
$5 \mathrm{~h}$ & 0,012655 & $\mathrm{~A}$ \\
$6 \mathrm{~h}$ & 0,023344 & $\mathrm{~A}$
\end{tabular}


Médias indicadas pela mesma letra não diferem significantemente entre si pelo Teste de Tukey $(\alpha=5 \%)$

\section{VARIACÃO DIÁRIA DA TAXA METABÓLICA EM ESCURO CONSTANTE}

Nos resultados coletados em escuro constante (figura 9B), a análise estatística indica que as médias dos valores de taxa metabólica não diferem significantemente segundo teste de KruskalWallis $(\mathrm{H}=34,6)$. O pós-teste da ANOVA (teste de Tukey) e o teste de Kruskal-Wallis (teste de Dunn) não indicam diferenças estatisticamente significativas nas comparações 2 a 2 (P > 0.05).

No escuro constante, a taxa metabólica tende a se manter relativamente baixa, semelhante ao obtido no escuro nos demais fotoperíodos (figuras 8 e 9).

\section{TEMPO DE CONFINAMENTO}

O tempo de confinamento das abelhas não parece afetar a taxa metabólica, considerando separadamente o claro e o escuro. Na fase de claro, foram considerados os dados entre $7 \mathrm{~h}$ e $17 \mathrm{~h}$; os dados das 6h não foram considerados nessa análise por apresentar valores intermediários entre o claro e o escuro, sendo uma transição entre a fase de claro e de escuro, e não refletindo apenas o tempo de confinamento. No claro, no fotoperíodo normal $(H=9,647)$, claro constante $(H=6,757)$ e 
fotoperíodo invertido (das $18 \mathrm{~h}$ às $5 \mathrm{~h})(\mathrm{H}=13,36)$ os dados de taxa metabólica nos diferentes horários não diferem, segundo o teste de Kruskal Wallis, não havendo diferenças entre os grupos comparados dois a dois pelo pós teste de Dunn $(\mathrm{P}>0.05)$.

O mesmo ocorre na fase de escuro, para o fotoperíodo normal das $19 \mathrm{~h}$ às $5 \mathrm{~h}(\mathrm{H}=9,45)$, escuro constante (das $0 \mathrm{~h}$ as $23 \mathrm{~h})(\mathrm{H}=34,6)$ e fotoperíodo invertido (das 6h às $17 \mathrm{~h})(\mathrm{H}=11,57)$, também não havendo diferenças entre os grupos pelo pós-teste de Dunn.

Assim, parece que as variações observadas na taxa metabólica não se referem a efeitos do tempo de confinamento.

\section{EFEITOS DE DIFERENTES TEMPERATURAS}

Por meio de observações visuais das abelhas forrageadoras dentro das câmaras respirométricas, nas diversas temperaturas, verificou-se que elas apresentam diferentes comportamentos:

- 10 e $15^{\circ} \mathrm{C}$ : as abelhas se locomovem muito pouco dentro da câmara e há maior quantidade de movimentos abdominais.

- 20 a $30^{\circ} \mathrm{C}$ : elas andam pela câmara respirométrica e realizam pequenos vôos, mas não todo o tempo.

- 35 e $40^{\circ} \mathrm{C}$ : elas ficavam agitadas, andando pela câmara mais do que nas temperaturas mais baixas.

$\mathrm{Na}$ figura 10 estão representados os valores de $\mathrm{VO}_{2}$ e de $\mathrm{QR}$ versus temperatura, no claro, de forrageadoras tratadas com solução de sacarose 50\%, coletoras de néctar/água (grupo "Néctar") e de pólen (grupo "Pólen”).

\section{$\underline{\text { VO}}_{2}$ EM DIFERENTES TEMPERATURAS}

Dentre as abelhas coletoras de néctar/água, a taxa metabólica diferiu nas diferentes temperaturas, segundo o teste de Kruskal Wallis $(\mathrm{H}=56,53 ; \mathrm{p}<0,001)$, sendo que os valores de $\mathrm{VO}_{2}$ a $10^{\circ} \mathrm{C}$ diferem dos a 15,20 e $25^{\circ} \mathrm{C}$, e os valores a $20^{\circ} \mathrm{C}$ diferem dos valores a 35 e $40^{\circ} \mathrm{C}(\mathrm{p}<0,001)$, conforme ilustrado na figura 10A. No caso das abelhas coletoras de pólen, a taxa metabólica também diferiu nas diferentes temperaturas $(\mathrm{H}=40,02 ; \mathrm{p}<0,001)$, ocorrendo o mesmo tipo de diferença descrito para coletoras de néctar/água. Na figura 10, médias indicadas pela mesma letra não diferem significantemente entre si pelo teste de Dunn.

Ressalta-se que os valores de $\mathrm{VO}_{2}$ de 15 a $30^{\circ} \mathrm{C}$ não diferem estatisticamente entre si.

\section{QR EM DIFERENTES TEMPERATURAS}

Os valores de QR diferiram nas diferentes temperaturas, dentro do grupo das coletoras de néctar/água $(\mathrm{H}=19,95 ; \mathrm{p}=0,0028)$ e dentro do grupo das coletoras de pólen $(\mathrm{H}=22,52 ; \mathrm{p}=0,001)$ 
(Figura 10B). Nos dois casos, as diferenças ocorreram entre os valores de $\mathrm{QR}$ a $40^{\circ} \mathrm{C}$, os quais diferem dos valores a 15,20 e $25^{\circ} \mathrm{C}(\mathrm{p}<0,05)$.

\section{EFEITO DO TIPO DE CARGA SOBRE VO 2 E QR}

$\mathrm{Na}$ figura 10 estão representados os valores de $\mathrm{VO}_{2}$ e de QR versus temperatura ambiente, de abelhas forrageadoras tratadas com solução de sacarose 50\%, coletoras de néctar/água (grupo "Néctar") e de pólen (grupo "Pólen”). Não foram detectadas diferenças, estatisticamente significativas, entre os valores de $\mathrm{VO}_{2}$ e QR de forrageadoras coletoras de néctar/água e de pólen ( $\mathrm{p}>0,05$ ) dentro da mesma temperatura (figura 10A), segundo o teste de Mann Whitney. Os valores de $U$ para as diferentes temperaturas estão apresentados na tabela 4.

Tabela 4. Resultados da análise de Mann Whitney (valores de U e de p), comparando forrageadoras coletoras de néctar/água com coletoras de pólen, quando a dados de VO2 e de QR, nas diferentes temperaturas.

\begin{tabular}{|c|c|c|c|c|}
\hline \multirow[t]{2}{*}{ Temperatura $\left({ }^{\circ} \mathrm{C}\right)$} & $\mathrm{U} \quad$ (comparando & $\mathrm{p}$ (comparando VO2) & $\mathrm{U}$ (comparando QR) & $\mathrm{p}$ (comparando QR) \\
\hline & \multicolumn{4}{|l|}{$\mathrm{VO} 2)$} \\
\hline 10 & 35 & 0,1618 & 17 & 0,0745 \\
\hline 15 & 112 & 0,6063 & 45 & 0,0948 \\
\hline 20 & 126 & 0,5733 & 59,5 & 0,0422 \\
\hline 25 & 79 & 0,2658 & 54,5 & 0,0171 \\
\hline 30 & 24 & 0,6943 & 26 & 0,8665 \\
\hline 35 & 24,5 & 0,6943 & 18,5 & 0,4557 \\
\hline 40 & 11 & 0,8413 & 17 & 0,9372 \\
\hline
\end{tabular}

Foram observadas diferenças significativas $(\mathrm{p}<0,05)$ nos valores de $\mathrm{QR}$ de forrageadoras coletoras de néctar/água e de pólen a 20 e $25^{\circ} \mathrm{C}$, indicado em letras maiúsculas na figura 10B. Além disso, também pode ser observado que, com relação à tendência central dos dados, as forrageadoras de pólen apresentam maiores valores médios de $\mathrm{VO}_{2}$ (figura $10 \mathrm{~A}$ ) e menores valores de QR (figura 10B).

Segundo o Coeficiente de Correlação de Spearman, foi detectada correlação significativa entre os valores de $\mathrm{VO}_{2}$ e QR (figura 11), tanto no grupo "Néctar" ( $\mathrm{r}=0,8571 ; \mathrm{p}=0,0238$ ) quanto no grupo "Pólen" ( $\mathrm{r}=0,9286 ; \mathrm{p}=0,0067)$. Ou seja, valores altos de $\mathrm{VO}_{2}$ coincidem com valores altos de QR e vice-versa, nas diferentes temperaturas.

Foram realizadas comparações de inclinação e intercepto intra-tratamento, e as forrageadoras analisadas (dos grupos "Néctar" e "Pólen") parecem apresentar similaridade de 
resposta (quanto a $\mathrm{VO}_{2}$ e $\mathrm{QR}$ ) nas diferentes temperaturas, ao se comparar os dados individuais separadamente.

Nas comparações entre-tratamentos, abordando os grupos "Pólen" e "Néctar" (figura 13) na análise de regressão linear dos valores de $\mathrm{VO}_{2}$ de 10 a $25^{\circ} \mathrm{C}$, foi detectada semelhança de inclinação e intercepto entre-grupos. Todavia, com os valores de QR, foi detectada diferença estatisticamente significativa $(\mathrm{P}<0,0001)$ entre os dois grupos, quanto ao intercepto. A $10^{\circ} \mathrm{C}$ os valores de QR do grupo "Néctar" apresentam maior dispersão do que o grupo "Pólen", no qual os valores se concentram entre 0,68 e 0,85 (figura 13 ).

$\mathrm{Na}$ figura 14, com os valores de $\mathrm{VO}_{2}$ e $\mathrm{QR}$ de 25 a $40^{\circ} \mathrm{C}$ foram detectadas diferenças significativas entre as inclinações e interceptos dos valores de $\mathrm{VO}_{2}(\mathrm{p}=0,0049)$ e os interceptos dos valores de QR ( $\mathrm{p}=0,0016)$ dos grupos "Néctar" e "Pólen".

Parece haver diferença nos valores de $\mathrm{QR}$ e $\mathrm{VO}_{2}$ das forrageadoras nas diferentes temperaturas, conforme a função no forrageio (coleta de néctar/água ou de pólen).

\section{DISCUSSÃO}

\section{ASPECTOS METODOLÓGICOS}

A montagem de um sistema de respirometria intermitente permite a aplicação de diferentes abordagens em pesquisas biológicas, como, por exemplo, nos estudos de taxa metabólica per se, individual e colonial, nos estudos sobre as necessidades energéticas em diferentes estados metabólicos e em diferentes condições ambientais, nas estimativas da utilização de substratos energéticos (por meio de cálculo do Quociente Respiratório), e com respeito aos efeitos de tratamento oral com diversas substâncias. No caso deste trabalho, a montagem do sistema de respirometria, acoplado ao sistema de válvulas manuais e à câmara climática, mostrou-se uma ferramenta eficaz para a busca de respostas a diversas questões ligadas ao metabolismo energético individual, envolvendo diferentes condições fotoperiódicas e temperaturas, e também aquelas ligadas ao efeito de substâncias por tratamento oral (capítulo 4).

O tempo de confinamento das abelhas não parece afetar a taxa metabólica: os animais são coletados durante a manhã e, durante a fase de claro, não parece haver variações nas taxas metabólicas segundo análise estatística (entre 7h e 17h59).

Foram realizados experimentos piloto com abelhas operárias jovens, coletadas na região dos discos de cria, mas os resultados não foram aqui incluídos devido a questões metodológicas e número amostral. O tempo de fechamento das câmaras respirométricas era muito longo, para que o sinal detectado no software fosse adequado e de cálculo confiável. Outra questão foi a coleta das operárias jovens entre os discos de cria, o que levava à necessidade de haver retirada do invólucro e 
fuga das abelhas jovens, que se dirigiam para a parte inferior da colônia, de difícil acesso. A alternativa adotada foi a colocação de discos de cria em caixa de madeira separada, conectada ao ninho original por meio de mangueira, para que as operárias recém emergidas fossem marcadas e coletadas. O problema neste caso foi que as demais operárias fechavam a conexão entre as duas caixas com material de vedação, e assim a caixa com a cria ficava sem o cuidado das operárias e não havia a termorregulação adequada. Além disso, os objetivos do capítulo acabaram por não abordar questões ontogenéticas.

\section{ISOLAMENTO E RITMOS BIOLÓGICOS}

Uma vantagem da utilização de $M$. quadrifasciata é que, uma vez que são abelhas eussociais, as operárias exercendo a mesma função na colônia (e então, provavelmente com idade semelhante, ligado ao polietismo etário), podem apresentar uma série de similaridades, já que estariam sob a influência dos mesmos fatores. Isso permite a aplicação de metodologias e análises como as de Takahashi-Del-Bianco et al (1992) (com formigas) e de Teixeira (2006) (com $M$. quadrifasciata), em experimentos objetivando detecção de ritmos biológicos e definição de períodos do ritmo. No trabalho de Teixeira (2006) cada série temporal de ritmo de taxa metabólica foi estabelecida pelo agrupamento de séries, com $24 \mathrm{~h}$ de duração cada, de diferentes indivíduos mantidos nas mesmas condições experimentais. A autora ressalta que este tipo peculiar de série temporal é aceito para esta espécie de abelha devido à característica eussocial de M. quadrifasciata, que resulta em alta similaridade entre resposta de operárias de uma mesma colônia, de idade e atividade similares. Porém, tal tipo de análise não foi aqui empregado devido às características da metodologia empregada. Em razão da suposta curta sobrevida das operárias isoladas da colônia, e às características da aparelhagem do sistema de respirometria, não adquirimos séries temporais de vários ciclos de $24 \mathrm{~h}$ para cada operária, como costuma ocorrer em experimentos cronobiológicos.

Operárias de abelhas melíferas, quando mantidas individualmente em laboratório, possuem uma vida mais curta em comparação com as abelhas em condições naturais (KAISER, 1988). O decréscimo na quantidade de sono (descanso) durante vários dias experimentais (SAUER et al, 2003) poderia ser uma razão. Contrera (2006) ressalta que há falta de trabalhos sobre a influência do tamanho do grupo e isolamento na sobrevivência de operárias de abelhas sem ferrão.

Contrera (2006) investigou a relação entre o tamanho do grupo versus a sobrevivência de operárias de M. quadrifasciata anthidioides e, de modo diferente de A mellifera (CHAUVIN, 1952, apud CONTRERA, 2006), em M. quadrifasciata não foram encontradas diferenças nas longevidades de operárias em grupos de diferentes tamanhos. Além disso, em mandaçaia a longevidade foi maior do que em operárias de A mellifera mantidas em condições semelhantes (CHAUVIN, 1952) e é possível que isso reflita maior resistência ao isolamento por $M$. 
quadrifasciata, em relação a A mellifera (CONTRERA, 2006). Insetos que vivem em ambientes imprevisíveis em geral apresentam maior longevidade (CAREY, 2001 apud CONTRERA, 2006) e Contrera (2006) acredita que se pelo menos algumas operárias podem sobreviver mais do que a média quando as condições ambientais são desfavoráveis, melhores as chances para a sobrevivência da colônia.

Assim, diante dos resultados de Contrera (2006) pode-se pensar que seja possível que as operárias de $M$. quadrifasciata possam ser mantidas isoladas durante mais dias para a coleta de séries temporais de taxa metabólica em diferentes condições fotoperiódicas e de temperaturas. A característica rítmica detectada na taxa metabólica, principalmente em claro constante (figura 8), poderia se tratar de um transiente ou pós-efeito (características de um ritmo biológico que derivam de condições de pré-tratamento tais como transientes de fase ou alterações do período). Caso se pretendesse caracterizar o tau das operárias, seria pertinente utilizar tempos maiores de aclimatação para entrada em livre-curso.

\section{RESPOSTAS INDIVIDUAIS E EFEITOS COLONIAIS}

Apesar de ser uma condição artificial para a espécie, faz-se necessário a realização de experimentos com operárias isoladas, para pesquisar a ritmicidade endógena. Assim, garantir-se-ia um protocolo experimental no qual o ritmo seja caracterizado sem a interferência de fatores sociais (arrastamento social ou modulação pela atividade da rainha), e mantendo a variação individual (TEIXEIRA, 2006). Por exemplo, Schmolz et al (2002) sugerem que as abelhas A mellifera nas colônias economizam energia durante o sono com um comportamento ectotérmico, mas escolhem locais dentro do ninho com temperaturas adequadas, provavelmente para promover processos regenerativos durante o sono. Nos resultados deste capítulo, durante a fase de escuro dos ciclos CE e CC a taxa metabólica era mais baixa em relação à fase de claro, e na termorregulação colonial (capítulo 2), no começo da noite (escuro), é que se encontram as maiores temperaturas na região dos discos de cria, conforme discutido adiante. Estudos com indivíduos isolados da colônia são efetivos para estudos de respostas individuais, mas envolvem um contexto que pode não ser sociobiologicamente relevante (MESHI e BLOCH, 2007). Assim, deve-se ter claro se a pergunta do trabalho envolve interesse nas respostas individuais de operárias isoladas, ou se quer considerar o contexto das influências sociais.

Atualmente estudos a respeito de influências sociais nos ritmos circadianos tem sido amparados por diversas novas metodologias, tais como sistemas automáticos de aquisição de dados, como o método desenvolvido por Meshi e Bloch (2007) para monitoramento de abelhas $A$ mellifera, com observações prolongadas automáticas e de alta qualidade e que pode ser adaptado para estudos com outros animais. 
No contexto colonial se insere também a influência da oviposição pela rainha, que em abelhas sem ferrão difere do que ocorre em Apini. Em Meliponini, ocorre um processo denominado POP, que se constitui em uma cadeia de eventos integrados, com a construção de novas células de cria, seguido pelo aprovisionamento com alimento, a oviposição pela rainha e a operculação das células. É um processo cíclico, rigidamente marcado por intervalos definidos e específicos para cada espécie (SOMMEIJER et al, 1984; ZUCCHI, 1993; BELLUSCI, 2003). O POP pode estar relacionado a ritmos ultradianos em abelhas (TEIXEIRA, 2003; TEIXEIRA, 2006), podendo existir um forte arrastamento social entre as operárias de uma colónia (SOUTHWICK e MORITZ, 1987), e entre operárias e rainha (MORITZ e SAKOFSKI, 1991). Teixeira (2006) sugere que é possível que em colônias de mandaçaia a atividade interna colonial seja em parte organizada temporalmente ao redor da oviposição pela rainha, e que estes processos estejam relacionados à incubação da cria em temperatura controlada, essencial para a sobrevivência da colônia.

Contrera et al (2002) investigaram uma possível ritmicidade na atividade de trofalaxis (troca de alimento entre abelhas operárias) em M. quadrifasciata, e sugerem que a ritmicidade na trofalaxis poderia melhorar a alimentação, aumentando as chances das abelhas jovens serem alimentadas pelas mais velhas e aumentando a difusão de informações dentro da colônia.

Além dos fatores sociais, segundo Fuchikawa e Shimizu (2007), as flutuações localizadas de temperatura, dentro do ninho, e a elevação da temperatura corpórea de forrageadoras pela manhã, são fatores que podem estar envolvidos no arrastamento social entre grupos de forrageadoras, com as condições térmicas atuando como Zeitgebers que podem sincronizar os ritmos circadianos de abelhas individuais dentro da colônia. Além disso, Moritz e Kryger (1994) verificaram que flutuações de temperatura intra-grupo podem afetar a sincronização de ritmos individuais dentro de grupos sociais.

\section{INFLUÊNCIAS DO CICLO CLARO/ESCURO NAS ABELHAS}

Nas diferentes condições de claro/escuro, abordadas neste capítulo, as mudanças detectadas podem não ocorrer apenas na taxa metabólica, podendo haver também outras mudanças fisiológicas e comportamentais que podem alterar os tipos de respostas desses animais aos diferentes estímulos (CIPOLLA-NETO et al, 1988).

Um padrão cíclico de metabolismo foi observado por Southwich (1982) em aglomerados (“clusters") de abelhas A mellifera, ocorrendo um modelo rítmico de taxa metabólica com picos ocorrendo durante o dia e quedas à noite. Este ritmo circadiano é ligado ao fotoperíodo, mas continua mesmo em condições constantes de iluminação (SOUTHWICK, 1982). O ritmo circadiano de taxa metabólica é similar ao de Kronenberg (1979) (apud SOUTHWICK, 1982) e ritmos metabólicos em clusters intactos também foram sugeridos por Southwick e Mugaas (1971) 
e Stussi (1972). No entanto, tudo indica que M. quadrifasciata não forme aglomerados semelhantes aos de A mellifera.

Diversos trabalhos com A mellifera indicam que esses insetos, quando estudados isoladamente, numa faixa de temperatura de 15 a $30^{\circ} \mathrm{C}$, apresentaram um ritmo circadiano no uso de energia caracterizado por dois períodos bem definidos: um período diurno, durante o qual a taxa metabólica é bem acentuada e um período noturno, com o metabolismo bem mais baixo (STUSSI, 1966, 1968, 1972a, b, STUSSI e HEUSNER, 1963), semelhante aos patamares aqui obtidos.

\section{CICLO CLARO/ESCURO (CE)}

Proni e Macieira (2004) detectaram, em condições de fotoperíodo normal a $30^{\circ} \mathrm{C}$, um padrão definido de ritmo circadiano metabólico em abelhas sem ferrão dos gêneros Trigona e Tetragonisca, apresentando maior consumo de $\mathrm{O}_{2}$ durante o dia, com pico entre $10 \mathrm{~h}$ e $15 \mathrm{~h}$. À noite, o consumo também diminui, alcançando níveis mínimos entre $2 \mathrm{~h}$ e $3 \mathrm{~h}$. Proni et al (2001) determinaram o ritmo circadiano, com ciclo ambiental normal 12h:12h (dia/claro e noite/escuro), do consumo de oxigênio para operárias forrageadoras isoladas de Plebeia droryana, cujos resultados indicaram um ritmo circadiano bem definido, mostrando uma atividade diurna para esta espécie, o que coincide com o vôo, o mesmo ocorrendo com M. quadrifasciata com relação à atividade de vôo. Os maiores valores de taxa metabólica das abelhas, durante a fase de claro, poderiam estar relacionados com a atividade de vôo e o forrageio por recursos, que ocorrem quando há condições de temperatura, umidade relativa e luminosidade adequadas e disponibilidade de recursos (abertura das flores para coleta de pólen e néctar, por exemplo) (Capítulo 2).

Além disso, o ritmo metabólico das abelhas poderia estar sob o efeito de arrastamento pelas condições fotoperiódicas. Quando exposto ao ciclo ambiental, o período do ritmo em livre curso (tau) torna-se muito similar ao do ciclo ambiental e tem suas fases acertadas por ele. Assim, no caso do ciclo claro/escuro, a taxa metabólica do indivíduo fica vinculada a fase do ciclo ambiental que é o Zeitgeber (ASCHOFF, 1960), no caso, ciclo claro/escuro. Detectou-se durante a fase de escuro os menores valores de taxa metabólica das forrageadoras, com um padrão rítmico apresentando dois patamares (um patamar com os valores baixos na fase de escuro e um patamar com os valores altos na fase de claro).

\section{FOTOPERÍODO INVERTIDO}

As forrageadoras apresentaram um padrão invertido de taxa metabólica, quando comparadas com abelhas mantidas em CE, sendo que esses resultados corroboram os de Proni et al (2004). Estes autores investigaram a taxa metabólica de operárias isoladas de Nannotrigona (Scaptotrigona) postica em fotoperíodo invertido por um período de 24 horas, à $30^{\circ} \mathrm{C}$, e obtiveram 
um padrão invertido de ritmo metabólico em comparação com o encontrado em condições fotoperiódicas normais. Os dados apresentados na figura 8 também parecem sugerir um ritmo metabólico invertido e a existência de um ritmo exógeno que surge como uma resposta a mudanças no ambiente, talvez como estratégia de sobrevivência e/ou como um caso de plasticidade fisiológica (PRONI et al, 2004). Além do mais, este poderia ser um caso de arrastamento de um possível ritmo endógeno pelas condições fotoperiódicas.

Esse tipo de resposta pode ser importante para a sobrevivência das abelhas, mostrando que a taxa metabólica destas pode apresentar plasticidade e se ajustar de acordo com as condições ambientais. Isto permite que o animal continue existindo em uma ampla gama de variações ambientais, incrementando desta maneira a eficácia biológica (PIANKA, 1982 apud PRONI e MACIEIRA, 2004).

\section{CLARO CONSTANTE (CC)}

Em CC (figura 9A) parece haver ritmicidade na taxa metabólica de forrageadoras, as mudanças de "patamares" de taxa metabólica parecem menos bruscas do que em CE (figura 8A), principalmente entre 5 e $8 \mathrm{~h}$ e entre 18 e $21 \mathrm{~h}$. No CC, foram tomados os cuidados para as abelhas não apresentarem contato com ciclos ambientais e, dessa maneira, os ritmos endógenos podem se expressar com menor influência de Zeitgebers, mas acreditamos que as abelhas não tenham entrado em livre curso devido ao tempo de experimento ter sido insuficiente para esse processo. Todavia, neste estudo não era objetivo o cálculo do período endógeno, que é a duração de um ciclo determinada pelos mecanismos endógenos (relógios biológicos), o que exigiria outro tipo de metodologia e análise.

O registro de atividade interna colonial (Capítulo 2) pode ajudar a entender os valores mais baixos de taxa metabólica durante a noite no caso das abelhas se encontrarem em um estado semelhante ao "sono", como aquele sugerido por Kaiser (1988) e Sauer et al (1998, 2003, 2004), com base em investigações eletrofisiológicas, eletromiográficas e comportamentais em A mellifera. Kaiser (1988) propõe que, durante a noite, as abelhas melíferas passam por processo similar ao sono dos mamíferos. Parâmetros importantes que representam sinais comportamentais de profundidade do processo de sono em abelhas são "quantidade de imobilidade antenal" e "duração de episódios de imobilidade antenal" (SAUER et al, 2004). É possível que durante os horários da noite, tanto em CE quanto em CC, as abelhas pudessem apresentar-se em um estado similar ao sono (SAUER et al, 1998, 2003, 2004), mas não há evidências experimentais desse processo em $M$. quadrifasciata.

\section{ESCURO CONSTANTE}


Em escuro constante e na fase de escuro dos ciclos CE quanto em CC, o escuro (ou o período da noite) parece ser um período no qual os valores de taxa metabólica estão mais reduzidos. Ao se comparar os resultados deste capítulo com os dados de termorregulação colonial (Capítulo 2), enfrentamos um paradoxo. Na termorregulação colonial, os valores de temperatura na região dos discos de cria nas colônias abertas, no começo da noite, ainda estão elevados (quando a taxa metabólica das operárias individuais reduz-se); a seguir, a temperatura diminui durante a madrugada. Pode-se pensar que as maiores temperaturas nos discos de cria, durante a noite, sejam um resultado de "inércia térmica" do calor remanescente do dia, já que a temperatura cai durante a madrugada. Nas colônias mantidas fechadas em temperatura controlada e em escuro constante, foi observado um padrão de termorregulação com periodicidades significativas desta vez não mais relacionadas à temperatura ambiente, refletindo uma característica endógena do controle de condições ambientais dentro da colônia.

A respeito da temperatura torácica, Fuchikawa e Shimizu (2007) verificaram que esta variável em operárias de Apis cerana japonica pode oscilar de forma diária. Durante o dia, há 7$8^{\circ} \mathrm{C}$ de elevação em relação à temperatura ambiente, e a temperatura torácica segue a temperatura ambiente durante a noite, continuando com uma periodicidade circadiana em escuro constante. Esta observação é interessante ao se pensar nos dados de termorregulação colonial e em uma abordagem integrativa da termorregulação colonial e individual em M. quadrifasciata. Seria interessante estudar a ritmicidade diária da temperatura torácica concomitantemente com a coleta de dados de taxa metabólica, ficando esta sugestão para trabalhos futuros.

Os baixos valores de $\mathrm{VCO}_{2}$ em escuro constante poderiam também ser casos de mascaramento negativo, devido à condição de escuro total para uma espécie diurna. Condições de iluminação fazem variar o tau que pode ter valores diferentes se obtido sob claro ou sob escuro constante (ASCHOFF, 1960; JOHSON et al., 2004). Luz de intensidade muito forte, escuro total para espécies diurnas, temperatura muito alta ou muito baixa, entre outras condições, podem abolir a expressão rítmica e a condição é chamada "não permissiva" (PITTENDRIGH, 1960) e o mecanismo pelo qual a expressão do ritmo é abolida é conhecido como "mascaramento negativo". (ASCHOFF, 1960). Caso se pudesse calcular as periodicidades significativas nos valores de taxa metabólica deste trabalho, poder-se-ia verificar se o escuro constante é uma condição não permissiva na qual um ritmo biológico não se expressa, ou se expressa de forma alterada. Mas em condições sociais, nos experimentos de termorregulação colonial realizados do capítulo 2, com colônias de abelhas mantidas fechadas em escuro constante, detectou-se um padrão de termorregulação indicativo de provável atividade metabólica para a termorregulação, o que parece não ter ocorrido de maneira evidente com as abelhas isoladas. Neste caso, é possível que os diversos fatores sociais e coloniais estejam atuando. 
Pode-se pensar também na questão da "hora subjetiva". Em Cronobiologia, "dia subjetivo"e "noite subjetiva" são as qualificações das fases nas quais ocorrem atividade e repouso de um organismo em livre-curso. Se o organismo for diurno, sua fase de atividade (ou, no caso deste trabalho, maiores valores de $\mathrm{VCO}_{2}$ ) será considerada como o dia subjetivo, e a de repouso (ou de menores valores de $\mathrm{VCO}_{2}$ ) como noite subjetiva. A duração total do dia subjetivo determina o "horário circadiano" (MARQUES et al, 1999). Teixeira (2006) detectou algumas discrepâncias entre os valores dos diversos indivíduos, sugerindo que algumas operárias se encontravam em fases distintas do ciclo circadiano no horário dos seus experimentos. O mesmo poderia ocorrer em alguns dados do presente trabalho, relacionado com diferenças individuais, e os valores de desvio padrão obtidos, principalmente em fotoperíodo invertido e claro constante, com abelhas possivelmente em fases distintas do ciclo e em diferentes horas subjetivas. Mas, novamente, coloca-se a questão de que talvez o período experimental tenha sido curto para as abelhas entrarem em livre curso e os dados representem um transiente.

\section{ASPECTOS FISIOLÓGICOS E HORMONAIS RELACIONADOS AO FOTOPERÍODO}

\section{DIAPAUSA}

A diapausa pode ser definida como um estado dinâmico de reduzida atividade metabólica, medida neuro-hormonalmente (TAUBER et al, 1986; DEHLINGER, 1986), podendo haver interrupção temporária do desenvolvimento ou da atividade reprodutiva (NECHOLS et al. 1999). Além disso, há persistência temporária de atividade metabólica reduzida, mesmo quando as condições favoráveis retornam (DEHLINGER, 1986), sendo em insetos a principal resposta adaptativa sazonal. Em alguns tipos de insetos, pode ocorrer por indução fotoperiódica (TAUBER e KYRIACOUS, 2001). A diapausa fotoperiódica de Drosophila melanogaster foi estudada por Willians e Sokolowski (1993) e Saunder (1997), autor que também aborda a indução fotoperiódica da diapausa larval em Calliphora vicina.

Especificamente em abelhas, há registros de diapausa em diversas famílias (ROUBIK, 1989). Em A mellifera, toda a colônia sofre alterações quando está sob condições desfavoráveis, principalmente relacionados à temperatura, e incluem seleção de locais para nidificação, estoque de grande quantidade de mel, agrupamento de indivíduos para melhor termorregulação e ausência de cria durante o outono e inverno (SEELEY, 1985).

É interessante se pensar em por que no inverno operárias de Apis apresentam longevidade maior e metabolismo mais reduzido (MICHENER, 1974), ocorrendo também maior longevidade em operárias que emergem nessa época em abelhas Plebeia saiquie (OLIVEIRA e IMPERATRIZFONSECA, 1973). Porém, não há relatos de quais alterações sazonais poderiam estar ocorrendo na 
fisiologia das abelhas no inverno, relacionadas à temperatura e/ou a outros fatores, que levariam à maior longevidade. Uma pista poderia ser a observação de que em Plebeia remota, na fase de maior atividade na construção de células de cria e de postura, os discos de cria geralmente não possuem invólucro; entretanto, à medida que a diapausa reprodutiva se aproxima, nota-se que o invólucro reaparece e o número e o espessamento dos trabiques de sustentação aumentam dentro do ninho (BORGES e BLOCHTEIN, 2006), podendo melhorar as condições de termorregulação e de incubação da cria.

Entre as abelhas sem ferrão, em algumas espécies de Plebeia ocorre parada na construção de células de cria pelas operárias e da postura pela rainha, durante os meses de outono e inverno (TERADA et al, 1975; WITTMANN, 1989; BENTHEM et al, 1995; PICK e BLOCHTEIN, 2002b). Atividade reduzida das operárias durante o inverno também foi descrito para Melipona rufiventris flavolineata (CECCATO, 1970). Embora não se possa afirmar com certeza, há indicações de tal fase de inatividade é uma verdadeira diapausa, pelo menos em relação às atividades de postura (RIBEIRO et al, 2003). Em Plebeia remota, tanto a temperatura quanto as condições internas do ninho poderiam talvez exercer uma influência na manutenção da diapausa reprodutiva, já que devem fazer parte das condições adversas que dificultam a continuidade da construção das células de cria e postura da rainha (RIBEIRO et al, 2003). Nessas abelhas, o desencadeamento da diapausa reprodutiva foi correlacionado com o fotoperíodo por estes autores, os quais enfatizam que a ocorrência deste fenômeno possibilita a presença das abelhas em regiões subtropicais, com condições ambientais adversas durante longos períodos. Neste caso, o comprimento do dia é o fator mais constante e regular e pode servir como um indicador de que uma fase difícil se aproxima. Todavia, a temperatura e precipitação, embora coincidindo sazonalmente com a menor incidência de horas de luz, provavelmente não funcionam como um gatilho da diapausa reprodutiva nessas abelhas. Embora relativamente correlacionados, não implicam necessariamente em uma relação causal do comportamento (RIBEIRO et al, 2003).

Em M. quadrifasciata há algumas evidências de ocorrência de diapausa na colônia, uma vez que Nogueira-Neto (1970) comenta que as abelhas dessa espécie, no Estado de São Paulo, às vezes param temporariamente a construção de discos de cria no início do inverno ou até mesmo no final do verão. Mas seriam necessários experimentos com exposição de colônias a condições controladas de fotoperiodismo e temperatura, para se tentar esclarecer se há de fato entrada em diapausa, qual o tipo e quais os fatores desencadeadores (RIBEIRO et al, 2003; TEIXEIRA, 2006).

\section{MELATONINA E DOPAMINA}


A melatonina é um hormônio produzido pela glândula pineal que poderia funcionar como mecanismo de sinalização orgânica da fase escura do ciclo claro/escuro em vertebrados, com seus níveis apresentando pico durante a fase de escuro, tal como pode ocorrer em insetos (HARDELAND e POEGGELER, 2003; GORBET e STEEL, 2003; ITOH et al, 1995). A melatonina também pode transmitir informação fotoperiódica ao corpo para regular os seus ritmos circadianos (ANDERA et al, 1994; ITOH et al, 1995a; ITOH e SUMI, 1998; GAO, 1997). Segundo Yang et al (2007), a melatonina é sintetizada no cérebro de abelhas A mellifera ligustica, e relacionada com o polietismo das operárias. Os autores detectaram diferenças estatisticamente significativas nos níveis de melatonina de operárias de diferentes idades e diferentes tarefas na colônia, com os níveis mais elevados detectados nas forrageadoras. De acordo com Huang et al (2007), os níveis de melatonina apresentaram ritmo diário nas abelhas Apis com 30 dias de idade, com dois picos, um às $7 \mathrm{~h}$ e outro às $19 \mathrm{~h}$, podendo haver uma relação entre os níveis de melatonina e os horários de nascer e ocaso do sol. Essas características sugerem que a melatonina pode estar envolvida na regulação da divisão de trabalho relacionada à idade em abelhas, desenvolvimento comportamental, polietismo e possivelmente também no ciclo vigília/sono de abelhas (HUANG et $a l, 2007)$.

Carrington et al (2006) examinaram as relações entre variações cíclicas nos níveis de dopamina, nos lobos ópticos do cérebro de abelhas A mellifera, e ritmicidade circadiana comportamental de forrageadoras, mostrando que mudanças no regime claro/escuro têm impacto significativo, não apenas no comportamento de forrageio, mas também nos níveis de dopamina. Todavia, não foi detectada correlação entre os níveis dessa substância e a atividade rítmica circadiana das abelhas. Os níveis de dopamina nos lobos ópticos do cérebro de forrageadoras de abelhas melíferas têm pico ao redor do meio dia, quando as abelhas estão forrageando ativamente (PURNELL et al, 2000), podendo desempenhar papéis na modulação da atividade circadiana das abelhas (CARRINGTON et al, 2006).

\section{INFLUENCIAS DA TEMPERATURA SOBRE AS ABELHAS}

\section{ASPECTOS METODOLÓGICOS}

Para as medições de $\mathrm{VO}_{2}$ e $\mathrm{QR}$, as abelhas foram colocadas dentro de câmaras respirométricas, e estas dentro de câmara climática, a qual era programada para manter a temperatura em condições controladas. Em experimentos-piloto, foram realizadas medições da temperatura dentro da câmara respirométrica, colocando carregadores de dados dentro desta, e verificando o quanto a temperatura programada na câmara climática equivale a que a abelha seria realmente exposta, e os valores se equivaleram. Stabentheiner et al (2003) apontam que pode haver 
erros na estimativa da temperatura na qual abelhas A mellifera estão sendo submetidas devido a modificações na temperatura do ar da câmara respirométrica decorrente da endotermia das abelhas. Admitindo-se o $\mathrm{VO}_{2}$ médio de abelhas ativas a $15^{\circ} \mathrm{C}$ (de $131,39 \mathrm{uL} \mathrm{O}_{2} \mathrm{~min}^{-1}$ ) e um aumento de temperatura de $1^{\circ} \mathrm{C}$ dentro a câmara metabólica, não considerar este aumento de temperatura pode levar a uma superestimativa do consumo de oxigênio, mas não maior do que $0,35 \%$, que é um valor baixo (STABENTHEIMER et al, 2003). Apesar de tais cálculos terem sido estimados para abelhas do gênero Apis, decidimos considerar as suas conclusões como também aplicáveis à Melipona, e assim considerar não relevante o aumento da temperatura do ar dentro da câmara respirométrica decorrente da possível endotermia da abelha.

As abelhas empregadas neste trabalho foram submetidas a diferentes temperaturas no mesmo dia, e não mantidas na mesma temperatura por longos períodos, o que poderia levar a maior aclimatação. Por exemplo, no estudo de Nespolo et al (2003), a aclimatação de grilos Hophlosphyrum griseus era realizada durante 1 semana, às condições do laboratório, e mais 2 semanas nas temperaturas determinadas $\left(7,17\right.$ ou $\left.27^{\circ} \mathrm{C}\right)$. No caso das abelhas M. quadrifasciata, tal procedimento não foi viável devido às características da aparelhagem do sistema de respirometria e à questão da sobrevida de insetos eussociais isolados da colônia, conforme discutido anteriormente.

\section{PREFERENCIAS TÉRMICAS DE ABELHAS}

O trabalho de Heran (1968) retrata um experimento de preferências térmicas em abelhas no qual se constatou que em indivíduos até 6 dias de idade permanecem entre 36,3 e $37,5^{\circ} \mathrm{C}$, indivíduos de 7 a 24 dias permanecem entre 32,5 a $36^{\circ} \mathrm{C}$, e abelhas acima de 27 dias de idade possuem "termopreferendum" entre 31,7 e $33,7^{\circ} \mathrm{C}$. Ou seja, abelhas mais jovens "preferem" temperaturas mais elevadas (HERAN, 1968), semelhante ao observado por Free e Spencer-Booth (1958), que verificaram que as temperaturas preferidas de abelhas A mellifera jovens variava de 35 a $37,5^{\circ} \mathrm{C}$, e de forrageadoras de 31,5 a $36,5^{\circ} \mathrm{C}$.

Hochachka e Somero (2002) apontam que animais que se locomovem selecionam temperaturas preferenciais, utilizando uma variedadede de estratégias, incluindo a seleção de horários do dia apropriados para o forrageio, como poderia ser o caso das abelhas. Em experimentos de preferências térmicas durante o sono, Schmolz et al (2002) verificaram que o maior número de operárias de $A$ mellifera foi encontrado a $28^{\circ} \mathrm{C}$, o mesmo também ocorrendo em condições naturais. Segundo estes autores, há economia de energia durante o sono com um comportamento ectotérmico, mas as abelhas escolhem locais dentro do ninho com temperaturas intermediárias moderadas, provavelmente para promover processos regenerativos durante o sono e não haver muita redução na taxa metabólica. Aqui pode-se retomar a questão das taxas metabólicas mais baixas no escuro constante e na fase de escuro dos ciclos $\mathrm{CE}$ e CC, conforme discutido acima. 
Sumpter e Broomhead (2000) recentemente estudaram o comportamento de um grupo de abelhas $A$ mellifera se movimentando livremente em um campo de temperaturas conhecidas $\left(8^{\circ} \mathrm{C}\right.$ a $18^{\circ} \mathrm{C}$ ). As abelhas se moviam aleatoriamente ou de forma organizada, dependendo da temperatura aplicada, e formavam clusters de diversos formatos. A temperatura no centro da estrutura aumentava até um determinado limite, a partir do qual as abelhas se reorganizavam em anéis cada vez maiores e retornavam à posição de disco, refletindo um possível comportamento de "aquecimento da colméia".

Aliados ao objetivo de caracterização do comportamento das abelhas em diferentes temperaturas, foram realizados, entre 2003 e 2004, experimentos preliminares para análise das preferências térmicas das forrageadoras, uma vez que ainda não se tinham informações a respeito das temperaturas mantidas dentro da colônia e das temperaturas na qual as abelhas regulam a temperatura torácica. Foi utilizada pista de gradiente térmico Eletrolab, do laboratório do Prof. Carlos Arturo Navas Ianini, e cada experimento foi realizado com um animal isoladamente, a fim de evitar uma possível atração por efeito de grupo. Ocorreram diversos problemas metodológicos tais como a operária ficar parada no local onde era colocada e não circular pela pista, além da questão de haver também um gradiente térmico vertical, dificultando a medição precisa da temperatura que estaria realmente afetando a operária. Além disso, havia questões cronobiológicas, como a variação diária das preferências térmicas. Assim, esses experimentos foram substituídos pelos estudos de taxa metabólica em diferentes temperaturas e medições de temperatura torácica do capítulo 4.

\section{EFEITOS DA TEMPERATURA SOBRE DIVERSOS PROCESSOS FISIOLÓGICOS}

Assim como esperado, a temperatura ambiente tem um efeito significante sobre os diversos processos fisiológicos e comportamentais em abelhas. Ao considerar diversos grupos animais, Hochachka e Somero (2002) delineiam como a temperatura afeta as propriedades estruturas e funcionais dos organismos, tendo como um dos focos a questão de qual é a natureza do estresse térmico. Além disso, descrevem como modificações nos níveis fisiológicos, bioquímicos e moleculares alteram a sensibilidade térmica dos organismos durante a adaptação evolutiva e a aclimatação fenotípica durante a vida do indivíduo. Ainda não se sabe ao certo de que forma a temperatura determina a taxa metabólica (FRAPPELL e BUTLER, 2004), podendo ser por maneira direta e mecanicista, dirigida diretamente pela energia cinética da célula (como proposto por GILLOOLY et al, 2001) ou a influência da temperatura é indireta e complexa, por meio de uma combinação de trade-off energético e adaptação evolutiva à temperatura (como sugerido por CLARKE, 2001 e CLARKE e FRASER, 2001). 
Segundo Clarke $(2003 ; 2004)$ ainda há falta de uma compreensão clara da relação entre a temperatura e o metabolsimo na escala do organismo. Pode-se explicar o comportamento bioquímico em uma baixa escala ou em níveis menores de organização, e gerar estatísticas a uma escala maior; interpolar a fisiologia na escala intermediária permanece um desafio (CLARKE, 2004).

As influências da temperatura ambiente sobre a taxa metabólica de abelhas A mellifera foram abordadas, por exemplo, por Cahill e Lustick (1976), Verma e Edwards (1971), Shueel e Dixon (1968), Crailsheim et al. (1999), Blatt e Roces (2001) e Stabentheiner et al (2003). De forma geral, a taxa metabólica de repouso de abelhas A mellifera aumenta com a temperatura ambiente (ALLEN, 1959. ROTHE e NACHTIGALL, 1989; SCHMOLZ et al, 2002; STABENTHEINER et al, 2003 ; KOVAC et al, 2007). Para abelhas sem ferrão, padrões semelhantes também detectados por Macieira et al (2001) para operárias de Nannotrigona postica (de 5 a $40^{\circ} \mathrm{C}$ ) e por Macieira e Proni (2005), com operárias de Trigona spinipes (de 5 a $35^{\circ} \mathrm{C}$ ). Proni e Hebling (1996) investigaram a capacidade termorregulatória das abelhas sem ferrão Tetragonisca angustula fiebrigi e Tetragonisca angustula angustula, durante o inverno e o verão e a taxa metabólica aumentou com elevação na temperatura. Mas, segundo Cahill e Lustik (1976), em zangões a taxa metabólica não exibia tal relação inversa à temperatura, sendo estável a baixos valores de temperatura ambiente.

Kovac et al (2007) estudaram a relação entre atividade respiratória de abelhas A mellifera em repouso e a temperatura ambiente, na faixa de $5-40^{\circ} \mathrm{C}$. Abelhas em repouso eram, com frequiência, fracamente endotérmicas de $14-30^{\circ} \mathrm{C}$. A taxa metabólica e troca gasosa de abelhas em temperaturas acima de $10^{\circ} \mathrm{C}$, ocorrem em ciclos descontínuos que são acompanhados por movimentos abdominais ventilatórios (LIGHTON e LOVEGROVE, 1990; KOVAC et al, 2007)

Alguns estudos demonstraram que ritmos de atividade locomotora de Apis cerana japonica (FUCHIKAWA e SHIMIZU, 2007ª) e A mellifera (MOORE e RANKIN, 1993) podem ser arrastados por ciclos de temperatura com $10^{\circ} \mathrm{C}$ de amplitude e que o tau do ritmo de RNAm de period sofreram compensação à temperatura, fator que também fortemente influenciou a amplitude dos ritmos circadianos transcricionais durante o livre curso (FUCHIKAWA E SHIMIZU, 2007a).

Almeida (2004) detectou padrão rítmico da atividade de operárias ao longo do tubo de saída para dentro do ninho em Frieseomelitta varia e Frieseomelitta doederleini. As amplitudes das fases de atividade e repouso das abelhas no tubo foram bastante modificadas em condições experimentais de temperaturas constantes $\left(28,38\right.$ e $\left.18{ }^{\circ} \mathrm{C}\right)$ e claro constante. Em temperatura baixa, as abelhas praticamente cessam suas atividades no tubo e na cria, enquanto que em temperatura alta, a amplitude aumenta consideravelmente (ALMEIDA, 2004).

\section{DESCRICÕES MATEMÁTICAS E NÍVEIS DE ORGANIZACC̃̃O}


Descrições matemáticas da dependência do metabolismo sobre a temperatura usam uma aproximação exponencial, baseado no conceito de energia de ativação de Arrhenius (por exemplo, HADLEY e HILL, 1969; LIGHTON e BARTHOLOMEW, 1988; LIGHTON, 1989) ou funções polinomiais (LIGHTON e BARTHOLOMEW, 1988; VOGT e APPEL, 1999). Kovac et al (2007) apresentam uma descrição matemática da taxa metabólica de repouso de A mellifera em uma larga faixa de temperatura ambiente.

O $\mathrm{Q}_{10}$ tem sido calculado para insetos (HEATWOLE, 1996), tais como formigas (LIGHTON e BARTHOLOMEW, 1988; LIGHTON, 1989) e abelhas (STABENTHEINER et al, 2003). Para o cálculo de $\mathrm{Q}_{10}$ utiliza-se a equação $\left[\mathrm{Q}_{10}=\left(\mathrm{k}_{2} / \mathrm{k}_{1}\right)^{10 / \mathrm{T} 2-\mathrm{T} 1}\right.$ ] onde $\mathrm{k}_{1}$ e $\mathrm{k}_{2}$ são as velocidades correspondentes às temperaturas $T_{1}$ e $T_{2}$, respectivamente. $O Q_{10}$ não permanece constante para todas as variações de temperatura que um animal pode tolerar, sendo, então, necessário especificar com precisão as condições sob as quais as observações foram feitas (PRECHT et al, 1973; PROSSER e HEATH, 1991; WITHERS, 1992; SCHMIDT-NIELSEN, 1996). $\mathrm{O}$ uso do $\mathrm{Q}_{10}$ para descrever os efeitos da temperatura não possui um fundamento teórico na termodinâmica, e, portanto, deve ser visto como uma variável empírica que mede a sensibilidade térmica de um determinado processo (CHAUI-BERLINCK et al., 2002; PASSOS, 2003) e como indicador da magnitude de mudanças fisiológicas induzidas por temperatura em taxas físicoquímicas e fisiológicas (CHAUÍ-BERLINCK et al, 2002).

Segundo Chauí-Berlinck et al (2002) há um longo debate na literatura a respeito da extensão na qual os valores de $\mathrm{Q}_{10}$ podem ser utilizados para tirar conclusões sobre o controle regulatório do metabolismo energético, com o principal ponto de discordância sendo sobre se é ou não adequado usar os conceitos derivados da teoria molecular nas respostas fisiológicas integrativas dos organismos. Os autores verificaram que valores típicos de $\mathrm{Q}_{10}$ não podem ser utilizados sem ambigüidades para deduzir controles regulatórios da taxa metabólica, a menos que os valores de $\mathrm{Q}_{10}$ sejam considerados parâmetros verdadeiros cujos valores são conhecidos de antemão (CHAUÍBERLINCK et al, 2002). Além disso, os valores de $\mathrm{Q}_{10}$ apenas informam sobre a sensibilidade térmica sob condições determinadas e, aplicados a taxas do organismo, não podem ser usados para propor mecanismos subjacentes ou eventos no nível bioquímico (CHAUÍ-BERLINCK et al, 2004) ou em diferentes níveis de organização.

\section{$\underline{\text { EFEITOS DE DIFERENTES TEMPERATURAS SOBRE O VO }} 2 \underline{\text { E QR }}$}

\section{TEMPERATURAS BAIXAS}

É possível, também, que as abelhas mantidas isoladas a $10^{\circ} \mathrm{C}$ e a $15^{\circ} \mathrm{C}$ limitassem a perda evaporativa de calor e não tivessem os estímulos para a termorregulação que poderiam existir caso 
a abelha estivesse na colônia, como o aquecimento pré-vôo e termorregulação colonial e, assim, a sua taxa metabólica é baixa a $10^{\circ} \mathrm{C}$ na ausência de estímulos sociais.

Foi detectada correlação significativa entre os valores de taxa metabólica e QR, tanto no grupo "Néctar" quanto no grupo "Pólen". Ou seja, valores altos de $\mathrm{VO}_{2}$ coincidem com valores altos de QR e vice-versa, nas diferentes temperaturas. A 20 e $25^{\circ} \mathrm{C}$, os valores de QR de forrageadoras de néctar/água eram significantemente maiores do que o $Q R$ de forrageadoras de pólen. Apesar de relatos de que os valores de QR são geralmente 1,0 para abelhas melíferas (ROTHE e NACHTIGALL, 1989) e M. bicolor (FRANÇOSO-JÚNIOR, 1999), os estudos geralmente não relataram se as abelhas eram forrageadoras de néctar ou de pólen.

Os menores valores de QR nas temperaturas mais baixas podem estar relacionados à maior tendência a termogênese, com utilização de outros substratos, além de carboidratos. Isso estaria de acordo com a hipótese de que durante períodos de maior requerimento de termogênese haveria mecanismos envolvendo vias octopaminérgicas, com utilização de substratos energéticos diferentes de carboidratos, como aminoácidos (LOLI e BICUDO, 2005). Conseqüentemente, menores valores de QR (Capítulo 4) Francoso-Júnior (1999) não descarta a possibilidade de que o QR possa ser diferente de 1,0 em $M$. bicolor, já que as proteínas podem também desempenhar um papel relevante no estado nutricional de muitas abelhas (CRAISSHEIM, 1990; ROUBIK, 1982). Entretanto, a $10^{\circ} \mathrm{C}$, foram obtidas as menores taxas metabólicas, o que não estaria de acordo com maiores gastos energéticos para a termogênese. Ao mesmo tempo, há que se considerar a diminuição da demanda tecidual de uma maneira global no organismo. Por exemplo, temperaturas corpóreas baixas mantidas por uma abelha, no caso de acidentalmente impedida de passar a noite dentro do ninho, pode representar uma estratégia de economia de energia para o aquecimento durante a manhã (GRODZICKI e CAPUTA, 2005).Talvez, a manutenção de menor $\mathrm{VO}_{2}$ a $10^{\circ} \mathrm{C}$ seja uma estratégia de economia de energia enquanto as abelhas "esperam" que a temperatura ambiente aumente e elas possam realizar aquecimento pré-vôo.

Conforme já discutido anteriormente, em baixas temperaturas, alguns insetos dependem, para a sua sobrevivência, de adaptações bioquímicas e fisiológicas que resultam em períodos de diapausa, que se caracteriza pela interrupção temporária do desenvolvimento ou da atividade reprodutiva (NECHOLS et al. 1999). Há registros de diapausa em diversas famílias de abelhas, com alterações quando está sob condições desfavoráveis, principalmente relacionados a baixas temperaturas no ambiente (ROUBIK, 1989; SEELEY, 1985). Há algumas espécies de abelhas sem ferrão que reduzem a sua atividade durante os meses de outono e inverno, como, por exemplo, Plebeia, (TERADA et al, 1975; WITTMANN, 1989; BENTHEM et al, 1995), Melipona rufiventris flavolineata (CECCATO, 1970) e M. quadrifasciata (NOGUEIRA-NETO, 1970). 
A $15^{\circ} \mathrm{C}$ foram obtidos os maiores valores de desvio padrão, podendo esta temperatura se localizar próximo a um valor tolerável sem grandes mudanças no $\mathrm{VO}_{2}$, a qual pode também estar relacionada com a atividade de vôo da espécie. A temperatura ambiente, juntamente com a umidade relativa, parecem ser fatores ambientais cruciais para os padrões de atividade de vôo e forrageio nas abelhas sem ferrão (capítulo 2). Assim, é importante para o desempenho das forrageadoras e tanto para a sua sobrevivência como indivíduo quanto para a sobrevivência da colônia que a sua taxa metabólica não se altere consideravelmente com mudanças de pequena magnitude na temperatura ambiente, com provisões adequadas de recursos alimentares e de materiais para a arquitetura do ninho.

\section{TEMPERATURAS ELEVADAS}

Em temperaturas altas, como 35 e $40^{\circ} \mathrm{C}$, não seria necessária a termogênese, e sim mecanismos de perda de calor, como observado por Kovac et al (2007) em A mellifera, as quais muitas, em temperaturas acima de $34^{\circ} \mathrm{C}$, mostravam esforços para resfriar o corpo via evaporação e por meio de regurgitação de gotas de fluido de suas peças bucais, para prevenir o superaquecimento do corpo. Observações similares foram feitas em uma vespa Pimpla turionellae por Kroder et al (2007). Além disso, a $35-40^{\circ} \mathrm{C}$, observou-se que também indivíduos de M. quadrifasciata apresentavam-se visualmente mais agitados, mas com $\mathrm{VO}_{2}$ menores do que os de 15 a $30^{\circ} \mathrm{C}$.

Queda semelhante do $\mathrm{VO}_{2}$ em altas temperaturas também foi obtida por Leonhard e Crailsheim (1999), que observaram que abelhas A mellifera carnica são ativas em ambientes com temperaturas entre 10 e $45^{\circ} \mathrm{C}$, sendo que a $51^{\circ} \mathrm{C}$ a taxa de consumo de $\mathrm{O}_{2}$ cai abaixo da curva obtida pra temperaturas menores. No trabalho desses autores, a taxa metabólica caiu a $51^{\circ} \mathrm{C}$, e no presente trabalho, a queda foi entre 35 e $40^{\circ} \mathrm{C}$, para $M$. quadrifasciata. Tais diferenças entre espécies podem estar relacionadas, entre outros fatores, a diferenças nas regiões geográficas de ocorrências das duas espécies. Espécies que vivem em ambientes mais frios tenderiam a apresentar maiores taxas metabólicas do que espécies que vivem em ambientes mais quentes, segundo o padrão obtido por Berrigan e Partridge (1997) para moscas Drosophila melanogaster de duas linhagens mantidas várias gerações a $18^{\circ} \mathrm{C}$ e a $25^{\circ} \mathrm{C}$ (na qual a taxa metabólica era 5 a $7 \%$ maior).

Os valores de QR a $40^{\circ} \mathrm{C}$ estão dentro do esperado para a oxidação de lipídios, proteínas e/ou uma mistura destes, estando menores do que se seria esperado para o consumo de carboidratos. $40^{\circ} \mathrm{C}$ pode ser uma temperatura muito alta para as abelhas, podendo indicar uma condição de préfalência metabólica, devido à hipertermia.

\section{INFLUENCIAS DO TIPO DE CARGA TRANSPORTADAPELA FORRAGEADORA}


De 25 a $40^{\circ} \mathrm{C}$, foram detectadas diferenças significativas entre as inclinações e interceptos dos valores de $\mathrm{VO}_{2}$ e os interceptos dos valores de QR dos grupos "Néctar" e "Pólen". Parece haver diferença nos valores de $\mathrm{QR}$ e $\mathrm{VO}_{2}$ das forrageadoras nas diferentes temperaturas, conforme a função no forrageio (coleta de néctar/água ou de pólen).

Neste trabalho, empregou-se forrageadoras coletoras de pólen, as quais não necessariamente participam dos processos de preparação, na colônia, do pólen coletado, e que, portanto, talvez não utilizassem o pólen de suas corbículas como complemento alimentar durante o período experimental. Entretanto, segundo Micheu et al (2000), a prolina, oriunda do pólen, é um aminoácido que pode ser utilizado por forrageadoras A mellifera carnica, apesar de o ser em quantidades baixas quando comparadas com a utilização de carboidratos.

Em A mellifera as forrageadoras de pólen possuíam taxas metabólicas aproximadamente $10 \%$ maiores do que as forrageadoras de néctar, não importando a quantidade de carga carregada. A temperatura torácica seguia a seguinte ordem: forrageadoras de pólen > néctar >água, e assim o tipo de carga carregada (pólen ou néctar) pode afetar os custos metabólicos durante o vôo (FEUERBACHER et al, 2003)

O pólen é carregado externamente nas pernas, enquanto o néctar é carregado internamente, potencialmente afetando o centro de massa da abelha no vôo. Mudanças no centro de massa podem afetar os ângulos do corpo, posição das asas, pode requerer mudanças corretivas ns movimentos de vôo para prevenir mudanças nos ângulos do corpo, etc. (FEUERBACHER et al, 2003). Além disso, as abelhas Apis tendem a se especializar em forragear por pólen ou néctar, e tal especialização é parcialmente gerada geneticamente (FEWELL e PAGE, 1993). As taxas metabólicas de vôo diferem entre linhagens genotípicas dentro de uma colônia (HARRISON et al, 1996), levando à questão de se diferenças genéticas entre forrageadoras por néctar ou pólen são também associadas com variação metabólica (FEUERBACHER et al, 2003).

Existe um conflito na literatura a respeito do efeito do carreamento de cargas sobre a taxa metabólica de vôo em abelhas melíferas, e tais diferenças podem estar relacionadas também a diferenças experimentais (WOLF et al, 1989; BALDERRAMA et a, 1992; MOFFATT, 2000; FEUERBACHER et al, 2003).

As variações nas taxas metabólicas entre forrageadoras de pólen e néctar poderiam também ser geradas por variação nas capacidades de resfriamento durante o vôo. As forrageadoras de néctar podem extrudar os seus conteúdos do papo para resfriamento evaporativo, resfriando o corpo, ao passo que forrageadoras de pólen não têm esta opção (HEINRICH, 1979).

Um fator a ser considerado, a respeito do $\mathrm{VO}_{2}$ nas forrageadoras, é a sua experiência de forrageio. As forrageadoras deste trabalho foram coletadas na entrada da colônia, após retornarem de vôos, podendo tanto ser operárias inexperientes que acabaram de iniciar o forrageio, quanto ser 
operárias mais velhas e experientes, que forrageiam há várias semanas (SCHEINER, 2003); tais diferenças poderiam acarretar certas variações individuais. Além disso, as forrageadoras que imaginamos ser forrageadoras de néctar, por não apresentarem material aparente nas corbículas, poderiam ser forrageadoras de água, ao invés de néctar. O tipo de carga (néctar, água ou pólen) pode afetar a relação entre a temperatura torácica e a temperatura ambiental (FEUERBACHER et al, 2003).

O carreamento de pólen, de néctar ou de água pode estar ligado a uma série de fatores, tais como modificações na massa corpórea, nos custos metabólicos do vôo, no centro de massa do animal, na taxa metabólica de vôo, entre outros. Segundo Yang et al (2007), em abelhas melíferas os níveis mais elevados de melatonina foram observados nas forrageadoras coletoras de pólen e em Apis cerana cerana foram detectados os maiores níveis de melatonina nas forrageadoras coletoras de néctar.

Pierrot e Schlindwein (2003) estudaram a atividade de vôo em Melipona scutellaris e observaram que mais de $90 \%$ dos vôos para coleta de pólen ocorreram nas primeiras horas da manhã, quando a temperatura é menor. Assim, a necessidade de vôo em temperaturas mais baixas ou mais altas pode estar relacionada a possíveis diferenças na $\mathrm{VO}_{2}$ de forrageadoras de pólen em relação às de néctar. Apesar de não haver diferenças significativas, as médias de $\mathrm{VO}_{2}$ de forrageadoras coletoras de pólen são maiores em todas as temperaturas, em relação às forrageadoras coletoras de néctar (figura 10).

A maior coleta de pólen pela manhã pode também estar ligada ao oferecimento deste. A secreção de néctar e a liberação de pólen pelas plantas é diferente ao longo do dia, variando no seu início, hora de pico e duração (ROUBIK, 1989). Bruijn e Sommeijer (1997) sugerem que o pico de forrageio durante a manhã, em Melipona, pode ser considerado adaptativo: nas regiões tropicais, a disponibilidade de pólen não é um fator limitante, mas competição intra-específica pode ocorrer, envolvendo colônias fracas, médias e fortes.

\section{HETEROTERMIA EM ABELHAS}

As abelhas empregadas neste trabalho estavam isoladas, sem os diversos fatores sociais que poderiam motivar o aquecimento pré-vôo e vôos de forrageio. É possível que se fosse medida a taxa metabólica de vôo, com as abelhas submetidas aos diversos estímulos ambientais e sociais, os padrões de variação de $\mathrm{VO}_{2}$ nas diferentes temperaturas pudessem ser diferentes, com estímulos à termogênese. É necessário cautela nas generalizações a respeito da termorregulação em abelhas de diferentes espécies, principalmente nas comparações com A mellifera. As abelhas sem ferrão, nativas do Brasil, estão adaptadas aos trópicos e seu clima, não sendo tão necessária a produção de calor em escalas tão altas como em Apis, principalmente as européias, habitantes de regiões mais 
frias. Conforme será exposto no capítulo 4, em M. quadrifasciata parece haver produção de calor no tórax, verificado por meio de experimentos envolvendo medição de temperatira torácica. Havendo termogênese, $M$. quadrifasciata se inclui no grupo de insetos endotermos-heterotermos.

Além disso, nas condições experimentais, não se sabe ao certo como está a questão da necessidade e motivação para o aquecimento dos músculos torácicos de vôo, e quais seriam seus efeitos diferenciados no $\mathrm{VO}_{2}$ e QR; estas questões são também discutidas no capítulo 4.

Há diversos estudos que abordam a evolução da endotermia, com foco principalmente em vertebrados (FRAPPELL e BUTLER, 2004; HILLENIUS e RUBEN (2001ª), mamíferos e aves (GRIGG et al, 2001; KOTEJA et al, 2001), peixes (DICKSON e GRAHAM, 2001), e vertebrados ancestrais (SEYMOUR et al, 2001). Sobre a heterotermia há, infelizmente, poucos trabalhos como a heterotermia em mamíferos e aves (COOPER e GEISER, 2008), antílopes do deserto (OSTROWSKI e WILLIAMS, 2006), peixes (KATZ, 2002), mamíferos de zonas áridas (MITCHELL et al, 2002; HWANG et al, 2007), entre outros.

Em insetos, a heterotermia é discutida principalmente por Heinrich (1972, 1974, 1979, 1981, 1997), Heath e Heath (1982), Bartholomew (1981), Josephson (1981). Mais trabalhos e discussões nessa área seriam interessantes para o conhecimento de mais detalhes da termogênese em insetos endotermos-heterotermos, a influência da temperatura sobre sua taxa metabólica e temperatura torácica, e mecanismos de termogênese (LOLI e BICUDO, 2005). Há a possibilidade de que mudanças diárias na temperatura corpórea das forrageadoras de Apis cerana japonica possam atuar como um Zeitgeber interno pela flutuação da temperatura dentro do ninho (FUCHIKAWA e SHIMIZU, 2007).

\section{CONCLUSÕES}

- diferentes ciclos de claro/escuro afetam a taxa metabólica de forrageadoras;

- parece haver um ritmo exógeno que aparece como uma resposta a mudanças no ciclo claro/escuro, como ocorrido em fotoperíodo invertido;

- o claro se mostrou uma condição adequada (ao se comparar claro e escuro) para os experimentos do capítulo 4, por ser a condição na qual a forrageadora se encontrava ao ser coletada, não sendo necessário tempo de aclimatação muito longo para a condição experimental; 
- como não foi encontrada diferença estatisticamente significativa entre a taxa metabólica das abelhas, no claro, entre $7 \mathrm{~h}$ e $17 \mathrm{~h}$, essa é uma janela temporal na qual podem ser realizados estudos de efeitos de substâncias, sem alterações na $\mathrm{VO}_{2}$ relativas à fase do dia;

- a temperatura tem um efeito significativo sobre a taxa metabólica de forrageadoras;

- entre 15 e $30^{\circ} \mathrm{C}$ não há diferenças estatísticas entre os valores de $\mathrm{VO}_{2}$ e QR, sendo esta uma faixa de temperatura adequada na qual podem ser realizados estudos de efeitos de substâncias, sem alterações na $\mathrm{VO}_{2}$ relativas à temperatura;

- parece haver diferença nos valores de $\mathrm{QR}$ e $\mathrm{VO}_{2}$ das forrageadoras, nas diferentes temperaturas, conforme a função no forrageio (coleta de néctar/água ou de pólen), sendo importante atentar a este fato na escolha de forrageadoras para experimentos de $\mathrm{VO}_{2}$ e QR.

\section{REFERÊNCIAS BIBLIOGRÁFICAS}

ALMEIDA, G.F. (2004) Estudo de componentes rítmicos detectados na colônia de Frieseomelitta varia (Hymenoptera: Apidae: Meliponinae). Dissertação de Mestrado, FFCLRP-USP.

BARTHOLOMEW, G.A. (1981) A matter of size: an examination of endothermy in insects and terrestrial vertebrates. In: Insect thermoregulation (B. Heinrich, ed.) Wiley-Interscience Publication, USA.

BELLUSCI, S; MARQUES, M.D. (2001) Circadian activity rhythm of the foragers of a eusocial bee (Scaptotrigona affdepilis, Hymenoptera, Apidae, Meliponinae) outside the nest. Biological Rhythm Researc 32(2): 117-24.

BELLUSCI, S. (1998) Caracterização do ritmo de atividade / repouso em livre curso de Scaptotrigona aff. depilis (Moure, 1942) (Hymenoptera: Apidae: Meliponinae). Dissertação de Mestrado FFCLRPUSP.

BELLUSCI, S. (2003). Colônia de abelhas eussociais: modulação de ritmos com ênfase no processo de construção de células de cria e postura em duas espécies de abelhas sem ferrão, Frieseomellita doederleini e Frieseomellita varia (Hymenoptera, Apidae). Tese de Doutorado. FFCLRP, USPRP.

BELLUSCI, S. e MARQUES, M.D. (2001) Circadian activity rhythm of the foragers of a eusocial bee (Scaptotrigona aff depilis, Hymenoptera, Apidae, Meliponinae) outside the nest. Biological Rhythm Research 32(2): 117-24.

BERTALANFFY, L (1975) Teoria geral dos sistemas. Petropolis : Vozes.

BLATT, J e ROCES, F. (2001) Haemolymph sugar levels in foraging honeybees (Apis mellifera): dependence on metabolic rate and in vivo measurement of maximal rates of trehalose synthesis. J Exp Biol 204: 2709-16.

BLOCK, B.A. (1994) Thermogenesis in muscle. Annu. Rev. Physiol. 56: 535-77.

CALLEGARI-JACQUES, Sm. M. (2003) Bioestatística - Princípios e Aplicações. Artmed Editora S.A , São Paulo.

CHAUÍ-BERLINCK, J.G. e BICUDO, J.E. (2006) Respirometria - a técnica. Livraria Santos Editora Ltda.

CHAUÍ-BERLICK, J.G.; MONTEIRO, L.H.; NAVAS, C.A ; BICUDO, J.E. (2002). Temperature effects on energy metabolism: a dynamic system analysis..Proc Biol Sci 269(1486):15-9.

CHAUÍ-BERLINCK, J.G.; NAVAS, C.A ; MONTEIRO, L.H. BICUDO, J.E. (2004). Temperature effects on a whole metabolic reaction cannot be inferred from its components. Proc R Soc Lond B 271: $1415-9$. 
CHAUÍ-BERLINCK, J.G. e BICUDO, J.E. (2006) Respirometria - a técnica. Livraria Santos Editora Ltda.

CONTRERA, F. A. L; HILÁRIO, S.D.; KOEDAM, D.; IMPERATRIZ-FONSECA, V.L. (2002) Rhythmicity in trophallactic activity of Melipona quadrifasciata workers (Apidae : Meliponin). Proceedings of the VI Encontro sobre abelhas, Ribeirão Preto.

CONTRERA, F. A L. (2004) Trofaláxis e contatos sociais em abelhas sem ferrão do gênero Melipona Illiger, 1806 (Apidae, Meliponini). Tese de Doutorado, Instituto de Biociências da USP.

FRANÇOSO-JR, O A. (1999) Estudo comparativo do metabolismo aeróbico de Melipona bicolor Lepeletier (Hymenoptera: Apidae: Meliponinae). Tese de Doutorado, Instituto de Biociências da USP.

GUIBU, L.S.; IMPERATRIZ-FONSECA, V.L. (1984) Atividade externa de Melipona quadrifasciata Lepeletier (Hymenoptera, apidae, Meliponinae), Ciên e Cult. 36 supl. (7): 623.

HEARD, T.; HENDRIKZ, J.K. (1993) Factors influencing flight activity of colonies of the stingless bee Trigona carbonaria (Hymenoptera, Apidae) Austral J Zool 41(4): 343-53.

HEINRICH, B. (1980) Mechanims of body temperature regulation in honeybees, Apis mellifera. J Exp Biol 85: 61-87.

HEINRICH, B. (1993) The Hot-Blooded Insects. Cambridge, MA. Harvard University Press.

HEINRICH, B. (1979) Keeping a cool head: honeybee thermoregulation. Science 205: 1269-71.

HEINRICH, B. (1993) The Hot-Blooded Insects. Cambridge, MA. Harvard University Press.

HEINRICH, B. (1996) The thermal warriors: strategies of insect survival. Cambridge, Mass. Harvard University Press.

HEINRICH, S.D. e RAVEN, P.H. (1972) Energetics and pollination ecology. Science 176(4035): 597-602.

HERAN, H. (1968) Régulation thermique et sens thermique chez l'abeille in Chauvin, R. Traité de biologie de l'abeille - II. Maison et cie, Paris.

HILÁRIO, S.D; IMPERATRIZ-FONSECA, V.L.; KLEINERT, A (2000) Flight activity and colony strenght in the stingless bee Melipona bicolor bicolor (Apidae: Meliponinae). Rev Bras Biol 60(2): 299306.

HOCHACHKA, P.; SOMERO, G.N. (1984) Biochemical adaptation. Princeton University Press.

HOCHACHKA, P.; SOMERO, G.N. (2002) Biochemical adaptation - mechanisms and process in physiological evolution. Oxford University Press.

IMPERATRIZ-FONSECA, V.L.; KLEINERT-GIOVANINI, A ; PIRES, J.T. (1985) Climate variations influence on the flight activity of Plebeia remota Hilmberg. Rev Bras Entomol 29(3/4): 42734.

IWANA, S. (1977) A influência dos fatores climáticos na atividade externa de Tetragonisca angunstula (Apidae: Meliponinae) Bolm Zool Univ S Paulo 2: 189-201.

KAISER, W. (1988) Busy bees need rest, too - behavioural and electromyographical sleep signs in honeybees. J. Comp. Physiol. A, 163: 565-584.

KERR, W. ; AKAHIRA, Y.; CAMARGO, C. (1975) Sex determination in bees IV Genetic control of juvenile hormone production in Melipona quadrifasciata (Apidae) Genetics 81(4): 749-56.

LOLI, D. e BICUDO, J.E.P.W. (2005) Control and regulatory mechanisms associated with thermogenesis in flying insects and birds. Bioscience Reports 25 (3/4): 149-80.

MARQUES, M. D.; GOLOMBEK, D.; MORENO, C. Adaptação Temporal. In: Marques, N. \& MennaBarreto, L. (1997) Cronobiologia: princípios e aplicações. EDUSP, São Paulo.

MICHENER, C.D. (1974) The social behavior of the bees. Cambridgs, Massachusts: The Belknap Press of Harvard University Press.

MICHEU, S.; CRAILSHEIM, K.; LEONHARD, B. (2000) Importance of proline and other amino acids during honeybee flight. Amino Acids 18: 157-75.

MINORS, D.S.; WATERHOUSE, J.M. (1987) The problem of masking and some ways to deal with it. In: Chronobiology and Chronomedicine. Frankfurt, Peter Lang, pp. 119-35.

MOFFATT, L. (2000) Changes in the metabolic rate of the foraging honeybee: effect of the carried weight or the reward rate? J Com Physiol A 186: 299-306.

MOORE, D.; SIEGFRIED, D.; WILSON, R.; RANKIN, M (1989) The influence of time of day on the foraging behavior of the honeybee Apis mellifera. J Biol Rhythm 4: 305-25.

MOORE, D.; RANKIN, M (1993) Light and temperature entrainment of a locomotor rhythm in honeybees. Physiol Entomol 18: 271-8.

MOORE, D. (2001) Honey bee circadian clocks: behavioral control from individual workers to wholecolony rhythms. J Insect Physiol 47: 843-57. 
PACHECO, R.L.F.; KERR, W.E. (1989) Temperaturas em abelhas da espécie Melipona compressipes fasciculata. Ciên. E Cult 41(5): 490-5.

PIANKA, E.R. (1982) Ecología Evolutiva. Barcelona, Ed. Omega S.A., XI+365p.

PICK, R.A; BLOCHTEIN, B (2002). Atividades de vôo de Plebeia saiqui (Holmberg) (Hymenoptera, Apidae, Meliponinae) durante o período de postura da rainha e em diapausa. Revista Brasilieira de Zoologia 19(3): 827-39.

PIERROT, L.M.; SCHLINDWEIN, C. (2003) Variation in daily flight activity and foraging patterns in colonies of uruçu - Melipona scutellaris Latreile (Apidae, Meliponini). Rev Brasil Zool 20(4): 565-71.

PRONI, E.; HEBLING, M.J. (1996) Thermoregulation and respiratory metabolism in two Brazilian stingless bee subspecies of different climatic distribution, Tetragonica angustula fiebrigi and $T A$ angustula (Hymenoptera: Apidae: Meliponinae). Entomologia Generalis 20(4): 281-9.

PRONI, E. A (1995) Fisiologia e capacidade de termorregulação em ninhos de Tetragonisca angustula e Plebeia juliani. Tese de Doutorado, UNESP, Rio Claro.

PRONI, E.A. MACIEIRA, OJD.; Franchi, M.N. Morais, A.; Tristão, F.S. (2001) V Congresso Brasileiro de Ecologia, Brasil.

RANDALL, D.; BURGGREN, W. and FRENCH, K. (2000) Eckert - Fisiologia animal: princípios e aplicações. Guanabara Koogan S.A

ROBERTS, S.P.; HARRISON, J.F. (1999) Mechanisms of thermal stability during flight in the honeybee Apis mellifera. J Exp Biol 202: 1523-33.

ROTHE, U.; NACHTIGALL, W (1989) Flight of the honeybee. IV Respiratory quotients and metqbolic rate during sitting, walking and flying. J Comp Physiol 158: 739-49.

ROUBIK, D.W. (1989) Ecology and natural history of tropical honeybees. Cambridge Univ. Press, New York.

ROUBIK, D.W. \& BUCHMANN, S.L. (1984) Nectar selection by Melipona and Apis mellifera (Hymenoptera: Apidae) and the ecology of nectar intake by bee colonies in a tropical forrest. Oecologia (Berlin) 61: 1-10.

Saunders, D.S. (2002) Insect Clocks $3^{\text {rd }}$ ed. Elsevier Science, Amsterdam.

SAUER, S., HERRMANN, E. and KAISER, W. (1998) Covariation of behavioural sleep signs and resting respiration in honey bees. J. Sleep Res., 7 (Suppl. 2): 240.

SAUER, S.; KINKELIN, M.; HERRMANN, E.; KAISER, W. (2003) The dynamics of sleep-like behaviour in honeybees. J Comp Physiol A 189: 599-607

SAUER, S.; HERRMANN, E.; KAISER, W. (2004) Sleep deprivation in honey bees. J Sleep Res 13: 14552.

SCHEINER, R. et al (2002) Behavioural pharmacology of octopamine, tyramine and dopamine in honey bees. Behavioural Brain Research 136: 545-53.

SCHMOLZ, E.; et al (2000) Thermoanalitical investigations on paper cover of social wasps. Thermochimica Acta 361(1-2): 121-9.

SCHMOLZ, E.; HOFFMEISTER, D.; LAMPRECHT, I. (2002). Calorimetric investigations on metabolic rates and thermoregulation of sleeping honeybees (Apis mellifera carnica). Thermochimica Acta 382(1):221-227(7)

SUMPTER, D.J.T.; BROOMHEAD, D.S. (2000) Shape and dynamics of thermoregulating honey bee clusters. J Theor Biol 201: 1-14.

STABENTHEINER, A; PRESSL, H.; PAPST, T.; HRASSNIGG, N.; CRAILSHEIM, K. (2003) Endothermic heat production in honeybee winter clusters. J Exp Biol 206: 353-8

TAKAHASHY-DEL-BIANCO, M. ; HEBLING, M.J.A. (1992) Circadian oscillatory patterns of oxygen uptake in individual workers of the ant Camponotus rufipes. Physiological Entomology, Amsterdam, 17: 377-383.

TEIXEIRA, L.V. (2003). Aspectos temporais em colônias de Frieseomellita varia: influência das estações do ano, hora do dia e clima nas atividades de construção de células e de vôo. Hymenoptera: Apinae: Meliponini). Monografia. FFCLRP-USP, Ribeirão Preto.

TEIXEIRA, L.V. (2006) Variações ontogenéticas nos parâmetros do ritmo respiratório de operárias de Meliponaquadrifasciata (Hymenoptera, Apidae, Meliponini). Dissertação de Mestrado, FFCLRP, Ribeirão Preto, SP. 
VIEIRA, S. (2003) Bioestatística - Tópicos Avançados. Editora Campus Ltda, Rio de Janeiro.

WITHERS, P.C. (1977) Measurement of $\mathrm{VO}_{2}, \mathrm{VCO}_{2}$ and evaporative water loss with a flow through mask.

J Appl Physiol 42(1): 120-3.

ZAR, J.H. (1999) Biostatistical analysis. Upper Saddle River, N.J : Prentice Hall

ZUCCHI, R.; SAKAGAMI, S.F. (1972) Capacidade termo-reguladora em Trigona spinipes e em algumas outras espécies de abelhas sem ferrão (Hymenoptera: Apidae: Meliponinae), p. 301-309. In: C. Cruz-Landim; N.J. Hebling,; E. Lello \& C.S. Takahashi (Eds). Livro em Homenagem a Warwik Estevan Kerr. Rio Claro, Ed. UNESP.

ZUCCHI, R.; SILVA-MATOS, E. V. D NOGUEIRA-FERREIRA, F. H.; AZEVEDO, G. G. (1999). On the cell provisioning and oviposition process (POP) of the stingless bees nomenclature reappraisal and evolutionary considerations (Hymenoptera, Apidae, Meliponinae). Sociobiology 34(1):6586 


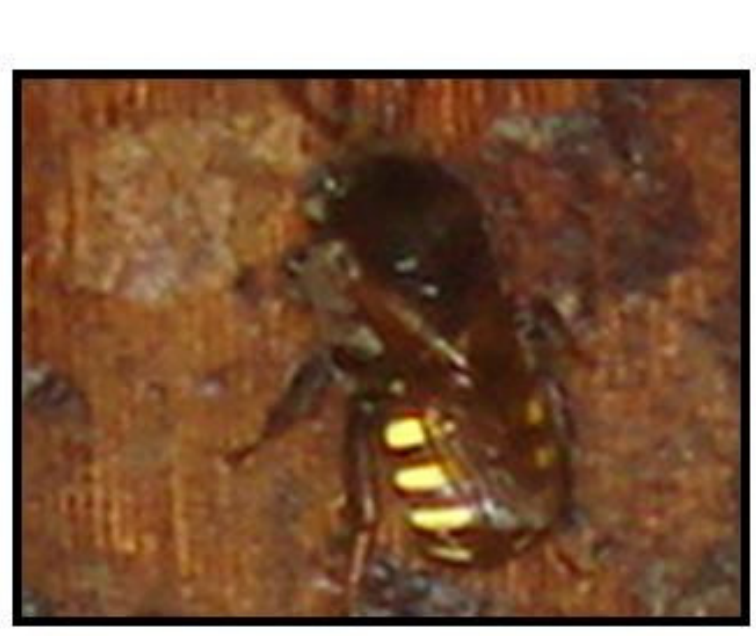

A

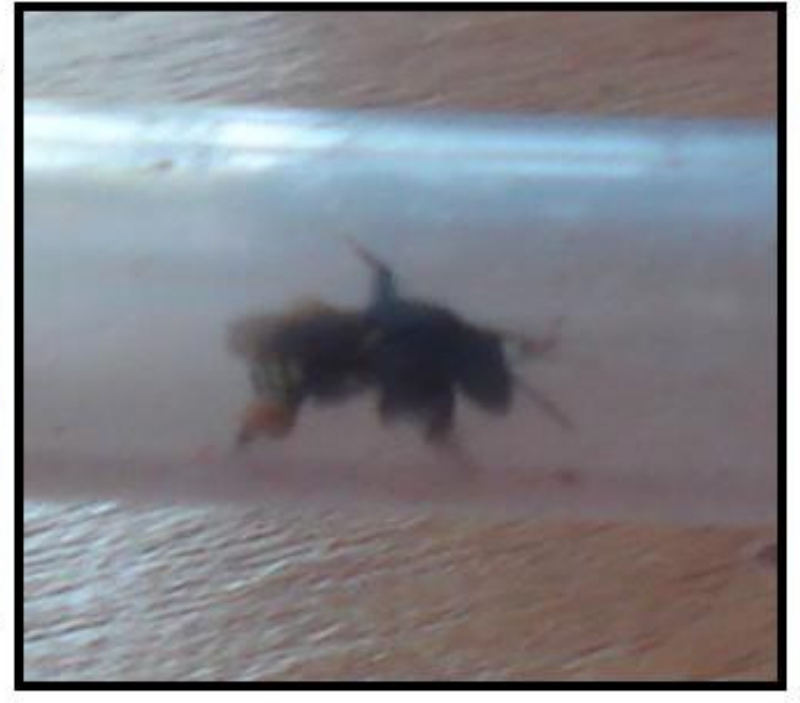

B

Figura 1. Operária forrageira de Melipona quadrifasciata sem material coletado aparente (A) e contendo pólen nas corbículas (B) (Fotos de D. Loli)
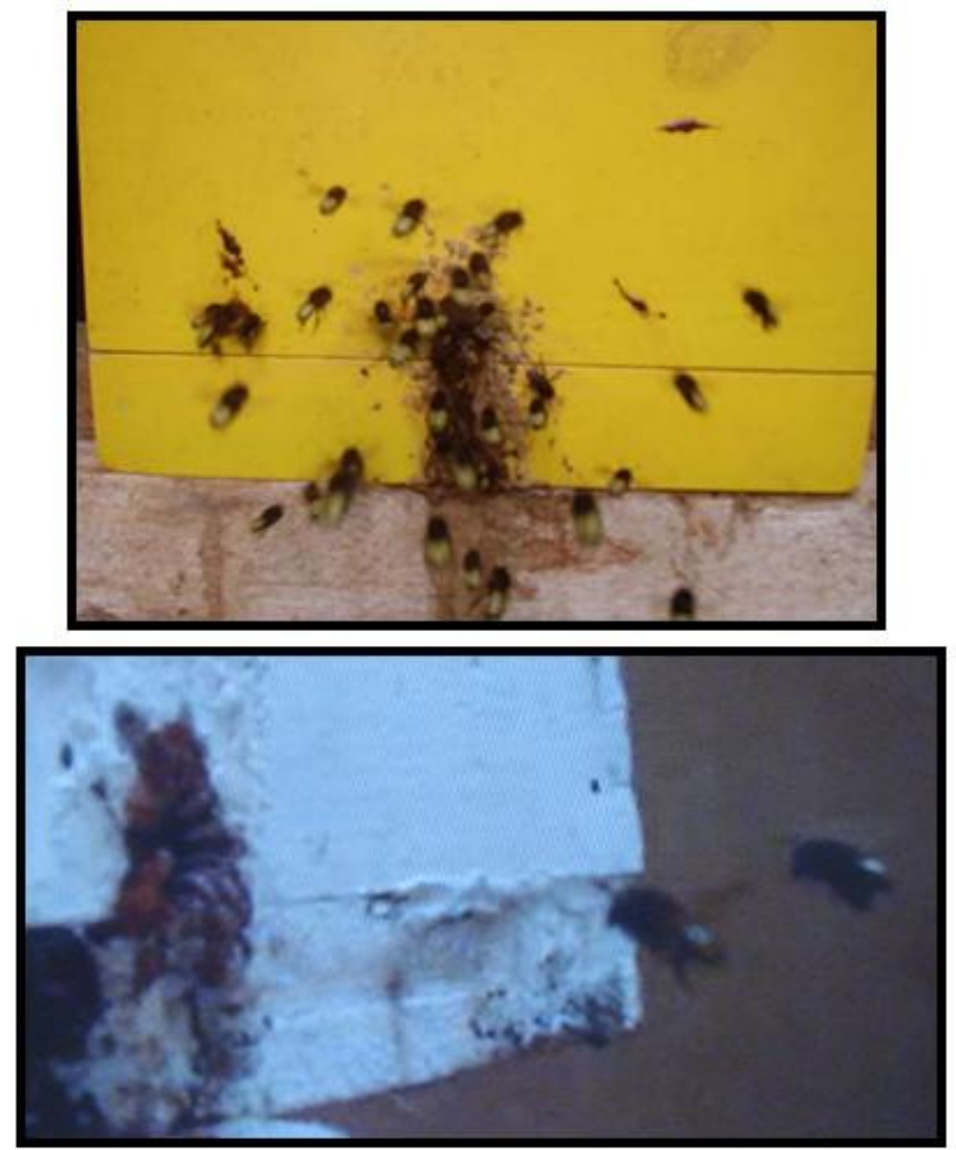

Figura 2. Operárias campeiras (forrageiras) retornando ao ninho, após vôo de forrageamento (Fotos de R. S. Guimarães e D. Loli) 


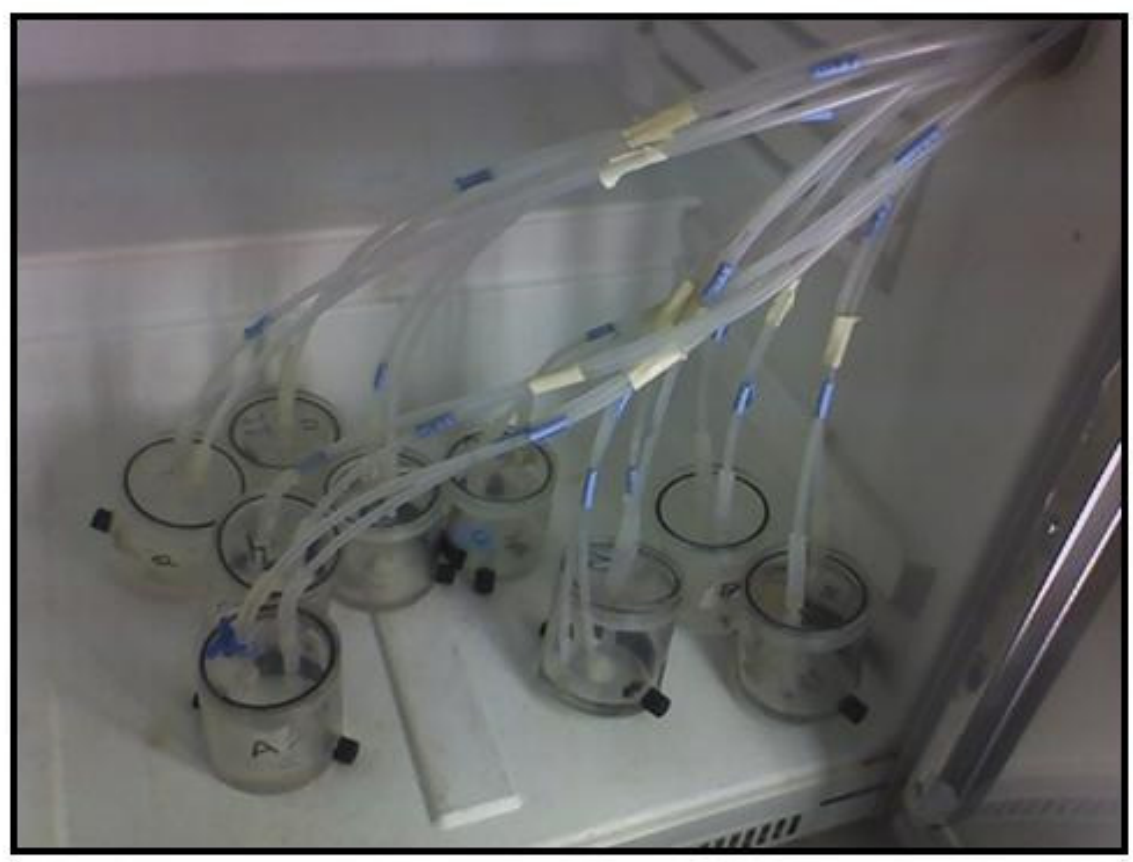

Figura 3. Câmaras respirométricas cilíndricas, de acrílico, contendo operárias forrageiras, mantidas em câmara climática Eletrolab $122 \mathrm{FC}$. (Foto de D. Loli)

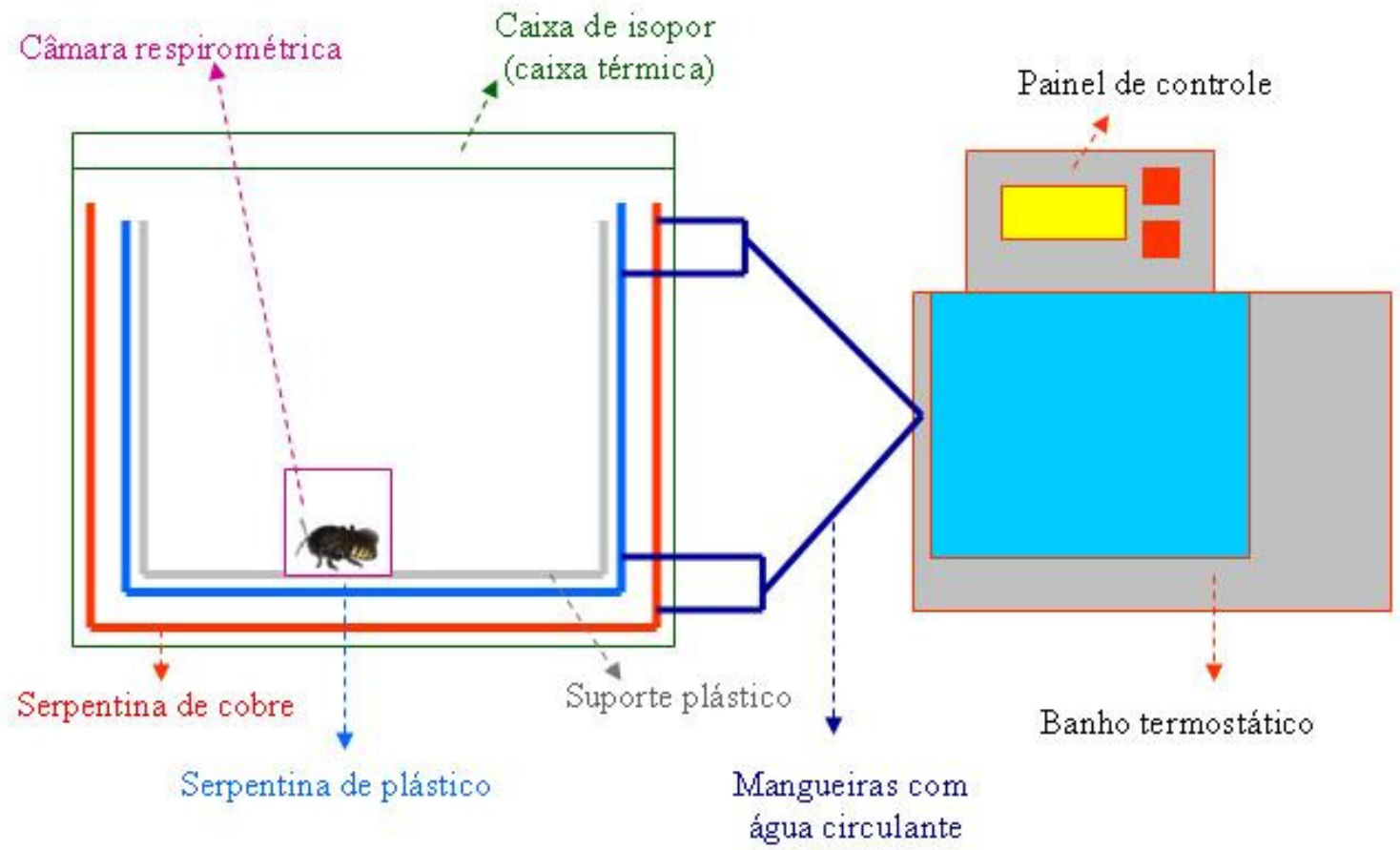

Figura 4. Esquema do sistema provisório construído para manter as câmaras respirométricas a temperatura constante, baseado em Françoso-Júnior (1999). A caixa térmica construída consiste de caixa de isopor, com serpentinas de cobre e plástico enrolada em sua superfície interna. As serpentinas são conectadas a banho ultratermostático por mangueiras e as câmaras respirométricas contendo a abelha são colocadas no interior da caixa térmica. 


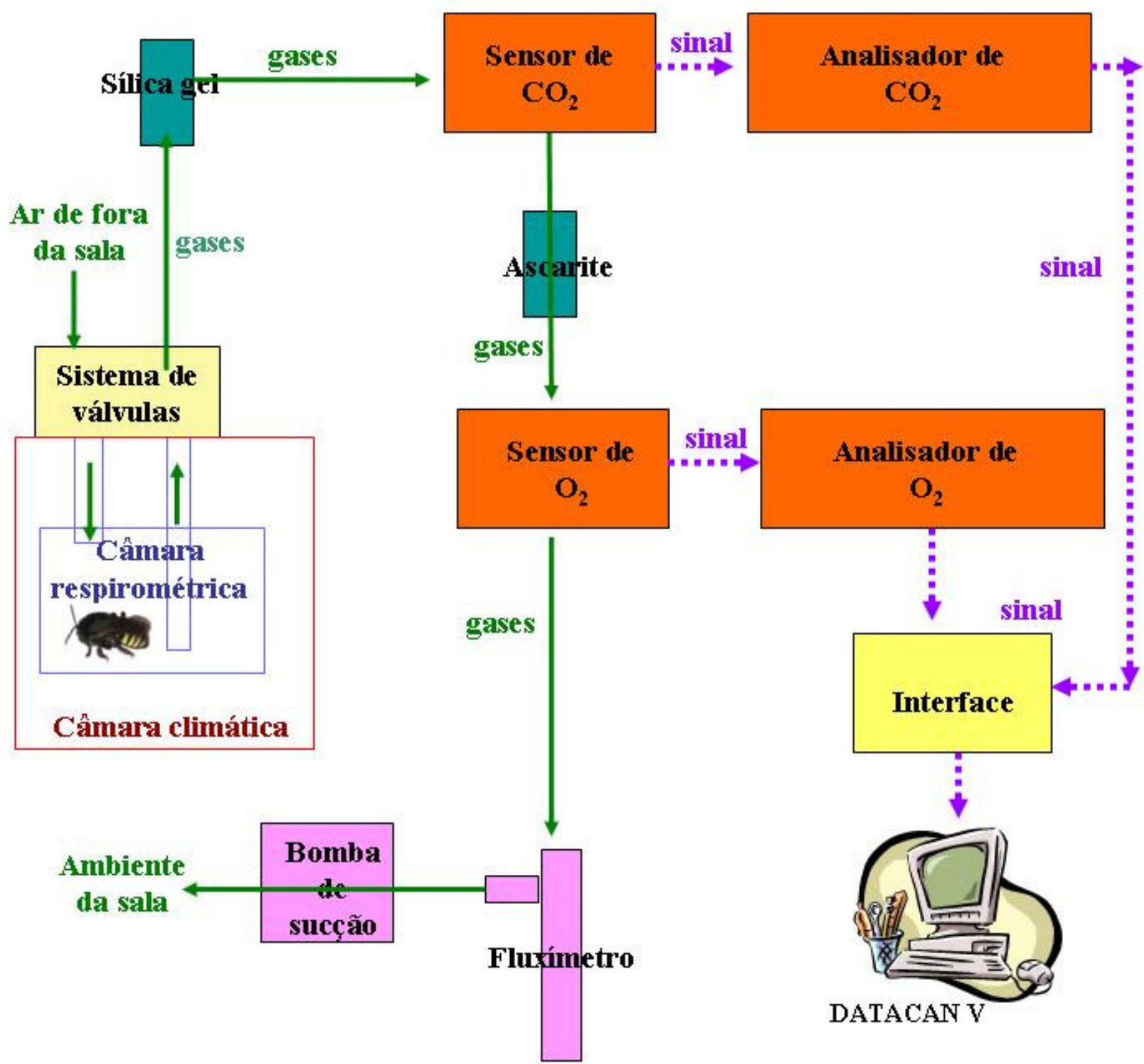

Figura 5. Esquema geral do sistema de respirometria intermitente. Há câmara respirométrica com a abelha, que permanece um certo intervalo de tempo em regime fechado. Há a passagem de gás padrão do experimento (por exemplo, ar ambiente) pelo sensor, vindo através de um desvio, ou seja, sem passar pela câmara (sistema de válvulas manuais). Isso fornece a linha de base para os sensores. Em um dado instante, a câmara tem suas válvulas de entrada e saída abertas e o fluxo é retirado do desvio e passado pela câmara respirométrica. $O$ ar que sai das câmaras contendo o animal passa por um frasco contendo sílica gel azul, para remoção do vapor de água. Em seguida, o ar flui inicialmente para o sensor de $\mathrm{CO}_{2}$, fluindo a seguir por um tubo contendo ascarite, para absorção do $\mathrm{CO}_{2}$, e depois para o sensor de $\mathrm{O}_{2}$, passando pelo fluxímetro e bomba de sucção (flechas verdes contínuas). Os sinais elétricos detectados nos sensores são transferidos para os analisadores. Entre os analisadores de gases e o computador, existe uma interface, envolvida na conversão dos dados elétricos dos analisadores em dados para o software (flechas roxas descontínuas) 

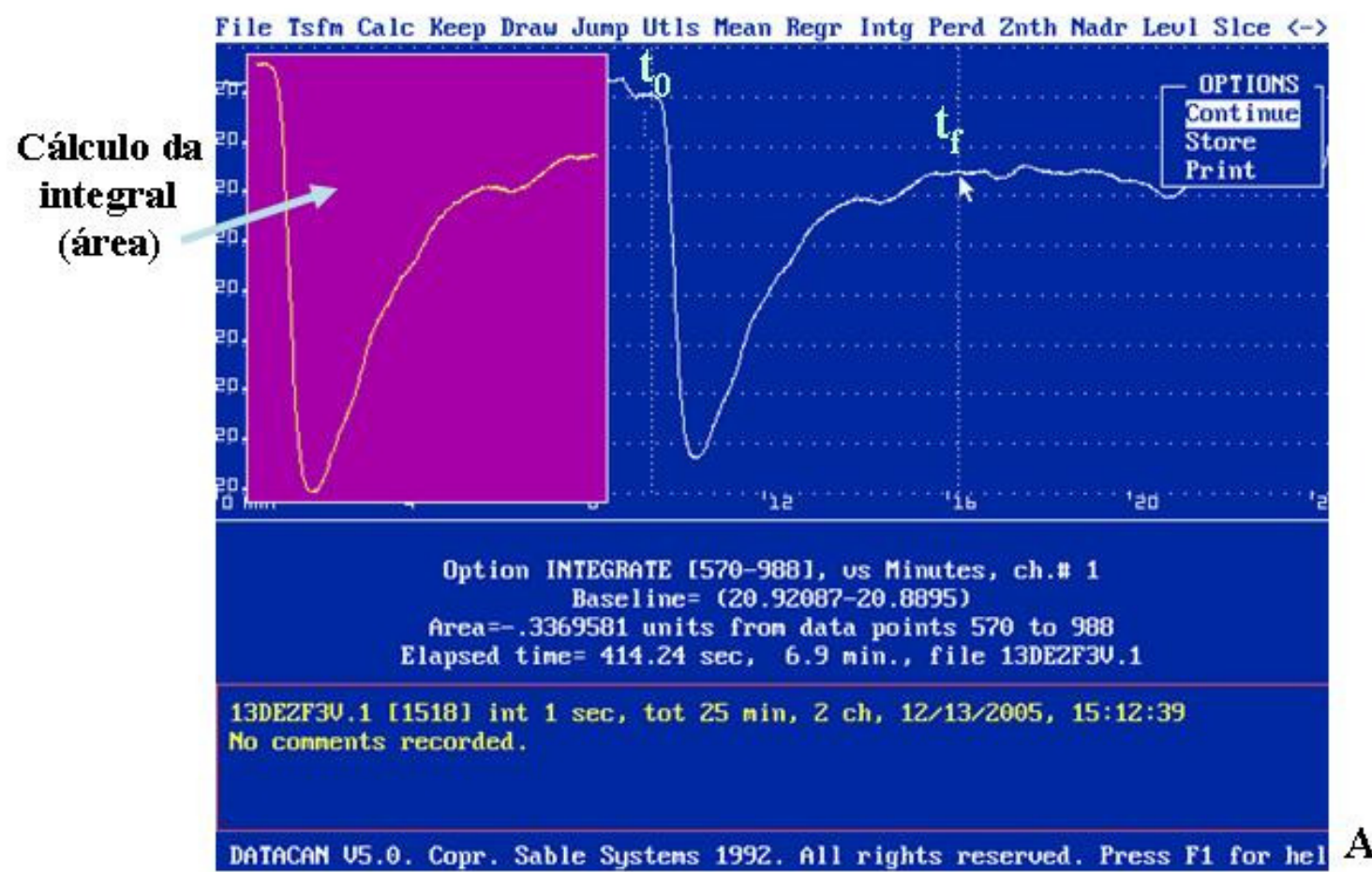

File Isfm Calc Keep Draw Jump Utls Mean Regr Intg Perd 2nth Nadr Leul Slce «

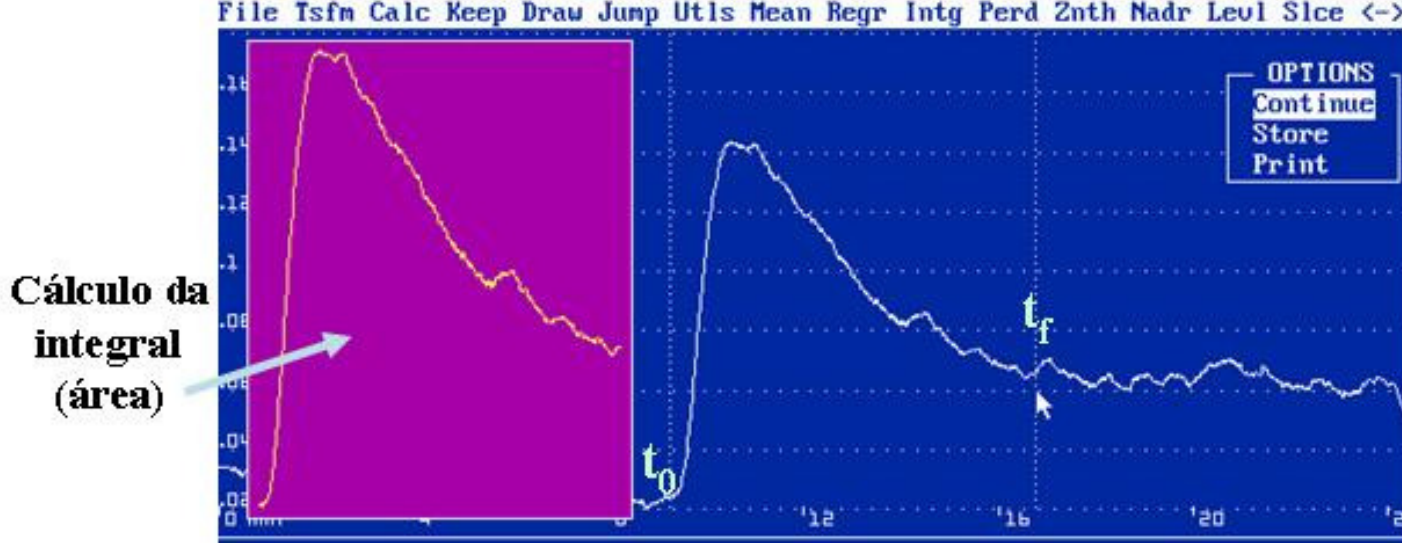

Option INTEGRATE [563-1018], us Minutes, ch.\# 2 Baseline $=(2.428778 \mathrm{E}-02-6.564999 \mathrm{E}-02)$

Area $=.3753892$ units from data points 563 to 1018

Elapsed time $=450.82 \mathrm{sec}, 7.51 \mathrm{~min} .$, file 13DEZF3U.1

13DEZF3U.1 [1518] int $1 \mathrm{sec}$, tot $25 \mathrm{~min}, 2 \mathrm{ch}, 12 / 13 / 2005,15: 12: 39$

No connents recorded.

DATACAN U5.0. Copr. Sable Sustens 1992. All rights reserued. Press F1 for hel

B

Figura 6. Exemplo de sinal que é obtido durante a lavagem de uma câmara respirométrica em um sistema de respirometria intermitente, mostrando a tela no software de análise de dados de respirometria intermitente (Datacan V Sable Systems). $E$ É calculada a integral do sinal de saída obtido entre $t_{0}$ e $t_{\mathrm{f}}$. Na figura estão representada o sinal para o consumo de oxigênio $(A)$ e produção de gás carbônico $(B)$, úteis, por exemplo, para o cálculo do quociente respiratório (QR) 


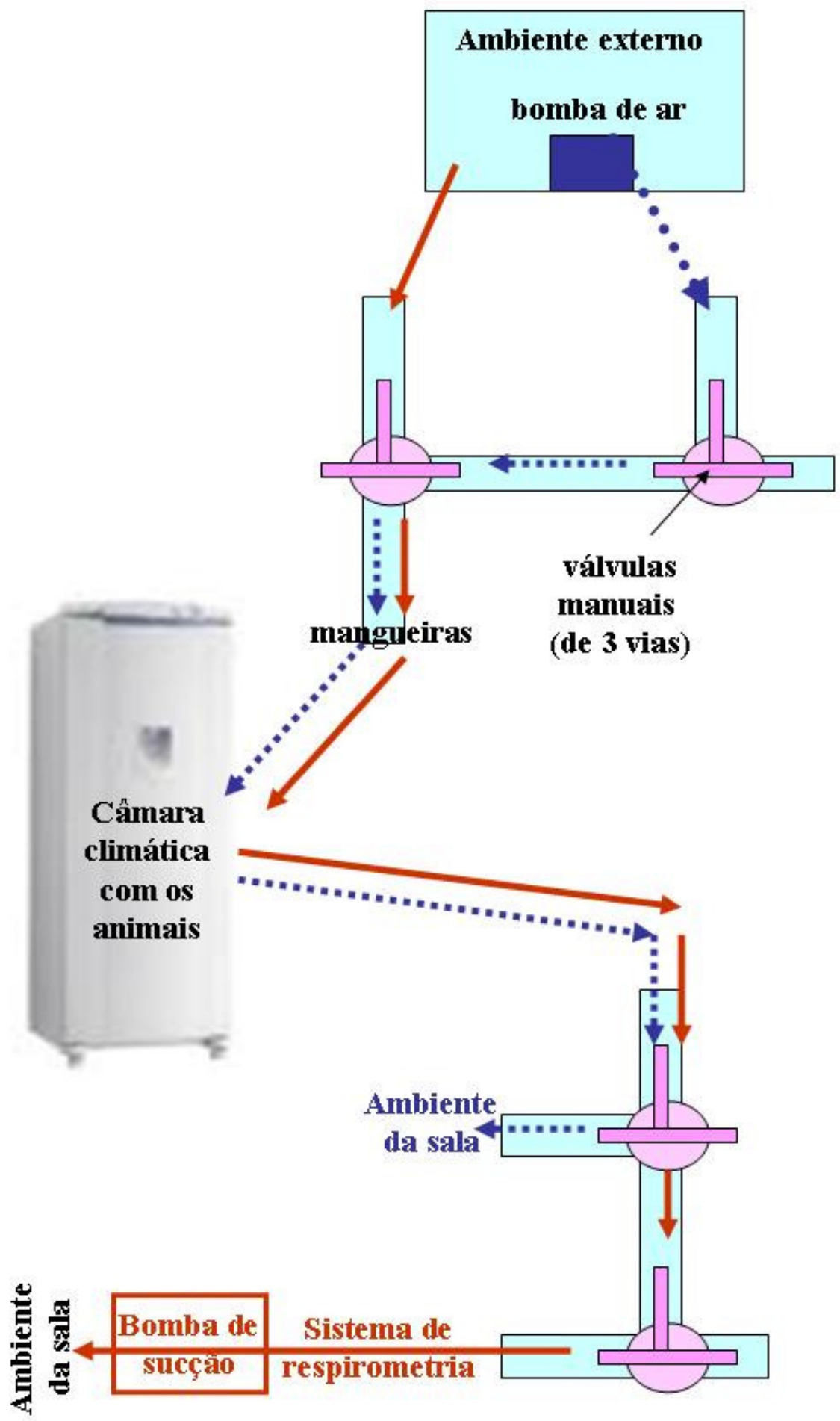

Figura 7. Esquema geral do funcionamento das válvulas manuais no sistema de respirometria intermitente. As câmaras metabólicas têm as suas válvulas fechadas, e após o tempo adequado, são abertas e os gases são direcionados ao sistema de respirometria por sua bomba de sucção (flechas vermelhas). Para evitar hipóxia e hipercapnia dos animais não analisados no momento, o sistema permite que ar externo seja circulado nas diversas câmaras metabólicas dentro da câmara climática por meio de bombas de ar independentes do sistema de respirometria (flechas azuis descontínuas). 

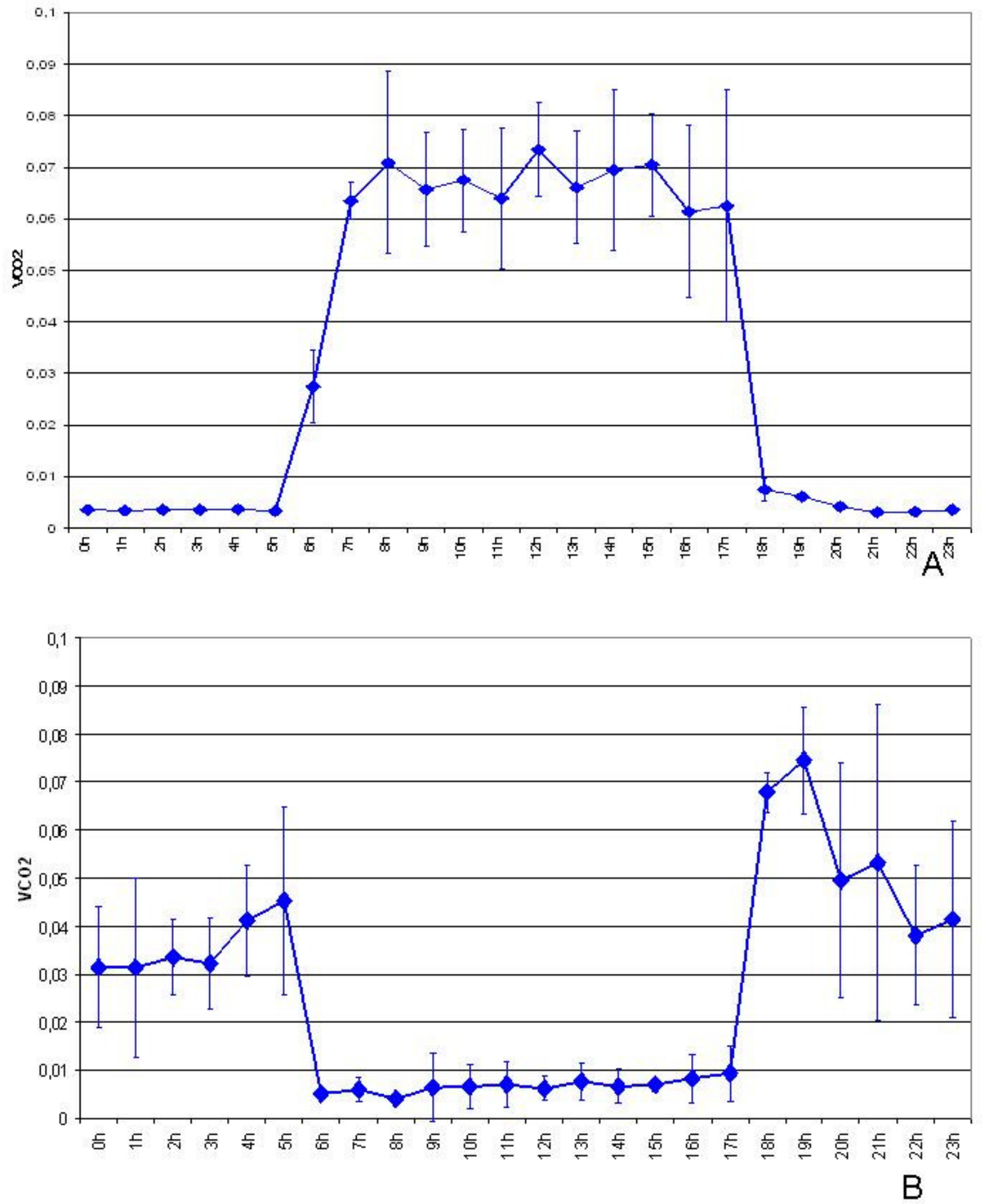

Figura 8. (A): Taxa metabólica $\left(\mathrm{mL} \mathrm{CO} \mathrm{Cm}_{2} \mathrm{~min}^{-1}\right.$ de abelhas forrageiras mantidas em fotoperíodo normal 12:12h (dia/claro; noite/escuro). (B): Taxa metabólica de abelhas forrageiras mantidas em fotoperíodo invertido $12: 12 \mathrm{~h}$ (dia/escuro; noite/claro). Em B observa-se um padrão invertido de taxas metabólicas com relação a $\mathrm{A}$, entretanto, com valores no claro (das $18 \mathrm{~h}$ às $6 \mathrm{~h}$ ) menores do que os valores no claro no fotoperíodo normal em $\mathrm{A}$. Em ambos os casos, parece haver arrastamento de um possivel ritmo endógeno de taxa metabólica pelo ciclo claro/escuro. 

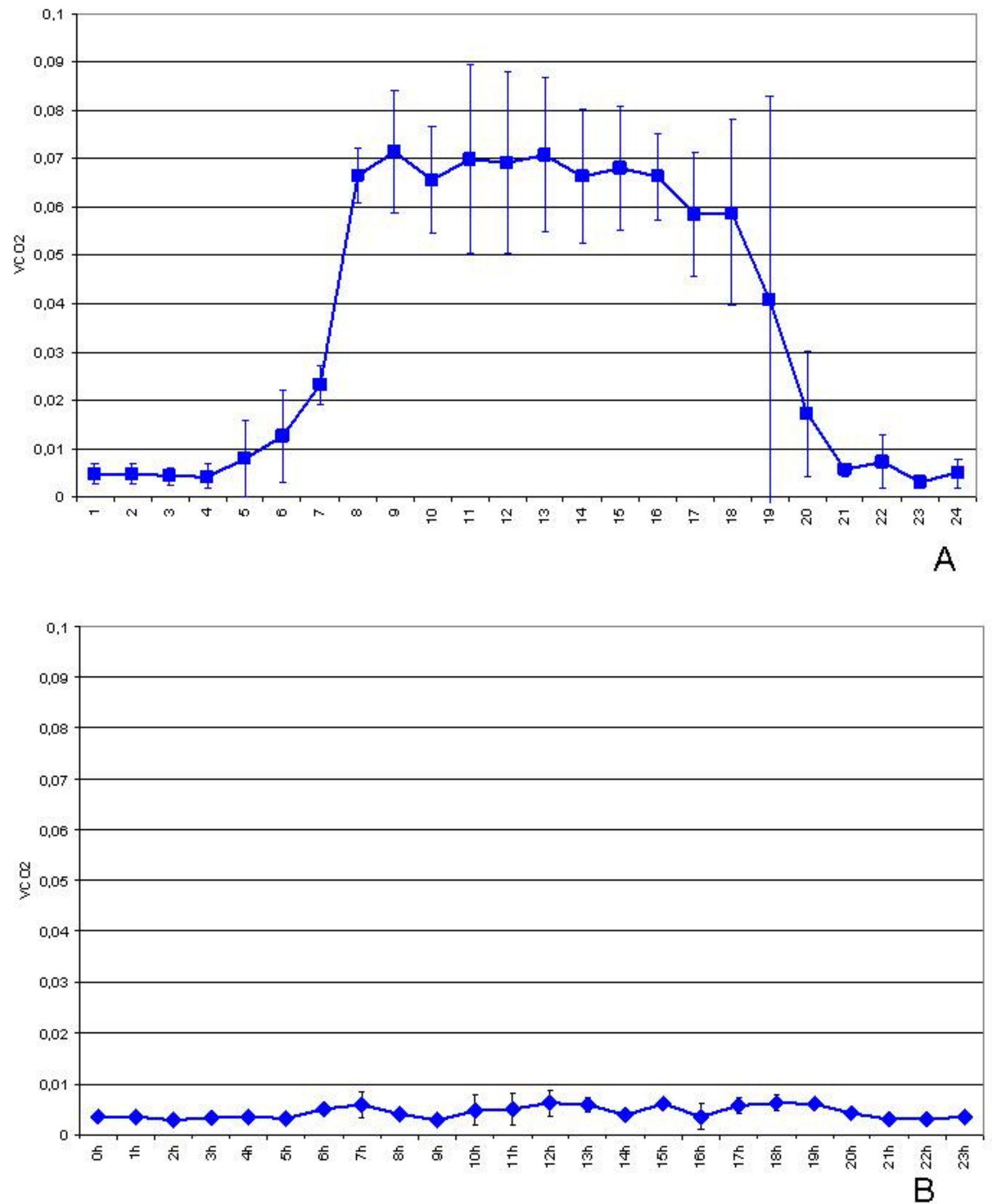

Figura 9. Taxa metabólica $\left(\mathrm{mL} \mathrm{CO} \mathrm{Cin}^{-1}\right)$ de abelhas forrageiras mantidas em câmara climática a $28^{\circ} \mathrm{C}$, em claro constante (A) e em escuro constante (B). No claro constante o padrão é semelhante ao obtido em fotoperiodo $12: 12 \mathrm{~h}$, entretanto, no claro constante, as mudanças de "patamar" de taxa metabólica parecem menos bruscas do que em fotoperíodo $12: 12 \mathrm{~h}$. No escuro constante, a taxa metabólica tende a se manter relativamente baixa, semelhante ao obtido no escuro nos demais fotoperíodos. 

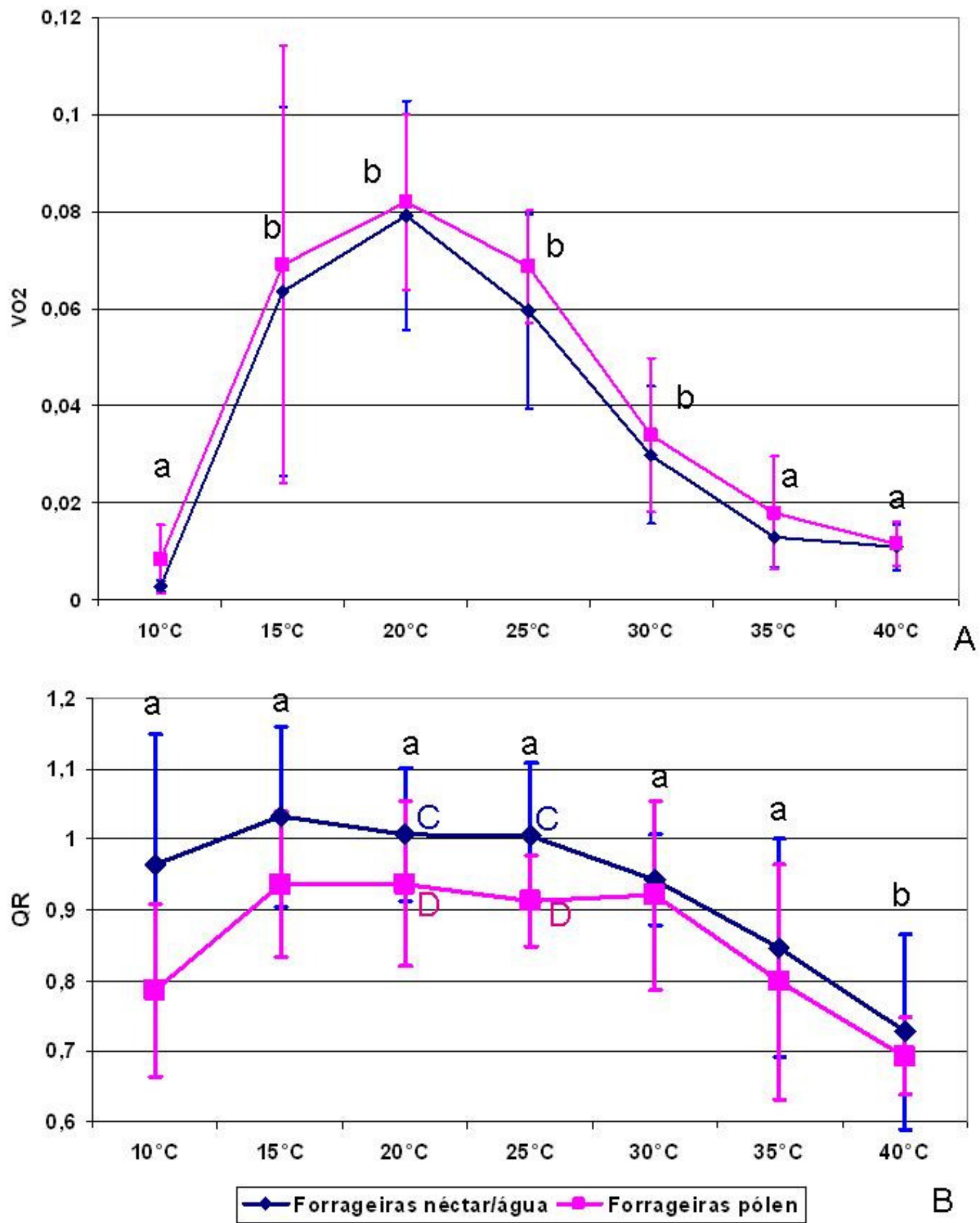

Figura 10. Valores de taxa metabólica $\mathrm{VO}_{2}\left(\mathrm{~mL} \mathrm{O}_{2} \mathrm{~min}^{-1}\right.$ abelha-1) (A) e de Quociente Respiratório (QR) $\left(\mathrm{VCO}_{2} / \mathrm{VO}_{2}\right)$ versus temperatura na câmara climática, no claro, de forrageiras tratadas com solução de sacarose $50 \%$. Estão separados os resultados correspondentes a forrageiras coletoras de néctar/água e de pólen. Médias indicadas pela mesma letra não diferem significantemente entre si pelo Teste de Dunn ( $\alpha=5 \%)$ 

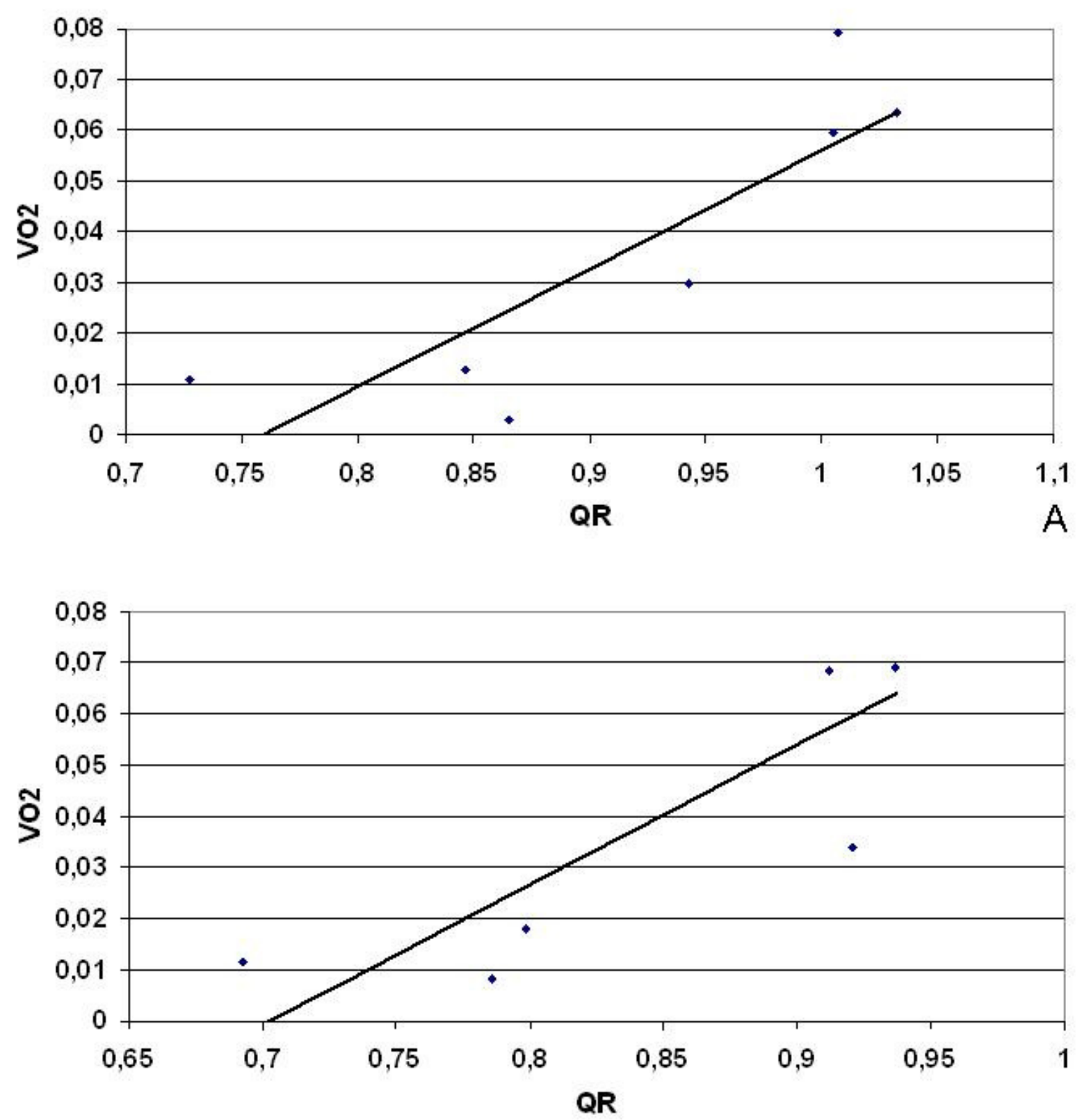

B

Figura 11. Gráficos de dispersão dos valores médios de $\mathrm{VO}_{2}$ (eixo y) e de $\mathrm{QR}$ (eixo $\mathrm{x}$ ) de $10 \mathrm{a} 40^{\circ} \mathrm{C}$, em forrageiras coletoras de néctar/água (A) e coletoras de pólen (B). $\mathrm{O}$ Coeficiente de Correlação de Spearman calculado $(\mathrm{r}=0,8571$ e $\mathrm{r}=0,9286)$ indicam que valores altos de $\mathrm{VO} 2$ parecem coincidir com valores altos de $\mathrm{QR}$ e vice versa, nas diferentes temperaturas. 
Néctar

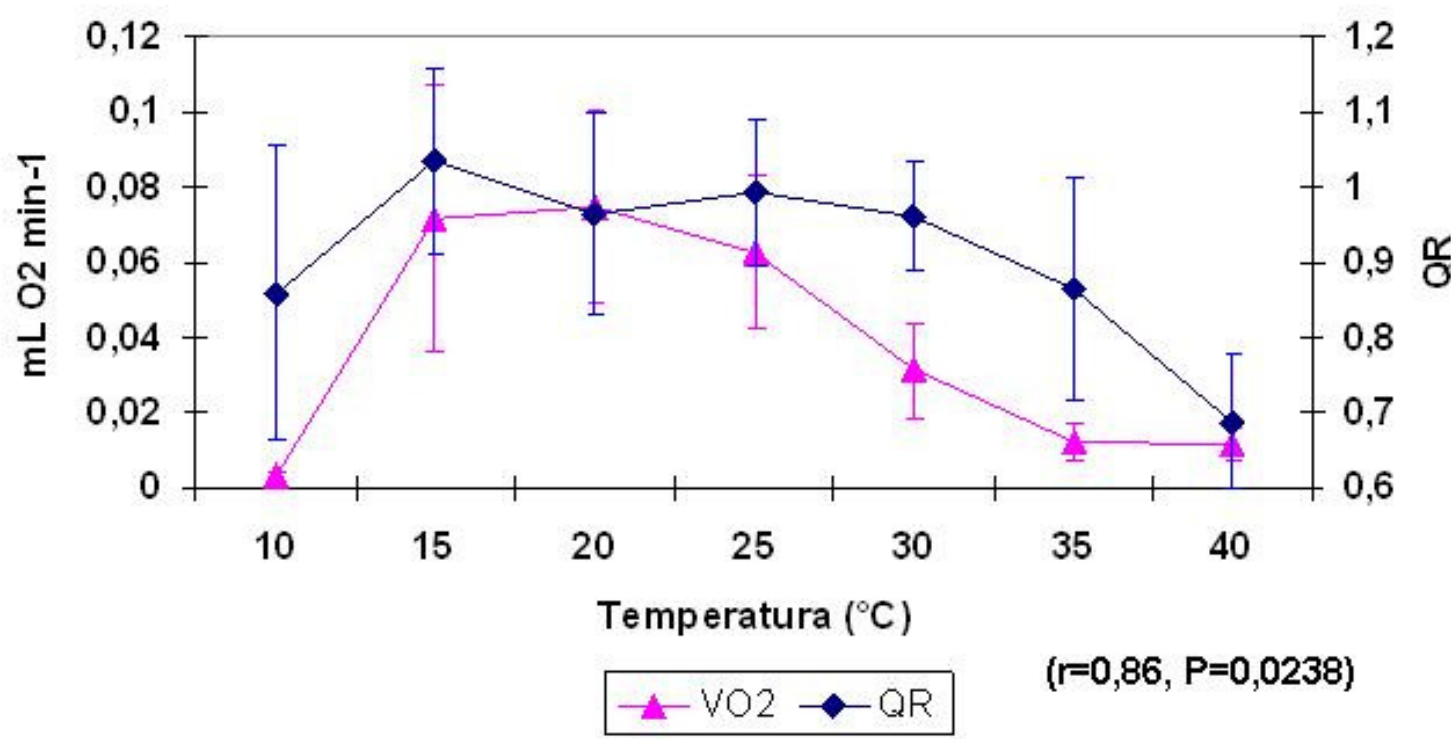

A

Pólen

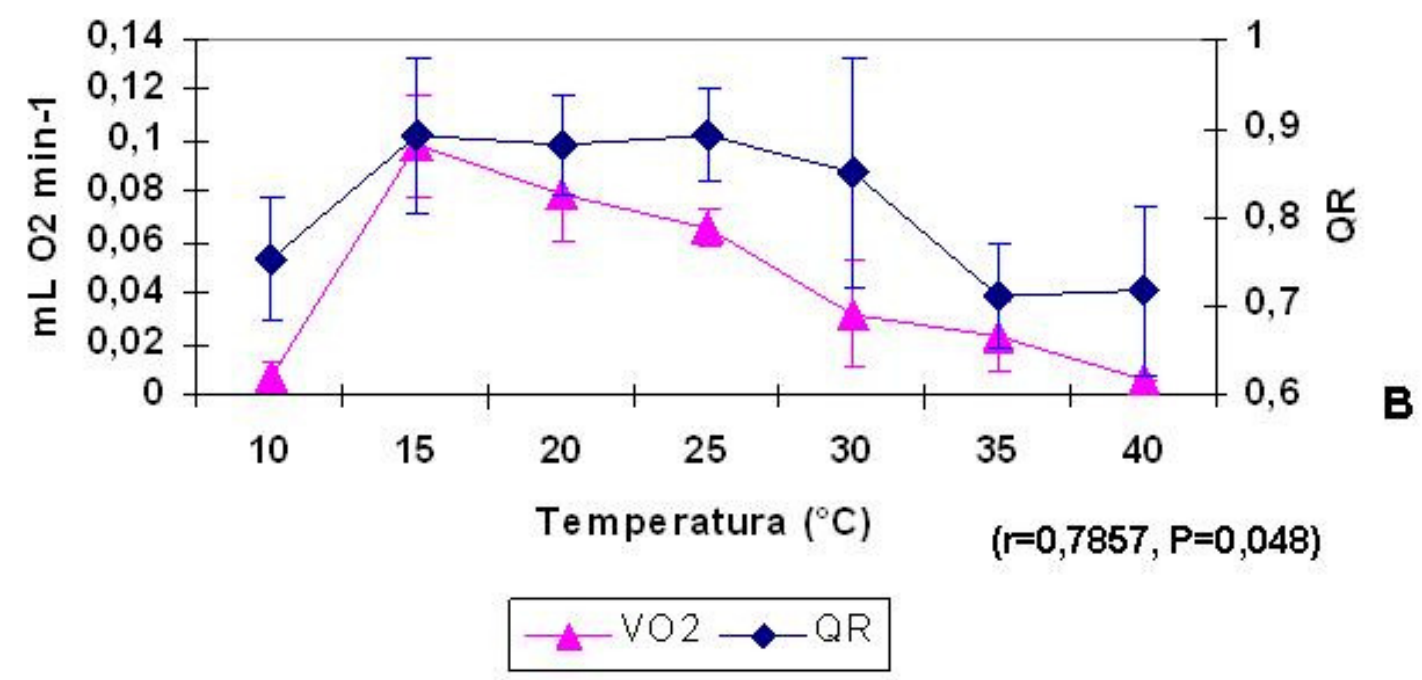

Figura 12. Valores de taxa metabólica ( $\mathrm{VO} 2, \mathrm{~mL} \mathrm{O} 2 \mathrm{~min}-1$ ) e de Quociente Respiratório $(\mathrm{QR})$ de forrageiras coletoras de néctar/água $(A)$ e de pólen $(B)$. Foi detectada correlação entre os valores de $\mathrm{VO} 2 \mathrm{e} Q R$, com $\mathrm{r}$ e $\mathrm{P}$ indicados nos gráficos. 
lléctar

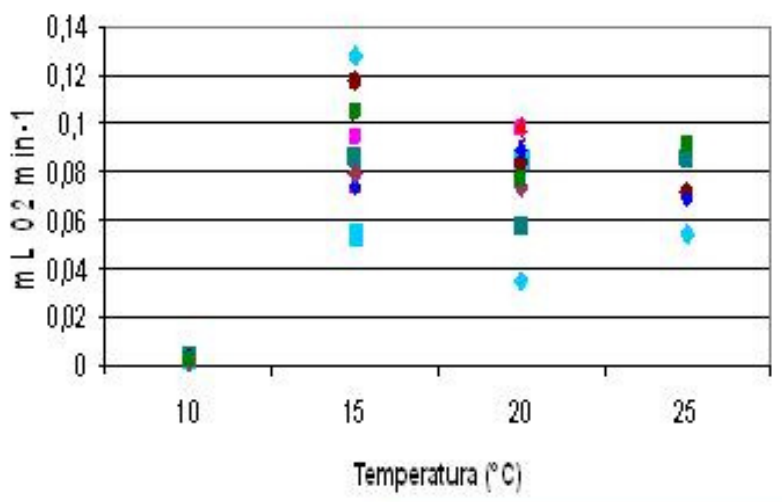

Pólen

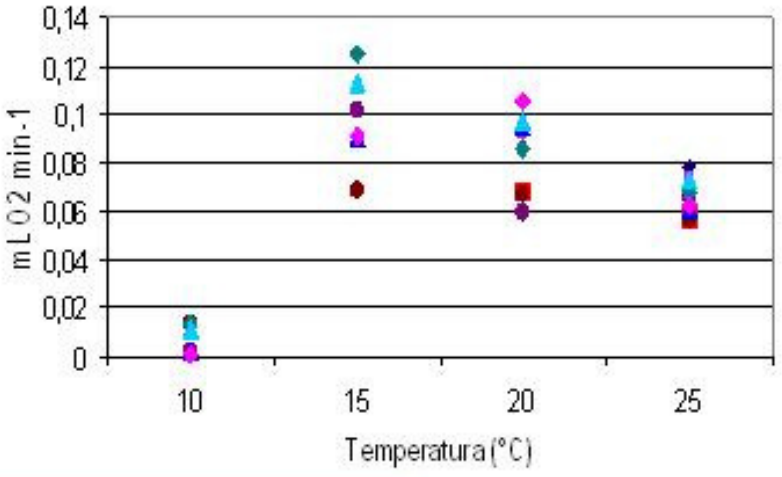

Inclinação: diferenças não significativas ( $P=0,1158)$

Intercepto: diferenças năo significativas $(P=0,5205)$
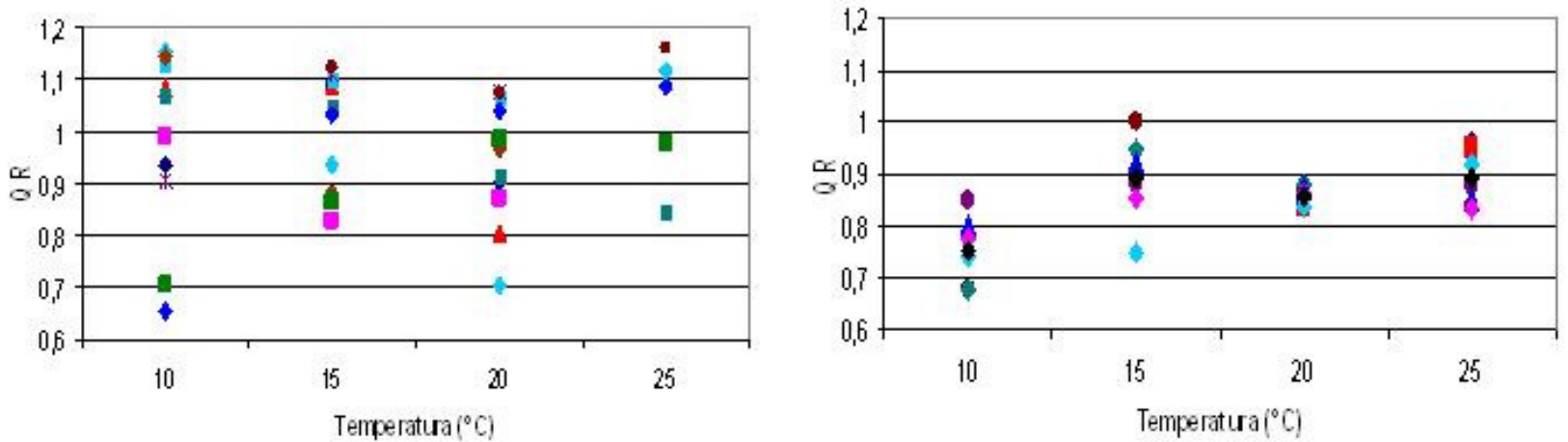

Inclinação: diferenças nẫo significativas ( $P=0,2987)$ Intercepto: diferenças significativas $(P<0,0001)$

Figura 13. Comparações dos valores de $\mathrm{VO} 2$ e $\mathrm{QR}$ de forrageiras coletoras de néctar/água (grupo "Néctar") e coletoras de pólen (Grupo "Pólen") de 10 a $25^{\circ} \mathrm{C}$. Foi detectada diferença estatisticamente significativa entre os valores de intercepto dos dados de $\mathrm{QR}(\mathrm{P}<0,0001)$ 
Nécta

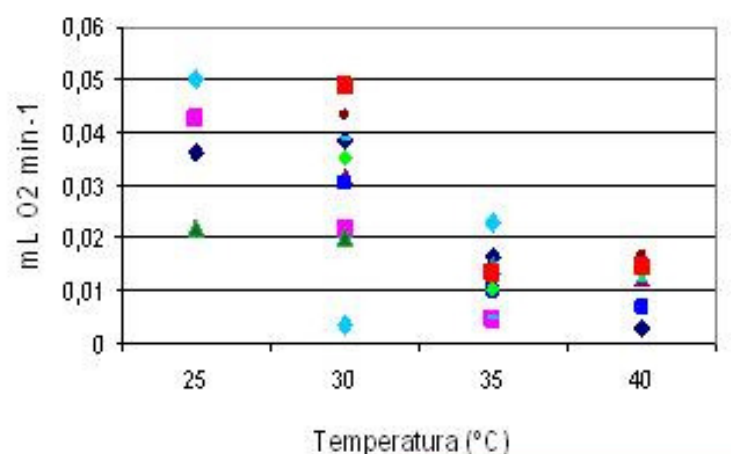

Pólen

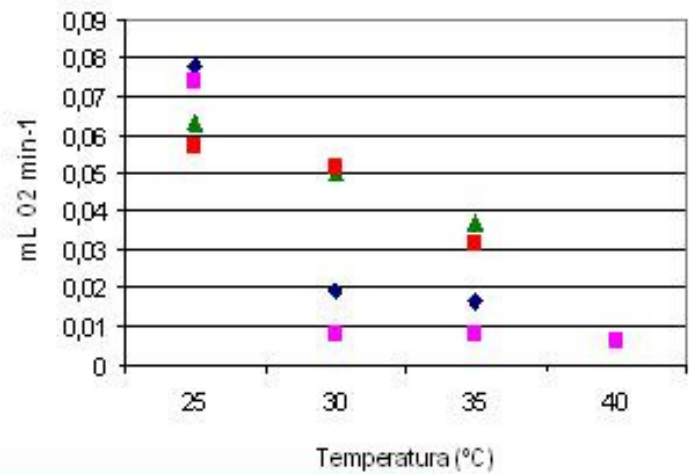

Temperatura $\left({ }^{\circ} \mathrm{C}\right)$

Inclinaçẫo: diferenças significativas ( $P=0,00494)$

Intercepto: năo foi possivel calcular

Nédar

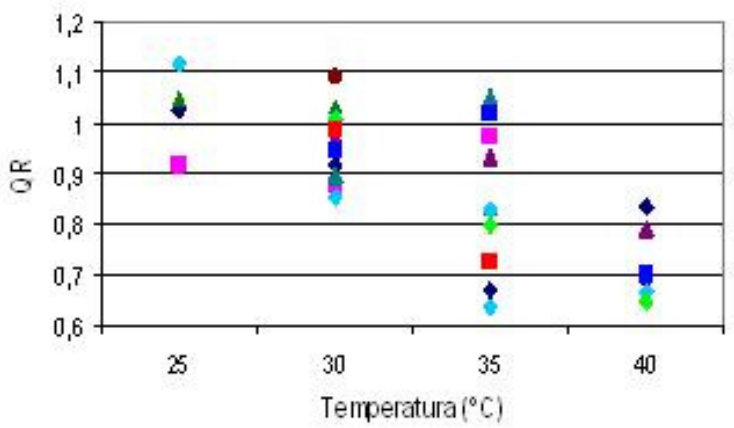

Pólen

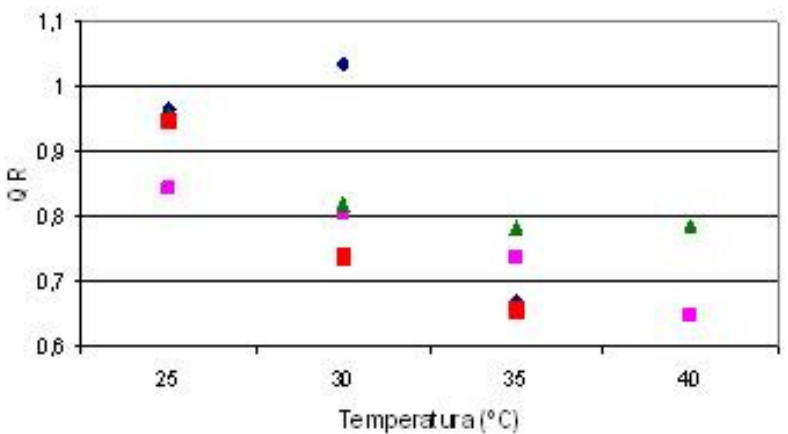

Inclinação: diferenças não significativas ( $P=0,2244)$ Intercepto: diferenças significativas ( $P=0,001602)$

Figura 14. Comparações dos valores de $\mathrm{VO} 2$ e $\mathrm{QR}$ de forrageiras coletoras de néctar/água (grupo "Néctar") e coletoras de pólen (Grupo "Pólen") de 25 a $40{ }^{\circ} \mathrm{C}$. Foi detectada diferença estatisticamente significativa entre os valores de inclinação $(\mathrm{P}=0,00494)$ dos dados de VO2, e entre os valores de intercepto de $\mathrm{QR}(\mathrm{P}=0,001602)$. 


\section{Capítulo 4}

Efeitos de modificações em vias octopaminérgicas sobre a taxa metabólica, temperatura torácica e utilização de substratos energéticos em abelhas Melipona quadrifasciata

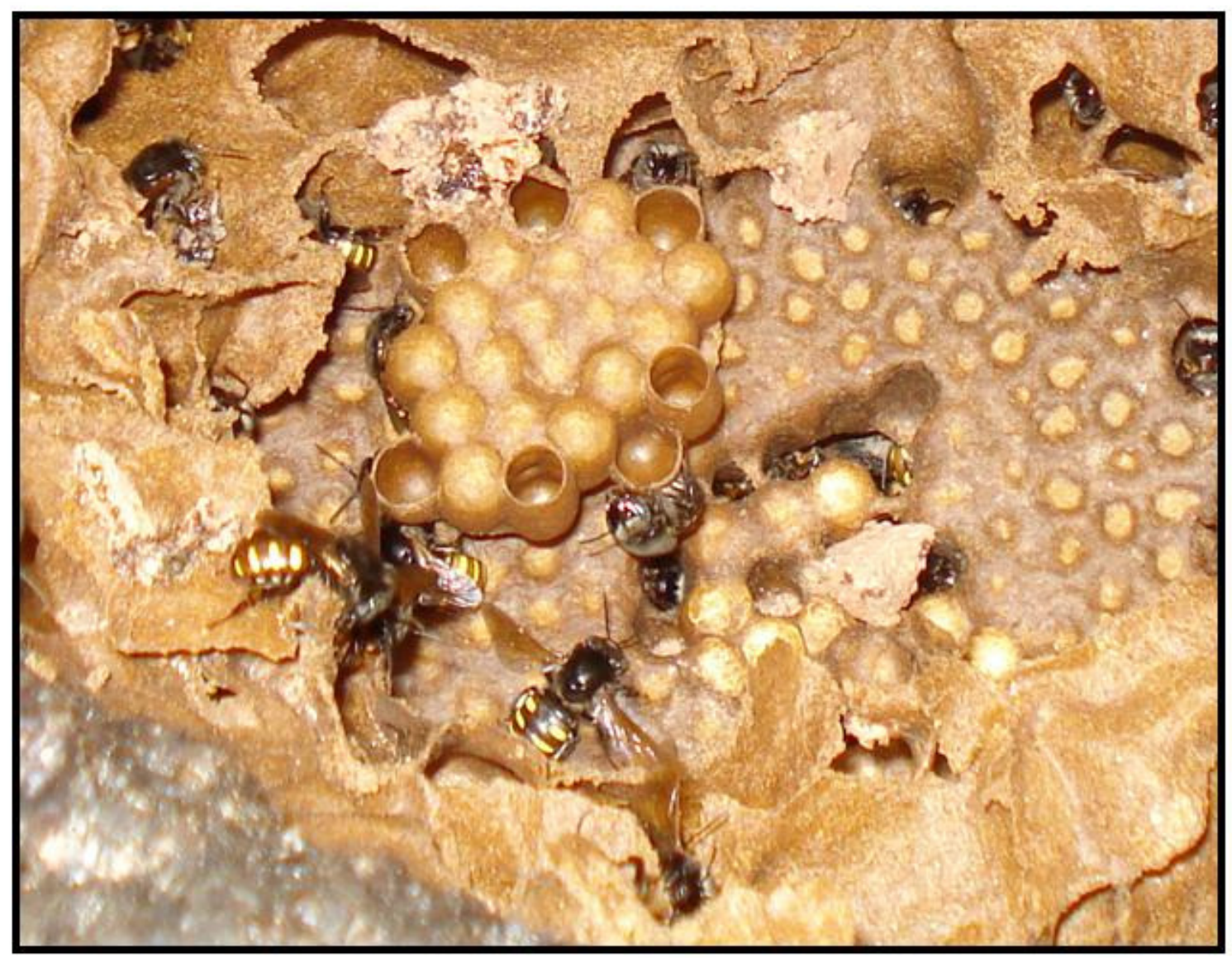




\section{Capítulo 4. Efeitos de modificações em vias octopaminérgicas sobre a taxa metabólica, temperatura torácica e utilização de substratos energéticos em abelhas Melipona quadrifasciata}

\section{RESUMO}

Em insetos endotérmicos são conhecidos dois mecanismos fisiológicos de termogênese, o tremor muscular (o mais comum) e ciclos fúteis envolvendo fosfofrutoquinase e frutose 1,6 bifosfatase (descrito para mamangavas Bombus). As aminas biogênicas, em especial a octopamina, desempenham um amplo espectro de funções como neurotransmissores, neuromodulares e neurohormônios. O sistema noradrenérgico/adrenérgico dos vertebrados é funcional e estruturalmente equivalente ao sistema octopaminérgico/tiraminérgico dos insetos. $\mathrm{O}$ emprego de um bloqueador beta-adrenérgico via tratamento oral em abelhas pode levar a hipotermia, sugerindo que possivelmente há o envolvimento de uma via octopaminérgica no metabolismo energético e termogênese de abelhas, sendo este o tema principal deste capítulo, aplicado à M. quadrifasciata. Objetivou-se verificar o efeito tempo-dependente de bloqueadores beta-adrenérgicos e octopaminérgicos sobre a taxa metabólica e temperatura torácica de forrageadoras e verificar se a octopamina e methoprene (análogo de hormônio juvenil) compensam os efeitos dos bloqueadores. Além disso, também se analisou se com o emprego dos bloqueadores há alterações dos substratos energéticos catabolizados, considerando o quociente respiratório $(\mathrm{QR})$ e a atividade enzimática (Vmax de hexoquinase, trealase, HOAD e glicogênio fosforilase). Com o emprego dos bloqueadores, foram detectadas alterações no QR e na atividade de enzimas do músculo torácico de vôo, como a hexoquinase, HOAD e glicogênio fosforilase, sugerindo que podem ocorrer alterações nos substratos energéticos oxidados. A diminuição da temperatura torácica obtida em forrageadoras tratadas com Alprenolol sugere o envolvimento de vias octopaminérgicas na termogênese em $M$. quadrifasciata; todavia, é necessário cautela já que não se sabe se tais efeitos são decorrentes de interferências na produção de calor e/ou um subproduto da diminuição da taxa metabólica. Os resultados não provam que há mecanismos de termogênese sem tremor muscular em abelhas, envolvendo octopamina e hormônio juvenil, mas indicam um possível envolvimento destas substâncias na taxa metabólica e oxidação de diferentes substratos energéticos.

\section{INTRODUČ̃̃O}

TERMORREGULACÃO INDIVIDUAL EM INSETOS 
A endotermia é cara em animais pequenos como os insetos, que se aquecem durante períodos de intensa atividade e podem se resfriar, mantendo a sua temperatura corpórea controlada (JOSEPHSON, 1981). Todos os insetos endotérmicos são heterotermos (BARTHOLOMEW, 1981). Bartholomew (1981) compara a endotermia entre diversos grupos de insetos e indica a hipótese de que a heterotermia evoluiu repetidamente e independentemente em espécies pertencentes a várias ordens e famílias em Insecta, e também surgiu várias vezes em Mammalia e Aves. A múltipla convergência de padrões fisiológicos comuns observada em tipos de animais tão diferentes seria uma evidência de que a heterotermia é fortemente favorecida pela seleção natural (BARTHOLOMEW, 1981).

A termorregulação em insetos endotérmicos envolve o uso de sistemas neuromusculares e circulatórios pré-existentes adaptados primariamente para outras funções. A produção de calor durante o aquecimento pré-vôo seria uma variação do comportamento de vôo em si (BARTHOLOMEW, 1981). O comportamento de termorregulacao propiciou o desenvolvimento de uma vida social e a conquista de ambientes diversos, como os desertos, as florestas tropicais e o Ártico (DARCHEN, 1973; MICHENER, 1974; HEINRICH e ESCH, 1994).

As temperaturas corpóreas de abelhas inativas são próximas às temperaturas ambientais (ectotermia), entretanto, em diversos contextos, abelhas são capazes de regular a temperatura torácica através da produção interna de calor, mantendo esta controlada e independente da temperatura ambiente (HEINRICH, 1981; PACHECO e KERR, 1989; HEINRICH e ESCH, 1994).

A termogênese em insetos, obtida fisiologicamente, ocorre durante diversos tipos de atividade, como vôo, corrida, canto, aquecimento pr- vôo, atividades sociais, defesa contra predadores, incubação da cria (termorregulação colonial), entre outros (ZUCCHI e SAKAGAMI, 1972; DARCHEN, 1973; HEINRICH, 1981; ROUBIK e PERALTA, 1983; BLOCK, 1994).

Nos insetos podem ocorrer diversos mecanismos de termorregulação, que incluem mecanismos comportamentais (como ajustes posturias no vôo, posicionamneto no solo e controle do fluxo de calor dentro de colônias), anatômicos (abundância e distribuição de pelos) e fisiológicos (como controle da perda de calor e produção metabólica de calor) (HEINRICH, 1981). Além de fatores endógenos, outros fatores influenciam a termorregulação das abelhas, tais como a pilosidade, a cor, o tamanho corpóreo, tipo de nidificação, entre outros. As estruturas internas do ninho, e/ou o local onde ele está alojado (ocos de árvores, por exemplo), podem também proporcionar isolamento térmico das abelhas e da colônia como um todo (ZUCCHI e SAKAGAMI, 1972; DARCHEN, 1973; ROUBIK e PERALTA, 1983). Mas, essencialmente, todos os aumentos endotérmicos da temperatura corpórea acima da temperatura ambiente são resultado do calor produzido pelos músculos torácicos de vôo. 
A estabilização da temperatura torácica envolve a regulação da perda de calor, por exemplo pela variação do fluxo de hemolinfa ao abdômen, em certas mariposas, libélulas, mamangavas (HEINRICH, 1993), ou, no caso das abelhas, pela regulação do fluxo de hemolinfa para a cabeça, com perda de calor a altas temperaturas ambiente, sendo esta estabilização aumentada pela evaporação ou regurgitação de néctar (HEINRICH, 1980ab; COOPER et al., 1985; WOODS et al., 2005).

\section{MECANISMOS DE TERMOGÊNESE}

Até o momento são conhecidos dois mecanismos fisiológicos de termogênese em insetos, um deles sendo o aquecimento por tremor muscular o qual, segundo Heinrich (1996), é encontrado em insetos grandes, como libélulas (Odonata), mariposas e borboletas (Lepidoptera), certos gafanhotos (Ortophetera), cigarras (Homoptera), moscas (Diptera), besouros (Coleoptera), vespas e abelhas (Hymenoptera). O outro mecanismo é a ocorrência de ciclos fúteis em mamangavas do gênero Bombus, nativas de ambientes frios (NEWSHOLME et al , 1972; CLARK et al., 1973; HOCHACKA e SOMERO, 1984; HEINRICH, 1993)

O tremor muscular é comum também em mamíferos e aves, sendo aparentemente uma resposta generalizada dos endotermos ao frio (BLOCK, 1994). A evolução dos tremores musculares em insetos é relacionada com a evolução do vôo, mas não com a localização do inseto na árvore filogenética (HEINRICH, 1996).

Para certas espécies de abelhas do gênero Bombus (mamangavas) é descrita a termogênese por ciclos fúteis envolvendo hidrólise de ATP via funcionamento simultâneo de fosfofrutoquinase (PFK, uma enzima importante da glicólise) e de frutose-1,6-bifosfatase (FBPase, envolvida na gliconeogênese) ((NEWSHOLME et al , 1972; CLARK et al., 1973; HOCHACKA e SOMERO, 1984; HEINRICH, 1993). Um sinal regulatório neste sistema seria o $\mathrm{Ca}^{2+}$. Este tipo de ciclo fútil poderia ser útil para suplementar a termogênese ou amplificar o fluxo glicolítico (STAPLES et al, 2004). Todavia, estudos com abelhas sem ferrão Melipona bicolor (FRANÇOSO-JÚNIOR, 1999) e com espécies de Bombus norte-americanas (STAPLES et al, 2004) detectaram baixa atividade de FBPase, provavelmente não ocorrendo ciclos fúteis envolvendo FBPase nessas abelhas.

Nos vertebrados endotérmicos têm sido descritos mecanismos de termogênese envolvendo proteínas desacopladoras (UCPs), que, envolvem lipólise, liberação de ácidos graxos e sinalizações com $\mathrm{Ca}^{2+}$. Análogos de UCPs foram encontrados em diversos grupos de animais, desde invertebrados, até aves, insetos e até mesmo em plantas (ARGYOPOULOS e HARPER, 2002; SILVA, 2003; FRIDELL et al, 2004; SOKOLOVA e SOKOLOV, 2005) e poderiam desempenhar papéis importantes no metabolismo mitocondrial e/ou papéis na termogênese (ARGYOPOULOS e HARPER, 2002). É possível que catecolaminas estejam envolvidas nesses ciclos fúteis de $\mathrm{Ca}^{2+}$ 
mediados por ácidos graxos, em mamíferos (BLOCK, 1994). Hanak e Jezek (2001) e Sokolova e Sokolov (2005) apresentam hipóteses filogenéticas envolvendo UCPs em diversos grupos animais, como humanos, peixes e moscas. Os insetos possuem proteínas desacopladoras, com atividade desacopladora aumentada por ácidos graxos e inibida pelo nucleotídeo purina GDP, compartilhando com as outras UCPs os mecanismos reguladores de UCP conhecidos até o momento (FRIDELL et al, 2004), mas funções termogênicas das UCPs nos insetos ainda não estão esclarecidas.

Em vertebrados homeotérmicos, os mecanismos fisiológicos de produção de calor estão mais elucidados do que em insetos. Os principais são o tremor muscular, ciclos fúteis (envolvendo principalmente Cálcio) e proteínas desacopladoras (UCPs). Nestes processos está envolvido o sistema noradrenérgico e adrenérgico, com atuação da norepinefrina e epinefrina, ocorrendo também ampla lipólise relacionada à termogênese.

Conforme relatado em artigo de revisão (LOLI e BICUDO, 2005), sugerimos que em insetos talvez existam mecanismos de termogênese sem tremor muscular, que poderiam envolver vias octopaminérgicas, interação de octopamina com hormônio juvenil, UCPs e oxidação de substratos energéticos diferentes de carboidratos, detalhado adiante.

\section{SUBSTRATOS ENERGÉTICOS EM INSETOS}

Em insetos, os substratos energéticos envolvidos na atividade de vôo e termogênese variam entre os grupos e com o comportamento e tipo de vôo. Insetos que apresentam vôos de longa duração utilizam uma mistura de glicose e lipídios (exemplo: gafanhotos durante as primeiras horas de vôo) ou apenas lipídios (exemplo: gafanhotos durante vôos migratórios, mariposas). Alguns insetos utilizam também prolina durante o metabolismo nos músculos de vôo, como alguns besouros, gafanhoto, mosca tse-tse, que apresentam altas concentrações de prolina em seus músculos de vôo. Por outro lado, insetos com vôos de duração não muito longa (ou forrageio) normalmente utilizam carboidratos, trealose e glicogênio (endógena ou derivada de depósitos em corpos gordurosos); abelhas e vespas (Hymenoptera) estão nessa categoria (HOCHACHKA e SOMERO, 1984).

Os himenópteros, em particular, utilizam principalmente carboidrato como fonte de energia (ROTHE e NACHTIGALL, 1989) uma vez que esse substrato permite melhores desempenhos para vôos de curta duração. Durante o forrageio, precisam ser processos relativamente rápidos o transporte de moléculas de açúcares do estômago de mel aos músculos de vôo, para dar combustível ao vôo e a degradação enzimática de polímeros de carboidratos (HRASSNIGG et al., 2005). No vôo, as abelhas têm a sua taxa metabólica aumentada a valores relativamente altos (NACHTIGALL et al., 1989; HARRISON e FEWELL, 2002; FEUERBACHER et al., 2003). 
Os principais constituintes da alimentação das abelhas são néctar ou mel, a fonte primária de carboidratos; e pólen, que contém não apenas proteínas, mas também lipídios e carboidratos (TURUNEN e CRAILSHEIM, 1996; HRASSNIGG et al., 2005). Uma vez que os zangões e as operárias não estocam quantidades relevantes de reservas de energia no seu corpo, apenas quantidades pequenas de glicogênio (PANZENBOCK e CRAILSHEIM, 1997) e de gordura (HRASSNIG e CRAILSHEIM, 2005), elas usam quase que apenas a energia estocada no sistema digestório, primeiramente uma solução de vários açúcares (mel). A energia para ativação dos músculos, nas abelhas, vem da oxidação dos açúcares, que ocorre nas mitocôndrias (SUAREZ et al., 1996), as quais são abundantes nos músculos e recebem oxigênio vindo quase que diretamente do exterior através de um elaborado sistema traqueal (RUPPERT e BARNES, 1996).

Há também evidências de que em abelhas o metabolismo do aminoácido prolina também seja importante. Crailsheim (1990) verificou que as proteínas, principalmente oriundas do pólen, podem ser utilizadas por Apis como substrato energético, e a prolina é predominante na sua hemolinfa (MICHEU et al., 2000).

As abelhas melíferas obtêm os lipídios necessários a partir do consumo de pólen. A quantidade total de pólen e a quantidade de ácidos graxos livres na região endoperitrófica da parede intestinal dependem da idade da abelha. As quantidades aumentam nos três primeiros dias de vida das abelhas, atingem o máximo em oito dias de idade e então decrescem continuamente aos menores valores, detectados nas forrageadoras, e a atividade lipolítica também depende da idade (LOIDL e CRAILSHEIM, 2001). Dados a respeito dos lipídios em abelhas são escassos, entretanto desempenham importantes papéis na dieta das abelhas. Os lipídios geralmente servem como componentes estruturais essenciais das membranas celulares, assim como fontes de energia, e são particularmente importantes para o desenvolvimento dos corpos gordurosos das abelhas de inverno (KUNERT e CRAILSHEIM, 1988; LOIDL e CRAILSHEIM, 2001).

\section{AMINAS BIOGENICAS EM VERTEBRADOS E INSETOS}

As aminas biogênicas são sintetizadas a partir de três diferentes aminoácidos (BLENAU e BAUMANN, 2001), são importantes moduladores do comportamento em vertebrados e invertebrados, e estão envolvidas em diversas ações fisiológicas e comportamentais atuantes em quase todos os órgãos (ROEDER, 2005).

Em vertebrados, as principais aminas biogênicas identificadas são dopamina, norepinefrina, epinefrina, serotonina e histamina, sendo geralmente a norepinefrina a envolvida nas sinalizações ligadas a termogênese sem tremor muscular (EVANS, 1985, 1993; ROEDER, 1999, BLENAU e BAUMANN, 2001; Roeder, 2005). Em invertebrados, as aminas biogênicas são dopamina, 
tiramina, octopamina, serotonina e histamina. (EVANS, 1985, 1993; ROEDER, 1999, BLENAU e BAUMANN, 2001; ROEDER, 2005)

Um fato interessante é que a norepinefrina dos vertebrados é semelhante estruturalmente à octopamina dos insetos, havendo nesta um grupo $\mathrm{OH}$ a menos. Além de semelhança estrutural, há semelhanças funcionais, e então se considera que o sistema noradrenérgico / adrenérgico dos vertebrados (que é relacionado à termogênese) é funcional e estruturalmente equivalente ao sistema octopaminérgico / tiraminérgico dos insetos. (EVANS, 1985, 1993; ROEDER, 1999, BLENAU e BAUMANN, 2001; ROEDER, 2005).

Esses sistemas possuem papéis fisiológicos similares, o que aponta para que o sistema adrenérgico / octopaminérgico / tiraminérgico tenha surgido cedo na evolução (ROEDER, 2005). Este autor apresenta e discute as numerosas similaridades entre os dois sistemas. Há diversas características dos receptores de octopamina que os assemelham aos receptores beta-adrenérgicos de vertebrados (ligados à termogênese em vertebrados). Assim, os receptores de octopamina de insetos são considerados homólogos aos beta-adrenérgicos de vertebrados (BOUNIAS, 1986; ROEDER, 1999, 2005).

\section{A OCTOPAMINA NAS ABELHAS}

Nos insetos, as aminas biogênicas, em especial a octopamina, desempenham um amplo espectro de funções, como neurotransmissores, neuromoduladores e neurohormônios (HOMBERG, 2002; ROEDER, 1999; 2005). Elas ocupam importantes papéis na aprendizagem e memória de insetos, modulação de receptores sensoriais e interneurônios envolvidos no controle comportamental, aumento na tensão de vários músculos esqueléticos, estimulação do metabolismo energético, ventilação e circulação (AGRÍCOLA et al, 1989; ROEDER, 1999; HOMBERG, 2002; ROEDER, 2005; UNOKI et al, 2005).

Além disso, em abelhas melíferas, algumas das funções da octopamina são modulação da divisão de trabalho (BARRON e ROBINSON, 2005; BARRON et al, 2002; SCHULZ e ROBINSON, 2001), do comportamento higiênico (SPIVAK et al, 2003) e reconhecimento de companheiras de ninho (ROBINSON et al, 1999). A octopamina também pode ser utilizada como um sinal que predispõe os insetos ao aumento do exercício, da taxa metabólica e termogênese (BELZUNCES et al, 1996, CANDY et al, 1997), requeridos, por exemplo, para escapar e para o vôo, uma situação semelhante à "luta ou fuga" descrita para vertebrados, sob a ação da norepinefrina (CANDY et al, 1997). A octopamina está presente em concentrações relativamente altas em tecidos neuronais e não neuronais de insetos e entre seus alvos estão órgãos periféricos, órgãos sensoriais, e processos no sistema nervoso central. Os efeitos da octopamina incluem modulação de receptores sensoriais e interneurônios envolvidos no controle comportamental, 
aumento na tensão de vários músculos esqueléticos, estimulação do metabolismo energético, ventilação e circulação (AGRÍCOLA et al, 1989; ROEDER, 1999; HOMBERG, 2002; ROEDER, 2005).

Em abelhas forrageadoras ocorrem níveis significantemente maiores das três aminas biogênicas do que em abelhas mais jovens, que trabalham dentro da colônia (WAGENER-HULME et al., 1999), o mesmo ocorrendo com os níveis de hormônio juvenil (HJ) em A. mellifera (ROBINSON et al., 1989; HUANG et al., 1994; FAHRBACH, 1997). Condições externas e de dentro da colônia afetam os níveis de aminas biogênicas no sistema nervoso central de abelhas operárias; tais níveis, por outro lado, podem ajustar o desempenho de tarefas de operárias individuais por modulação dos níveis de HJ (HARTFELDER, 2000).

Podem ocorrer interações entre o hormônio juvenil (HJ) e octopamina em diversos grupos de insetos. Por exemplo, a produção de HJ pelos corpora allata (CA) de fêmeas adultas de barata Diploptera punctata pode ser modulada por tratamento com octopamina, que tem sido identificada nos CA e os efeitos podem ser bloqueados com um bloqueador de receptor de octopamina, "phentolamine". A octopamina poderia ser um neuromodulador natural da produção de HJ pelos CA, regulando seus canais iônicos (THOMPSON et al., 1990).

O HJ influencia diversos aspectos da maturação de abelhas adultas que são envolvidos na divisão de trabalho, incluindo secreções exócrinas, responsividade a estímulos olfativos, idade do início da atividade de vôo (revisto por BLOCH et al., 2002) e níveis de octopamina nos lobos antenais (SCHULZ et al.., 2002).

O prejuízo no vôo de abelhas Apis alatectomizadas (com retirada dos CA) poderia ser consequiência das menores taxas metabólicas, refletindo desenvolvimento inadequado e/ou funcionamento inadequado dos músculos de vôo. A falha no vôo dessas abelhas poderia ocorrer porque a falta de HJ poderia provocar atrasos no desenvolvimento muscular ou provocar exaustão prematura no vôo, falhas na termogênese ou problemas na habilidade aprender/lembrar o local da colônia (SULLIVAN et al, 2003).

A transmissão de sinais octopaminérgicos em insetos tem despertado interesse e recebido atenção na literatura, pois a octopamina não é presente em quantidades significativas em vertebrados, e assim este sistema pode ser empregado para o desenvolvimento de inseticidas atuando em receptores de octopamina (HOMBERG, 2002).

Segundo Barron et al (2007) aminas biogênicas podem ser oferecidas a abelhas via tratamento oral, dissolvidas em solução de sacarose ou mel. Alguns estudos utilizando medições dos conteúdos de aminas biogênicas no cérebro de abelhas mostraram que há aumento dosedependente dos níveis cerebrais de octopamina, após o tratamento oral com esta substância (Barron et al, 2002; Schulze robinson, 2001; Schulz et al, 2002). 


\section{BETA-BLOQUEADORES E OCTOPAMINA}

Em abelhas melíferas, Belzunces et al. (1996) investigaram os efeitos de compostos "adrenérgicos" na termorregulação de indivíduos mantidos a $22^{\circ} \mathrm{C}$ e com temperatura torácica monitorada por infravermelho, tratados com agonistas adrenérgicos, epinefrina e efedrina, e com agente beta-bloqueador, alprenolol, que leva a uma hipotermia, dose dependente. Segundo esses autores, um mecanismo semelhante ao beta-adrenérgico de vertebrados parece estar envolvido na termorregulação de abelhas melíferas e particularmente na termogênese. Os autores sugerem que mecanismos envolvendo "norepinefrina" (octopamina) são bons candidatos para o controle neural e metabólico da termorregulação nesses insetos, nos quais a localização exata dos centros de termorregulação não é conhecida. A via "adrenérgica" poderia estar envolvida na regulação central ou periférica da temperatura corpórea (BELZUNCES et al. 1996)

Agentes beta-bloqueadores em abelhas podem antagonizar os efeitos da octopamina, uma vez que, como referido acima, os receptores de octopamina de insetos são considerados homólogos aos receptores adrenérgicos de vertebrados (BOUNIAS, 1986; ROEDER, 1995). Existem vários tipos de bloqueadores de receptores de ocotpamina e um deles, a Mianserina é, segundo Degen et al (2000), o bloqueador de octopamina com a maior afinidade pelo receptor.

A respeito dessas questões, redigimos um artigo de revisão (LOLI e BICUDO, 2005) que aborda os mecanismos regulatórios de termogênese em insetos voadores e aves, com enfoque comparativo dos mecanismos de produção de calor em vertebrados e invertebrados.

\section{PERGUNTAS}

A pergunta principal do capítulo é se há envolvimento de uma via octopaminérgica no metabolismo energético e termogênese de M. quadrifasciata.

Foram estudados os efeitos de Hormônio Juvenil, Octopamina e seus bloqueadores (Alprenolol e Mianserina), com base nas semelhanças entre o sistema adrenérgico / noradrenérgico dos vertebrados e o sistema tiraminérgico / octopaminérgico dos insetos (EVANS, 1985, 1993; ROEDER, 1999, BLENAU e BAUMANN, 2001; ROEDER, 2005), suas relações com hormônio juvenil e suas hipotéticas ações na termorregulação e no metabolismo energético de abelhas (BELZUNCES et al, 1996).

Com relação ao metabolismo energético e termogênese, são analisados os efeitos das substâncias sobre a taxa metabólica e temperatura torácica de forrageadoras. A respeito dos efeitos dos bloqueadores sobre a utilização de substratos energéticos, são analisados o quociente respiratório $(\mathrm{QR})$ e a atividade (Vmax) de algumas enzimas que poderiam apresentar atuação importante nas abelhas e na utilização de substratos energéticos. 


\section{OBJETIVOS}

OBJETIVO GERAL: Reunir evidências de uma hipotética via octopaminérgica envolvida na termogênese e taxa metabólica de forrageadoras.

\section{OBJETIVOS ESPECÍFICOS:}

- Verificar o efeito tempo-dependente de bloqueadores beta-adrenérgico e octopaminérgicos sobre a taxa metabólica e temperatura torácica de forrageadoras

- Verificar se a Octopamina e o análogo de HJ Methoprene "compensam" os efeitos dos bloqueadores

- Analisar se, com o uso dos bloqueadores, há alterações dos substratos energéticos catabolizados (considerando quociente respiratório [QR] e atividade enzimática [Vmax])

\section{MATERIAIS E MÉTODOS}

\section{SISTEMA BIOLÓGICO}

Foram utilizadas forrageadoras de Melipona quadrifasciata coletadas ao retornarem à colônia após vôos de forrageito (MICHEU et al., 2000), sem carga visível nas corbículas. A seguir, as abelhas foram pesadas e acondicionadas individualmente em câmaras respirométricas, cerca de 2 minutos após a captura (FEUERBACHER et al, 2003). Elas foram mantidas na câmara climática a $22^{\circ} \mathrm{C}$ no claro ao menos 1 hora antes do início da coleta de dados (com renovação do ar por meio de bombas), para se tentar assegurar uniformidade na aclimatação. A coleta de dados foi realizada entre $10 \mathrm{~h}$ e $18 \mathrm{~h}$, com a especificação do tempo de tratamento.

\section{CÁLCULOS DE TAXA METABÓLICA E QUOCIENTE RESPIRATÓRIO}

Para os cálculos de $\mathrm{VO}_{2} \mathrm{VCO}_{2}$ e QR foram utilizados procedimentos de respirometria intermitente, com lavagens periódicas (WITHERS, 1977, FRANÇOSO-JÚNIOR, 1999; CHAUÍBERLINCK e BICUDO, 2006), conforme descrito no capítulo 3.

Nos cálculos de taxa metabólica a unidade escolhida foi $\mathrm{mL} \mathrm{O}_{2} \min ^{-1}$ abelha ${ }^{-1}$.

O quociente respiratório $(\mathrm{QR})$ foi obtido através da razão $\frac{\dot{\mathrm{V}}_{\mathrm{CO}_{2}}}{\dot{\mathrm{V}}_{\mathrm{O}_{2}}}$, calculados a partir do sistema de respirometria intermitente, onde $\mathrm{VO}_{2}$ equivale ao consumo de $\mathrm{O}_{2}$ e $\mathrm{VCO}_{2}$ à produção de $\mathrm{CO}_{2}$. O QR fornece informações a respeito do substrato energético catabolizado, pela estequiometria da oxidação de carboidratos, proteínas e lipídios. . 


\section{TIPOS DE TRATAMENTO}

A fim de verificar o efeito das substâncias empregadas, têm-se duas opções: ou elas podem ser ingeridas (BARRON e ROBINSON, 2005) ou injetadas (SCHEINER et al, 2002). Neste trabalho, foi empregado tratamento oral (ingestão). O composto era adicionado à solução de sacarose 50\%, na concentração adequada, a qual era oferecida embebida em algodão (que evita que a abelha se "afogue" no alimento). O algodão era colocado dentro da câmara respirométrica, juntamente com a abelha, que necessita ingerir alimento durante o período experimental.

Tratamento oral com octopamina é um método não-invasivo de elevar cronicamente os níveis de octopamina no cérebro de abelhas Apis, mas não altera os níveis de dopamina ou serotonina (SCHULZ e ROBINSON, 2001; BARRON e ROBINSON, 2005). Este tipo de tratamento já foi realizado anteriormente por Belzunces et al (1996) e validado por Barron e Robinson (2005) em A. mellifera.

\section{SUBSTÂNCIAS UTILIZADAS NOS TRATAMENTOS}

As substâncias foram adquiridas da Sigma Aldrich:

- Octopamina (hidrocloreto de octopamina), $\mathrm{C}_{8} \mathrm{H}_{11} \mathrm{NO}_{2} \cdot \mathrm{HCl}$ ): agonista de receptor alfaadrenérgico e neurotransmissor, neuromodulador e neurohormônio de insetos (ROEDER, 1999, 2005);

- Alprenolol (hidrocloreto de alprenolol, $\mathrm{C}_{15} \mathrm{H}_{23} \mathrm{NO}_{2} \cdot \mathrm{HCl}$ ): antagonista de receptores $\beta_{1}$ e $\beta_{2}$ adrenérgicos de vertebrados, que pode diminuir a temperatura torácica de abelhas (BELZUNCES et al, 1996);

- Mianserina (hidrocloreto de mianserina), $\mathrm{C}_{18} \mathrm{H}_{20} \mathrm{~N}_{2}$. $\mathrm{HCl}$ ): antagonista/agonista inverso de receptores de serotonina e bloqueia receptores de histamina $\mathrm{H}_{1}$ e $\alpha_{2}$ adrenérgicos, além de ser o antagonista de receptor de Octopamina com a maior afinidade pelo receptor (DEGEN et al, 2000);

- Methoprene (ácido metoprênico), $\mathrm{C}_{16} \mathrm{H}_{28} \mathrm{O}_{3}$ ): análogo de Hormônio Juvenil de insetos (WITHERS et al, 1995; SCHULZ et al, 2002a,b; GROZINGER e ROBINSON, 2007)

- Ácido ascórbico $\left(\mathrm{C}_{6} \mathrm{H}_{8} \mathrm{O}_{6}\right)$ : antioxidante, possivelmente envolvido na diminuição da oxidação de aminas biogênicas (SCHEINER et al., 2002).

Além dos efeitos dessas substâncias, quando administradas isoladamente, objetiva-se também verificar se há "compensação" ou "neutralização" dos efeitos decorrentes da ingestão dos bloqueadores (alprenolol e mianserina) com o acréscimo de octopamina e methoprene.

Foi testado se os efeitos do alprenolol, na taxa metabólica, referem-se à ingestão do alprenolol e não a efeito de substâncias "voláteis" liberadas pela solução de sacarose $50 \%$ + 
alprenolol, que poderiam alterar a taxa metabólica. Foi colocado, em algumas câmaras respirométricas, um tubo perfurado contendo algodão com essa solução. Assim, os "voláteis" das substâncias presentes eram liberados, mas o alprenolol estava inalcançável para a ingestão pela abelha. Além do tubo, foi colocado na câmara respirométrica algodão com solução de sacarose $50 \%$, a fim de manter a umidade do ambiente e fornecer alimento à abelha. Tal condição está mostrada, no item Resultados, como "Tubos".

\section{EFEITO TEMPO E DOSE DEPENDENTE}

Os efeitos tempo e dose dependente das substâncias foram testados nos grupos controle e experimentais, com a realização de tratamentos durante 8 horas, e compilação de resultados de hora em hora. Foi realizada coleta de dados preliminares baseada na literatura, com o intuito de determinar quais quantidades de cada substância seriam utilizadas, com baixo índice de mortalidade. As concentrações testadas para cada substância foram:

- Alprenolol: $10^{-1} \mathrm{M}$ e $10^{-2} \mathrm{M}$ (BELZUNCES et al, 1996);

- Octopamina $10^{-2} \mathrm{M}$ e $10^{-3} \mathrm{M}$ (SCHULZ e ROBINSON, 2001; BARRON et al, 2002; BARRON e ROBINSON, 2005);

- Methoprene $2 \mathrm{mg} / \mathrm{mL}$

- Ácido ascórbico $\left(10^{-2} \mathrm{M}\right)$ (SCHEINER et al, 2002);

- Mianserina $10^{-3} \mathrm{M}$ e $10^{-2} \mathrm{M}$ (DEGEN et al, 2000)

\section{MEDICÕES DE TEMPERATURA TORÁCICA}

Para a medição da temperatura torácica externa das abelhas, foram realizados testes com diversas opções de termômetros, com o objetivo de encontrar o tipo mais adequado ao tamanho e características do animal; o eleito foi o termômetro infravermelho Raytek Raynger IPJ. A sala foi mantida na mesma temperatura que a câmara climática, por meio de ar condicionado, para evitar muitas variações decorrentes da abertura da câmara. Tomou-se o cuidado de afastar fontes externas de calor que poderiam influenciar os resultados, como equipamentos e contato das mãos.

No início da manhã foi realizada coleta de forrageadoras, que eram individualmente acondicionadas em recipientes de tule, os quais permitem ventilação e acesso a alimento (solução de sacarose $50 \%$ + tratamento), justapostos ao tule. Estes recipientes foram colocados em bandejas, dentro das quais foram colocados pedaços de algodão embebido em água para manter a umidade, e o tudo era mantido em temperatura $\left(22^{\circ} \mathrm{C}\right)$ controlada.

As medições de temperatura torácica foram realizadas a cada 30 minutos e foram testadas abelhas do grupo "Sacarose", "Alprenolol” e "Alprenolol + Octopamina". 


\section{CÁLCULO DE ATIVIDADE ENZIMÁTICA (Vmax)}

A velocidade máxima de reação ( $\max$ ) de algumas enzimas do músculo torácico de vôo de abelhas foi comparada entre o grupo controle e alguns grupos experimentais. A dosagem de enzimas é feita através da medida de sua atividade, que é avaliada pela velocidade da reação que a enzima catalisa. Uma amostra da solução contendo a enzima (tecido) é incubada com concentrações altas de substratos, para garantir a velocidade máxima e impedir que pequenas variações na concentração do substrato possam afetar as medidas. A descrição matemática dos fenômenos cinéticos enzimáticos é dada pela equação de Michaelis-Menten. Quando a concentração de substrato é muito alta, a velocidade é constante e máxima, independendo da concentração de substrato. Os valores de Vmax servem como limites superiores do fluxo em passos específicos das vias metabólicas, e podem ser usados como medidas das capacidades funcionais em análises bioquímicas (SUAREZ et al, 1997).

Os protocolos experimentais para cálculo de Vmax foram estabelecidos baseados em protocolos já existentes para abelhas A. mellifera (SUAREZ et al, 1996), Melipona bicolor (FRANÇOSO-JÚNIOR, 1999) e do grupo Euglossine (SUAREZ et al, 2005). As enzimas foram medidas em condições que rendessem os maiores valores de Vmax, e não com a intenção de simular condição pseudo-intracelular in vitro. Isto é consistente com o objetivo de determinar valores de Vmax in vitro em condições ótimas (SUAREZ et al, 2005).

\section{AS ENZIMAS ANALISADAS}

As enzimas escolhidas foram:

- Hexoquinase: HK, E.C. [enzyme code] 2.7.1.1. Do processo glicolítico, fosforila glicose para gerar glicose-6-fosfato e determina a velocidade na qual a glicose é catabolizada. Em termos fisiológicos, os índices de $\mathrm{HK}$ têm sido utilizados para medir o catabolismo aeróbico de carboidratos (SIDELL et al, 1995);

- Trealase: TR, E.C.3.2.1.28. Na hemolinfa é responsável pela hidrólise do dissacarídeo trealose em 2 moléculas de glicose (BECKER et al, 1996; SUAREZ et al, 2005). Em abelhas possui funções fisiológicas in vivo ainda obscuras;

- Glicogênio fosforilase: GP, E.C.2.4.1.1. O glicogênio torácico pode ser utilizado para controlar as concentrações de hexose fosfato durante transições entre repouso e vôo (CRABTREE e NEWSHOLME, 1975; SAKTOR, 1976) ou estender a faixa de vôo (HARRISON, 1986) em abelhas A. mellifera. Suarez et al (2005) detectaram atividades de GP altas o suficiente para sustentar taxas glicolíticas, em abelhas Euglossine;

- Beta-hidroxiacil-CoA desidrogenase: HOAD, E.C.1.1.1.35. Da oxidação de ácidos graxos. Não foi detectável nos extratos torácicos de nenhuma das espécies de abelhas Euglossine estudadas por 
Suarez et al (2005) e nem em Melipona bicolor (FRANÇOSO-JÚNIOR, 1999). Em Apis, seria excessivamente baixa para sustentar o vôo (CRABTREE e NEWSHOLME, 1972). Foi aqui empregada para investigar possível oxidação de ácidos graxos com os tratamentos.

\section{PROCEDIMENTOS E CÁLCULOS}

Foram congelados tórax de forrageadoras coletadas após 2 horas (t1) e 5h (t2) de tratamento dentro da câmara climática a $22^{\circ} \mathrm{C}$, e que foram submetidas aos tratamentos "Sacarose", “Alprenolol" e "Mianserina". Foi necessária a escolha de apenas três grupos experimentais e apenas duas janelas temporais, devido à limitação da quantidade e preço de reagentes.

As concentrações do substrato e ativadores foram variadas, em experimentos preliminares, para assegurar que as taxas relatadas fossem obtidas em condições de saturação e não inibitórias, e a pH ótimo

- PREPARO DO TECIDO: as forrageadoras submetidas aos tratamentos foram retiradas das câmaras respirométricas após o tempo determinado ( $2 \mathrm{~h}$ ou $5 \mathrm{~h}$ de tratamento) e seus tórax foram imediatamente separados, evitando-se manipulação desnecessária e a exposição do tecido durante muito tempo em temperatura ambiente. Os tecidos foram colocados em tubos de congelamento e estes dentro de nitrogênio líquido. Após cerca de 20 minutos, os tubos foram transferidos para freezer $-80^{\circ} \mathrm{C}$ para armazenamento.

- DESCONGELAMENTO: no dia do experimento, os tubos de congelamento foram retirados do freezer $-80^{\circ} \mathrm{C}$ e o tórax de cada abelha pesado separadamente. O tecido foi colocado em tubos plásticos de homogeneização, ao qual foi acrescido tampão de homogeneização gelado, 19 vezes o volume do tórax (diluição 1:20, para cada tubo com extrato bruto). Na diluição foi considerado 1 grama $=1 \mathrm{~mL}$. O tecido foi picado com tesoura e se procedia à homogeneização, sempre com os tubos no gelo.

- HOMOGENEIZAÇÃO: com o tubo plástico sobre o gelo, o pistilo do homogeneizador foi colocado dentro do tubo e homogeneizava-se cerca de 10 segundos, 3 vezes. O processo visava triturar, homogeneizar o material e romper as células. O tampão de homogeneização (pH 7,3) constituía-se de 25mM Hepes, 2 mM EDTA, 0.5\% Triton X100 e 100 mM DTT (este último adicionado no dia).

- SONICAÇÃO: o tubo plástico era segurado apoiado no gelo, com cuidado para o pistilo não tocar as paredes do tubo nem mãos. Três ciclos de sonicação eram feitos, de dez segundos de sonicação e dez segundos de intervalo. A seguir todo o conteúdo era transferido para o tubo eppendorf respectivo e colocado na geladeira, enquanto outros tubos eram sonicados. A sonicação visa romper todas as membranas celulares e mitocondriais, liberando para a solução as enzimas compartimentalizadas. 
- CENTRIFUGAÇÃO: os tubos eppendorf foram retirados rapidamente da geladeira e colocados em centrífuga, seguido de um pulso de centrifugação durante 5 a 10 segundos; nesta etapa, foi formado um leve precipitado. Nas etapas seguintes o sobrenadante foi utilizado, exceto no caso de ensaio de glicogênio fosforilase, para o qual foi utilizado extrato não centrifugado devido às características moleculares da enzima.

\section{- ENSAIOS}

A atividade máxima das enzimas foi medida por espectrofotometria, a $25^{\circ} \mathrm{C}$, através da monitoração contínua das alterações de absorbância. Foram empregados métodos baseados nas alterações de absorbância de NADH e NADP ${ }^{+}$a 340 nm, ou DTNB a 412 nm, em condições de saturação de substrato e não inibitórias, de acordo com modificações a partir de Bergmeyer (1983) e Carvalho (2004).

Os ensaios para a determinação da atividade das enzimas foram realizados em espectrofotômetro Beckman DU-70 equipado com um controlador de temperatura Peltier (Beckman), em cubetas de vidro para $1 \mathrm{~mL}$. O preparo dos tampões de homogeneização e de ensaio para as diferentes enzimas foi baseado em Suarez et al (1996, 2005), Françoso-Júnior (1999) e Carvalho (2004)

Foram realizados experimentos piloto, baseados na literatura, nos quais se variou as concentrações do substrato e de alguns outros reagentes para assegurar que as taxas relatadas fossem obtidas em condições de saturação e não inibitórias, e a pH ótimo.

Os tampões de ensaio empregados foram:

- HK e HOAD: 50 mM Hepes, $100 \mathrm{mM} \mathrm{KCl,} 10$ mM MgCl 2 (pH 7,0);

- TR: 50 mM Fosfato de Potássio (pH 6,6);

- GP: 100 mM Fosfato de Potássio (pH 7,4).

\section{- CÁLCULOS DE Vmax}

Para o cálculo da atividade enzimática nas condições do ensaio a seguinte equação é normalmente empregada:

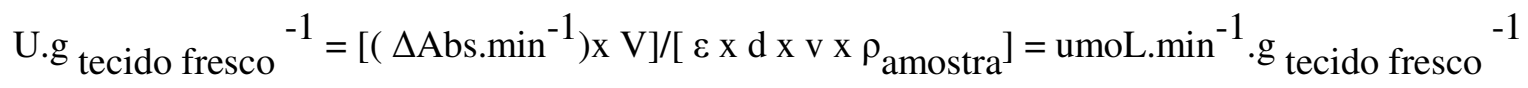

Onde:

- $\Delta$ Abs.min ${ }^{-1}=$ alteração de absorbância por minuto

- V = volume do ensaio $(\mathrm{L})$

- $\varepsilon=$ coeficiente de absorção molar $\left(\mathrm{L}_{\mathrm{mol}} \mathrm{mol}^{-1} \cdot \mathrm{mm}^{-1}\right)$

- $\mathrm{d}=$ distância percorrida pela luz na solução (mm)

- $\mathrm{v}=$ volume da amostra no ensaio (L) 
$-\rho_{\text {amostra }}=$ concentração de massa da amostra $\left(\mathrm{g} \cdot \mathrm{L}^{-1}\right)$

As unidades são expressas no sistema SI (Sistema Internacional de Unidades).

Para propósitos práticos foi utilizada a concentração da substância em mmol.L $\mathrm{L}^{-1}\left(=\mu \mathrm{moL} \cdot \mathrm{mL}^{-1}\right)$. Então, para o NADH, $\varepsilon \times \mathrm{d}=6,22 \mathrm{Lmmol}^{-1}\left(=\mu \mathrm{moL} \cdot \mathrm{mL}^{-1}\right)$ e a distância d $=10 \mathrm{~mm}$. A razão V/v informa, em outras palavras, qual é a diluição da amostra no ensaio. Já a concentração da amostra ( $\rho_{\text {amostra }}$ ) representa a diluição feita na homogeneização. Como os tecidos de um modo geral apresentam cerca de $80 \%$ de água, normalmente é aceito que $1 \mathrm{~g}$ de tecido equivale a $1 \mathrm{~mL}$. Assim, foi possível simplificar a equação acima para facilitar o cálculo de atividade enzimática:

U.g tecido fresco ${ }^{-1}=\left[\left(\Delta\right.\right.$ Abs.min $\left.{ }^{-1}\right) \times$ diluição no ensaio x diluição na homogeneização $] / 6,22$

Todas as diluições da amostra foram consideradas nos cálculos. Os resultados de atividade específica foram expressos em $\mu \mathrm{moL}$ de substrato convertido a produto por minuto por grama de tecido úmido, nas condições do ensaio, equivalente a unidade U.g tecido $^{-1}$.

As taxas dos controles (background, brancos), obtidas sem um substrato, são medidas e subtraídas das taxas obtidas com todos os substratos presentes. Todos os ensaios foram realizados, no mínimo, em duplicata (BERGMEYER, 1983; CARVALHO, 2004).

A porcentagem da GP ativa (GPa) em relação a GP total (GPt) foi calculada segundo a equação: $\% \mathrm{GPa}=(\mathrm{Gpa} * 100) / \mathrm{GPt}$.

\section{ANÁLISE DE DADOS}

Nos gráficos, os valores foram apresentados como média \pm desvio padrão. Médias indicadas pela mesma letra (sobrescritas) não diferem significantemente entre si. $\mathrm{O}$ “*” sobrescrito indica grupo que diferiu estatisticamente dos demais $(\alpha=0,05)$. Os dados foram separados por horários, ou seja, o grupo experimental " $8 \mathrm{~h}$ ", por exemplo, representa os dados coletados entre $8 \mathrm{~h}$ e $8 \mathrm{~h} 59$. O horário de verão foi desconsiderado. Os testes estatísticos foram baseados em Zar (1999), Vieira (2003) e Callegari-Jacques (2003). Os cálculos estatísticos foram realizados com o auxílio do programa GraphPad Prism 3.02

\section{TAMANHO AMOSTRAL}

O tamanho amostral mínimo foi estimado para comparar os valores de taxa metabólica de forrageadoras tratadas com sacarose, com as tratadas com solução de sacarose contendo alprenolol e/ou octopamina. Cálculos foram utilizados para determinar quantas abelhas deviam ser estudadas 
para que se possa identificar uma diferença entre tratamentos de pelo menos $0,05 \mathrm{~mL} \mathrm{CO}_{2} \mathrm{~min}^{-1}$, com poder estatístico de $80 \%$. Essas análises foram realizadas com nível de significância de 5\%.

\section{VARIACÃO DIÁRIA DA VO}

Os resultados dos experimentos de fotoperíodo descritos no capítulo 3 mostraram que entre $7 \mathrm{~h}$ e $17 \mathrm{~h}$ não foi detectada variação estatisticamente significativa nos valores de taxa metabólica das forrageadoras tratadas com solução de sacarose 50\%, mantidas no claro. Entretanto, esses dados foram coletados a $28^{\circ} \mathrm{C}$, e neste capítulo trabalhamos a $22^{\circ} \mathrm{C}$ (segundo BELZUNCES et al, 1996). Apesar de no capítulo 3 também ter sido mostrado que entre 15 e $30^{\circ} \mathrm{C}$ não há variação estatisticamente significativa na taxa metabólica de forrageadoras, foi realizada também análise (teste de Kruskal Wallis) da variação da taxa metabólica de forrageadoras alimentadas com solução de sacarose $50 \%$, mantidas a $22^{\circ} \mathrm{C}$, no claro (denominadas, nos dados, como "Sacarose"), das $12 \mathrm{~h}$ às $17 \mathrm{~h} 59$, testando-se os intervalos de hora em hora.

\section{TESTES DE NORMALIDADE}

Foram realizados testes de normalidade (do software SPSS: testes de Kolmogorov-Smirnov e Shapiro-Wilk) e de homogeneidade de variâncias a fim de verificar se a população original de onde os dados são provenientes segue uma distribuição normal e se testes estatísticos paramétricos são adequados. Foram testados os valores de taxa metabólica de abelhas do grupo "Sacarose", mantidas no claro a $22^{\circ} \mathrm{C}$.

\section{TESTE DE KRUSKAL WALLIS}

Foi utilizado o teste de Kruskal-Wallis para testar a hipótese de que várias populações têm a mesma distribuição. Para identificar diferenças significativas entre grupos tomados 2 a 2 , foi empregado o procedimento não-paramétrico de comparações múltiplas semelhantes ao teste paramétrico de Tukey, denominado Teste de Dunn

\section{TESTE DE MANN WHITNEY}

Para comparar valores Vmax de enzimas no $\mathrm{t}_{1}$ e $\mathrm{t}_{2}$ foi aplicado o teste de Mann Whitney, para testar a hipótese de que duas populações têm a mesma distribuição. O teste é baseado em postos e é uma alternativa não paramétrica ao teste t no caso de amostras independentes.

\section{CORRELACÕES}

A fim de verificar se há correlação entre variáveis foi utilizado o cálculo do Coeficiente de Correlação de Spearman, que é uma alternativa não-paramétrica para o Coeficiente de Correlação de Pearson.

\section{REGRESSÃO LINEAR}

A taxa metabólica, o quociente respiratório e a temperatura torácica das abelhas são funções do tempo de tratamento e, assim, o procedimento adequado para análise deve incluir o tempo como variável independente. Foi escolhida a Regressão Linear (RegLin) como método de análise, que 
visa avaliar uma possível dependência de y $\left(\mathrm{VO}_{2}, \mathrm{QR}\right.$, temperatura torácica) em relação a x (tempo de tratamento). O objetivo não é expressar matematicamente esta relação por meio de uma equação, nem estabelecer um modelo matemático preciso para a dependência temporal do y em relação ao tempo de tratamento, mas sim caracterizar se os diferentes tratamentos diferem e resultam em diferentes dependências. Os dados foram apresentados como gráficos de dispersão dos pontos. Para a obtenção das retas de regressão e comparação entre as inclinações e interceptos (o que nos dá a eventual diferença de dependência temporal) foram empregadas funções internas do programa GraphPad Prism 3.02.

\section{COMPARACÕES INTRA-TRATAMENTO}

Inicialmente foi verificada, por Regressão Linear, a semelhança de inclinação e intercepto dos valores individuais de abelhas submetidas ao mesmo tratamento, para verificar se todas respondem de maneira semelhante. $\mathrm{O}$ valor de $\mathrm{x}$ era a variável independente (tempo de tratamento) e o y a $\mathrm{VO}_{2}$, QR ou temperatura torácica, de cada indivíduo. Havendo uniformidade de resposta individual, com semelhança de inclinação e intercepto, os dados de todos os animais submetidos ao mesmo tratamento podiam ser reunidos ("pool") e comparados com outros tratamentos e/ou com o grupo controle (nas comparações entre-tratamentos).

No caso de haver diferenças, por exemplo, com relação ao intercepto, este, e a sua medida de dispersão (no caso, o desvio padrão) foram comparados por meio de análise de variância. Com esta análise, foram verificados quais grupos de indivíduos têm interceptos semelhantes. Esses grupos, de valores homogêneos, foram comparados separadamente com os demais grupos experimentais.

\section{COMPARACÕES ENTRE TRATAMENTOS}

Foram comparados os interceptos e as inclinações de dois grupos por vez, a fim de detectar as diferenças e as similaridades entre os diversos tratamentos.

\section{RESULTADOS}

\section{OBSERVACÕES DOS ANIMAIS EXPERIMENTAIS E COLETA DE DADOS}

Após o período experimental, todas as abelhas que receberam bloqueador (alprenolol ou mianserina) apresentavam prejuízo na atividade de vôo, verificado quando as forrageadoras eram devolvidas ao ninho.

No sistema de respirometria intermitente, para o cálculo do $\mathrm{VO}_{2}$ nas forrageadoras tratadas com solução de sacarose $50 \%$ acrescida de bloqueadores, foi necessário aumentar o tempo de fechamento das válvulas manuais das câmaras respirométricas quando não era obtida deflexão significativa nos sensores que fosse adequada para o cálculo da integral entre $t_{0} \mathrm{e} \mathrm{t}_{\mathrm{f}}$. 
Uma vez que cerca de $50 \%$ das abelhas tratadas com Mianserina $10^{-2} \mathrm{M}$ e Alprenolol $10^{-1} \mathrm{M}$ morreram, foram utilizados nas análises apenas os resultados obtidos com Mianserina $10^{-3} \mathrm{Me}$ Alprenolol 10-2M.

\section{TAMANHO MÍNIMO AMOSTRAL}

O cálculo do tamanho mínimo da amostra resultou em um valor de n de 3,16. Foi definido, então, o n mínimo para as comparações de diferentes tratamentos em cada horário (intervalos de 1h), foi $\mathrm{n}=4$, viável para o tempo de realização do projeto e para as diferentes situações experimentais propostas.

\section{TESTE DE NORMALIDADE}

Os resultados dos testes de normalidade indicam que os dados de taxa metabólica de forrageadoras do grupo "Sacarose", mantidas a $22^{\circ} \mathrm{C}$, não apresentam distribuição normal (Gaussiana). Assim, conforme já exposto, na análise estatística foram empregados métodos não paramétricos. Os resultados dos testes de normalidade indicam que os dados de taxa metabólica de forrageadoras alimentadas com solução de sacarose $50 \%$, mantidas a $22^{\circ} \mathrm{C}$, não têm distribuição normal (Gaussiana). Assim, conforme já exposto, na análise estatística empregou-se métodos não paramétricos.

\section{VARIACÃO DIÁRIA DA TAXA METABÓLICA}

A variação da taxa metabólica de forrageadoras do grupo controle, das $12 \mathrm{~h}$ às $17 \mathrm{~h} 59$, está apresentada na figura 1. Esses valores se referem ao $\mathrm{VCO}_{2}\left(\mathrm{~mL} \mathrm{CO} 2 \mathrm{~min}^{-1}\right)$ (conforme também utilizado por BLATT e ROCES, 2001) pois na época dos experimentos o analisador e o sensor de $\mathrm{O}_{2}$ estavam em conserto.

Não foi detectada diferença estatisticamente significativa entre os horários $(\mathrm{H}=4,917$; $\mathrm{p}=0,4261$ ), assim como também ocorreu com os valores de taxa metabólica a $28^{\circ} \mathrm{C}$ na fase de claro do capítulo 3. Desse modo, foi possível realizar experimentos de efeitos de substâncias sobre o $\mathrm{VO}_{2}$ nessa janela temporal, de forma que as alterações observadas fossem devido ao tratamento e não devido à variação diária da taxa metabólica.

\section{OCTOPAMINA E ÁCIDO ASCÓRBICO}

Não foi detectada diferença estatisticamente significativa nos valores de taxa metabólica de forrageadoras dos grupos "Octopamina", “Ácido Ascórbico" e "Sacarose” (figura 2) (H=4,519; $\mathrm{P}=0,6069)$ pelo teste de Kruskal Wallis, de dados compilados das 12 às $17 \mathrm{~h} 59$. Assim, o foco é dado nos grupos nos quais foi detectada diferença significativa, para diminuir o grande número de 
grupos experimentais. Todavia, optamos por acrescentar o ácido ascórbico junto com a octopamina e alprenolol em um mesmo tratamento (grupo "Alprenolol + Octopamina + Ácido Ascórbico"), a fim de verificar se a "compensação" ou "neutralização" dos efeitos do alprenolol é maior com o ácido ascórbico, o qual diminuiria a oxidação da octopamina (SCHEINER et al, 2002).

Os seguintes grupos experimentais foram eleitos:

- Sacarose (controle)

- Alprenolol $10^{-2} \mathrm{M}$

- Mianserina $10^{-3} \mathrm{M}$

- Methoprene $2 \mathrm{mg} \mathrm{mL}^{-1}$

- Octopamina $10^{-2} \mathrm{M}+$ Alprenolol $10^{-2} \mathrm{M}$

- Octopamina $10^{-2} \mathrm{M}+$ Mianserina $10^{-3} \mathrm{M}$

- Methoprene $2 \mathrm{mg} \mathrm{mL}^{-1}+$ Alprenolol $10^{-2} \mathrm{M}$

- Methoprene $2 \mathrm{mg} \mathrm{mL}^{-1}+$ Mianserina $10^{-3} \mathrm{M}$

- Alprenolol $10^{-2} \mathrm{M}+$ Octopamina $10^{-2} \mathrm{M}+$ Ácido ascórbico $10^{-2} \mathrm{M}$

\section{$\underline{\text { TAXA METABÓLICA }}$}

\section{COMPARAÇÕES INTRA-TRATAMENTO $\left(\mathrm{VO}_{2}\right)$}

Nas figuras 3A a 10A encontram-se os resultados da verificação de similaridade de inclinação e intercepto dos valores de $\mathrm{VO}_{2}$ dos tratamentos (comparações intra-tratamento). As retas de regressão individuais estão mostradas apenas na figura 3, estando ausentes nas demais para facilitar visualização dos resultados.

Na tabela 1 estão resumidos os resultados das análises de Regressão Linear das comparações intra-tratamento quanto ao $\mathrm{VO}_{2}$ e estão indicados os valores de p. Não foram detectadas diferenças significativas entre os valores de inclinação e intercepto intra-tratamento, exceto nos interceptos do grupo "Alprenolol” $\left(\mathrm{VO}_{2}\right)$.

Tabela 1. Verificação de similaridade de inclinação e intercepto (intra-tratamento) dos valores de $\mathrm{VO}_{2}$ versus tempo de tratamento. Estão indicados os valores de $p$ da análise de Regressão Linear

\begin{tabular}{ccc}
\hline TRATAMENTO & INCLINAÇÃO & INTERCEPTO \\
\hline Sacarose & $\mathrm{P}=0,5567$ & $\mathrm{P}=0,1408$ \\
Alprenolol & $\mathrm{P}=0,2312$ & Diferenças significativas \\
& & $(\boldsymbol{P}=\mathbf{0 , 0 0 0 9})$ \\
Alprenolol + Octopamina & $\mathrm{P}=0,9405$ & $\mathrm{P}=0,1012$
\end{tabular}



Alprenolol + Octopamina +
$\mathrm{P}=0,3648$
$\mathrm{P}=0,8318$
Ácido ascórbico
Mianserina
$\mathrm{P}=0,7215$
$\mathrm{P}=0,5767$
Mianserina + Octopamina
$\mathrm{P}=0,8749$
$\mathrm{P}=0,4551$
Methoprene
$\mathrm{P}=0,999$
$\mathrm{P}=0,7249$
Methoprene + Alprenolol
$\mathrm{P}=0,9387$
$\mathrm{P}=0,898$
Methoprene + Mianserina
$\mathrm{P}=0,4101$
$\mathrm{P}=0,5095$

No caso da figura 6A (grupo Alprenolol) as inclinações dos diferentes indivíduos são semelhantes, mas os interceptos diferem. Neste caso foi verificado, por meio de análise de variância, os valores de quais indivíduos são semelhantes. Esses dois conjuntos foram então agrupados separadamente e utilizados separadamente nas comparações entre - tratamentos. Nos demais grupos, há similaridade de resposta individual frente ao tratamento, e então os valores de taxa metabólica de todos os indivíduos submetidos ao mesmo tratamento puderam ser reunidos para as comparações entre-tratamentos.

\section{COMPARACÕES ENTRE-TRATAMENTOS $\left(\mathrm{VO}_{2}\right)$}

Nas comparações dos valores de taxa metabólica entre-grupos, de hora em hora, foram detectadas diferenças significativas entre os grupos experimentais (figuras 11 a 18). Na tabela 2 estão resumidos os resultados das comparações, considerando o $\mathrm{VO}_{2}$. As diferenças significativas ( $\mathrm{p}<0,05)$ estão destacadas em itálico.

Tabela 2. Comparações entre-tratamentos, considerando os valores de $\mathrm{VO}_{2}$. Estão indicados os valores de $p$ da análise de Regressão Linear

\begin{tabular}{ccc}
\hline COMPARAÇÕES & INCLINAÇÃO & INTERCEPTO \\
\hline Sacarose vs Mianserina & Diferenças significativas & Não foi possível calcular, pois \\
Sacarose vs Alprenolol & $(P<0,0001)$ & inclinações diferem muito. \\
Sacarose vs Alprenolol + & Diferenças significativas & Não foi possível calcular, pois \\
Octopamina & $(P<0,02)$ & inclinações diferem. \\
Sacarose vs Alprenolol + & $(\mathrm{P}=0,1072)$ & Diferenças significativas \\
Octopamina + Ácido ascórbico & $(\mathrm{P}=0,0658)$ & $(P<0,0001)$ \\
Sacarose vs Mianserina + & & Diferenças significativas \\
Octopamina & $(\mathrm{P}=0,3108)$ & $(P<0,0001)$ \\
& & Diferenças significativas \\
\end{tabular}


Mianserina vs Mianserina +

Octopamina

Alprenolol vs Alprenolol +

Octopamina

Alprenolol + Octopamina +

Ácido ascórbico vs Alprenolol

+ Octopamina

Sacarose vs Methoprene

Sacarose vs Methoprene

+ Alprenolol

Sacarose vs Methoprene +

Mianserina

Methoprene vs Methoprene +

Alprenolol

Methoprene vs Methoprene +

Mianserina

Methoprene + Alprenolol vs

Methoprene + Mianserina
Diferenças significativas

$(P=0,0002693)$

$(\mathrm{P}=0,4684)$

$(\mathrm{P}=0,2472)$

$(\mathrm{P}=0,3534)$

$(\mathrm{P}=0,3322)$
Não foi possível calcular, pois inclinações diferem.

$\mathrm{P}=0,6058$

$\mathrm{P}=0,2631$

$\mathrm{P}=0,352$

$\mathrm{P}=0,5619$

$\mathrm{P}=0,4907$

$\mathrm{P}=0,1696$

$\mathrm{P}=0,1758$
Diferenças significativas

$P<0,0001$

Diferenças significativas

$P<0,0001$

Diferenças significativas

$P<0,0001$

Diferenças significativas

$P<0,0001$

$\mathrm{P}=0,726$

É interessante notar que quando a octopamina e o methoprene são adicionados aos bloqueadores, não há diferença de inclinação quando comparado com o grupo controle ("Sacarose").

\section{QUOCIENTE RESPIRATÓRIO (QR)}

\section{COMPARACÕES INTRA-TRATAMENTO (QR)}

Quanto ao QR, os resultados das comparações intra-tratamento estão representados nas figuras 3B a 10B e resumidos na tabela 3. Não foram detectadas diferenças significativas entre os valores de inclinação e intercepto dos indivíduos submetidos ao mesmo tratamento.

Tabela 3. Verificação de similaridade de inclinação e intercepto (intra-tratamento) dos valores de QR versus tempo de tratamento. Estão indicados os valores de $p$ da análise de Regressão Linear

\section{TRATAMENTO}

Sacarose

Alprenolol
INCLINAÇÃO

$$
\mathrm{P}=0,4128
$$

$\mathrm{P}=, 3818$
INTERCEPTO

$$
\mathrm{P}=0,2702
$$

$\mathrm{P}=0,7843$ 

Alprenolol + Octopamina
$\mathrm{P}=0,8870$
$\mathrm{P}=0,4528$
Alprenolol + Octopamina +
$\mathrm{P}=0,7122$
$\mathrm{P}=0,9489$
Ácido Ascórbico
Mianserina
$\mathrm{P}=0,7691$
$\mathrm{P}=0,8461$
Mianserina + Octopamina
$\mathrm{P}=0,5750$
$\mathrm{P}=0,6096$
Methoprene
$\mathrm{P}=0,9629$
$\mathrm{P}=0,1414$
Methoprene + Alprenolol
$\mathrm{P}=0,8164$
$\mathrm{P}=0,2204$
Methoprene + Mianserina
$\mathrm{P}=0,5918$
$\mathrm{P}=0,6612$

\section{COMPARACÕES ENTRE-TRATAMENTOS (QR)}

Nas figuras 11B a 18B estão representadas comparações entre tratamentos e na tabela 4 os resultados das análises.

Tabela 4. Comparações entre-tratamentos, considerando os valores de QR. Estão indicados os valores de $p$ da análise de Regressão Linear

\begin{tabular}{|c|c|c|}
\hline COMPARAÇÕES & INCLINAÇÃO & INTERCEPTO \\
\hline Sacarose vs Mianserina & $\begin{array}{c}\text { Diferenças significativas } \\
(P<0.0001)\end{array}$ & $\begin{array}{c}\text { Não foi possível calcular, pois } \\
\text { inclinações diferem muito. }\end{array}$ \\
\hline Sacarose vs Alprenolol & $\begin{array}{c}\text { Diferenças significativas } \\
(P=0,0004118)\end{array}$ & $\begin{array}{c}\text { Não foi possível calcular, pois } \\
\text { inclinações diferem }\end{array}$ \\
\hline $\begin{array}{c}\text { Sacarose vs Alprenolol }+ \\
\text { Octopamina }\end{array}$ & $(\mathrm{P}=0,1403)$ & $\begin{array}{c}\text { Diferenças significativas } \\
(P<0,0001)\end{array}$ \\
\hline $\begin{array}{c}\text { Sacarose vs Alprenolol + } \\
\text { Octopamina + Ácido ascórbico }\end{array}$ & $\begin{array}{c}\text { Diferenças significativas } \\
(P=0,00095)\end{array}$ & $\begin{array}{c}\text { Não foi possível calcular pois } \\
\text { inclinações diferem }\end{array}$ \\
\hline $\begin{array}{c}\text { Sacarose vs Mianserina }+ \\
\text { Octopamina }\end{array}$ & $(\mathrm{P}=0,5292)$ & $\begin{array}{c}\text { Diferenças significativas } \\
(P<0,0001)\end{array}$ \\
\hline $\begin{array}{c}\text { Mianserina vs Mianserina }+ \\
\text { Octopamina }\end{array}$ & $\begin{array}{c}\text { Diferenças significativas } \\
(P=0,0007268)\end{array}$ & $\begin{array}{c}\text { Não foi possível calcular pois } \\
\text { inclinações diferem }\end{array}$ \\
\hline $\begin{array}{c}\text { Alprenolol vs Alprenolol }+ \\
\text { Octopamina }\end{array}$ & $\begin{array}{c}\text { Diferenças significativas } \\
(P=0,02815)\end{array}$ & $\begin{array}{c}\text { Não foi possível calcular pois } \\
\text { inclinações diferem }\end{array}$ \\
\hline $\begin{array}{l}\text { Alprenolol + Octopamina + } \\
\text { Ácido ascórbico vs Alprenolol } \\
\text { + Octopamina }\end{array}$ & $(\mathrm{P}=0,1186)$ & $(\mathrm{P}=0,3903)$ \\
\hline Sacarose $v s$ Methoprene & $\mathrm{P}=0,2939$ & $\mathrm{P}=0,5764$ \\
\hline Sacarose vs Methoprene & $\mathrm{P}=0,3127$ & $P<0,0001$ \\
\hline
\end{tabular}


+Alprenolol

Sacarose vs Methoprene +

Mianserina

Methoprene vs Methoprene +

Alprenolol

Methoprene vs Methoprene +

Mianserina

Methoprene + Alprenolol vs

Methoprene + Mianserina
Diferenças significativas

$\mathrm{P}=0,7271$

$P<0,0001$

Diferenças significativas

$\mathrm{P}=0,1039$

$P<0,0001$

Diferenças significativas

$\mathrm{P}=0,3071$

$P<0,0001$

Diferenças significativas

$\mathrm{P}=0,6796$

$\mathrm{P}=0,6514$

\section{TEMPERATURA TORÁCICA}

\section{COMPARACÕES INTRA-TRATAMENTO (Temperatura torácica)}

Na figura 19 estão apresentados os resultados dos efeitos de sacarose (controle), alprenolol e de alprenolol + octopamina sobre a temperatura torácica externa de forrageadoras e as comparações intra-tratamento. Verifica-se que nas abelhas tratadas com alprenolol e/ou octopamina os valores de temperatura tendem a diminuir. As análises estão resumidas na tabela 5.

Tabela 5. Verificação de similaridade de inclinação e intercepto (intra-tratamento) dos valores de temperatura torácica versus tempo de tratamento. Estão indicados os valores de $p$

\begin{tabular}{ccc}
\hline TRATAMENTO & INCLINAÇÃO & INTERCEPTO \\
\hline Sacarose & $(\mathrm{P}=0,8975)$ & $(\mathrm{P}=0,06228)$ \\
Alprenolol & $(\mathrm{P}=0,7629)$ & $(\mathrm{P}=0,0873)$ \\
Alprenolol + Octopamina & $(\mathrm{P}=0,6844)$ & $(\mathrm{P}=0,405)$ \\
\hline
\end{tabular}

Há similaridade de inclinação e intercepto em diferentes indivíduos submetidos ao mesmo tratamento, os quais têm respostas similares.

\section{COMPARACÕES ENTRE-TRATAMENTOS (Temperatura torácica)}

$\mathrm{Na}$ figura 20 estão representadas comparações entre tratamentos, cujos resultados estão resumidos na tabela 6 .

Tabela 6. Comparações entre-tratamentos, considerando os valores de temperatura torácica. Estão indicados os valores de $p$ da análise de Regressão Linear 
COMPARAÇÕES

Sacarose vs Alprenolol

Sacarose vs Alprenolol +

Octopamina

Alprenolol vs Alprenolol +

Octopamina
INCLINAÇÃO

Diferenças significativas

$(P<0,0001)$

$(\mathrm{P}=0,0377)$

Diferenças significativas

$(P=0,0001997)$
INTERCEPTO

Não foi possível calcular pois inclinações diferem muito

Diferenças significativas

$(P<0,0001)$

Não foi possível calcular pois inclinações diferem

O bloqueador Alprenolol parece estar envolvido na diminuição da temperatura torácica, efeitos em parte diminuídos com a presença da octopamina.

\section{ATIVIDADE ENZIMÁTICA}

As concentrações do substrato e outros reagentes foram variadas e as concentrações escolhidas (quantidades por $\mathrm{mL}$ ) estão expostas na tabela 7, na qual as substâncias que tiveram as suas quantidades variadas e testadas estão marcadas com asterisco. Nas cubetas, as substâncias eram colocadas na ordem em que estão expostas na tabela, para evitar reações inadequadas.

Tabela 7. Quantidades escolhidas de substâncias e reagentes para ensaios de atividade enzimática.

\begin{tabular}{|c|c|c|c|}
\hline Hexoquinase & Trealase & HOAD & Glicogênio fosforilase \\
\hline Tampão de ensaio & Tampão de ensaio & Tampão de ensaio & Tampão de ensaio \\
\hline $10 \mathrm{mM} \mathrm{MgCl}_{2}$ & $1,1 \mathrm{mM} \mathrm{MgCl}{ }_{2}$ & $0,15 \mathrm{mM}$ NADH & $10 \mathrm{mM} \mathrm{MgCl}_{2}$ \\
\hline $100 \mathrm{mM} \mathrm{KCl}$ & $0,5 \mathrm{mM}^{\mathrm{NADP}}{ }^{+}$ & & $0,5 \mathrm{mM} \mathrm{NADP}^{+}$ \\
\hline $0,5 \mathrm{mM} \mathrm{NADP}^{+}$ & $1,1 \mathrm{mM}$ ATP & $15 \mathrm{uL}$ extrato de torax & $4 \mathrm{uM}$ Glicose $1,6 \mathrm{BF}$ \\
\hline $1 \mathrm{mM}$ ATP & *2,5 U Hexoquinase & & *2U PGM \\
\hline $5 \mathrm{mM}$ DTT & *2,5 U G6PDH & & *2,5U G6PDH \\
\hline *2,5U G6PDH & $15 \mathrm{uL}$ extrato de tórax & & $15 \mathrm{uL}$ extrato não \\
\hline 15uL extrato de tórax & & & centrifugado \\
\hline Ler branco $3 \mathrm{~min}$ & Ler branco $3 \mathrm{~min}$ & Ler branco $3 \mathrm{~min}$ & Ler branco $3 \mathrm{~min}$ \\
\hline $\begin{array}{c}* 2,5 \text { mM D-Glicose } \\
\text { (substrato) }\end{array}$ & $\begin{array}{c}* 10 \text { mM trealose } \\
\text { (substrato) }\end{array}$ & $\begin{array}{c}* 0,2 \text { mM Acetoacetil } \\
\text { CoA (substrato) }\end{array}$ & 2mg Glicogênio \\
\hline Ler experimental $3 \mathrm{~min}$ & Ler experimental $3 \mathrm{~min}$ & Ler experimental $3 \mathrm{~min}$ & $\begin{array}{l}\text { Ler GP ativa } \\
* 2 \mathrm{mM} \text { AMP } \\
\text { Ler GP total }\end{array}$ \\
\hline
\end{tabular}


Abreviaturas:

AMP: Adenosina 5 monofosfato

ATP: Adenosina 5 trifosfato

CoA: Coenzima A

DTT: Ditiotreitol

G6PDH: Glicose 6 fosfato desidrogenase

Glicose 1,6 BF: Glicose 1,6 Bifosfato

NADH: Nicotinamida adenina dinucletotídeo, forma reduzida

$\mathrm{NADP}^{+}$: Nicotinamida adenina dinucleotídeo fosfato

PGM: Fosfoglicomutase

Nas figuras 21 e 22 estão os resultados de $\operatorname{Vmax}\left(\mathrm{U}\right.$. g tecido $\left.{ }^{-1}\right)$ das 4 enzimas testadas, nos grupos Sacarose, Alprenolol e Mianserina, e as análises estão resumidas na tabela 8, com resultados de testes de Kruskal Wallis (com representação de seu H e p), seguido do pós-teste de Dunn (com p).

Tabela 8. Resultados de análises de Kruskal Wallis, seguido do pós-teste Dunn, comparando os valores de atividade enzimática nos grupos Sacarose (Sac), Alprenolol (Alp) e Mianserina (Mia).

\section{Hexoquinase}

T1

$$
H=8,713 ; p=0,0128
$$

(há diferenças significativas)

Sac vs Mia $\quad P<0,05$

Sac vs Alp $\quad \mathrm{P}>0,05$

Mia vs Alp P $>0,05$
$\mathrm{T} 2$

$$
\mathrm{H}=0,2178, \mathrm{p}=0,8968
$$

\begin{tabular}{cccc} 
Sac vs Mia & $\boldsymbol{P}<0,05$ & Sac vs Mia & $\mathrm{P}>0,05$ \\
Sac vs Alp & $\mathrm{P}>0,05$ & Sac vs Alp & $\mathrm{P}>0,05$ \\
Mia vs Alp & $\mathrm{P}>0,05$ & Mia vs Alp & $\mathrm{P}>0,05$ \\
\hline
\end{tabular}

\section{$\underline{\text { Trealase }}$}

T1

$\mathrm{H}=2,91 ; \mathrm{p}=0,2333$

Sac vs Mia

Sac vs Alp

Mia vs Alp

$$
\mathrm{P}>0,05
$$

$\mathrm{P}>0,05$

$\mathrm{P}>0,05$
$\mathrm{T} 2$

$\mathrm{H}=0,5142, \mathrm{p}=0,7733$

Sac vs Mia

$\mathrm{P}>0,05$

Sac vs Alp

$\mathrm{P}>0,05$

Mia vs Alp

\section{HOAD}

T1

$$
H=6,141 ; p=0,0464
$$

(diferenças significativas)
T2

$$
H=6,763, p=0,034
$$

(diferenças significativas) 
$\begin{array}{llll}\text { Sac vs Alp } & \mathrm{P}>0,05 & \text { Sac vs Alp } & \mathrm{P}>0,05\end{array}$

$\begin{array}{llll}\text { Mia vs Alp } & \mathrm{P}>0,05 & \text { Mia vs Alp } & \mathrm{P}>0,05\end{array}$

\section{Glicogênio fosforilase ativa}

T1

$$
H=11,9 ; p=0,0026
$$

(há diferenças significativas)

Sac vs Mia

$P<0,05$

Sac vs Alp

$\mathrm{P}>0,05$

Mia vs Alp

$P<0,001$
$\mathrm{T} 2$

$\mathrm{H}=3,695 ; \mathrm{p}=0,1576$

\section{Glicogênio fosforilase total}

$\mathrm{T} 1$

$\mathrm{H}=1,04 ; \mathrm{p}=0,5945$ (não há diferenças significativas)
Sac vs Mia

Sac vs Alp

Mia vs Alp
$\mathrm{P}<0,05$

$\mathrm{P}>0,05$

$\mathrm{P}>0,05$

\begin{tabular}{|c|c|c|c|}
\hline \multicolumn{4}{|c|}{ Glicogênio fosforilase total } \\
\hline \multicolumn{2}{|c|}{$\mathrm{T} 1$} & \multicolumn{2}{|c|}{$T 2$} \\
\hline \multirow{2}{*}{\multicolumn{2}{|c|}{$\begin{aligned} H=1,04 ; p= & 0,5945 \text { (não há diferenças } \\
& \text { significativas) }\end{aligned}$}} & \multicolumn{2}{|c|}{$H=7,418 ; p=0,0245$} \\
\hline & & \multicolumn{2}{|c|}{ (diferenças significativas) } \\
\hline Sac vs Mia & $\mathrm{P}>0,05$ & Sac vs Mia & $P<0,05$ \\
\hline Sac vs Alp & $P>0,05$ & Sac vs Alp & $\mathrm{P}>0,05$ \\
\hline Mia vs Alp & $\mathrm{P}>0,05$ & Mia vs Alp & $\mathrm{P}>0,05$ \\
\hline \multicolumn{4}{|c|}{ \% Glicogênio fosforilase ativa } \\
\hline \multicolumn{2}{|c|}{$\mathrm{T} 1$} & \multicolumn{2}{|c|}{$\mathrm{T} 2$} \\
\hline \multicolumn{2}{|c|}{$H=0,905 ; p=0,636$} & \multicolumn{2}{|c|}{$H=2,765 ; p=0,251$} \\
\hline Sac vs Mia & $\mathrm{P}>0,05$ & Sac vs Mia & $\mathrm{P}>0,05$ \\
\hline Sac vs Alp & $P>0,05$ & Sac vs Alp & $\mathrm{P}>0,05$ \\
\hline Mia vs Alp & $\mathrm{P}>0,05$ & Mia vs Alp & $\mathrm{P}>0,05$ \\
\hline
\end{tabular}

Nas comparações intra-tratamento entre $t_{1} e t_{2}$, as diferenças significativas entre os dois tempos de tratamento, pelo teste de Mann Whitney, foram detectadas entre os valores de Hexoquinase $(U=4 ; p=0,014)$ e de GP ativa $(U=0 ; p=0,0002)$ do grupo "Mianserina" e os valores de \%GP ativa do grupo "Alprenolol" ( $\mathrm{U}=10 ; \mathrm{p}=0,0207)$.

\section{DISCUSSÃO}

\section{ANÁLISE DA METODOLOGIA}

\section{TIPO DE TRATAMENTO (ORAL)}

Há diversos métodos de tratamento de abelhas com aminas biogênicas, tais como a ingestão (tratamento oral), injeção e aplicações tópicas (BARRON et al, 2007). Neste trabalho, o método 
escolhido foi o tratamento oral, que é simples e não invasivo. Foi realizada coleta de dados preliminares sobre injeção de compostos (BARRON et al, 2007) através da cutícula do abdômen de abelhas, anestesiadas previamente em gelo. Mas o acesso a seringas Hamilton foi próximo ao final do período de realização do presente trabalho, não tendo sido possível a obtenção de um número amostral adequado para análise. Desse modo, neste trabalho os dados se referem a resultados apenas com tratamento oral, que parece ser eficiente para estudos de efeitos sobre a taxa metabólica, temperatura torácica e QR das abelhas.

Algumas situações observadas sugerem que as substâncias acrescentadas na solução de sacarose foram realmente ingeridas e absorvidas no tratamento oral: (i) ao final dos experimentos as forrageadoras tratadas com alprenolol e mianserina apresentavam prejuízo na atividade de vôo, ao contrário das abelhas do grupo controle, que voavam assim que libertas; (ii) em experimentos preliminares para escolha da concentração das substâncias, as forrageadoras tratadas com mianserina $10^{-2} \mathrm{M}$ e com alprenolol $10^{-1} \mathrm{M}$ morreram; (iii) minutos após serem acondicionadas nas câmaras respirométricas, era observada extensão da probóscide das abelhas, que a encostavam na solução de sacarose fornecida, com provável ingestão; (iv) a uniformidade nas respostas aos tratamentos (quantificada pela semelhança de inclinação e intercepto [comparações intratratamento]). Assim, a metodologia para oferecimento das substâncias (tratamento oral) é um método não-invasivo que permitiu analisar o problema. Validações do método foram apresentadas por Barron e Robinson (2005) e Barron et al (2007) para A. mellifera.

Os resultados do grupo "Tubos" não diferem do grupo controle ("Sacarose"). No grupo experimental ("Tubos") a solução de sacarose com alprenolol (similar à administrada às abelhas do grupo "Alprenolol”) estava dentro da câmara respirométrica, mas inalcançável à ingestão pela abelha, indicando que os efeitos do alprenolol na taxa metabólica são provavelmente devido à ingestão e a absorção, e não a efeitos tóxicos de substâncias voláteis e aromas exalados pelo alprenolol

Tratamento oral com octopamina em A. mellifera aumenta os níveis dessa amina biogênica na hemolinfa do abdômen e no cérebro (BARRON et al, 2007), observação concordante com rápidas mudanças de comportamento observadas após ingestão de octopamina (PANKIW e PAGE, 2003; SPIVAK et al, 2003).

Uma desvantagem do oferecimento de aminas biogênicas via tratamento oral é que há variação na dose entre as abelhas, dependendo da quantidade de alimento consumido por cada operária (BARRON et al, 2007), podendo levar a diferenças individuais, por exemplo quanto ao intercepto das diferentes indivíduos nas comparações intra-tratamento do grupo "Alprenolol" (figura 6A). 


\section{INGESTÃO E ABSORCÃ̃}

A efetividade do tratamento oral depende criticamente da habilidade do composto ser absorvido e passar intacto, do intestino para a hemolinfa, e desta para o cérebro atravessando a barreira "cérebro-hemolinfa" (CALRSON et al, 2000). Ainda não é claro que tipo de mecanismos de transporte há na passagem da octopamina do intestino para a hemolinfa (BARRON et al, 2007), onde a octopamina atuaria de maneira sistêmica.

Barron et al (2007) sugerem que a octopamina pode passar do intestino para a hemolinfa e também atravessar a barreira "cérebro-hemolinfa" (CALRSON et al, 2000), atingindo o cérebro. De acordo com Carlson et al (2000), os nervos e gânglios dos insetos são cobertos por uma camada de células ligadas por junções estreitas e septadas que formam uma barreira "cérebro-hemolinfa" bloqueando a passagem de moléculas entre a hemolinfa e os tecidos nervosos. Mas algumas moléculas pequenas, como neurotransmissores, podem atravessar esta barreira (BARRON et al, 2007)

Barron et al (2007) sugerem que a barreira "cérebro-hemolinfa" das abelhas não é geralmente uma barreira efetiva para moléculas menores que $500 \mathrm{Da}$, tais como as aminas biogênicas, que são moléculas pequenas, sintetizadas a partir de aminoácidos (BLENAU e BAUMANN, 2001) que podem então atravessar essa barreira e atingir o cérebro e sistema nervoso (BARRON et al, 2007) O alprenolol, e a mianserina também são moléculas pequenas, com tamanho similar ao do octopamina e poderiam passar do intestino para a hemolinfa, ligando-se aos receptores de Octopamina, e podendo, a partir daqui, ter vários alvos diferentes.

\section{ACÕES DA OCTOPAMINA}

Pressume-se que nas abelhas, após a ingestão e absorção, os compostos circulem pelo corpo via hemolinfa para afetar os órgãos alvo (BARRON et al, 2007), onde a octopamina poderia atuar como um neurohormônio, agindo em receptores específicos existentes nas células alvo (ROEDER, 2005), como as células musculares. Em condições fisiológicas a octopamina pode atuar também, além de neurohormônio, como um neurotransmissor e um neuromodulador em insetos (ROEDER, 2005).

Uma vez na hemolinfa, não se pode afirmar em que órgãos ou sistemas exatamente as substâncias dos tratamentos atuariam, já que há receptores de Octopamina espalhados por quase todo o corpo das abelhas, e o tratamento oral com a octopamina expõe todos os tecidos das abelhas ao composto ingerido (BARRON et al, 2007). As alterações observadas na taxa metabólica e temperatura torácica, com o uso dos bloqueadores de receptores octopaminérgicos, poderiam estar relacionadas, por exemplo, a ações sobre o coração dorsal, sistema traqueal e mesmo músculos de vôo, que são órgãos com receptores de Octopamina (ROEDER et al, 2003; ROEDER, 2005). 
Ao longo do tempo dos experimentos é possível que a octopamina e seus subprodutos sejam filtrados pelos túbulos de Malpighi e se acumulem no intestino posterior (BEYENBACH, 2003; BARRON et al, 2007) e muitos compostos podem ser rapidamente excretados (BEYENBACH, 2003).

Seria interessante uma caracterização dos efeitos dos tratamentos ao longo de mais horas, para verificar a filtração e diminuição dos efeitos. Todavia, tal período seria de até 12 horas, caso se estivesse interessado nos efeitos sobre a taxa metabólica, devido à alteração diária do $\mathrm{VO}_{2}$, que diminui durante a fase de escuro ou durante a "noite subjetiva" do claro constante, como referido no capítulo 3, dificultando a interpretação dos resultados.

Segundo Scheiner et al. (2002), o ácido ascórbico $\left(\mathrm{C}_{6} \mathrm{H}_{8} \mathrm{O}_{6}\right)$ pode ser adicionado aos tratamentos envolvendo aminas biogênicas, como a octopamina, para minimizar a oxidação destas. Já Barron e Robinson (2005) não utilizam o ácido ascórbico na solução de sacarose ao administrar as aminas biogênicas. O tratamento "Alprenolol + Octopamina + Ácido ascórbico" não diferiu do grupo "Alprenolol + Octopamina" quanto à inclinação e intercepto ( $\mathrm{P}>0,05$; tabela 2), sugerindo que o ácido ascórbico na solução de sacarose não modifica os valores de taxa metabólica e QR. Possivelmente, o ácido ascórbico não influencia a oxidação das aminas biogênicas (SCHEINER $e t$ al., 2002), no que se refere ao que poderia ser verificado em relação a efeitos da octopamina em reverter os efeitos do alprenolol.

\section{EFEITOS DO BLOQUEIO}

$\mathrm{Na}$ figura 23 é apresentado um resumo dos efeitos de octopamina, methoprene e bloqueadores (alprenolol e mianserina) sobre a taxa metabólica, quociente respiratório, atividade enzimática e temperatura torácica de forrageadoras, com destaque para alguns pontos discutidos neste capítulo.

O alprenolol e a mianserina são moléculas com tamanho similar ao da octopamina, e poderiam passar pela parede do sistema digestório e ir para a hemolinfa, podendo a partir daqui ter diferentes alvos. Esses bloqueadores se ligariam aos receptores aos quais são antagonistas, no caso os receptores de octopamina em insetos, levando a uma diminuição da resposta intracelular decorrente das vias de segundo mensageiro ativadas pela ligação do agonista octopaminérgico.

Em insetos, no mesmo indivíduo, há diversos subtipos de receptores de octopamina, que podem ser ativados em paralelo (EVANS e MAQUEIRA, 2005). Tal co-ativação potencialmente pode levar a amplificações ou diminuição de diversas respostas celulares, podendo variar também de acordo com o tipo de receptor de amina biogênica e o tecido no qual está sendo expresso (EVANS e MAQUEIRA, 2005; ROEDER, 2005). A octopamina e o antagonista alprenolol 
fornecidos nos tratamentos poderiam se ligar de maneiras diferencias aos diversos tipos de receptores, levando a variações individuais e a diversas respostas intracelulares.

Agentes beta-bloqueadores em abelhas podem antagonizar os efeitos da octopamina, uma vez que os receptores de octopamina de insetos são considerados homólogos aos receptores adrenérgicos de vertebrados (BOUNIAS, 1986; ROEDER, 1995).

\section{EFEITOS DO BLOQUEIO NA VO}

Com relação ao grupo controle foram detectadas diferenças significativas nas comparações de valores de taxa metabólica dos grupos "Mianserina" e "Alprenolol" (em relação à inclinação e intercepto) e com os grupos "Alprenolol + Octopamina", "Alprenolol + Octopamina + Acido Ascórbico", "Mianserina + Octopamina", "Methoprene + Alprenolol", "Methoprene +Mianserina" (em relação a apenas o intercepto)

Com o emprego de alprenolol e mianserina foi observada diminuição da taxa metabólica, o que pode estar relacionado à menor estimulação de fluxo glicolítico, e diminuição da ativação das vias de segundo mensageiros. Isto, por sua vez, resulta na diminuição das respostas fisiológicas decorrentes da ativação de receptores de Octopamina, como pode ocorrer em resposta à ligação de Octopamina (WORM, 1980; EVANS, 1980, 1985, SUAREZ et al, 2005). A diminuição da taxa metabólica observada nas forrageadoras poderia estar relacionada, por exemplo, a ações sobre o coração dorsal, sobre o sistema traqueal e mesmo sobre os músculos de vôo, que são órgãos com receptores de Octopamina (ROEDER et al, 2003; ROEDER, 2005).

\section{EFEITOS COMPENSATÓRIOS DE OCTOPAMINA E METHOPRENE}

A especificidade da resposta octopaminérgica na termogênese e alteração da taxa metabólica nas abelhas é reforçada pela observação de que a octopamina parece, ao menos em parte, antagonizar os efeitos do Alprenolol e da Mianserina.

Nas comparações de VO2 e QR entre tratamentos, os grupos "Sacarose vs Alprenolol" e "Sacarose vs Mianserina" diferem com relação à inclinação e intercepto. Mas "Sacarose vs Alprenolol + Octopamina" e "Sacarose vs Mianserina + Octopamina" diferem apenas quanto ao intercepto, apresentando inclinações semelhantes (tabelas 2 e 4).

Ao analisar visualmente os gráficos (figuras 5 e 7) verifica-se que nos grupos “Alprenolol + Octopamina"e "Mianserina + Octopamina", após um certo tempo, os valores de taxa metabólica e QR tendem a subir novamente, além de aparente atraso na resposta de queda de taxa metabólica com bloqueador + octopamina. É interessante notar que quando a octopamina e o methoprene são adicionados aos bloqueadores, não há diferença de inclinação quando comparada com o grupo 
controle ("Sacarose"), provavelmente devido algum efeito compensatório, indicando possíveis efeitos "compensatórios" da octopamina.

Essas análises sugerem que, com o emprego de octopamina, os efeitos dos bloqueadores são atenuados, possivelmente por concorrência pelo receptor. O mesmo padrão ocorre nas comparações envolvendo o methoprene no lugar da octopamina. Seus efeitos podem estar relacionados à possível interação entre o Methoprene absorvido e a octopamina do animal.

Quando o Methoprene é ingerido com os bloqueadores, após cerca de 5-6h de tratamento a taxa metabólica diminuída começa a aumentar, podendo se relacionar a possíveis interações entre o Hormônio Juvenil (HJ) e a Octopamina, sugeridas para alguns grupos de insetos (THOMPSON et al, 1990; SCHULZ et al, 2001), e, indiretamente, “compensação" dos efeitos dos bloqueadores pela Octopamina.

O Methoprene é um análogo do hormônio juvenil (HJ) de insetos, sendo uma molécula maior do que a Octopamina e seus bloqueadores (Methoprene $=\mathrm{C}_{16} \mathrm{H}_{28} \mathrm{O}_{3}$ com peso molecular [FW] de 268,4 ao passo que a Octopamina é $\mathrm{C}_{8} \mathrm{H}_{11} \mathrm{NO}_{2}$ com peso molecular de 189,6). O HJ poderia aumentar os níveis cerebrais de Octopamina em abelhas (SCHULZ et al, 2001) e/ou a produção de HJ pelos corpora allata poderia ser modulada por tratamento com octopamina em baratas (THOMPSON et al, 1990).

Segundo Santana e Hartfelder (2002), machos de M. quadrifasciata apresentam títulos de HJ elevados em idades entre 5 e 10 dias de vida, relacionadas ao mecanismo de maturação sexual. Em operárias dessa espécie, os títulos de HJ parecem não estar relacionados à divisão de trabalho. Fatores exógenos, como por exemplo a nutrição, podem alterar os títulos de HJ na hemolinfa, ou ainda a síntese e secreção de aminas biogênicas. Condições externas e de dentro da colônia afetam os níveis de aminas biogênicas no sistema nervoso central de abelhas operárias; esses níveis, por outro lado, podem ajustar o desempenho de tarefas de operárias individuais por modulação dos níveis de hormônio juvenil (HJ) (HARTFELDER, 2000). O HJ em abelhas pode afetar o início do forrageio de abelhas, pelo menos em parte, ao aumentar os níveis cerebrais de octopamina (SCHULZ et al., 2001).

O prejuízo no vôo de abelhas Apis alatectomizadas (SULLIVAN et al, 2003) (com a retirada dos corpora allata, produtores de HJ) poderia ser consequiência das menores taxas metabólicas, refletindo desenvolvimento inadequado e/ou funcionamento inadequado dos músculos de vôo. A falha no vôo dessas abelhas poderia ocorrer porque a falta de HJ poderia provocar atrasos no desenvolvimento muscular ou provocar exaustão prematura no vôo, falhas na termogênese ou problemas na habilidade aprender/lembrar o local da colônia (SULLIVAN et al, 2003). Em abelhas forrageadoras Apis ocorrem níveis significantemente maiores das três aminas biogênicas do que em abelhas mais jovens, que trabalham dentro da colônia (WAGENER-HULME et al., 1999), o mesmo ocorrendo com o HJ 
(FAHRBACH, 1997; HUANG et al., 1994; ROBINSON et al., 1989). Este fato coincide com a atividade de vôo e com mudanças nutricionais (alimentação mais rica em carboidratos e mais pobre em proteínas) e modificações nas proteínas da hemolinfa, como a vitelogenina (AMDAM et al, 2003, 2004, 2006; OMHOLT e AMDAM, 2004; GUIDUGLI et al, 2005) nas forrageadoras.

Em A. mellifera Amdam et al (2003) abordam a expressão de vitelogenina, que estaria sob controle hormonal, não sendo sintetizada apenas pela rainha reprodutiva, mas também pelas operárias estéreis. À medida que as operárias ficam mais velhas, os seus níveis de HJ aumentam, coincidindo com alterações na produção de vitelogenina (AMDAM et al, 2003).

Segundo Santana e Hartfelder (2002), machos de M quadrifasciata apresentam títulos de HJ elevados em idades entre 5 e 10 dias de vida, relacionadas ao mecanismo de maturação sexual. Em operárias, o título de $\mathrm{HJ}$ parece não estar relacionado à divisão de trabalho. Interações entre HJ e octopamina nessa espécie não estão totalmente elucidadas.

O hormônio juvenil (HJ) tem sido considerado um regulador do desenvolvimento comportamental em abelhas melíferas (ROBINSON, 1992; HUANG e ROBINSON, 1995). As forrageadoras apresentam os níveis mais elevados de HJ, e as abelhas mais jovens, os menores. Mas operárias podem também iniciar o forrageio mesmo após allatectomia (SULLIVAN et al, 2000). Estes resultados sugerem que o HJ pode não ser essencial para o forrageio normal, mas constitui parte de uma rede de interações (AMDAM et al, 2006).

\section{TEMPERATURA TORÁCICA}

Nas abelhas tratadas com alprenolol e/ou octopamina os valores de temperatura tendem a diminuir. Possivelmente o efeito "compensatório" da octopamina, sobre os efeitos do alprenolol na temperatura torácica, diminui com o passar do tempo.

Uma grande evidência de ações de vias octopaminérgicas na termogênese de forrageadoras de . quadrifasciata seria diminuição da temperatura torácica de abelhas tratadas com o bloqueador Alprenolol. Todavia, é necessário cautela, pois não se pode afirmar se tais efeitos são decorrentes realmente da diminuição da termogênese (com ou sem tremor muscular) ou se são um sub-produto da diminuição da taxa metabólica. Os dados de temperatura torácica se referem à temperatura superficial (externa) do tórax das abelhas, e não à temperatura interna, uma vez que esse tipo de resultado é o que é possível com os termômetros infravermelhos utilizados. Assim, a taxa metabólica e a temperatura torácica superficial se complementam dando informações dos efeitos das substâncias administradas.

O termômetro empregado para as medições necessita que as abelhas sejam manipuladas juntamente com os recipientes de tule nos quais estão acondicionadas. Os valores de temperatura torácica podem ser, efetivamente, os valores que as abelhas manteriam na condição experimental 
ou estarem relacionados a um aquecimento pré-vôo para fuga. Estudos mais detalhados da temperatura torácica requerem materiais e métodos diferentes. Apesar desse eventual problema, nas abelhas tratadas com bloqueadores, a temperatura torácica é menor, sugerindo que há menor termogênese com o bloqueio dos receptores de octopamina.

A diminuição da temperatura torácica nas abelhas tratadas com Alprenolol coincide com os achados de Belzunces et al (1996). Segundo estes autores, uma via "adrenérgica" (octopaminérgica) pode estar envolvida diretamente na regulação central ou periférica da temperatura corpórea das abelhas. Baixas doses de agonistas não têm efeito, mas altas doses causam hipotermia, efeito que também ocorre no tratamento com Alprenolol. Segundo esses autores, um mecanismo semelhante ao beta-adrenérgico de vertebrados parece estar envolvido na termorregulação de abelhas melíferas e particularmente na termogênese. Os autores sugerem que mecanismos envolvendo "norepinefrina" (octopamina) são bons candidatos para o controle neural e metabólico da termorregulação nesses insetos, nos quais a localização exata dos centros de termorregulação não é conhecida (BELZUNCES et al, 1996). Há diversas semelhanças entre o sistema adrenérgico/noradrenérgico dos vertebrados e o sistema tiraminérgico/octopaminérgico dos insetos (EVANS, 1985, 1993; ROEDER, 1999, BLENAU e BAUMANN, 2001; ROEDER, 2005),

A termogênese nas abelhas em geral ocorre principalmente em duas situações, na produção de calor nos músculos torácicos de vôo para o aquecimento pré-vôo e para a regulação da temperatura dentro das colônias, principalmente na região dos discos de cria (termorregulação colonial). Em outras situações, as abelhas seriam ectotérmicas (sendo, assim, insetos endotermos heterotermos) (HEINRICH, 1979, 1993; KOVAC et al, 2007)

Na condição na qual as abelhas são submetidas para a obtenção da taxa metabólica (isoladas dentro das câmaras respirométricas), cálculo do QR e medição de temperatura torácica (recipientes de tule), não se pode afirmar que as abelhas iriam ter necessidade de produzir calor, e os efeitos detectados na taxa metabólica não seriam necessariamente relacionados à termogênese. A principal motivação para a termogênese poderia ser o aquecimento pré-vôo para a fuga. Todavia, supõe-se que passado um tempo após as abelhas serem colocadas na condição experimental, antes do início das medições, possa ocorrer aclimatação.

\section{QUOCIENTE RESPIRATÓRIO}

Com os bloqueadores alprenolol e mianserina poderiam ocorrer mudanças que alterassem a razão produção de $\mathrm{CO}_{2}$ /consumo de $\mathrm{O}_{2}$, provavelmente decorrente de alterações no substrato energético catabolizado, deixando de ser preferencialmente carboidratos, para ser uma mistura de outros substratos (lipídios e/ou proteínas) 
Uma vez que com Alprenolol e Mianserina os valores de $\mathrm{QR}$ tendem a ser menores do que 0,8, possivelmente há oxidação de uma mistura de substratos energéticos, com relevante contribuição de lipídios e proteínas, e não apenas carboidratos (como acontece nas abelhas tratadas com solução de sacarose 50\%, que apresentam QR próximo a 1,0).

Apesar de ser conhecido que as abelhas em geral utilizam principalmente carboidratos como substrato energético para o vôo, há evidências de que também seja importante o metabolismo do aminoácido prolina (MICHEU et al, 2000)

\section{ATIVIDADE ENZIMÁTICA}

Nas comparações com o grupo controle foi verificado que nas abelhas tratadas com mianserina ocorreu diminuição da atividade enzimática (Vmax) de hexoquinase (no tempo 1) e da Glicogênio Fosforilase total (no tempo 2) e aumento da Glicogênio Fosforilase ativa (no tempo 1) e da HOAD (nos tempos 1 e 2) (Figuras 21 e 22).

Diversos autores sugerem que insetos Hymenoptera, como as abelhas, utilizam principalmente carboidratos como fonte de energia, uma vez que esse substrato permite melhores desempenhos para vôos de curta duração tal como ocorre durante o forrageio das abelhas (SACKTOR, 1970; ROTHE e NACHTIGALL, 1989; FRANÇOSO-JÚNIOR, 1999; Suarez et al, 2005). Para sustentar vôos prolongados, a musculatura de vôo, exclusivamente aeróbica, depende de contínuo aporte de carboidratos, os quais, por razões de economia de espaço, não podem ser estocados em grandes quantidades (CRABTREE e NEWSHOLME, 1975; ROTHE e NACHTIGALL, 1989, FRANÇOSO-JÚNIOR, 1999).

As reservas de energia normalmente reduzidas em abelhas melíferas são compensadas por amplas reservas estocadas no mel das colônias, de forma que cada forrageadora apenas necessita estocar em seu corpo combustível suficiente para o vôo. A maior desvantagem é o atraso em mobilizar e transportar os substratos energéticos do proventrículo para os músculos de vôo (CANDY, 1989). Todavia, de uma perspectiva energética, o armazenamento de açúcares no sistema digestório pode ser considerado vantajoso, uma vez que a estocagem e subseqüente mobilização de reservas de glicogênio nos corpos gordurosos, ou até músculos, são energeticamente mais caras do que a utilização direta de açucares do proventrículo (WHEELER, 1989, LETA et al, 1996). As modificações nas vias metabólicas de estocagem de energia, produção e utilização permitem que os organismos tenham vantagens em condições favoráveis, e que possam sobreviver em condições desfavoráveis (NEWSHOLME e CRABTREE, 1986).

Neste item procurou-se entender como certas características fisiológicas podem ser modificadas em resposta aos tratamentos, e como isso se reflete na questão dos substratos energéticos utilizados, com alterações na Vmax de diversas enzimas. Como hipótese das principais 
alterações, podemos destacar os ajustes na concentração de estoques energéticos intracelulares e nos níveis e tipos de enzimas das vias glicolítica e aeróbia.

\section{HOAD E ÁCIDOS GRAXOS}

Foi detectada diferença significativa no Vmax de HOAD dos grupos Controle e Mianserina $(\mathrm{P}<0,05)$, que aumenta com o tratamento. A diferença não foi detectada com o bloqueador Alprenolol, somente com Mianserina. A vantagem deste último seria um bloqueio mais específico do receptor de octopamina, já que segundo Degen et al (2000) a mianserina é o bloqueador de octopamina com a maior afinidade pelo receptor.

É possível que, com o bloqueio pela mianserina, haja alterações que reflitam em maior beta oxidação lipídica, com possível uso de ácidos graxos como substratos energéticos, quando os valores de taxa metabólica e temperatura torácica são menores. A HOAD participa da oxidação de ácidos graxos e não foi detectável em extratos torácicos de abelhas Euglossine (SUAREZ et al, 2005) e de Melipona bicolor (FRANÇOSO-JÚNIOR, 1999). No caso de envolvimento de lipídios na termogênese, os ácidos graxos poderiam ser gerados por estimulação da lipólise por mecanismos de segundo mensageiros envolvendo AMPc, PKA e PKC (detalhes adiante), decorrentes de ativação de receptores de Octopamina, mas nas forrageadoras possivelmente a lipólise não é muito comum. Há indícios de possibilidade de oxidação de lipídios e outros substratos nas operárias em determinadas situações, uma vez que as abelhas em geral possuem corpos gordurosos, que contém também, além de trealose e prolina (MICHEU et al, 2000; HRASSNIGG et al, 2003) estoques de gorduras (SNODGRASS, 1956; ROBBS et al, 1985; CVACKA et al, 2006), que poderiam ser mobilizados em situações específicas.

Por meio do consumo de pólen as abelhas Apis podem obter os lipídios e ácidos graxos necessários, consumo este que varia ontogeneticamente, assim como a atividade lipolítica e a quantidade total de pólen e de ácidos graxos livres na região endoperitrófica da parede intestinal. As quantidades aumentam nos três primeiros dias de vida das abelhas, atingem o máximo em 8 dias de idade e então decrescem continuamente aos menores valores, detectados nas forrageadoras (LOIDL e CRAILSHEIM, 2001). Os lipídios são particularmente importantes para o desenvolvimento dos corpos gordurosos das abelhas no inverno (KUNERT e CRAILSHEIM, 1988; LOIDL e CRAILSHEIM, 2001).

\section{TREALASE}

Os mecanismos e vias relacionados à trealase se referem à utilização de carboidratos e à regulação dos níveis de açúcares na hemolinfa: com o aumento da taxa metabólica, o consumo de trealose aumenta, assim como a atuação da trealase. Isto leva a uma sinal de feedback ao 
proventrículo, que então libera mais solução de sacarose no ventrículo. A clivagem de sacarose no ventrículo permite que tanto glicose e frutose entrem na hemolinfa. A glicose é transformada em trealose nos corpos gordurosos, enquanto que a frutose é convertida à glicose na hemolinfa por uma hexoquinase ou fosfoglicoisomerase (CANDY et al, 1997). Todavia, não foram observadas diferenças significativas entre os grupos, com relação à trealase.

\section{GLICOGÊNIO FOSFORILASE}

Foi detectada diminuição da GPtotal (t2) e aumento da GP ativa (t1) no grupo tratado com Mianserina. Em abelhas A. mellifera açúcares da hemolinfa e estoques de glicogênio são fontes importantes de carboidratos para o metabolismo energético (LETA et al, 1996). As concentrações de glicogênio medidas por esses autores são baixas, como relatado por Neukirch (1982) e Harrison (1986), e consistente com os corpos gordurosos reduzidos de abelhas melíferas, comparado com outros insetos (DEAN et al, 1985; LETA et al, 1996).

Crabtree e Newsholme (1972) relatam que as atividades de glicogênio fosforilase nos músculos de vôo de A. mellifera são insuficientes para sustentar as taxas de fluxo glicolítico durante o vôo. Por outro lado, capacidades máximas para o quebra de glicogênio são suficientes para prover hexose fosfato a taxas requeridas para sustentar o vôo em abelhas Euglossinae (SUAREZ et al, 2005). Além disso, tem sido proposto que o glicogênio torácico pode ser utilizado para controlar as concentrações de hexose fosfato durante transições entre repouso e vôo (CRABTREE e NEWSHOLME, 1975; SAKTOR, 1976) ou estender a faixa de vôo (HARRISON, 1986) em abelhas melíferas. Todavia, esses dados se referem à atividade de vôo e preparo para o forrageio, não estando necessariamente ligados à termogênese.

$\mathrm{Na}$ literatura há algumas informações conflitantes a respeito das quantidades de reservas de glicogênio nos músculos de vôo de operárias de abelhas de diferentes idades e espécies. Por exemplo, Neukirch (1982) sugere que operárias de A. mellifera iniciando a sua fase de forrageio apresentam as maiores quantidades de glicogênio em seus músculos de vôo, e são capazes de repôlas. Uma forrageadora poderia sintetizar glicogênio até durante o vôo, uma habilidade também detectada em mosquitos (NAYAR e VAN HANDEL, 1971). Mas em abelhas sem ferrão, da espécie Scaptotrigona postiça, foi observado pouco glicogênio disponível, nas operárias forrageadoras, o que parece não afetar sua capacidade de vôo (ADADE e CRUZ-LANDIM, 2004).

Menor quantidade de glicogênio em forrageadoras de Scaptotrigona postica também foi detectada por Poiani e Cruz-Landim (2006), na fibra cardíaca de operárias. Os autores sugerem que quando o consumo de oxigênio é menor (por exemplo, em operárias que exercem funções dentro da colônia), há maior armazenamento de glicogênio devido sua menor utilização. E que a atividade de 
forrageio exige grande consumo de energia pelas forrageadoras as quais, portanto, se consomem mais, acumulam menos glicogênio na musculatura (POIANI e CRUZ-LANDIM, 2006).

Nas forrageadoras tratadas com a Mianserina, a Vmax de GP ativa era maior do que no grupo controle, o que estaria de acordo com maior utilização de glicogênio associado a um maior consumo de energia segundo Poiani e Cruz-Landim (2006), mas nas forrageadoras tratadas com Mianserina a taxa metabólica era menor. Por outro lado, a menor Vmax de GP total no grupo "Mianserina" é consistente com menor utilização de glicogênio, maior acúmulo e menores valores de taxa metabólica das abelhas segundo esses autores.

\section{PROTEÍNAS E AMINOÁCIDOS}

Apesar de ser conhecido que as abelhas em geral utilizam principalmente carboidratos como substrato energético para o vôo, há também evidências de que também seja importante o metabolismo do aminoácido prolina, que diminui na hemolinfa durante o vôo (MICHEU et al, 2000).

Em abelhas Euglossine (SUAREZ et al, 2005) a prolina poderia desempenhar função anaplerótica (por exemplo, aumentando intermediários do ciclo de Krebs) requerida para altas taxas de atividade do ciclo de Krebs (SACKTOR e CHILDRESS, 1967), sendo que malato é incapaz de desempenhar tal papel, segundo Suarez et al (2005). As funções anapleróticas são reações que ocorrem para repor os intermediários do ciclo do ácido cítrico ao serem removidos para servirem de precursores biossintéticos para outras reações.

A utilização de prolina em $M$. quadrifasciata não foi especificamente abordada neste trabalho, mas poderia estar inserida nos resultados de QR (entre 0,7 e 0,8 ) obtidos com tratamento com bloqueadores. Como sugestão, seria interessante o estudo de atividade enzimática de enzimas ligadas à utilização de prolina em abelhas.

A seguir estão apresentadas hipóteses de vias de oxidação de substratos energéticos e de mecanismos de ação intracelulares. Ressaltamos que os resultados do presente capítulo não confirmam todas as vias apresentadas nas figuras 24 a 26, as quais são hipóteses baseadas na literatura relacionada a abelhas.

\section{ESQUEMA DE VIAS DE OXIDACÃO DE SUBSTRATOS EM ABELHAS}

Hipóteses a respeito da utilização de diferentes substratos energéticos em abelhas estão expostos na figura 24 , em um esquema resumido de vias propostas para a sinalização e oxidação de substratos. Estão relacionados papéis desempenhados por reações mitocondriais e citoplasmáticas, no músculo de vôo, corpos gordurosos e na hemolinfa. Nem todas as reações estão incluídas. Estão indicadas possíveis atuações das enzimas utilizadas neste trabalho (HK, HOAD, TR e GP), bem 
como função anaplerótica da prolina (SUAREZ et al, 2005). O esquema foi elaborado com base principalmente em Suarez et al (2005) para A. mellifera, mas também em informações de Bloch (1994), Becher et al (1996), Françoso-Júnior (1999), Lorenz et al (1999; 2001), Bicker (1999), Schulz et al. (2001), Sinakevitch et al (2003) e Roeder (2005).

\section{RECEPTORES DE OCTOPAMINA E VIAS CELULARES}

A ativação ou inativação de receptores de octopamina em insetos pode gerar uma variedade de respostas celulares dependendo da via de segundos mensageiros envolvidos e do tipo celular. Estão apresentadas, na figura 25, hipóteses de vias intracelulares ativadas por receptores de aminas biogênicas em insetos, envolvendo proteínas G estimulatórias ou inibitórias e AMPc (figura 25A), e vias envolvendo proteína Gq/o e fosfolipase $C$, sinalização IP3/DAG e ciclagem de $\mathrm{Ca}^{2+}$ (figura 25B). O esquema é baseado em Farooqui et al (2004) e Blenau e Baumann (2001) para A mellifera e Drosophila melanogaster. A PKA e a PKC fosforilam uma variedade de alvos celulares, levando a diferentes respostas, de acordo com a situação e com o tipo de célula e, em abelhas, a PKA e a PKC desempenham diversos papéis na sinalização sensorial e aprendizagem (GRUMBAUM e MULLER, 1998; MULLER e HILDEBRANDT, 2002) e apresentam marcante expressão nos corpos cogumelo e nos lobos antenais de abelhas A. mellifera, neurópilos envolvidos no processamento de informação sensorial e antenal, e na aprendizagem e memória. A localização de PKA e PKC coincide com a ocorrência de octopamina e seus receptores no cérebro de abelhas $A$. mellifera (BICKER, 1999; GROHMANN et al, 2003; FAROOQUI et al, 2004; SINAKEVITCH et $a l, 2005)$, sendo assim mais uma pista de que os mecanismos intracelulares decorrentes da ativação de receptores de octopamina poderiam envolver essas quinases, conforme descrito acima. Além disso, indivíduos das três castas de abelhas Apis (rainha, operárias e zangões) apresentam expansão dos neurópilos dos corpos cogumelos em associação temporal com o início do vôo e essa expansão em abelhas pode estar associada com a aprendizagem da localização do ninho (FAHRBACH et al., 1997).

\section{CICLAGEM DE $\mathrm{Ca}^{2+}$}

Os detalhamentos das sinalizações relacionadas com o tremor muscular e com a termogênese sem tremor nas células de insetos não estão totalmente elucidados. Há a hipótese de que mudanças na concentração de $\mathbf{C a}^{2+}$ intracelular poderiam alavancar a termogênese (BLOCK, 1994; BLENAU e BAUMANN, 2001). Os íons $\mathrm{Ca}^{2+}$ desempenham papéis muito importantes na regulação de diversos processos celulares por meio de controle enzimático ou atividade por meio de canais iônicos. 
$\mathrm{Na}$ figura 26 estão esquematizados mecanismos de ação intracelulares, decorrentes de estimulação octopaminérgica em células musculares de insetos, envolvendo ciclagem de $\mathrm{Ca}^{2+}$, baseados em Bloch (1994), Lowell e Spiegelman (2001) e Blenau e Baumann (2001). Uma hipótese é que a estimulação da célula ocorra via inervações de porção termogênica dos músculos torácicos e/ou após estimulação de receptores por octopamina. Poderia haver estimulação por neurônios octopaminérgicos e pela octopamina deles liberada (atuação como neurotransmissor) ou presente na hemolinfa (atuando como neurohormônio, como poderia ocorrer no caso da ingestão de solução de sacarose contendo octopamina). Segundo Grohmann et al (2003) concentrações nanomolares a micromolares de octopamina induzem aumentos oscilatórios na concentração intracelular de $\mathrm{Ca}^{2+}$ (GROHMANN et al, 2003).

A estimulação poderia levar à despolarização e liberação de $\mathrm{Ca}^{2+}$ a partir de depósitos intracelulares (como retículo sarcoplasmático, RS), com aumento do $\mathrm{Ca}^{2+}$ citoplasmático, resultando em uma série de respostas celulares, com estimulação de processos oxidativos. Os ligantes no retículo sarcoplasmático podem ser, por exemplo, íons ou ácidos graxos, os quais também poderiam desempenhar, nas mitocôndrias, funções ligadas às proteínas desacopladoras (UCPs) (LOWELL e SPIEGELMAN, 2001). AS UCPs existem em insetos (FRIDELL et al, 2004), mas não foram atribuídas a elas funções termogênicas neste grupo, mas em alguns organismos unicelulares poderiam ser uma proteína de resposta ao frio (JARMUSZKIEWICZ et al. 2004), sugerindo que as suas atuações na resposta o frio não são restritas a mamíferos e aves.

Nem todos os hipotéticos mecanismos propostos na figura 26 existiriam em insetos, havendo a necessidade de dados bioquímicos e estruturais, que sugiram que a produção de calor em insetos possa estar relacionada com a liberação de $\mathrm{Ca}^{2+}$ de estoques citoplasmáticos, a proteínas desacopladoras e oxidação de diferentes substratos energéticos.

\section{CONCLUSÕES}

Os resultados obtidos neste trabalho fornecem evidências de efeitos de vias octopaminérgicas em M. quadrifasciata.

A diminuição da temperatura torácica em forrageadoras tratadas com Alprenolol sugere o envolvimento de vias octopaminérgicas na termogênese em M. quadrifasciata. Mas é necessário cautela já que não se sabe se tais efeitos são decorrentes de interferências na produção de calor ou um sub-produto da diminuição da taxa metabólica 
Os resultados não provam que há mecanismos de termogênese sem tremor muscular em abelhas, envolvendo octopamina e HJ, mas indicam um possível envolvimento destas substâncias na taxa metabólica e oxidação de diferentes substratos energéticos.

Com o bloqueio de receptores de octopamina podem ocorrer alterações na atividade de enzimas do músculo torácico de vôo, como a hexoquinase, HOAD e glicogênio fosforilase.

\section{REFERÊNCIAS BIBLIOGRÁFICAS}

ADADE, C.M. e CRUZ-LANDIM, C (2004). Differentiation and aging of the flight muscle in Scaptotrigona postica Latreille (Hymenoptera, Apidae) workers. Rev. Bras. Zool. 21(2): 379-384.

AMDAM GV, NORBERG K, HAGEN A, OMHOLT SW (2003) Social exploitation of vitellogenin. Proc Natl Acad Sci U S A. 100(4):1799-802.

AMDAM GV, et al. (2004). Hormonal control of the yolk precursor vitellogenin regulates immune function and longevity in honeybees. Exp Gerontol. 39(5):767-73.

AMDAM GV, et al (2006) Downregulation of vitellogenin gene activity increases the gustatory responsiveness of honey bee workers (Apis mellifera). Behav Brain Res. 169(2):201-5.

ARGYOPOULOS, G.; HARPER, M. (2002) Invited review: uncoupling proteins and thermoregulation. J. Appl. Physiol. 92: 2187-98.

BARTHOLOMEW, G.A. (1981) A matter of size: an examination of endothermy in insects and terrestrial vertebrates. In: Insect thermoregulation (B. Heinrich, ed.) Wiley-Interscience Publication, USA.

BECKER, A., SCHLODER, P., STEELE, J. E. and WEGENER, G. (1996). The regulation of trehalose metabolism in insects. Experientia 52,433 -439.

BELZUNCES, L.P.; VANDAME, R. And GU, X. (1996) Modulation of honeybee thermoregulation by adrenergic compounds. Neuroreport. 7(10):1601-4.

BERGMEYER, H.U. (1983) Methods of enzymatic analysis, vol 2. Enzymes. Verlag Chemic, Wheinheim.

BICKER, G (1999). Biogenic amines in the brain of the honeybee: cellular distribution, development, and behavioral functions. Microsc Res Tech. 44(2-3):166-78.

BLATT, J e ROCES, F. (2001) Haemolymph sugar levels in foraging honeybees (Apis mellifera): dependence on metabolic rate and in vivo measurement of maximal rates of trehalose synthesis. $\mathbf{J}$ Exp Biol 204: 2709-16.

BLENAU, W. and BAUMANN, A. (2001) Molecular and pharmacological properties of insect biogenic amines receptors: lessons from Drosophila melanogaster and Apis mellifera. Archives of Insect Biochemistry and Physiology 48: 13-38.

BLOCH, G.; SULLIVAN, J.P.; ROBINSON, G. (2002) Juvenile hormone and circadian locomotor activity in the honey bee Apis mellifera. J Insect Physiol 48(12): 1123-32.

BLOCK, B.A. (1994) Thermogenesis in muscle. Annu. Rev. Physiol. 56: 535-77.

CANDY, D.J.; BECKER, A.; WEGENER, G. (1997). Coordination and integration of metabolism in insect flight. Comp Biochem Physiol 117B(4): 497-512.

CALLEGARI-JACQUES, Sm. M. (2003) Bioestatística - Princípios e Aplicações. Artmed Editora S.A, São Paulo.

CARVALHO, J.E. (2004) Correlações entre as capacidades metabólicas energéticas, o ambiente térmico e a atividade em anfíbios anuros do gênero Scinax (Anura/Hylidae). Tese de Doutorado. Departamento de Fisiologia do IBUSP.

CHAUÍ-BERLINCK, J.G. e BICUDO, J.E. (2006) Respirometria - a técnica. Livraria Santos Editora Ltda.

CLARK, M.G.; et al (1973) Estimation of the fructose diphosphatase - phosphofructokinase substrate cycle in the flight muscle of Bombus affinisi. Biochem. J. 134: 589-97.

CRABTREE, B. and NEWSHOLME, E. A. (1972a). The activities of lipases and carnitine palmitoyltransferase in muscles from vertebrates and invertebrates. Biochem. J. 130,697 -705. 
CRABTREE, B. and NEWSHOLME, E. A. (1972b). The activities of phosphorylase, hexokinase, phosphofructokinase, lactate dehydrogenase and the glycerol 3-phosphate dehydrogenases in muscles from vertebrates and invertebrates. Biochem. J. 126, 49-58.

CRABTREE, B. and NEWSHOLME, E. A. (1975). Comparative aspects of fuel utilization and metabolism by muscle. In Insect Muscle (ed. P. N. R. Usherwood), pp.405 -491. London: Academic Press.

CRAILSHEIM, K (1990) The protein balance of the honey bee worker. Apidologie 21: 417-29.

CVACKA, J.; et al (2006). Analysis of triacylglycerols in fat body of bumblebees by chromatographic methods. J Chromatogr 1101(1-2):226-37.

DARCHEN, R. 1973. La thermoregulation et 1' ecologie de quelques especies d'abeilles sociales d'Afrique (Apidae, Trigonini et Apis mellifica Var. Adansonii). Apidologie, 4:341-370.

DEAN, R.L., LOCKE, M. and COLLINS, J.V., (1985). Structure of the fat body. In: Biochemistry and Pharmacology, G.A., Kerkut and Gilbert, L.I., Editors, 1985. Comprehensive Insect Physiology, Pergamonn Press, New York, pp. 155-210

DEGEN, J.; GEWECKE, M.; ROEDER, T. (2000) Octopamine receptors in the honey bee and locust nervous system: pharmacological similarities between homologous receptors of distantly related species. British Journal of Pharmacology 130, 587-594.

EVANS, P.D. (1980) Biogenic amines in the insect nervous system. Adv. Insect Physiol. 15: 317-473.

EVANS, P.D. (1985) Octopamine. In: Comprehensive insect physiology, biochemistry, and pharmacology (G.A. Kerkut and L.I Gilbert, eds.), vol 11: Pharmacology. Oxford, Pergamon Press, pp. 499-530.

EVANS, P.D. (1993) Molecular studies on insect octopamine receptors. In: Comparative molecular neurobiology (Y. Pichon, ed.) Basel, Birkháuser, pp. 286-296.

EVANS, P.D. e MAQUEIRA, B. (2005). Insect octopamine receptors: a new classification scheme based on studies of cloned Drosophila G-protein coupled receptors. Invert Neurosci. 5(3-4):111-8.

FAHRBACH, S.E. (1997) Regulation of age polyethism in bees and wasps by juvenile hormone. Adv. Study Behav. 26: 285-316.

FAHRBACH, S.E.; GIRAY, T.; FARRIS, S.M.; ROBINSON, G.E. (1997) Expansion of the neuropil of the mushroom bodies in male honeybees is coincident with initiation of flight. Neurosci. Lett. 236(3):135-8.

FRANÇOSO-JR, O A. (1999) Estudo comparativo do metabolismo aeróbico de Melipona bicolor Lepeletier (Hymenoptera: Apidae: Meliponinae). Tese de Doutorado, Instituto de Biociências da USP.

FRIDELL, Y.C.; SANCHES-BLANCO, A.; SILVIA, B.A.; HELFAND, S.L. (2004) Functional characterization of a Drosophila mitochondrial uncoupling protein. J Bioenergetics and Biomembranes 36(3):219-28.

Grohmann, L. et al (2003) Molecular and functional characterization of an octopamine receptor from honeybee (Apis mellifera) brain. J. Neurochem. 86(3):725-35.

GUIDUGLI, KR, et al (2005). Vitellogenin regulates hormonal dynamics in the worker caste of a eusocial insect. FEBS Lett. 579(22):4961-5.

HARRISON, J. M. (1986). Caste-specific changes in honeybee flight capacity. Physiol. Zool. 59,175 -187.

HEINRICH, B. (1980) Mechanims of body temperature regulation in honeybees, Apis mellifera. J Exp Biol 85: 61-87.

HEINRICH, B. (1993) The Hot-Blooded Insects. Cambridge, MA. Harvard University Press.

HEINRICH, B. (1979) Keeping a cool head: honeybee thermoregulation. Science 205: 1269-71.

HEINRICH, B. (1993) The Hot-Blooded Insects. Cambridge, MA. Harvard University Press.

HEINRICH, B. (1996) The thermal warriors: strategies of insect survival. Cambridge, Mass. Harvard University Press.

HEINRICH, S.D. e RAVEN, P.H. (1972) Energetics and pollination ecology. Science 176(4035): 597-602.

HOCHACHKA, P.; SOMERO, G.N. (1984) Biochemical adaptation. Princeton University Press.

HOCHACHKA, P.; SOMERO, G.N. (2002) Biochemical adaptation - mechanisms and process in physiological evolution. Oxford University Press.

HOMBERG, U. (2002) Neurotransmitters and neuropeptides in the brain of the locust. Microscopy Res and Tech 56: 189-209.

HRASSNIGG N.; LEONHARD, B, CRAILSHEIM, K. (2003). Free amino acids in the haemolymph of honey bee queens (Apis mellifera L.) Amino Acids.24(1-2):205-12. 
HRASSNIGG, N.; BRODSCHNEIDER, R et al (2005) Unlike nectar foragers, honeybee drones (Apis mellifera) are not able to utilize starch as fuel for flight. Apidologie 36: 547-57.

HUANG, Z.-Y., ROBINSON, G.E. and BORST, D.W (1994) Physiological correlates of division of labor among similarly aged honey bees. J. Comp. Physiol. A 174: 731-739.

LETA, M.A.; GILBERT C.; MORSE R.A. (1996) Levels of Hemolymph Sugars and Body Glycogen of Honeybees (Apis mellifera L.) from Colonies Preparing to Swarm. Journal of Insect Physiology, 42(3): 239-245(7).

LOIDL, A; CRAILSHEIM, K (2001) Free fatty acids digested from pollen and triolein in the honeybee (Apis mellifera carnica Pollmann) midgut. J Comp Physiol [B]. 171(4):313-9

LORENZ, M.W. et al (1999). Hypertrehalosemic peptides in the honeybee (Apis mellifera): purification, identification and function. J Insect Physiol 45(7): 647-53.

LOWELL, B.B.; SPIEGELMAN, B.M. (2000) Towards a molecular understanding of adaptive thermogenesis.Nature.404 (6778):652-60.

MICHENER, C.D. (1974) The social behavior of the bees. Cambridgs, Massachusts: The Belknap Press of Harvard University Press.

MICHEU, S.; CRAILSHEIM, K.; LEONHARD, B. (2000) Importance of proline and other amino acids during honeybee flight. Amino Acids 18: 157-75.

NAYAR, J.K. e VAN HANDEL, E (1971) The fuel for sustained mosquito flight. J. Insect Physiol 17: 471-81.

NEUKIRCH, A (1982) Dependence of the life span of the honeybee (Apis mellifica) upon flight performance and energy consumption. J Comp Physiol B 146(1): 35-40.

NEWSHOLME, E.A. et al (1972) The activities of fructose diphosphatase in flight muscles from the bumblebee and the role of this enzyme in heat generation. Biochem. J. 128: 89-97.

NEWSHOLME, E.A e CRABTREE, B (1986) Maximum catalytic activity of some key enzymes improvision of physiologically useful information about metabolic flux. J Exp Biol 239(2): 15967

OMHOLT SW, AMDAM GV (2004) Epigenetic regulation of aging in honeybee workers. Sci Aging Knowledge Environ (26):pe28.

PACHECO, R.L.F.; KERR, W.E. (1989) Temperaturas em abelhas da espécie Melipona compressipes fasciculata. Ciên. E Cult 41(5): 490-5.

POIANI, S.B.; CRUZ-LANDIM, C. (2006) Histologia e ultra-estrutura do vaso dorsal de Scaptotrigona postica (Hymenoptera, Apidae) em operárias e rainhas de diferentes idades. Iheringia, Ser. Zool. 96(1)

ROBINSON, G.E., PAGE, J.RE., STRAMBI, C.; STRAMBI, A. (1989) Hormonal and genetic control of behavioral integration in honey bee colonies. Science 246: 109-12.

ROEDER, T. (1995). Pharmacology of the octopamine receptor from locust central nervous tissue (OAR3). Br J Pharmacol. 114(1):210-6.

ROEDER, T. (1999) Octopamine in invertebrates. Prog. Neurobiol. 59: 533-61.

ROEDER, T. (2005) Tyramine and octopamine: ruling behavior and metabolism. Annu Rev Entomol 50: 447-77.

ROTHE, U.; NACHTIGALL, W (1989) Flight of the honeybee. IV Respiratory quotients and metqbolic rate during sitting, walking and flying. J Comp Physiol 158: 739-49.

ROUBIK, D.W.; PERALTA, F.J.A. (1983) Thermodinamics in nests of two Melipona species in Brazil. Acta Amaz 13(2): 453-66.

SACKTOR, B. (1976). Biochemical adaptations for flight in the insect. Biochem. Soc. Symp. 41,111 -131

SACKTOR, B e CHILDRESS, C.C. (1967) Metabolism of proline in insect flight muscle and its significance in stimulating the oxidation of of pyruvate. Arch. Biochem. Biophys. 120: 583 -588

SANTANA, W.C.; HARTFELDER, K. (2002) Hormônio juvenil e ecdisteróides na vida adulta de machos, rainhas e operárias de Melipona quadrifasciata Lep (Apidae. Meliponinae): relação com a reprodução e divisão de trabalho. Dissertação de Mestrado, FFCLRP, SP.

SCHULZ, D. J.; ROBINSON, G. E. (2001). Octopamine influences division of labor in honey bee colonies. J. Comp. Physiol. A 187: 53-61.

SCHULZ, D.J.; SUlLIVAN, J.P.; ROBINSON, G. (2002) Juvenile hormone and octopamine in the regulation of division of labor in honeybees colonies. Horm Behav 42(2): 222-31.

SCHEINER, R. et al (2002) Behavioural pharmacology of octopamine, tyramine and dopamine in honey bees. Behavioural Brain Research 136: 545-53. 
SIDELL, B.D.; CROCKETT, E.L.; DRIEDZICK, W.R. (1995). Antartic fish tissues preferencially catabolize monoenoic fatty acids. J Exp Zool 271: 73-81.

SINAKEVITCH, I.; NIWA, M.; STRAUSFELD, N. (2005) Octopamine like- immunoreactivity in the honeybee and cockroach: comparable organization in the brain and subesophageal ganglion. $\mathbf{J}$ Comp Neurol 488: 233-54.

SNODGRASS, R.E. (1956) Anatomy of the honey bee. Comstock Publishing Associates, Cornell University, New York.

SOKOLOVA, I.M.; SOKOLOV, E.P. (2005) Evolution of mitochondrial uncoupling proteins: novel invertebrate UCP homologues suggest early evolutionary divergence of the UCP family. FEBS Letters 579: 313-7.

SUAREZ, R.K.; LIGHTON, J.R.B.; JOOS, B.; ROBERTS, S.P. ; HARRISON, J.F. (1996) Energy metabolism, enzymatic flux capacities, and metabolic flux rates in flying honeybees. Proc Natl Acad Sci USA 93: 12616-20.

SUAREZ, R.K.; et al (2005) Energy metabolism in orchid bees flight muscles: carbohydrate fuels all. J Exp Biol 208: 3573-9.

SUAREZ, R.K.; DARVEAU, CA; HOCHACHKA, P.W. (2005). Roles of hierarchical and metabolic regulation in the allometric scaling of metabolism in Panamanian orchid bees.. J Exp Biol. 208(Pt 18):3603-7.

SULLIVAN, J.P.; et al (2003) Juvenile hormone and division of labor in honey bees colonies: effects of allatectomy on flight behavior and metabolism. J Exp Biol 206: 2287-96.

SULLIVAN, J.P.; JASSIM, O ; FAHRBACH, S.; ROBINSON, G. (2000) Juvenile hormone paces behavioral development in the adult worker honey bee. Hormones and Behavior 37: 1-14.

SULLIVAN, J.P.; FAHRBACH, S.; Harrison, J.F.; CAPALDI, E.; FEWELL, J.; ROBINSON, G. (2003) Juvenile hormone and division of labor in honey bees colonies: effects of allatectomy on flight behavior and metabolism. J Exp Biol 206: 2287-96.

THOMPSON, C.S.; YAGI, K.J.; CHEN, Z.F. and TOBE, S.S. (1990) The effects of octopamine on juvenile hormone biosynthesis, electrophysiology, and cAMP content of the corpora allata of the cockroach Diploptera punctata. J._Comp. Physiol. B. 160(3): 241-9

VIEIRA, S. (2003) Bioestatística - Tópicos Avançados. Editora Campus Ltda, Rio de Janeiro.

WAGENER-HULME, C.; et al (1999) Biogenic amines and division of labor in honey bee colonies. J. Comp. Physiol. A, 184: 471-479

WITHERS, P.C. (1977) Measurement of $\mathrm{VO}_{2}, \mathrm{VCO}_{2}$ and evaporative water loss with a flow through mask. J Appl Physiol 42(1): 120-3.

ZAR, J.H. (1999) Biostatistical analysis. Upper Saddle River, N.J : Prentice Hall

ZUCCHI, R.; SAKAGAMI, S.F. (1972) Capacidade termo-reguladora em Trigona spinipes e em algumas outras espécies de abelhas sem ferrão (Hymenoptera: Apidae: Meliponinae), p. 301-309. In: C. Cruz-Landim; N.J. Hebling,; E. Lello \& C.S. Takahashi (Eds). Livro em Homenagem a Warwik Estevan Kerr. Rio Claro, Ed. UNESP.

ZUCCHI, R.; SILVA-MATOS, E. V. D NOGUEIRA-FERREIRA, F. H.; AZEVEDO, G. G. (1999). On the cell provisioning and oviposition process (POP) of the stingless bees nomenclature reappraisal and evolutionary considerations (Hymenoptera, Apidae, Meliponinae). Sociobiology 34(1):65-86 


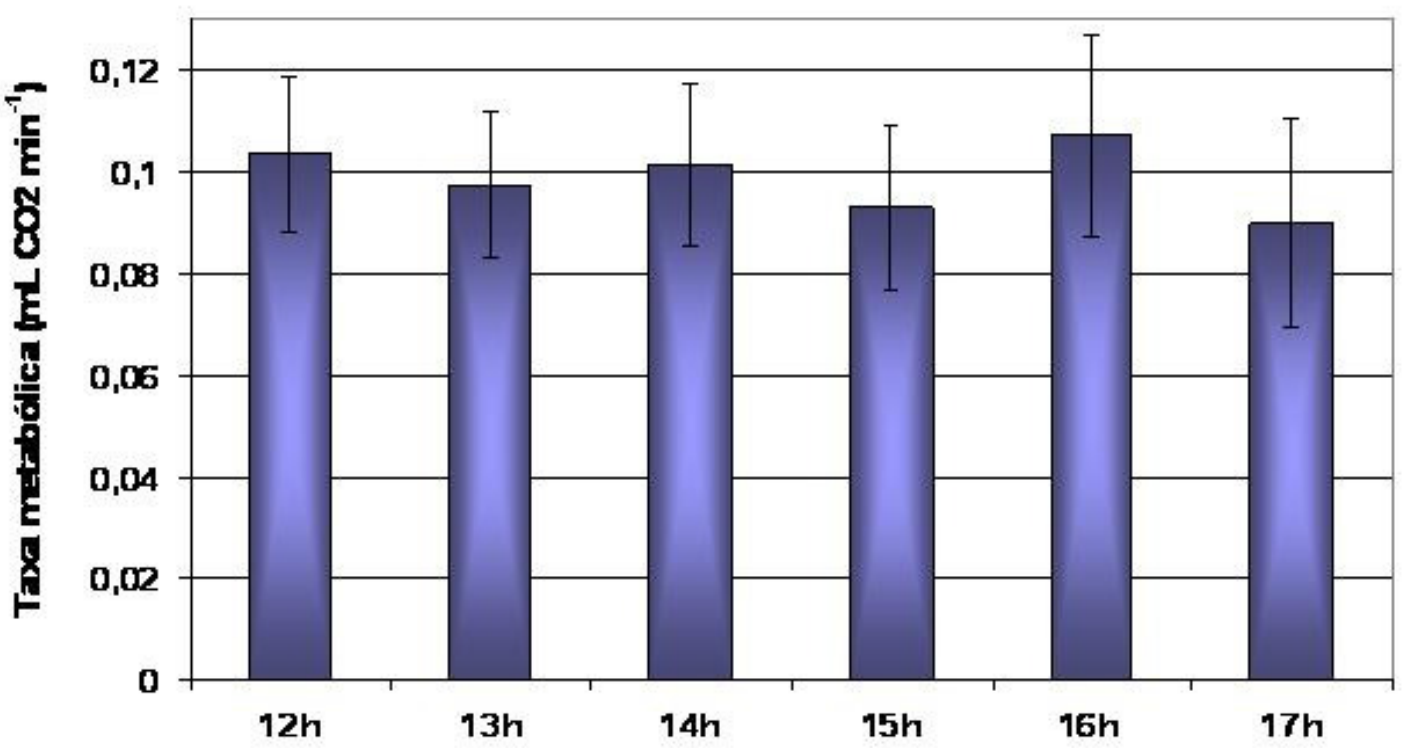

Figura 1. Taxa metabólica ( $\mathrm{mL} \mathrm{CO} \mathrm{CO}_{2} \mathrm{~min}^{-1}$ ) de forrageadoras do grupo controle ou "Sacarose", tratadas com solução de sacarose $50 \%$ e mantidas a $22^{\circ} \mathrm{C}$. $\mathrm{N}=7$ para cada horário. Não foi detectada diferença estatisticamente significativa entre os horários, segundo o teste de Kruskall-Wallis $(\mathrm{H}=4,917 ; \mathrm{p}=0,4261)$ e o teste de Dunn ( $\mathrm{p}>0,05$ ), indicando que entre $12 \mathrm{~h}$ e $17 \mathrm{~h} 59$ não há variação significativa da taxa metabólica..

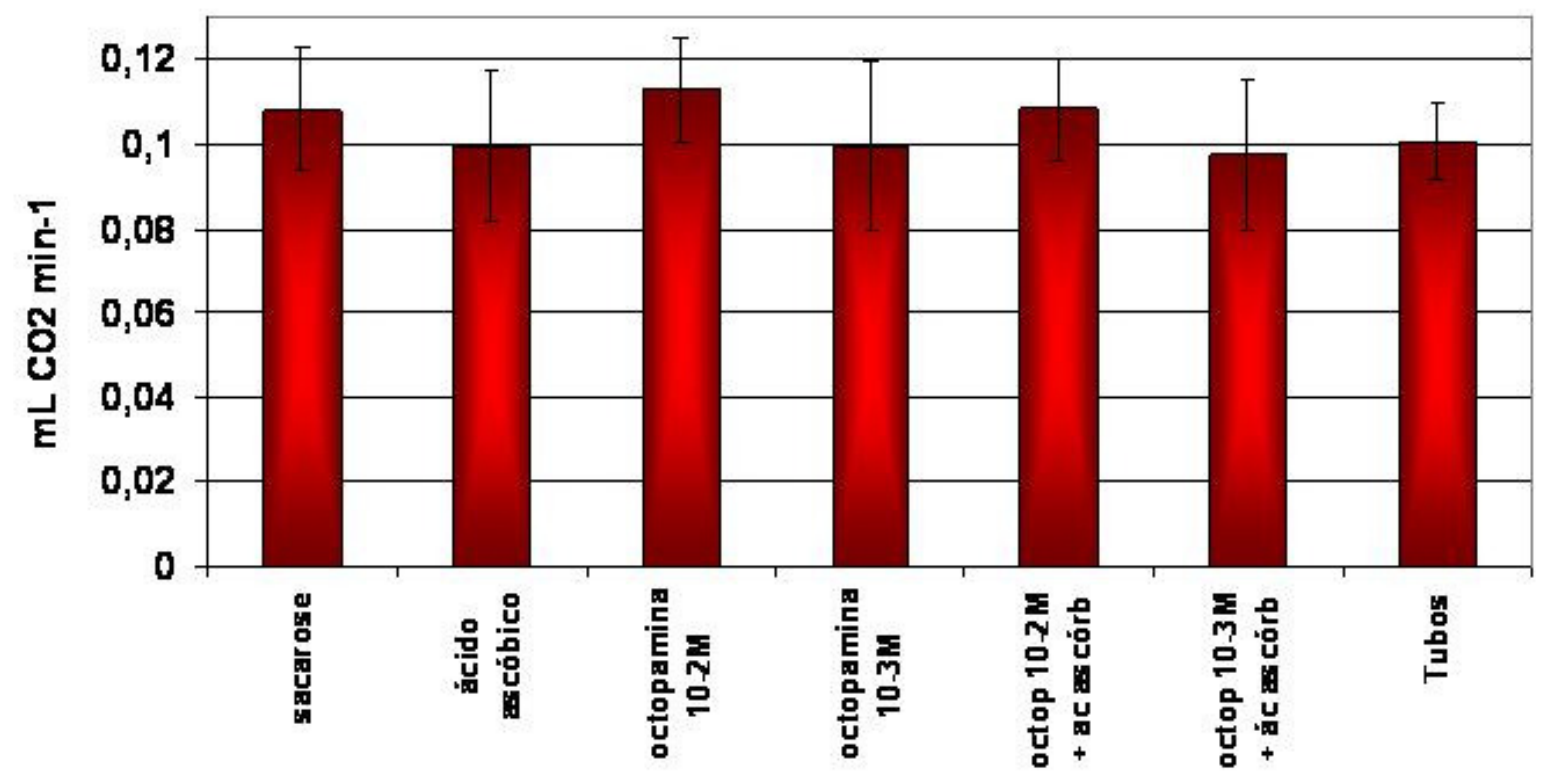

Figura 2. Taxa metabólica ( $\mathrm{mL} \mathrm{CO}_{2} \mathrm{~min}^{-1}$ ) de forrageadoras na situação "Sacarose" (tratadas com solução de sacarose 50\%) e também submetidas a diferentes tratamentos com ácido ascórbico e octopamina. Não foi detectada diferença estatisticamente significativa entre os tratamentos, segundo o teste de Kruskall-Wallis $(\mathrm{H}=4,519 ; \mathrm{p}=0,6069)$ e o teste de Dunn $(\mathrm{p}>0,05)$, indicando que a octopamina e o ácido ascórbico não alteram significantemente a taxa metabólica 


\section{COMPARACÕES INTRA-TRATAMENTOS: Sacarose (arupo controle)}

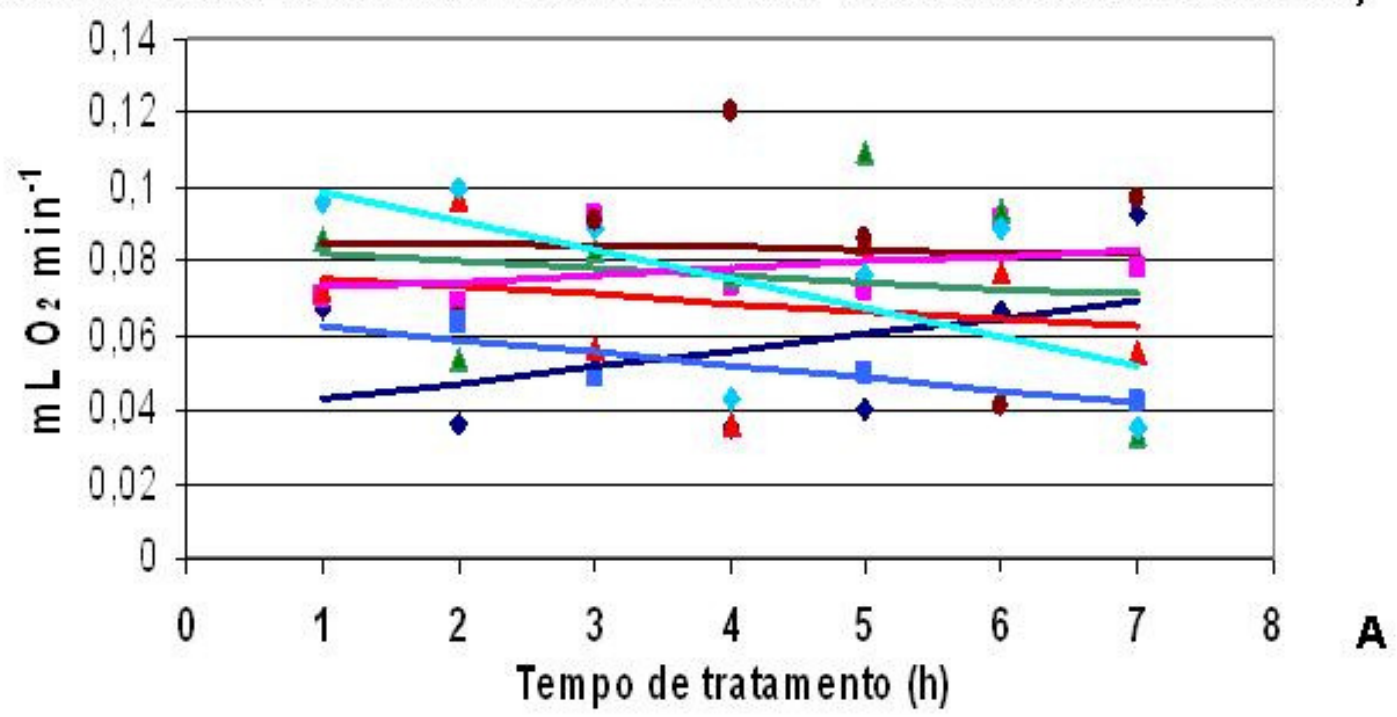

Inclinação: diferenças não significativas $(\mathrm{P}=0.5567)$.

Interc epto: diferenças não significativas $(\mathrm{P}=0.1408)$.

É possivivel calcular uma inclinação $(-0,001265)$ e um intercepto $(0,076)$ para todos os dados Inclinações não significantemente diferentes de zero $(\mathrm{P}>0,05)$

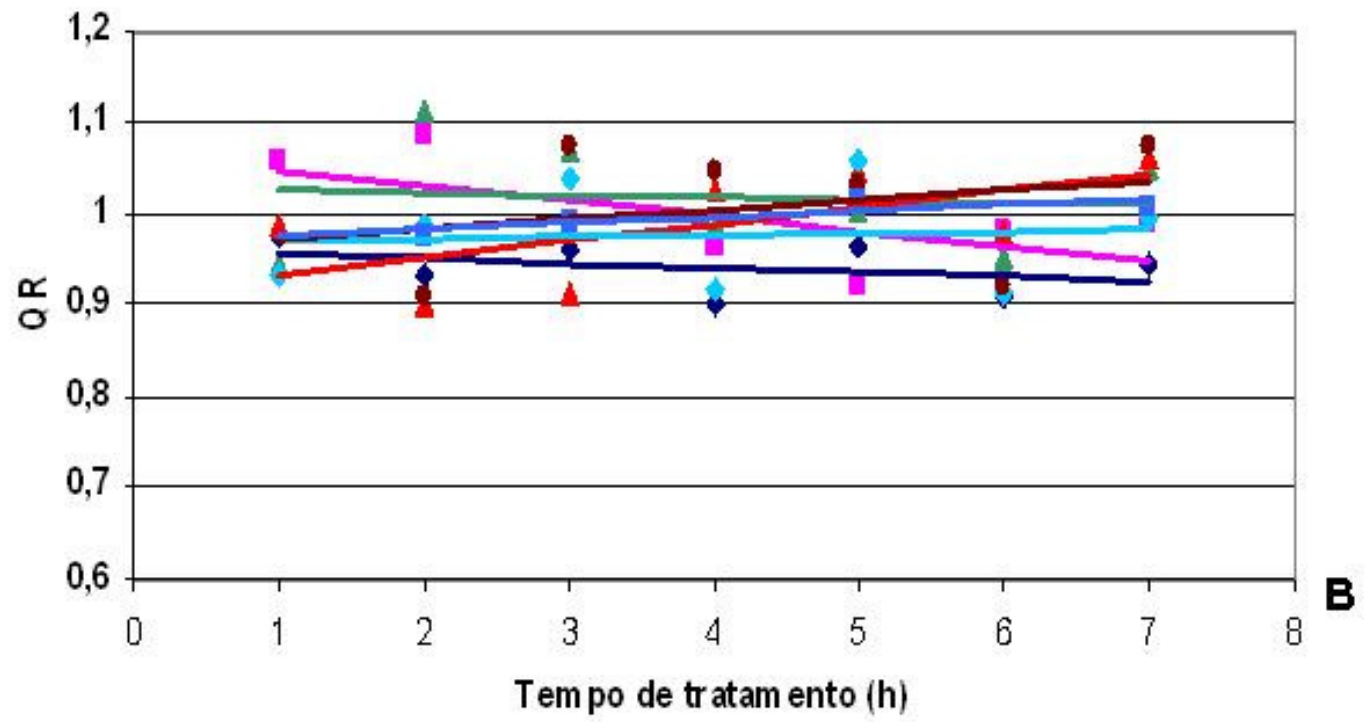

Inclinação: diferenças não significativas $(\mathrm{P}=0.4128)$

Interc epto: diferenças não significativas $(\mathrm{P}=0.2702)$

É possivel calcular uma inclinação $(0.000977026)$ e um intercepto $(0.985462)$ para todos os dados Inclinações não signific antemente diferentes de zero $(P>0,05)$

Figura 3. Comparaçôes intra-tratamento, com verificação de similaridade de inclinação e intercepto dos valores de taxa metabólica $\left(\mathrm{mL} \mathrm{O}_{2} \mathrm{~min}^{-1}\right)(\mathrm{A})$ e de quociente respiratório $(\mathrm{QR})(\mathrm{B})$ de forrageiras tratadas com solução de sacarose $50 \%$ (Grupo controle ou "Sacarose"). N=7 
COMPARAÇÕES INTRA-TRATAMENTOS: Mianserina

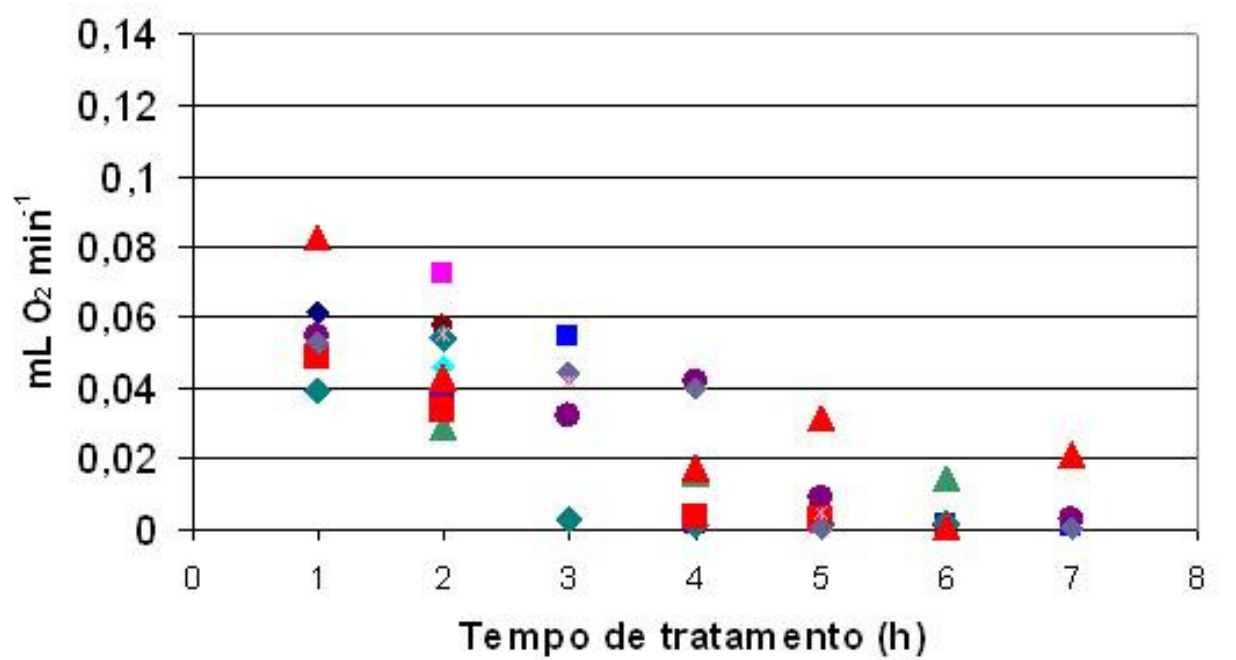

A

Inclinação: diferenças não significativas $(\mathrm{P}=0.7215)$

Interc epto: diferenças não significativas ( $\mathrm{P}=0.5767)$

É possivivel calcular uma inclinação $(-0,0108859)$ e um intercepto $(0.0681017)$

para todos os dados

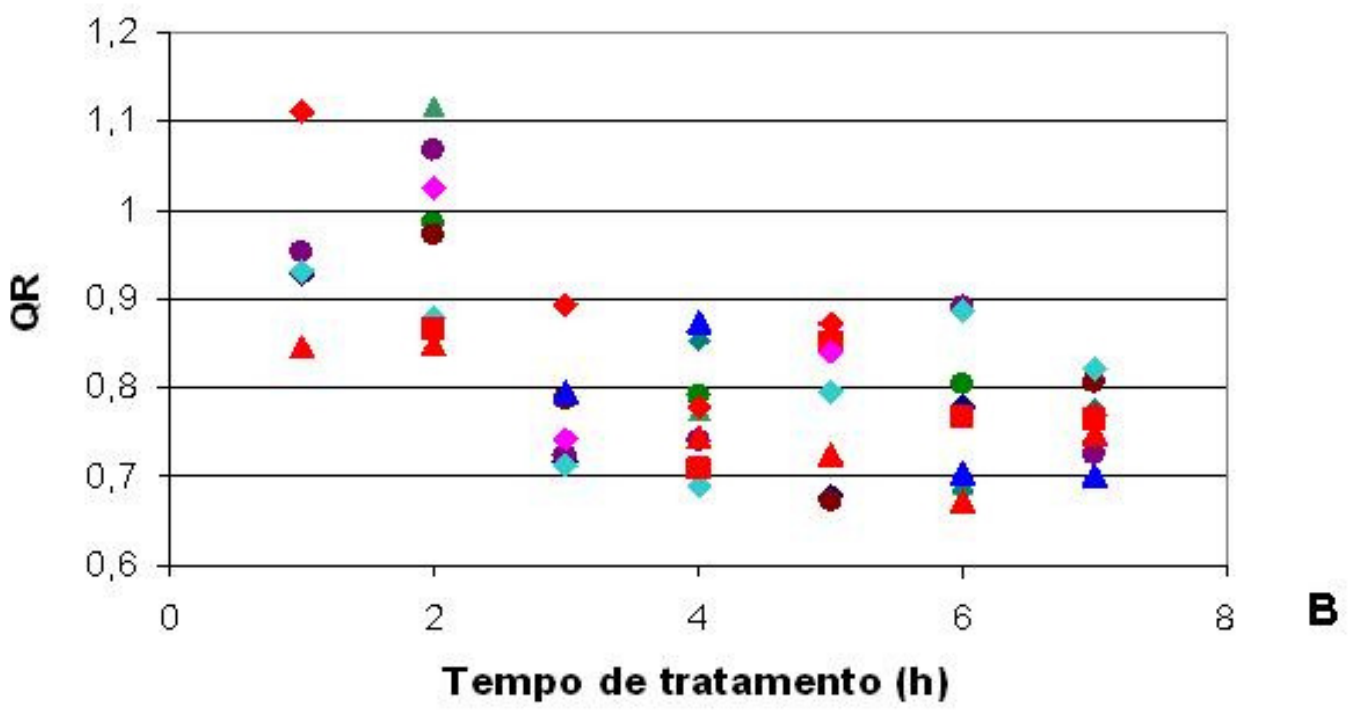

Inclinação: diferenças não significativas $(\mathrm{P}=0.7691)$

Intercepto: diferenças não significativas $(\mathrm{P}=0.8461)$

É possível calcular uma inclinação $(-0,0342688)$ e um interc epto (0.956986)

para todos os dados

Figura 4. Comparações intra-tratamento, com verificação de similaridade de inclinação e intercepto dos valores de $\mathrm{VO}_{2}(\mathrm{~A})$ e de $\mathrm{QR}(\mathrm{B})$ de forrageadoras tratadas com Mianserina. Neste, e nos gráficos das figuras 5 a 10 , as retas de regressão não estão apresentadas para melhor visualização dos pontos de dados. 


\section{COMPARAÇÕES INTRA-TRATAMENTOS: Mianserina + Octopamina}

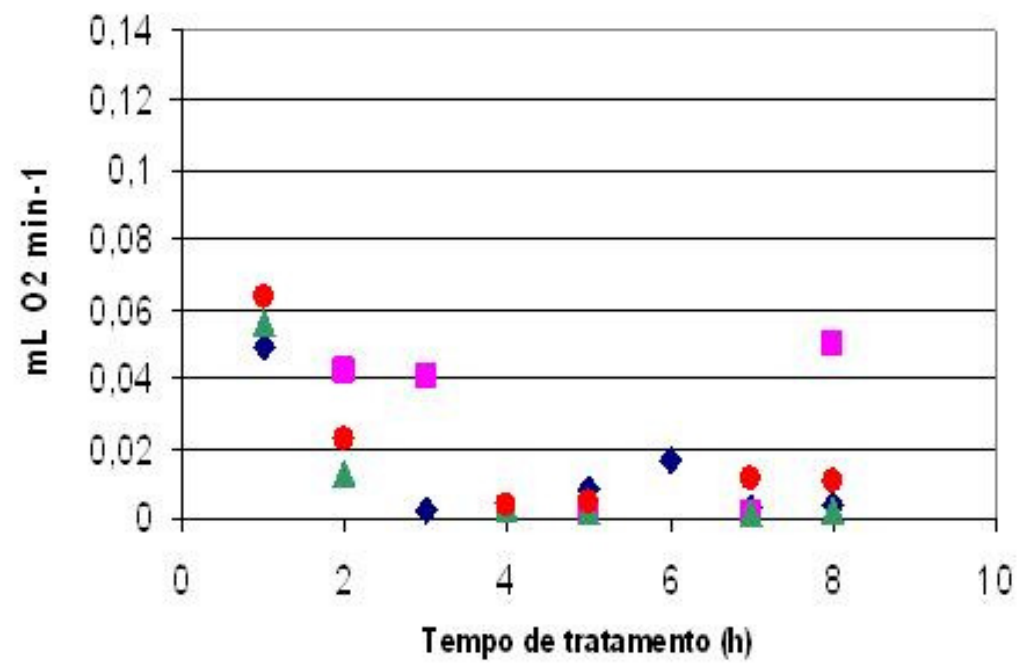

A

Inclinação: diferenças não significativas $(\mathrm{P}=0.8749)$

Interc epto: diferenças não significativas $(\mathrm{P}=0.4551)$

É possivel calcular uma inclinação $(-0,0048047)$ e um intercepto $(0.0408604)$

para todos os dados

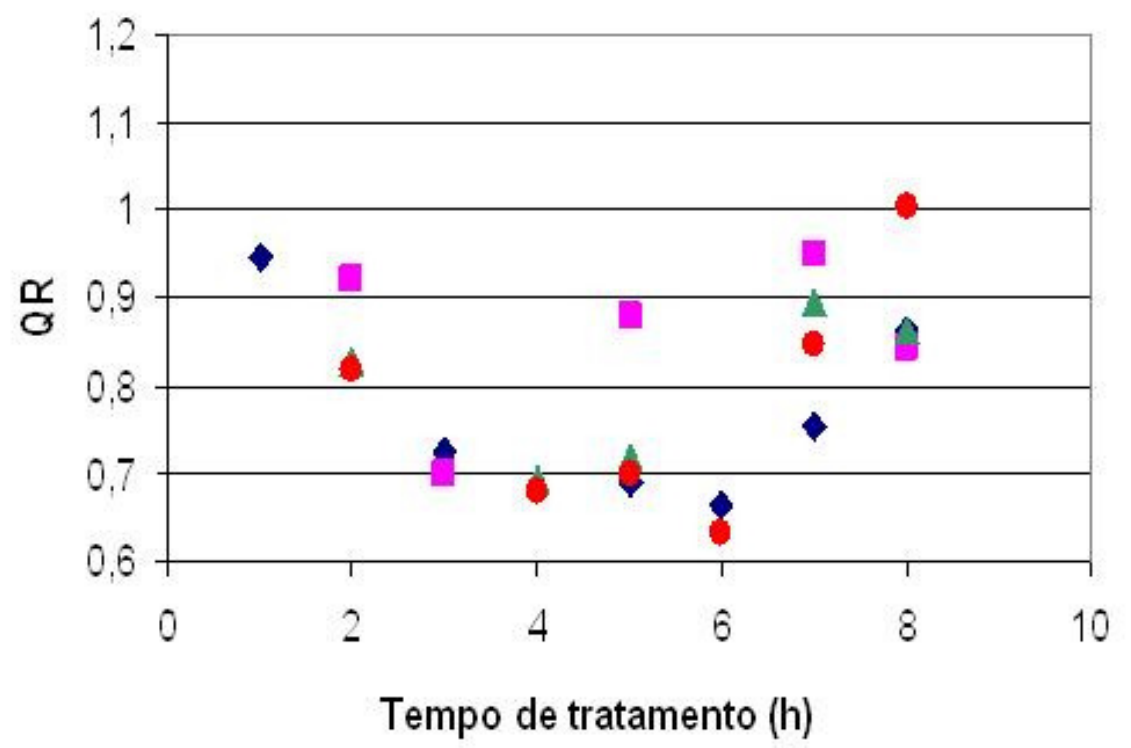

B

Inclinação: diferenças não significativas $(\mathrm{P}=0.575)$

Interc epto: diferenças não significativas $(\mathrm{P}=0.6096)$

É possivel calcular uma inclinação $(0.00791376)$ e um intercepto $(0.76026)$

para todos os dados

Figura 5. Comparações intra-tratamento, com verificação de similaridade de inclinação e intercepto dos valores de $\mathrm{VO} 2$ (A) e de $\mathrm{QR}$ (B) de forrageadoras tratadas com Mianserina + Octopamina. 
COMPARAÇÕES INTRA-TRATAMENTOS: Alprenolol

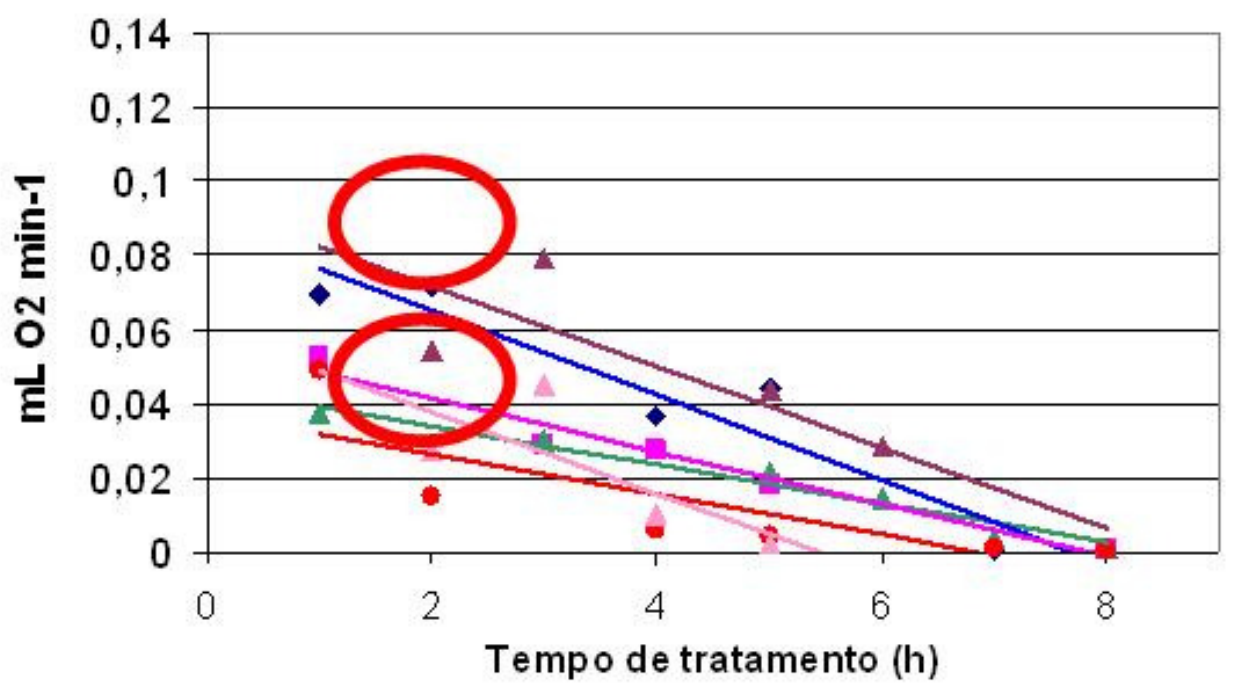

A

Inclinação: diferenças não significativas $(\mathrm{P}=0.2312)$

É possivel calcular uma inclinação (-0.00781569) para todos os dados Intercepto: diferenças significativas $(\mathrm{P}=0.0009269)$ Interceptos: ANOVA: $[\mathrm{A}$ e D ] e $[\mathrm{B}, \mathrm{C}, \mathrm{D}, \mathrm{E}, \mathrm{F}]$

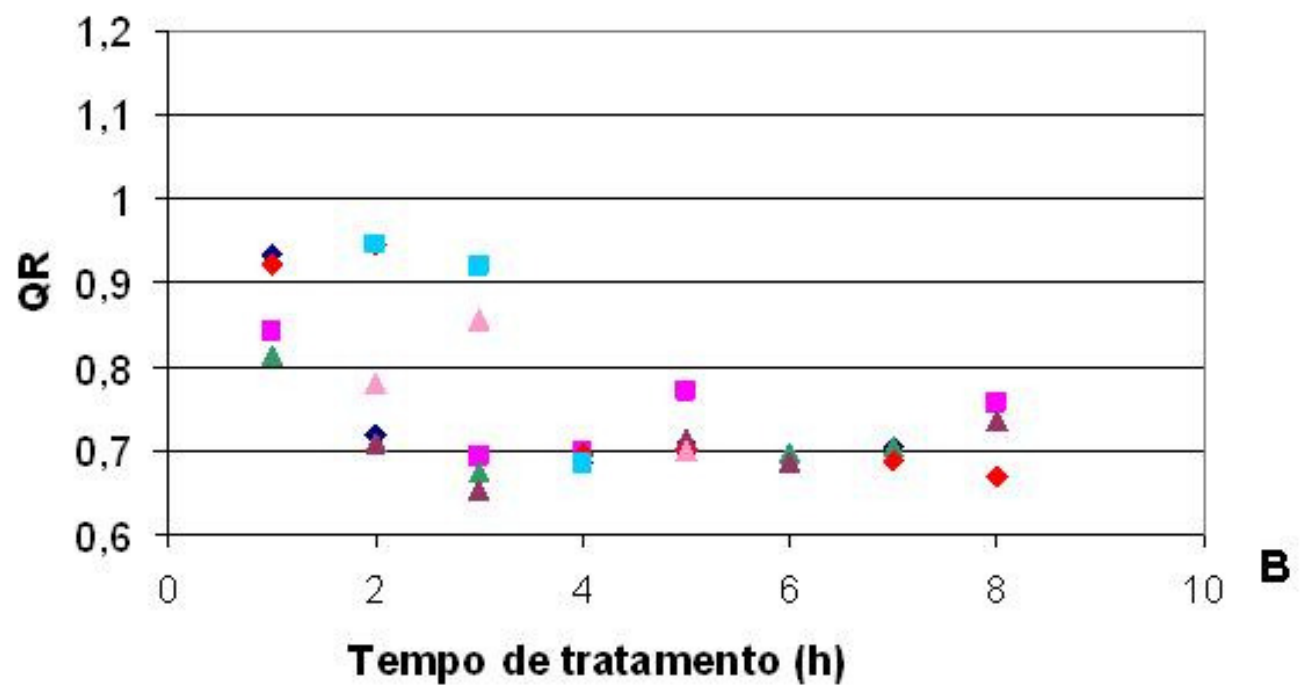

Inclinação: diferenças não significativas $(\mathrm{P}=0.3818)$

Interc epto: diferenças não significativas $(\mathrm{P}=0.7843)$

É possivel calcular uma inclinação (-0.0249008) e um intercepto (0.861403) para todos os dados

Figura 6. Comparações intra-tratamento, com verificação de similaridade de inclinação e intercepto dos valores de VO2 (A) e de QR (B) de forrageadoras tratadas com Alprenolol. 
COMPARAÇÕES INTRA-TRATAMENTOS: Alprenolol + Octopamina

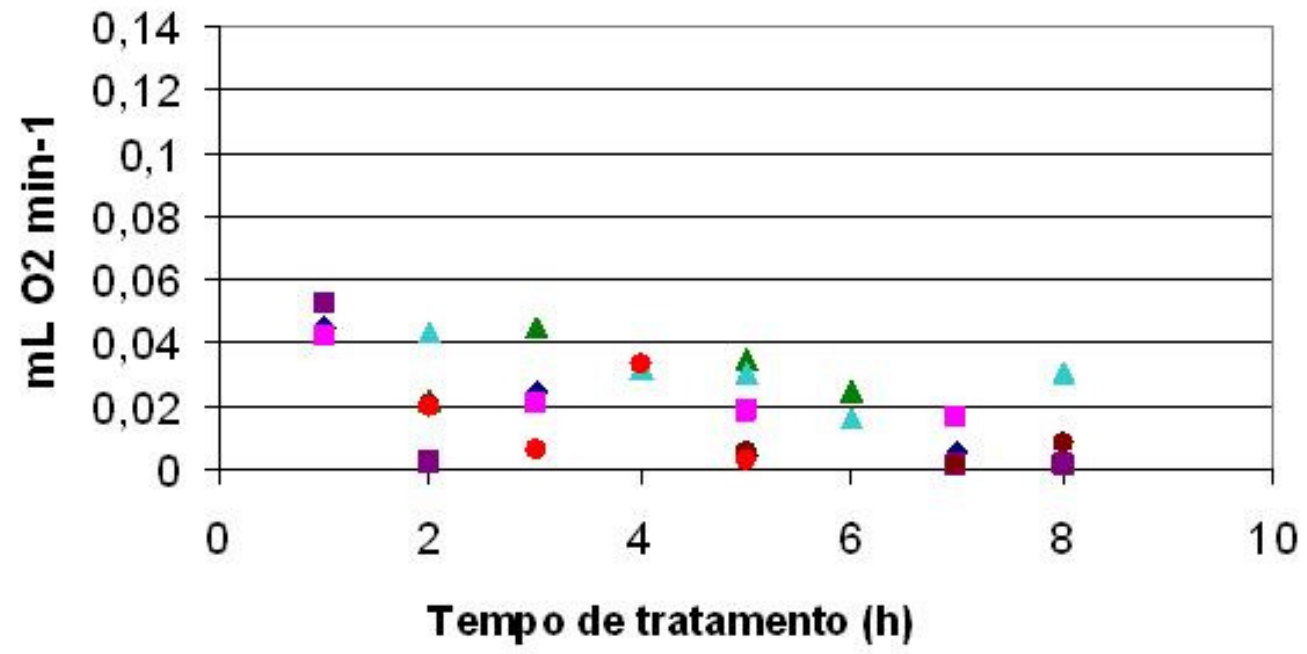

A

Inclinação: diferenças não significativas $(\mathrm{P}=0.9405)$

Interc epto: diferenças não significativas $(\mathrm{P}=0.1012)$

É possivel calcular uma inclinação $(-0.00422401)$ e um intercepto $(0.0393666)$

para todos os dados

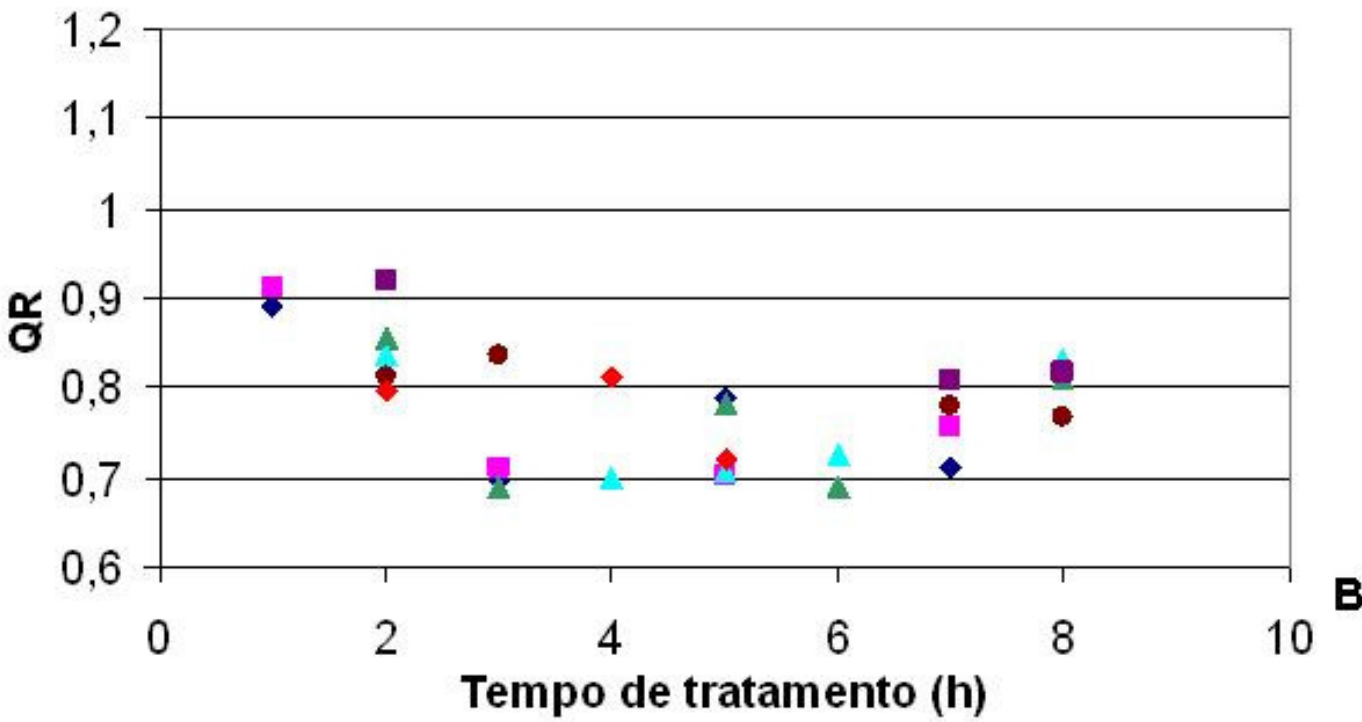

Inclinação: diferenças não significativas $(\mathrm{P}=0.887)$

Intercepto: diferenças não significativas $(\mathrm{P}=0.4528)$

É possivel calcular uma inclinação (-0.0126707) e um intercepto (0.839103)

para todos os dados

Figura 7. Comparações intra-tratamento, com verificação de similaridade de inclinação e intercepto dos valores de $\mathrm{VO} 2$ (A) e de $\mathrm{QR}$ (B) de forrageadoras tratadas com Alprenolol + Octopamina. 
COMPARAÇÕES INTRA-TRATAMENTOS: Alprenolol + Octopamina + Ácido ascórbico

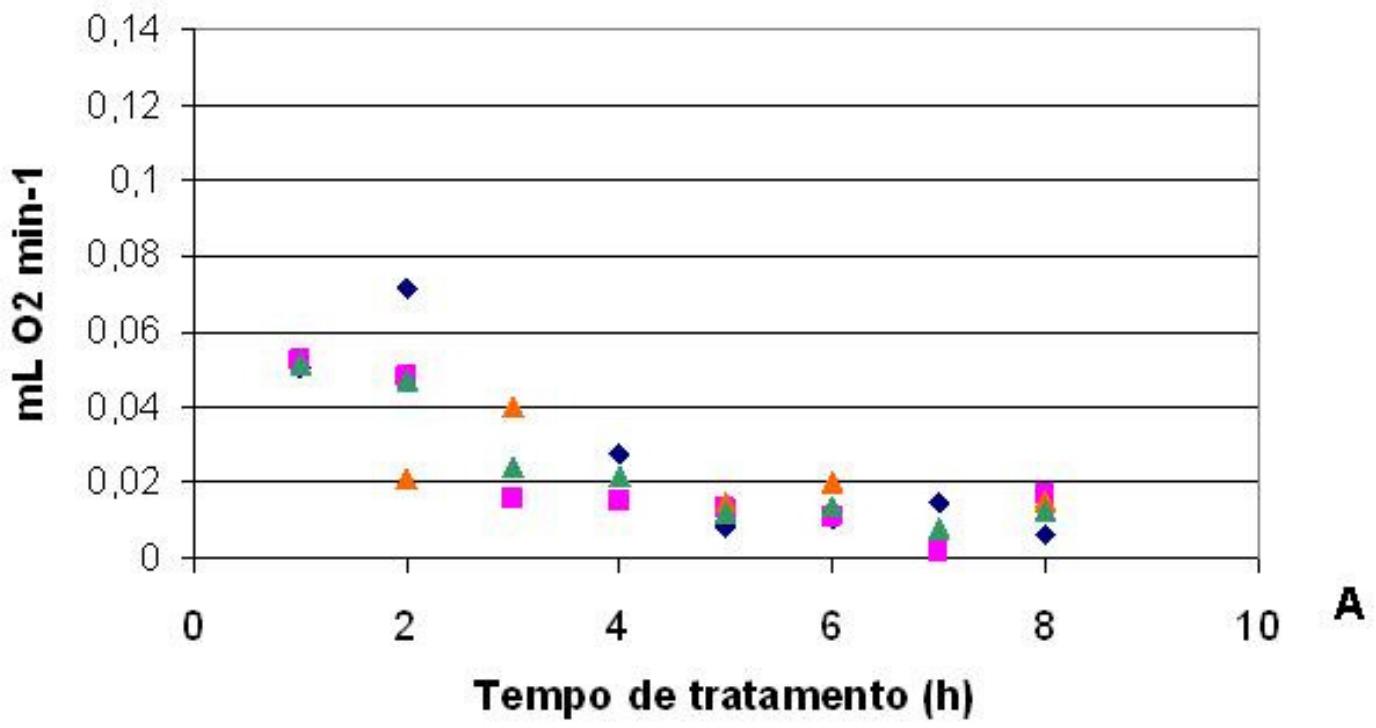

nclinação: diferenças não significativas $(\mathrm{P}=0.3648)$

Interc epto: diferenças não significativas $(\mathrm{P}=0.8318)$

É possivel calcular uma inclinação (-0.00579883) e um intercepto (0.0441748)

para todos os dados

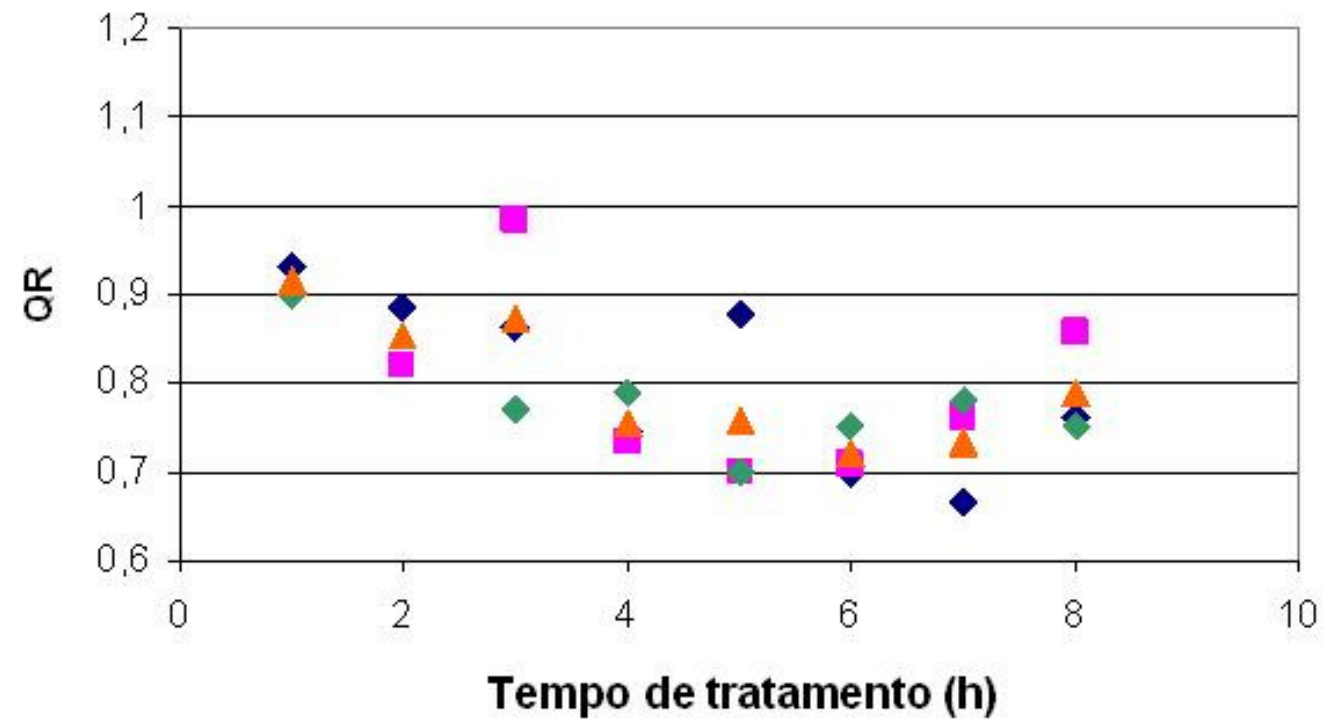

B

Inclinação: diferenças não significativas $(\mathrm{P}=0.7122)$

Intercepto: diferenças não significativas $(\mathrm{P}=0.9489)$

É possivel calcular uma inclinação (-0.022091) e um intercepto (0.898113)

para todos os dados

Figura 8. Comparações intra-tratamento, com verificação de similaridade de inclinação e intercepto dos valores de VO2 (A) e de QR (B) de forrageadoras tratadas com Alprenolol + Octopamina + Ácido ascórbico 
COMPARAÇÕES INTRA-TRATAMENTOS: Methoprene

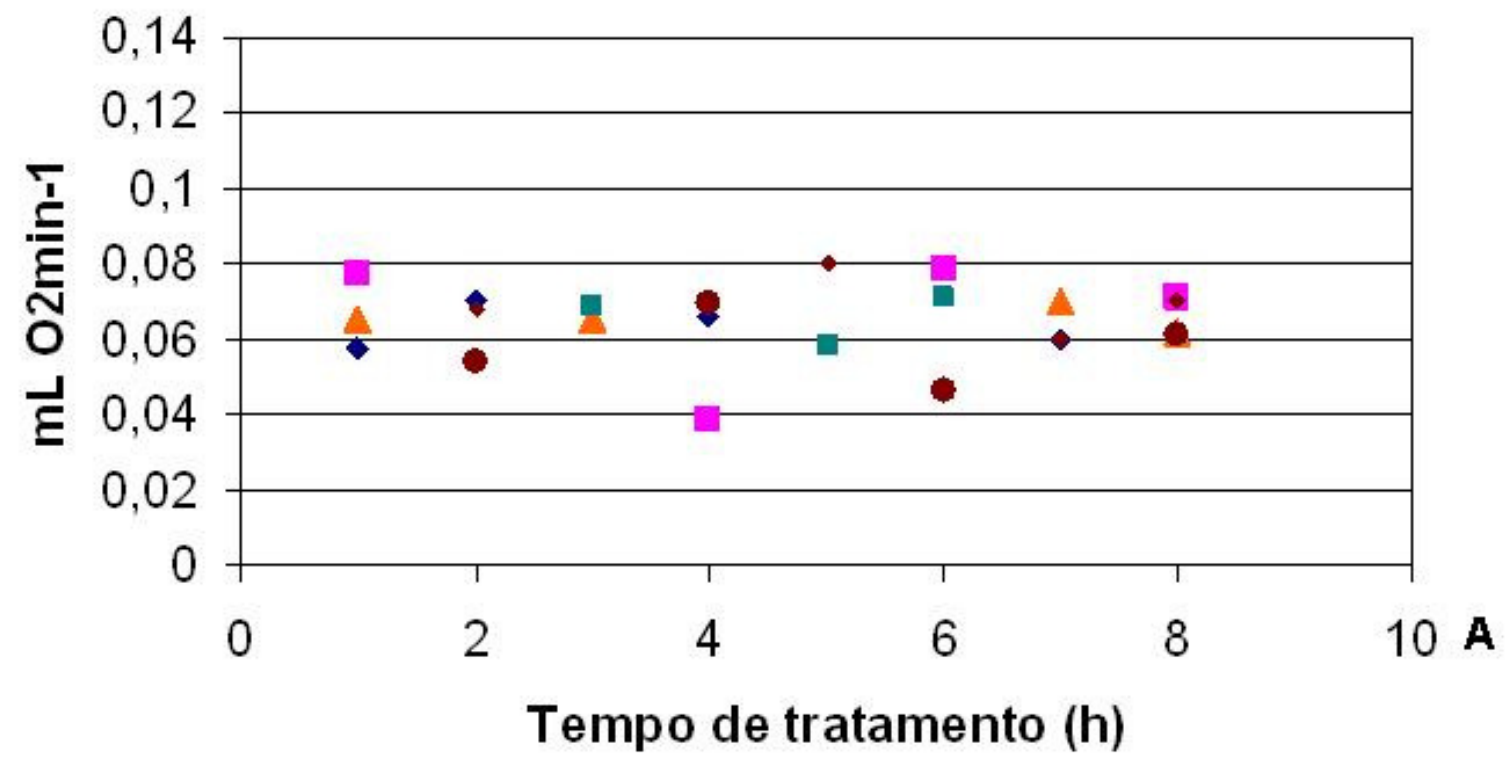

Inclinação: diferenças não significativas $(\mathrm{P}=0.9999)$

Interc epto: diferenças não significativas $(\mathrm{P}=0.7249)$

É possivel calcular uma inclinação $(-0,000103181)$ e um interc epto $(0.0653569)$

para todos os dados

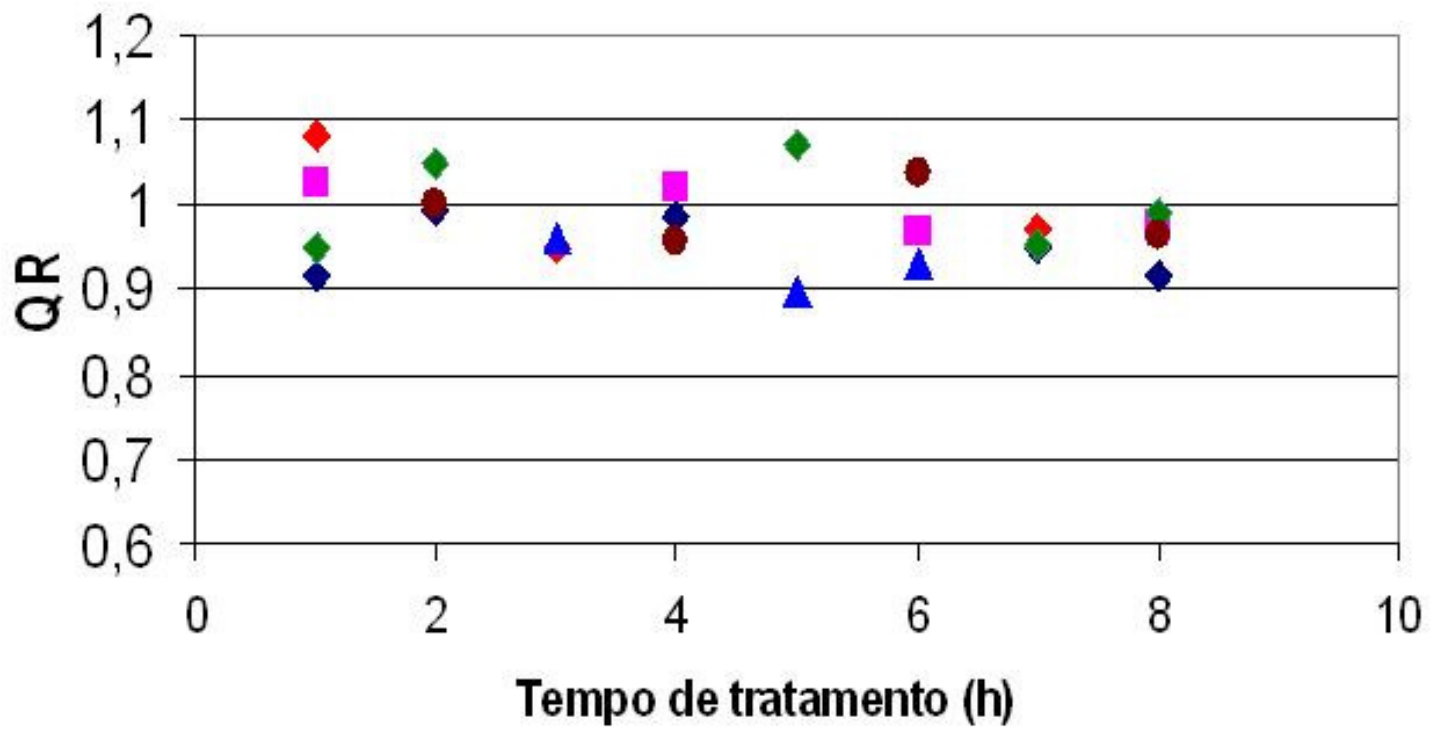

B

Inclinação: diferenças não significativas $(\mathrm{P}=0.9629)$

Interc epto: diferenças não significativas $(\mathrm{P}=0.1414)$

É possivel calcular uma inclinação $(-0.00533721)$ e um intercepto $(1,00574)$

para todos os dados

Figura 9. Comparações intra-tratamento, com verificação de similaridade de inclinação e intercepto dos valores de $\mathrm{VO} 2$ (A) e de QR (B) de forrageadoras tratadas com Methoprene 
COMPARAÇÕES INTRA-TRATAMENTOS: Methoprene + Alprenolol

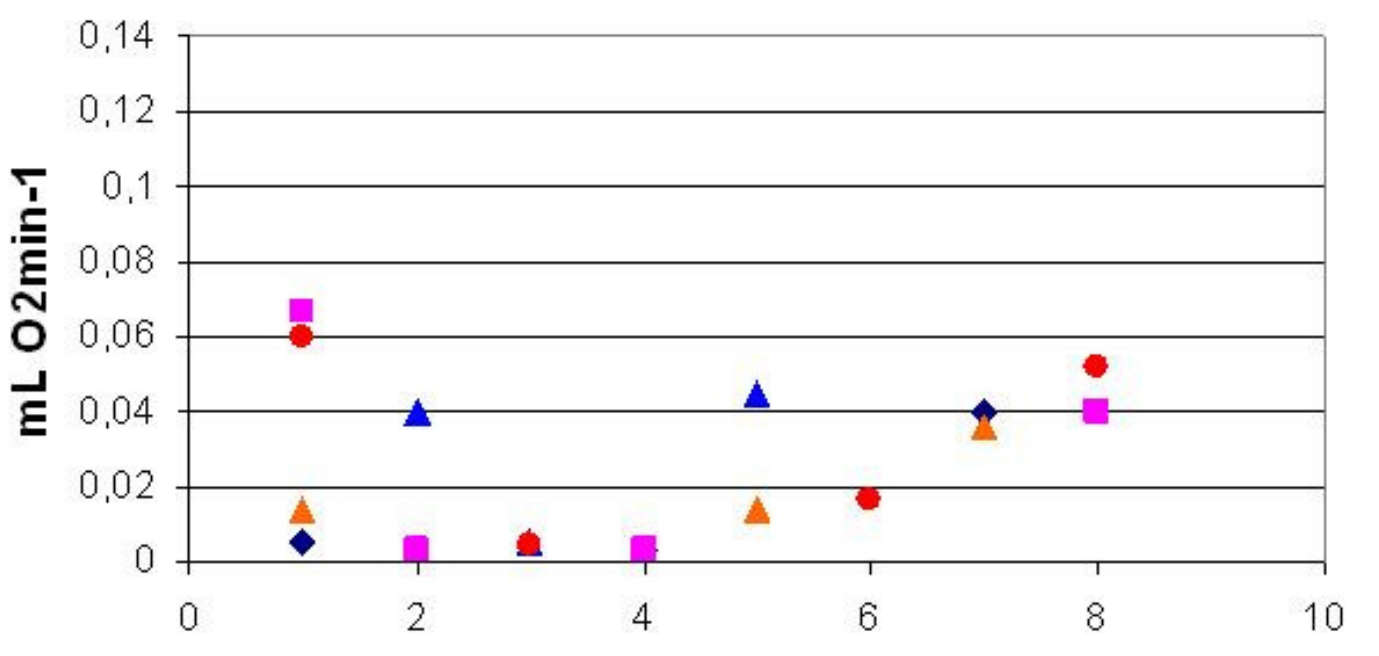

A

Tempo de tratamento (h)

Inclinação: diferenças não significativas $(\mathrm{P}=0.9387)$

Interc epto: diferenças não significativas ( $\mathrm{P}=0.8980)$

É possivel calcular uma inclinação $(0,00533721)$ e um intercepto $(0,0202898)$

para todos os dados

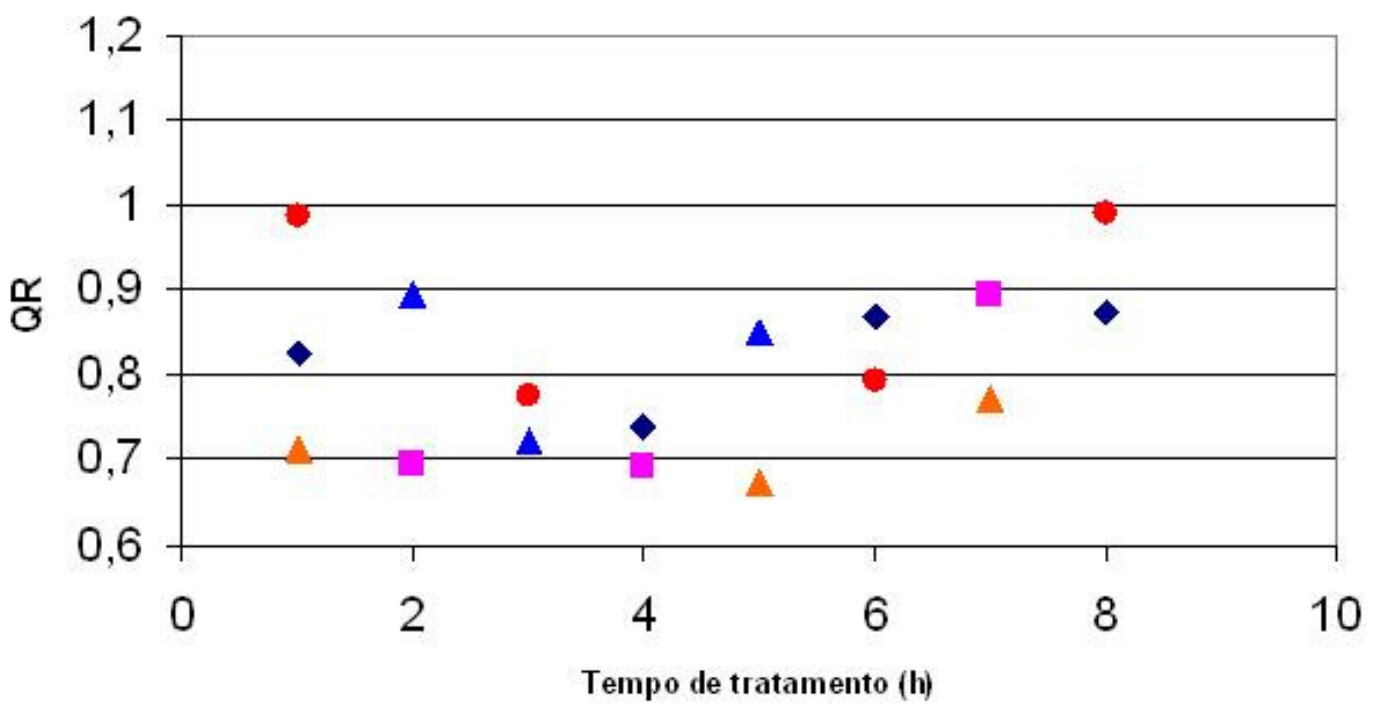

B

Inclinação: diferenças não significativas $(\mathrm{P}=0.8164)$

Intercepto: diferenças não significativas $(\mathrm{P}=0.2204)$

É possivel calcular uma inclinação $(0,0105823)$ e um intercepto $(0.76487)$

para todos os dados

Figura 10. Comparações intra-tratamento, com verificação de similaridade de inclinação e intercepto dos valores de $\mathrm{VO} 2$ (A) e de QR (B) de forrageadoras tratadas com Methoprene + Alprenolol 
COMPARAÇÕES ENTRE-TRATAMENTOS: Sacarose versus Mianserina

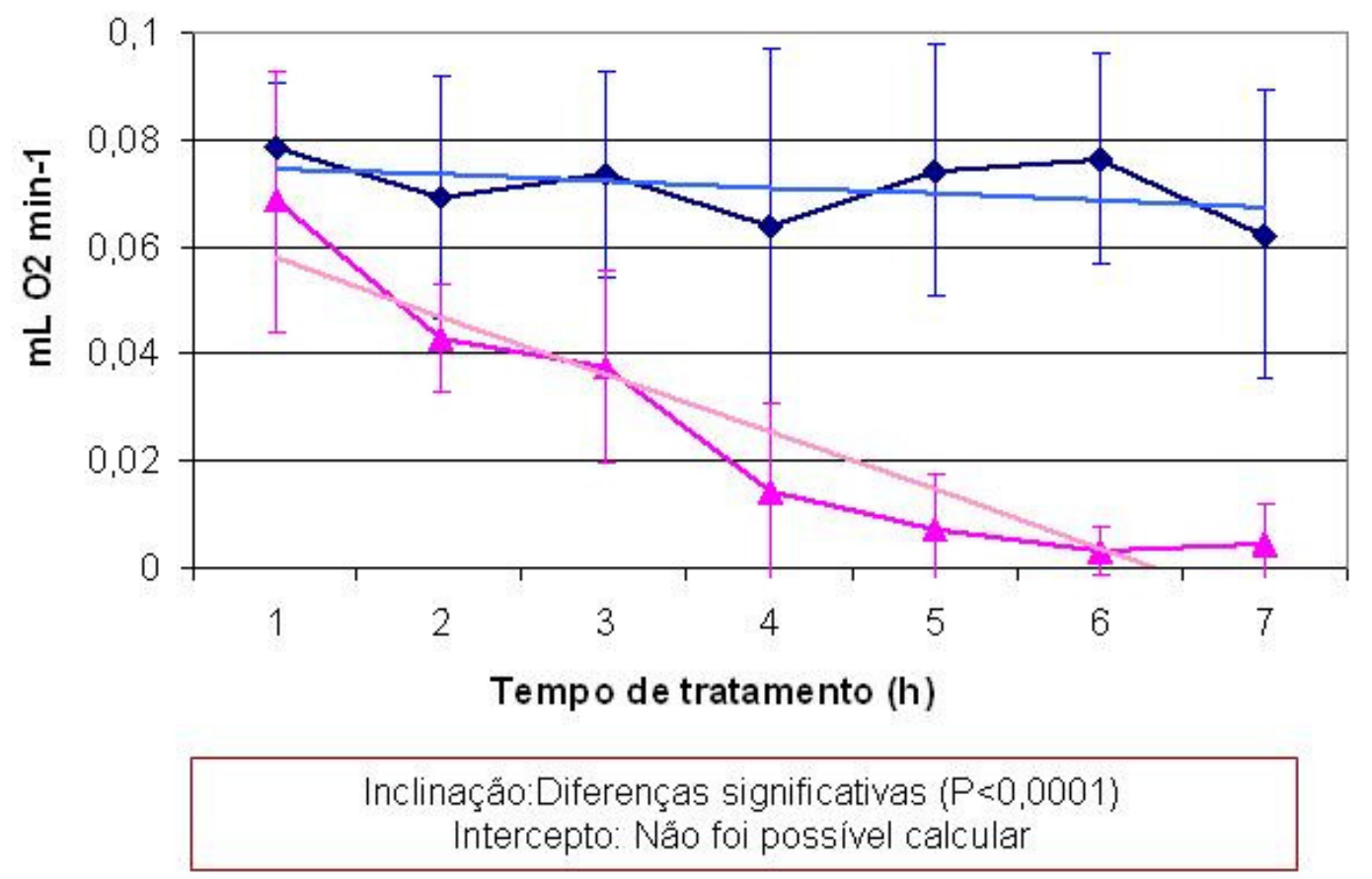

A

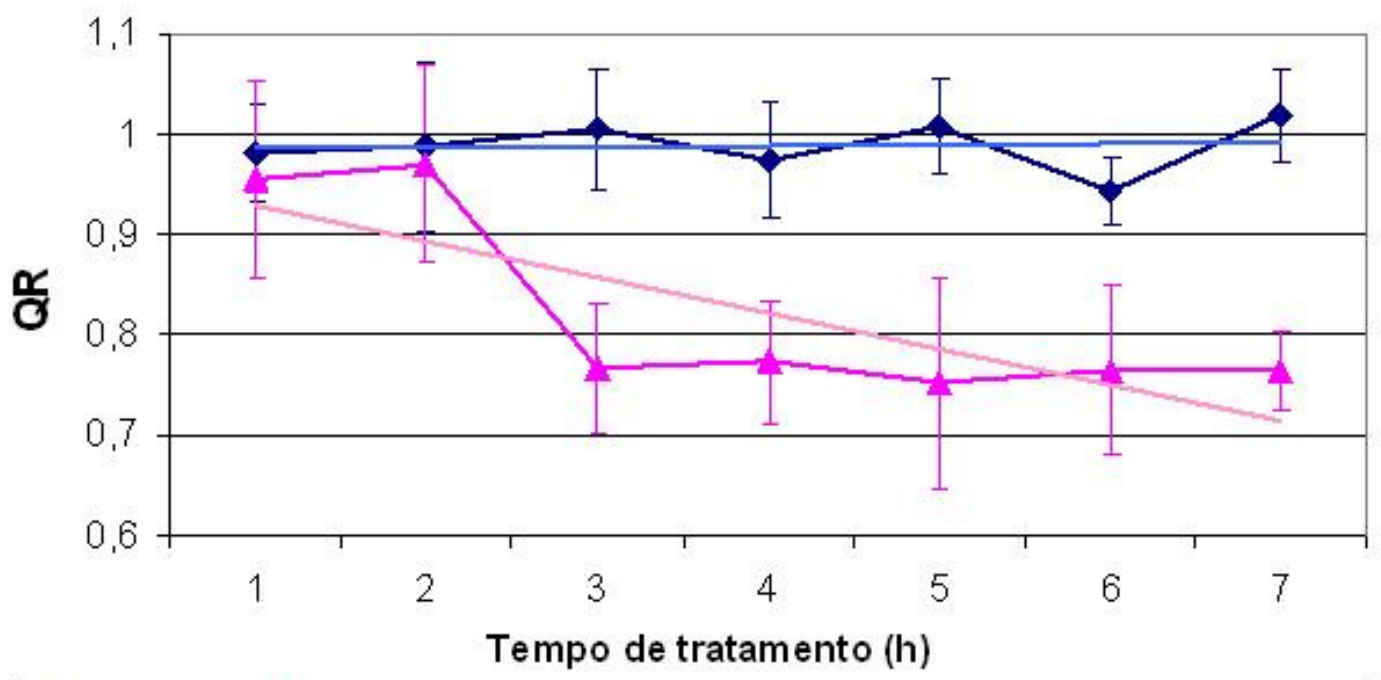

$\rightarrow$ Sacarose - - Mianserina 10-3M _Linear (Sacarose) _L Linear (Mianserina 10-3M)

Inclinaçẫo: Diferenças significativas ( $\mathrm{P}<0.0001)$

Intercepto: Nẫo foi possivel calcular

Figura 11. Comparações dos valores de $\mathrm{VO} 2$ e $\mathrm{QR}$ do grupo "Sacarose" e "Mianserina". Mianserina parece alterar a taxa metabólica e o $Q R$ das forrageiras tratadas. 


\section{COMPARAÇÕES ENTRE-TRATAMENTOS}

Sacarose versus Alprenolol (conjuntos 1 e 2)
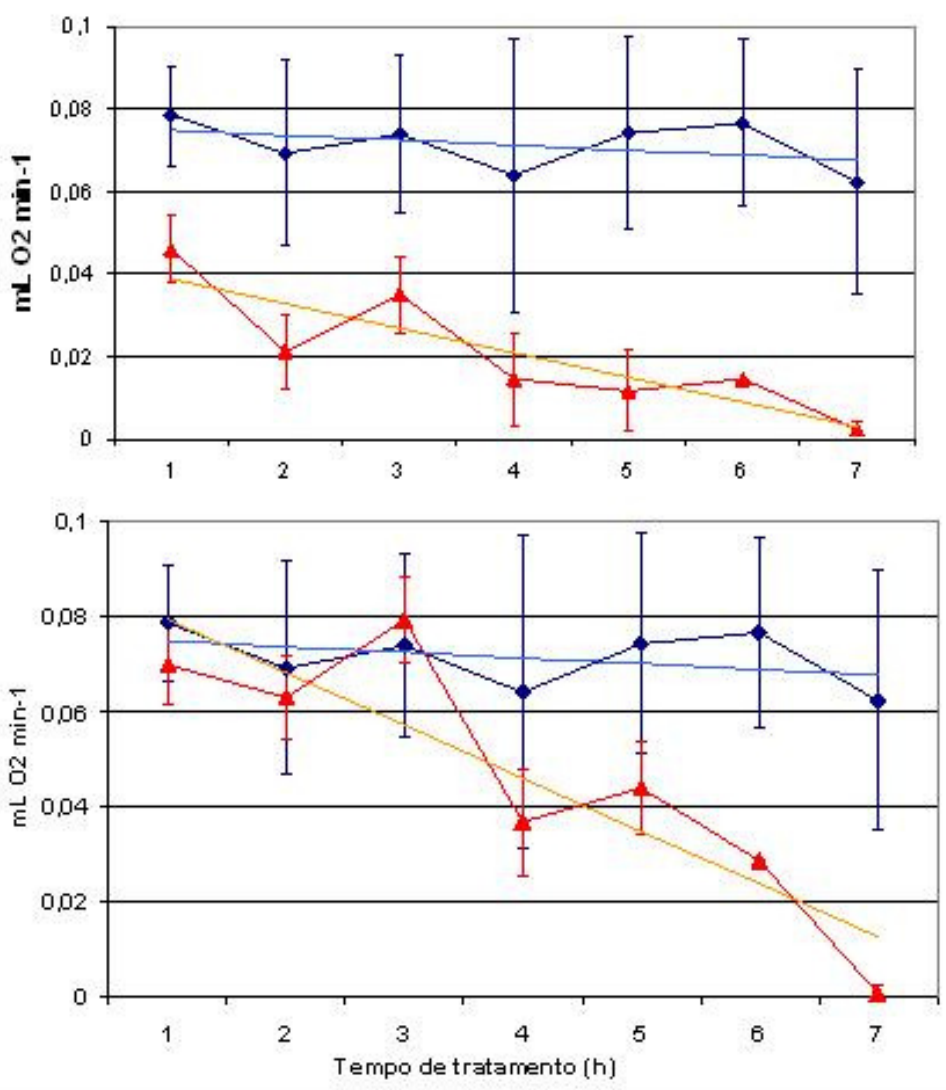

A

Inclinaçôes dos 2 tratamentos diferem significantemente $(P<0,02)$ Intercepto: não é possivel calcular pois as inclinaçôes diferem

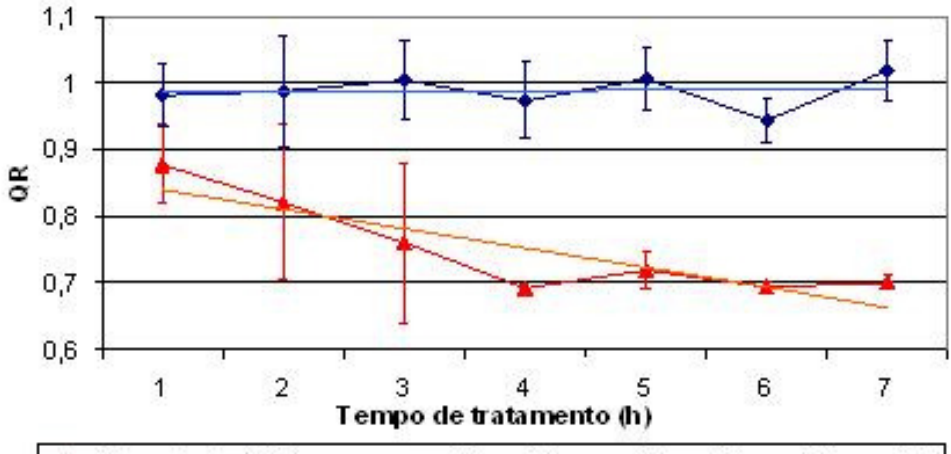

-Alprenolol $\rightarrow-$ Sacarose - Linear (Sacarose) - Linear (Alprenolol)

B

Inclinação: diferenças significativas ( $\mathrm{P}=0.0004118$ )

Intercepto: não é possivel calcular pois as inclinaçôes diferem

Figura 12. Comparações dos valores de VO2 e QR do grupo "Sacarose" e "Alprenolol" (grupos 1 e 2 de dados, segundo semelhança de interceptos. Alprenolol parece alterar a taxa metabólica e o $\mathrm{QR}$ das forrageiras tratadas. 
COMPARAÇÕES ENTRE-TRATAMENTOS

Sacarose versus Alprenolol + Octopamina

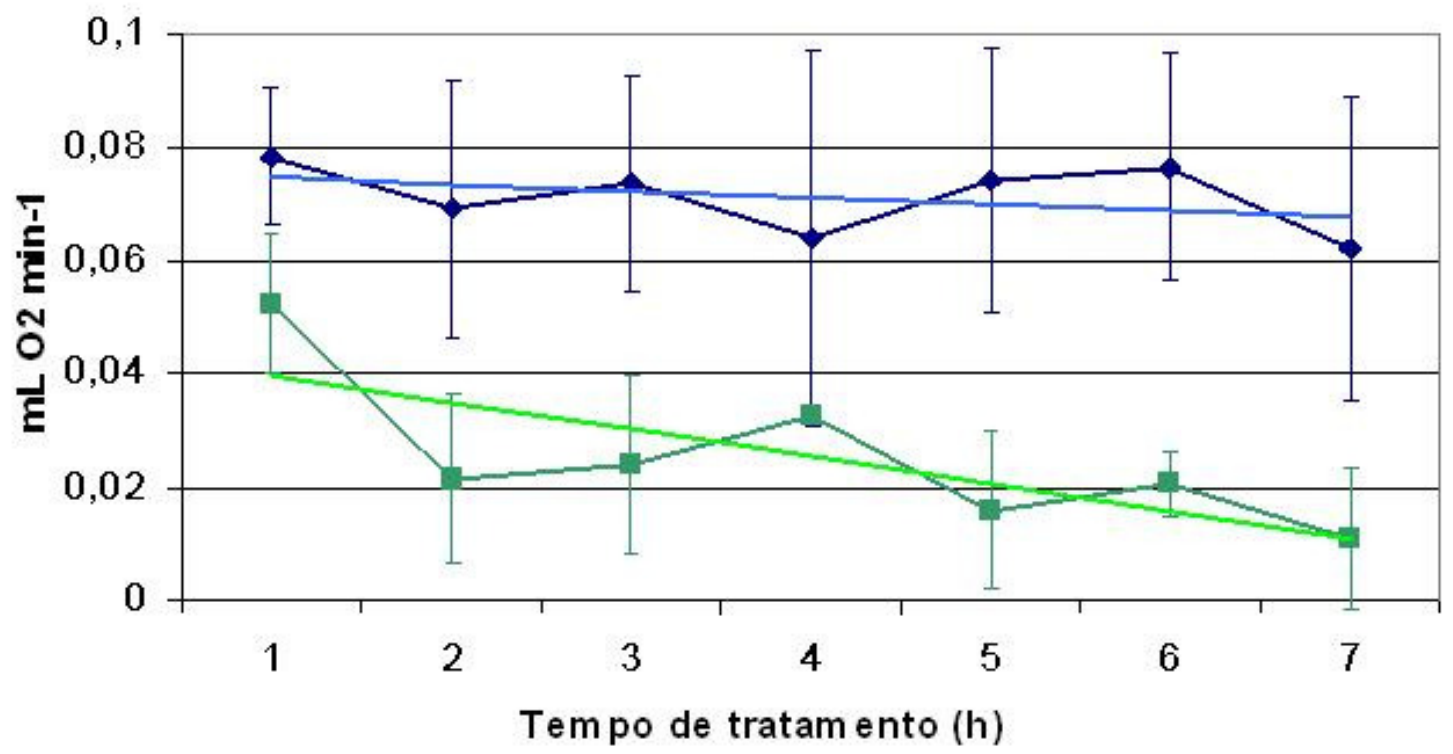

A

Inclinação: semelhantes ( $P=0,1072)$

Intercepto: diferem significantemente $(P<0,0001)$

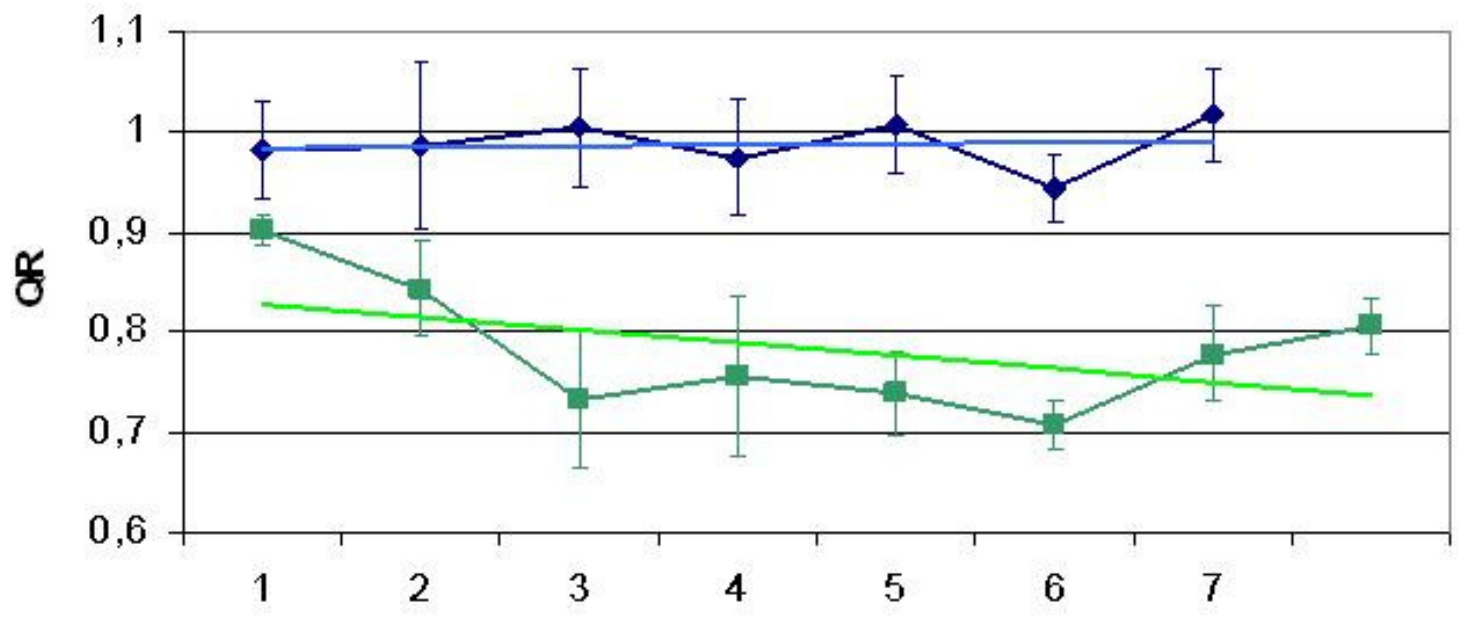

Tempo de tratamento (h)

Sacarose - Alprenolol + Octopamina —-Linear (Sac arose) —-Linear (Alprenolol + Octopamina)

Figura 13. Comparações dos valores de $\mathrm{VO} 2$ e $\mathrm{QR}$ do grupo "Sacarose" e "Alprenolol + Octopamina". A Octopamina parece reverter os efeitos do alprenolol, sugerindo especificidade de bloqueio. 
COMPARAÇÕES ENTRE-TRATAMENTOS Sacarose versus Alprenolol + Octopamina + Ácido ascórbico

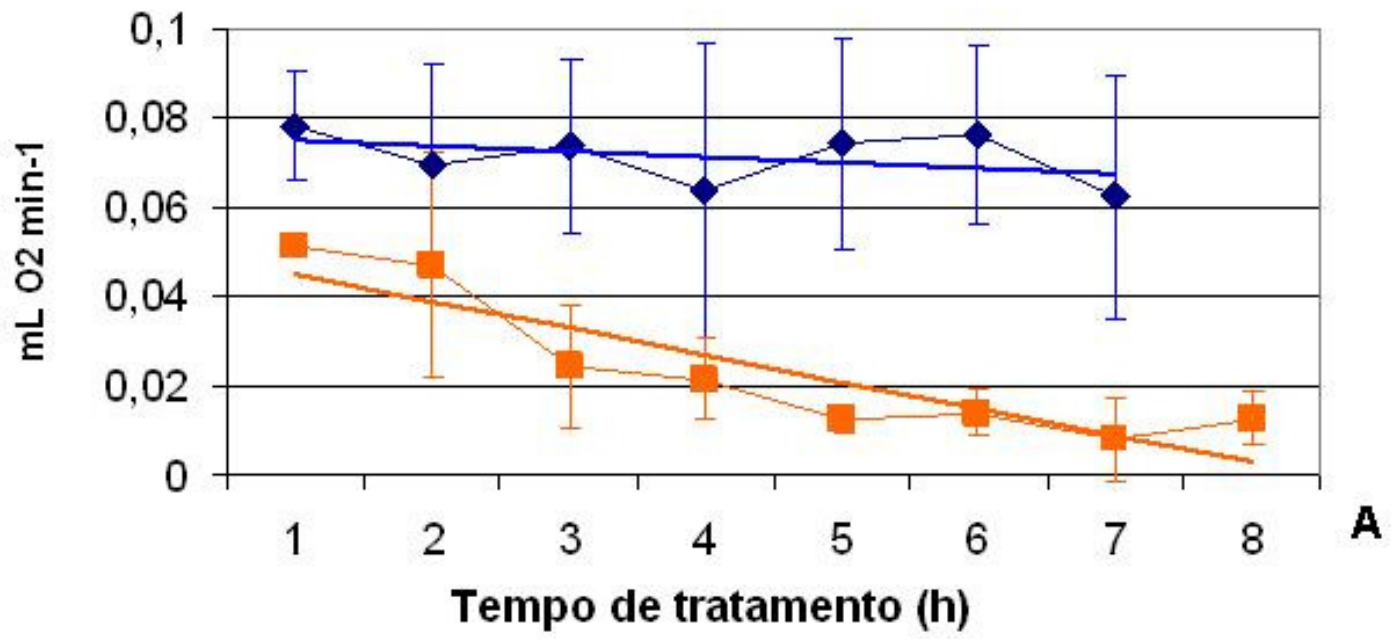

Inclinaçäo: semelhantes ( $P=0.0658$ ) Intercepto: diferem significantemente $(P<0,0001)$

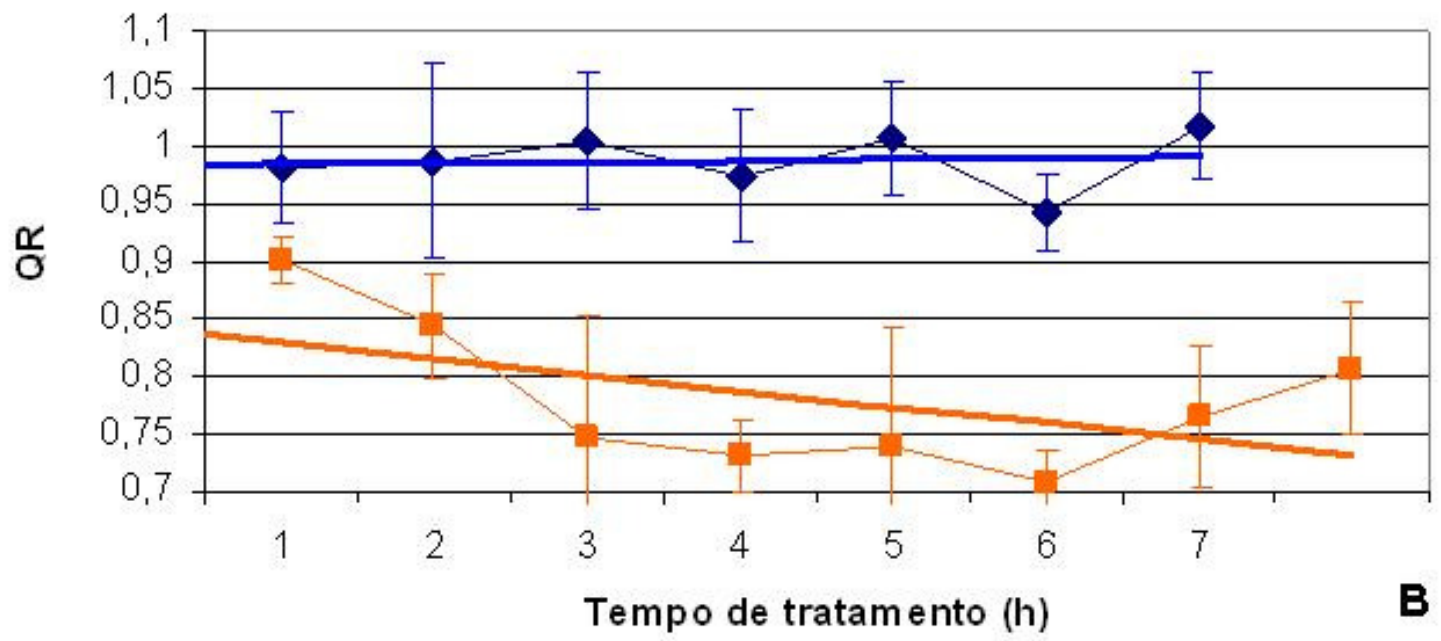

\begin{tabular}{|l}
$-\longrightarrow$ Sacarose \\
- A Iprenolol + octopamina + acido ascórbico \\
- Linear (Sac arose) \\
\end{tabular}

Inclinaçäo: diferem significantemente ( $\mathrm{P}=0.0009476)$ Intercepto: nẫo foi possivel calcular (diferem)

Figura 14. Comparações dos valores de VO2 e $\mathrm{QR}$ do grupo "Sacarose" e "Alprenolol + Octopamina + Ácido ascórbico". A octopamina parece reverter os efeitos do Alprenolol, sugerindo especificidade de bloqueio 


\section{COMPARAÇÕES ENTRE-TRATAMENTOS Sacarose versus Mianserina + Octopamina}

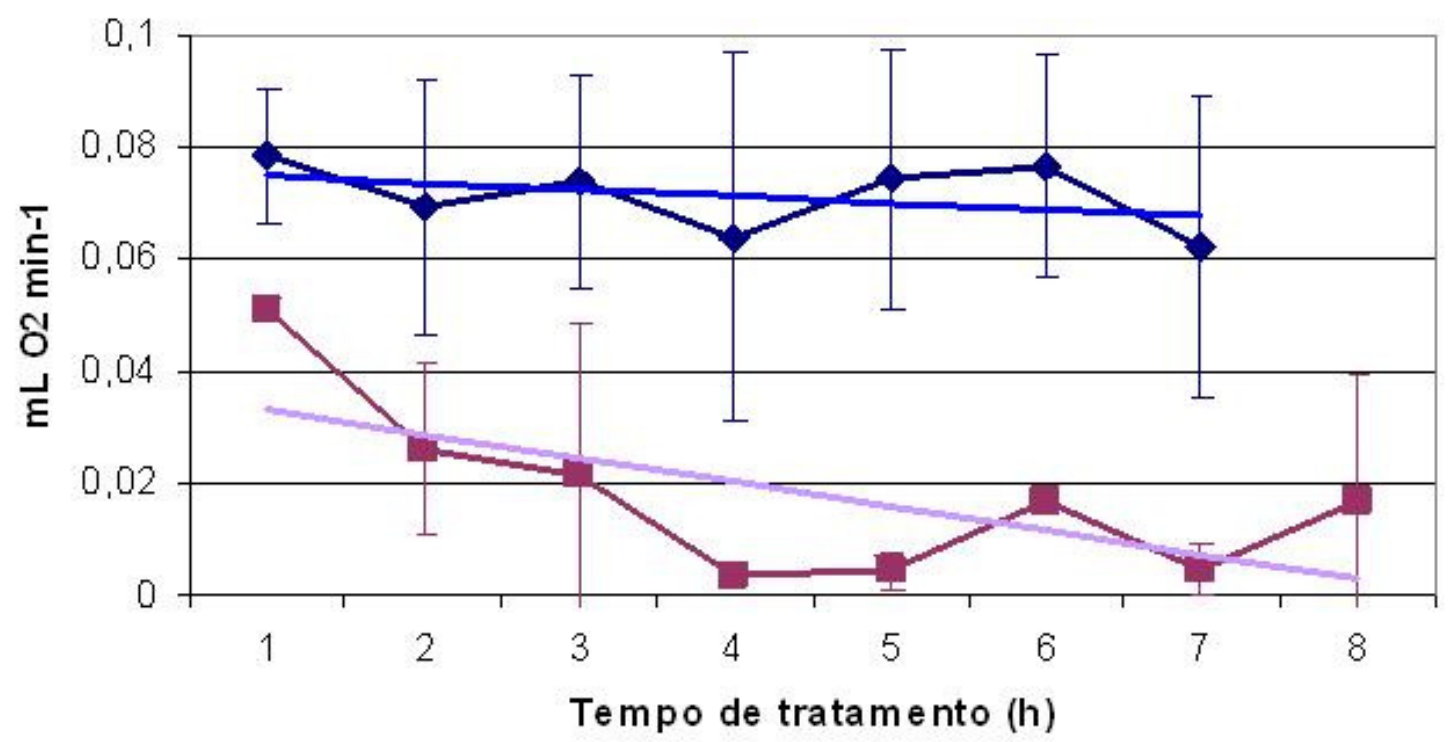

Inclinaçẫo: semelhantes $(P=0,3108)$

Intercepto: diferem significantemente ( $\mathrm{P}<0,0001)$

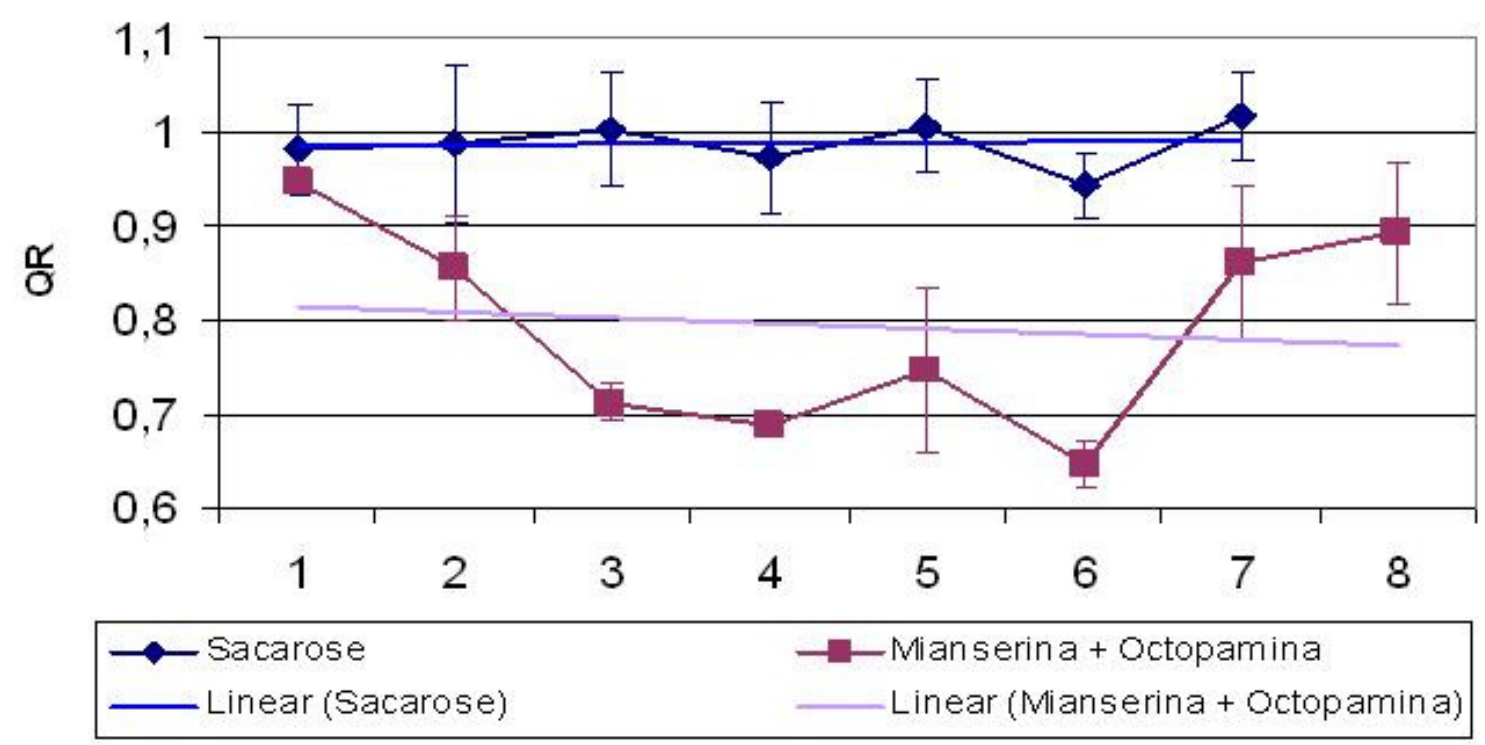

B

Figura 15. Comparações dos valores de VO2 e QR do grupo "Sacarose" e "Mianserina + Octopamina". A Octopamina parece reverter os efeitos da Mianserina, sugerindo especificidade de bloqueio 


\section{COMPARAÇÕES ENTRE-TRATAMENTOS Mianserina versus Mianserina + Octopamina}

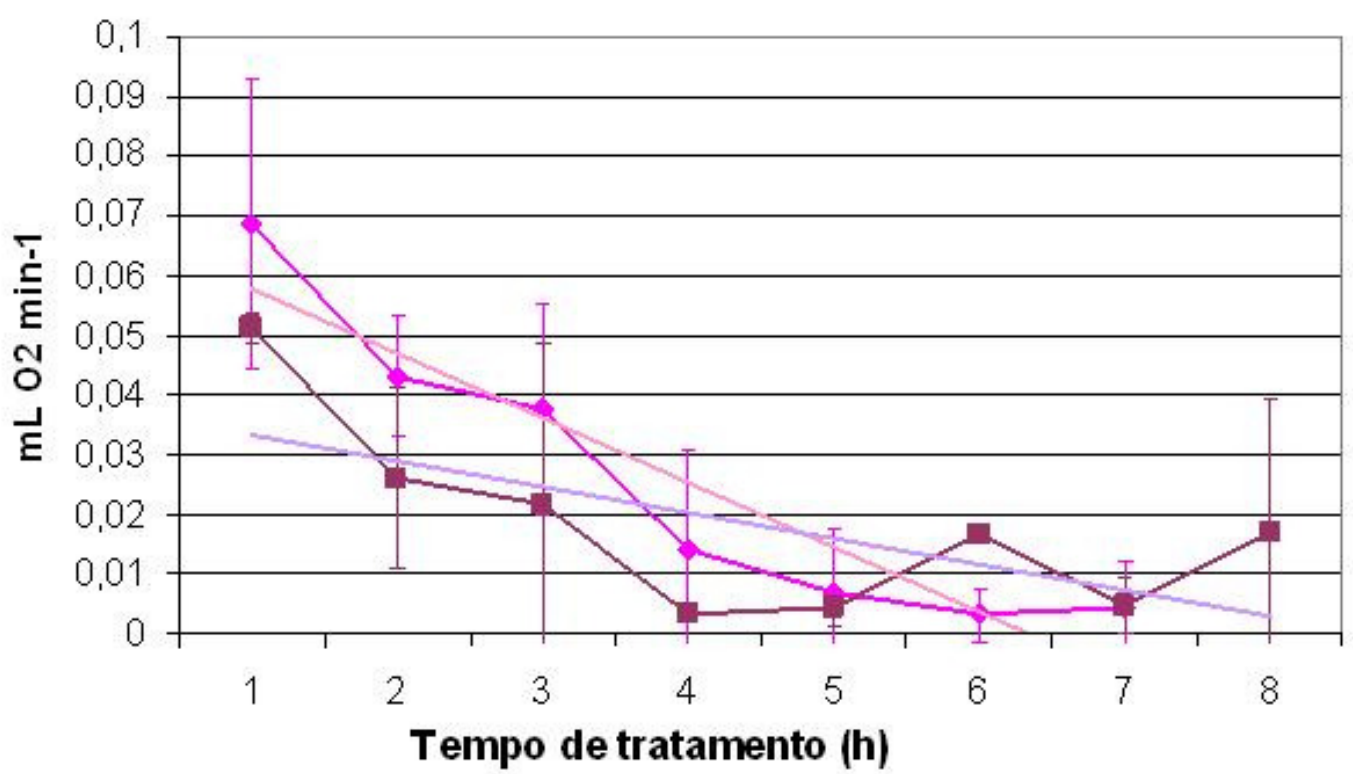

A

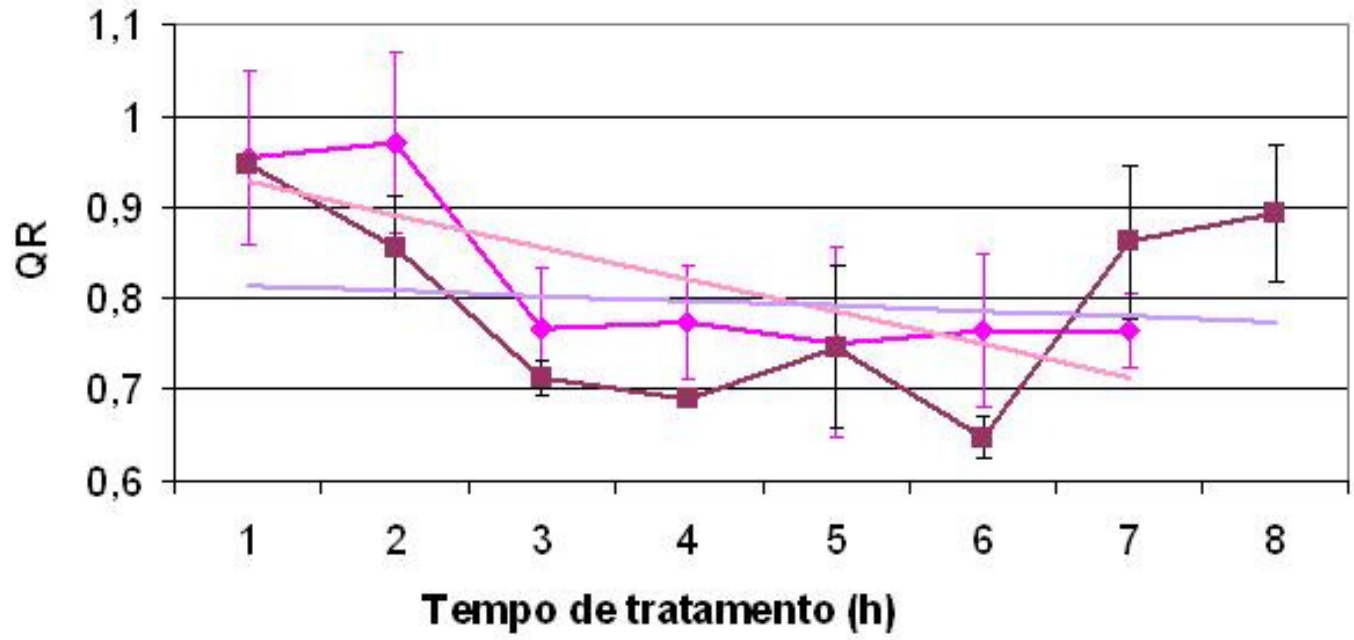

\begin{tabular}{|ll|}
\hline - Mians erina & - - Mianserina + Octopamina \\
Linear (Manserina) & - Linear (Mianserina + Octopamina)
\end{tabular}

B

Inclinaçấo: diferenças significativas ( $\mathrm{P}=0,0007268)$

Intercepto: nẫo é possivel calcular pois as inclinaçốes diferem

Figura 16. Comparações dos valores de $\mathrm{VO} 2$ e $\mathrm{QR}$ do grupo "Mianserina" e "Mianserina + Octopamina". A Octopamina parece reverter os efeitos da Mianserina, sugerindo especificidade de bloqueio 
COMPARAÇÕES ENTRE-TRATAMENTOS Alprenolol versus Alprenolol + Octopamina

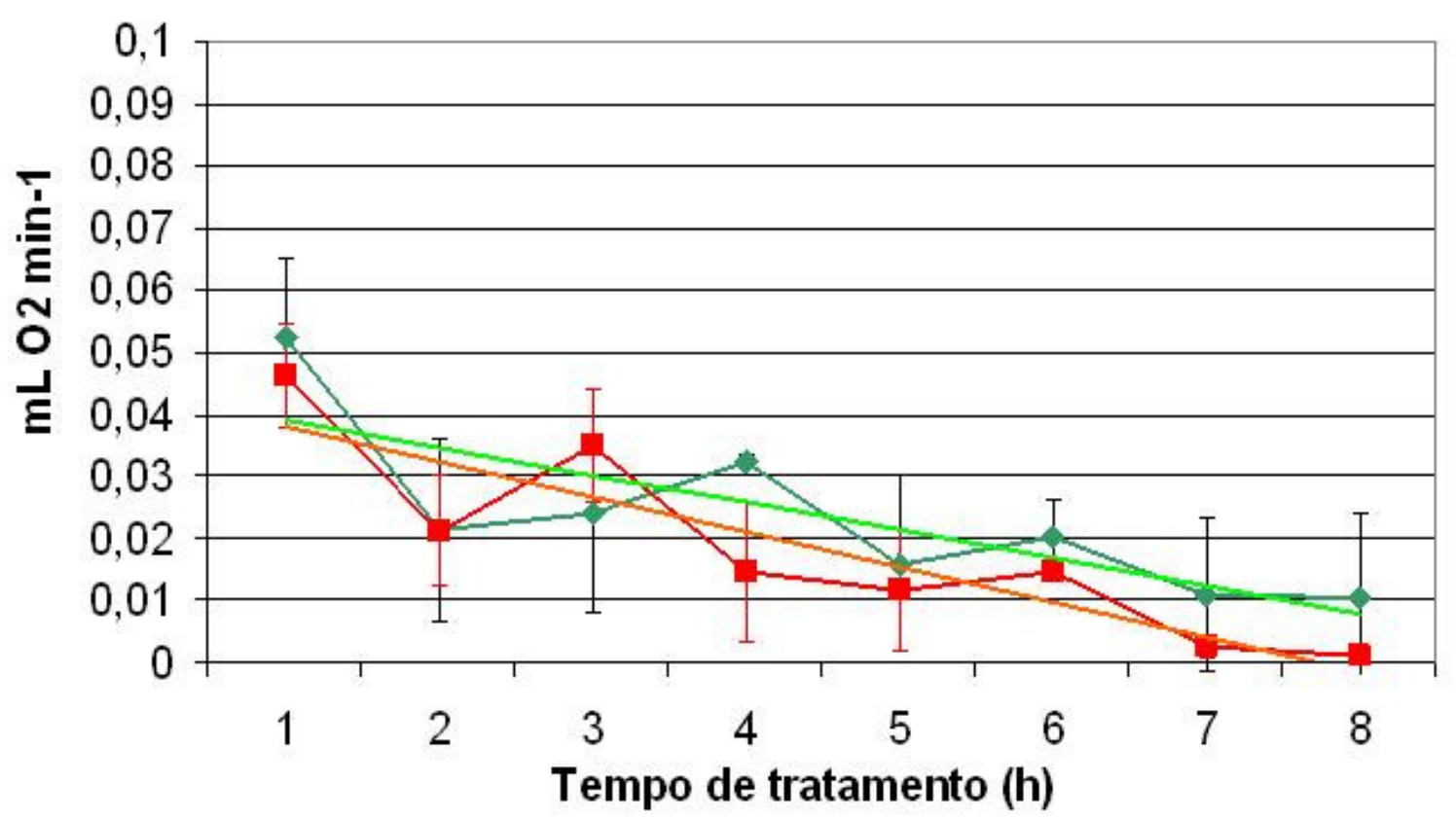

Inclinação: semelhantes ( $\mathrm{P}=0.4684)$

Interceptos: semelhantes $(\mathrm{P}=0.3322$

A

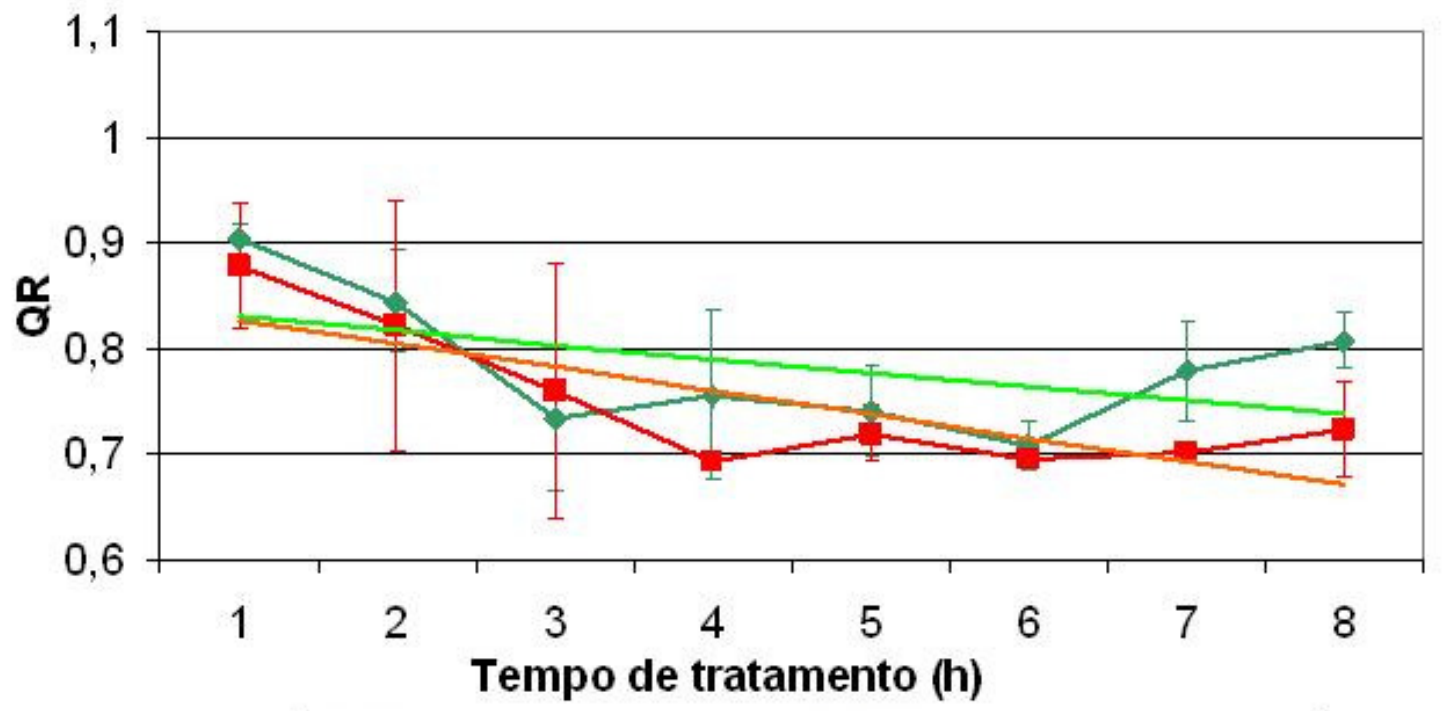

\begin{tabular}{ll}
$\longrightarrow$ - Alprenolol + Octopamina & - - Alprenolol \\
$\longrightarrow$ Linear (Alprenolol + Octopamina) & Linear (Alprenolol) \\
\hline
\end{tabular}

B

Inclinação: diferenças significativas ( $\mathrm{P}=0.02815)$

Intercepto: Não é possivel calcular diferenças

Figura 17. Comparações dos valores de VO2 e QR do grupo "Alprenolol" e "Alprenolol + Octopamina". A Octopamina parece reverter os efeitos do Alprenolol, sugerindo especificidade de bloqueio 
COMPARAÇÕES ENTRE-TRATAMENTOS Alprenolol + Octopamina versus Alprenolol + Octopamina + Ácido ascórbico
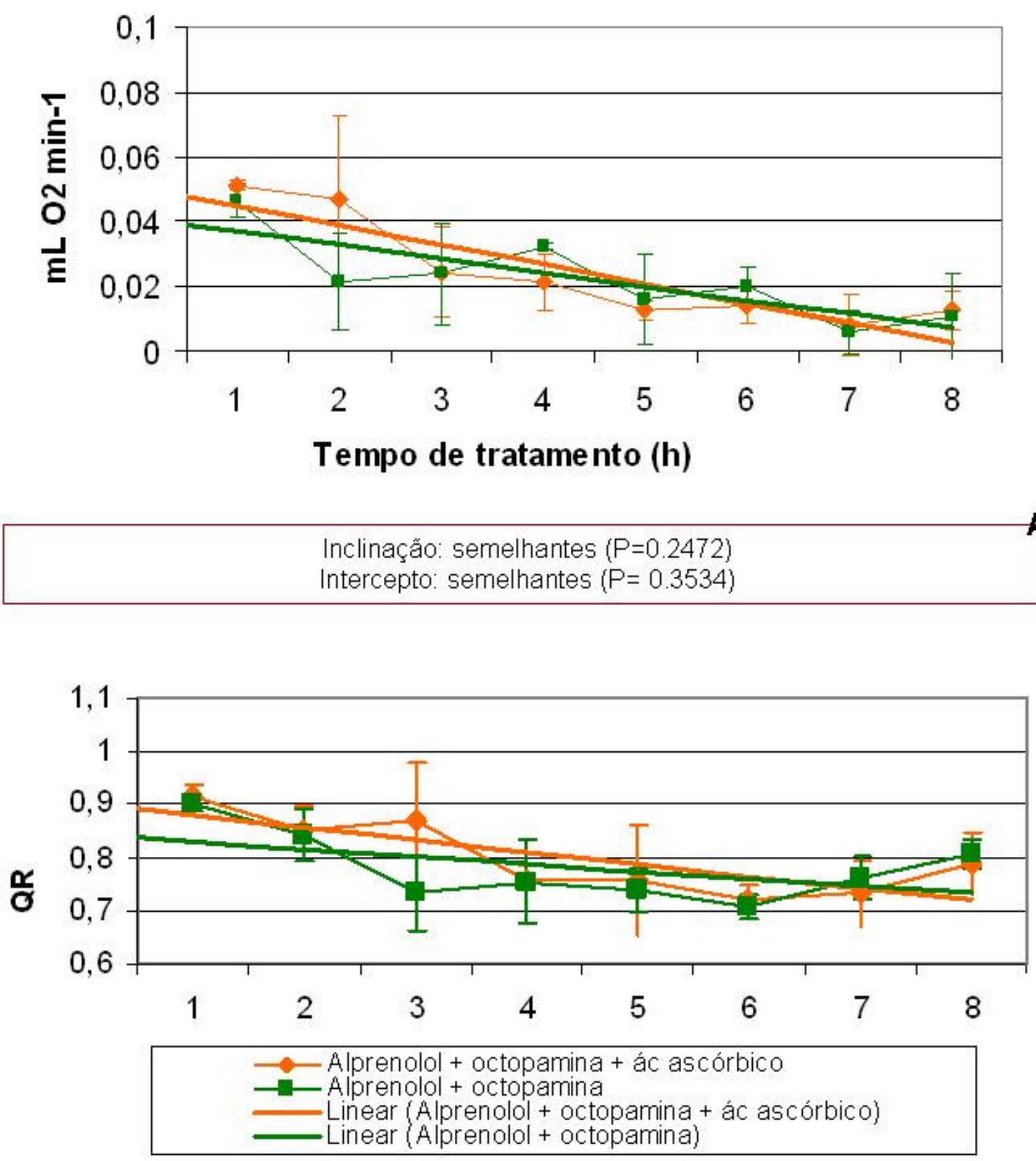

Figura 18. Comparações dos valores de $\mathrm{VO} 2$ e $\mathrm{QR}$ do grupo "Alprenolol + Octopamina" e "Alprenolol + Octopamina + Ácido ascórbico". O ácido ascórbico parece não ter efeitos sobre os valores de taxa metabólica e $Q R$ das forrageiras tratadas. 
Sacarose

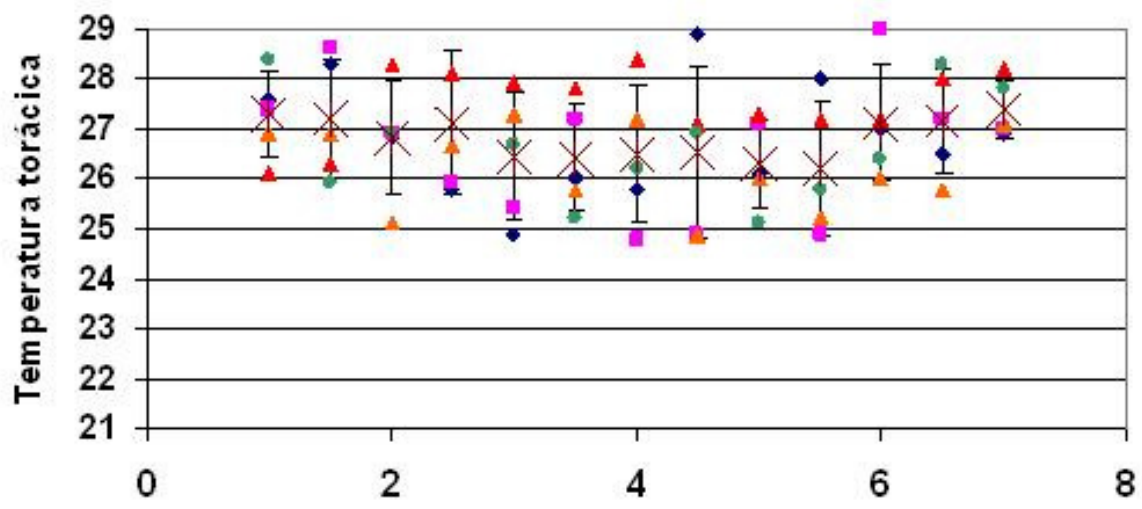

Diferenças não significativas na inclinação $(\mathrm{P}=0.8975) \mathrm{e}$ intercepto $(\mathrm{P}=0.06228)$

A

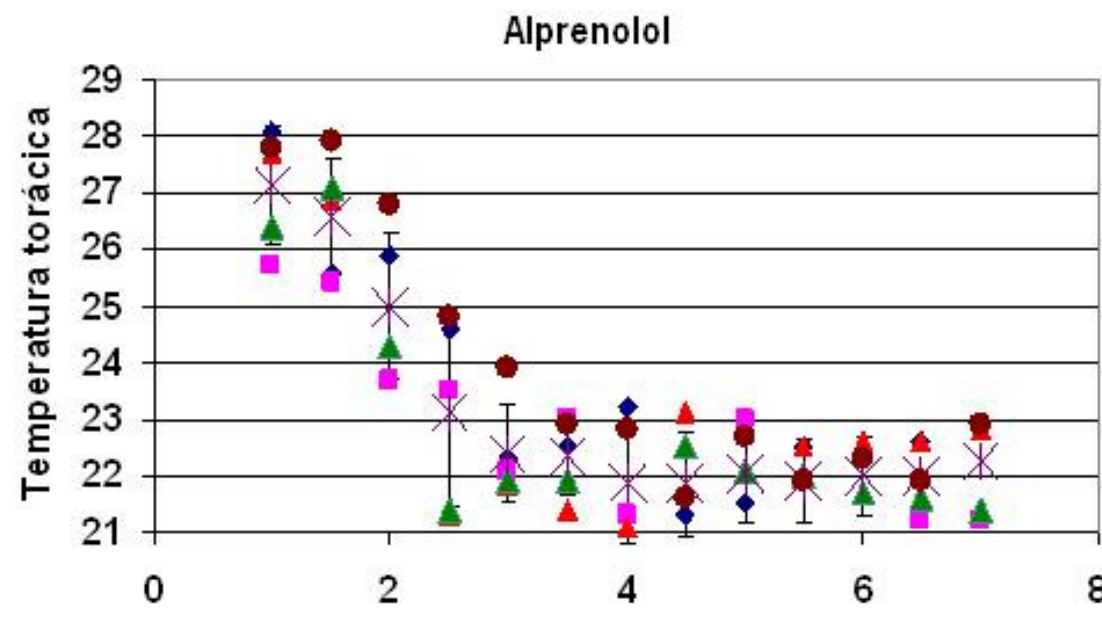

Diferenças não significativas na inclinação $(P=0,7629) \mathrm{e}$ intercepto $(\mathrm{P}=0,0873)$

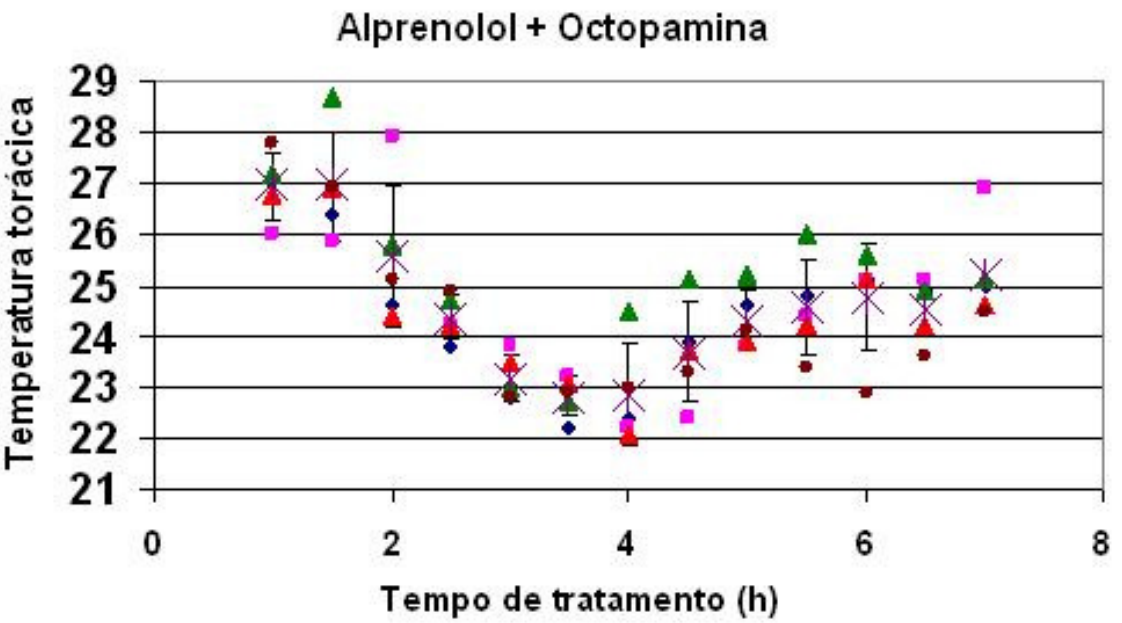

Diferenças não significativas na inclinação $(\mathrm{P}=0,6844) \mathrm{e}$ intercepto $(\mathrm{P}=0,405)$

Figura 19. Comparações intra-tratamento, com verificação de similaridade de inclinação e intercepto dos valores de temperatura torácica de forrageiras tratadas com solução de sacarose (grupo controle) (A), com alprenolol (B) e com alprenolol + octopamina (C). Nota-se que há similaridade de inclinação e intercepto em diferentes indivíduos submetidos ao mesmo tratamento. 
Sacarose vs Alprenolol

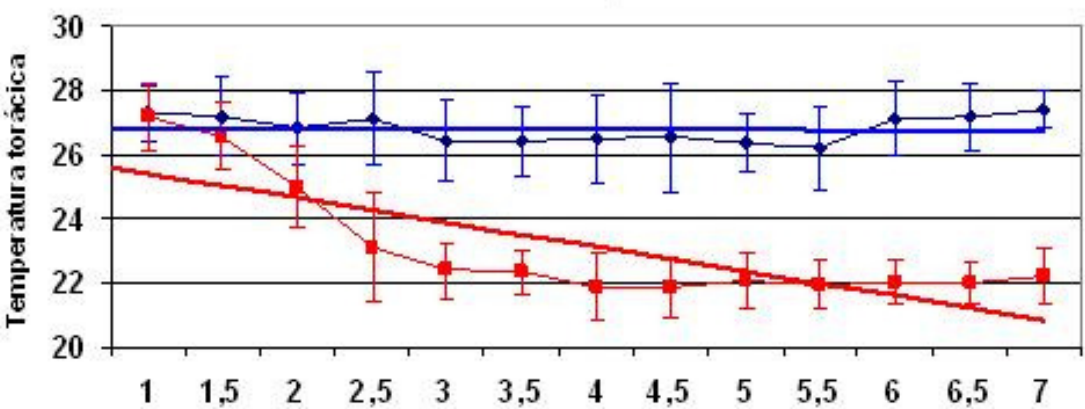

- - Sacarose $\rightarrow$ - Aprenolol _Linear (Sacarose) —Linear (Ajprenolol)

Sacarose vs Alprenolol + O ctopamina

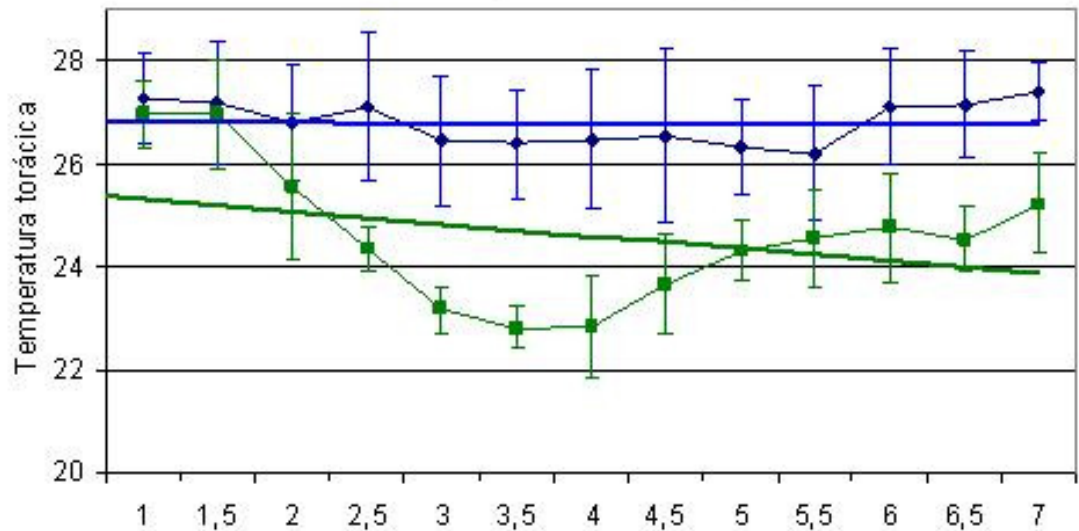

$\rightarrow-$ Sacarose

Linear (Sacarose)

- Aprenolol + Odopam ina Linear (Ajprenolol + Odopam ina)

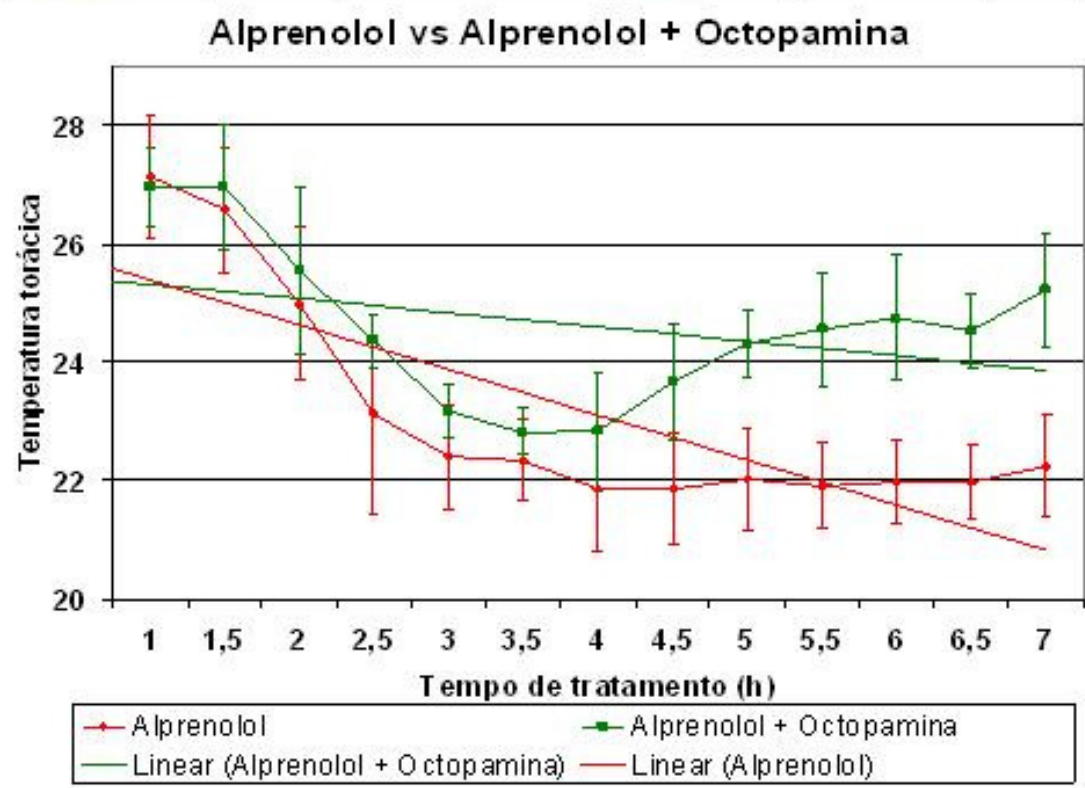

Inclinação: diferenças significativas $(\mathrm{P}<0,0001)$ Intercepto: não foi possivel calcular

\section{A}

Inclinação: diferenças não significativas $(\mathrm{P}=0,06377)$

Intercepto: diferenças significativas $(\mathrm{P}<0,0001)$

B

Inclinação: diferenças significativas $(\mathrm{P}=0.0001997$ Intercepto: não foi possivel calcular

C

Figura 20. Comparações entre-tratamentos, dos valores de temperatura torácica . A: Sacarose versus Alprenolol. B: Sacarose vs Alprenolol + Octopamina. C: Alprenolol vs Alprenolol + Octopamina. Parece haver efeito do tratamento com Alprenolol sobre a temperatura torácica, sendo parcialmente revertido pela Octopamina. 

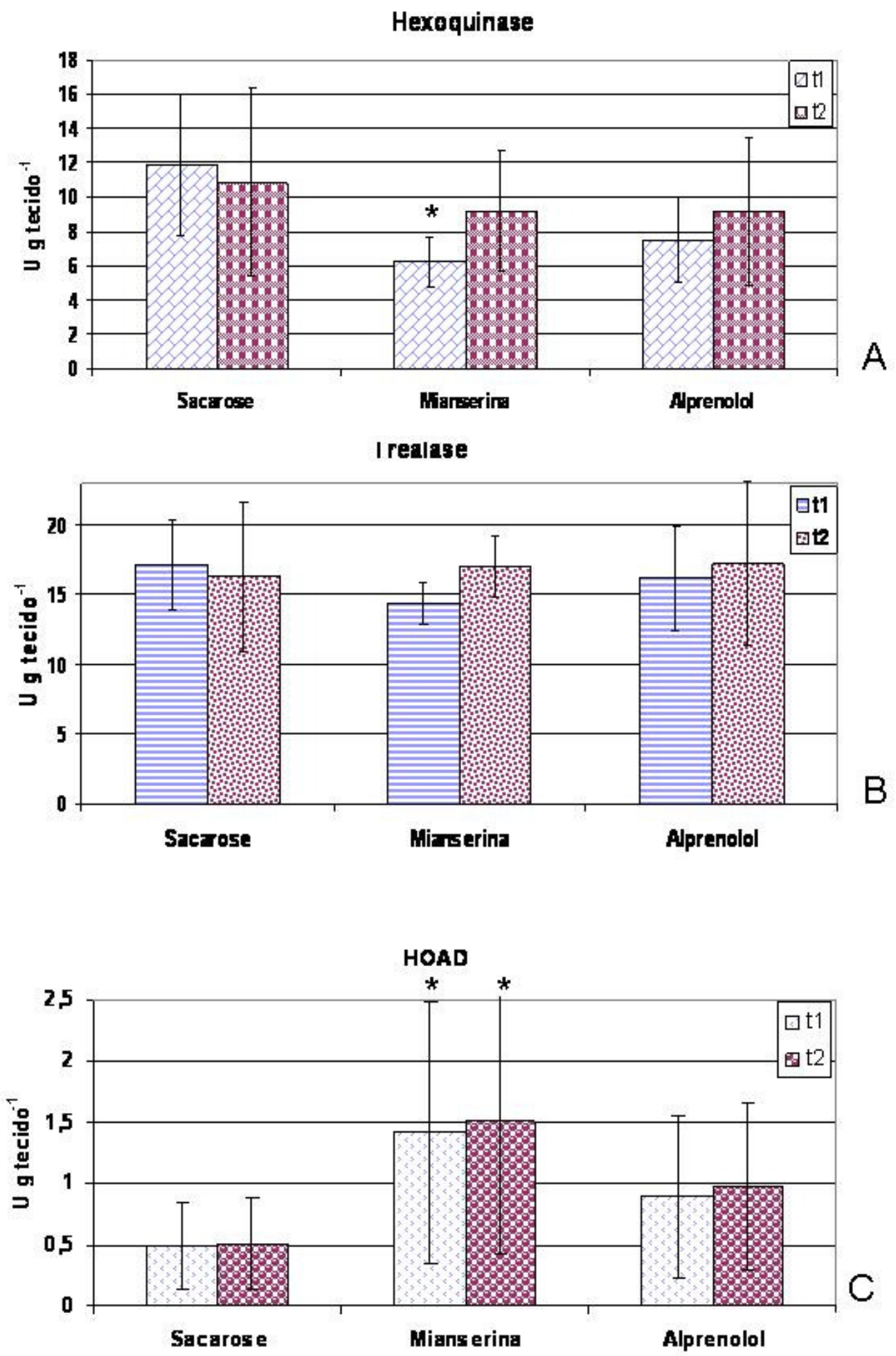

Figura 21. Atividade enzimática (U . g tecido ${ }^{-1}$ ) de hexoquinase (A), trealase (B) e de HOAD (C) calculadas a partir de extrato de tórax de forrageiras do grupo Sacarose, Mianserina e Alprenolol no tempo $t_{2}$ (5h). Foi detectada diferença significativa entre os grupos Sacarose e Mianserina com relação a HOAD, segundo testes de Kruskall Wallis e pós teste Dunn. 


\section{GP ativa}

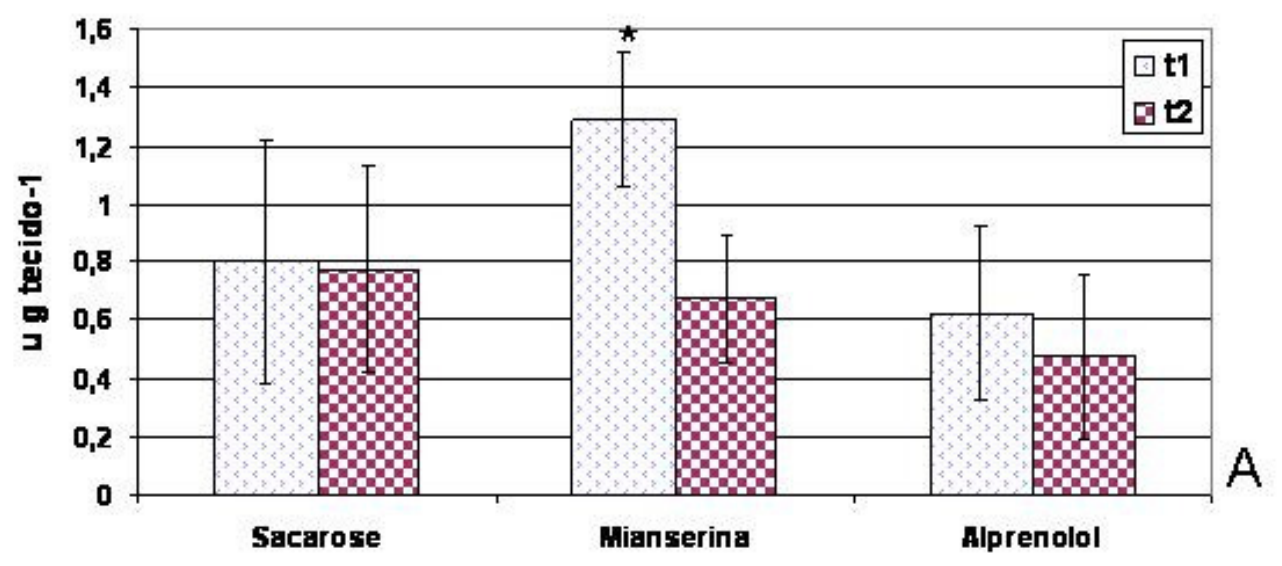

GP total

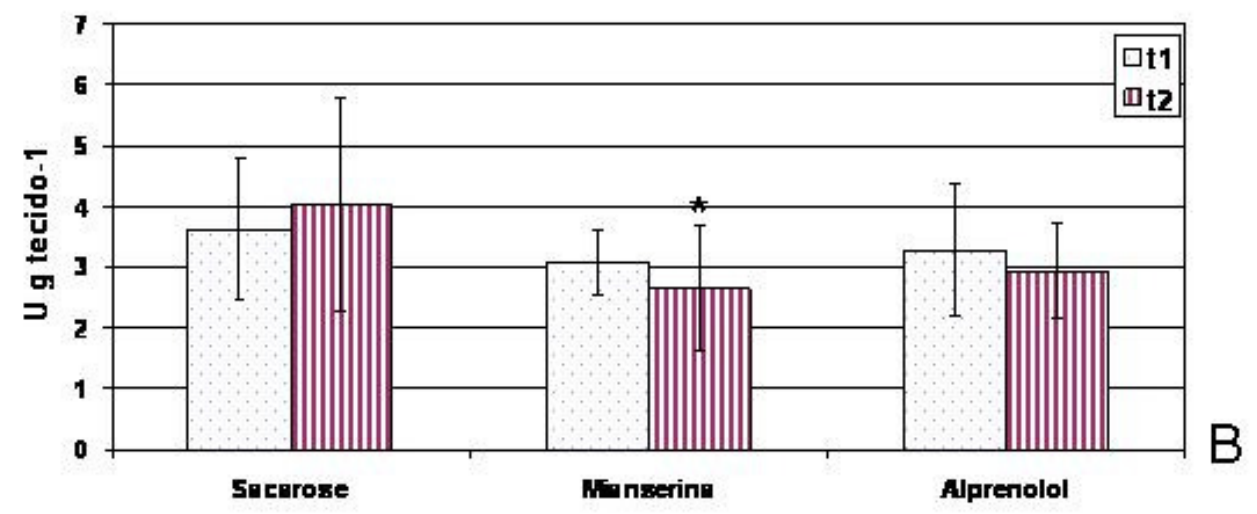

\% GP ativa

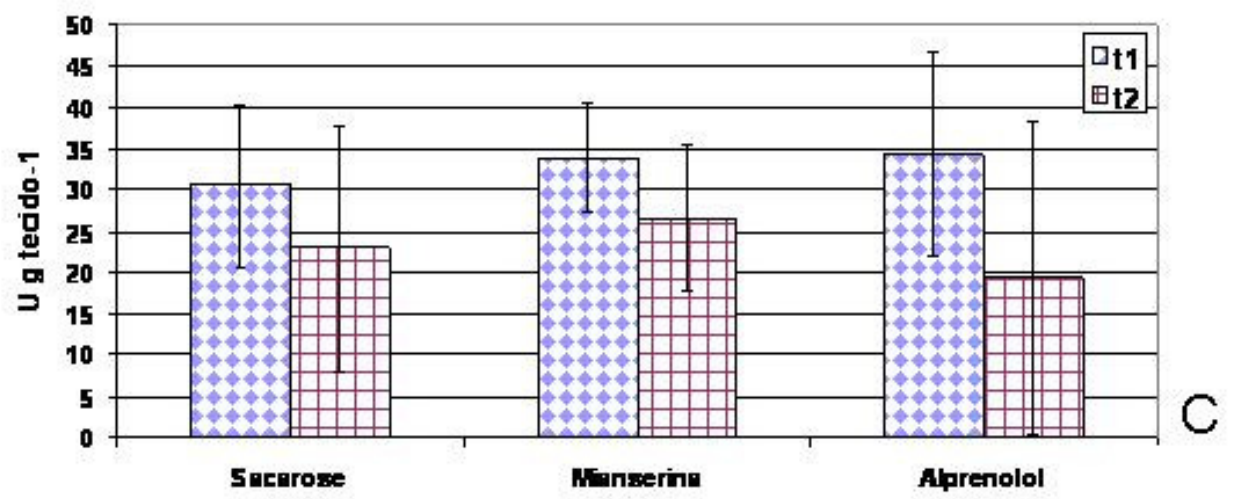

Figura 22. Atividade enzimática (U . g tecido-1) de Glicogênio Fosforilase ativa (A), Glicogênio Fosforilase total (B), e \% de Glicogênio fosforilase ativa (C) calculadas a partir de extrato de tórax de forrageiras do grupo Sacarose, Mianserina e Alprenolol no tempo $t_{2}$ (5h). Os grupos Sacarose e Mianserina diferem significantemente quanto a GP ativa e GP total, segundo testes de Kruskall Wallis e pós teste Dunn 


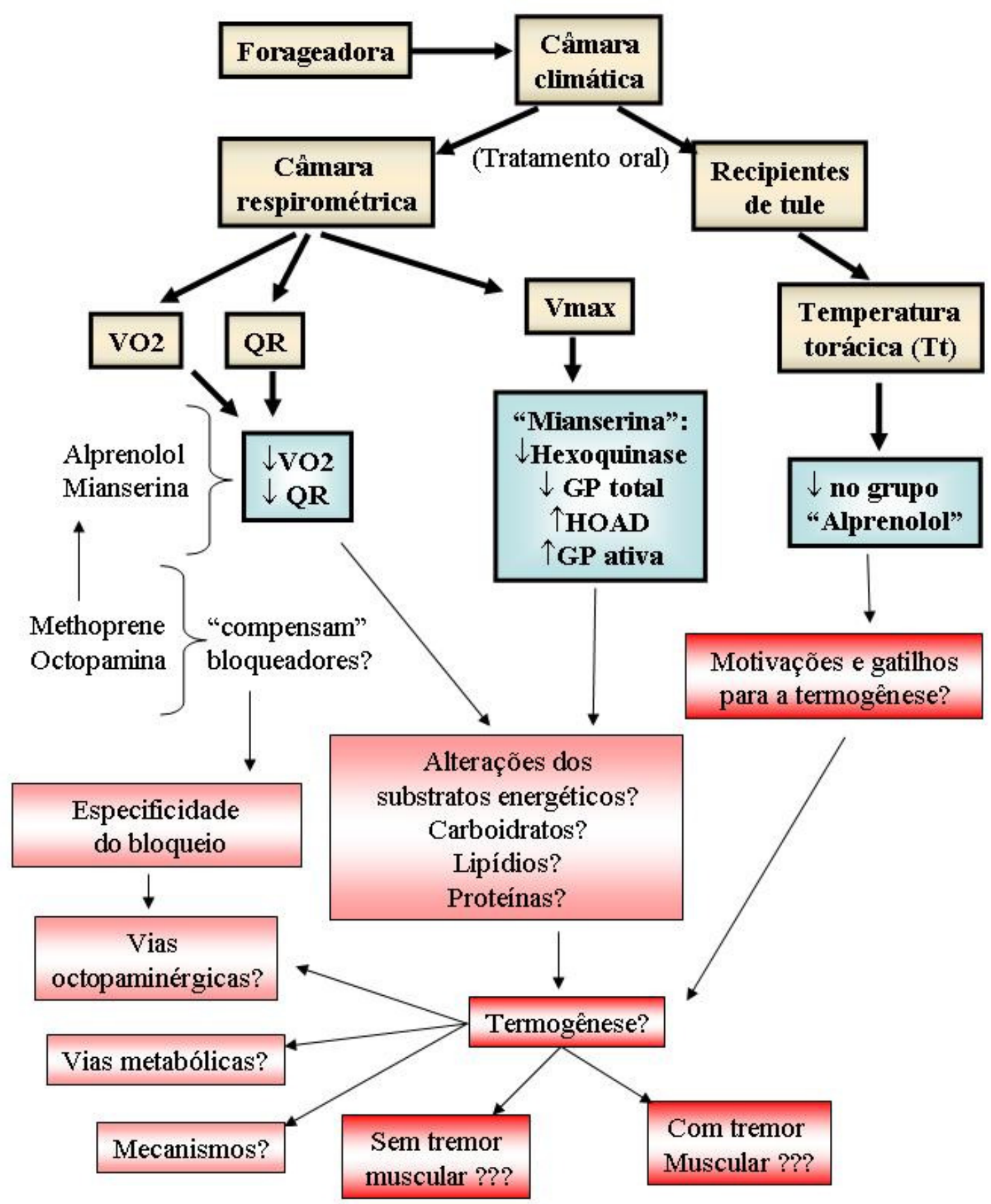

Figura 23. Resumo dos efeitos de octopamina,methoprene e bloqueadores (alprenolol e mianserina) sobre a taxa metabólica, quociente respiratório, atividade enzimática e temperatura torácica de abelhas forrageadoras de $M$ quadrifasciata (em negrito), com destaque para alguns pontos de discussão, envolvendo oxidação de substratos, metabolismo energético e mecanismos de termogênese. . 


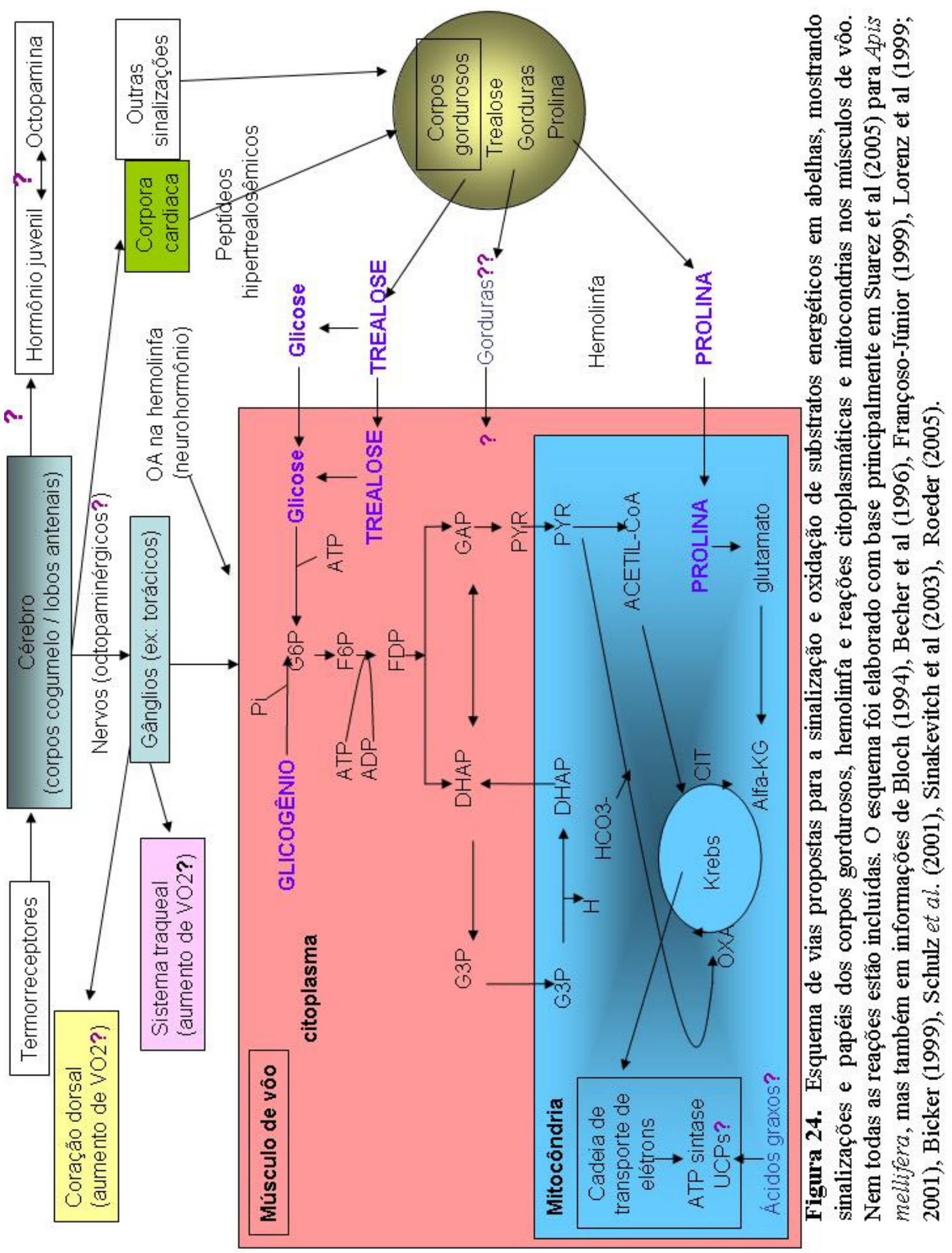



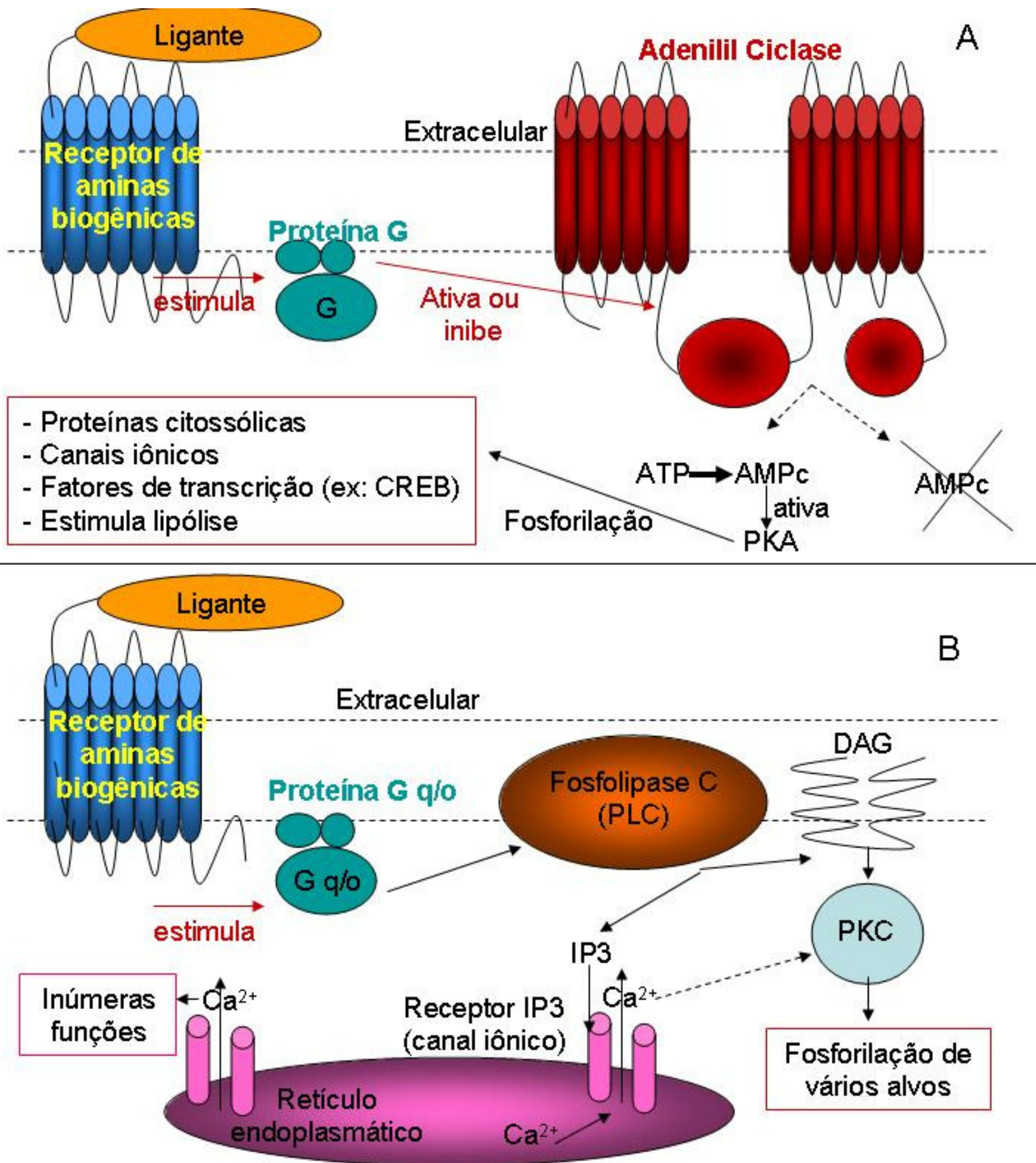

Figura 25. Esquemas de hipóteses de vias de sinalização ativadas por receptores de aminas biogênicas de insetos, baseadas em Farooqui et al (2004) e Blenau e Baumann (2001) para Apis mellifera e Drosophila melanogaster. A: o receptor acoplado ao seu ligante ativa a proteína $G$ inibitória ( $G i)$ ou estimulatória (Gs). Neste caso, leva a aumento da atividade enzimática da adenilil ciclase, que cataliza a conversão de $\mathrm{ATP}$ a $\mathrm{AMP}$ c, podendo ocorrer, por exemplo, ativação da PKA, a qual, quando ativada, pode modificar as propriedades de vários tipos de moléculas e de uma série de diferentes alvos intracelulares. B: pode haver estimulação da atividade de fosfolipase $\mathrm{C}$, que hidrolisa um substrato ligado a membrana, o fosfatidilinositol 4,5 bifosfato. A clivagem deste origina dois segundos mensageiros, $\mathbb{P} 3$ e DAG. $O \mathbb{P} 3$ no citoplasma se ligado a receptores específicos na membrana de estoques intracelulares de $\mathrm{Ca} 2+$, havendo liberação de $\mathrm{Ca} 2+$ ao citoplasma, que pode desempenhar inúmeras funções. $\mathrm{A}$ atividade da fosfolipase $\mathrm{C}$ origina, além de $\mathbb{P} 3$, também $\mathrm{DAG}$, que ativa a $\mathrm{PKC}$, que também requer ions $\mathrm{Ca} 2+$. 


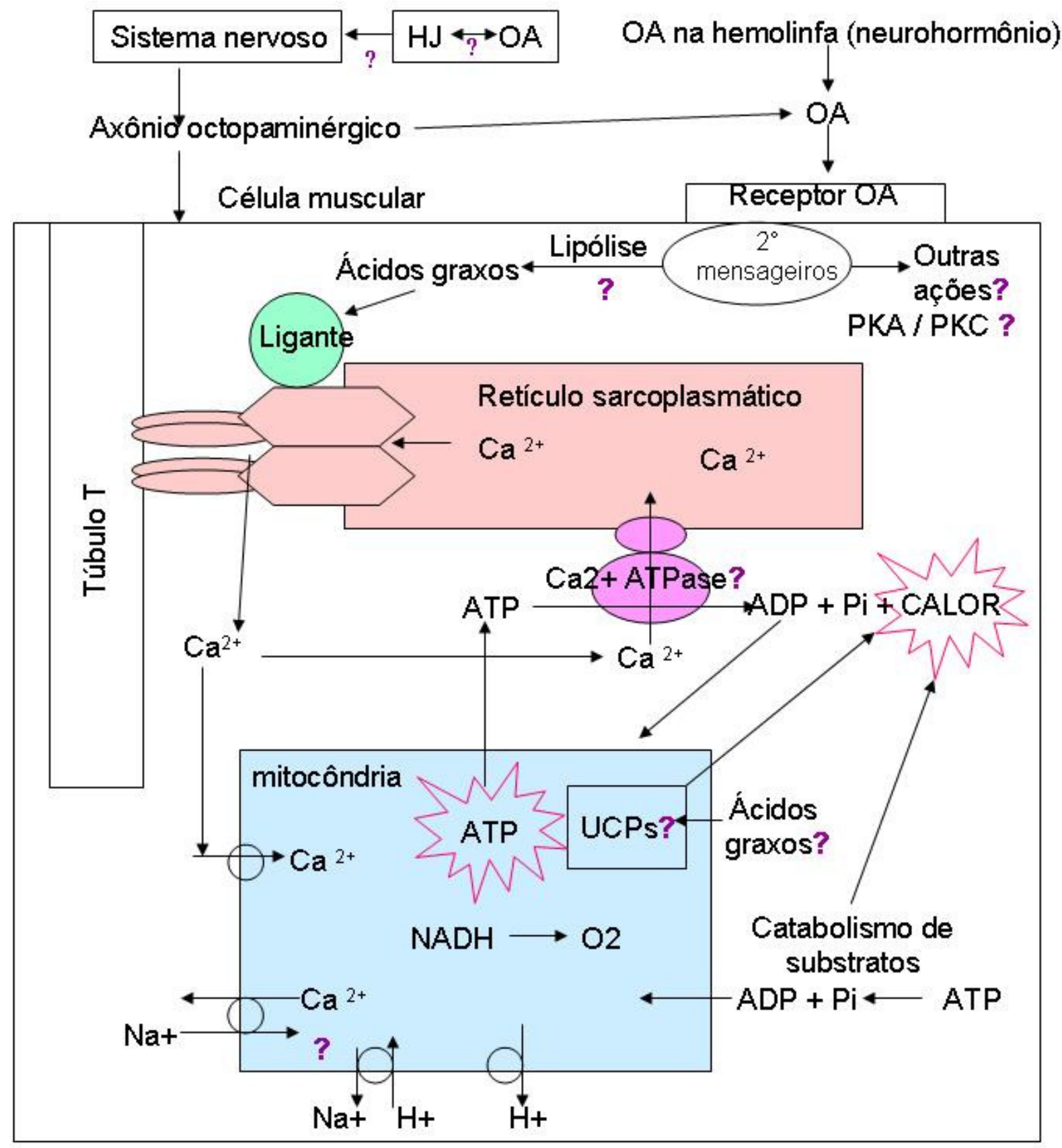

Figura 26. Hipóteses de mecanismos de ação intracelulares, decorrentes de estimulação octopaminérgica em células musculares de insetos, envolvendo ciclagem de $\mathrm{Ca} 2+$, baseados em Bloch (1994), Lowell e Spiegelman (2001) e Blenau e Baumann (2001). Uma hipótese é que a estimulação da célula ocorre via inervações de porção termogênica dos músculos torácicos e/ou após estimulação de receptores por octopamina da hemolinfa. A estimulação poderia levar a despolarização e liberação de Ca2+ a partir de depósitos intracelulares (como retículo sarcoplasmático, RS), havendo aumento no $\mathrm{Ca} 2+$ citoplasmático, que pode resultar em uma série de respostas celulares; tal liberação poderia ser também estimulada por ligantes ou hormônios. $O$ transporte de $\mathrm{Ca} 2+$ citoplasmático de volta aos estoques poderia resultar em hidrólise de ATP, pela $\mathrm{Ca} 2+$ ATPase do RS, havendo aumento do ADP citossólico, que poderia ser importado para dentro da matriz mitocondrial, assim aumentado os níveis ADP/ATP, que resulta em estimulação de processos oxidativos. 


\section{Capítulo 5. Discussão geral e conclusões.}

A investigação de termorregulação colonial, metabolismo energético individual e mecanismos de termogênese em $M$. quadrifasciata foi o tema deste estudo. Cada um dos capítulos focalizou aspectos específicos, abordando séries temporais de temperatura, umidade relativa, taxa metabólica, quociente respiratório, temperatura torácica e atividade enzimática e influências de fatores ambientais. Obteve-se uma gama de informações novas para a espécie, abordando de maneira abrangente diversos aspectos da heterotermia de $M$. quadrifasciata, sob os pontos de vista individual e colonial. $\mathrm{O}$ quanto os resultados aqui obtidos podem ser ampliados à espécie e/ou às abelhas sem ferrão em geral ainda depende de uma resposta definitiva. A vantagem de usar diversas colônias reside, entre outros fatores, na ampliação da variabilidade genética e melhora da verificação de padrões comuns à espécie.

O capítulo 2 evidenciou que há variação diária no controle de temperatura e umidade relativa dentro de ninhos de $M$. quadrifasciata, na região dos discos de cria, com amplitudes menores que as ambientais e detecção de periodicidades, que foram comparadas entre as diversas séries temporais. As periodicidades detectadas em séries temporais de fatores ambientais (como temperatura ambiente, umidade relativa do ambiente e luminosidade) coincidem com as periodicidades em séries temporais registradas na região dos discos de cria, sugerindo influência das condições ambientais sobre a manutenção da homeostase na colônia.

Quanto à atividade de vôo, suas séries temporais apresentavam periodicidades similares às ambientais, mas também eram relacionadas às da região dos discos de cria. Forrageadoras poderiam medir todos os parâmetros relevantes e processar informações relacionadas aos recursos ambientais e necessidades da colônia a fim de otimizar as suas decisões de forrageio (OSTER e WILSON, 1978; SCHMID-HEMPEL et al, 1985). Em ambientes instáveis e variáveis, pode haver vantagem em fazerna tomada de decisões rápidas. Além do mais, diversos mecanismos podem ter sido selecionados de modo a permitir que as sociedades animais apresentem respostas adaptativas a um meio ambiente complexo (CAMAZINE et al, 2001; DETRAIN e DENEUBOURG, 2002).

As abelhas eussociais como Melipona quadrifasciata apresentam grande plasticidade comportamental e, nas colônias, dispõem de sistemas altamente flexíveis de divisão de trabalho (SEELEY, 1995), importantes para respostas a alterações ambientais. Mas é necessário atentar para as diferenças no polietismo etário entre Apini e Meliponini.

Em colônias mantidas em condições constantes, as periodicidades detectadas na região da cria eram diferentes das periodicidades de temperatura da câmara climática, programada para temperatura constante, sugerindo componentes endógenos na ritmicidade colonial. Apesar de ser necessário estudos cronobiológicos mais específicos, para confirmação de que o ritmo é endógeno, 
tais como curvas de resposta de fase, as séries temporais de colônias em condições constantes indicam que as abelhas mantêm a temperatura na região dos discos de cria em níveis controlados e de maneira cíclica. Em abelhas, não se sabe como cada operária reage na termorregulação, se elas formam uma resposta termorregulatória de grupo, com termogênese coordenada, ou se a termorregulação colonial é subproduto da produção individual de calor (BÜDEL, 1968; HEINRICH, 1996; WEINDELMÜLLER et al, 2002).

A temperatura ambiente, a umidade relativa e a luminosidade são variáveis ambientais que apresentam periodicidades semelhantes, já que estão todas submetidas aos ciclos geofísicos do ambiente. Estes três aspectos ambientais medidos parecem influenciar ou arrastar as séries temporais coloniais, mas é difícil afirmar qual deles é o maior responsável neste caso, já que se interrelacionam.

A ritmicidade na termorregulação colonial tem sido descrita para diversos gêneros de abelhas sem ferrão, como os trabalhos de Moo et al (2000) em Melipona beecheii, os de Hilario e ImperatrizFonseca (2002) em Melipona bicolor, os de Almeida (2004) em Frieseomelitta varia, e os de Proni e Hebling (1996) em Tetragonisca angustula fiebrigi e Tetragonisca angustula angustula. A ritmicidade foi detectada principalmente na região onde se encontra a cria, ressaltando a importância do controle de temperatura nesta região da colônia.

Nos capítulos 3 e 4, a abordagem foi individual. No capítulo 3, investigou-se os efeitos do ciclo claro/escuro e da temperatura sobre a taxa metabólica de operárias forrageadoras. $\mathrm{O}$ estudo foi realizado por meio de respirometria intermitente, com comparações dos efeitos do ciclo claro/escuro a $28^{\circ} \mathrm{C}$ (fotoperíodo normal, fotoperíodo invertido, claro e escuro constante) sobre a taxa metabólica, e os efeitos da temperatura ambiente $\left(10\right.$ a $\left.40^{\circ} \mathrm{C}\right)$ sobre a taxa metabólica e quociente respiratório $(\mathrm{QR})$ de forrageadoras. Estas variáveis foram escolhidas por influenciarem diretamente as abelhas. Tem sido sugerido que o Zeitgeber mais importante para a atividade das abelhas é o ciclo claro-escuro (MOORE et al., 1989; MOORE e RANKIN, 1993; MOORE, 2001), influenciando a divisão de trabalho na colônia, os padrões de forrageio, de atividade de vôo e "arrastando" os seus ritmos endógenos. A temperatura também é um importante Zeitegeber que influencia o ritmo circadiano de insetos (SAUNDERS, 2002). No capítulo 2 pôde ser verificado que estes dois parâmetros ambientais, juntamente com a luminosidade, apresentam aspectos rítmicos que afetam as respostas coloniais das abelhas.

No capítulo 3 foi detectada resposta individual frente a esses fatores e observado que os diferentes ciclos de claro/escuro afetaram a taxa metabólica das abelhas. Foram detectados, em fotoperíodo normal e claro constante, dois "patamares" com valores de taxa metabólica baixos entre $19 \mathrm{~h}$ e $5 \mathrm{~h}$. Em fotoperíodo invertido foram registrados valores baixos na fase de escuro, que ocorria entre $6 \mathrm{~h}$ e $18 \mathrm{~h}$, obtendo-se um padrão invertido de taxa metabólica, sugerindo que parece haver um 
ritmo exógeno que surge como resposta a mudanças fotoperiódicas. Este tipo de resposta pode ser importante para a sobrevivência das abelhas, mostrando que a taxa metabólica destas pode apresentar plasticidade e se ajustar de acordo com as condições ambientais, permitindo o sucesso do animal em uma ampla gama de variações ambientais, incrementando desta maneira a eficácia biológica (PIANKA, 1982 apud PRONI e MACIEIRA, 2004).

A temperatura também apresentou efeito significativo sobre a taxa metabólica e QR das forrageadoras, com valores diminuídos a 35 e $40^{\circ} \mathrm{C}$ e mais ainda a $10^{\circ} \mathrm{C}$. Parece haver diferenças nos valores de taxa metabólica e QR de forrageadoras conforme a função no forrageio (coleta de néctar/água ou de pólen), destacando a importância de se atentar a este fato na escolha de forrageadoras para experimentos de taxa metabólica e QR.

Esses experimentos foram importantes para a caracterização da taxa metabólica e QR de abelhas submetidas a diferentes condições ambientais, fornecendo um panorama para a escolha de janelas temporais, condições de iluminação e de temperatura para experimentos com esta espécie. Além disso, pode ser verificado que a temperatura e os ciclos claro/escuro afetam as abelhas tanto no nível colonial quanto individual.

Além de variações nas condições de temperatura e iluminação, alterações em processos fisiológicos podem afetar o metabolismo energético e a termorregulação, e entre eles destacam-se alterações em vias octopaminérgicas e heterotermia. O capítulo 4 focalizou em aspectos do metabolismo energético, termogênese e oxidação de substratos energéticos, sob influências de modificações em vias octopaminérgicas. Foram estudados os efeitos de Hormônio Juvenil, Octopamina e seus bloqueadores (Alprenolol e Mianserina), com base nas semelhanças entre o sistema adrenérgico / noradrenérgico dos vertebrados e o sistema tiraminérgico / octopaminérgico dos insetos (EVANS, 1985, 1993; ROEDER, 1999, BLENAU e BAUMANN, 2001; ROEDER, 2005), suas relações com hormônio juvenil e suas hipotéticas ações na termorregulação e no metabolismo energético de abelhas (BELZUNCES et al, 1996).

Foi trabalhada a hipótese de que em abelhas um mecanismo semelhante à ativação de receptores beta-adrenérgicos de vertebrados poderia estar envolvida na termogênese de indivíduos e em aspectos de seu metabolismo energético (BELZUNCES et al, 1996, LOLI e BICUDO, 2005). A questão foi trabalhada por meio de tratamento oral com octopamina, methoprene (análogo de hormônio juvenil), alprenolol (bloqueador beta-adrenérgico) e mianserina (bloqueador octopaminérgico) em diferentes combinações.

Foi observado que a diminuição da temperatura torácica em forrageadoras tratadas com o bloqueador alprenolol sugere o envolvimento de vias octopaminérgicas na termogênese em $M$. quadrifasciata. Mas é necessário cautela já que não se sabe se tais efeitos são decorrentes de interferências na produção de calor ou um subproduto da diminuição da taxa metabólica. Os 
resultados não provam que há mecanismos de termogênese sem tremor muscular em abelhas, envolvendo octopamina e HJ, mas indicam um possível envolvimento destas substâncias na taxa metabólica e oxidação de diferentes substratos energéticos. Sugere-se a necessidade de dados bioquímicos e estruturais, que indiquem se a produção de calor em insetos pode estar relacionada com a liberação de $\mathrm{Ca}^{2+}$ de estoques citoplasmáticos, a proteínas desacopladoras e oxidação de diferentes substratos energéticos.

Também foi observado que com o bloqueio de receptores de octopamina podem ocorrer alterações na atividade de enzimas do músculo torácico de vôo de abelhas individuais, como a hexoquinase, HOAD e glicogênio fosforilase. Modificações nas vias metabólicas de estocagem de energia e sua utilização, frente a alterações ambientais, permitem que os organismos possam sobreviver em condições desfavoráveis (NEWSHOLME e CRABTREE, 1986).

Quando bloqueadores foram fornecidos às colônias (capítulo 2), observou-se alterações no padrão das periodicidades das séries temporais, indicando que as colônias tratadas parecem responder menos à temperatura ambiente do que as colônias não tratadas, e mais à umidade relativa, sugerindo alterações nas respostas à temperatura ambiente. Além disso,é uma sugestão de que o emprego de bloqueadores, que são ingeridos por abelhas individuais na colônia, pode afetar a resposta colonial da termorregulação, evidenciando o envolvimento de vias octopaminérgicas no controle de temperatura.

Dentro de uma perspectiva comparativa, pode-se apontar semelhanças entre efeitos de modificações em vias octopaminérgicas/tiraminérgicas de insetos e noradrenérgicas/tiraminérgicas de vertebrados, quanto ao metabolismo energético e termogênese, sugerindo a possibilidade de existência de mecanismos de termogênese sem tremor muscular em insetos, que poderiam envolver proteínas desacopladoras, tal como ocorre em vertebrados, Todavia, os resultados do capítulo 4 não provam tal afirmação, mas apontam evidências de via octopaminérgica envolvida na taxa metabólica e temperatura torácica de forrageadoras.

Os três capítulos supra citados, em conjunto, contribuem para a compreensão de questões relacionadas à heterotermia em $M$. quadrifasciata, abordando o tema de forma a integrar informações referentes ao comportamento, fisiologia, respostas individuais e coloniais, importantes ao se pesquisar um inseto eussocial.

\section{CONCLUSÕES}

\section{Capítulo 2}

- há controle de temperatura dentro de ninhos de Melipona quadrifasciata; 
- a regulação de temperatura e umidade relativa dentro da colônia apresenta variação diária, relacionada, em colônias mantidas abertas, à temperatura ambiente, umidade relativa do ambiente e/ou luminosidade, além de ritmos endógenos.

- as periodicidades detectadas na atividade externa de vôo parecem estar relacionadas às periodicidades de fatores ambientais (temperatura ambiente, umidade relativa do ambiente e/ou luminosidade) e também de fatores coloniais, como a temperatura na região dos discos de cria;

- a regulação da temperatura e da umidade relativa dentro da colônia, na região dos discos de cria, parece expressar uma ritmicidade endógena quando em condições de temperatura e escuro constante;

- bloqueadores de receptores de octopamina afetam o padrão das periodicidades das séries temporais, sugerindo que as colônias tratadas respondem menos à temperatura ambiente e mais à umidade relativa do ambiente.

\section{Capítulo 3}

- diferentes ciclos de claro/escuro afetam a taxa metabólica de forrageadoras;

- parece haver um ritmo exógeno que aparece como uma resposta a mudanças no ciclo claro/escuro, como ocorrido em fotoperíodo invertido;

- o claro se mostrou uma condição adequada (ao se comparar claro e escuro) para os experimentos do capítulo 4, por ser a condição na qual a forrageadora se encontrava ao ser coletada, não sendo necessário tempo de aclimatação muito longo para a condição experimental;

- como não foi encontrada diferença estatisticamente significativa entre a taxa metabólica das abelhas, no claro, entre $7 \mathrm{~h}$ e $17 \mathrm{~h}$, essa é uma janela temporal na qual podem ser realizados estudos de efeitos de substâncias, sem alterações na $\mathrm{VO}_{2}$ relativas à fase do dia;

- a temperatura tem um efeito significativo sobre a taxa metabólica de forrageadoras;

- entre 15 e $30^{\circ} \mathrm{C}$ não há diferenças estatísticas entre os valores de $\mathrm{VO}_{2} \mathrm{e} \mathrm{QR}$, sendo esta uma faixa de temperatura adequada na qual podem ser realizados estudos de efeitos de substâncias, sem alterações na $\mathrm{VO}_{2}$ relativas à temperatura;

- parece haver diferença nos valores de $\mathrm{QR}$ e $\mathrm{VO}_{2}$ das forrageadoras, nas diferentes temperaturas, conforme a função no forrageio (coleta de néctar/água ou de pólen), sendo importante atentar a este fato na escolha de forrageadoras para experimentos de $\mathrm{VO}_{2} \mathrm{e} \mathrm{QR}$.

\section{Capítulo 4}

- os resultados obtidos neste trabalho fornecem evidências de efeitos de vias octopaminérgicas em M. quadrifasciata. 
- a diminuição da temperatura torácica em forrageadoras tratadas com Alprenolol sugere o envolvimento de vias octopaminérgicas na termogênese em M. quadrifasciata. Mas é necessário cautela já que não se sabe se tais efeitos são decorrentes de interferências na produção de calor ou um sub-produto da diminuição da taxa metabólica

- os resultados não provam que há mecanismos de termogênese sem tremor muscular em abelhas, envolvendo octopamina e HJ, mas indicam um possível envolvimento destas substâncias na taxa metabólica e oxidação de diferentes substratos energéticos.

- com o bloqueio de receptores de octopamina podem ocorrer alterações na atividade de enzimas do músculo torácico de vôo, como a hexoquinase, HOAD e glicogênio fosforilase.

\section{REFERÊNCIAS BIBLIOGRÁFICAS}

ALMEIDA, G.F. (2004) Estudo de componentes rítmicos detectados na colônia de Frieseomelitta varia (Hymenoptera: Apidae: Meliponinae). Dissertação de Mestrado, FFCLRP-USP.

BELZUNCES, L.P.; VANDAME, R. And GU, X. (1996) Modulation of honeybee thermoregulation by adrenergic compounds. Neuroreport. 7(10):1601-4.

BLENAU, W. and BAUMANN, A. (2001) Molecular and pharmacological properties of insect biogenic amines receptors: lessons from Drosophila melanogaster and Apis mellifera. Archives of Insect Biochemistry and Physiology 48: 13-38.

BÜDEL, A (1968) Le microclimat de la ruche. In: Chauvin, R (ed). Traité de Biologie del'Abeille. Paris: Masson \& Cie 4:2-53

CAMAZINE, S. et al (2001). Self-Organization in Biological Systems. Princeton, New Jersey. Princeton University Press.

DETRAIN, C..; DENEUBOURG, J.L. (2002) Complexity of environment and parsimony of decisions rules in insect societies. Biol Bull 202: 268-74.

EVANS, P.D. (1985) Octopamine. In: Comprehensive insect physiology, biochemistry, and pharmacology (G.A. Kerkut and L.I Gilbert, eds.), vol 11: Pharmacology. Oxford, Pergamon Press, pp. 499-530.

EVANS, P.D. (1993) Molecular studies on insect octopamine receptors. In: Comparative molecular neurobiology (Y. Pichon, ed.) Basel, Birkháuser, pp. 286-296.

EVANS, P.D. e MAQUEIRA, B. (2005). Insect octopamine receptors: a new classification scheme based on studies of cloned Drosophila G-protein coupled receptors. Invert Neurosci. 5(34):111-8.

MOO, V.H; QUEZADA, E.J.J.; NAVARRO, J.; RODRIGUES, C.L. (2000) Patterns of intranidal temperature flutuations for Melipona beecheii colonies in natural nesting cavities. $\mathbf{J}$ Apicultural Res (1-2):3-7.

MOORE, D.; SIEGFRIED, D.; WILSON, R.; RANKIN, M (1989) The influence of time of day on the foraging behavior of the honeybee Apis mellifera. J Biol Rhythm 4: 305-25.

MOORE, D.; RANKIN, M (1993) Light and temperature entrainment of a locomotor rhythm in honeybees. Physiol Entomol 18: 271-8.

MOORE, D. (2001) Honey bee circadian clocks: behavioral control from individual workers to whole-colony rhythms. J Insect Physiol 47: 843-57.

NEWSHOLME, E.A e CRABTREE, B (1986) Maximum catalytic activity of some key enzymes improvision of physiologically useful information about metabolic flux. J Exp Biol 239(2): $159-67$ 
OSTER, G.F.; WILSON, E.O. (1979). Caste and ecology in the social insects. Monogr Popul Biol. 12:1-352

PIANKA, E.R. (1982) Ecología Evolutiva. Barcelona, Ed. Omega S.A., XI+365p.

PRONI, E.; HEBLING, M.J. (1996) Thermoregulation and respiratory metabolism in two Brazilian stingless bee subspecies of different climatic distribution, Tetragonica angustula fiebrigi and $T$ A angustula (Hymenoptera: Apidae: Meliponinae). Entomologia Generalis 20(4): 281-9.

PRONI, E. A (1995) Fisiologia e capacidade de termorregulação em ninhos de Tetragonisca angustula e Plebeia juliani. Tese de Doutorado, UNESP, Rio Claro.

PRONI, E.A. MACIEIRA, OJD.; Franchi, M.N. Morais, A.; Tristão, F.S. (2001) V Congresso Brasileiro de Ecologia, Brasil.

ROEDER, T. (1995). Pharmacology of the octopamine receptor from locust central nervous tissue (OAR3). Br J Pharmacol. 114(1):210-6.

ROEDER, T. (1999) Octopamine in invertebrates. Prog. Neurobiol. 59: 533-61.

ROEDER, T. (2005) Tyramine and octopamine: ruling behavior and metabolism. Annu Rev Entomol 50: 447-77.

Saunders, D.S. (2002) Insect Clocks $3^{\text {rd }}$ ed. Elsevier Science, Amsterdam.

SCHMID-HEMPEL, P. (1984). The importance of handling time for the flight directionality in bees. Behav Ecol Sociobiol 15: 303-9.

WEINDENMULLER, A; KLEINEDAM, C; TAUTZ, J (2002) Collective control of nest climate parameters in bumblebees colonies. An Behav 63(6): 1065-71. 


\section{Resumo}

Em abelhas eussociais o controle das condições internas coloniais (temperatura e umidade relativa) e manutenção do micro-clima são importantes para a incubação da cria e sobrevivência da colônia. Um dos principais mecanismos para controle da temperatura colonial é a escolha do local de nidificação, como ocos de troncos de árvores, tal qual ocorre nas abelhas sem ferrão Melipona quadrifasciata, sistema biológico deste estudo. Além de mecanismos comportamentais, em Hymenoptera são também conhecidos mecanismos fisiológicos de termorregulação (termogênese) como a ocorrência de ciclos fúteis (descritos para mamangavas Bombus) e o tremor muscular. A termogênese em abelhas ocorre principalmente durante incubação da cria, atividades sociais e aquecimento pré-vôo. Não foram detalhados até o momento mecanismos fisiológicos de termogênese diferentes do tremor muscular e/ou a sua regulação em abelhas. As aminas biogênicas, especialmente a octopamina, desempenham um amplo espectro de funções em abelhas, e é sugerido que o sistema noradrenérgico/adrenérico de vertebrados é funcional e estruturalmente equivalente ao sistema octopaminérgico/tiraminérgico de insetos. O emprego de bloqueador beta-adrenérico em abelhas pode levar a hipotermia, emergindo a hipótese de que haveria envolvimento de uma via octopaminérgica na energética e termogênese de abelhas. Os principais aspectos da termorregulação focados neste trabalho são a termorregulação colonial, a energética individual e mecanismos de termogênese em Melipona quadrifasciata. Com relação à termorregulação colonial, o objetivo principal foi descrevê-la em duas regiões do ninho (discos de cria e potes de alimento), por meio de registro de séries temporais de temperatura e umidade relativa, e estudo da atividade externa de vôo. Foi detectada ritmicidade nas séries temporais de colônias abertas, com influência das periodicidades da temperatura ambiente, umidade relativa e luminosidade, sobre as séries temporais registradas dentro da colônia. As séries temporais de atividade de vôo apresentavam periodicidades similares às ambientais, mas também eram relacionadas às da cria. Em colônias fechadas, as séries temporais dos discos de cria apresentavam periodicidades próximas a $24 \mathrm{~h}$ e $12 \mathrm{~h}$, sugerindo aspecto endógeno da regulação de temperatura e umidade próximo à cria. Também, objetivou-se caracterizar o efeito do tipo de iluminação e de diferentes temperaturas. Foram estudados, por meio de respirometria intermitente, os efeitos do ciclo claro/escuro a $28^{\circ} \mathrm{C}$ (fotoperíodo normal, fotoperíodo invertido, claro e escuro constante) sobre a taxa metabólica, e os efeitos de diferentes temperaturas ambientais $\left(10\right.$ a $\left.40^{\circ} \mathrm{C}\right)$ sobre a taxa metabólica e quociente respiratório (QR). Os diferentes ciclos de claro/escuro afetaram a taxa metabólica, sendo observados, em fotoperíodo normal e claro constante, dois "patamares" com valores de taxa metabólica baixos entre $19 \mathrm{~h}$ e $5 \mathrm{~h}$. Em fotoperíodo invertido, valores diminuídos foram registrados na fase de escuro, que ocorria entre $6 \mathrm{~h}$ e $18 \mathrm{~h}$, obtendo-se um padrão invertido de taxa metabólica, sugerindo um ritmo exógeno em resposta a mudanças fotoperiódicas. Entre 7h e 17h59, no claro, ressalta-se que não há diferenças estatisticamente significativas na taxa metabólica. A temperatura tem um efeito significativo sobre a taxa metabólica e QR das forrageadoras, com valores diminuídos a 35 e $40^{\circ} \mathrm{C}$ e mais ainda a $10^{\circ} \mathrm{C}$. Entre 15 e $30^{\circ} \mathrm{C}$ não há diferenças significativas. Na terceira parte do trabalho objetivou-se verificar o efeito tempo-dependente de bloqueadores beta-adrenérgicos e octopaminérgicos (Alprenolol e Mianserina) sobre a taxa metabólica e temperatura torácica de forrageadoras e verificar se a octopamina e methoprene (análogo de hormônio juvenil) compensam os efeitos dos bloqueadores. Também foi analisado se há alterações dos substratos energéticos catabolizados, considerando o quociente respiratório (QR) e a atividade enzimática (Vmax de hexoquinase, trealase, HOAD e glicogênio fosforilase). Com o emprego dos bloqueadores, foram detectadas alterações no QR e na atividade das enzimas hexoquinase, trealase, HOAD e glicogênio fosforilase. A diminuição da temperatura torácica obtida em forrageadoras tratadas com Alprenolol sugere o envolvimento de vias octopaminérgicas na termogênese em $M$. quadrifasciata; todavia, não se sabe se tais efeitos são decorrentes de interferências na produção de calor e/ou um subproduto da diminuição da taxa metabólica. No nível colonial, ninhos tratados com os mesmos bloqueadores parecem apresentar periodicidades de séries temporais mais similares à da umidade relativa do ambiente e menos à da temperatura ambiente, sugerindo menor resposta às variações de temperatura. Os resultados não provam que há mecanismos de termogênese sem tremor muscular em abelhas, envolvendo octopamina e hormônio juvenil, mas indicam um possível envolvimento destas substâncias na taxa metabólica e oxidação de diferentes substratos energéticos. Sob uma visão comparativa, pode-se apontar semelhanças entre efeitos de modificações em vias octopaminérgicas/tiraminérgicas de insetos e noradrenérgicas/tiraminérgicas de vertebrados, quando à energética e termogênese. Os resultados não 
provam tal afirmação, mas apontam evidências do papel da via octopaminérgica na taxa metabólica e temperatura torácica de forrageadoras.

\section{Abstract}

In eusocial insects, such as stingless bees, the control of nest conditions and maintenance of the colonial microclimate are important to brood incubation, development of eggs, larvae and pupae, and survival of the colony. One of the main thermoregulatory mechanisms to control nest temperature is the microhabitat selection to build the nest, such as tree holes, characteristic of the stingless bee Melipona quadrifasciata, the biological system chosen for this study. In addition to the behavioral mechanisms involved in thermoregulation, physiological mechanisms underlying thermogenesis are also found in Hymenoptera, such as futile cycles (in bumblebees) and shivering thermogenesis. Thermogenesis in bees is detected mainly during brood incubation, social interactions and pre-flight warming; additional possible physiological mechanisms have not yet been investigated with enough detail.. Biogenic amines, especially octopamine, play important physiological roles in bees. Although octopamine and norepinephrine are chemically not identical, it appears that octopaminergic systems of invertebrates and noradrenergic systems of vertebrates are homologous. Oral treatment with beta-blockers can cause hypothermia, leading to the hypothesis that an octopaminergic pathway involved in bee energetics and thermogenesis might exist. The main aspects investigated in the present study are the colonial thermoregulation, the energetics of individual bees, and the mechanisms associated with thermogenesis in $M$. quadrifasciata. With regards to the colonial thermoregulation, temperature and humidity, time series were recorded inside and outside the nest, in two colonial compartments, i.e., brood and pots. In addition, flight activity was also recorded. Flight activity time series presented similar periodicities in both ambient and brood series. In closed colonies, maintained under constant conditions, the brood time series presented periodicities close to $24 \mathrm{~h}$ and $12 \mathrm{~h}$, suggesting endogenous aspects and rhythm. Another goal of this study was to characterizing the effects of the lightdark cycles and ambient temperatures. This was achieved using intermittent respirometry, and the effects of the light-dark cycles at $28^{\circ} \mathrm{C}$ (normal photoperiod, inverted photoperiod, constant light and constant dark) on metabolic rate, and the effects of different temperatures $\left(1040^{\circ} \mathrm{C}\right)$ on metabolic rate and respiratory quotient (RQ) were measured. The different light-dark cycles affected the metabolic rate under normal photoperiod and constant light. Two "platforms," with low metabolic rate values were detected between $19 \mathrm{~h}$ and $5 \mathrm{~h}$. When the photoperiod was inverted, lower values were recorded in the dark phase, between $6 \mathrm{~h}$ and $18 \mathrm{~h}$, resulting in an inverted pattern of metabolic rate, thus suggesting an exogenous response to photoperiodic changes. Between $7 \mathrm{~h}$ and $17 \mathrm{~h} 59$, in the light phase, metabolic rate did not change significantly. The temperature has a significant effect on metabolic rate and RQ of the foragers, and reduced values at 10, 35 and $40^{\circ} \mathrm{C}$ were detected. Between 15 and $30^{\circ} \mathrm{C}$ no significant differences were detected. In the third part of this work the aim was to verify the time-dependent effects of beta-blockers (Alprenolol and Mianserina) on metabolic rate and thoracic temperature of foragers, and to verify whether octopamine and methoprene (analogous to juvenile hormone) compensate the effects of beta-blockers. Alterations of substrates oxidation, considering the RQ and the activity (Vmax) of specific enzymes, such as hexokinase, trehalase, HOAD and glycogen phosphorylase, were also investigated. Treatments with blockers caused alterations in the RQ and in the enzyme activities of hexokinase, HOAD and glycogen phosphorylase. The reduced values of thoracic temperature in foragers treated with Alprenolol suggests the involvement of octopaminergic pathways in thermogenesis; however, it is not yet known if such effects are due to interferences in the heat production and/or represent a by-product of a reduced metabolic rate. At the colonial level, nests treated with blockers presented colonial time series periodicities more similar to the ambient humidity series than to the ambient temperature series, suggesting therefore that the responses to ambient temperature are reduced. These results do not prove that mechanisms of nonshivering thermogenesis are present in bees, involving both octopamin and juvenile hormone, but they can indicate possible involvements of these substances in metabolic rate, energetics and fuel utilization. Under a comparative approach, one can suggest similarities between the effects caused by modifications in the noradrenergic and octopaminergic pathways on the energetics and thermogenesis of $M$. quadrifasciata. The results, however, do not prove such hypothesis, but they suggest an octopaminergic influence on both metabolic rate and thoracic temperature of M. quadrifasciata foragers 